\title{
Tessituras híbridas ou o duplo regresso: \\ Encontros latino-americanos e traduções culturais do debate sobre o Retorno à Cidade
}

Gisela Barcellos de Souza

Tese apresentada à Faculdade de Arquitetura e Urbanismo para obtenção do título de Doutor em Arquitetura e Urbanismo.

Área de concentração: História e Fundamentos da Arquitetura e do Urbanismo.

Orientador:

Dr. Paulo Júlio Valentino Bruna

São Paulo, 2013 
AUTORIZO A REPRODUÇÃO E DIVULGAÇÃO TOTAL OU PARCIAL DESTE TRABALHO, POR QUALQUER MEIO CONVENCIONAL OU ELETRÔNICO, PARA FINS DE ESTUDO E PESQUISA, DESDE QUE CITADA A FONTE.

E-MAIL: gisela.barcellosdesouza@gmail.com

Souza, Gisela Barcellos de

S729t Tessituras híbridas ou o duplo regresso : encontros latinoamericanos e traduções culturais do debate sobre o retorno à cidade / Gisela Barcellos de Souza. - São Paulo, 2013.

436 p. : il.

Tese (Doutorado - Área de Concentração: História e Fundamentos da Arquitetura e do Urbanismo) - FAUUSP.

Orientador: Paulo Júlio Valentino Bruna

1. História da arquitetura - América Latina 2. V Seminário de Arquitetura Latino Americana 3. Morfologia urbana 4. Espaço urbano 5. Hibridismo (Cultura) I.Título

CDU $72.03(8=6)$ 
SOUZA, Gisela Barcellos. Tessituras híbridas ou o duplo regresso: Encontros latinoamericanos e traduções culturais do debate sobre o Retorno à Cidade. Tese apresentada à Faculdade de Arquitetura e Urbanismo para obtenção do título de Doutor em Arquitetura e Urbanismo.

Aprovado em:

\section{Banca Examinadora}

Prof. Dr. Paulo Júlio Valentino Bruna Instituição: FAUUSP

Julgamento

Assinatura

Prof. Dr. Instituição Julgamento Assinatura

Prof. Dr. Instituição Julgamento Assinatura

Prof. Dr. Instituição Julgamento Assinatura

Prof. Dr. Instituição Julgamento Assinatura 

a Alberto Morello Barcellos

(in memoriam) 



\section{Agradecimentos}

Agradeço ao professor Dr. Paulo Bruna pela orientação, pelas críticas pungentes e concisas, pelo incentivo e apoio ao longo deste trabalho. Além do mais, agradeço-lhe, também, por ter intermediado o contato com Horacio Torrent para a realização do estágio de doutorado no Chile, fundamental para o desenvolvimento desta pesquisa.

Ao professor Horacio Torrent, que me recebeu e orientou durante o estágio na Facultad de Arquitectura Diseño y Estudios Urbanos da Universidad Católica de Chile, pelas longas conversas sobre esta investigação, pelos registros documentais e materiais bibliográficos repassados, por ter intermediado o contato inicial com os arquitetos chilenos entrevistados e por todo apoio durante este processo.

Aos arquitetos entrevistados, que gentilmente cederam parte de seu tempo a esta pesquisa, permitindo-me, através de seus depoimentos, compreender melhor as nuances do objeto investigado: Carlos Eduardo Comas, Ruth Verde Zein, Hugo Segawa, Rogério de Oliveira, Humberto Eliash, Pedro Murtinho, Cristián Boza, Cristián Fernández Cox, Enrique Browne, Eduardo San Martín, Fernando Montes, Ramón Guritérrez, Jorge Moscato, Antonio Díaz del Bo, Silvia Arango e Jorge Ramírez.

Em especial, agradeço aos professores Carlos Eduardo Comas, Ruth Verde Zein e Hugo Segawa que, ainda no ano de 2009, repassaram-me materiais, referências e concederam-me pistas iniciais sobre o tema desta investigação. Mais especificamente, agradeço aos dois primeiros pelas críticas ao projeto de pesquisa apresentado no Seminário do PROCAD, que permitiram a revisão do recorte da problemática de pesquisa.

À Capes pela bolsa concedida para realização de Estágio de Doutorado junto ao programa de doutorado da Facultad de Arquitectura Diseño y Estudios Urbanos da Universidad Católica de Chile, durante o período de um ano.

À Universidade Estadual de Maringá e, especialmente, aos colegas do Departamento de Arquitetura e Urbanismo pelo afastamento de dois anos, que me possibilitou a realização do estágio em Santiago do Chile e a conclusão da redação desta tese.

Aos amigos Francisco José Peralta e Patrícia Talhari pelo tratamento das imagens e pela revisão do abstract, respectivamente.

Aos meus pais, llca e Rogério, que me serviram de exemplo ao longo da vida e sempre depositaram confiança em mim, acompanhando-me em cada etapa e motivando-me a avançar em novos desafios. Ao Adson, por ter me acompanhado em minha estadia em Santiago do Chile e, sobretudo, pela paciência, pelo carinho e pelo apoio ao longo deste trabalho. 

1.

Um galo sozinho não tece a manhã: ele precisará sempre de outros galos.

De um que apanhe esse grito que ele e o lance a outro; de outro galo que apanhe o grito que um galo antes e o lance a outro; e de outros galos que com muitos outros galos se cruzem os fios de sol de seus gritos de galo para que a manhã, desde uma tela tênue, se vá tecendo, entre todos os galos.

2.

E se encorpando em tela, entre todos, se erguendo tenda, onde entrem todos, se entretendendo para todos, no toldo (a manhã) que plana livre de armação.

A manhã, toldo de um tecido tão aéreo que, tecido, se eleva por si: luz balão.

[João Cabral de Melo Neto, "Tecendo a manhã", 1966] 



\section{Resumo}

A presente pesquisa busca contribuir à compreensão do processo de constituição de debates na cultura arquitetônico-urbanística, atentando, em específico, ao aspecto da migração e adaptação de determinadas discussões de seus contextos originais para outros, à fusão e à agregação de novos significados que ocorre neste deslocamento. Para tanto, enfoca-se o V Seminário de Arquitetura Latino-americana (SAL), realizado em Santiago do Chile, em 1991. O objetivo geral é demonstrar, através do estudo da conjuntura que permitiu a realização do V SAL, a existência de uma hibridação entre os debates relativos a uma possível identidade latino-americana e à revisão do movimento moderno a partir do vocabulário tipo-morfologia entre meados dos anos 1980 e início dos anos 1990. Dissonante com o que foi habitualmente escrito e divulgado sobre os debates produzidos no interior destes seminários no período entre 1985 e 1995, no V SAL - cujo tema fora "Nuestro Espacio Público: Propuestas Morfológicas" - não teve seu debate pautado em questões referentes à "modernidade apropriada" ou à interação entre "o espírito do tempo e o do lugar". A tese embasa-se através de três hipóteses complementares. A primeira hipótese é que V SAL não foi uma ruptura, nem mesmo uma cesura dentro da história dos Seminários de Arquitetura Latino-americana; mas sim a assunção pública e o ápice de um debate sobre a cidade latino-americana e sua morfologia que esteve latente desde os primeiros eventos e foi majoritariamente omitido pela crítica. A segunda hipótese é que a realização do V SAL não se explica somente pela história própria dos Seminários de Arquitetura Latino-Americana; pelo contrário, este evento se insere uma série de traduções culturais do debate tipomorfológico que buscaram vínculos latino-americanos como forma de garantir sua legitimação - e para qual parte de seus organizadores contribuiu ativamente. A terceira e última hipótese é que estes encontros e traduções culturais distintos não foram inócuos, através deles permitiram-se hibridações de conceitos e recombinações de significados nos debates originais e a construção de representações comuns sobre a morfologia de uma "cidade latino-americana" e a forma de se intervir nela, cujos vestígios transparecem nos debates dos SAL. Dois eixos de análises organizam o conjunto de métodos empregados e se manifestam na estrutura da tese: um insere o $\mathrm{V}$ SAL dentro da trajetória dos Seminários de Arquitetura Latino-americana; outro busca, a partir deste referencial, desconstruir as redes de profissionais e as traduções culturais que permitem compreender a realização do evento de Santiago do Chile. 



\section{Abstract}

This research has as the purpose to contribute to understanding the process of setting up debates in architectural-urban culture, noting in particular the aspect of migration and adaptation of certain ideas from their original contexts to other ones, the fusion and the addition of new meanings that occurs among these displacements. Therefore, we focus in the $V$ Seminar of Latin-American Architecture (SAL), which had place in Santiago, Chile, in 1991. Our goal is to demonstrate, by studying the circumstances that allowed the realization of SAL $\mathrm{V}$, the existence of hybridization between the debate about a possible Latin American identity and the revision of the Modern Movement by applying the type-morphology vocabulary, between mid-1980s and early 1990s. Dissonant with what was usually written and published about the debate that took place in those seminars between 1985 and 1995, the V SAL - whose theme was "Our Public Space: Morphological proposal" - has not discussed the "appropriated modernity" neither "the interaction between the spirit of the time and spirit of the place". The thesis relies on three complementary hypotheses. The first one is that the V SAL was not a break, nor even a gap in the history of the Seminars of Latin-American Architecture: it was the assumption and the summit of a public debate about the Latin-American city and its morphology that was underlying since the first seminar and was largely omitted by critics. The second hypothesis is that the realization of the V SAL cannot be explained only by the history of the SAL itself: on the contrary, this event is part of a series of cultural translations of the type-morphological debate that used to seek Latin-American bonds in order to ensure its legitimacy - in which part of V SAL's organizers had actively contributed. The third and final hypothesis is that these meetings and cultural translations were not innocuous: they allowed the construction of hybrid concepts, as well as new meanings in common representations about the urban form of the "Latin American city" and about how should be interventions in it, whose traces are apparent in the debates in SAL. Two axes of analysis organize the set of methods employed in the structure of the thesis: one inserts the V SAL within the path of seminars Latin American Architecture; the other searches, from this reference, to deconstruct professional networks and translations cultural that enable understanding the event of Santiago de Chile. 



\section{Lista de Ilustrações}

Figura 1: Fotografia dos participantes do Encontro de Caburga, em abril de 1984. Fonte: ARS, n.5, 1984.

Figura 2: Fotografia da montagem dos painéis da mostra "Arquitetura Brasileira Atual", realizada em agosto de 1983 no CAYC, em Buenos Aires. Fonte: Revista Projeto, n.54, ago. 1983.

Figura 3: Material de divulgação da mostra “Arquitetura em Chile" realizada no CAYC, em 1984. Fonte: Acervo pessoal de Pedro Murtinho.

Figura 4: Participantes da exposição "Arquitectura en Chile", realizada no Cayc entre julho e agosto de 1984. Fonte: Acervo pessoal de Pedro Murtinho.

Figura 5: Fotografia da IV Bienal de Arquitetura do Chile, mostra realizada em agosto de 1983. Fonte: Acervo pessoal de Pedro Murtinho.

Figura 6: Humberto Eliash, Rogelio Salmona e Pedro Murtinho em Santiago do Chile, em 1983, por ocasião da realização da IV Bienal. Fonte: Acervo pessoal de Pedro Murtinho

Figura 7: Divulgação do primeiro SAL, realizado entre 20 a 24 de maio na Faculdade de Arquitetura e Urbanismo da Universidad de Buenos Aires, na e dição da revista Summa, número 212, de maio de 1985. Fonte: Summa, n. 212, mai. 1985.

Figura 8: Cartaz do I SAL. Fonte: Acervo pessoal de Enrique Browne. .78

Figura 9: Assis Reis, Joaquim Guedes e Severiano Porto na plateia do I SAL. Fonte: Summa, n. 217, set. 1985

Figura 10: Fotografia da mesa redonda do I SAL, realizada na chácara de Lala Méndez, em maio de 1985. Fonte: Summa, n. 214, jul. 1985.

Figura 11: Oscar Tenreiro, Ramón Gutiérrez, Cristián Boza e Pedro Belaúnde em conversa informal durante o I SAL. Fonte: Summa, n. 217, set. 1985.

Figura 12: Segundo Encontro de Revistas, realizado em 1986, durante a V Bienal de Arquitetura de Quito. Ao fundo da esquerda para direita: Sergio Trujillo, Alex Moreno, Mauricio RiveroBorrel, Cristián Boza, Hernán Cordero, Paul Aguiar, Rolando Moya. De costas: Jaime Márquez e José Manuel López. Fonte: ARS, n. 7, nov. 1986.

Figura 13: Palestra de Severiano Porto no II SAL, em 1986. Fonte: Revista Projeto, n. 96, jan. 1987.

Figura 14: Participantes das mesas redondas do II SAL, realizadas na chácara de Lala Méndez, em dezembro de 1986. Fonte: GUTIÉRREZ, R.; MÉNDEZ, P. (org). Seminario de Arquitetura Latinoamericana (SAL). Haciendo el Camino al andar 1985-2011. Buenos Aires: CEDODAL, 2011.

Figura 15: Exposição de Edward Rojas em mesa redonda do II SAL. Fonte: Revista Projeto, n.96, jan. 1987.

Figura 16: Mesa redonda de críticos no II SAL. Da esquera para a direita: Willian Niño, Marina Waisman, Ramón Gutiérrez, Silvia Arango e Ruth Verde Zein. Fonte: Revista Projeto, n.96, jan. 1987.

Figura 17: Mesa redonda do II SAL. Em torno da mesa, da esquerda para direitra: Marina Waisman, Ramón Gutiérrez, Silvia Arango e Ruth Verde Zein. Fonte: Summa, n.236, abr. 1987. .91

Figura 18: Capa dos Anais do III SAL, realizado em Manizales, em 1987. Fonte: Fotografia da autora. 
Figura 19: Capa dos Anais do IV SAL, realizado em Tlaxcala, em 1989. Fonte: Fotografia da autora.

Figura 20: Cartaz do III SAL, realizado em Manizales, em 1987. Fonte: Acervo pessoal de Enrique Browne.

Figura 21: Inauguração do III SAL: Silvia Arango, Humberto Eliash, Jorge Moscato, Enrique Browne e Alberto Saldarriaga. Fonte: GUTIÉRREZ, R.; MÉNDEZ, P. (org). Seminario de Arquitetura Latinoamericana (SAL). Haciendo el Camino al andar 1985-2011. Buenos Aires: CEDODAL, 2011.

Figura 22: Ruth Verde Zein, Carlos Eduardo Comas e Humberto Eliash em conversa informal durante o III SAL. Fonte: Acervo pessoal de Humberto Eliash. 100

Figura 23: Cartaz do IV SAL, realizado em Tlaxcala, em 1989. Fonte: Acervo pessoal de Enrique Browne. 102

Figura 24: IV SAL, realizado em Tlaxcala, em 1989. Fonte: Acervo pessoal de Humberto Eliash. 103 Figura 25: Cristián Boza, Eduardo San Martín, Cristián Fernández Cox, Alberto Petrina, Humberto Eliash e Carlos Eduardo Comas no IV SAL. Fonte: Acervo pessoal de Humberto Eliash................127

Figura 26: Capa dos Anais do V SAL. Fonte: Fotografia da autora...........................................136

Figura 27: Fotografia dos integrantes do grupo Cedla em 1978. Fonte: ARS, n.1, jul. 1978 ........148

Figura 28: John Muller e Sue Rogers em evento na sede do CEDLA. Fonte: Acervo pessoal de Pedro Murtinho. 150

Figura 29: Peter Eisenman na sede do CEDLA em 1979 - ocasião em que foi ao Chile a convite da II Bienal. Fonte: acervo pessoal de Pedro Murtinho 150

Figura 30: Capa do livro "Inventario de una Arquitectura Anónima” de Boza e Duval, 1982. Fonte: fotografia da autora. 152

Figura 31: Páginas destinadas à descrição do tecido urbano do setor Concha y Toro, em Santiago Poniente. Fonte: BOZA, C; DUVAL, H., op. cit, 1982.

Figura 32: Capa da publicação referenta aos trabalhos desenvolvidos no atelier de projeto ministrado por Murtinho e Eliash na Universidad Católica em 1981. Fonte: Fotografia da autora.

154

Figura 33: Capa da revisa ARS de julho de 1984, destinada à divulgação das apresentações e debates do Encontro de Caburga. Fonte: fotografia da autora. ...................................................156

Figura 34: Seção de trabalho no evento de Caburga. Fonte: ARS, n.5, jul. 1984. 156

Figura 35: Capa do número 6 da revista ARS, de setembro de 1985, o primeiro número monográfico sobre a arquitetura da periferia. Fonte: Fotografia da autora. 157

Figura 36: Projeto para Santiago Poniente desenvolvido pelo CEDLA, em 1977. Da esquerda para a direita: (a) situação existente no momento da realização da proposta, com destaque para os edifícios mantidos na proposta; (b) estrutura de espaços públicos do projeto, com destaque em preto para os edifícios conservados na proposta; (c) inserção do projeto em seu entorno. Fonte: ARS, n.1, jul. 1978 166

Figura 37: Maquete do projeto para Santiago Poniente desenvolvido pelo CEDLA, em 1977. Fonte: Acervo pessoal de Pedro Murtinho.

Figura 38: Planta do térreo do projeto urbano para Santiago Poniente. Fonte: ARS, n. 1, jul. 1978.

Figura 39: Perpectiva do projeto desenvolvido por Léon Krier para o Concurso de la Villette de 1976. Fonte: BOZA, Cristián; MORENO G., Manuel; DUVAL V., Hernán. Taller Boza-Duval-Moreno: 
nivel ejercitación. Santiago: Pontificia Universidad Católica de Chile, Escuela de Arquitectura, 1980.

Figura 40: Projeto por Léon Krier para o Concurso de la Villette de 1976.Fonte: KRIER (org) Rational Architecture :The Reconstruction of the European city, Bruxelles, A.A.M, 1978.

Figura 41: O espaço típico de uma Cité, croqui do processo de elaboração do projeto para Santiago Poniente elaborado em 1977 pelo CEDLA. Fonte: CEDLA, n.1, ago.1977 . 170

Figura 42: Quarteirão do projeto para Santiago Poniente elaborado em 1977, a borda edificada e a estrutura interna de cités e travessas. Fonte: ARS, n.1, jul. 1978. 170

Figura 43: Croquis que sintetizam a leitura e o conceito da proposta de revisão de normas para Santiago Poniente desenvolvida em 1991. Fonte: MURTINHO, P.; FERNÁNDEZ, C. et al. Proposición de normativa urbana para Santiago Poniente. In: BOZA et al, 1991. 171

Figura 44: Simulação da aplicação das normas vigentes para Santiago Poniente em 1991. Fonte: MURTINHO, P.; FERNÁNDEZ, C. et al. Proposición de normativa urbana para Santiago Poniente. In: BOZA et al, 1991.

Figura 45: Entorno da Praça Brasil após simulação da revisão das normas proposta por Murtinho y Asociados, Cristián Fernández y Asociados e Manuel Fernantes, 1991. Fonte: MURTINHO, P.; FERNÁNDEZ, C. et al. Proposición de normativa urbana para Santiago Poniente. In: BOZA et al, 1991. 173

Figura 46: Ramón Gutiérrez, Lala Méndez Mosquera e Pedro Belaúnde no V SAL. Fonte: GUTIÉRREZ, R.; MÉNDEZ, P. (org). Seminario de Arquitetura Latinoamericana (SAL). Haciendo el Camino al andar 1985-2011. Buenos Aires: CEDODAL, 2011. 179

Figura 47: Alberto Petrina, Manuel Moreno, Pedro Murtinho e Edward Rojas em mesa de apresentação de trabalhos no V SAL. Fonte: GUTIÉRREZ, R.; MÉNDEZ, P. (org). Seminario de Arquitetura Latinoamericana (SAL). Haciendo el Camino al andar 1985-2011. Buenos Aires: CEDODAL, 2011. 184

Figura 48: Sequencia de espaços públicos no setor Guayaquil do centro histórico Medellín, proposta de Ramiro Henao V., apresentada no V SAL. Fonte: Acervo pessoal de Humberto Eliash.

Figura 49: Detalhe de quarteirão que sintetiza a proposta de revisão de normativas em Ciudad Salitre elaborada por Sérgio Trujillo Jaramillo e Juan Manuel Gutierrez Alvarez. BOZA et al. (org). Seminario de Arquitectura Latinoamericana. Nuestro Espacio Urbano: Propuestas Morfológicas. V, 1991. Santiago do Chile. Anais... Santiago do Chile: s.n. 1991

Figura 50: Plano Estratégico para o Antigo Porto Madero, concluído em 1990, com a consultoria de Joan Busquets, Jordi Borja e Joan Alemagni e apresentado em 1991 no V SAL. Fonte: LIERNUR, J. F. (org). Puerto Madero Waterfront. Munique: Prestal Verlag, 2007. 191

Figura 51: Projeto para a Gleba SOPAL no Parque dos Maias, Porto Alegre, desenvolvido junto ao PROPAR e apresentado por Comas no V SAL. COMAS, C. E. et al. Uma superquadra periférica de Porto Alegre. Relatório de estudo de desenho urbano. [memorial do projeto apresentado no $\mathrm{V}$ SAL]. Porto Alegre: s.n., 1991

Figura 52: Projeto SINAFA desenvolvido pela Província de Buenos Aires e coordenado por Carlos A Dodero. Fonte: BOZA et al. (org). Seminario de Arquitectura Latinoamericana. Nuestro Espacio Urbano: Propuestas Morfológicas. V, 1991. Santiago do Chile. Anais... Santiago do Chile: s.n. 1991.

Figura 53: Projeto para Mixquic, cidade incorporada à periferia da Cidade do México, elaborado para o V SAL sob a coordenação de González Lobo. Fonte: BOZA et al. (org). Seminario de Arquitectura Latinoamericana. Nuestro Espacio Urbano: Propuestas Morfológicas. V, 1991. Santiago do Chile. Anais... Santiago do Chile: s.n. 1991. 194 
Figura 54: Prancha do projeto desenvolvido por Rafael Rangel Lopez para o V SAL "Rescatar la identidad Barrial de la Ciudad" Fonte: BOZA et al. (org). Seminario de Arquitectura Latinoamericana. Nuestro Espacio Urbano: Propuestas Morfológicas. V, 1991. Santiago do Chile. Anais... Santiago do Chile: s.n. 1991. 195

Figura 55: Marina Waisman, Jorge Zingoni e Sergio Trujillo no VI SAL, em Caracacas, 1993. Fonte: Fonte: GUTIÉRREZ, R.; MÉNDEZ, P. (org). Seminario de Arquitetura Latinoamericana (SAL). Haciendo el Camino al andar 1985-2011. Buenos Aires: CEDODAL, 2011. 208

Figura 56: Capa do número 19 da revista 2c - Construcción de la Ciudad, de novembro de 1981, em que foi publicado dossiê sobre a colonização do interior da Argentina a partir da colaboração de Ramón Gutiérrez. Através deste número, o editor da revista - Salvador Tarragó - afirmava buscar a aproximação com o público latino-americano. Fonte: fotografia da autora. 224

Figura 57: Tecido urbano do quarteirão de São Bartolomeu em Veneza, em 1950, por Saverio Muratori, em Studi per un' operante storia di Venezia, 1959. Fonte: Panerai et al. Analyse Urbaine. Marseille: Paranthèses, 1999. .226

Figura 58: Estudos dos tipos edilícios encontrados em Bolonha. Fonte: CERVALLATI, P. L. Bolonia : política y metodología de la restauración de centros históricos. Barcelona: GG, 1976

229

Figura 59: Perspectiva de quarteirão no bairro Solferino após restauração. Fonte: CERVALLATI, P. L., op. cit, 1976. 229

Figura 60: Capa da edição número 2 de abril de 1975 da revista 2c Construcción de la Ciudad -, revista catalã vigente entre 1972 e 1985. Fonte: fotografia da autora...... 236

Figura 61: Capa da edição número 5 de outubro de 1975 da revista 2c Construcción de la Ciudad. Fonte: fotografia da autora. .236

Figura 62: Fotografia dos trabalhos sobre Berlim apresentados na exposição de arquitetura organizada por Aldo Rossi junto à XV Trienal de Milão de 1973. Abaixo: análise da história urbana de Barcelona elaborada pelo grupo 2c Fonte: Revista 2C, n.2, 1975, p.15. .240

Figura 63: Análise da história urbana de Barcelona elaborada pelo grupo 2c exposta na mostra de arquitetura organizada por Aldo Rossi junto à XV Trienal de Milão de 1973. Abaixo: Fonte: Revista 2C, n.2, 1975, p.15. 240

Figura 64: Capa do catálogo bilíngüe "Rational Architecture/Architecture Rationnelle", publicado em 1978 pela AAM, referente à exposição homônima realizada em Londres, em 1975. Fonte: Fotografia da autora. 241

Figura 65: Capa do livro "Propos sur la reconstruction de la ville européenne : Déclaration de Bruxelles", organizado por Barey e publicado em 1980 pela AAM. Fonte: Fotografia do autor...242

Figura 66: Publicação da Declaração de Bruxelas no livro "Propos sur la reconstruction de la ville européenne : Déclaration de Bruxelles", referente ao Colóquio "A Reconstrução da Cidade Europeia". Fonte: BAREY, A., op. cit., 1980. .242

Figura 67: Capa da publicação "Proyecto y Ciudad Histórica”, organizada por Tarragó e Beramendi em 1977 e decorrente . I Seminario Internacional de Arquitectura de Compostela realizado em 1976. Fonte: Fotografia do autor

Figura 68: Foto de Léon Krier e Cristián Boza na página da revisa ARS número 1 que introduz o texto de Léon Krier. Fonte: ARS, n.1, jul. 1978. 270

Figura 69: Plantas e elevações do projeto desenvolvido para Pudahuel (Chile) durante o Taller de Verano, coordenado por Moscato e Eliash, em 1985. Fonte: ARS, n.6, set. 1985. 284

Figura 70: Plano Especial de Reforma Interior para o bairro Saint-Josep, desenvolvido por Busquet em 1979 e apresentado na V Bienal de Arquitetura do Chile. Fonte: CA, n.44, jun. 1986 
Figura 71: Ensaio, desenvolvido por Eliash, de classificação de tipos de tecidos da periferia. Fonte: ELIASH, H. La periferia dibujada. In: ARS. Santiago de Chile: CEDLA, n.7, nov. 1986.

Figura 72: Livro de San Martín, publicado em 1992 e desenvolvido a partir da versão preliminar apresentada no IV SAL. Fonte: Fotografia da autora. 292

Figura 73: Catálogo da V Bienal do Chile, de 1985. Fonte: Fotografia da autora. .294

Figura 74: Quadro que ilustrava o artigo "Reivindicación mundial de la crítica" de Marina Waisman em sua publicação na revista CA 36. Fonte: WAISMAN. Reivindicación Mundial de la Crítica. In: CA. Santiago de Chile: Colegio de Arquitectos, n. 36, dez. 1983, p. 30-31. 301

Figura 75: Capa do livro "Centros Historicos: América Latina”, publicado na coleção SomoSur da Escala e organizado por Ramón Gutiérrez em 1990. Fonte: Fotografia da autora. .303 



\section{Sumário}

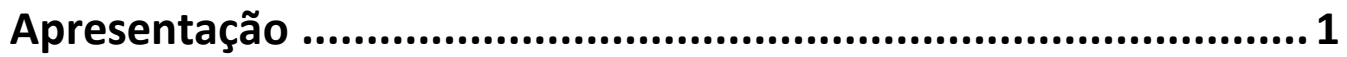

Dois debates ....................................................................................... 5

A hibridação no V SAL............................................................................. 11

Objetivos e Hipóteses............................................................................... 17

Estrutura da tese e eixos de análise ..................................................... 18

1. Recorte historiográfico, métodos e conceitos operacionais $\mathbf{2 1}$

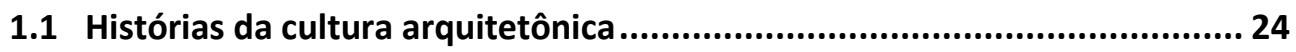

Entre a História Cultural e a Intelectual ........................................................................ 29

A cultura arquitetônica como objeto de estudo ........................................................... 33

1.2 Recortes temporais e Métodos ................................................... 35

1.3 Fontes e corpora ..................................................................... 40

1.4 Conceitos operacionais........................................................... 44

\section{Ecos e escoamentos: a cidade latino-americana e sua}

morfologia nos primeiros SAL ..................................................... 51

2.1 Ensaios de um intercâmbio e elementos catalisadores ........................... 56

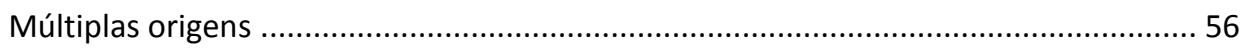

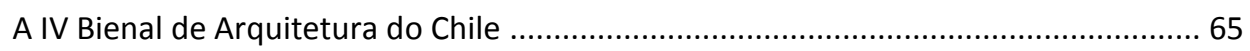

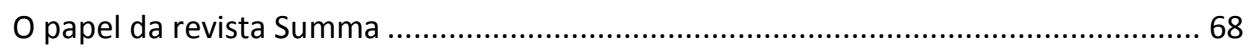

Um tema latente e a oportunidade para desenvolvê-lo........................................... 73

2.2 Uma orquestra polifônica — primeiros seminários................................. 76

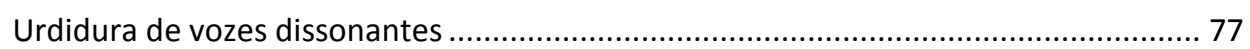

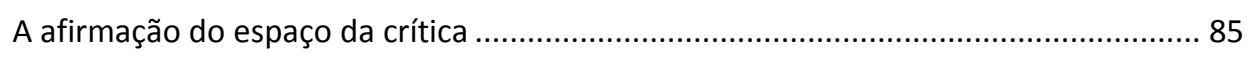

Diáfanas representações da cidade latino-americana em meio ao debate................... 90

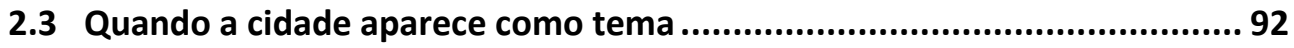

Traços distintivos e precisões sobre o recorte............................................................. 93

O contexto: ampliação do debate e busca por novos paradeiros ............................... 97

A periferia urbana, o centro histórico e o avesso à cidade europeia .......................... 105

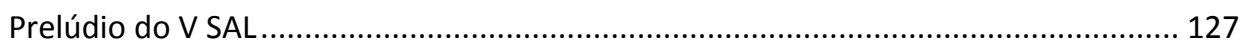

3. Tecendo as partes da cidade latino-americana: o V SAL ... 131

3.1 O preparo da trama........................................................................ 134

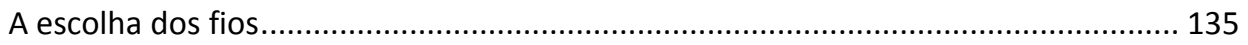

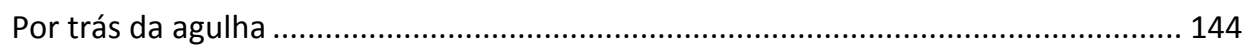

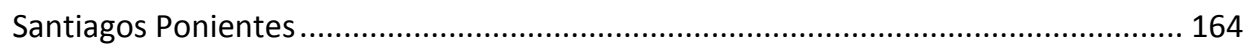

3.20 tecido e sua distensão...................................................... 174

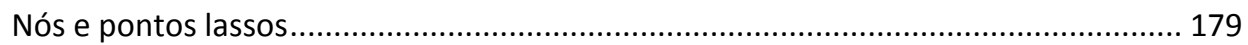

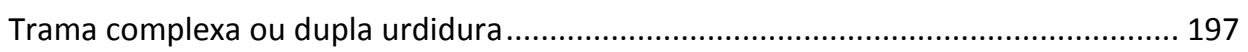

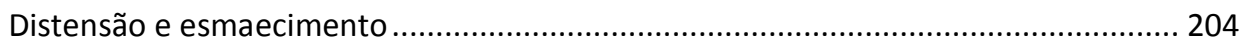


4. Encontros, Traduções culturais e Bricolagens.....................219

4.1 A Cidade Redescoberta: o debate no contexto europeu através dos pontos

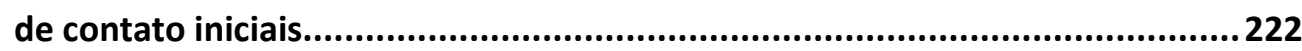

O debate sobre a tipo-morfologia no contexto europeu ............................................. 226

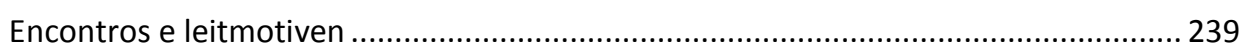

4.2 Entre dois mundos: encontros e traduções culturais iniciais ......................247

Viagens de Rossi à América Latina: entre resistências e redes de leitores ................. 248

Conexões via Londres: as relações entre Léon Krier, Fernando Montes e o CEDLA .... 266

4.3 A construção de bricolagens ou a impossibilidade da cidade europeia ....274

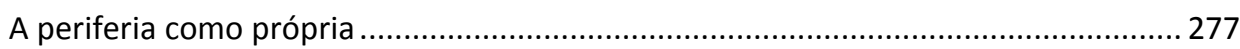

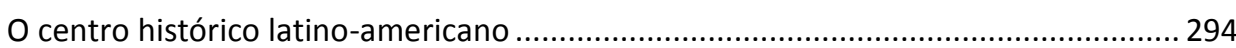

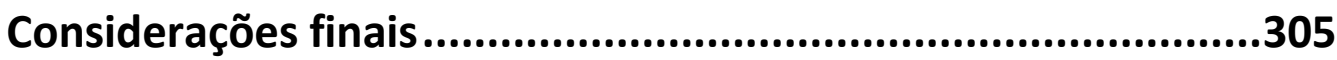

Referências bibliográficas........................................................311

Livros, Artigos, Capítulos de Livros e Teses:...................................................313

Anais, Cadernos de Resumos e Convocatórias e Programas de eventos ...........336

Crônicas e notas de divulgação de eventos de autoria indefinida (de responsabilidade da equipe de redação da revista ou do jornal): .....................337

Entrevistas/Depoimentos:............................................................................338

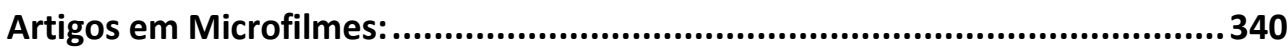

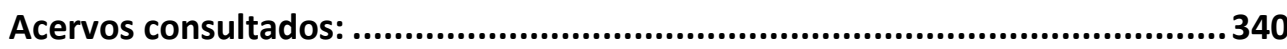

\section{Apêndice A - Eventos e congressos profissionais americanos e} latino-americanos, 1920-2003 ..............................................341

\section{Apêndice B - Registros de apresentações nos SAL entre 1985 e 1995}

e participantes recorrentes ..................................................347

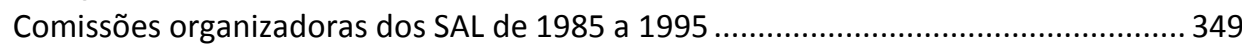

Personagens assíduas nos SAL entre 1985 e 1995, segundo os registros impressos... 350

Total de apresentações e palestras nos SAL por país entre 1985 e 1995, de acordo com

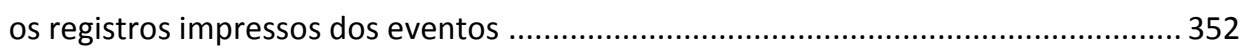

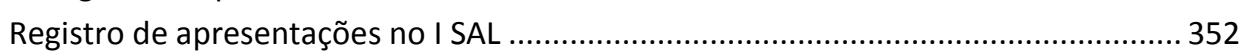

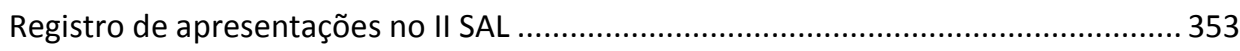

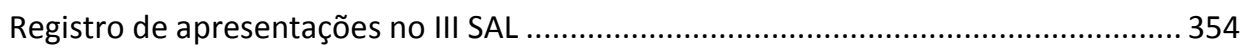

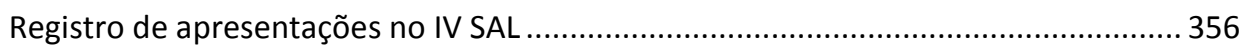

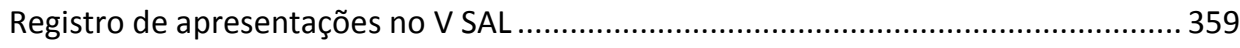

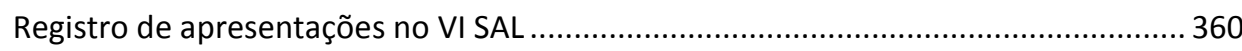

Registros de apresentações no VII SAL .................................................................... 361

Signatários da Convocatória de Buenos Aires ................................................................ 366

Signatários do Acordo de Santiago - I Encontro de Revistas Latinoamericanas de

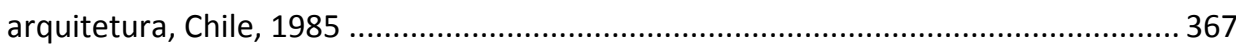

Signatários do Acordo do II Encontro de Revistas Latinoamericanas de arquitetura -

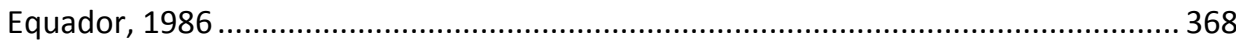


Signatários do Acordo IV Encontro de Revistas Latinoamericanas de arquitetura, México, 1989

\section{Apêndice C - Escrutínio dos artigos e projetos constantes nos Anais do V SAL ................................................................................ 369 \\ Súmula da análise de conteúdo dos textos constantes nos Anais do V SAL................. 371 \\ Intervenções em situações urbanas de cidade antiga com fachada contínua.............. 376 \\ Intervenções em situações urbanas com trama urbana tipo cidade-jardim. ............... 394 \\ Intervenções em situações urbanas com edificação isolada de média altura............. 395 \\ Intervenções em situações urbanas com características de periferia marginal. .......... 396 \\ Intervenções que não correspondem diretamente às situações urbanas da

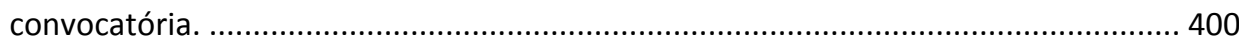

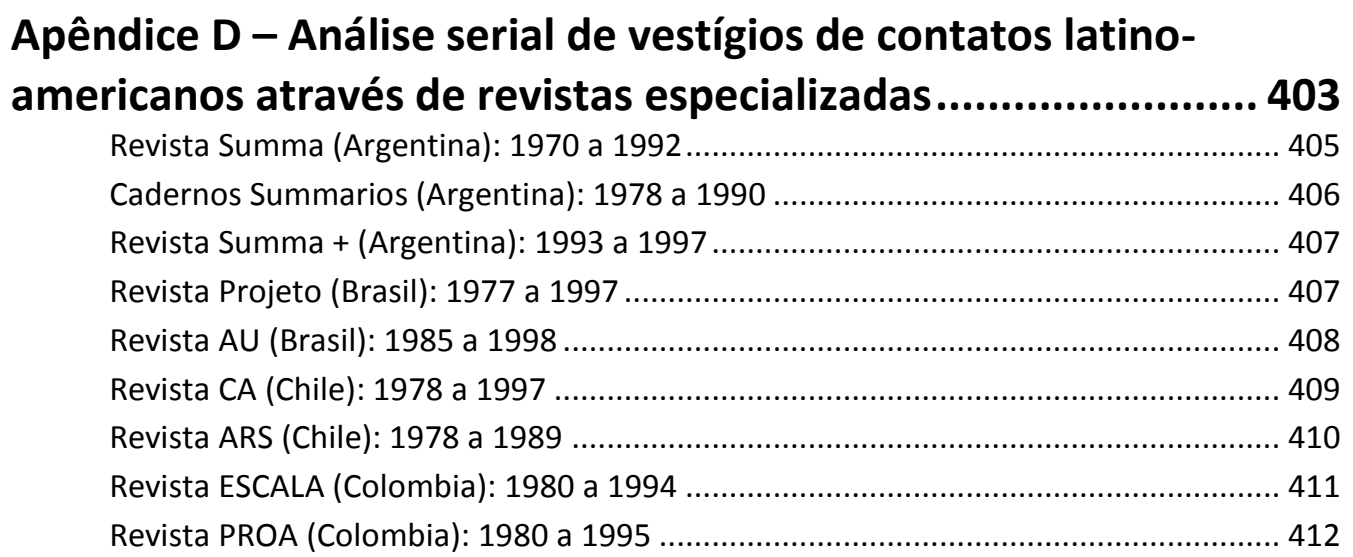




Apresentação 
2 Tessituras híbridas ou o duplo regresso: Encontros latino-americanos e traduções 2 culturais do debate sobre o Retorno à Cidade 
A abordagem da forma como se constroem determinados debates em arquitetura e urbanismo, das matrizes das ideias e dos ideários ${ }^{1}$ que transparecem entre a prática e o discurso que a justifica e/ou fundamenta, não é uma tarefa simples. Se, por um lado, a prática e o discurso arquitetônico-urbanístico pertencem a esferas distintas ou camadas, como prefere Secchi -; por outro, os contornos que as delimitam reconfiguram-se continuamente, ora aproximando-as, ora afastando-as. A possibilidade de correspondência linear e exata parece negada pela origem: o discurso e a prática obedecem a lógicas distintas. O seu oposto, contudo - ou seja, a concepção de uma total autonomia entre ambas as esferas - também se afigura pouco factível, pois, como nos adverte Bernardo Secchi, "uma dimensão opaca de acontecimentos e de processos que interligam vestígios [da prática] e discursos de maneira nem sempre clara e previsível" ${ }^{2}$.

Este caráter dúbio do discurso em arquitetura e urbanismo "ora percebido como subjacente à prática, ora com estrangeiro a esta" ${ }^{3}$ fora o ponto de partida de Adrian Forty, em seu o livro "Words and Buildings". A partir da analogia com os estudos de Roland Barthes sobre a moda, Forty propôs que a arquitetura fosse abordada como um sistema complexo, composto, no caso, por quatro partes: as edificações, as fotografias, os desenhos e o discurso crítico. Apoiando-se nesta definição inicial, o historiador

\footnotetext{
${ }^{1}$ Utilizamos a palavra "ideário", segundo sua definição como "programa de ação, conjunto de aspirações" (HOUAISS, 2000). A opção pelo emprego da palavra "ideário" e não "doutrina", vocábulo por diversas vezes apontado como sinônimo, se faz no sentido que o emprego desta última exige uma coerência entre um conjunto de ideias a serem transmitidas e ensinadas através de revistas, manifestos e escolas próprias, como o afirma Cohen (1998) -, fato que não se percebe no objeto de estudo desta pesquisa.

${ }^{2}$ SECCHI, B. Primeira Lição de Urbanismo. São Paulo: Perspectiva, 2006, p.19.

${ }^{3}$ FORTY, A. Words and Building. A vocabulary of Modern Architecture. London: Thames \& Hudson, 2000, p.14.
} 
britânico debruçou-se sobre um dos elementos deste sistema - o discurso -, enfocando um aspecto ainda pouco estudado em arquitetura e urbanismo: "o constante fluxo entre palavras e significados, de significados que perseguem palavras e de palavras que escapam de significados" ${ }^{4}$.

O interesse de Adrian Forty pela construção de debates na história da arquitetura e do urbanismo está, contudo, longe de representar uma iniciativa isolada. Observa-se atualmente um número crescente de investigações sobre a cultura arquitetônica, entendida como "os debates, as indagações, os questionamentos e as hipóteses que estiveram por trás de projetos e ações individuais" e "a articulação de diferentes ideias de como a arquitetura deveria ser praticada, como ela deveria ser" ${ }^{5}$. Esta tem sido objeto de estudo tanto de trabalhos que enfatizam a contribuição de determinados historiadores e críticos para sua constituição - como o fez de Anthony Vidler, a respeito da historiografia da arquitetura moderna ${ }^{6}$ - quanto daqueles que priorizam o enfoque dos aspectos pertinentes às diferentes gerações de profissionais como o Higgott ${ }^{7}$.

A presente pesquisa busca, assim como as investigações supracitadas, compreender o processo de constituição de debates na cultura arquitetônicourbanística $^{8}$. Atenta-se, particularmente, para o aspecto da migração e adaptação de determinadas discussões de seus contextos originais para outros e, sobretudo, para o processo de fusão e de agregação de novos significados que ocorre neste deslocamento - como afirma Adrian Forty, "através da tradução as palavras ganham tanto quanto perdem" ${ }^{\prime \prime}$. Logo, a fim de examinar esta questão, tem-se por objeto de estudo a hibridação - que se observa em países latino-americanos, entre meados dos anos 1980 e início de 1990 -, entre debates que são correntemente tratados como distintos pela

\footnotetext{
4 Ibidem.

5 HIGGOTT, Andrew. Mediating Modernism. Architectural cultures in Britain. Nova York: Routledge. 2007, p.5.

${ }^{6}$ Referimo-nos aqui ao conjunto de ensaios sobre o trabalho de quatro historiadores - Emil Kaufmann, Colin Rowe, Reyner Banham e Manfredo Tafuri - publicado sob o título de "Histories of the immediate Present. Inventing Architectural Modernism", publicado pela MIT Press, em 2008.

${ }^{7}$ HIGGOTT, op. cit., 2007.

${ }^{8}$ Ao longo do texto empregaremos a expressão "cultura arquitetônica" para nos referimos, de modo simplificado, àquela relativa à arquitetura e ao urbanismo praticados por arquitetos.

${ }^{9}$ FORTY, A. op cit., 2000, p.16
} 
historiografia: as questões relativas à identidade, ao lugar e à região, de um lado, e, de outro, aquela relativa à tipo-morfologia ${ }^{10}$.

\section{Dois debates}

Inseridas no âmbito da revisão do Movimento Moderno, estas pautas de discussão possuem, no cenário europeu e no norte-americano, personagens e embasamentos teóricos distintos. De modo geral, nas revisões historiográficas existentes, a diferenciação entre ambas parece corresponder, também, a uma disjunção temporal - e, até mesmo, geocultural. Esta é, por exemplo, a interpretação defendida por Nan Ellin que, em sua análise sobre as construções teóricas do urbanismo de revisão do Movimento Moderno, associa o debate sobre a tipo-morfologia ao continente europeu - ao surgimento da Tendenza e à afirmação do neorracionalismo na década de 1970 -, enquanto vincula a discussão sobre lugar e identidade ao debate do Regionalismo Crítico que enquadra no eixo anglo-americano no início da década seguinte $^{11}$. Asserções semelhantes - sem, no entanto, manifestar a ênfase em fronteiras linguísticas que estruturam o texto de Ellin - são recorrentes em diversas revisões destes debates: de curtos ensaios a livros que se debruçam sobre as discussões teóricas do período, passando por antologias.

Neste contexto encontram-se, por exemplo, os ensaios de Montaner em "La Modernidad Superada" que tratam destes dois debates ${ }^{12}$. De forma sintética, o autor catalão define o debate arquitetônico em torno da ideia de lugar como aquele "relacionado com o processo fenomenológico da experiência do mundo por parte do corpo humano" ${ }^{13}$. Neste sentido, sua manifestação arquitetônica na grande escala se traduz "como genius loci, como capacidade de fazer aflorar as preexistências

${ }^{10}$ Empregamos a expressão condensada "tipo-morfologia" - cunhada pelos franceses, cf. COHEN, 1998 - para nos referirmos à relação entre os tipos edilícios e a morfologia urbana; ou à empreitada, como definem Panerai e Mangin, que se torna patente ao final dos anos setenta, de "pensar a cidade a partir do edifício (...) [e] o urbanismo sob os aspectos morfológicos" - cf. PANERAI; MANGIN. Projet Urbain. Paris: Ed. Parenthèses, 2005, p.13.

${ }^{11}$ ELLIN, Nan. Postmodern Urbanism. New York: Princeton Architectural Press, 1996.

${ }^{12}$ Referimo-nos aos capítulos "Espacio y antiespacio, lugar y no lugar en la arquitetura moderna" e "Tipo y estrutura. Eclosión del concepto de tipología", ambos publicados em "La modernidad superada. Arquitectura, arte y pensamiento Del siglo XX" em 1997.

${ }^{13}$ MONTANER, Josep María. La modernidad superada. Arquitectura, arte y pensamiento Del siglo XX. Barcelona: Editorial Gustavo Gili, 1997, p.38 
ambientais, como objetos reunidos no lugar"14 ${ }^{\prime 1}$. Páginas adiante, em outro ensaio deste mesmo livro, Montaner define o interesse pela relação entre tipos edilícios e a morfologia urbana a partir de seu distanciamento do referencial da Fenomenologia, e, sobretudo, de oposição ao Regionalismo:

Recorrer ao conceito de tipologia significa na atualidade evitar todo regionalismo e defender soluções morfológicas de caráter universal; [...] significa situar-se junto aos antídotos do empirismo. Nisto, por tanto, Aldo Rossi, Giorgio Grassi, Carlo Aymonino, Luciano Semerani, Guido Canella e outros autores superam a influência neoempirista e fenomenológica presente em seu mestre Nathan Rogers e tendem a um tipo de cultura mais acadêmica e estática ${ }^{15}$.

A exceção à interpretação corrente destas pautas de debate se configura através o recente livro "The Story of Post-Modernism" de Charles Jencks ${ }^{16}$ que, ao revisar seu diagrama sobre as origens e evolução do Pós-modernismo - a árvore genealógica proposta pela primeira vez em seu polêmico livro "The Language of PostMordern Architecture" em $1978^{17}$-, afirma o Regionalismo Crítico dos anos 1980 como a confluência entre tradições das décadas de 1960 e 1970 que nomeia como "neovernacular" e "Adhoc Urbanist"18 - na qual insere os arquitetos da chamada Tendenza. Ou seja, pela interpretação de Jencks haveria uma relação de parentesco entre o interesse pelos aspectos tipo-morfológicos e àquele relativo ao binômio lugar e identidade.

A despeito da tentativa de Jencks de aproximar ambos os debates - ainda que não tenha buscado demonstrá-lo ${ }^{19}$-; o fato é que, quando se observam as referências

\footnotetext{
${ }^{14}$ MONTANER, J. M., op cit., 1997, p.38.

${ }^{15}$ MONTANER, J. M., op cit, 1997, p.129-130.

${ }^{16}$ JENCKS, Charles. The Story of Post-Modernism, West Sussex : John Wiley \& Sons Ltd., 2011.

${ }^{17}$ JENCKS, Charles. The Language of Post-Modern Arquitecture. New Haven : Yale University Press, 1978.

${ }^{18}$ Para Jencks o "neo-vernacular" dos anos 1960 e 1970 corresponderia à prática arquitetônica e urbanística de François Spoerry em Port Grimaud, do grupo ARAU de Bruxelas e de Ralf Erskine, entre ourtos. Em "Adhoc Urbanist", Jencks enquadra arquitetos associados à Tendenza, ao neorracionalismo, ao Townscape Mouvement e, até mesmo, John Tunner. Cf. JENCKS, C., op. cit., 2011.

${ }^{19}$ Ao trabalhar com a ideia de correntes - ou de tempestades, metáfora que enuncia na introdução -, Jencks não deixa claro quais são os elos que permitem as passagens e a verificação das confluências que aponta. (Cf. JENCKS, 2011).
} 
destas pautas, verifica-se que estas se apoiaram em matrizes conceituais distintas. 0 primeiro debate retoma o conceito de "tipo" tal qual este fora desenvolvido pela tradição disciplinar de fins do século XVIII e do século XIX ${ }^{20}$ - sobretudo na definição de Quatremère de Quincy ${ }^{21}$ - e o contextualiza na forma urbana através de empréstimos oriundos, entre outros, da geografia urbana (como o conceito de "fato urbano" de Marcel Poëte, por exemplo) e das ciências sociais (o estruturalismo de Levi-Strauss e o emprego do conceito de "memória coletiva" de Maurice Halbwachs) ${ }^{22}$. O interesse pelas relações entre identidade e lugar, por outro lado, apoia-se, inicialmente, na conferência de Heidegger "Habitar, construir, pensar" - proferida em Darmstadt de $1951^{23}$ - e, posteriormente, na relação entre civilização universal e cultura local proposta por Paul Ricoeur em $1961^{24}$ - inserindo-se, através deste referencial, reflexões sobre o conceito de região em termos socioeconômicos e culturais. Em poucas palavras - tal qual Josep Maria Montaner ${ }^{25}$ e Kate Nesbitt ${ }^{26}$ o sublinham -, a retomada da discussão sobre o tipo em arquitetura vem apoiada pelo estruturalismo, enquanto o interesse pela relação lugar e identidade embasa-se na fenomenologia.

Para além de suas bases teóricas, a questão temporal também se afigura como elemento distanciador entre ambos os debates. Tanto Ellin ${ }^{27}$, quanto Mallgrave e

\footnotetext{
${ }^{20}$ Ver a respeito da ideia de tipo entre fins do século XVIII e início do XIX: PEREIRA, Renata Baesso. Arquitetura, imitação e tipo em Quatremère de Quincy. Tese de doutorado. Faculdade de Arquitetura e Urbanismo, Universidade de São Paulo, São Paulo, 2008.

${ }^{21}$ Refere-se à definição de tipo em oposição à de modelo - que deve ser copiado tal qual -, como algo mais ou menos vago, resultado de ampla tradição e cuja imitação aceita mudanças e permite variações formais. Cf. QUATREMÈRE DE QUINCY, A. C. "Type". Encyclopédie Methodique - Architecture. Liège: chez Panckoucke, Tome III, 1825, p. 543-545. Disponível em: <http://catalogue.bnf.fr/ark:/12148/bpt6k85720c >. Acessado em: 02 de outubro de 2011.

${ }^{22}$ Citamos aqui, somente a título de exemplo, algumas das refências de Aldo Rossi em "A Arquitetura da cidade", publicado pela primeira vez em 1966 - cf. ROSSI, A. L’Architecture de la Ville. Trad. Françoise Brun, Gollion: InFolio, 2001.

${ }^{23}$ Cf. HEIDEGGER, M. Habitar, contruir, pensar. Trad. Schuback. 1951. Disponível em: http://www.prourb.fau.ufrj.br/jkos/p2/heidegger_construir,\%20habitar,\%20pensar.pdf. Acesso em: 10/06/2012.

${ }^{24} \mathrm{O}$ texto "Civilization universelle et cultures nationales" foi publicado originalmente em $1961 \mathrm{e}$, posteriormente, foi reproduzido no livro "Histoire et Verité" - cf. RICOEUR, Paul. Civilization universelle et cultures nacionales. In: RICOEUR, Paul. Histoire et Verité. Paris: Seuil, 2001, p.286299.

${ }^{25}$ MONTANER, J. M., op cit, 1997.

${ }^{26}$ NESBITT, Kate (org). Uma nova Agenda para a Arquitetura. Antologia Teórica 1965-1995. São Paulo: Cosac Naify, 2006

${ }^{27}$ ELLIN, N., op.cit., 1996.
} 
Goodman $^{28}$ caracterizam o debate sobre questões relativas à identidade, ao lugar e à região nos anos 1980, momento em que os ensaios de Frampton sobre o "regionalismo crítico" foram publicados ${ }^{29}$, apoiando-se na expressão cunhada por Tzonis e Lefaivre em dois ensaios publicados em $1981^{30}$. Mallgrave e Goodman destacam, no entanto, que o ponto de virada não esteve naqueles ensaios de Tzonis e Lefaivre sobre o regionalismo na arquitetura moderna grega, mas sim no "editorial com o qual ele [Frampton] abriu sua primeira edição de Opposition, em outubro de $1974^{31}$, intitulado On Reading Heidegger"32. Em sua inspiração heideggeriana, Frampton não estava sozinho; acompanhava-o Christian Norberg-Schulz que, anos antes, havia publicado em Londres o livro "Existence, Space and Architecture" (1971) $)^{33}$ e, na sequência, publicaria na revista da Architectural Associtation o artigo "O fenômeno do Lugar" (1976) ${ }^{34}$.

Estas referências à conferência de Heidegger no início dos anos 1970 coincidem com a primeira tradução de "Habitar, construir, pensar" para o inglês - publicada em 1971 - e parecem ratificar a afirmação de Jarzombek de que, após esta publicação, o texto obteve grande sucesso entre o ambiente arquitetônico ${ }^{35}$. Portanto, ao longo década de 1970, a associação entre identidade e lugar se dá apoiada na fenomenologia de Heidegger e, mais especificamente, em sua indagação sobre o significado de "habitar" - vocábulo que, compreendido em sua origem etimológica no antigo altoalemão, revela sua proximidade com o "construir" e o "ser"; ou seja, desvela-se como traço fundamental do "ser-no-mundo" heideggeriano ${ }^{36}$.

${ }^{28}$ MALLGRAVE, H. F.; GOODMAN, D. An Introduction to Architectural Theory. 1968 to the Present. New York: Wiley-Blackwell, 2011.

${ }^{29}$ O primeiro da série de ensaios que Frampton publicou sobre o assunto, intitulado "Prospects for a Critical Regionalism", teve lugar em 1983 na edição número 20 da revista Pespecta: The Yale Architectural Journal - cf. NESBITT, K. (org), op. cit., 2006.

${ }^{30}$ Referimo-nos aos dois ensaios em que Tzonis e Lefaivre analisam a arquitetura grega e propõe a expressão "regionalismo" para se referir a um modernismo regional na Grécia nos anos 1950. Cf. NESBITT, K. (org), op. cit., 2006, e MALLGRAVE, H. F.; GOODMAN, D., op. cit., 2011.

${ }^{31}$ FRAMPTON, K. On Reading Heidegger. In : HAYS, K. M. (org) Oppositions Reader. New York : Princenton Architectural Press, 1998.

32 MALLGRAVE, H. F.; GOODMAN, D., op. cit., 2011, p.99.

${ }^{33}$ NORBERG-SCHULZ, C. Existence, Space and Architecture. Londres : Studio Vista, 1971.

${ }^{34}$ Texto inicialmente publicado em 1976 na Architectural Association Quartely n.4, republicado em NESBITT, K.(org), op. cit.,2006, p.444-456.

35 JARZOMBEK, Mark. The Cunning of Architecture's Reason. Footprint Delf School of Design Journal, Delft : TU Delft - Techne Press, outono 2007, pp. 31-46.

36 Cf. HEIDEGGER, M. Habitar, contruir, pensar. Trad. Schuback. 1951. Disponível em: http://www.prourb.fau.ufrj.br/jkos/p2/heidegger_construir,\%20habitar,\%20pensar.pdf. Acesso 
No início dos anos 1980, entretanto, Frampton amalgamaria seu interesse inicial por Heidegger com suas leituras de Ricoeur e colocaria o "compromisso com o lugar" e a "identidade local" como elementos-chave no que definiu como "Regionalismo Crítico". Em seu novo emprego por Frampton, a identidade desvincula-se, portanto, de sua origem filosófica no conceito de "ser-no-mundo" e passa a ser vista como elemento de resistência à homogeneização da civilização universal na arquitetura e no urbanismo:

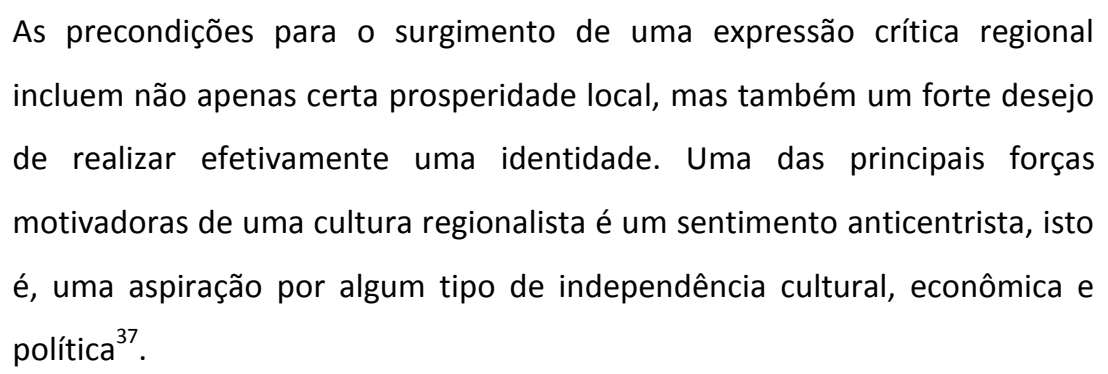

Se, como caracterizam Ellin, Mallgrone e Goodman, o "regionalismo crítico" conheceu uma forte penetração em textos críticos dos anos 1980, fortuna semelhante obteve o estudo das relações entre tipos edilícios e morfologia urbana na década precedente. Sua inserção na cultura arquitetônica europeia dos anos 1970 fora tamanha que, nas palavras de Montaner, findou por banalizar o conceito de tipologia e conduziuIhe à "dissolução [de sua] força crítica" nos anos $1980^{38}$ - momento em que, paradoxalmente, encontra maior ressonância na cultura arquitetônica norteamericana $^{39}$. De forma semelhante, Devillard e Jannière, também, afirmam a importância da recorrência às questões tipo-morfológicas - associadas, frequentemente, à ideia "retorno à cidade" - no debate disciplinar europeu dos anos 1970. Segundo as autoras, o recurso a estas referências caracterizaria um movimento, associado aos desdobramentos das pesquisas italianas a partir dos trabalhos de Saverio Muratori em Veneza, em meados dos anos $1950^{40}$ :

em: 10/06/2012.

${ }^{37}$ FRAMPTON, K. Perspectivas para um regionalismo crítico. In: NESBITT, K. (org). Uma nova Agenda para a Arquitetura. Antologia Teórica 1965-1995. São Paulo: Cosac Naify, 2006, p.504520.

${ }^{38}$ MONTANER, J. M., op cit, 1997, p134-135, passim.

${ }^{39}$ Cf. ELLIN, Nan, op.cit. 1996.

${ }^{40}$ DEVILLARD, V. ; JANNIÈRE,H. Espaces publics, communauté et voisinage, 1945-1955. In: PICONLEFBVRE, V.(org). Les espaces publics modernes, situations et propositions. Paris: Groupe Moniteur, 1997, p.15-32. 
Dentro desta perspectiva, o espaço público designa as figuras urbanas tradicionais (a praça, a rua, etc.). A reabilitação de suas formas específicas, o estudo de sua "sedimentação" tem por objetivo a crítica dos espaços julgados "a-históricos", "sem limites" e "isótropos" do Movimento Moderno ${ }^{41}$.

Dois textos são apontados de forma recorrente pelas revisões como marcos na retomada do interesse pelo conceito de tipo na cultura arquitetônica ${ }^{42}$ : "On the Typology of Architecture" de Argan, publicado na Architectural Design em $1963^{43} \mathrm{e}$ "L'Architettura della Città" de Aldo Rossi, de 1966. O primeiro, apesar de abordar o conceito de tipo a partir de sua proximidade com a iconografia ${ }^{44}$ e de sua participação no processo de criação - sem tratar de relações com o contexto urbano - é usualmente associado à recuperação da definição de Quatremère de Quincy. O segundo, por outro lado, é frequentemente caracterizado como um manifesto original do chamado neorracionalismo e como seu texto de maior influência ${ }^{45}$.

Obviamente que, para além do distanciamento presente nos grandes panoramas, os fatos sempre se mostram mais complexos e estabelecem algumas pontes entre estes debates. Um leitor atento lembraria que há em ambos a noção de contexto ou que Rossi dedica algumas páginas ao conceito de locus no capítulo "A natureza dos fatos urbanos" do livro "Arquitetura da Cidade". Entretanto, o locus de Rossi é definido como uma "relação ao mesmo tempo particular e universal que existe entre uma situação local dada e as construções que aí se encontram"46. Neste sentido, o locus rossiano é um lugar edificado, local de inserção de uma vila ou cidade; longe, portanto, de permitir sua interpretação "como paisagem característica" que é observada em

\footnotetext{
${ }^{41}$ DEVILLARD; JANNIÈRE, loc. cit. 1997, p.18.

${ }^{42}$ Conferir em: MALLGRAVE, H. F.; GOODMAN, D., op. cit., 2011; MONTANER, J. M., op cit, 1997, ELLIN, Nan, op.cit. 1996; MONTANER, Josep Maria. Después Del movimiento moderno: arquitectura de la segunda mitad del siglo XX. Barcelona: Gustavo Gili, 1993.

${ }^{43}$ Republicado no livro "Projeto e Destino". Cf. ARGAN, G. C. Sur le concept de typologie architecturale. In : Projet et Destin. Art, architecture, urbanisme. Châtillon: Editions de la Passion, 1993, p.57-61

44“É fácil estabelecer uma analogia entre tipologia arquitetônica e iconografia. Como a iconografia da arte figurativa, a tipologia não é um fator dominante, mas um fator sempre presente, de maneira mais ou menos manifesta, no processo artístico." ARGAN, G. C., loc. cit, 1993, p.57.

${ }^{45}$ MONTANER, J. M., op cit, 1997; ELLIN, Nan, op.cit. 1996; MONTANER, J. M., op cit, 1993.

${ }^{46}$ ROSSI, op. cit., 2001, p.141.
} 
Frampton e Norberg-Schulz ${ }^{47}$. Ou seja, o contexto para aqueles que se dedicaram às questões tipo-morfológicas era necessariamente urbano. Interessava-os, portanto, a busca e a caracterização de elementos universais e constantes na estrutura urbana lida como "artefato construído no tempo" ${ }^{48}$-, os quais se opõem, por princípio, à ideia de identidade e regionalismo.

\section{A hibridação no V SAL}

Ao contrário do cenário descrito nas páginas antecedentes, no contexto latinoamericano observa-se, entre meados dos anos 1980 e início dos anos 1990, certa recorrência na associação entre traduções culturais do debate sobre a tipo-morfologia ou o "retorno à cidade" ${ }^{49}$ existente - e a busca de uma identidade latino-americana. Dentre os testemunhos desta hibridação, o V Seminário de Arquitetura Latinoamericana (SAL) - realizado sob a temática "Nuestro Espacio Urbano: Propuestas Morfológicas" - afigura-se como aquele evento passível de maior visibilidade. Sua inserção em uma sequência de seminários que teve grande influência na constituição da cultura arquitetônico-urbanística entre meados dos anos 1980 e início dos anos 1990 os SAL - justifica, portanto, a escolha deste evento, em específico, como o recorte a partir do qual nossa problemática geral é abordada.

Não obstante sua importância no cenário latino-americano no período entre o lançamento do debate, durante o primeiro evento realizado em 1985, e a afirmação de seu desgaste na sétima edição, em $1995^{50}$; os Seminários de Arquitetura Latino-

\footnotetext{
${ }^{47}$ MONTANER, J. M., op cit, 1997, p.38.

${ }^{48}$ Cf. Rossi, op. cit, 2001.

${ }^{49}$ Empregamos a expressão "retorno à cidade" pela ideia de duplo regresso que esta implica ao ser associada a encontros latino-americanos; ou seja, a cultura arquitetônico-urbanística volta-se à cidade existente e ao subcontinente.

${ }^{50}$ O reconhecimento do desgaste do debate durante o VII SAL, realizado em 1995 em São Paulo e São Carlos, aparece quase como unânime. O lapso temporal de quatro anos entre este evento e o VIII SAL - realizado em novos moldes em Lima - afigura-se, ainda, como elemento confirmatório da superação das questões iniciais que motivaram a organização dos primeiros seminários. Refletindo sobre as conclusões do evento que o Brasil então sediara, Ruth Verde Zein afirmava, em 1995: "Os debates durante o SAL deixaram bem claro que as posturas 'de resistência', de dez anos atrás, foram sendo ultrapassadas por seus próprios idealizadores com a progressiva consolidação de suas propostas, indicando que, aparentemente, a época das grandes narrativas de latinoamericanidad já passou." - cf. ZEIN, Revistas \& Revistas. In: Projeto. São Paulo: Projeto, no 190, out. 1995, p.90.
} 
americana foram objeto de raras revisões, constituindo-se, ainda hoje, uma lacuna historiográfica ${ }^{51}$. Estas infrequentes - e, em geral, breves - narrativas de conjunto coincidem na representação destes seminários a partir da imagem que fora amplamente fora divulgada nas revistas de arquiteturas da região; descrevendo-os, por conseguinte, como espaços que se dedicaram à reflexão sobre questões pertinentes identidade e ao regionalismo ${ }^{52}$. Segawa, em uma tentativa de resumir em poucas linhas as discussões fomentadas nestes eventos, diferenciou-as em dois momentos: um em que se empregaram e se desenvolveram conceitos de grande fortuna crítica nas décadas que Ihe antecederam - e cuja cunhagem deu-se junto aos debates cepalinos ${ }^{53}$-; outro no qual se ensejou a formulação de expressões e síntese próprias:

[Os SAL] trataram de temas candentes nas décadas de 1960 e 1970, como "centro", "periferia", "dependência" e "marginalização" em um gesto de desapego ao vocabulário esquerdista dominante anteriormente, conceitos que ganharam mais consistência e reprodutibilidade; com o passar da década de 1980 as de 1990 se sintetizam na ideia elaborada pelo chileno

\footnotetext{
${ }^{51}$ Recentemente, editou-se o livro "Seminario de Arquitetura Latinoamericana (SAL). Haciendo el Camino al andar 1985-2011", organizado por Ramón Gutiérrez, que reúne textos curtos sobre aspectos da história destes eventos escritos a partir da memória daqueles que ainda hoje participam dos SAL - cf. GUTIÉRREZ, R.; MÉNDEZ, P. (org). Seminario de Arquitetura Latinoamericana (SAL). Haciendo el Camino al andar 1985-2011. Buenos Aires: CEDODAL, 2011. Devido à própria condição de envolvimento de seus autores, o conjunto de eventos entre $1985 \mathrm{e}$ 2009 são tratados por estes como um contínum, sem diferenciar de maneira significativa o período em que tiveram maior penetração na cultura arquitetônica regional. Antecederam a esta publicação: SEGAWA, Hugo. La condición Latinoamericana. In: Arquitectura Latinoamericana Contemporánea. Gustavo Gili, 2005. p.50-54; GARCÍA MORENO, Beatriz. Región y Lugar. Arquitectura Latinoamericana Contemporánea, Bogotá: Pontificia Universidad Javeriana, 2000; RAMíREZ NIETO, Jorge. El pensamiento a través de los Seminarios de Arquitectura latinoamericana. In: Anais do XI Seminario de Arquitectura Latinoamericana. Oaxtepec (México), 2005; ZEIN, Ruth Verde, FERNANDEZ COX, Cristián. Regional Study Brazil. In: HERRLE, P. e SCHMITZ, S. Constructing Indentity in Contemporany Architecture. Case Studies from the South. Berlim: LIT VERLAG, 2009. Este último não trata especificamente sobre os SAL, mas aborda-o, ao longo do texto, que analisa a construção de identidade na arquitetura brasileira. Além dos textos supracitados, há, obviamente, uma série de outros textos sobre a "história dos SAL" que foram escritos na flor do momento, motivados portanto pelo desejo de construir uma coerência no encadeamento destes que lhes permitisse a afirmação como um movimento.

${ }^{52}$ Veja-se, por exemplo: SEGAWA. loc. cit., 2005; ZEIN; FERNANDEZ COX. loc. cit, 2005; GARCíA MORENO, op. cit, 2000.

${ }^{53}$ À respeiro ver: GORELIK, Adrián. A produção da "cidade latino-americana". In: Tempo Social, São Paulo, v. 17, n. 1, jun 2005. Assim como: LOVE, Joseph. Ideias e Ideologias Econômicas na América Latina, c.1930-c.1990. In: BETHELL (org.) A América Latina após 1930: Ideiais, Cultura e Sociedade. São Paulo: Edusp, 2011, p.161-242.
} 
Cristián Fernández Cox (1935), propagada com a expressão “modernidade apropriada" $^{54}$.

A ideia de "modernidade apropriada" 55 fora, como destaca Segawa, inúmeras vezes repetida em textos críticos e ensaios da época ${ }^{56}$, escritos, em geral, por autores que eram assíduos aos SAL. Soma-se, também, a esta noção, outra que também obteve grande publicidade na mídia especializada, sobretudo nos primeiros seminários: a "relação entre o espírito do tempo e o espírito do lugar", proposta por Browne como caminho para a definição da identidade na arquitetura latino-americana ${ }^{57}$. Ambas foram frequentemente identificadas a um suposto discurso dos Seminários de Arquitetura Latino-americana, cuja afirmação da existência fora corrente em textos produzidos sob a motivação de seu período áureo ${ }^{58}$ e insere-se na tentativa de alguns de seus participantes em institucionalizá-los. Para García Moreno, a repetição destas noções em publicações da época ${ }^{59}$ denotaria o grau de relevância de determinadas questões nos encontros em detrimento de outras: "a maior importância e difusão da reflexão [dos seminários] recaiu sobre a relação entre obra arquitetônica e identidade, carregando consigo algumas modificações em direção às questões de região e lugar" ${ }^{60}$.

Contudo, dissonante com o que fora habitualmente escrito e divulgado sobre estes seminários, o V SAL, realizado em Santiago do Chile, em 1991, não fora pautado em questões referentes à "modernidade apropriada" ou à interação entre "o espírito do tempo e o do lugar". A equipe responsável por sua orquestração, coordenada por

\footnotetext{
${ }^{54}$ SEGAWA, Hugo. loc. cit., 2005, p.51.

55 Noção definida por Cox como uma modernidade adequada, tornada própria e passível de apropriação - cf. FERNANDEZ COX, Modernidad Apropriada, Modernidad Revisada y Modernidad Reecantada. In: Arango, Modernidad y Postmodernidad en América latina. Bogotá: Escala, 1991.

${ }^{56}$ SEGAWA, Hugo. loc. cit., 2005, p.51.

57 Esta noção fora proposta por Browne logo no primeiro SAL e desenvolvida por este em numerosos textos posteriores - ver, por exemplo, BROWNE. Algunas características de la nueva arquitectura latinoamericana. In: Arango, op. cit., 1991.

${ }^{58}$ Trata-se de uma afirmação recorrente nos textos de muitos dos participantes do SAL escritos até meados dos anos 1990. Veja-se, a título de exemplo a seguinte afirmação de Arango: "Não creio que seja exagerado dizer que o IV SAL significou a consolidação de uma 'comunidade latinoamericana' e a fixação de um 'discurso' reconhecível com uma presença sólida que já não podia se desconhecer." ARANGO, Silvia. Diez años de los "SAL" en América latina. In: PROA, Bogotá: Ediciones PROA, 425, jun.1995, p.20-22.

59 O recorte analisado pela pesquisadora colombiana corresponde praticamente aos textos reunidos em Arango, op. cit., 1991.

${ }^{60}$ GARCÍA MORENO, op. cit, 2000, p.52.
} 
Cristián Boza, tratou de estabelecer, em sua convocatória - assinada por Enrique Browne, Cristián Fernández Cox, Pedro Murtinho -, um minucioso enquadramento das palestras e dos projetos a serem apresentados neste evento ${ }^{61}$. Nesta, declarava-se publicamente o objetivo de promover a ampliação da atuação dos SAL; este deveria passar a contemplar, também, a reflexão sobre a deterioração do espaço urbano das cidades latino-americanas e buscar a definição de orientações comuns para reversão deste processo:

Não pode deixar de nos inquietar o fato de, apesar de termos alcançado no plano da obra arquitetônica em si algumas atitudes e critérios comuns, estarmos muito longe de que ocorra o análogo no espaço urbano: não temos posturas claras para a ampla diversidade de situações urbanas concretas tais como: o centro histórico, a periferia marginal, a cidade moderna de grande altura, a cidade moderna de média altura, a cidade jardim ou o "subúrbio norte-americano" de um ou dois pavimentos, etc. ${ }^{62}$.

Apesar de ser apresentada como uma nova pauta de discussão nos SAL, para muitos de seus participantes - inclusive dentre aqueles mais engajados em sua construção - a reflexão sobre a relação entre os tipos edilícios e a forma urbana em cidades latino-americanas não era algo novo ou recente. Marina Waisman, por exemplo, considerada a grande intelectual dos $S A L^{63}$, empreendera esta análise já em seu livro " $L a$ estrutura histórica del entorno", publicado em $1972^{64}$, no qual desenvolvera, a partir de seu interesse pela historiografia, uma classificação tipológica própria. Tais questões continuaram a motivar seu interesse ao longo dos anos 1980. Na condição de diretora da coleção Summarios, a arquiteta argentina organizou uma série de números sobre assuntos relativos à tipo-morfologia e ao racionalismo - sobretudo entre os anos de 1983 e $1985^{65}$. A redução da frequência nestes números específicos sobre o assunto,

\footnotetext{
${ }^{61}$ O V SAL e sua construção serão objetos de uma análise mais detalhada no capítulo 3.

${ }^{62}$ BROWNE, Enrique; FERNANDEZ COX, Cristián; MURTINHO, Pedro. Convocatoria del V Seminario de Arquitectura Latinoamericana. Nuestro Espacio Urbano: Propuestas Morfológicas. In: V Seminario de Arquitectura Latinoamericana. Nuestro Espacio Urbano: Propuestas Morfológicas. Santiago do Chile. 1991.

${ }^{63}$ Cf. ARANGO, Sílvia. Introducción. In: WAISMAN. El Interior de la Historia. Bogotá: Escala, 1990.

${ }^{64}$ WAISMAN, Marina. La estructura histórica del entorno. Buenos Aires: Ediciones Nueva Visión, 1972.

${ }^{65}$ A coleção Summarios inicia-se em novembro de 1976 e passa a contar com a direção de Marina Waisman a partir de novembro de 1979, no número 37. No período entre janeiro de 1983 e março de 1985 há um grande número de edições sobre a tipo-morfologia e o racionalismo, veja-
} 
entre os anos de 1985 e $1990^{66}$, não parece indicar a arrefecimento da questão; Waisman retomou-a continuamente, o que pode ser verificado em seus artigos, bem como no livro "El Interior de la Historia", publicado em $1990^{67}$.

Para além de Waisman, outros habitués do debate dos Seminários de Arquitetura Latino-americana também já haviam inserido questões relativas à tipomorfologia em sua pauta de reflexão muito antes do evento de Santiago do Chile. 0 coordenador do V SAL, por exemplo, Cristián Boza, criara em 1977 - juntamente com Pedro Murtinho, Humberto Eliash e outros arquitetos chilenos -, o Centro de Estudios de la Arquitectura (CEDLA). Este instituto privado de investigações arquitetônicas fora responsável pelo desenvolvimento de ensaios e de pesquisas no âmbito da tipomorfologia, os quais foram publicados em sua própria revista, a ARS. Sílvia Arango, por sua vez, participara, da mesa redonda do evento denominado "Espacio Urbano", organizado pela Universidad de los Andes, em agosto de 1982, para a qual foram convidados os arquitetos Oriol Bohigas, Álvaro Siza, Fernando Montés e Aldo Rossi ${ }^{68}$. No Brasil, Carlos Eduardo Comas desenvolveu no início dos anos 1980, em diferentes ocasiões, críticas à produção habitacional do BNH a partir da análise das relações estabelecidas entre os tipos edilícios e a conformação dos espaços públicos ${ }^{69}$ que foram amplamente difundidas. A atuação de Comas junto ao Propar, nos anos 1980 e início dos anos 1990, fora marcada, também, pela organização de eventos que trataram sobre o assunto $^{70}$.

se, por exemplo: "Lugares de la ciudad", no62, janeiro de 1983; "Volver a vivir - I. La ciudad", no64, abril de 1983; "Aprender arquitectura", no68, agosto de 1983; "Franco Purini", no71, novembro de 1983; "Arquetipos y Modernidad I", no73, janeiro de 1984; "Arquetipos y Modernidad II", no74/57, março de 1984; "Restauración urbana", no 76, abril de 1984; “Renovación urbana", no77, de maio de 1984; “Tipologia II", n86/87, de fevereiro/março de 1985. Antes da direção de Waisman, encontramos, no entanto, dois números que abordam a questão: "Morfologia", no 9/10, de júlio/agosto de 1977; "Racionalismo a tres voces. UngersRossi-Krier", no22, agosto de 1978.

${ }^{66}$ A edição da coleção Summarios encerra-se em 1990, completando 12 anos de publicação.

${ }^{67}$ WAISMAN. El Interior de la Historia. Bogotá: Escala, 1990.

${ }^{68}$ Ver SALDARRIAGA. Alberto. Arquitetura, Espacio Urbano y Latinoamérica. In: Proa. Bogotá: Ed. Proa, n. 305 Abril 1982. Bem como, a transcrição da mesa redonda deste evento em "Espacio Público. Mesa Redonda" - Proa. Bogotá: Ed. Proa, n. 321 ago. 1983.

${ }^{69}$ Cf. COMAS, Carlos Eduardo. O espaço da Arbitrariedade. Considerações sobre o conjunto habitacional e o projeto da cidade brasileira. In: Revista do Servidor Público, vol. III, no 1, jan./mar 1983.

${ }^{70}$ Cf. MARQUES, Sérgio. A Revisão do Movimento Moderno? A arquitetura no Rio Grande do Sul nos anos 80. Porto Alegre: Editora Ritter dos Reis, 2002. 
Engajados em maior ou menor grau na tradução cultural do debate relativo à tipo-morfologia - bem como em sua operacionalização na prática de projeto -, as personagens supracitadas não se encontravam sozinhos nesta empreitada. Simultaneamente, outros profissionais latino-americanos também se interessavam pela forma urbana - apoiando-se muitas vezes em matrizes distintas ${ }^{71}-$, sem, no entanto, se envolverem diretamente no debate sobre uma possível identidade latino-americana ${ }^{72}$.

A problemática desta pesquisa surge da constatação de dois aspectos em específico. A repetição, por um lado, entre personagens que estiveram à frente de ambos os debates - o relativo aos SAL e o outro sobre a tipo-morfologia. Por outro, a divergência entre a especificidade temática do seminário realizado em Santiago do Chile e a recorrência com que o trabalho crítico no interior dos SAL é descrito sob as pautas relativas à identidade e ao regionalismo. Como compreender o fato que se tenha ensejado a organização de um evento no qual não se discutiram as noções que foram tantas vezes associadas à atuação dos SAL? Seria o V SAL uma nova pauta de discussão nestes eventos? Representaria este um hiato na série de eventos realizados entre 1985 e 1995? Ou seria a manifestação de algo que estivera latente e fora ocultado pela crítica? E a questão latino-americana, por sua vez, estaria presente no trabalho supracitado de tradução cultural das questões relativas à tipo-morfologia? Ou estes debates eram compreendidos como completamente distintos pelos profissionais neles engajados, sem a possibilidade do estabelecimento de qualquer diálogo entre ambos? Enfim, haveria alguma interferência entre estes debates que ocorreram simultaneamente e com a repetição de alguns dentre suas personagens que estiveram à sua frente?

\footnotetext{
${ }^{71}$ No Brasil, especificamente, as pesquisas sobre a Sintaxe Espacial obtiveram grande fortuna crítica nos anos 1980 no meio acadêmico e no debate profissional relativo ao "desenho urbano" - ou projeto urbano, expressão que julgamos mais adequada, que não era, porém, empregada na época. Veja-se, a título de exemplo, a frequência com que autores como Hillier e Hanson são citados nos anais dos dois Seminários de Desenho Urbano (SEDUR) realizados nos anos de $1984 \mathrm{e}$ 1986 (cf. Turkienicz, 1984; Turkienicz e Malta, 1986).

${ }^{72}$ Citamos, a título de exemplo, os trabalhos desenvolvidos por Corona Martinez e Fernando Diez em Buenos Aires junto à Universidad de Belgrano, que trataram os aspectos da tipo-morfologia sem jamais envolver-se com o debate da identidade latino-americana. A título de exemplo, ver: DIEZ, F. Buenos Aires y algunas constantes en las transformaciones urbanas. Buenos Aires: Editorial de Belgrano, 1996.
} 


\section{Objetivos e Hipóteses}

O Objetivo geral desta pesquisa é demonstrar, através do estudo da conjuntura que permitiu a realização do V SAL, a existência de uma hibridação - construída entre encontros e traduções culturais - entre os debates relativos a uma possível identidade latino-americana e à revisão do movimento moderno a partir do vocabulário tipomorfologia.

A partir deste objetivo geral, estabelecem-se os seguintes objetivos específicos:

(a) Contribuir para os estudos relativos ao processo de constituição de debates na cultura arquitetônico-urbanística;

(b) Demonstrar que, ao contrário do que fora correntemente afirmado, os Seminários de Arquitetura Latino-americana não tiveram um único discurso representativo; mas, pelo contrário, foram compostos por diversos e numerosos centros de interesses que ocorriam paralelamente;

(c) Identificar, em meio aos registros relativos aos Seminários Latino-americanos, elementos que permitam escrutinar o enraizamento da temática abordada pelo SAL V dos debates de eventos anteriores;

(d) Evidenciar a existência de uma rede de trocas entre profissionais latinoamericanos que legitima traduções individuais do debate sobre a tipomorfologia;

(e) Demonstrar a construção de um debate sobre a morfologia e a forma de intervenção em cidades latino-americanas através traduções culturais, encontros latino-americanos e hibridações.

A partir do exposto, postulam-se três hipóteses complementares, expostas a seguir, que nortearão esta pesquisa:

A primeira hipótese que se pretende demonstrar é que $V$ SAL não foi uma ruptura, nem mesmo uma cesura dentro da história dos Seminários de Arquitetura Latino-americana; mas sim a assunção pública e a apoteose de um debate sobre a cidade latino-americana e sua morfologia que esteve latente desde os primeiros eventos e foi majoritariamente omitido pela crítica. 
A segunda hipótese é que a realização do V SAL não se explica somente pela história própria dos Seminários de Arquitetura Latino-Americana; pelo contrário, este evento se insere uma série de traduções culturais do debate tipo-morfológico que buscaram vínculos latino-americanos como forma de garantir sua legitimação - e para qual parte de seus organizadores contribuiu ativamente.

A terceira e última hipótese é que estes encontros e traduções culturais distintos não foram inócuos, através deles permitiram-se hibridações de conceitos e recombinações de significados nos debates originais e a construção de representações comuns sobre a morfologia de uma "cidade latino-americana" e a forma de se intervir nela, cujos vestígios transparecem nos debates dos SAL.

\section{Estrutura da tese e eixos de análise}

A fim de demonstrar as hipóteses e alcançar os objetivos acima apontados esta pesquisa foi organizada a partir de dois eixos de escrutínio distintos: um que insere o $\mathrm{V}$ SAL dentro da trajetória dos Seminários de Arquitetura Latino-americana; outro que busca, a partir deste referencial, desconstruir as redes de profissionais e as traduções culturais que permitem compreender a realização do evento de Santiago do Chile. Ambos os eixos de análise - através dos SAL e para além dos SAL - serviram para estruturar os capítulos da tese.

O primeiro capítulo "Recorte históriográfio, métodos e conceitos operacionais" destina-se à exposição dos pressupostos e fundamentos teóricos que serviram de fundamento para a pesquisa. Neste sentido, o capítulo aborda questões relativas à historiografia - procurando situar o trabalho histórico empreendido em relação às histórias da arquitetura e aos diferentes domínios da disciplina histórica -, além de expor e explicar os métodos, os recortes temporais, corporas e conceitos operacionais empregados ao longo da tese.

Após esta breve introdução, passa-se a análise da problemática de fato. Logo, o segundo capítulo "Ecos e Escoamentos" aborda o debate sobre a forma das cidades latino-americanas através dos SAL, ou seja, busca demonstrar a primeira hipótese desta tese. Para tanto, parte-se da recuperação dos vestígios de contatos iniciais que podem ser associados ao surgimento dos Seminários de Arquitetura Latino-americana, para, na 
sequência, expor como foram os primeiros quatro seminários e como a problemática da especificidade da cidade latino-americana e sua morfologia transparecia naqueles eventos. Recuperam-se, portanto, os temas e as representações recorrentes com os quais se tratou a questão, ou seja, as construções teóricas manifestas nos debates dos seminários anteriores ao V SAL e que permitiram que este tivesse lugar: a periferia, o centro histórico e a oposição frente à cidade europeia.

O terceiro capítulo, intitulado "Tecendo as partes da cidade latino-america", cumpre dentro da estrutura da tese o papel de ponto de encontro entre os dois eixos de escrutínio. Nele tem-se especificamente análise do V SAL, o qual teve como tema central a morfologia dos espaços urbanos latino-americanos. Ao desvelar os apectos e debates que se encobriam sob a organização deste evento, inicia-se a demonstração de que a temática V SAL, apesar de enraizar-se na história própria dos Seminários de Arquitetura Latino-americana, não tem sua explicação restrita à esta; para além dos debates construídos através destes eventos sequenciais, outros encontros, intercâmbios e discussões se revelam na estrutura proposta para o evento. Salienta-se, neste momento, o papel específico dos organizadores do evento: os objetivos velados e os vínculos subliminares estabelecidos com a história profissional destes arquitetos e com a atuação do grupo ao qual perteceram ao longo dos 1980: o CEDLA. Na sequência, aborda-se a narrativa do evento em si, examina-se como a convocatória foi recebida e a desilusão frente à impossibilidade de concretização do amplo debate que se esperava. Conclui-se o capítulo com um breve percurso através dos dois eventos posteriores, mostrando o esmaecimento do debate sobre a forma da cidade latino-americana somado a distenção da rede de profissionais frente ao novo cenário constituído nos anos 1990.

O último capítulo, "Encontros, Traduções Culturais e Bricolagens", enquadra-se a partir do segundo eixo de análise - ou seja, para além dos SAL - e se destina à demonstração das segunda e terceira hipóteses. Procura-se comprovar como, neste contexto inicial, o estabelecimento de vínculo latino-americanos desempenha um duplo papel: ao mesmo tempo em que legitima as traduções individuais, transforma-as e constrói ressonâncias de ideias entre estas. Aborda-se, inicialmente, como se estabeleceu o debate sobre a tipo-morfologia no continente europeu, sublinhando os contatos que profissionais latino-americanos estabeleceram com este ambiente. $\mathrm{Na}$ sequência, analisam-se os encontros e as traduções culturais iniciais que se estabeleceram na América Latina em torno deste debate, ressalta-se o papel das visitas 
de profissionais europeus, bem como a construção de intercâmbios incipientes. Novamente, procura-se recuperar a história do CEDLA - grupo ao qual parte significativa da comissão organizadora do V SAL pertenceu - através de destas trocas e traduções. A última parte do capítulo analisa as bricolagens de debates e conceitos nas quais se manifesta a hibridação entre o debate sobre a tipo-morfologia e a ideia de identidade latino-americana. Retomam-se, portanto, as representações desveladas em meio aos debates dos SAL no segundo capítulo, procurando mostrar os intercâmbios e os eventos que permitiram sua construção.

As conclusões dos segundo, terceiro e quarto capítulo são retomadas e comparadas em nossas "Considerações finais", nas quais se retomam as hipóteses e suas demonstrações.

Para além do corpo do trabalho, quatro apêndices complementam a estrutura da tese, apresentando dados que, devido ao tamanho ou à especificidade, não teriam lugar dentro do texto. Trata-se da sistematisação de dados complementares, que serviram às demontrações da tese e/ou poderão servir à outros pesquisadores. No "Apêndice A", sintetizam-se cronologicamente dados sobre encontros profissionais latino-americanos, ou mesmo americanos, entre 1920, data do primeiro Congresso Panamericano de Arquitetos, e 2003, quando se retomam os Congressos Interamericanos de Planejamento. O objetivo deste apêndice é demostrar que os Seminários de Arquitetura Latino-americana não são os únicos eventos a reunir os profissionais do sub-continente, nem foram originais ao fazê-lo, mas que, no entanto, diferenciam-se dos demais por não terem contado com um vínculo institucional para sua realização. O "Apêndice B" pretende resgatar os registros dos SAL entre 1985 e 1995, sistematizando alguns dados a partir destes. Optou-se por anexar aqui uma lista com as apresentações e conferências que tiveram lugar nos SAL I, II, III, IV, VI e VII, visto que os anais e registros destes eventos são, em geral, de difícil acesso, dispersos entre bibliotecas do sub-continente e acervos pessoais de arquitetos. No "Apêndice C" encontra-se uma súmula da análise que foi realizada dos artigos e projetos constantes nos registros do V SAL. No último apêndice - o "Apêndice $D$ " -, apresenta-se a análise serial dos vestígios de contatos entre profissionais latino-americanos que transparecem em nove publicações periódicas do sub-continente: a Summa, a Summários e a Summa+, da Argentina; a Projeto e a AU, do Brasil; a CA e a ARS, do Chile; a Escala e a PROA, da Colômbia. 


\section{Recorte historiográfico, métodos e conceitos operacionais}


$22 \mid \begin{aligned} & \text { Tessituras híbridas ou o duplo regresso: Encontros latino-americanos e traduções } \\ & \text { culturais do debate sobre o Retorno à Cidade }\end{aligned}$ 
Em seus grandes panoramas, a escrita da história é correntemente descrita pela clássica distinção entre as etapas que envolvem sua produção: a definição das fontes, a análise dos dados, a interpretação e, por último, a redação ${ }^{1}$. Entretanto, entre uma etapa e outra, revelam-se abismos. Como nos adverte Certeau ${ }^{2}$, os critérios para definição das fontes bem como os métodos para análise e para manipulação dos dados são, por diversas vezes, velados pelas camadas da interpretação que se sobrepõem na redação final e que conectam os fatos históricos de forma quase mágica. A compreensão sobre como se dá a prática historiográfica, passa, portanto, por procurar levantar estes véus que, frequentemente, escondem seu processo de produção.

O trabalho de pesquisa ao qual nos propomos tem por âncora a análise histórica. Ao empreendê-lo, portanto, é necessário o entendimento das questões que a operação historiográfica envolve. Deve-se, sobretudo, enxergar com certa nitidez a partir de qual "lugar social” ${ }^{3}$ se escreve, ou seja, sob quais pressupostos teóricos e com quais vinculações aos trabalhos precedente de outros historiadores. Neste contexto, procuraremos, nas páginas que seguem, compreender quais seriam as implicações de enquadrar o trabalho historiográfico a partir da noção de "cultura arquitetônica", bem como constituir, a partir de sua operacionalização, um arcabouço metodológico e conceitual para análise de nossa problemática de investigação.

Iniciaremos com uma breve situação contextual de escritos sobre a prática da historiografia arquitetônica e, mais especificamente, sobre a constatação das mudanças pelas quais esta disciplina vem passando nas últimas décadas. Na sequência,

\footnotetext{
${ }^{1}$ Ver, à título de exemplo: CONFORTI, Claudia. Instruments et méthodes de l'architecture contemporaine. Un parallèle avec l'histoire de l'architecture de la période moderne. In : Les Cahiers de la recherche architecturale et urbaine. Paris : Éditions du Patrimoine, 2002, p.127132, bem como GROAT, Linda; WANG, David. Architectural Research Methods. New York: John Wiley \& Sons, 2002.

2 CERTEAU, Michel de. A operação historiográfica. In: A escrita da história. Rio de Janeiro : Forense Universitária, 2006.

${ }^{3}$ Referimo-nos aqui ao "lugar social" tal qual definido por Michel Certeau - cf. CERTEAU, M., op. cit., 2006.
} 
discorreremos sobre as definições e os significados ensejados à noção de "cultura arquitetônica" através da diferenciação da historiografia construída através seu emprego daquelas outras que se relacionam a conceitos que thes são vizinhos - e que já possuem certa tradição disciplinar. Procuraremos compreender este novo interesse temático - e os objetos enquadrados a partir deste - através dos diálogos que estabelece com outros domínios da história - a Cultural e a Intelectual. Realizado este percurso sobre os limites semânticos da expressão "cultura arquitetônica" e as implicações disciplinares de seu emprego, definiremos, apoiando-nos neste referencial, os recortes temporais, métodos de análise e tratamento das fontes e os conceitos operacionais utilizados no desenvolvimento da pesquisa.

\subsection{Histórias da cultura arquitetônica}

Em 1970, Renato de Fusco insurgia-se contra a ausência de escritos sobre a prática da historiografia arquitetônica e aventurava-se a tecer um ensaio no qual ensejava a transcrição, para esta disciplina, dos princípios e métodos da história geral. À diferença dos demais historiadores, afirmava De Fusco, "os da história da arquitetura ou da arte - salvo algumas exceções notáveis - sempre deram por conhecidos, implícitos e intuitivos os princípios da historiografia e, até mesmo, a ideia de história" ${ }^{4}$. Passados quarenta anos, em meio a "viradas" de ordens distintas - a cultural e a linguística -, as práticas das historiográficas, em seus diversos domínios, modificaram-se amplamente; a escassez, no entanto, de textos que as abordem no âmbito da história da arquitetura ainda permanece.

De fato, se o ato de refletir sobre "a escrita da história", seus métodos e seus recortes, parece recorrente para historiadores de modo geral, o mesmo não ocorre quando se trata daqueles que se dedicam especificamente à história da arquitetura e do urbanismo. Ao esforço empenhado por autores como De Fusco ${ }^{5}$ e Argan $^{6}$, somam-se outros que procuraram contribuir para o preenchimento desta lacuna. Entre estes, destacam-se, ainda hoje, os ensaios de Marina Waisman - publicados sob os títulos " $L a$

\footnotetext{
${ }^{4}$ DE FUSCO, Renato de. História y Estructura. Teoría de la historiografía arquitectónica. Madri: Alberto Corazón, 1974, p.7.

${ }^{5}$ DE FUSCO, R. op. cit., 1974.

${ }^{6}$ ARGAN, Giulio Carlo. História da arte como história da cidade. São Paulo: Martins Fontes,1993.
} 
estructura histórica del entorno", de 19727 , e "El interior de la historia", de 1990 - que, sob a perspectiva latino-americana, buscavam definir novos parâmetros para a história da arquitetura por meio de seu cotejamento com a história da arte e com a história geral, assim como através da proposição da adaptação de pressupostos historiográficos oriundos da Escola dos Annales.

Precisou-se esperar, no entanto, a virada do século XX para que surgissem publicações que procurassem ampliar este quadro composto por iniciativas individuais através da confrontação direta entre os métodos utilizados por diferentes historiadores da arquitetura e do urbanismo e de sua correlação com as demais vertentes historiográficas. Referimo-nos aqui a duas edições especiais de revistas acadêmicas: o "Journal of the Society of Arquitectural History", em sua edição de setembro de 1999, e o número 9-10 dos "Cahiers de la Recherche Architecturale et Urbaine", de 2002 - cuja organização fora, em parte, motivada pela publicação norte-americana precedente ${ }^{9}$. Nos editoriais de ambas manifesta-se uma inquietação semelhante sobre as mudanças e os novos rumos tomados pela disciplina - verificados a partir dos anos 1970, no cenário norte-americano ${ }^{10}$, e da década de 1980 , no francês ${ }^{11}$. Tais transformações, fomentadas pelo intercâmbio maior com outras disciplinas e pelo emprego de novos métodos historiográficos ${ }^{12}$, encontrariam seus primeiros vestígios ainda no final dos anos 1960. Paulatinamente, a história operativa - tal qual a definira Tafuri ${ }^{13}$ - cederia lugar a uma história interpretativa ${ }^{14}$ :

Desde o final dos anos 1960, a teoria arquitetônica teve que lidar com o colapso do Movimento Moderno, a introdução de políticas ideológicas e

\footnotetext{
${ }^{7}$ WAISMAN, Marina. La estructura histórica del entorno. Buenos Aires: Ediciones Nueva Visión, 1972.

${ }^{8}$ WAISMAN, Marina. El Interior de la Historia. Bogotá: Escala, 1990.

${ }^{9}$ FROMMEL, Sabine. Pourquoi s'intéresser aux méthodes ? In : Les Cahiers de la recherche architecturale et urbaine. Paris : Éditions du Patrimoine, 2002, p.5-11.

${ }^{10}$ BLAU, Eve. Architectural History 1999/2000: A Special Issue of "JSAH" In: Journal of the Society of Architectural Historians, v. 58, n.3, Architectural History, set., 1999, p.278-280.

${ }^{11}$ FROMMEL, S., loc. cit., 2002.

12 “Movimentos como o estruturalismo, o pós-estruturalismo, o pós-modernismo ou o feminismo, e métodos como a micro-história ou o retorno à história cultural nos despertaram para problemáticas inéditas" (FROMMEL, loc. cit.,2002, p.5).

${ }^{13}$ TAFURI, M. Teorias e história da arquitetura. Lisboa: Presença. 1979.

${ }^{14}$ SCHWARZER, Mitchell. History and Theory in architectural periodicals. Assembling Oppositions. In: Journal of the Society of Architectural Historians, v. 58, n.3, Architectural History, set., 1999, p.342-348.
} 
identitárias e a explosiva assimilação de ideias filosóficas continentais. Durante os mesmos anos, a história da arquitetura teve que abandonar sua crença na causalidade, objetividade e teleologia, e aceder à retórica, à interpretação e à narrativa de finitude aberta. ${ }^{15}$

Ora, se, como afirmava Lucien Febvre, a "história é filha de seu tempo" ${ }^{16}$, não seria de se estranhar que a multiplicação de teorias arquitetônicas, como aponta Schawrzer, viesse obter desdobramentos sobre a historiografia colocando em desuso as ambições teleológicas e totalizadoras. Neste contexto, assiste-se, atualmente, a um significativo interesse por textos de arquitetura e urbanismo - sejam eles considerados manifestos, teorias ou críticas -, o qual pode ser constatado tanto através do volume crescente de antologias que são publicadas $^{17}$, assim como pela afirmação da cultura arquitetônica e urbanística como objeto de estudo por parte da historiografia recente.

Visto que o objeto de nossa pesquisa aborda o V SAL como local em que se manifestam debates constituídos na cultura arquitetônica latino-americana, entre os anos 1980 e início dos anos 1990; é preciso compreendê-lo, também, dentro desta noção. Logo, antes de enveredarmo-nos pela narrativa desta conjuntura, devemos desvelar as implicações de se enquadrar a história da arquitetura a partir daquela expressão. A transformação de textos - que, historicamente, foram utilizados como fontes ou como apoio para interpretação de obras arquitetônicas e/ou urbanísticas - em foco temático passível de ser interpretado com relativa autonomia pela história da arquitetura estaria associada a uma nova prática historiográfica? Para responder tal questionamento, devemos compreender melhor as acepções sob as quais a supracitada expressão foi empregada.

Malgrado a noção de "cultura arquitetônica" ser recorrente em parte historiografia recente, sobretudo na de origem anglófona, prescinde-se, em geral, da indicação de seu sentido. Se seu emprego atual motiva novos recortes historiográficos, a utilização desta noção no âmbito da arquitetura e do urbanismo, no entanto, possui

\footnotetext{
${ }^{15}$ SCHWARZER, M. loc. cit. 1999, p.342.

${ }^{16}$ LEBVRE, apud SALGUEIRO, 2001, p.13.

17 Veja-se, a título de exemplo: NESBITT, Kate (org). Uma nova Agenda para a Arquitetura. Antologia Teórica 1965-1995. São Paulo: Cosac Naify, 2006; HAYS, Michael (org). Architecture Theory since 1968. New York: MIT Press, 2000; OCKMAN, Joan (org.) Architecture Culture 19431968. A Documentary Anthology. New York: Rizzoli, 2007; JENCKS, Charles; KROPF, Karl. Theories and Manifestos of Contemporany Architecture. London: Academy Editions, 1999.
} 
longa datação. Segundo Jean-Louis Cohen ${ }^{18}$, Bruno Zevi teria sido o responsável por sua introdução na disciplina, cunhando-a, em 1949, como forma de oposição "ao discurso 'unilateral' de Giedion" ${ }^{19}$. Contudo, independentemente do contexto específico em que esta expressão fora criada - e dos limites semânticos que possuía neste ${ }^{20}$-, para desenvolver nossa problemática é preciso apreender o significado coetâneo de seu uso. Qual a diferença, por exemplo, em se fazer uma história da cultura arquitetônica e outra de sua teoria ou de sua crítica?

Recorramos, portanto, às definições e aos empregos que foram ensejados àquela primeira para, posteriormente, diferenciá-la da história realizada a partir dos outros conceitos elencados. Por sua amplitude e capacidade de abarcar a diversidade dos estudos que foram realizados sob esta expressão, a definição que Andrew Higgott sistematizou em seu livro "Mediating Modernism" nos parece suficientemente adequada. Para este autor, a "cultura arquitetônica" é o conjunto de "debates, indagações, questionamentos e hipóteses que estiveram por trás de projetos e ações individuais" bem como "a articulação de diferentes ideias de como a arquitetura deveria ser praticada, como ela deveria ser" ${ }^{21}$. Trata-se, portanto, da forma de pensar a arquitetura em um determinado período, de um conjunto de representações que são partilhadas por arquitetos e que se manifestam tanto na prática da arquitetura, quanto em seu discurso e em seus meios de veiculação.

De modo geral, os estudos que se apoiam na expressão "cultura arquitetônica" afirmam, frequentemente, a autonomia relativa entre os diversos elementos que a compõem ${ }^{22}$ - obras, projetos, discursos, fotografias e desenhos ${ }^{23}$. Dentre as

\footnotetext{
${ }^{18}$ COHEN, Jean-Louis. Préface. In: JANNIERE, H., Politiques éditoriales et architecture « moderne " : L'émergence de nouvelles revues en France et en Italie (1923-1939). Paris, ed. Arguments, 2002

${ }^{19}$ Jean Louis Cohen refere-se, nesta passagem, ao texto "Della cultura architettonica: mesaggio al Congrès International d'Architecture Moderne", publicado no Metron, em 1949, como reação ao congresso de Bergamo. Cf. COHEN, loc. cit, 2002, p.I.

${ }^{20}$ Eric Mumford dedica algumas páginas às críticas de Zevi ao CIAM tecidas no texto "Della cultura achitettonica" - cf. MUMFORD, Eric. The CIAM discourse on urbanism, 1928-1960. Cambridge: The MIT Press, 2000.

${ }^{21}$ HIGGOTT, A. op. cit. 2007, p.5.

22 Jannière pondera em seu livro sobre as políticas editoriais das revistas "Architecture d'Aujourd'hui", "La Casabella", "Domus" e "Cahiers d'Art" a autonomia da mídia afirmada por Colomina (1996): "a imprensa, a mídia, não [seria] somente um meio para divulgação cultural de algo previamente existente, mas também um contexto de produção com sua própria autonomia". Cf. JANNIERE, H. Politiques éditoriales et architecture « moderne » : L'émergence de
} 
possibilidades geradas à historiografia através de seu emprego, Jannière ${ }^{24}$ destaca a abordagem dos aspectos estratégicos das publicações arquitetônicas e dos espaços de midiatização; estes não são mais percebidos, portanto, "unicamente como vetores de difusão de doutrinas e de imagens, nem como espaços de representação arquitetônica” ${ }^{25}$. Em outras palavras, o uso desta expressão permite a compreensão de que não somente a arquitetura é um fenômeno histórico, mas também o são, como destaca Forty ${ }^{26}$, as suas representações bidimensionais - desenhos e fotografias - e a linguagem que é empregada em sua comunicação. Assim como para aquela primeira, os significados destas últimas também "só podem ser interpretados através das convenções de representação disponíveis em seu período" histórico ${ }^{27}$.

Para que esta breve definição torne-se mais clara, deve-se diferenciar um estudo que se apoie nesta expressão e de outro que pretenda realizar uma história das teorias arquitetônicas, ou de suas críticas, ou mesmo de seus manifestos. Certamente, cada uma destas classes de textos auxilia, individualmente, para a definição de como a arquitetura e o urbanismo "deveriam ser". Todavia, a história da teoria da arquitetura, entendida como um "discurso sobre a prática e a produção da disciplina" cuja natureza é "especulativa, antecipatória e catalizadora" ${ }^{28}$, mostrará os pressupostos e os conceitos propostos para a prática da arquitetura por um ou mais autores inseridos em seu tempo. Já a compreensão histórica da crítica, analisará diacronicamente quais os parâmetros que foram utilizados por críticos no julgamento das obras - e, talvez, indo um pouco mais além, reconhecerá as tradições nas quais estes se inserem ${ }^{29}$. Uma história de manifestos - ou seja, textos de divulgação pública das opiniões de um grupo $^{30}$ - colocará em evidência uma multiplicidade de facções arquitetônicas e, provavelmente, as querelas existentes entre estas. Todas estas classes de textos juntamente com eventos, exposições, escritos e imagens de divulgação de projetos,

nouvelles revues en France et en Italie (1923-1939). Paris, ed. Arguments, 2002.

${ }^{23}$ COLOMINA, B., op. cit, 1996.

${ }^{24}$ JANNIERE, H., op. cit., 2002.

${ }^{25}$ JANNIERE, H., op. cit., 2002, p.1.

${ }^{26}$ FORTY, Adrian. op. cit, 2000.

${ }^{27}$ FORTY, Adrian. op. cit, 2000, 14.

${ }^{28}$ NESBITT, K. (org.), op. cit., 2006, p.15.

${ }^{29}$ MONTANER, Josep Maria. Arquitetura e crítica. Barcelona: Gustavo Gili, 2007.

${ }^{30}$ BURGER, Marcel. Les manifestes: paroles de combat. De Marx à Breton. Lonay: Delachaux et Nieslé, 2002. 
obras de grande fortuna crítica, entre outros - contribuem para constituição da cultura arquitetônica de um determinado período e são, portanto, passíveis de se tornarem objetos de análise da historiografia em questão. Entretanto, nos três outros tipos de história supracitados a recuperação do texto, de sua autoria e sua inserção diacrônica constitui-se no objetivo final da pesquisa. Ou seja, a diferença entre aquelas historiografias e a da "cultura arquitetônica" não está, necessariamente, no tipo de acervo que é analisado, mas sim na forma que este o é.

Para a história da cultura arquitetônica o texto, quando analisado, não é um fim, mas sim um meio. Neste tipo de historiografia os elementos que constituem o corpus de análise - sejam fotografias, diagramações de revistas especializadas, exposições, etc. são compreendidos como parte de uma conjuntura maior, como vestígios ou aspectos intermediários através dos quais se procura desvelar debates e redes profissionais, inferir representações coletivas e construir genealogias de ideias ${ }^{31}$ e de temáticas ${ }^{32}$.

\section{Entre a História Cultural e a Intelectual}

Realizada a análise da conotação da "cultura arquitetônica" a partir do cotejamento de seu emprego com o de outros conceitos na história da arquitetura, devemos agora percorrer um trajeto a partir de outro referencial: aquele relativo à disciplina histórica, de modo geral. Qual seria a natureza desta história apoiada na noção de "cultura arquitetônica"? Qual o diálogo que esta estabeleceria com as demais vertentes historiográficas?

A utilização do vocábulo "cultura" poderia nos levar a aproximá-la da História Cultural - dentro dos contornos que esta disciplina assumiu após sua redescoberta nos anos 1970. Entretanto, o interesse pelo anônimo e popular, pelas práticas, mentalidades, representações e construções culturais em seu sentido amplo, não parece ter lugar na história que enfoca a "cultura arquitetônica". A capacidade semântica deste dispositivo - como o nomeia, Jean-Louis Cohen $^{33}$ - restringe-se, em geral, aos conhecimentos de um campo profissional específico.

\footnotetext{
${ }^{31}$ LUCAN, Jacques. Quatre points de méthode. In : Les Cahiers de la recherche architecturale et urbaine. Paris : Éditions du Patrimoine, 2002, p.179-181.

${ }^{32}$ COHEN, loc. cit, 2002.

${ }^{33}$ COHEN, loc. cit, 2002,
} 
Não obstante a tentativa de predição de Lipstadt de que, após a conferência "Reconceptualizing the Modern: Architectural Culture, 1943-1968" ${ }^{34}$, "passar[ia] a ser impossível ignorar o cruzamento da cultura arquitetônica com vetores culturais externos $^{\prime 35}$; a busca por um enraizamento para além dos próprios limites disciplinares afigura-se como exceção. A corrente distinção entre a "cultura arquitetônica" em si e de suas "essências exóticas", tal como propôs Jean-Louis $\operatorname{Cohen}^{36}$, confirma esta tendência. Dentro deste contexto, Antoine Picon ${ }^{37}$ atenta para o risco da proposição de analogias precipitadas entre a esfera arquitetônica e aquelas relativas a outros domínios culturais:

\begin{abstract}
Aproximações superficiais e falsas analogias são correntemente fundadas sobre uma visão demasiado unitária da cultura de uma época, que esquece que camadas inteiras desta cultura revelam sistemas de temporalidades distintas. (...) Os ritmos das rupturas [em diferentes domínios] não são os mesmos; a coincidência cronológica é, frequentemente, apenas obra do acaso ${ }^{38}$.
\end{abstract}

A partir do exposto pode-se constatar que, se por um lado a enunciação da arquitetura como uma construção cultural - ou como vestígio de "estruturas culturais profundas"39- é recorrente; por outro, esta postura nem sempre repercute numa aproximação aos chamados "estudos culturais". Ao contrário do que Peter Burke ${ }^{40}$ indicara como uma nova tendência da História da Arte - a saber, a História Visual, proposta a partir do diálogo com a História Cultural -, quando se trata da chamada "cultura arquitetônica" as interpretações pautadas na interação com outros campos

\footnotetext{
${ }^{34}$ Conferência realizada na Harvard's Graduate School of Design, em abril de 1998. O título deste evento foi dado em homenagem ao livro "Architecture Culture, 1943-1968: A Documentary Anthology" de Joan Ockman, cuja primeira edição ocorrera cinco anos antes (LIPSTADT, loc. cit., 1999).

${ }^{35}$ LIPSTADT, Hélène. Responding to the Postmodern by Reconceptualizing the Modern: "Architectural Culture, 1943-1968". In: Assemblage, No. 39, Aug., 1999, p. 118.

${ }^{36}$ COHEN apud LIPSTADT, loc. cit., 1999.

${ }^{37}$ PICON, Antoine. Architecture, sciences et techniques. Problematiques et méthodes. In : Les Cahiers de la recherche architecturale et urbaine. Paris : Éditions du Patrimoine, 2002, p.151-160. ${ }^{38}$ PICON, Antoine. loc. cit., 2002, p.158.

39 John Pinto afirma que: "A história da arquitetura testemunha uma verdadeira pertinência para dar conta concretamente de estruturas culturais profundas que moldam a sociedade e desenham o comportamento humano". Cf. PINTO, John. Histoire de l'architecture, une discipline des sciences humaines. Les enjeux du rapprochement entre histoiriens de l'art et architectes. In : Les Cahiers de la recherche architecturale et urbaine. Paris : Éditions du Patrimoine, 2002, p.162.

${ }^{40}$ BURKE, Peter. O que é história cultural? Rio de Janeiro: Zahar, 2008.
} 
profissionais ou mesmo com a cultura popular - salvo algumas relevantes exceções ${ }^{41}$ dá-se em limites estritos, ou são vistas com alguma desconfiança.

Certamente, o uso desta expressão por parte dos historiadores da arquitetura insere-se no contexto descrito por aquele historiador britânico como a tendência, que data dos anos 1970 ou 1980, de utilizar a palavra "cultura" para explicar situações antes compreendidas através de questões sociais e econômicas ${ }^{42}$. Entretanto, não se pode deixar de observar que as definições ensejadas para a "cultura arquitetônica" apoiam-se em vocábulos como "ideias" e "debates" ${ }^{43}$. Ora, sabe-se que as ideias e os sistemas de pensamento caracterizam o objeto de estudo da chamada História Intelectual - ao contrário daquela "cultural", cuja ênfase se dá em noções mais vagas como "mentalidades, suposições e sentimentos" ${ }^{44}$. Seria então a história da "cultura arquitetônica" uma História Intelectual?

Definida por Carlos Altamirano ${ }^{45}$ como a história que privilegia dos "fatos do discurso", a História Intelectual - também chamada de História das Ideias - possui longa tradição historiográfica. A publicação do livro de Arthur O. Lovejoy "The Great Chain of Being", em 1936, e a criação do "Journal of the History of Ideas", em 1940 por aquele mesmo autor, são considerados os "marcos iniciais da criação [desta] disciplina ou subárea de conhecimento" ${ }^{46}$.

A operação historiográfica que a caracterizou até os anos 1970 pautava-se na exposição "do pensamento de cada autor (...) cujas ideias supunha-se possível interpretar com exatidão" ou na tentativa de agrupar pensadores "buscando identificar famílias intelectuais construídas em torno de certas correntes de pensamento" ${ }^{47}$. Encontramos, dentre aquelas histórias que têm por objeto a teoria e a crítica da

${ }^{41}$ A exceção deve ser feita aos trabalhos de Colomina (1996) e de Ksiazek (1993) que, justamente, buscavam compreender, de formas distintas, a interação entre a cultura arquitetônica e a mídia, no primeiro caso, e a cultura de massa, no segundo.

${ }^{42}$ BURKE, P., op. cit., 2008.

${ }^{43}$ Cf. HIGGOTT, A. op. cit. 2007 e OCKMAN, op. cit., 2007

${ }^{44}$ BURKE, P., op. cit., 2008, p.69.

${ }^{45}$ ALTAMIRANO, Carlos. Ideias para um programa de História intelectual. In: Tempo Social, São Paulo, v. 19, n. 1., jun. 2007, p. 9-17.

${ }^{46}$ CARVALHO, José Murilo de. História intelectual no Brasil: a retórica como chave de leitura. In: Topoi, no1, Rio de Janeiro, jan/dez, 2000, p. 123.

${ }^{47}$ CARVALHO, J. M. loc. cit., 2000, p.125 
arquitetura ou da arte - abordadas no item anterior -, diversos exemplos que se inserem nesta longa tradição historiográfica ${ }^{48}$.

A pertinência dos traços que caracterizaram a História das Ideias durante quase quarenta anos, contudo, fora colocada em cheque nas últimas décadas do século XX. $O$ desenvolvimento e a adoção de novas abordagens e práticas por parte Ciências Humanas, de modo geral, fez com que esta história se tornasse alvo de críticas; apontava-se sua ingenuidade analítica. Contestava-se a ausência de "qualquer discussão sobre autoria, recepção, linguagem, texto" bem como a crença de que o autor do texto seria seu principal determinante ${ }^{49}$.

Dois fatores contribuíram para a revisão de suas práticas: um interno à disciplina, outro externo. O primeiro manifestara-se na forma de uma nova orientação da História das Ideias Políticas - oriunda, sobretudo, dos trabalhos dos chamados "contextualistas ingleses" dos anos 1970 - que passou a exigir que as ideias fossem relacionadas aos seus contextos de enunciação, a seus ambientes históricos e culturais $^{50}$. Propôs-se, desta forma, que o objetivo da História Intelectual passasse a ser o estudo um determinado circuito de ideias, inserido em sua temporalidade, em seu contexto e nas redes em cujas quais seus autores estavam envolvidos. $O$ segundo fator foi a chamada "virada linguística" dos anos 1960, que colocou em foco o discurso e a linguagem na filosofia. A afirmação do papel da linguagem na construção da realidade e o desgaste da suposição de existência de um "saber privilegiado", de um "discurso científico unitário sobre o mundo" ${ }^{51}$, reavivaram o interesse por uma História das Ideias. Esta, por sua vez, passou a incorporar a análise das estruturas linguísticas e da dimensão retórica do discurso ${ }^{52}$.

Grosso modo, poderíamos afirmar que a historiografia da "cultura arquitetônica", ao tratar de ideias específicas, aproxima-se mais da História das Ideias,

\footnotetext{
${ }^{48}$ Veja-se, por exemplo, no contexto brasileiro a "História das Ideias Estéticas no Brasil", de José Antônio Tobias, na qual o autor justamente afirmava vincular-se às discussões historiográficas em questão. Cf. TOBIAS, J. A. História das Idéias Estéticas no Brasil. São Paulo: Editorial Grijalbo, 1967.

${ }^{49}$ CARVALHO, J. M. loc. cit., 2000, 124.

${ }^{50}$ BARROS, José d'Assunção. História das Ideias - em torno de um domínio historigráfico. In: Locus. Revista de história. Juiz de Fora, v.13, n.1, 2007, p. 199-209.

${ }^{51}$ ALTAMIRANO, loc. cit., 2007, p. 9.

52 CARVALHO, J. M. loc. cit., 2000.
} 
compreendida dentro dos novos contornos que acabamos de descrever. De fato, a contribuição da "virada linguística" também é perceptível em autores que abordam a "cultura arquitetônica" por meio do enfoque no discurso. A ressonância dos livros como "O Sistema da Moda" de Barthes e "A Arqueologia do Saber" de Foucault, por exemplo, é perceptível em autores como Forty e Higgott ${ }^{53}$. Entretanto, como vimos no item anterior, nem toda historiografia que se apoia na noção de "cultura arquitetônica" enfatiza o aspecto do discurso - e, quando o faz, este é compreendido como parte de um sistema ${ }^{54}$. Por outro lado, devido, entre outros, aos múltiplos objetos em que se baseiam suas análises, a história da "cultura arquitetônica" mantém, também, um diálogo com a História Cultural com graus variáveis de profundidade.

Sem se enquadrar por em uma vertente historiográfica específica, a história da cultura arquitetônica assume uma posição intermediária, oscilando entre uma e outra. Esta situação é, por vezes, admitida pelos historiadores da arquitetura. Antoine Picon, por exemplo, ao defender uma História Intelectual da Arquitetura, enumera objetos de estudo que a aproximam da História Cultural - "a articulação das representações e das práticas" e "maneira pela qual os elementos imateriais da cultura, teorias ou esquemas cognitivos, se inscrevem nos dispositivos materiais" ${ }^{\prime 55}$.

\section{A cultura arquitetônica como objeto de estudo}

$\mathrm{O}$ ato de separar objetos de origens diversas e de redistribuí-los a fim de transformá-los em documentos é, como afirma Certeau ${ }^{56}$, um ato fundador; marca-se, desta forma, a atuação inicial do historiador. Não existe, portanto, neutralidade na definição dos fatos a serem estudados. Ao contrário, sejam estes escolhidos pela possibilidade de totalização teleológica - cada vez menos buscada - ou por sua

\footnotetext{
${ }^{53}$ Barthes é citado como referência em Higgott (2007) e Forty (2000). Ao contrário de Higgott (2007), Forty não cita diretamente Foucault, porém percebe-se a ressonância do filósofo francês e de sua compreensão do discurso como o não-dito em passagens como esta: "A significação de grande parte do vocabulário crítico encontra-se não tanto em algum significado específico que possa ter, mas sobretudo em tudo aquilo que não significa, tudo o que exclui" (FORTY, op. cit. 2000, p.15)

${ }^{54}$ FORTY, Adrian. op. cit, 2000.

${ }^{55}$ PICON, Antoine. loc. cit., 2002, p.160.

${ }^{56}$ CERTEAU, M., op. cit., 2006.
} 


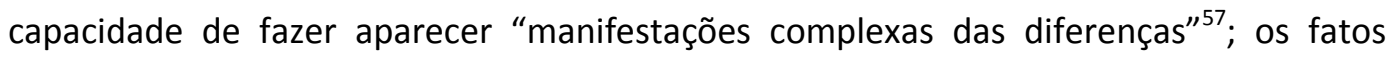
enunciam "escolhas que lhes são anteriores, que não resultam, pois, da observação"

Ao enfocar, a partir do V SAL, o processo de hibridação na cultura arquitetônica latino-americana entre traduções culturais do debate sobre a tipo-morfologia e a busca de uma identidade regional, estabelecemos laços, voluntários ou não, com outras pesquisas que se apoiaram nessa noção. Devemos, portanto, buscar esclarecer quais são as escolhas que antecedem a definição da cultura arquitetônica como objeto de estudo.

De representações e significados associados ao uso de determinadas palavras no discurso arquitetônico ${ }^{59}$, a relações estabelecidas entre a arquitetura e a mídia ${ }^{60}$ ou políticas editoriais de determinadas revistas especializadas ${ }^{61}$; os objetos que são recortados a partir da expressão "cultura arquitetônica" são os mais variados. Se fatos históricos tão distintos são passíveis de afirmação através de um mesmo dispositivo, é preciso avaliar claramente o que estes possuem em comum.

Primeiramente, a prática arquitetônica nunca é o foco direto destas pesquisas. Obras e projetos realizados aparecem como elementos que testemunham as discussões - ou, por vezes, contrapõem-se a estas -, como construções culturais. Segundo Colomina, "isto não significa abandonar o objeto arquitetônico tradicional, a construção" ${ }^{\prime \prime 2}$, porém olhá-lo atentamente sob outro viés.

Construções devem ser entendidas nos mesmos termos que desenhos, fotografias, escritos, filmes e publicidades; não apenas porque estas são as mídias nas quais as encontramos mais frequentemente, mas também pelo fato de as construções serem elas mesmas um mecanismo de representação ${ }^{63}$.

Outro aspecto recorrente é que o fato histórico nunca é um componente isolado, mas sim um conjunto de relações entre as quais debates arquitetônicos se desvelam. Neste, sentido, não se trata da obra de um autor ou de um grupo de

\footnotetext{
${ }^{57}$ CERTEAU, M., op. cit., 2006, p.88.

${ }^{58}$ CERTEAU, M., op. cit., 2006, p.67.

${ }^{59}$ FORTY, Adrian. op. cit, 2000.

${ }^{60}$ COLOMINA, B., op. cit, 1996.

${ }^{61}$ JANNIERE, H., op. cit., 2002.

${ }^{62}$ COLOMINA, B. op. cit, 1996, p.13.

${ }^{63}$ COLOMINA, B. op. cit, 1996, p.13-14.
} 
arquitetos de forma isolada, mas sim como parte dos sistemas de representação que se sobrepõem na arquitetura ${ }^{64}$. Trabalha-se frequentemente - tal qual na problemática de nossa pesquisa - com redes de profissionais, trocas e intercâmbios culturais e com a transformação e/ou construção de debates e de noções através destes ${ }^{65}$.

\subsection{Recortes temporais e Métodos}

Realizado este percurso sobre a historiografia enquadrada a partir da noção de "cultura arquitetônica" é preciso definir quais os tipos de recortes temporais adequados ao estudo de nossa problemática. De modo geral, dentre as novas abordagens historiográficas na arquitetura, observa-se tanto aquelas que priorizam as largas durações, quanto as que optam pelos curtos ciclos.

Entre os defensores da longue durée, encontram-se Sabine Frommel ${ }^{66}$ e John Pinto $^{67}$ que veem nas narrativas que empreendem este tipo de análise um novo fôlego para a história da arquitetura e uma maneira de torná-la interessante a um público mais vasto. Em geral, apoiam-se nestes grandes panoramas - ou big pictures - estudos que abordam construções coletivas de representações, como o americanismo para Cohen $^{68}$, ou processos de acumulação e de inflexão nos significados que se amalgamam em determinadas palavras - tal qual o abordado por Forty ${ }^{69}$.

No outro extremo, estão aqueles que apontam o risco de grandes panoramas recaírem em visões unitárias e frágeis e que propõem uma maior aproximação à microhistória. Os jogos de escala dentro micro-história são, todavia, condição necessária para garantir sua própria inteligibilidade: "a existência [das big pictures] representa [...] uma das condições necessárias para que os estudos mais pontuais apresentem sua

\footnotetext{
${ }^{64}$ COLOMINA, B., op. cit, 1996.

${ }^{65}$ COHEN, Jean-Louis. The italiophiles at Work. In: Hays (org). Architecture theory since 1968. Nova York : MIT Press, 1998.

${ }^{66}$ FROMMEL, S., loc. cit., 2002.

${ }^{67}$ PINTO, John, loc. cit., 2002.

${ }^{68}$ COHEN, J-L. Scènes de la vie future: l'architecture européenne et la tentation de l'Amérique 1893-1960. Paris: Flammarion/Centre Canadien de l'Architecture,1995.

${ }^{69}$ FORTY, Adrian. op. cit, 2000.
} 
significação, até mesmo para confirmar sua validade" ${ }^{70}$. Neste contexto, encontram-se, em geral, análises que se dedicam mais intensamente a curtos ciclos temporais, tal qual a análise das significações pela noção de "modernismo" na Inglaterra no segundo pósguerra empreendidas por Higgott ${ }^{71}$, ou a exposição da construção do olhar de determinados historiadores através das redes das quais participavam e de sua contribuição para a invenção da noção de Arquitetura Moderna, realizada por Vidler ${ }^{72}$.

Ao enfocar a realização do V SAL como recorte a partir do qual os elementos constituintes de nossa problemática podem ser desvelados, aproximamo-nos desta última vertente. Trata-se de um evento pontual cuja manifestação histórica se dá no curto ciclo que se avizinha, portanto, das problemáticas da micro-história. Assim como nesta, enfoca-se estudo de um pequeno objeto como forma de revelar "contradições nos sistemas normativos"; "as lacunas e os espaços deixados em aberto pelas inconsistências" destes sistemas ${ }^{73}$. Neste sentido, priorizam-se, em sua análise, a descrição densa de pequenos recortes temporais. Contudo, fazemos apelo ao longo do texto a jogos de escalas - temporais e contextuais - para que significado destes curtos ciclos e do fragmento estudado se revele.

Se, como afirmava Michel de Certeau ${ }^{74}$ ao escrever sobre a multiplicação dos campos de interesse dos historiadores, a história não permanece inerte face aos novos objetos e métodos que lhe são propostos. Deveríamos, portanto, perguntar-nos neste momento sobre quais seriam as práticas associadas a história cujo foco é o conjunto de ideias e debates. Se olharmos para as disciplinas com as quais a compreensão diacrônica da "cultura arquitetônica" estabelece interfaces, entretanto, perceberemos que - seja na história que, no escrutínio de uma determinada questão, traz em primeiro plano as ideias ou os sistemas de pensamento, seja naquela cuja perspectiva de análise dá-se através da noção de cultura - é recorrente a asserção de que a variedade de métodos atualmente empregados impede sua definição a partir destes ${ }^{75}$. No âmbito da

\footnotetext{
${ }^{70}$ PICON, Antoine. loc. cit., 2002, p.159.

${ }^{71}$ HIGGOTT, A. op. cit. 2007.

72 VIDLER, Antony. Histories of the Immediate Present. Inventing Architectural Modernism. Cambridge: MIT Press, 2008.

73 LEVI, G. Sobre a Micro-história. In : BURKE (org.) A Escrita da História. Novas perspectivas. São Paulo: Ed. UNESP, 1992, p.155.

${ }^{74}$ CERTEAU, M., op. cit., 2006.

${ }^{75}$ Cf. ALTAMIRANO, loc. cit., 2007 e BURKE, P., op. cit., 2008.
} 
historiografia da "cultura arquitetônica", a situação não parece diferir muito; verifica-se uma grande variedade métodos que são empregados em sua análise.

De modo geral, observa-se que ao método de crítica documental que caracterizava a busca de objetividade na dita história tradicional - ou seja, a história política que enfatizava os grandes homens e os grandes acontecimentos - soma-se uma série de outros métodos, alguns oriundos da história, outros de campos disciplinares distintos. Se há alguma característica que possa abarcar, de modo geral, a história da arquitetura e do urbanismo em seus contornos atuais, esta seria, como o destaca Frommel $^{76}$, a busca por uma maior exatidão e rigor nas análises, por uma ampliação do olhar e por um aprofundamento das interpretações ensejadas.

A prática da história anterior à revisão da Escola dos Annales caracterizava-se somente pela realização da crítica externa e interna das fontes impressas. Em outras palavras, analisavam-se criticamente os aspectos externos ao documento - verificação de sua autenticidade, identificação de sua procedência e de possíveis alterações através de cópias - bem como aqueles que the eram considerados internos - avaliação do engajamento ideológico do autor e do grau de conhecimento direto e efetivo que poderia ter dos fatos. Estas práticas, como já afirmamos, continuam a fazer parte do metier do historiador e são estendidas, em parte, aos novos tipos fontes que foram incorporadas à sua prática: as imagens e entrevistas. Sua busca de objetividade, no entanto, não se resume mais à compreensão dos limites das fontes disponíveis. 0 emprego de novas técnicas visa, justamente, preencher a lacuna entre a separação das fontes e a interpretação.

Neste contexto insere-se a chamada "história serial", técnica desenvolvida por historiadores franceses nos anos 1960 para análise de séries cronológicas de documentos $^{77}$. Através do escrutínio sequencial de textos que apresentam certa homogeneidade entre si, procura-se desvelar com maior precisão o aparecimento de elementos que podem servir de base para interpretação. Trata-se de uma técnica que pode ser aplicada tanto a textos, quanto a imagens (representações de projetos e fotografias) e que vem sendo amplamente utilizada pelos historiadores da arquitetura. A análise sequencial de publicações em revistas, por exemplo, já foi incorporada à prática

\footnotetext{
${ }^{76}$ FROMMEL, S., loc. cit., 2002.

${ }^{77}$ BURKE, P., op. cit., 2008.
} 
corrente, sobretudo para aqueles que se dedicam à arquitetura contemporânea ${ }^{78}$. Dentre os diversos exemplos que poderiam ser citados, apontamos aqui o resgate dos debates sobre a noção de "modernismo" realizada por Higgott ${ }^{79}$ através da análise acurada de sequências de edições de revistas - como a Architectural Review nos anos 1950 e a Architectural Design e a Archigram nos anos 1960.

Outro método correntemente empregado no exame de textos é a análise de conteúdo. Trata-se de um conjunto de técnicas para descrição objetiva do conteúdo de mensagens, desenvolvido por faculdades de jornalismo dos Estados Unidos no início do século XX, que conheceu amplo desenvolvimento durante a Segunda Guerra Mundial ${ }^{80}$. Através do exame das referências a um determinado tema, ou conjunto de temas, em um corpus de textos, a análise do conteúdo busca "evidenciar indicadores que permitam inferir sobre uma outra realidade que não a da mensagem" ${ }^{\prime 11}$. Grosso modo, as técnicas de análise do conteúdo dividem-se entre as que são qualitativas - ou seja, as que verificam "a presença ou ausência de uma dada característica de conteúdo" 82 - e as que são quantitativa - através das quais se identifica a frequência com que estas aparecem.

As técnicas quantitativas da análise de conteúdo, de modo geral, não têm sido aplicadas em estudos sobre a história da arquitetura e do urbanismo. Szambien ${ }^{83}$ explica que, apesar de a informação sobre a frequência de determinadas palavras possibilitar argumentos complementares, esta poderiam, também, levar a conclusões equivocadas; a posição da palavra no discurso seria, portanto, mais importante que sua repetição. Ao adaptar as diversas técnicas de análise do conteúdo para as pesquisas em arquitetura e urbanismo, tanto Eleb $^{84}$ quanto Szambien ${ }^{85}$ optam por uma abordagem simplificada, distinguindo apenas a análise longitudinal - que permite observar diacronicamente as inflexões de uma temática - e a transversal - a qual permite a comparação de sua abordagem sincrônica entre diferentes autores. Este tipo de método fora utilizado, por

\footnotetext{
${ }^{78}$ Cf. CONFORTI, Claudia. loc. cit, 2002.

${ }^{79}$ HIGGOTT, A. op. cit. 2007.

${ }^{80}$ BURKE, P., op. cit., 2008

${ }^{81}$ BARDIN, Laurence. Análise de Conteúdo. Lisboa: Edições 70, 2009, p.48

${ }^{82}$ BARDIN, L. op. cit., 2009, p.22

${ }^{83}$ SZAMBIEN, Werner. Symétrie, goût, caractère. Théorie et terminologie de l'architecture à l'âge classique 1550-1800. Paris : Picard, 1986.

${ }^{84}$ ELEB, Monique. Généalogie de l'habitation et histoire sociale. In : Les Cahiers de la recherche architecturale et urbaine. Paris : Éditions du Patrimoine, 2002, p.137-150.

${ }^{85}$ SZAMBIEN, Werner. op. cit. , 1986.
} 
exemplo, por Adrian Forty em "Words and Building", para o qual o livro de Szambien ${ }^{86}$ servira de referência.

Frequentemente confundida com a análise de conteúdo, a análise do discurso motivou raros estudos em arquitetura e urbanismo. Desenvolvido pela linguística nos anos 1960, este método utiliza-se de técnicas de taxonomia semelhantes às da análise de conteúdo. Seu objetivo, no entanto, é reconhecer "as regras de encadeamento das frases, [...] descrever as unidades (as macro unidades que são os enunciados) e a sua distribuição" ${ }^{87}$. Apesar de pouco utilizada em pesquisas da arquitetura e do urbanismo, seu emprego pode revelar formas de estruturação do discurso recorrentes, como nos mostra Choay ${ }^{88}$ em seu estudo sobre as teorias da arquitetura e do urbanismo.

A interpretação dos elementos gráficos apoia-se, de modo geral, na análise comparada. Continua-se, portanto, com a tradição que caracterizou a atuação no seio do Instituto Warburg e cuja vulgarização na arquitetura deu-se, sobretudo, através dos trabalhos de Wittoker e de Rowe ${ }^{89}$. Entretanto, alguns pesquisadores vêm combinando este a outros métodos de análise. Colomina ${ }^{90}$, por exemplo, adaptou o close reading dos estudos literários para o âmbito da arquitetura, ampliando suas possibilidades para uma leitura conjunta das relações entre texto e imagens.

Se textos e imagens são amplamente utilizados na história da cultura arquitetônica, o mesmo não ocorre com as fontes orais. Observa-se ainda certa resistência a este tipo de fonte. A recorrência a entrevistas dá-se, em arquitetura e urbanismo, em ocasiões nas quais se possui poucas informações documentais ou estas são insuficientes. Logo, não é de se estranhar que este método seja majoritariamente empregado na história da arquitetura e do urbanismo contemporâneos. Conforti ${ }^{91}$ alerta para os riscos destes testemunhos que, geralmente, estão engajados nos debates do momento estudado. A historiadora italiana destaca, ainda, a necessidade de sua confrontação a outras fontes. Entretanto, independentemente da preferência, que

\footnotetext{
${ }^{86}$ SZAMBIEN, Werner. op. cit. , 1986.

${ }^{87}$ BARDIN, L. op. cit., 2009, p.46.

${ }^{88}$ CHOAY, Françoise. La règle et le modèle: sur la théorie de l'architecture et del'urbanisme. Paris: Seuil, 1986.

${ }^{89}$ VIDLER, A., op. cit., 2008.

${ }^{90}$ COLOMINA, B., op. cit, 1996.

${ }^{91}$ CONFORTI, Claudia. loc. cit, 2002.
} 
demonstram os historiadores pelas fontes impressas e da tendência a incorporar entrevistas e depoimentos, apenas quando aquelas primeiras falham: "os dados das fontes orais servem para confirmar outras fontes, assim como outras fontes servem para confirmá-los" ${ }^{\prime 92}$. Revelam, portanto, outras facetas da problemática em estudo; permitem sua reavaliação a partir de novos olhares. Os riscos apontados por Conforti ${ }^{93}$ podem ser contornados através de uma leitura objetiva dos dados obtidos através de fontes orais. Pode-se aplicar-Ihes, para tanto, técnicas de análise de conteúdo e/ou do discurso, já abordadas.

Ao longo de nossa pesquisa, empregamos, com graus de profundidade distintos, o conjunto dos métodos supracitados. A história serial - com as devidas críticas interna e externa das fontes - e a análise do conteúdo - longitudinal e transversal -, contudo, constituiram o cerne dos instrumentos utilizados na análise e na interpretação dos dados. Através destes, buscou-se verificar o enraizamento do debate sobre a cidade latino-americana e sua morfologia nos Seminários de Arquitetura Latino-americana, bem como em encontros e traduções culturais que ocorrem paralelamente àqueles. Para a análise do V SAL em específico, utilizou-se o close reading - tal qual utilizado nos estudos literários - para analisar a convocatória do evento e desvelar aspectos subjascentes a esta e a análise comparada para a leitura de projetos. A análise do discurso foi empregada pontualmente, quando se mostrou eficaz para algum tipo de comprovação: como na análise da convocatória ou na comparação entre a sequência argumentativa de textos distintos. De modo geral, as fontes impressas assumiram, ao longo da pesquisa, um caráter dúbio, ora sendo compreendidas como fontes - passíveis de críticas externa e interna -, ora como corpus a ser analisado através de técnicas da análise de conteúdo. Dados obtidos através de fontes orais, por outro lado, foram sempre cotejados entre si e àqueles impressos, a fim de revelar novas possibilidades interpretativas.

\subsection{Fontes e corpora}

O conjunto de fontes e os corpora utilizados em nossa pesquisa distinguem-se para cada um dos eixos de análise. No primeiro eixo - ou seja, aquele que analisa a

\footnotetext{
${ }^{92}$ PRINS, G. História Oral. In : BURGE (org.) A Escrita da História. Novas perspectivas. São Paulo: Ed. UNESP, 1992, p.163-198.

${ }^{93}$ CONFORTI, Claudia. loc. cit, 2002.
} 
problemática através dos SAL - contou-se, com um corpus composto pelos remanescentes impressos dos debates dos SAL entre 1985 e 1995: publicações diversas que relatavam os eventos em revistas especializadas; anais, quando existentes; programações dos seminários; caderno de resumos e outras publicações associadas os eventos. Os dados obtidos através deste corpus foram cotejados aos relatos das fontes orais. Para além da verificação do debate estudado nos sete primeiros seminários, buscou-se também neste eixo recolher dados diversos que pudessem auxiliar na compreensão do surgimento destes eventos, bem como da afirmação de seu desgaste em 1995. Para tanto, lançou-se mão de dados obtidos através da análise serial de revistas especializadas da região - ver Apêndice $D$-, fontes secundárias diversas e das entrevistas. No eixo que analisa a problemática para além dos SAL, que se destina à demonstração das segunda e terceira hipóteses, abordou-se uma gama mais ampla de publicações. Livros e revistas publicados por arquitetos envolvidos com os debates constituíram o cerne de nosso corpus que foi cotejado a fontes secundárias que nos permitiram compreender as matizações do debate sobre a tipo-morfologia em distintos contextos e aos dados obtidos através da análise sequencial de revistas especializadas da região, junto às quais se procurou vestígios impressos de outros encontros latinoamericanos sobre a temática. Neste segundo eixo, as entrevistas serviram-nos tanto para confirmar algumas hipóteses iniciais construídas na análise do corpus impresso quanto para revelar novas pistas a partir das quais buscou-se informações impressas que pudessem confirmar ou não sua veracidade.

De modo geral, buscou-se revelar, através do recurso às entrevistas, outras facetas da problemática em estudo; reavaliar os eventos e intercâmbios a partir do olhar de suas personagens. Ao todo foram realizadas 16 entrevistas semiestruturadas com profissionais argentinos, brasileiros, chilenos e colombianos que participaram da construção destes debates. Entre os entrevistados, distinguem-se três grupos: aqueles que, além de terem se envolvido com os SAL, organizaram o V SAL; aqueles que tiveram uma participação importante nestes seminários, mas que, porém, não participaram diretamente da organização do evento de Santiago do Chile; e, por último, profissionais latino-americanos que, apesar de nunca terem se envolvido com os SAL, estabeleceram intercâmbios que foram muito importantes com grupo CEDLA, do qual participou parte significativa dos arquitetos que organizaram o quinto seminário. As entrevistas, a grosso modo, buscaram compreender o grau de envolvimento do entrevistado com os debates 
analisados, sua visão sobre os eventos dos quais participou, bem como resgatar elementos de sua história profissional que permitissem compreender melhor seu ponto de vista.

No primeiro grupo, portanto encontram-se aqueles arquitetos chilenos responsáveis pela do V SAL: Cristián Boza - coordenador do evento -, Humberto Eliash, Pedro Murtinho, Eduardo San Martín, Cristián Fernández Cox e Enrique Browne ${ }^{94}$. Os primeiros três nomes fundaram o grupo CEDLA em 1977 e estiveram envolvidos com as atividades deste instituto ao longo dos anos 1980, principalmente na primeira metade da década ${ }^{95}$. Já os dois últimos, Fernández Cox e Browne, foram os fundadores do chamado Taller América, cujo surgimento foi frequentemente citado entre os precedentes que levaram a constituição dos SAL. Neste corpo de entrevistados, Pedro Murtinho é o único que participou de somente dois SAL no período analisado - o primeiro e o quinto seminário -, pois, apesar de sempre ter se interessado sobre a identidade latino-americana, para ele os seminários eram um grupo de amigos que já encontrava com frequência em outras situações, não lhe parecendo tão importante a participação nos debates dos seminários em $\mathrm{si}^{96}$. Os demais arquitetos deste conjunto fazem parte do que pode se chamar de os habitués dos SAL, ou seja, estavam entre aqueles que participaram ativamente em pelo menos quatro dos sete primeiros seminários - ver síntese dos registros impressos de participantes assíduos nos seminários entre 1985 e 1995 no Apêndice B.

No segundo grupo estão arquitetos que não contribuíram diretamente na elaboração do V SAL, mas que fizeram parte de intercâmbios estabelecidos em torno dos seminários e colaboraram com sua construção: Ramón Gutiérrez e Jorge Moscato, da Argentina; Silvia Arango e Jorge Ramírez, da Colômbia; Ruth Verde Zein, Hugo Massaki Segawa, Carlos Eduardo Comas e Rogério de Castro Oliveira, do Brasil. Este último arquiteto, apesar de não pertencer ao grupo de participantes assíduos dos seminários - ver Apêndice B -, foi incluído, inicialmente, nesta lista, pois seu nome constava na programação do V SAL como o responsável pela apresentação e comentário

\footnotetext{
${ }^{94} \mathrm{O}$ único integrante da comissão organizadora que não pôde ser entrevistado foi Manuel Moreno, visto que, lamentavelmente, este faleceu em 2002.

${ }^{95}$ Manuel Moreno também fez parte do grupo CEDLA.

${ }^{96}$ Cf. MURTINHO, Pedro. Depoimento. [20 de agosto de 2011]. Santiago do Chile: Arquivo digital da gravação (1hora e 57min.). Entrevista concedida a Gisela Barcellos de Souza.
} 
dos projetos brasileiros e nos parecia uma peça chave para a compreensão da participação brasileira neste evento - durante a entrevista verificou-se que este, por motivos pessoais, não pode comparecer ao seminário e que seu papel foi assumido por Carlos Eduardo Comas $^{97}$. Dois arquitetos que havíamos incluído neste grupo de entrevistados não puderam ser contatados: Juvenal Baracco e Cesar Naselli ${ }^{98}$.

Para além destes dois grupos de arquitetos que estiveram - direta ou indiretamente - envolvidos com a história dos SAL, foram também entrevistados dois arquitetos cujo contato estabelecido que cumpriu um papel fundamental nos primeiros anos do grupo CEDLA: o argentino Antonio Díaz del Bo (Tony Díaz) e chileno Fernando Montes. Antonio Díaz del Bo foi um dos fundadores de La Escuelita em Buenos Aires e o responsável por organizar duas visitas de Aldo Rossi ao Cone Sul. Já o arquiteto Fernando Montes encontrava-se na França desde a década de 1960, tendo participado amplamente dos debates e eventos sobre a tipo-morfologia no continente europeu. Ambos arquitetos representaram, como abordaremos no capítulo quatro, pontes entre o debate europeu e o contexto latino-americano e o intercâmbio estabelecido com estes possibilitou a legitimação de traduções culturais iniciais do CEDLA.

O projeto de pesquisa, o roteiro das entrevistas, bem como Termo de Consentimento Livre e Esclarecido foram elaborados em conformidade com as resoluções do Conselho Nacional de Ética em Pesquisa e submetido à aprovação do comitê de ética pertinente ${ }^{99}$. O contato inicial deu-se através de e-mail, no qual explicou-se o objeto de estudo da pesquisa, seus objetivos e a importância da realização da entrevista. Enviou-se, também, em anexo o projeto de pesquisa e o Termo de Consentimento Livre e esclarecido para apreciação do entrevistado. As entrevistas foram realizadas em local escolhido pelo entrevistado - em idioma de sua preferência ${ }^{100}$

\footnotetext{
${ }^{97}$ Seu depoimento acabou tratando de outros intercâmbios latino-americanos realizados através do PROPAR/UFRGS que auxiliaram na elaboração do capítulo 4.

${ }^{98}$ Juvenal Baracco não respondeu a nenhum dos e-mails enviados e Cesar Naselli não pode ser entrevistado por motivo de saúde.

${ }^{99}$ Devido ao fato de a autora ser professora junto à Universidade Estadual de Maringá, submeteu-se o projeto de pesquisa junto ao Comitê Permanente de Ética em Pesquisa com Seres Humanos (COPEP) dessa intistuição. O Certificado de Apresentação para Apreciação Ética (CAAE) do projeto, do roteiro e do Termo de Consentimento Livre e Esclarecido é: 0030.0.093.000-11.

${ }^{100}$ As entrevistas com os brasileiros foram, obviamente, realizada em português. No entanto, entre o grupo de entrevistados oriundos de países hispanofônicos, Fernando Montes preferiu realizar a entrevista em francês, visto que reside na França desde a década de 1960 e se sente mais à vontade com este idioma.
} 
- e tiveram duração variável entre uma hora e trinta minutos a quatro horas. Em diversos casos a entrevista foi realizada ao longo de três encontros. Somente o depoimento de Antonio Díaz del Bo (Tony Díaz) foi realizado via e-mail, visto que este arquiteto reside atualmente na Espanha. Os demais depoimentos foram gravados e, posteriormente, transcritos. Os arquivos digitais, suas transcrições e os Termos de Consentimento Livre e Esclarecido firmados pelos entrevistados permanecem arquivados sob a responsabilidade da autora conforme recomendações do Conselho de Ética de Pesquisa com Seres Humanos.

\subsection{Conceitos operacionais}

Antes de passarmos à exposição dos métodos, é preciso discorrer um pouco sobre alguns conceitos nos quais esta tese se apoia, ou seja: encontros culturais, intercâmbios, tradução cultural, bricolagem, hibridação cultural e representações coletivas. Trata-se de uma terminologia que tem sido frequentemente utilizada pelos chamados estudos culturais e que aproxima, portanto, o presente trabalho à História Cultural. O enfoque desta pesquisa é, mais especificamente, aquele da circulação de ideias, que, como bem o pontou Alicia Novick, distingue-se das abordagens sob a perspectiva da Teoria da dependência e das relações centro-periferia que caracterizou boa parte da produção intelectual latino-americana do segundo pós-guerra ${ }^{101}$. Tal qual define Novick:

A descontextualização que sofrem as ideias e modelos que se gestaram como respostas frente a problemas específicos e que em seu translado perdem o sentido original é o nó central da circulação das ideias. Isto é assim porque não se trata de contrastar os modelos originais e suas réplicas na condição de caricatura disformes, mas sim de colocar em foco os controversos caminhos que conduzem de um a outro ${ }^{102}$.

\footnotetext{
${ }^{101}$ NOVICK, Alicia. Intercambios Internacionales en construcción de la ciudad. Apuntes para un estado del Arte. In: SALGADO e BERTONI (org.) Da construção do Território ao Planejamento das Cidades. São Calos: Rima, 2010, p. 81-89.

${ }^{102}$ NOVICK, Alicia. loc. cit, 2010, p. 83.
} 
O uso da expressão "encontros culturais" vulgarizou-se entre os historiadores, segundo Burke, sobretudo a partir de 1992, com as comemorações dos 500 anos das Américas ${ }^{103}$. Seja pela necessidade de revisão histórica de expressões etnocêntricas como "descoberta", seja pela "importância dos encontros culturais em nossa época"104, o fato é que o interesse pelos processos de encontro culturais têm motivado cada vez mais a atenção de historiadores, assim como pesquisadores das mais diversas disciplinas ${ }^{105}$. Dentro desta perspectiva, como afirma Burke, os conceitos de troca e encontro "são úteis em discussões sobre interações dentro de uma cultura assim como entre culturas" ${ }^{106}$. Sob esta definição genérica de espaço de estabelecimento de trocas e de promoção de transformações entre ambientes culturais distintos, os "encontros culturais" podem representar tanto processos que perpassam largas durações - nos quais os agentes envolvidos possuem graus de engajamento e de consciência distintos -, quanto construções cuidadosamente idealizadas por seus atores e cuja viabilização dáse em um curto ciclo.

Observa-se, de modo geral, o emprego de uma série de sinônimos para os "encontros culturais"; dois dentre eles são, no entanto, mais recorrentes: trocas culturais e intercâmbios. Porém, avaliando-se as situações em que estes termos são empregados, percebem-se as nuances semânticas entre a opção por um sinônimo ou outro. A expressão "troca cultural" é mais frequente ${ }^{107}$ e assume um caráter mais vago tanto no aspecto temporal, quanto no dos agentes envolvidos. Já o uso do vocábulo intercâmbio parece ocorrer em contextos mais precisos. Usa-se para descrever encontros culturais específicos, tais como intercâmbio entre periódicos ${ }^{108}$ ou intercâmbios científicos ${ }^{109}$. Nota-se certa preferência por este termo quando a interação cultural envolve a afirmação da identidade ou a defesa das ideias de um grupo ${ }^{110}$.

\footnotetext{
${ }^{103}$ BURKE, Peter. O que é história cultural? Rio de Janeiro: Zahar, 2008.

${ }^{104}$ BURKE, op. cit., 2008, p.154

${ }^{105}$ BURKE, Peter. Hibridismo cultural. São Leopoldo: UNISINOS, 2003.

${ }^{106}$ BURKE, op. cit., 2003, p.74

${ }^{107}$ Cf. BURKE, 2003 e 2008.

108 PALLARES-BURKE, Maria Lúcia. The Spectator, ou as metamorfoses do periódico: um estudo em tradução cultural. In: BURKE e PO-CHIA HSIA (org.) Tradução Cultural nos primórdios da Europa Moderna. São Paulo: Ed. UNESP, 2009, p. 163-181.

109 PANTIN, Isabelle. O papel das traduções culturais nos intercâmbios científicos nos séculos XVI e XVII. In: BURKE e PO-CHIA HSIA (org.) Tradução Cultural nos primórdios da Europa Moderna. São Paulo: Ed. UNESP, 2009, p. 185-202.

${ }^{110}$ PANTIN, loc. cit., 2009.
} 
A compreensão dos chamados intercâmbios e encontros cultuais passa, também, pela análise da constituição de redes de profissionais - ou "comunidades epistêmicas", como nomeia Novick:

[...] um dos recursos para dar conta destas comunidades consiste em traçar trajetórias individuais que permitam estabelecer entre as lógicas locais e as redes que se tecem no âmbito internacional. Neste contexto, o estudo do perfil dos especialistas permite um panorama mais completo que o que surgiria somente da consideração da formação individual, pois dá conta dos estudos cursados, viagens, encontros e percursos profissionais. Também informam sobre associados e oponentes que ajudam a compreender a adscrição a um grupo e a um campo de ideias, a examinar a coerência entre as representações e as práticas ${ }^{111}$.

De modo geral, ao longo desta pesquisa, diferenciam-se os encontros culturais, em seu largo espectro possível, daqueles cuja concretização depende do engajamento direto e ideológico dos agentes envolvidos. Para tanto, emprega-se o vocábulo "intercâmbio" sempre que se percebe uma atuação programática através destas interações culturais. Quando esta não é verificada, opta-se pela expressão mais genérica, ou seja, pelos "encontros culturais".

Assim como os chamados "encontros culturais", as reações e seus desdobramentos são diversos e não podem ser tratados por termos semelhantes. Entre as metáforas mais empregadas, três, em específico, nos interessam e são operacionalizadas nesta pesquisa: tradução cultural, bricolagens e hibridação cultural.

Oriunda da analogia com a aprendizagem de uma língua estrangeira, a metáfora "tradução cultural", como um dos mecanismos de produção de novas formas híbridas, foi utilizada inicialmente por antropólogos nos anos 1950 e $1960^{112}$. Sob a perspectiva da História Cultural, a partir do final dos anos $1970^{113}$, conformaram-se novos contornos a estes estudos. Estes passaram a ser descritivos - "enfatizando o que os tradutores

\footnotetext{
${ }^{111}$ NOVICK, Alicia. loc. cit, 2010, p. 86.

${ }^{112}$ BURKE, op. cit., 2003.

${ }^{113}$ BURKE e PO-CHIA HSIA. Introdução. In: BURKE e PO-CHIA HSIA (org.) Tradução Cultural nos primórdios da Europa Moderna. São paulo: Ed. UNESP, 2009, p. 7-10.
} 
fazem, e não o que eles deveriam fazer"114 - e a enfocar o público, "vendo as traduções como 'fatos da cultura que hospeda' e como agentes da mudança naquela cultura"115.

Grosso modo, expressão "tradução cultural" é usada em substituição ao conceito de "mal-entendido", que implicava na existência de uma alternativa correta ${ }^{116}$. Através da ideia de tradução cultural, abordam-se as "adaptações criativas"117, realizadas por indivíduos ou grupos:

O termo 'tradução' [...] tem a grande vantagem de enfatizar o trabalho que tem que ser feito por indivíduos ou grupos para domesticar o que é estrangeiro, em outras palavras, as estratégias e as táticas empregadas ${ }^{118}$.

Aborda-se, portanto, o trabalho de adaptação que é empreendido pelos tradutores culturais. Como mediadores deste processo, os tradutores são correntemente descritos como "pessoas deslocadas" por serem detentoras de uma consciência dúplice ${ }^{119}$. Devido a esta importância dada à ação de indivíduos em específico a "tradução cultural" nos parece o termo mais adequado para abordar, nesta pesquisa, o processo de penetração no subcontinente do debate sobre a tipomorfologia - ou o "retorno à cidade" - e a proposição de formulações e adaptações próprias que são ensejadas em textos de arquitetos latino-americanos.

Apesar de serem frequentemente tratados como processos semelhantes ${ }^{120}$, ao longo da tese diferenciam-se as traduções culturais das bricolagens. Utilizam-se as primeiras para tratar das situações em que ainda se busca a afirmação de um vínculo mesmo que ínfimo - com o contexto original das ideias e textos adaptados ao contexto local. A noção de bricolagem, por outro lado, é empregada na tese quando discursos de diferentes origens são recortados, retirados de seus contextos e encaixados em uma nova construção teórica e já não se pode mais perceber de forma clara a existência de ligações com um debate em específico. Estas últimas são diferenciadas, portanto, das traduções culturais pelo fato de negarem, omitirem ou minimizarem a contribuição das

\footnotetext{
${ }^{114}$ BURKE e PO-CHIA HSIA, loc. cit., 2009, p.8.

${ }^{115}$ BURKE P PO-CHIA HSIA, loc. cit., 2009, p.8.

${ }^{116}$ BURKE, op. cit., 2008.

${ }^{117}$ PALLARES-BURKE, loc. cit., 2009.

${ }^{118}$ BURKE, op. cit., 2003, p.58.

${ }^{119}$ BURKE, op. cit., 2003.

${ }^{120}$ Cf. BURKE, op. cit., 2003
} 
fontes originais. Apoiamo-nos, portanto, no conceito de bricolagem, tal qual definido por Levi-strauss, pela abertura e capacidade de modificação constante que ele destaca na atitude do bricoleur:

O conjunto de meios do bricoleur não é definível por um projeto [...]; os elementos são recolhidos ou conservados em virtude do princípio que "um dia poderá servir". Tais elementos são, portanto, particularizados pela metade: suficientemente para que o bricoleur não tenha necessidade do equipamento e do saber de todo estado da arte; mas não ao ponto de que cada elemento seja restrito à um emprego preciso e determinado. Cada elemento representa um conjunto de relações, ao mesmo tempo concretas e virtuais; são operadores, porém ulitizáveis em vista de operações de qualquer um no seio de um tipo ${ }^{121}$.

Ao contrário das ideias de tradução cultural e de bricolagem, no conceito de hibridação desaparece o papel dos agentes envolvidos. Através desta metáfora emprestada à botânica, analisam-se "modificações das quais os agentes não têm consciência"122. De forma semelhante, Nestor Cancline a define como os "processos socioculturais nos quais estruturas ou práticas discretas, que existiam de forma separada, se combinam para gerar novas estruturas, objetos e práticas" ${ }^{123}$. Porém, como nos adverte o antropólogo argentino, "hibridação não é sinônimo de fusão sem contrações" ${ }^{124}$. Este conceito é utilizado ao logo da tese de forma semelhante ao emprego dado à noção de "encontros culturais", ou seja, para descrever as recombinações de significados no largo espectro, na construção de representações coletivas sobre a morfologia das cidades latino-americanas e a forma de se intervir nelas.

Por último, falta-nos ainda explicar o emprego da noção de "representações coletivas" em nossa terceira hipótese. De modo geral, este termo tem sido empregado pela historiografia a fim de dar "lugar para o que é imaginado". Utilizamo-lo no sentido em que foi definido por Roger Chartier, ou seja, como relação entre um objeto ausente e uma imagem presente:

\footnotetext{
${ }^{121}$ LEVI-STRAUSS, Claude. La pensée sauvage. Paris: Plon, 1962, p.27.

${ }^{122}$ BURKE, op. cit., 2003, p.84.

${ }^{123}$ CANCLINI, Nestor García. Culturas Híbridas. São Paulo : Edusp, 2008, p.XIX.

${ }^{124}$ CANCLINI, Nestor García. Culturas Híbridas. São Paulo : Edusp, 2008, p.XVIII.
} 
[...] a noção de representações coletivas, tomada emprestada de Mauss e Durkheim, nos faculta pensar de maneira mais complexa e dinâmica as relações entre os sistemas de percepção e de juízo e as fronteiras que atravessam o mundo social. [...] Os esquemas que geram as representações devem ser considerados, ao mesmo tempo, como produtores do social visto que enucíam as decomposições e classificações posteriores ${ }^{125}$.

${ }^{125}$ CHARTIER, Roger. El mundo como representación. Estudios sobre história cultural. Barcelona: Gedisa, 1992, p.IV 
50 | $\begin{aligned} & \text { Tessituras híbridas ou o duplo regresso: Encontros latino-americanos e traduções } \\ & \text { culturais do debate sobre o Retorno à Cidade }\end{aligned}$ 


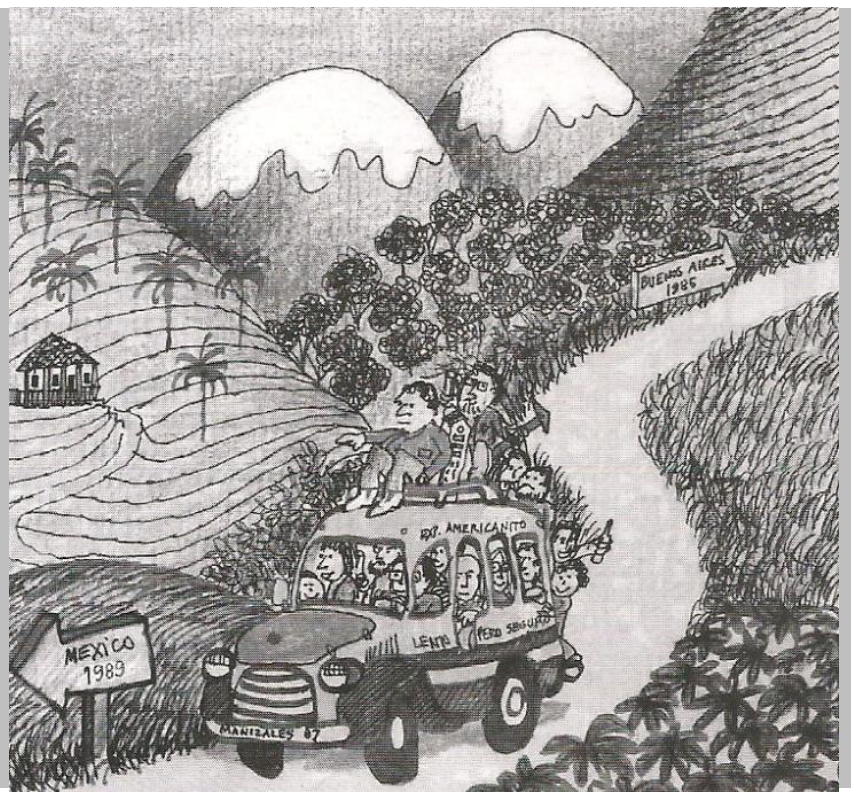

2. Ecos e escoamentos: a cidade latino-americana e sua morfologia nos primeiros SAL 
52 Tessituras híbridas ou o duplo regresso: Encontros latino-americanos e traduções culturais do debate sobre o Retorno à Cidade

Interpretação de Humberto Eliash sobre o III SAL, realizado em Manizales, 1987.

Fonte: GUTIÉRREZ, R.; MÉNDEZ, P. (org). Seminario de Arquitetura Latinoamericana (SAL). Haciendo el Camino al andar 1985-2011. Buenos Aires: CEDODAL, 2011. 
Todo trabalho de desconstrução de um discurso envolve outro, que normalmente lhe precede temporalmente, de reconstrução. Ao se desmontar uma sequência argumentativa, deve-se romper os elos que the garantiam sua coerência interna, individualizar cada uma de suas partes para, somente então, retrilhar suas origens e especular suas possíveis interferências. Este procedimento pressupõe, portanto, a explicitação da estrutura textual; coloca-se em evidência a ordem em que os argumentos são apresentados e as relações ali possibilitadas. Em outras palavras, antes de destecer-se sua urdidura, refaz-se a fim de torná-la patente.

A abordagem que propomos para a análise da convergência, na cultura arquitetônico-urbanística dos anos 1980 e 1990, entre traduções culturais do debate sobre o "retorno à cidade" - ou a revisão do Movimento Moderno a partir do vocabulário tipo-morfológico - e o estabelecimento de encontros latino-americanos é semelhante àquela de um texto. Logo, a decomposição dos mecanismos através dos quais se deu a matização de debates estrangeiros - e de como estes foram pautados pela busca da afirmação de laços no subcontinente - é precedida, nesta tese, pela descrição de uma esfera na qual esta hibridação torna-se nítida. À exposição desta, destinam-se este capítulo e o subsequente.

As pesquisas sobre a cultura arquitetônico-urbanística usualmente apoiaram-se na análise de ideias e debates veiculados por revistas e livros de grande repercussão no meio acadêmico e/ou profissional. Entretanto, ao escolher um elemento a partir do qual seria possível reconstruir a tessitura híbrida que esta tese pretende demonstrar, optouse por abordar o V SAL, evento que se insere na história dos Seminários de Arquitetura Latino-americana que - acompanhados, a partir de 1987, pela realização simultânea de encontros entre representantes das revistas de arquitetura, nos quais se definiam diretrizes editorias comuns ${ }^{1}-$ foram extremamente influentes na conformação do

\footnotetext{
1 Ruth Verde Zein explicava, em 1995, o surgimento dos encontros de revistas como um acontecimento espontâneo: estes teriam "nasc[ido] quase que espontaneamente, aproveitando a óbvia coincidência de, em toda a América Latina, as pessoas que estão à frente das discussões
} 
debate dos anos 1980/90 no subcontinente. A escolha de um seminário em específico como objeto de análise coloca a problemática da recuperação de seus vestígios. Eventos, ao contrário de publicações, ocorrem em uma circunstância determinada temporal e espacialmente; após esta, extinguem-se. Por mais que se possam encontrar registros de suas conferências em forma de Anais - como é o caso para parte de nosso corpus -, os debates ali ensejados, a não ser que tenham sido integralmente transcritos, serão sempre entrevistos através de fontes secundárias, impressas ou orais.

A especificidade temática do seminário realizado em Santiado do Chile - a morfologia dos espaços urbanos latino-americanos - diverge, certamente, com a recorrência com que o trabalho crítico no interior dos SAL foi descrito sob as pautas relativas à identidade e ao regionalismo. Poder-se-ia buscar compreender este contraste como um hiato, como avaliava Arango ${ }^{2}$, ou como o início de uma segunda fase dos SAL, na qual se rumava à afirmação de seu esgotamento que ocorrera no evento brasileiro, tal qual propôs Ramirez Nieto ${ }^{3}$. Entretanto, o grau de envolvimento que ainda demonstravam seus participantes com os seminários neste momento - testemunhado, entre outros, na edição de livros que pretendiam tornar público os debates que ocorriam nestes seminários ${ }^{4}$ - não parece permitir tal interpretação. Além disso, mesmo que este fora o início do fim, seria necessário buscar seu enraizamento nos debates anteriores, desvelar os elementos que poderiam ter permitido a assunção pública de uma mudança tão brusca nos rumos do debate.

A hipótese que se pretende demonstrar neste capítulo é que o quinto seminário não fora uma ruptura, nem mesmo uma cesura; mas sim a assunção pública de um debate majoritariamente omitido pela crítica. Ao contrário do que se procurou afirmar

críticas, históricas e teóricas serem, ao mesmo tempo, editores ou colaboradores assíduos de publicações arquitetônicas, unindo em sua atividade duas faces de uma proposta: debater arquitetura e divulgá-la", cf. ZEIN, R. V. Revistas \& Revistas. In: Projeto. São Paulo: Projeto Editores, no 190, out. 1995.

2 ARANGO, Silvia. Diez años de los "SAL" en América latina. In: PROA, Bogotá: Ediciones PROA, 425, jun.1995, p.20-22.

3 RAMíREZ NIETO, Jorge. El pensamiento a través de los Seminarios de Arquitectura latinoamericana. In: Anais do XI Seminario de Arquitectura Latinoamericana. Oaxtepec (México), 2005; bem como: Refexiones en torno de los Seminarios de Arquitectura Latinoamericana. In: GUTIÉRREZ, R.; MÉNDEZ, P. (org) Seminarios de Arquitectura Latinoamericana (SAL). Haciendo camino al andar. Buenos Aires: CEDODAL, 2011, p.27-44.

${ }^{4}$ Veja-se, por exemplo, ARANGO, Silvia (org). Modernidad y Postmodernidad en América latina. Bogotá: Escala, 1991.; WAISMAN. El interior de la Histoira. Bogotá: ESCALA, 1990; TOCA, Antonio (org). Nueva Arquitectura en América Latina: Presente y Futuro. México: GG, 1990. 
repetidamente, os Seminários de Arquitetura Latino-americana não tiveram um único discurso representativo; estes foram compostos por diversos centros de interesses que ocorriam paralelamente. Neste contexto, o evento realizado no Chile insere-se como a apoteose da trajetória de discussões específicas sobre a cidade latino-americana e sua morfologia, a qual, ainda latente nos primeiros eventos, ganhou corpo ao longo do terceiro e do quarto SAL.

Nas páginas que se seguem, procuraremos demonstrar nossa hipótese através de duas posturas distintas. Nos dois primeiros subcapítulos, abordaremos a diversidade de origens bem como a pluralidade de discursos presente nas duas primeiras realizações destes eventos. Mostrar-se-á como a temática relativa à especificidade das cidades latino-americana transparece, ainda que tenuemente, nos primeiros seminários. A partir do terceiro subcapítulo, entraremos na caracterização dos debates que tiveram lugar nos III e IV SAL. Buscaremos, inicialmente, construir, através da identificação dos traços distintivos desses eventos e do grau vinculação à história dos SAL que possuíam seus debatedores. Por último, análisaremos das formas com que a cidade é discutida nestes eventos; desvelando, portanto, as ressonâncias entre determinadas temáticas e o esmaecimento de outras. Em outras palavras, oscila-se, ao longo do texto entre uma análise longitudinal, que busca um encadeamento entre os fatos, e uma análise transversal e temática que revela a recorrência e as transformações das representações da cidade nestes debates.

Antes de passarmos ao desenvolvimento do texto de fato, é preciso caracterizar brevemente o corpus no qual se apoia nossa análise. Procurou-se recuperar, no trabalho de recomposição destes acontecimentos, os seus primeiros vestígios e contrastá-los, sempre que possível, às interpretações que deles foram feitas. Dos dois primeiros seminários, contudo, não há muitos elementos com os quais se possa trabalhar como fonte primária. Organizados pela revista Summa, sua realização fora cuidadosamente preparada através da precedência de dossiês específicos sobre a arquitetura iberoamericana; seus resultados, no entanto, podem apenas ser entrevistos em números posteriores. Esta revista seguiu, em geral, a mesma estrutura para a publicação do debate fomentado nestes eventos: a redação de uma crônica geral, na qual transparecem as impressões de seus contribuintes, e a transcrição integral de sua mesa redonda de encerramento - no caso do segundo seminário, houve duas, porém apenas uma foi divulgada. Visto que não temos acesso às conferências que compuseram estes 
encontros, as transcrições das mesas redondas constituíram-se como nossas fontes primárias mais próximas do que foram aqueles debates. O cotejamento com outras narrativas e fontes, no entanto, foi fundamental em nosso ensaio de reconstrução destes primeiros episódios. Esta empreitada talvez pareça mais simples para os III e IV SAL, visto que as palestras apresentadas nestes foram publicadas integralmente em forma de anais. Organizadas nestes por seções temáticas, as contribuições, no entanto, são todas tratadas por igual - excetuando-se às conferências de abertura. Esta indistinção na publicação garante, por um lado, sua neutralidade - não há uma ordem de juízo nesta -, porém, por outro, não permite a percepção, nem mesmo especulação, sobre as repercussões que as exposições individuais obtiveram entre os demais debatedores e no público presente. Buscou-se contornar esta questão com, novamente, a recorrência a outras fontes - impressas e orais -; a identificação de reverberações em debates posteriores; e a caracterização do grau de envolvimento das personagens com a história dos seminários.

\subsection{Ensaios de um intercâmbio e elementos catalisadores}

A organização de um intercâmbio entre diversos países não é, obviamente, mera obra do acaso; menos ainda, seria a produção explicável pela atuação de um único grupo. Formados em meados dos anos 1980, pode-se afirmar que os Seminários de Arquitetura Latino-americana foram preparados em meio a uma série de eventos e encontros culturais que ocorreram entre o final da década de 1970 e início dos anos 1980. Esses testemunham não apenas uma vontade de aproximação entre arquitetos de um mesmo continente, como também constituem os primeiros pontos de contato entre personagens que posteriormente construiriam esta rede de relações e de trocas manifesta naqueles seminários.

\section{Múltiplas origens}

Assídua nos ensejos de revisão destes seminários, a explicação do surgimento dos SAL por meio de origens múltiplas parece configurar-se como a mais bem aceita ${ }^{5}$.

\footnotetext{
${ }^{5}$ Dentre as revisões dos SAL, as tentativas de explicação para o seu surgimento, estas coincidem na proposição de origens múltiplas. Ver, por exemplo, RAMIREZ NIETO, loc. cit. 2005, RAMIREZ
} 
Neste sentido, as primeiras exposições bienais de arquitetura em países latinoamericanos - a de Santiago do Chile, em 1977, e a de Quito, em $1978^{6}$ - são apontadas como foros originais, nos quais se agregaram os países do Cone Sul, de uma parte, e os países andinos, de outra ${ }^{7}$. A existência destes antecessores coloca, por vezes, em xeque até mesmo a originalidade do Primeiro Seminário de Arquitetura Latinoamericana, realizado em Buenos Aires, em 1985. Segundo Arango ${ }^{8}$ e Salmona ${ }^{9}$, para os colombianos, o I SAL é considerado como o segundo encontro de arquitetura latinoamericana, visto que o primeiro seria um evento que teve lugar em Cáli, em 1980, e que agregou profissionais de Cuba, do México, do Uruguai e do Peru ${ }^{10}$.

NIETO, loc. cit. 2011; ARANGO, loc. cit., 1995; GUTIÉRREZ, R. Seminarios de arquitectura latinoamericana. Una experiencia de reflexión y acción (1985-2009) In: GUTIÉRREZ, R.; MÉNDEZ, P. (org). Seminario de Arquitetura Latinoamericana (SAL). Haciendo el Camino al andar 19852011. Buenos Aires: CEDODAL, 2011, p.19-26.

${ }^{6}$ Curiosamente, não se estabelecem, através das Bienais de Quito, vículos fortes com arquitetos equatorianos, visto que seu engajamento nos primeiros SAL foi pouco expressivo - ver Apêndice B. Contudo, estas bienais serviram como pontos de contatos iniciais entre profissionais de distintos países latino-americanos, dentre estes alguns dos que viriam a fazer parte dos SAL. No início dos anos 1980, a PROA divulgava não apenas a participação de arquitetos colombianos nestas bienais, como também a premiação destes. Foi na terceira bienal de Quito, realizada em 1982, por exemplo, que Silvia Arango conheceu Marina Waisman - cf. ARANGO, Silvia. Depoimento. [11 de novembro de 2011]. Campinas: Arquivo digital da gravação (1hora e 11min.). Entrevista concedida a Gisela Barcellos de Souza. Na ocasião, Marina Waisman compunha o jurado de avaliação dos trabalhos teóricos e Silvia Arango recebeu prêmio para dois ensaios que havia apresentado - Cf. PREMIOS de la tercera Bienal de Arquitectura, In: Revista PROA, Bogotá: Ediciones PROA, 314, jan.1983, p.57.

${ }^{7}$ A importância destes dois eventos para a urdidura dos intercâmbios latino-americanos é reafirmada, posteriormente, na escolha destes eventos para realização simultânea dos dois primeiros Encontros de Revistas Latino-americanas - o primeiro ocorreu junto com a $\vee$ Bienal de Arquitetura de Santiago do Chile, em 1985, e o segundo ocorreu paralelamente com a V Bienal de Quito, em 1986. A partir do III SAL, realizado em 1987 em Manizales (Colômbia), os encontros de revistas passaram a acompanhar os Seminários de Arquitetura Latino-americana, seguindo a mesma numeração.

${ }^{8}$ ARANGO, Silvia. Diez años de los "SAL" en América latina. In: Revista PROA, Bogotá: Ediciones PROA, 425, jun.1995, p.20-22.

${ }^{9}$ SALMONA, Rogelio. Clausura al III Encuentro de Arquitectura Latinoamericana. In: III Encuentro de Arquitectura Latinoamericana. Buenos Aires: CAPBA D III, 1988, p.111.

${ }^{10}$ Trata-se do Encontro Latino-americano de Cáli, que ocorreu entre 2 e 7 de julho de 1980 e foi organizado por Salmona e sediado na Universidad del Valle de Cali. Dele participaram, além de colombianos, arquitetos do Peru, de Cuba, do Uruguai e do México - entre eles, Mariano Arana, do Uruguai, Fernando Salinas, de Cuba, Juvenal Baracco, do Peru, e Ernesto Alba, do México (SALMONA, loc. cit.,1988). Sobre a importância deste evento para os colombianos, Silvia Arango (1995, p.18) afirma que: "foi ali onde conhecemos a aventura da auto-gestão da UAM, as experiências da revolução cubana e os esforços para salvar o patrimônio histórico de Montevidéu". 
Poderíamos, por outro lado, buscar antecedentes ainda mais longínquos e apontar analogias com outros eventos sequenciais anteriores que promoveram intercâmbios latino-americanos. Tratar-se-ia, por exemplo, de aproximar a iniciativa dos SAL daquela que a Federação Pan-americana de Associações de Arquitetos inaugurou em Montevidéu, em 1920, com a realização do I Congresso Pan-americano de Arquitetura. Ratificando a importância deste precedente, Ramón Gutierrez, chegou a afirmar que "até o surgimento dos Seminários de arquitetura latino-americana (SAL) na década de 1980, os Congressos Pan-americanos eram os únicos cenários qualificados para a reflexão e intercâmbio"11. Para além de julgamentos de qualidade ou de especificidade temática, no entanto, verifica-se que desde meados dos anos 1950 outros eventos também serviram de ponto de encontro de arquitetos e urbanistas latinoamericanos: os Congressos Interamericanos de Planejamento ${ }^{12}$, organizados pela SIAP Sociedade Interamericana de Planejamento - e as Conferências Latino-americanas de Escolas e Faculdade de Arquitetura (CLEFA), organizadas pela União de Universidades da América Latina - ver Apêndice A.

Contudo, apesar destes eventos testemunharem o interesse em encontros periódicos entre profissionais latino-americanos, estes antecedentes divergem dos Seminários de Arquitetura Latino-americana em um ponto em específico: a questão da representatividade institucional. Ao contrário daqueles que o precederam, os SAL não contaram com uma estrutura formal, nem com o apoio de uma instituição ou entidade em específico. Como afirmam recorrentemente aqueles que participaram dos primeiros seminários, sua realização se deu pautada em relações interpessoais, sem hierarquias ou

11 GUTIÉRREZ, Ramón. Los congresos Panamericanos. Apuntes para la trayectoria de la arquitectura en Iberoamérica. In: GUTIÉRREZ, Ramón; TARTARINI, Jorge; STAGNO, Bruno. Congresos Panamericanos de Arquitectos, 1920-2000. Aportes para su história. Buenos Aires: CEDODAL e FPAA, 2007.

12 Os Congressos Interamericanos de Planejamento, realizados pela primeira vez em 1956 - ver Apêndice A -, contaram historicamente com a contribuição de profissionais de origens diversas, caracterizando a abordagem multidisciplinar dessa disciplina. Entretanto, a história da Sociedade Interamericana de Planejamento (SIAP) é marcada pela ampla participação de arquitetos. $\mathrm{O}$ argentino Jorge Enrique Hardoy, por exemplo, esteve à frente da junta diretora desta sociedade por quatro gestões consecutivas - entre 1968 e 1974 (cf. CAMACHO, 2007). Além disso, como revela Camacho (2007), um levantamento realizado em 1978 sobre o perfil dos sócios da SIAP, demonstrava que arquitetos e engenheiros representavam 58\% dos associados. CAMACHO, Luís Eduardo. Sociedade Interamericana de Planificación. SIAP 50 años de vida institucional y Programática. In: Revista Bitácora Urbano-Territorial, Bogotá: Universidad Nacional de Colombia, vol.1, $\mathrm{n}^{\circ} 11,2007$, p.268-284. 
postulados oficiais ${ }^{13}$. Negar a ascendência a qualquer um dentre os eventos supracitados parecia, portanto, um ponto de partida lógico, como se verifica no trecho abaixo de autoria de Alberto Petrina:

Esta tarefa [dos SAL] não reconhece antecedentes, já que os Congressos Pan-americanos se instalaram sempre em um plano institucional de sindicato profissional que limitou os alcances de sua ação a temáticas e a núcleos necessariamente reduzidos. ${ }^{14}$

Logo, a partir desta negação inicial de filiação, encontros diversos - informais ou formais - entre os profissionais que ajudaram a construir os SAL parecem assumir maior importância. Arango ${ }^{15}$ destaca, por exemplo, o papel dos historiadores, cujos trabalhos de investigação teriam levado ao estabelecimento de laços em diversos países latino-americanos. Nesta mesma direção, Ramírez Nieto ${ }^{16}$ nomeia como "fatos coesivos" as pesquisas realizadas por Ramón Gutiérrez para elaboração de seu livro “Arquitectura y Urbanismo en Iberoamérica" (1983) e as investigações de Enrique Browne viabilizadas com o auxílio da bolsa que recebeu em 1983 da Fundação Guggenheim que resultaram no livro "Otra Arquitectura en América latina" (1988) ${ }^{17}$.

A estes eventos, poderíamos somar outros diversos, cuja contribuição individual para a constituição dos Seminários de Arquitetura Latino-americana talvez tenha sido de

\footnotetext{
${ }^{13}$ Veja-se, a título de exemplo, a descrição de Ruth Verde Zein sobre estes seminários: "Os seminários do SAL eram dirigidos sem regras prioritárias e/ou estrutura hierárquica: era como uma festa entre amigos, em que as pessoas curtiam a companhia de cada um, enquanto mantinham um grande nível de pertinência durante os debates. Isto funcionava bem porque $o$ consenso ainda estava por ser descoberto; um fascinante, porém ainda inconsciente, acordo mútuo sobre as principais realizações - muitos pontos de vista eram debatidos naquele momento." ZEIN, Ruth Verde, FERNANDEZ COX, Cristián, Regional Study Brazil. In: HERRLE, P. e SCHMITZ, S. Constructing Indentity in Contemporany Architecture. Case Studies from the South. Berlim: LIT VERLAG, 2009, p.57.

${ }^{14}$ PETRINA, Alberto, 1993. Balance del VI Seminario de Arquitectura Latinoamericana. In: Las Últimas Arquitecturas. Encuentro Reflexión y Crítica. Ponencias y Debates. Buenos Aires: s.l., 1993, p.19.

${ }^{15}$ ARANGO, Silvia, loc. cit.,1995, p.20.

${ }^{16}$ RAMÍREZ NIETO, Jorge. "El pensamiento a través de los Seminarios de Arquitectura latinoamericana", in: Anais do XI Seminario de Arquitectura Latinoamericana. Oaxtepec (México), 2005.

${ }^{17}$ Através do processo de pesquisa que precedeu a elaboração deste livro, Browne viajou pela América Latina e estabeleceu contato com pessoas que, posteriormente, participariam dos SAL: Rogelio Salmona, Silvia Arango, Ruth Verde Zein, Mariano Arana, Alberto Petrina e Ramón Gutiérrez - a quem já conhecia, porém estreitou laços neste momento. BROWNE, Enrique. Depoimento. [13 de setembro de 2011]. Santiago do Chile: Arquivo digital da gravação (2horas e 1min.). Entrevista concedida a Gisela Barcellos de Souza.
} 
importância menor, mas que, em seu conjunto, testemunham uma série de pequenas iniciativas de aproximação. Fato é que, desde meados da década de 1970, pode-se acompanhar nas revistas de arquitetura do subcontinente uma inserção crescente de temas e reportagens sobre a produção de arquitetos de latino-americanos. Esta se manifestou tanto de forma discreta, como a postura inicial da Revista Summa - que inseriu, sem qualquer menção em seu editorial, correspondentes no Brasil, em 1975, e, posteriormente, no Peru e no Chile, respectivamente em 1980 e 1981 -, como também de forma declarada, tal qual aparece na Revista ARS - periódico do Centro de Estudios de la Arquitectura (CEDLA) ${ }^{18}$ - na qual seu então editor, Humberto Eliash, afirmava, em 1979:

A revista ARS começa a partir deste número a publicação de uma série de artigos sobre a Arquitetura Contemporânea Latino-americana. Conscientes da falta de conhecimento e informação que existe sobre a própria realidade americana em nosso campo, o Centro de Estudios de la Arquitectura inicia esta ofensiva com a difusão de ensaios críticos, projetos e obras na revista ARS e, posteriormente, com conferências sobre o mesmo tema na sede do CEDLA. ${ }^{19}$

O estabelecimento deste intercâmbio incipiente também foi pautado pela ação de algumas instituições, como o Taller América, por exemplo. Criado a partir de uma comissão do Colégio de Arquitetos do Chile em $1982^{20}$, este grupo interdisciplinar de discussão, conduzido por Sergio Larraín, Cristián Fernandez e Enrique Browne, organizou-se em torno do interesse comum sobre o estudo de "como a cultura ocidental se transforma quando se enraíza na América" ${ }^{21}$. Responsável pela promoção de atividades diversas e de edições, o Taller América organizou, logo em 1983, um seminário sobre "Identidade Cultural na América Latina", ministrado pelo sociólogo

\footnotetext{
${ }^{18} \mathrm{O}$ Centro de Estudios de la Arquitectura - CEDLA - foi um instituto privado de investigações arquitetônicas, criado em 1977. Durante seu período de atividade, o instituto permaneceu vinculado a dois escritórios junto aos quais trabalhavam os seus fundadores: Boza, José Larraín e Jorge Luhrs; Pedro Murtinho, Francisco Muzard e Humberto Eliash Díaz. No início dos anos 1980, somaram-se Manuel Moreno e Hernán Duval. Abordar-se-á a atuação do CEDLA nos capítulos 3 e 4.

${ }^{19}$ ELIASH, H. Arquitectura Contemporánea Latinoamericana. In: ARS, n.3, 1979, p.109

${ }^{20}$ GARCÍA ALVARADO, Rodrigo. Esbozos de Teoría de la Arquitectura en Chile. In: Arquitectura del Sur. Concepción: Universidad de Bio-Bio, n. 32, 2005.

${ }^{21}$ BROWNE, E. Otra Arquitetura en América latina. Barcelona: Gustavo Gili, 1988, p.17.
} 
Pedro Morandé22 . De acordo com Enrique Browne, a ideia de organizar o Taller América surgiu em uma conversa entre ele e Cristián Fernández Cox:

Lembro que estávamos fascinados por um sociólogo chamado Pedro Morandé, que era muito influenciado por Octavio Paz. [...] Então convidamos pessoas e, claro, decidimos convidar alguém que fosse realmente dirigente e o nome óbvio era Sergio Larraín. Convidamos Sergio Larraín e as reuniões passaram a se realizar no recém-fundado Museo Precolombino - cujo acervo havia sido doado por ele - numa sala estupenda. Havia mais ou menos na mesa central umas 20 pessoas e, em torno desta, mais umas 30 pessoas sentadas. Ou seja, havia [como público assistente aos seminários] algo em torno de 40 ou 50 pessoas. ${ }^{23}$

O mentor intelectual do Taller Amércia seria, portanto, aos olhos de Browne ${ }^{24}$, Cristián Fernández Cox. Partindo de uma "intuição de que a identidade cultural chilena era parte de uma identidade maior que é a identidade ibero-americana”25, Fernández Cox foi inicialmente solicitar ao sacerdote Hernán Alesandri ${ }^{26}$ - amigo de longa data para que ministrasse palestras que abordassem esta temática. Alessandri, segundo Fernández Cox, teria sido o responsável pela indicação do nome de Pedro Morandé, quem, além de marcar a atuação inicial do Taller América através de seus seminários, definiria, também, o tipo de abordagem - que buscava um enraizamento da questão em um espectro cultural mais amplo que o da arquitetura - que foi buscado em debates posteriores. No segundo ano, no entanto, Browne apresentou de forma sequencial os esboços dos capítulos de seu livro, então em desenvolvimento, Otra Arquitectura ${ }^{27}$,

${ }^{22}$ ZEIN, R. V. e FERNANDEZ COX, C., loc. cit., 2009, p.56.

${ }^{23}$ BROWNE, Enrique. Depoimento. [13 de setembro de 2011]. Santiago do Chile: Arquivo digital da gravação (2horas e $1 \mathrm{~min}$.). Entrevista concedida a Gisela Barcellos de Souza.

${ }^{24}$ BROWNE, Enrique. Depoimento. [13 de setembro de 2011]. loc. cit.

${ }^{25}$ FERNÁNDEZ COX, Cristián. Depoimento. [31 de setembro de 2011]. Santiago do Chile: Arquivo digital da gravação (1hora e 56min.). Entrevista concedida a Gisela Barcellos de Souza.

${ }^{26}$ Hernán Alesandri Morandé foi um sacerdote do schönstattiano chileno - movimento cristão do qual Cristián Fernándex Cox fez parte durante sua juventude - e foi fundador da Corporação Beneficente María Ayuda, criada em 1983 com o objetivo de resgatar crianças e adolescentes em situação de vulnerabilidade social. FERNÁNDEZ COX, Cristián. Depoimento. [31 de setembro de 2011]. loc. cit.

27 Segundo Browne, as discussões preliminares no âmbito dos seminários do Taller América foram muito importantes para a redação final do livro, pois este buscou incorporar as observações que lhe eram feitas. BROWNE, Enrique. Depoimento. [13 de setembro de 2011]. loc. cit. 
fazendo com que questões especificas à arquitetura latino-americana também fossem discutidas neste espaço.

Como afirmam aqueles que participaram do Taller América, o período de sua atuação mais intensa ocorreu em seus dois primeiros anos de funcionamento ${ }^{28}-$ ou seja, 1983 e 1984. Contudo, a ressonância na cultura arquitetônica chilena que as ideias ali debatidas encontraram é passível de ser reconhecida em diversos eventos posteriores. Dentre estes, destacamos aqui o chamado Encontro de Caburga ${ }^{29}$, organizado pelo CEDLA e realizado em abril de 1984, em que arquitetos chilenos, o argentino Roberto Fernández e peruano Juvenal Baracco encontram-se para discutir, entre outros, o tema da identidade cultural.

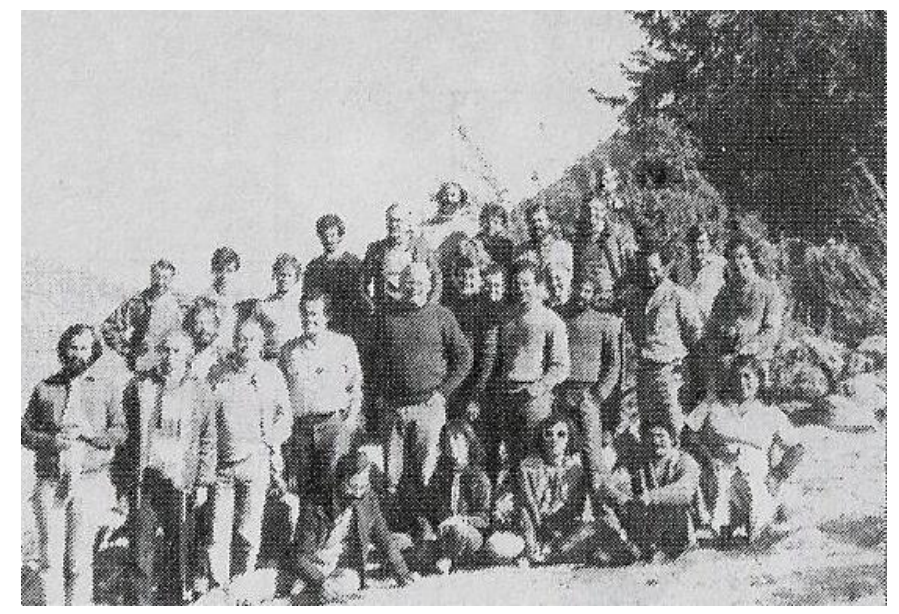

Figura 1: Fotografia dos participantes do Encontro de Caburga, em abril de 1984. Fonte: ARS, n.5, 1984.

Outras instituições, embora não tivessem o interesse direto no estabelecimento de um intercâmbio latino-americano, acabaram por contribuir inicialmente para sua concretização, tal qual fora o caso do CAYC - Centro de Arte y Comunicación -, representado na figura polêmica de Jorge Glusberg ${ }^{30}$. Envolvido em projeto de

\footnotetext{
${ }^{28}$ BROWNE, Enrique. Depoimento. [13 de setembro de 2011] e MURTINHO, Pedro. Depoimento [20 de agosto de 2011]. A data de término do Taller América não é precisa, visto que apenas ocorreu um arrefecimento de suas atividades e não houve um marco oficial de seu encerramento. Segundo Cristián Fernández Cox - depoimento [31 de outubro de 2011] - o Taller América teria mantido suas atividades por 4 ou 5 anos. Esta data parece coincidir com o último evento organizado pelo Taller América do qual encontramos registro ao longo de nossa pesquisa: o seminário Raúl Zurita, intitulado "Lenguaje y Nuevo Mundo", realizado em dezembro de 1987 cf. ARS, n 10, maio 1988, p.78. Os seminários do Taller América foram originalmente gravados e suas fitas foram entregues ao acervo do Colegio de Arquitectos de Chile; contudo, após sucessivas trocas de gestões, este material se perdeu.

${ }^{29} \mathrm{O}$ significado deste encontro será retomado no capítulo 4.

${ }^{30}$ O papel ambíguo Jorge Glusberg durante o período da ditadura argentina - que oscilou, no período entre 1971 e 1983, entre etapas de menor e outras de maior afinidade com o governo militar (cf. Cancline, 2008, p.94-95) -, somado a seu controle do meio artístico argentino
} 
divulgação da produção argentina e na condição um dos fundadores do Comitê Internacional de Críticos de Arquitetura (CICA) ${ }^{31}$, Glusberg organizou através do CAYC diversas atividades e exposições na Argentina e no exterior ${ }^{32}$. Dentre estas, algumas delas permitiram o estabelecimento de alguns contatos entre profissionais latinoamericanos como: a exposição da obra de Joaquim Guedes no CAYC, em 1978; as exposições produção arquitetônica então atual do Brasil e da Argentina, organizadas em $1983^{33}$, com a contribuição da Revista Projeto, e a exposição "Arquitectura en Chile" que teve lugar em julho e agosto de 1984.

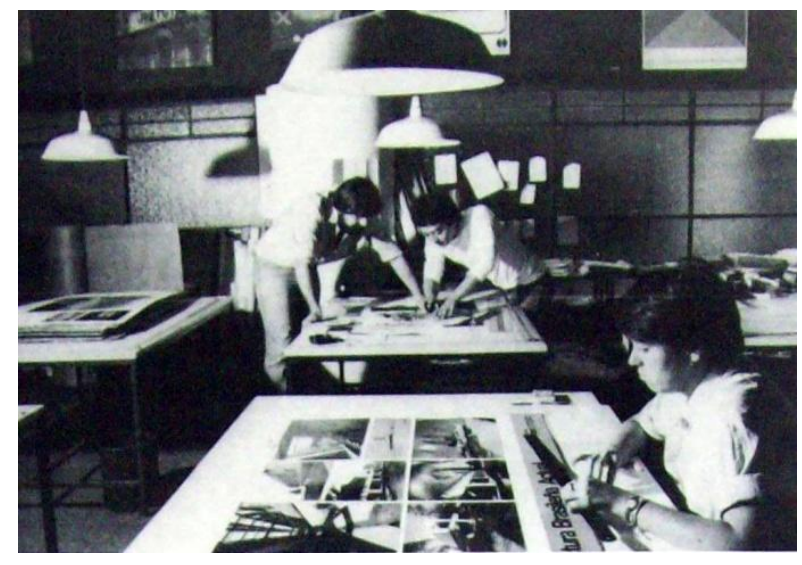

Figura 2: Fotografia da montagem dos painéis da mostra "Arquitetura Brasileira Atual", realizada em agosto de 1983 no CAYC, em Buenos Aires. Fonte: Revista Projeto, n.54, ago. 1983.

Estas exposições panorâmicas sobre a produção arquitetônica do Brasil e do Chile, articuladas através do CAYC, contaram também com a realização de seminários ${ }^{34}$

exercido através da presidência da Associação Argentina de Críticos de Arte e da vice-presidência da Associação Intenacional de Críticos, dividia, ainda no final dos anos 1980, as opiniões de artistas e de críticos a seu respeito, bem como ao CAYC (García et al, 1987, apud Cancline, 2008).

${ }^{31}$ O CICA foi criado em 1978, durante o XIII Congresso da UIA. Além de ter participado do conselho director deste comitê por muitos anos, o nível de engajamento de Glusberg em sua criação evidencia-se no fato deste ter organizado a segunda reunião do CICA no CAYC, em 1980. Cf. ELGUEZABAL, Eduardo. Simposio de la Crítica: crónicas y comentarios. In: Summa. Buenos Aires: Ed. Summa, 151, jul. 1980.

${ }^{32}$ Apesar de ter auxiliado a revista Summa na organização do Primeiro Seminário de Arquitetura Latino-americana, analisando-se a atuação do CAYC no final da década de 1970 e início da década de 1980, não se percebe de forma nítida uma busca de uma aproximação com a América Latina, mas sim um projeto de internacionalização da arquitetura argentina. No mesmo ano em que Carlos Nelson dos Santos ministra um seminário no CAYC, por exemplo, Glusberg organiza também outro seminário com Mario Botta e, no ano seguinte, 1984, traz à Argentina Joseph Kleihues e Robert Krier.

${ }^{33}$ Em Buenos Aires, a mostra "Arquitectura Brasileña Actual" ocorreu em agosto de 1983. Por outro lado, a exposição "Arquitetura Argentina Atual" teve lugar no Rio de Janeiro, na sede do IAB, em agosto de 1983. Ambas foram retomadas em São Paulo em outubro daquele mesmo ano. Cf. Arquitetura Argentina Atual. In: Projeto, São Paulo, n. 54, p.18.

${ }^{34}$ Durante a realização da mostra "Arquitectura Brasileña Actual" ocorreu o seminário "Realidade e utopia no planejamento urbano no Brasil" ministrado por Carlos Nelson dos Santos, entre 4 e 6 de agosto de 1983, na sede do CAYC — cf. revista Summa, n.191, set. de 1983, p. 23. Já durante a 
concomitantes às mostras em Buenos Aires e são frequentemente apontadas no discurso dos entrevistados ${ }^{35}$ como pontos importantes no estabelecimento do intercâmbio latino-americano - apesar da diferença de escala entre ambas ${ }^{36}$. O reconhecimento de sua relevância já era salientado no momento de sua organização. Para o editor da Revista Projeto, Vicente Wissenbach, trava-se de uma "oportunidade de maior aproximação com os outros países da América Latina" e "transformou-se numa obrigação, numa tarefa à qual não [se] pod[ia] fugir" ${ }^{\prime 37}$. Avançando nesse sentido, Pedro Murtinho, curador da mostra chilena, revelava em seu discurso preocupações e questões que, no ano seguinte, seriam objeto de discussão do primeiro SAL:

Assumimos, portanto, nossa dependência cultural e continuamos olhando em direção ao "centro", porém, a partir de nossa ótica latino-americana. Isto não tem a ver com uma postura chauvinista ou folclórica. A crise de nossa cultura não está tanto em nossa própria produção, mas sim nas categorias conceituais com que os países do centro nos compreendem. [...] O sentindo, portanto, que se dá à exposição de nossas obras, organizada pelo CAYC, é aquele de reunir esforços para nos apresentar como uma boa, sã e coerente periferia frente ao centro Europa-Estados Unidos. ${ }^{38}$

exposição "Arquitectura en Chile" houve três colóquios: "Da práxis à teoria na arquitetura chilena (1970-1985)", do qual participaram Eliash, Moreno e Victor Gubbins; "A identidade cultural e a arquitetura chilena", com contribuições de Cristián Fernández Cox, Pedro Murtinho e Enrique Browne; e, por último, "Tipologias urbanas no Chile", com a participação de Boza, Duval e Edward Rojas - cf. LA ARQUITECTURA de Chile en Buenos Aires. El Clarin, Buenos Aires, Arquitectura, Ingeniaria, Planeamiento y Diseño, p.3, 24 de julho de 1984.

${ }^{35}$ Para o caso da mostra brasileira, Ruth Verde Zein destaca os contatos que estabeleceu neste momento com Alberto Petrina, Severiano Porto e Éolo Maia - ZEIN, Ruth Verde. Depoimento. [05 de abril de 2011]. A importância da mostra chilena é destacada nos depoimentos de Eliash [06 de julho de 2011], Murtinho [20 de outubro de 2011], Boza [outubro 2011] e Moscato [25 de agosto de 2011] e, no entanto, minimizada no depoimento de Browne [7 de setembro de 2011].

${ }^{36}$ A exposição "Arquitectura Actual Brasileña" contou com o trabalho desenvolvido por 85 escritórios de arquitetura - mais de 300 arquitetos envolvidos (cf. Projeto, n. 53, jul,1983) - que atenderam ao pedido da Revista Projeto e foram organizados por Ruth Verde Zein e Hugo Segawa, na condição de redatores deste periódico - cf. ZEIN, Ruth Verde. Depoimento. [05 de abril de 2011], loc. cit.. Enquanto na exposição "Arquitectura en Chile" participaram apenas 16 escritórios selecionados por Pedro Murtinho.

${ }^{37}$ WISSENBACH, V. Editorial. In: Projeto, São Paulo, n. 53, jul,1983, p.3.

${ }^{38}$ MURTINHO, Pedro. Nuestra Participación. In: Arquitectura en Chile. Buenos Aires: CAYC, 1984, p.2-3. 


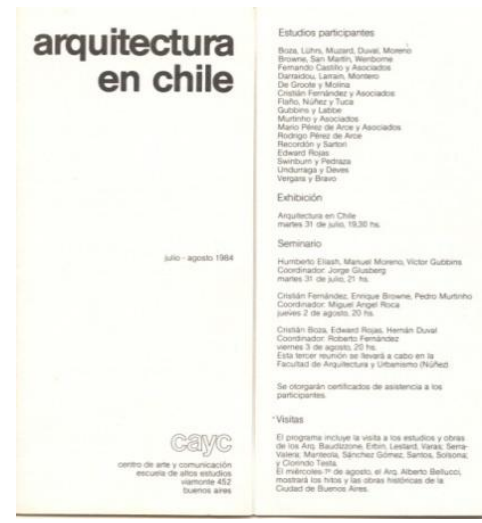

Figura 3: Material de divulgação da mostra "Arquitetura em Chile" realizada no CAYC, em 1984. Fonte: Acervo pessoal de Pedro Murtinho.

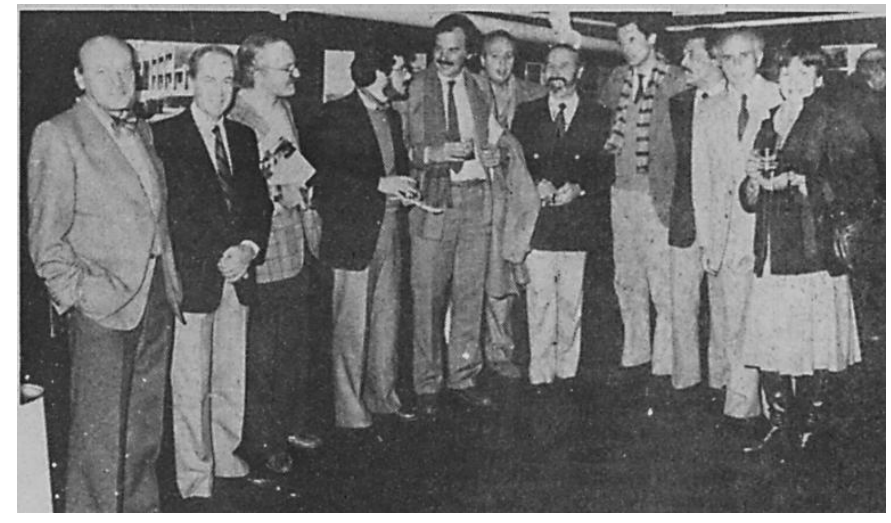

Figura 4: Participantes da exposição "Arquitectura en Chile", realizada no Cayc entre julho e agosto de 1984. Fonte: Acervo pessoal de Pedro Murtinho.

\section{A IV Bienal de Arquitetura do Chile}

O evento, no entanto, que seria o responsável por reunir publicamente, entre seus convidados especiais, arquitetos e críticos cuja atuação seria fundamental para a consecução do Primeiro Seminário de Arquitetura Latino-americana, foi a IV Bienal de Arquitetura do Chile, realizada em agosto de 1983. Segundo Fernández Cox ${ }^{39}$, esta bienal, presidida por Pedro Murtinho, fora a primeira a propor um tema que de fato inquietava os arquitetos chilenos naquele momento e que se refletia no conjunto da exposição. A situação política do Chile teria impedido, nas palavras Murtinho, uma ação mais propositiva nas primeiras Bienais: "Nas primeiras bienais fomos espectadores de eventos distantes de nós. Foi o preço para podermos realmente estabelecê-las e concedê-las uma categoria de grande evento" ${ }^{40}$.

No título da IV Bienal, "Patrimônio e Presente: A Recuperação Crítica do Passado" percebe-se, obviamente, a ressonância de duas exposições de grande importância na cultura arquitetônica internacional: "A presença do Passado", título da primeira mostra de arquitetura da Bienal de Veneza, organizada por Porthoguesi em 1980; assim como a ideia de "Reconstrução Crítica", noção desenvolvida por Kleihues e chave para a definição das bases da IBA-Berlim. Entretanto, através da definição dos convidados estrangeiros postulava-se um olhar ibero-americano sobre o tema. Ao lado

\footnotetext{
${ }^{39}$ FERNÁNDEZ COX, Cristián. Tres notas para una reflexión sobre las bienales. In: CA. Santiago do Chile: Colégio de Arquitetos do Chile, n. 52, junho de 1988, p.62.

${ }^{40}$ Futuro de las Bienales. Mesa Redonda. In: CA. Santiago do Chile: Colégio de Arquitetos do Chile, n. 52, junho de 1988, p.68.
} 
de Álvaro Siza, Rafael Moneo e Manuel Solà-Morales, portanto, foram também convidados para a seção "Encontro" ${ }^{41}$ arquitetos e críticos latino-americanos: Rogelio Salmona, Juvenal Baracco, Mariano Arana e Marina Waisman - que participariam da mesa redonda do I SAL e engajar-se-iam nos seminários subsequentes -; Jorge Glusberg (que auxiliaria na montagem deste primeiro evento); Ricardo Legorreta e Roberto Fernández ${ }^{42}$. Trava-se, como afirma Murtinho ${ }^{43}$, de uma tomada de partido consciente; face à grave crise econômica chilena de 1982, da qual o país tentava se recuperar, aproveitou-se para fazer um evento decididamente ibero-americano:

Para todas as bienais anteriores vinham os arquitetos do Star System: vinham americanos, franceses - um pouco como o CAYC, de Jorge Glusberg, que convida a todo o cenário internacional, com o orgulho de que venham à Bienal. Eu fiz uma Bienal [...] "sem fones de ouvido", ou seja, era em espanhol. ${ }^{44}$

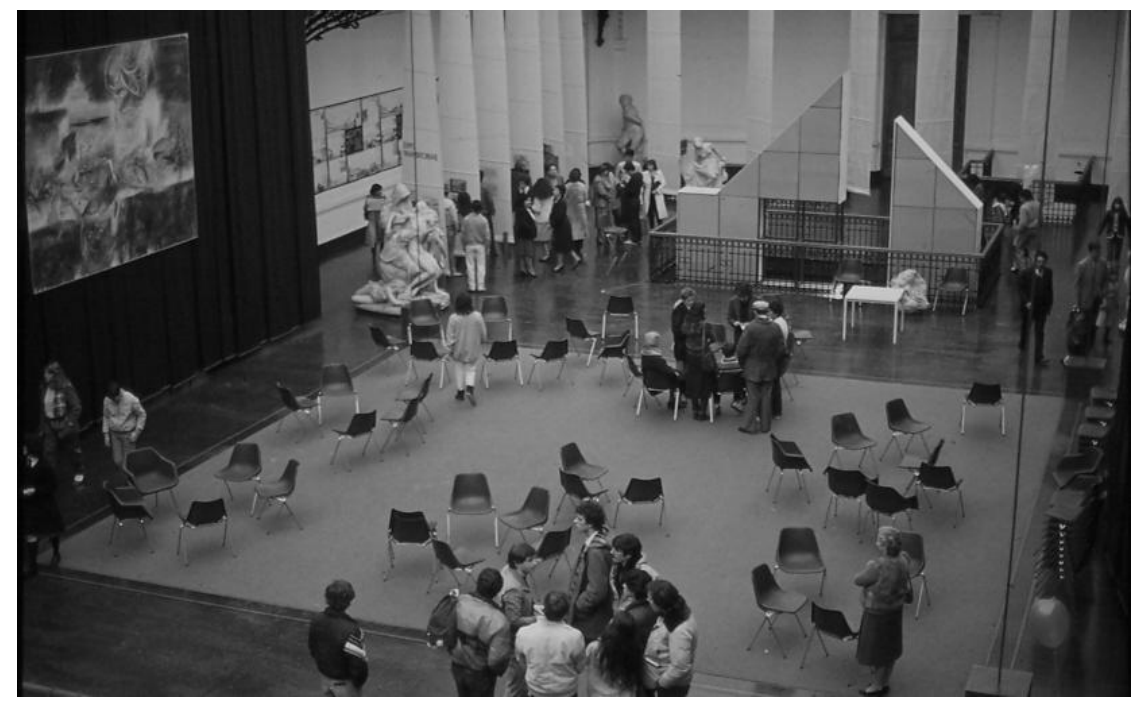

Figura 5: Fotografia da IV Bienal de Arquitetura do Chile, mostra realizada em agosto de 1983. Fonte: Acervo pessoal de Pedro Murtinho.

\footnotetext{
${ }^{41}$ Proposta logo na primeira Bienal, realizada em 1977, esta seção tornou-se um dos pilares das mostras chilenas, sendo o local para o qual convidados estrangeiros eram convidados a debater suas ideias.

${ }^{42}$ Ricardo Legorreta e Roberto Fernández não participaram do I SAL. Para maiores informações sobre a IV Bienal do Chile, ver: CA números 35 e 36, bem como ZEIN, R. V. Patrimônio e presente na Bienal de Arquitetura do Chile. In: Projeto. São Paulo: Projeto, n. 71. jan. 1985, p.36-43.

${ }^{43}$ MURTINHO, Pedro. Depoimento. [20 de outubro de 2011]. Santiago do Chile: Arquivo digital da gravação (1hora e 51min.). Entrevista concedida a Gisela Barcellos de Souza.

${ }^{44}$ MURTINHO, Pedro. Depoimento. [20 de agosto de 2011]. Santiago do Chile: Arquivo digital da gravação (1hora e 57min.). Entrevista concedida a Gisela Barcellos de Souza.
} 
Para definir os convidados internacionais que participariam do evento - após ter sido nomeado como presidente da Bienal em setembro de 1982 -, Murtinho foi à capital da Argentina, pois, segundo o arquiteto chileno "Buenos Aires era uma referência

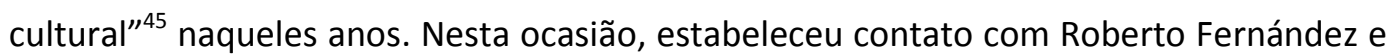
com Ramón Gutierrez, com quem discutiu os possíveis nomes de convidados para a Bienal $^{46}$. Durante sua estadia em Buenos Aires, coincidentemente, ocorria uma palestra de Rogelio Salmona ${ }^{47}$. Murtinho já havia escrito anteriormente a Salmona - após ter tomado conhecimento das "Torres del Parque" através de uma publicação convidando-lhe para a Bienal, porém este teria recusado inicialmente devido à situação política chilena sob a ditadura de Pinochet ${ }^{48}$. A estadia em Buenos Aires permitiu que os dois se conhecessem pessoalmente e que Salmona aceitasse o convite de ir a Santiago do Chile.

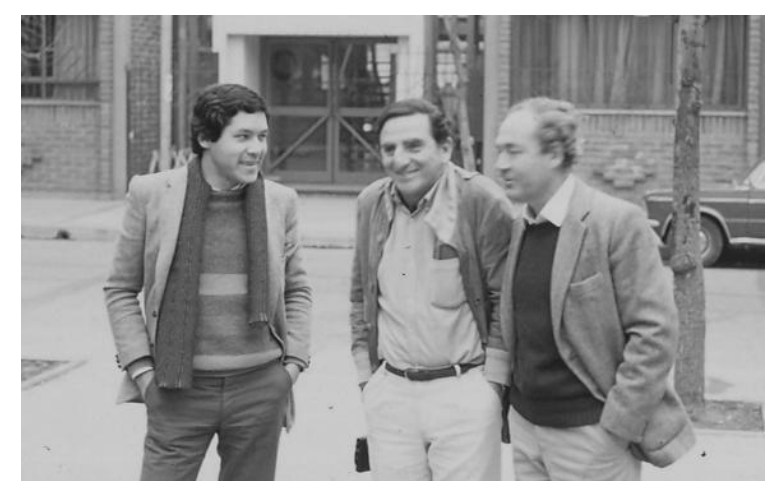

Murtinho destaca a importância deste encontro entre arquitetos da Argentina, Uruguai, Peru, Colômbia e México durante a IV Bienal: "Os convidados [...] não se conheciam antes. Salmona não era conhecido [no Chile]. Ninguém conhecia Legorreta. [...]Juvenal Baracco era ainda menos conhecido [do público chileno] que Salmona"49. Além de contar com as personagens protagonistas do primeiro seminário, questões que seriam objeto de debate futuro já estavam ali lançadas, como podemos perceber na palestra de Fernández $\mathrm{Cox}^{50}$, proferida durante a bienal. Nesta ocasião, o arquiteto

\footnotetext{
${ }^{45}$ MURTINHO, Pedro. Depoimento. [20 de agosto de 2011]. loc. cit.

${ }^{46}$ MURTINHO, Pedro. Depoimento. [20 de agosto de 2011]. loc. cit.

47 Trata-se da palestra ministrada por Salmona em Buenos Aires em dezembro de 1982. Cf SALMONA, R. Notas II. Entrevista a Salmona. In: A/Ambiente. Buenos Aires: CEPA, n. 36, p.32-36, março 1983.

${ }^{48}$ MURTINHO, Pedro. Depoimento. [20 de agosto de 2011]. loc. cit.

${ }^{49}$ MURTINHO, Pedro. Depoimento. [20 de outubro de 2011]. Santiago do Chile: Arquivo digital da gravação (1hora e 51min.). Entrevista concedida a Gisela Barcellos de Souza.

50 "Recado a los arquitectos de Hispanoamérica", cujo resumo foi publicado na revista CA número
} 
chileno já postulava um desajuste entre a busca - no caso, dita hispano-americana por uma "modernidade ilustrada" e a identificação de tudo que era próprio como antimoderno. Como alternativa, propunha uma perspectiva que tivesse como centro o contexto local, através da qual seria possível discernir "o que não é e o que é próprio (apropriável e apropriado) a nossa realidade" ${ }^{251}$.

\section{O papel da revista Summa}

Estabelecido este quadro geral, percebe-se que a construção de um intercâmbio latino-americano estava, no início dos anos 1980, posta claramente em pauta; bastava ser catalisada. Dentro deste contexto multilateral de interesse pelo estabelecimento de encontros e trocas culturais, não se pode, contudo, minimizar a relevância dos agentes catalisadores. Como entender que, face aos numerosos ensaios ensejados alhures, tenha cabido à revista Summa e a sua então editora, Lala Méndez Mosquera, o papel de encabeçá-la?

Em seu texto de apresentação do primeiro Seminário de Arquitetura Latinoamericana - realizado pela ação conjunta da Summa, da FAU-UBA e do CAYC -, Marina Waisman insere a realização deste seminário dentro de um contexto regional de percepção de que a "América Latina só interessa[va] a ela mesma"; ou seja, "quando se tomou consciência, por motivo da dívida externa que estrangula quase todos nossos países, de que estamos todos sendo confinados dentro de um único papel no contexto da economia mundial"52. Antes de apresentar este argumento comum ao subcontinente, porém, esta crítica apresenta outro de grande apelo emotivo para os argentinos naquele momento: a Guerra das Malvinas.

De fato, a Guerra das Malvinas parece ter motivado uma mudança de postura no editorial da Summa; a inserção de latino-americanos deixou de ser uma discreta curiosidade pela produção alheia para se tornar uma bandeira. Logo, aceleraram-se as transformações que se mostravam paulatinamente desde meados da década de 1970.0 primeiro passo, no entanto, foi a busca por uma identidade nacional. A partir deste

\footnotetext{
36 e na revista PROA número 337.

51 FERNÁNDEZ COX, Cristián. Recado a los arquitectos de Hispanoamérica. In: PROA, Bogotá: Ediciones Proa, n. 337, dez. 1984, p. 53.

52 WAISMAN, Marina, Primer Seminario de Arquitectura Latinoamericana. Un auspicioso comienzo. In: Revista Summa, Buenos Aires: Ediciones Summa, n. 217, set. 1985, p.26.
} 
trágico evento, é possível verificar um maior número de reportagens e artigos que buscam fomentar a caracterização nacional da arquitetura argentina. Esta mudança de postura é consciente e até mesmo anunciada nos editoriais de Lala Méndez Mosquera, como podemos ver no excerto abaixo, publicado em 1982:

A preparação de um número que mostrasse uma arquitetura argentina enquadrada na busca de valores próprios, locais, e que se configurasse, portanto, uma expressão mais ou menos consciente de uma identidade nacional, se constituiu em um compromisso interno imediato em nossa Redação a partir da Guerra das Malvinas. Há acontecimentos que modificam substancialmente nossos pontos de referência, nossa escala de valores, e este foi um deles. ${ }^{53}$

Com estas frases se inaugura uma nítida política editorial de "olhar para dentro". Em pouquíssimo tempo, esta postura entraria em ressonância com outras semelhantes nos países vizinhos. O "dentro" foi logo identificado também para além das fronteiras da própria Argentina; tornou-se, em apenas alguns meses, a América Latina como um todo. Citando as discussões do Congresso Brasileiro de Arquitetos realizado na Bahia, em 1982, Lala Méndez Mosquera reconhece a semelhança de debates entre os vizinhos: "o tema da adequação ao meio, inclusive a validade de tal 'adequação', se discute assiduamente entre nós e outros países" ${ }^{\prime 54}$. Encampando - e estendendo-a ao seu país - a posição afirmada no referido congresso de que "as posturas pós-modernas de nenhum modo podem servir como modelo aplicável a um país como o Brasil", a editora aponta como uma possível saída para a realidade latino-americana a tomada de uma atitude austera, que defina "um enquadramento correto e um posicionamento equilibrado de limites" ${ }^{\prime 55}$.

A abertura em direção a uma cultura arquitetônico-urbanística regional reafirma-se no aniversário da revista, em abril de 1983, com a afirmação de que a integração latino-americana seria uma espécie de antídoto:

\footnotetext{
53 MOSQUERA MENDEZ, Lala, Editorial. In: Revista Summa, Buenos Aires: Ediciones Summa, n. 180, out. 1982, p.15

54 MOSQUERA MENDEZ, Lala, Editorial. In: Revista Summa, Buenos Aires: Ediciones Summa, n. 182, dez. 1982, p.13.

${ }^{55}$ MOSQUERA MENDEZ, loc. cit., dez. 1982, p.13.
} 
Posso afirmar, neste aniversário, que pretendemos alcançar um ponderado equilíbrio em nossa prática, como postura geral explicita, entre o voltar-se para dentro e o para fora. [...] Significa propor-se o desenvolvimento de uma cultura nacional e regional (latinoamericana), sem intenção revanchista nem isolacionista: busquemos um equilíbrio interno, não dependente, que nos fortaleça para nos permitir avançar a par dos demais. ${ }^{56}$

Destarte, a partir deste número a rede de relações interpessoais, então incipiente, começa a ser referenciada e pontuada nos editoriais de Lala Méndez Mosquera. Compreende-se, dentro deste quadro, que a editora afirme concordar com Joaquim Guedes ao tecer reflexões sobre a dialética, que se dá no processo criativo, entre a busca do novo e o conhecimento da história ${ }^{57}$. Ou ainda, o fato desta mencionar uma entrevista com Rogelio Salmona ${ }^{58}$ para confirmar a busca, empenhada pela Summa, por novos caminhos, enquadrados em uma "problemática nitidamente latinoamericana" ${ }^{\prime 59}$. Em estratégia semelhante, Lala cita as palestras de Pedro Murtinho e de Humberto Eliash - ministradas no colóquio que ocorreu junto à exposição "Arquitectura en Chile", no CAYC - para fazer avançar o debate sobre a busca de uma identidade latino-americana ${ }^{60}$ :

"Hoje em dia, a situação histórica", disse recentemente Pedro Murtinho, "e o fracasso dos modelos desenvolvimentistas europeu e norte-americano repercutiu no interesse dos latino-americanos em direção à nossa própria reflexão sobre o ego cultural". Sob as pressões dos países desenvolvidos, a América Latina despertou para a busca e o reconhecimento de nosso passado. ${ }^{61}$

\footnotetext{
${ }^{56}$ MOSQUERA MENDEZ, Lala, Editorial. In: Revista Summa, Buenos Aires: Ediciones Summa, n. 186, abril 1983, p.15.

${ }^{57}$ MOSQUERA MENDEZ, Lala, Editorial. In: Revista Summa, Buenos Aires: Ediciones Summa, $\mathrm{n}$. 198, abril 1984, p.19.

${ }^{58}$ Lala Méndez Mosquera não apresenta referências específicas no texto, porém, pelas datas, provavelmente se trata da entrevista com Salmona publicada na revista A/Ambiente - cf. SALMONA, R. Notas II. Entrevista a Salmona. In: A/Ambiente. Buenos Aires: CEPA, n. 36, p.32-36, março 1983.

${ }^{59}$ MOSQUERA MENDEZ, Lala, loc. cit., abril 1984, p.19.

${ }^{60}$ MOSQUERA MENDEZ, Lala, Editorial. In: Revista Summa, Buenos Aires: Ediciones Summa, $\mathrm{n}$. 204, set 1984, p.22.

${ }^{61}$ MOSQUERA MENDEZ, Lala, Editorial. In: Revista Summa, Buenos Aires: Ediciones Summa, $\mathrm{n}$. 204, set 1984, p.22.
} 
Somar-se-iam a estes editoriais um número crescente de reportagens e artigos sobre temas latino-americanos, apesar das dificuldades de comunicação e de acesso às demais revistas do subcontinente, frequentemente mencionada ${ }^{62}$. De tal sorte que - à exceção de Assis $\operatorname{Reis}^{63}$-, os arquitetos convidados para apresentar suas obras e proferir as palestras magistrais do Primeiro Seminário de Arquitetura Latino-americana já haviam passado pelas páginas da revista Summa e/ou da coleção Summarios em anos e edições anteriores.

A importância do papel exercido por Lala Méndez Mosquera na organização dos primeiros seminários seria reconhecida, posteriormente, no III SAL. No evento realizado na Colômbia, rendeu-se uma homenagem especial em gratidão à sua contribuição e ao seu empenho pessoal para o estabelecimento destes intercâmbios:

A revista Summa teve, por conseguinte, nestes Encontros um papel preponderante. Queremos aproveitar que sua diretora Lala Méndez Mosquera está presente entre nós para lhe agradecer e lhe dar uma lembrança carinhosa assinada por todos os assistentes e convidados ${ }^{64}$.

Este reconhecimento da relevância da Summa e de sua editora na organização dos primeiros eventos, no entanto, desapareceria em algumas das narrativas de conjunto posteriores ${ }^{65}$ tendentes a representar o I SAL como um evento que se deu de forma espontânea em reação à I Bienal de Arquitetura de Buenos Aires - que havia alocado as palestras dos convidados norte-americanos e europeus no teatro San Martín e as dos arquitetos latino-americanos na Faculdade de Arquitetura da UBA. Oculta-se, no entanto, nesta interpretação, o fato de que o Seminario de Arquitetura Latino-

${ }^{62}$ WAISMAN, M. "Primer Seminario de Arquitectura Latinoamericana. Un auspicioso comienzo". In: Summa, Buenos Aires: Ediciones Summa, 217, set. 1985, p.26-27

${ }^{63} \mathrm{~A}$ inserção de Assis Reis deve-se, provavelmente, ao intercâmbio já estabelecido com a Projeto - desde o embrião desta revista junto ao IAB/SP - , entretanto, esta inserção deveria ser ainda mais estudada. Deve-se salientar, no entanto, que este arquiteto brasileiro não aparece entre as "personalidades convidadas para o evento" listadas em nota de divulgação publicada na Summa $\mathrm{n}^{\circ} 212$, de maio de 1985.

${ }^{64}$ Cf. SALMONA, Rogelio. Clausura al III Encuentro de Arquitectura Latinoamericana. In: III Encuentro de Arquitectura Latinoamericana. Buenos Aires: CAPBA D III, 1988, p.111.

${ }^{65}$ Esta interpretação tende a ampliar o papel de Gutiérrez na articulação dos primeiros SAL e foi ratificada pelos depoimentos de: Jorge Moscato (em 25 de agosto de 2011), Ramón Gutiérrez (em 11 de novembro de 2011), Humberto Eliash (em 18 de julho de 2011) e Cristián Boza (em 10 de outubro de 2011). Esta mesma abordagem é defendida por Gutiérres em: GUTIÉRREZ, R. Seminarios de arquitectura latino-americana. Uma experiencia de reflexión (1985-2009) In: GUTIÉRREZ, R.; MÉNDEZ, P. (org). Seminario de Arquitetura Latinoamericana (SAL). Haciendo el Camino al andar 1985-2011. Buenos Aires: CEDODAL, 2011. 
americana estava previsto, com este nome, no programa da I Bienal de Arquitetura de Buenos Aires ${ }^{66}$, como atividade cuja organização fora compartilhada entre a Summa, a Faculdade Arquitetura e Urbanismo da UBA e o CAYC. Décadas mais tarde, Gutiérrez chegaria a descrever, inclusive, a organização do segundo seminário pela revista Summa como fato circunstancial:

Na espontaneidade da circunstância, a consciência de nossas limitações para dar continuidade ao movimento que se iniciava, agravado em meu caso pessoal pelo fato de residir em uma periferia longínqua da metrópole portenha, fez com que buscássemos o apoio da equipe que, através da área da história da arquitetura, havíamos instrumentado e que se havia expressado em textos da revista Summa em torno de Marina Waisman. A solidariedade de Marina, unida à equipe de seus colaboradores, sobretudo Marcelo Martín, Julio Caccioatore, Miriam Chandler, Alberto Petrina, Patricia Méndez e Adriana Irigoyen, asseguraria a realização de um Segundo Encontro a realizar-se em Buenos Aires e convocado então por Lala Méndez Mosquera, diretora da casa editorial ${ }^{67}$.

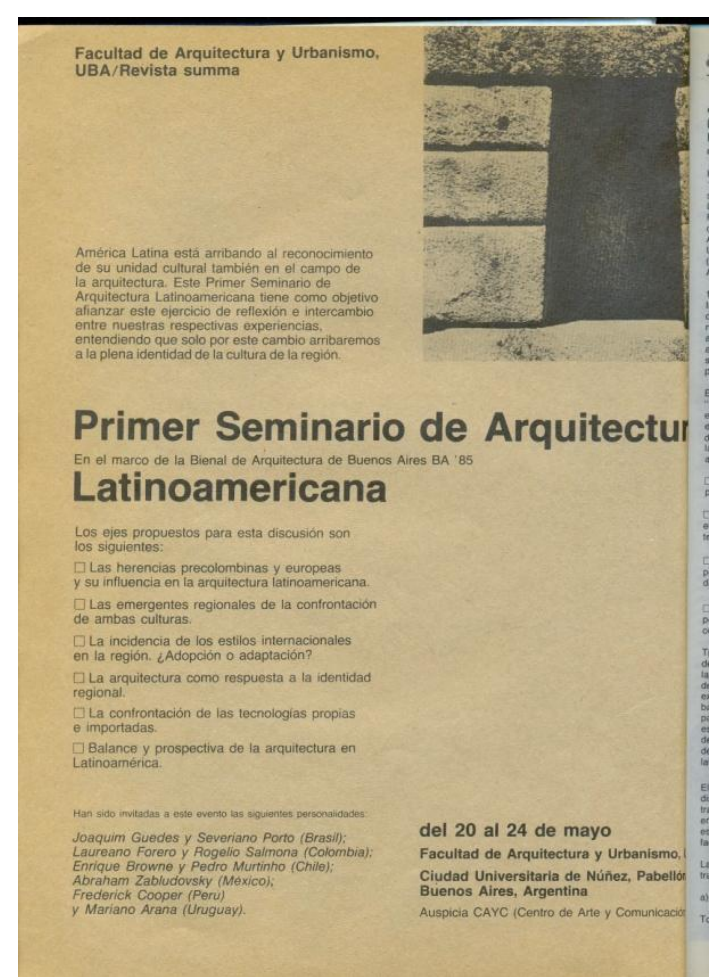

Figura 7: Divulgação do primeiro SAL, realizado entre 20 a 24 de maio na Faculdade de Arquitetura e Urbanismo da Universidad de Buenos Aires, na e dição da revista Summa, número 212, de maio de 1985. Fonte: Summa, n. 212, mai. 1985.

${ }^{66}$ EL PROGRAMA definitivo. Bienal Internacional de Arquitectura de Buenos Aires 85. Clarín Arquitectura, Ingenieria, Planeamiento y Diseño. Buenos Aires, Edición Especial, p.16, mai 1985. ${ }^{67}$ GUTIÉRREZ, R. loc. cit., 2011, p.20. 


\section{Um tema latente e a oportunidade para desenvolvê-lo}

Através deste breve percurso, percebe-se que, face à multiplicidade do somatório de pequenos fatos que compõe o pano de fundo para a criação dos SAL, qualquer tentativa de panorama incorreria em numerosas omissões. Entretanto, por mais amplo que seja este conjunto, este apenas nos evidencia a existência de um interesse multilateral pelo estabelecimento de um intercâmbio; pouco nos diz a respeito das motivações de fundo que conduziram a este. Em sua comunicação proferida no SAL IV, realizado em 1989, Carlos Eduardo Comas ensaia uma tentativa de generalização, afirmando que a "preocupação com a caracterização de nação latino-americana" era, em parte, fruto do desencanto comum "com a tecnolatria e o reducionismo universalista das soluções típicas da arquitetura e urbanismo 'desenvolvimentistas' das décadas de 60 e $70^{\prime \prime 68}$. Em outra, denotava também a perplexidade em relação aos rumos tomados pelos "movimentos arquitetônicos que agitaram Europa e Estados Unidos na década de 70, [reduzidos agora] a novos figurinos internacionais e descontextualizados" ${ }^{69}$.

O desencanto e o distanciamento em relação à diversidade da produção arquitetônica então dita "pós-moderna" também são afirmados por Ramírez Nieto ${ }^{70}$, que, em função destes, vê nos primeiros Seminários de Arquitetura Latino-americana uma atitude de resistência. Segundo este autor, em meio à ambiguidade das informações recebidas na Colômbia sobre a produção estrangeira coetânea, a Universidade Nacional da Colômbia organizou em 1980 um seminário para reflexão da produção nacional das últimas duas décadas - intitulado "Panorama da Arquitetura 1980-1960"71 —, o qual teria sido, neste país, o início da busca por critérios adequados à realidade local ${ }^{72}$. Arango, para além da resistência às influências estrangeiras, destaca, também, o papel específico de Rogelio Salmona, que teria sido o grande agente

68 COMAS, C. E, Identidade Nacional, caracterização arquitetônica. In: IV Encuentro de Arquitectura Latinoamericana/ México. "La Trindad”, Tlaxcala, Tlaxcala (México): Universidad Autónoma Metropolitana, 1989, paginação irregular.

${ }^{69}$ COMAS, C. E, 1989, paginação irregular.

70 RAMÍREZ NIETO, Jorge. El pensamiento a través de los Seminarios de Arquitectura latinoamericana. In: XI Seminario de Arquitectura Latinoamericana. Oaxtepec (México), 2005.

71 Neste seminário participaram, entre outros, Silvia Arango, Alberto Saldarriaga e Lorenzo Fonseca - cf. Ramírez Nieto, 2005.

72 RAMÍREZ NIETO, loc. cit. 2005. 
motivador do interesse pelos aspectos latino-americanos na cultura arquitetônica colombiana $^{73}$. Segundo a arquiteta colombiana, na virada dos anos 1970 aos anos 1980, Salmona começa a realizar uma série de viagens por países do subcontinente e "fica muito impressionado com a força da paisagem latino-americana" ${ }^{\prime 74}$.

Para além das atitudes de perplexidade, desencanto e resistência descritas acima pelos arquitetos brasileiro e colombianos, não se pode deixar de observar que o tema relativo à identidade - nacional ou latino-americana - não é uma invenção dos Seminários de Arquitetura Latino-americana, este foi abordado por agentes culturais distintos, em diferentes momentos ao longo do século vinte - vejam-se, por exemplo, os debates os primeiros Congressos Panamericanos de Arquitetos ${ }^{75}$. Contudo, ainda que se reconheça este tema como latente, os aspectos que o permitiram aflorar devem ser considerados. Através do percurso pelas múltiplas origens dos SAL, observa-se que, de modo geral, há um acúmulo de encontros entre os arquitetos que viriam a constituir estes seminários a partir do início dos anos 1980.

Não por acaso, a referência à situação econômica comum como um elemento que aproxima estes países é citada com frequência em narrativas da época e em depoimentos. Deve-se lembrar que, a despeito da primeira crise do petróleo, em 1973, os países do subcontinente mantiveram, na média, as taxas de crescimento semelhante ao período de prosperidade do segundo pós-guerra até o final da década, fomentadas pela facilidade do empréstimo de divisas e os juros baixos ${ }^{76}$. 0 grau de endividamento dos países latino-americanos entre 1973 e 1979, no entanto, tornou a região extremamente vulnerável ${ }^{77}$. O quadro de crescimento se inverteria, portanto, com a alta elevação dos juros em 1982 - após segunda crise do petróleo, em 1979, e os efeitos

\footnotetext{
${ }^{73}$ ARANGO, Silvia. Depoimento. [11 de novembro de 2011]. Campinas: Arquivo digital da gravação (1hora e 11min.). Entrevista concedida a Gisela Barcellos de Souza.

${ }^{74}$ ARANGO, Silvia. Depoimento. [11 de novembro de 2011]. Campinas: Arquivo digital da gravação (1hora e 11min.). Entrevista concedida a Gisela Barcellos de Souza.

${ }^{75}$ Esta questão foi abordada por Manuel Moreno em: MORENO, Manuel. Identidad y Arquitectura: un tema recurrente en el sur de América. In: Summa. Buenos Aires: Ed. Summa. N.286/287, jun./jul. 1991, p.103-105.

${ }^{76}$ Cf. FFRENCH-DAVIS, R.; MUÑOZ, O.; PALMA, J.G. As Economias Latino-americanas, 1950-1990. In: BETHELL (org) História da América Latina. América Latina após 1930: Economia e Sociedade. São Paulo: Edusp, 2009, p.129-231.

${ }^{77}$ FFRENCH-DAVIS, R.; MUÑOZ, O.; PALMA, J.G., loc cit., 2009.
} 
econômicos da implantação inicial das políticas econômicas de Reagan e Thatcher ${ }^{78}$-, o que viria a configurar a chamada Crise da Dívida Externa na América Latina.

De fato, parece haver uma correlação entre a crise de 1982 e o surgimento do interesse em refletir a partir da condição latino-americana. No Chile, não se pode esquecer que o Taller América foi gestado exatamente no mesmo ano da crise financeira. Além disso, a referência à crise apareceu nos depoimentos de Pedro Murtinho, Humberto Eliash e Enrique Browne ${ }^{79}$. Este último chegou a explicar através da crise, e da falta de trabalho no Chile no início dos anos 1980, o surgimento de seu interesse em postular a bolsa Fundação Guggenheim - através da qual se financiou a pesquisa que resultou no livro "Otra Arquitectura". A associação entre o interesse em discutir aspectos teóricos da arquitetura e a crise da década de 1980 também aparece nos depoimentos de Carlos Eduardo Comas e Hugo Segawa ${ }^{80}$. Para Ruth Verde Zein, o interesse pelo estabelecimento de intercâmbios latino-americanos nos anos 1980 corresponde a "um desejo geracional" ${ }^{\text {11. }}$.

No caso argentino, em específico, para além do aspecto da crise financeira e da Guerra das Malvinas, não se pode deixar de ressaltar o papel do engajamento político de viés nacionalista de alguns dos personagens que, posteriormente, estariam à frente da constituição dos SAL. Esta premissa não se aplica, obviamente, à Marina Waisman; contudo, não é possível deixar reconhecer a importância do peronismo no pensamento de Ramón Gutierrez, Alberto Petrina e Jorge Moscato ${ }^{82}$.

\footnotetext{
${ }^{78}$ Ver a este respeito: HARVEY, David. Condição Pós-Moderna. São Paulo: Ed. Loyola, 1992.

79 Cf. MURTINHO, Pedro. Depoimento. [20 de outubro de 2011]. Santiago do Chile: Arquivo digital da gravação (1hora e 51min.). Entrevista concedida a Gisela Barcellos de Souza. ELIASH, Humberto. Depoimento. [18 de julho de 2011]. Santiago do Chile: Arquivo digital da gravação (2horas e 13min.). Entrevista concedida a Gisela Barcellos de Souza. BROWNE, Enrique. Depoimento. [13 de setembro de 2011]. Santiago do Chile: Arquivo digital da gravação (2horas e 1 min.). Entrevista concedida a Gisela Barcellos de Souza.

${ }^{80}$ COMAS, Carlos Eduardo Dias. Depoimento. [01 de abril de 2011]. Porto Alegre: Arquivo digital da gravação (4horas e 37min.). Entrevista concedida a Gisela Barcellos de Souza. SEGAWA, Hugo Massaki. Depoimento. [06 de abril de 2011]. São Paulo: Arquivo digital da gravação (1hora $e$ 34min.). Entrevista concedida a Gisela Barcellos de Souza.

${ }^{81}$ ZEIN, Ruth Verde. Depoimento. [05 de abril de 2011]. São Paulo: Arquivo digital da gravação (1hora e 57min.). Entrevista concedida a Gisela Barcellos de Souza.

${ }^{82}$ Este é um aspecto destacado por Moscato e Schere no livro: MOSCATO, J.; SCHERE, R. Arquitectura e ideología. México: Menhir Libros. 2000. A importância deste engajamento político também compareceu nos depoimentos de Gutiérrez e Moscato -cf. GUTIÉRREZ, Ramón. Depoimento. [11 de novembro de 2011]. Campinas: Arquivo digital da gravação (1hora $e$ 39 min.). Entrevista concedida a Gisela Barcellos de Souza e MOSCATO, Jorge. Depoimento. [25 de
} 
Soma-se à percepção da situação econômica comum a ideia proximidade reforçada pela volta à democracia em muitos dos países latino-americanos, dentre os quais destacamos aqueles que seriam representados nos primeiros SAL: Peru, em 1980; Argentina, em 1983; o Brasil e Uruguai em $1985^{83}$ - apenas o Chile construiria uma exceção. O clima de otimismo frente à abertura política e cultural favoreceu a busca pelo estabelecimento de intercâmbios.

\subsection{Uma orquestra polifônica - primeiros seminários}

Realizado este breve percurso sobre os indícios de um interesse multilateral no estabelecimento de um intercâmbio de arquitetos latino-americanos, é preciso agora retomar a problemática deste texto. Logo, buscar-se-á demonstrar que os primeiros SAL, longe de refletirem consensos, foram tentativas de orquestração de vozes dissonantes. Entre estas, a cidade latino-americana nunca surgiu como um tema concreto; somente, porém, como conjunto de representações que surgiram em meio aos debates e serviram para urdidura das arguições ali apresentadas.

Como já afirmamos, as conferências e os debates dos dois primeiros Seminários de Arquitetura Latino-americana, ao contrário dos outros três eventos subsequentes, não foram objeto de publicação organizada em forma de anais. Tratava-se, naquele momento, de iniciar a construção de um espaço latino-americano para discussão de sua arquitetura. Obviamente, ao realizar estes primeiros eventos, não se tinha a certeza de sua continuidade, nem das proporções que estes tomariam. Responsável pela organização de ambos os eventos, a revista Summa preocupou-se em fomentar a discussão, mais que documentá-la.

Compreende-se, dentro deste contexto, a precedência a estes eventos de números intitulados "Arquitectura Ibero-americana" e "Arquitectura Ibero-americana II", publicados em abril de 1985 e em dezembro de 1986, respectivamente. Nestes números, a compilação de trabalhos de arquitetos cujas obras seriam apresentadas e

agosto de 2011]. Buenos Aires: Arquivo digital da gravação (2horas e 25min.). Entrevista concedida a Gisela Barcellos de Souza.

${ }^{83}$ Ver a respeito: HARTLYN, J. A democracia na América Latina após 1930. BETHELL (org) História da América Latina. América Latina após 1930: Estado e Política. São Paulo: Edusp, 2009, p.127197. 
discutidas nos seminários era acompanhada por textos teóricos que visavam ampliar a argumentação sobre o assunto ${ }^{84}$. Por ocasião do II SAL, procurou-se dilatar o debate através do envio de um questionário organizado pela Summa - com as perguntas que orientaram a mesa redonda do evento - a vinte arquitetos argentinos e, posteriormente, aos críticos Ruth Verde Zein, do Brasil, e Gustavo Medeiros, da Bolívia. As respostas recebidas a este questionário foram publicadas nos números da Summa que se dedicaram ao segundo seminário; tanto no primeiro, relativo à sua preparação, quanto nos dois subsequentes, que se destinaram ao seu registro.

Ora, se grande parte do que fora publicado nos números da revista Summa que compõem nosso corpus sobre os dois primeiros SAL não ocorrera de fato durante estes, há de se perguntar o que foram exatamente estes eventos. Para tanto, é preciso recorrer às breves crônicas que foram elaboradas sobre estes - as quais constam na Summa 217, de setembro de 1985, e 235, de março de 1987 -, bem como às transcrições das mesas redondas que foram divulgadas - edições número 214 , de julho de 1985 , e 235 , de abril de 1987 - aos depoimentos daqueles que participaram desdes eventos.

\section{Urdidura de vozes dissonantes}

Ambos os eventos tiveram organizadores semelhantes - com a revista Summa e a Universidade Nacional de Buenos Aires a sua frente ${ }^{85}$ - e ocorreram no mesmo local, a Faculdade de Arquitetura e Urbanismo da Universidade de Buenos Aires; os momentos em que se deram, contudo, foram bem distintos. Enquanto durante o I SAL esta instituição de ensino também fora palco das palestras noturnas da Primeira Bienal de Buenos Aires ${ }^{86}$; o segundo seminário, realizado um ano depois, foi "um dos

\footnotetext{
${ }^{84}$ No primeiro número nomeado Arquitectura Iberoamérica - Summa 212 -, publicaram-se os seguintes textos: "América Latina y la democracia moderna. La tradición antimoderna" de Octavio Paz; "La cultura latinoamericana ante los desafíos de la modernización" de Pedro Morandé; "Alineación e integración en el traspaso de las ideologías" de Marina Waisman; "Arquitectos sudamericanos, 1985: problemas, preocupaciones, perspectivas y responsabilidades" de Joaquim Guedes; "Las culturas, portadoras de la vida posible" de Carlos Fuente; e "Identidad y región: recorrido crítico de la arquitectura en América latina" de Jorge Glusberg. No segundo, o número 232 da Summa, a discussão fora introduzida apenas com o texto de Enrique Browne "Espiritu de la época y espiritu del lugar".

${ }^{85}$ No I SAL contou-se também com auxílio do CAYC.

${ }^{86}$ Artifício improvisado por Glusberg e Dujovne para contornar a situação inesperada de o número de inscritos ter superado a capacidade do local reservado para a bienal (cf. Glusberg,
} 
acontecimentos mais concorridos do ano na $\mathrm{FAU}^{\prime \prime 87}$ e aconteceu entre as avaliações dos trabalhos de conclusão de curso.

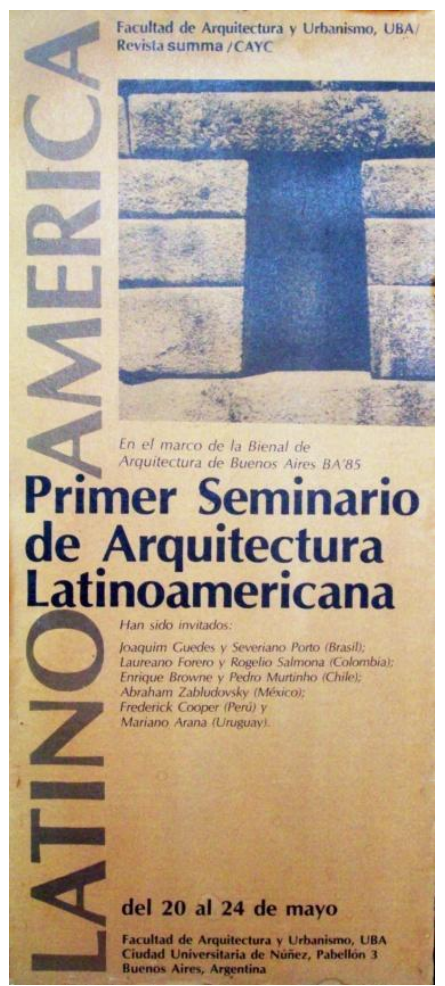

Figura 8: Cartaz do I SAL. Fonte: Acervo pessoal de Enrique Browne.

A simultaneidade da exposição bienal não pareceu, no entanto, diminuir o número de participantes do primeiro encontro latino-americano, realizado durante as manhãs de 20 a 25 de maio de 1985. Pelo contrário, ambos os eventos foram associados: propôs-se o I SAL como um marco da I Bienal ${ }^{88}$, cujo tema, "Identidade e Região", fora, nas palavras de Glusberg, "consequência das inquietudes que, nos últimos anos, se manifestam entre os arquitetos latino-americanos" ${ }^{\prime \prime 9}$. Destarte, as manhãs dedicadas ao SAL contaram com uma multidão de arquitetos e estudantes ${ }^{90}$. Nestas seções matutinas, os arquitetos convidados - Pedro Murtinho e Enrique Browne, do Chile; Mariano Arana, do Uruguai; Zabludovsky, do México; Rogelio Salmona e Laureano

1985).

${ }^{87}$ Crónica de II SAL. Latinoamérica: balance y prospectiva. In: Summa. Buenos Aires: Ediciones Summa, n. 235, março de 1987.

${ }^{88}$ Vinculação presente em nota de divulgação do Primeiro Seminário de Arquitetura Latinoamericana, publicada na Summa 212, de maio de 1987, bem como na transcrição da mesa redonda do I SAL, publicada na Summa 214, de julho de 1985, p.24.

${ }^{89}$ Glusberg, Jorge. Bienal Internacional de Arquitectura de Buenos Aires BA/85. In: Summa. Buenos Aires: Ediciones Summa, n. 217, setembro de 1985, p. 29.

90 Waisman, Marina. Primer Seminario de Arquitectura Latinoamericana. Un auspicioso comienzo. In: Summa. Buenos Aires: Ediciones Summa, n. 217, setembro de 1985, p. 26. 
Forero, da Colômbia; Joaquim Guedes, Assis Reis e Severiano Porto, do Brasil apresentaram suas obras e suas posturas teóricas.

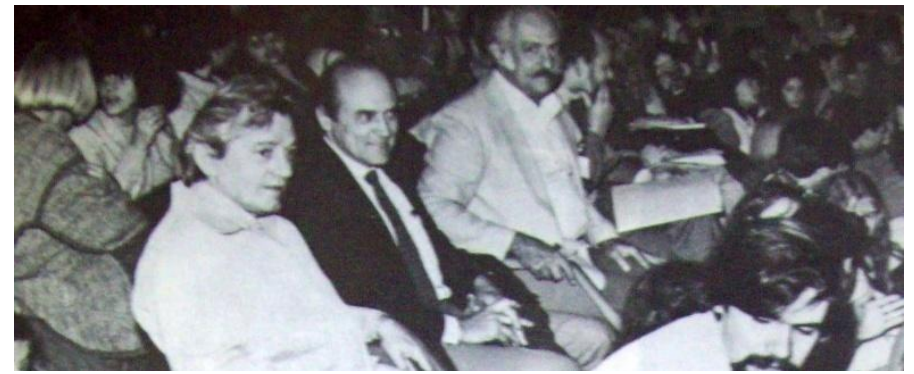

Figura 9: Assis Reis, Joaquim Guedes e Severiano Porto na plateia do I SAL. Fonte: Summa, $\mathrm{n}$. 217, set. 1985.

A crônica escrita por Marina Waisman nos permite perceber que as palestras então proferidas estavam longe de construir um consenso. $O$ debate fomentado na Argentina, principalmente pela ação de Lala Méndez Mosquera, através da Summa, e de Ramón Gutiérrez, encontrou ressonâncias diretas apenas entre os colombianos e, sobretudo, entre os chilenos - a cronista afirma que Browne, ao apresentar a sua proposta de conjunção entre o "espírito do tempo" e o "espírito do lugar", apresentara a reflexão mais sólida do simpósio ${ }^{91}$. Entre os demais países representados, a adesão por completo não ocorre: Mariano Arana enfocara, para a decepção dos organizadores, sua atuação política em detrimento da exposição dos trabalhos que vinha desenvolvendo em Montevidéu; Joaquim Guedes espantara os presentes com uma palestra que foi percebida como a "proposição de uma espécie de suicida laissez faire de ultradesenvolvimento" ${ }^{\prime 2}$; por último, Zabludovsky enfatizara em demasia os aspectos construtivos de sua obra, sem passar por questões teóricas ${ }^{93}$.

Apesar de reconhecer estas dissonâncias, o texto de Waisman procura dirimilas; reforçam-se, para tanto, os pontos comuns e tenta-se dotar de coerência o conjunto do evento. Assim, Rogelio Salmona e Severiano Porto - que recebera na bienal o prêmio latino-americano da UNBA - são apontados como as grandes estrelas do evento, em cujas obras as proposições teóricas de Browne tornavam-se patentes ${ }^{94}$. Dentre os resultados deste seminário, a cronista indica o descobrimento da qualidade da arquitetura latino-americana contemporânea, força a percepção coletiva de "afãs

\footnotetext{
91 Waisman, Marina. Primer Seminario de Arquitectura Latinoamericana. Un auspicioso comienzo. In: Summa. Buenos Aires: Ediciones Summa, n. 217, setembro de 1985, p. 26.

92 Waisman, Marina. loc. cit., set. 1985, p. 27.

${ }^{93}$ Waisman, Marina. loc. cit., set. 1985, p. 26-27.

${ }^{94}$ Waisman, Marina. loc. cit. set. 1985, p. 27.
} 
comuns de busca de uma identidade arquitetônica e da variedade de vias pelas quais esta pode seguir" significar "antes de tudo, estar em dia com o que ocorre na América Latina" ${ }^{96}$.

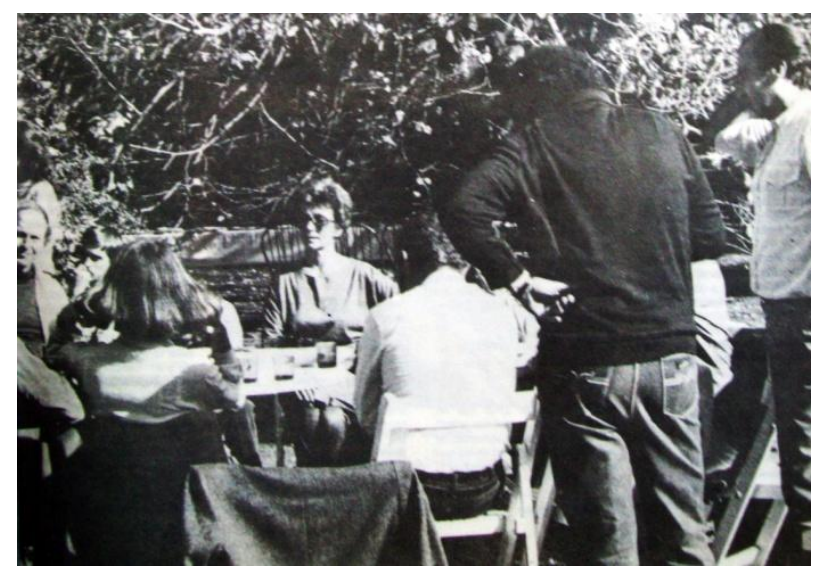

Figura 10: Fotografia da mesa redonda do I SAL, realizada na chácara de Lala Méndez, em maio de 1985. Fonte: Summa, n. 214, jul. 1985.

As diferenças, ligeiramente narradas por Marina Waisman, entre os palestrantes do primeiro SAL apareceram com maior nitidez na mesa redonda organizada pela Summa, na chácara de Lala Méndez ${ }^{97}$, e integralmente transcrita em seu número 214, de julho de 1985. Compuseram esta mesa os arquitetos cujas obras foram debatidas nas seções do SAL - exceto Zabludovsky -, bem como membros da Summa e outros arquitetos latino-americanos que haviam sido convidados pela Bienal - Juvenal Baracco e Pedro Belaúnde, do Peru, e Ruth Verde Zein ${ }^{98}$, do Brasil. A revista Summa fora representada por Lala Méndez Mosquera, Marina Waisman, Marcelo Martín, Julio Cacciatore e Miriam Chandler. $\mathrm{O}$ debate orientou-se em torno de três questões: a primeira relativa à adoção ou à adaptação de estilos internacionais incidentes na região; a segunda sobre a arquitetura como identidade regional e a terceira, e última, sobre as tecnologias próprias ${ }^{99}$.

As discussões iniciaram-se com a própria definição de América Latina e, consequentemente, de sua identidade. Salmona, por exemplo, defendia a

\footnotetext{
${ }^{95}$ Waisman, Marina. loc. cit., set. 1985, p. 27.

96 Waisman, Marina. Primer Seminario de Arquitectura Latinoamericana. Un auspicioso comienzo. In: Summa. Buenos Aires: Ediciones Summa, n. 217, setembro de 1985, p. 27.

${ }^{97}$ ZEIN, Ruth Verde. Depoimento. [05 de abril de 2011]. São Paulo: Arquivo digital da gravação (1hora e 57min.). Entrevista concedida a Gisela Barcellos de Souza.

${ }^{98}$ Segundo Ruth Verde Zein, sua participação na mesa redonda não foi programada, foi a convite de Joaquim Guedes e Severiano Porto. Cf. ZEIN, Ruth Verde. Depoimento. [05 de abril de 2011], loc. cit.

99 Primer Seminario de Arquitectura Latinoamericana. In: Summa, Buenos Aires: Ediciones Summa, 214, de julho de 1985, p.24.
} 
impossibilidade de resposta às questões postuladas sem sua matização prévia nas diferentes regiões do subcontinente, afirmando que não havia uma identidade homogênea e apoiada em contornos geográficos. Avançando nesta questão, alguns, como Murtinho, apontaram a existência de três regiões - a das grandes civilizações pré-colombianas, a do Cone Sul e a lusitana -, outros, como Arana, percebiam a diversidade dentro de um mesmo país. Para alguns, como Browne, a identidade latinoamericana era uma essência a descobrir; enquanto para outros, esta era patente Assis Reis, por exemplo, propunha a sua identificação a partir dos aspectos socioeconômicos e históricos comuns aos países latino-americanos. Em geral, apontouse uma crise de identidade cultural. No entanto, na posição extrema, Juvenal Baracco, afirmou a inexistência de "problemas de identidade"100 e que estas seriam uma construção de intelectuais e críticos.

Situação semelhante se repete quando se analisam as respostas sobre as outras questões do debate. Sobre o tema da penetração de influências estrangeiras no subcontinente, as posturas oscilaram, em geral, entre os que buscaram diferenciar seus impactos nas distintas regiões - afirmando que em determinadas situações estes foram extremamente nefastos -; e outros que defenderam que sempre houve uma tradução cultural. Neste contexto, a voz mais dissonante fora, de fato, a de Joaquim Guedes, que questionou a pertinência do debate ao afirmar ser impossível negar a invasão cultural internacional e ser preciso "viver com coragem, sem olhar para o passado" ${ }^{101}$ a fim de resolver os problemas mais prementes da sociedade contemporânea. Sobre o uso de tecnologias apropriadas, o debate mais acirrado deu-se entre Severiano Porto e Guedes, entre uma postura pela utilização de técnicas tradicionais regionais e a defesa do uso da pré-fabricação em massa.

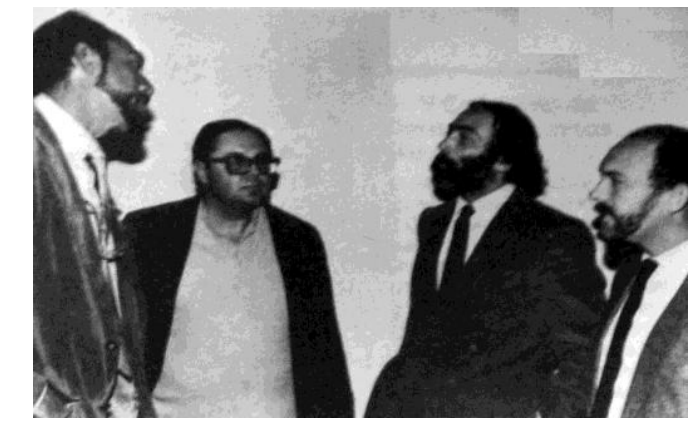

100 Primer Seminario de Arquitectura Latinoamericana. In: Summa, Buenos Aires: Ediciones Summa, 214, de julho de 1985, p.24.

${ }^{101}$ Primer..., loc. cit., jul. 1985, p.24.
Figura 11: Oscar Tenreiro, Ramón Gutiérrez, Cristián Boza e Pedro Belaúnde em conversa informal durante o I SAL. Fonte: Summa, n. 217, set. 1985. 
A existência de notas desarmônicas neste evento não impediu, no entanto, que este construísse algumas confluências de ideias que constituiriam o lastro sobre o qual se apoiaram os eventos subsequentes. Entre os eventos paralelos ao I SAL e à Primeira Bienal de Buenos Aires, houve uma reunião conduzida na Sociedade Central de Arquitetos Argentinos na qual se discutiu, elaborou, e referendou a "Convocatória para uma Proposta Iberoamericana em Arquitetura" ${ }^{102}$, posteriormente também nomeada de “Carta de Buenos Aires" ${ }^{103}$. Este documento, promovido, entre outros, por Ramón Gutiérrez , Lala Méndez Mosquera ${ }^{104}$ e Rogelio Salmona ${ }^{105}$, circulou entre outros eventos latino-americanos realizados no mesmo ano a fim de recolher assinaturas 150 arquitetos firmaram este documento, dos quais 111 eram argentinos, 16 chilenos, 9 uruguaios e 15 dividiam-se entre colombianos, peruanos, brasileiros ${ }^{106}$, equatorianos, costarriquenhos, boliviano e paraguaio ${ }^{107}$.

Este evento ocorreu como forma de reação à forma com que foi conduzida a I Bienal e ao papel secundário que foi delegado aos arquitetos latino-americanos, como descreve Ruth Verde Zein:

Eu me lembro da cena: o Salmona, o Ramón conversando e passando o abaixo-assinado, indignados [...] com a Bienal, com o internacionalismo do Glusberg. Eu estava lá numa situação delicada, porque eu era convidada do Glusberg. Nunca vi muita contradição entre as duas coisas, eu também achava interessante ver aqueles arquitetos internacionais. ${ }^{108}$.

Trata-se do único manifesto coletivo assinado e vinculado diretamente à esfera ampla dos SAL produzido durante os dez anos em que estes seminários tiveram uma atuação programática - e, inclusive, o evento que lhe deu origem foi considerado por

\footnotetext{
102 MOSQUERA MENDEZ, Lala. Editorial. In: Summa, Buenos Aires: Ediciones Summa, n. 218, outubro de 1985, p. 17.

103 GUTIÉRREZ, R., et al (org). Arquitectura Latinoamericana. Pensamiento y Propuesta. México: UAM/Unidad de Xochimilco. 1991.

104 GUTIÉRREZ, R., et al (org). op. cit., p.55.

${ }^{105}$ Cf. Proa Notícias. In: PROA, Bogotá: Ediciones Proa, n. 351, junho de 1986, p.26.

106 Apenas dois arquitetos brasileiros assinaram este documento: Maria Luiza de Carvalho (na condição de representante da revista Módulo) e Severiano Porto. GUTIÉRREZ, R., et al (org). op. cit., 1991, p. 56.

107 GUTIÉRREZ, R., et al (org). op. cit., 1991, p. 56.

${ }^{108}$ ZEIN, Ruth Verde. Depoimento. [05 de abril de 2011]. São Paulo: Arquivo digital da gravação (1hora e 57min.). Entrevista concedida a Gisela Barcellos de Souza.
} 
algumas revisões posteriores como sendo o primeiro SAL de fato ${ }^{109}$. Seus propósitos baseiam-se, grosso modo, na negação da "complacente atitude de transcrição da produção dos centros do pensamento arquitetônico"110; na proposição de uma "nova práxis arquitetônica [... que se apoie na] revalorização de nosso entorno e nossa história"111 e no respeito às identidades culturais; e na busca pela maior proximidade entre teoria e prática e pela elaboração de uma teoria válida, as quais passariam por uma reorientação do ensino no subcontinente ${ }^{112}$. Os subscritores deste manifesto se definem como "grupo de discussão e proposta que encarará encontros periódicos iberoamericanos, bem como uma equipe de reflexão tendente à elaboração de uma teoria arquitetônica própria"113.

Malgrado o fato de não ter ocorrido durante o I SAL, nem contado com a adesão de todos os arquitetos convidados pela Summa para apresentarem sua obra neste Assis Reis, Joaquim Guedes e Abraham Zabludovsky não constam na lista de subscritores - e de ter sido firmada ao longo de outros eventos posteriores, a Carta de Buenos Aires foi recebida pela mídia especializada como "encerramento e síntese do seminário"114.

Entre o primeiro e o segundo SAL, outros eventos congregariam os arquitetos latino-americanos novamente: as Bienais do Chile e do Equador e os dois primeiros Encontros Ibero-americanos de Revistas de Arquitetura - nomeados, a partir de sua terceira edição, simplesmente como latino-americanos - que ocorreram simultaneamente às duas exposições, uma em setembro de 1985 e outra em setembro de 1986, respectivamente. O primeiro encontro de revistas, que teve lugar em Santiago do Chile, interessa-nos, particularmente, por ter dado continuidade direta ao debate de Buenos Aires. Nele, "reafirmaram[-se] os conceitos básicos da Carta [de Buenos Aires] dando-lhes continuidade no tempo"115 e aplicando-os diretamente no trabalho editorial latino-americano. Desta reunião, participaram representantes de 24 revistas de

${ }^{109}$ Cf. GUTIÉRREZ, R. Seminarios de arquitectura latino-americana. Uma experiencia de reflexión (1985-2009) In: GUTIÉRREZ, R.; MÉNDEZ, P. (org). Seminario de Arquitetura Latinoamericana (SAL). Haciendo el Camino al andar 1985-2011. Buenos Aires: CEDODAL, 2011.

${ }^{110}$ MOSQUERA MENDEZ, Lala. Editorial. In: Summa, Buenos Aires: Ediciones Summa, n. 218, outubro de 1985, p. 17.

${ }^{111}$ MOSQUERA MENDEZ, Lala. loc. cit., out. 1985, p.17

${ }^{112}$ MOSQUERA MENDEZ, Lala. loc. cit., out. 1985, p.17

${ }^{113}$ MOSQUERA MENDEZ, Lala. loc. cit., out. 1985, p.17

${ }^{114}$ Cf. Proa Notícias. In: PROA, Bogotá: Ediciones Proa, n. 351, junho de 1986, p.26.

${ }^{115}$ Cf. Proa Notícias. In: PROA, Bogotá: Ediciones Proa, n. 351, junho de 1986, p. 26. 
arquitetura (23 latino-americanas e uma espanhola ${ }^{116}$ ) que definiram juntos os termos de um pacto - nomeado de "Acordo de Santiago do Chile" — no qual foi proposta uma série de metas e de compromissos mútuos a fim de ampliar a divulgação da produção ibero-americana e promover o intercâmbio entre estes meios de divulgação - desde o envio mútuo de índices, capas e notas de divulgação de cada edição até o compromisso de promover uma publicação anual de arquitetura ibero-americana. Ou seja, a partir desta primeira reunião, afirmava-se publicamente o engajamento dos meios de divulgação - e de editores seus responsáveis - na busca pela ampliação do conhecimento regional sobre a produção arquitetônica ibero-americana, postura reafirmada no encontro de Quito e que seria responsável pela conformação de um maior espaço ao papel da crítica no II SAL.

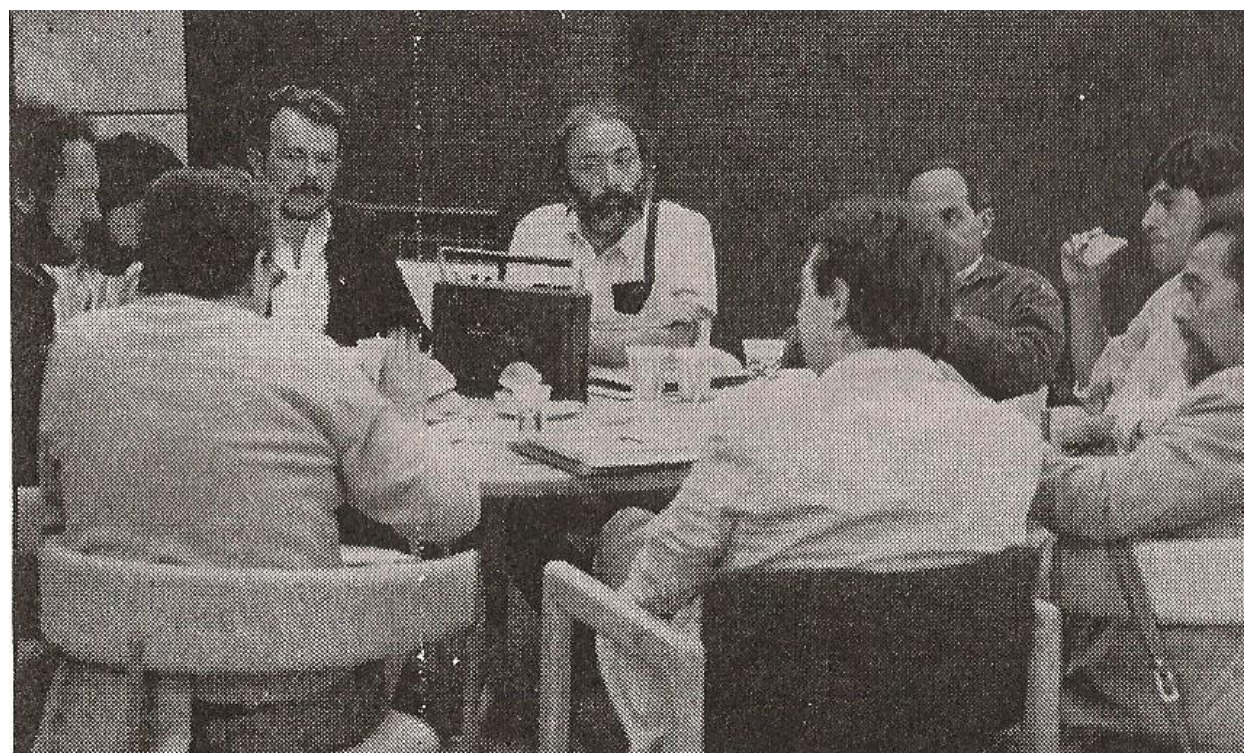

Figura 12: Segundo Encontro de Revistas, realizado em 1986, durante a $V$ Bienal de Arquitetura de Quito. Ao fundo da esquerda para direita: Sergio Trujillo, Alex Moreno, Mauricio Rivero-Borrel, Cristián Boza, Hernán Cordero, Paul Aguiar, Rolando Moya. De costas: Jaime Márquez e José Manuel López. Fonte: ARS, n. 7, nov. 1986.

${ }^{116}$ Salienta-se que o fato de haver um arquiteto espanhol - o arquiteto Joan Busquets, como
representante da revista UR - entre os participantes deste evento jamais fora mencionado nas
narrativas deste. Além deste participaram representante de revistas argentina (a/mbiente,
DANA, SCA, Summa e Trama); brasileiras (Módulo e Projeto); colombianas (Escala, Hito e Proa);
chilenas (Arq, Arquitecturas del Sur, ARS, Auca, CA e Taller América); equatoriana (Trama);
peruana (Habitar) e uruguaias (Arquitectura e Trazo) - cf. GUTIÉRREZ, R., et al (org). Arquitectura Latinoamericana. Pensamiento y Propuesta. México: UAM/Unidad de Xochimilco. 1991, p. 58-59. 


\section{A afirmação do espaço da crítica}

Antecedido pelos eventos supracitados, o II SAL, realizado de 9 a 13 de dezembro de 1986, apresentou certas inovações na sua grade: além da usual apresentação de reflexões sobre a própria obra, realizadas pela manhã, introduziram-se palestras noturnas proferidas por críticos latino-americanos. Outras novidades foram a realização atividades paralelas - mostras e a exibição de audiovisuais que ocorreram no Arquivo e Museu Histórico "Arturo Jauretche" do Banco de la Provincia de Buenos Aires $^{117}-$, e a proposição de contrapontos argentinos durante as seções matutinas na FAU/UNBA. Excetuando-se as palestras de abertura - voltadas ao debate sobre a tecnologia apropriada e proferidas por Rogelio Salmona e Severiano Porto -, nos demais dias do evento, propôs-se a apresentação de trabalhos de $\operatorname{argentinos}^{118}$, seguidas das de arquitetos de outro país latino-americano ${ }^{119}$.

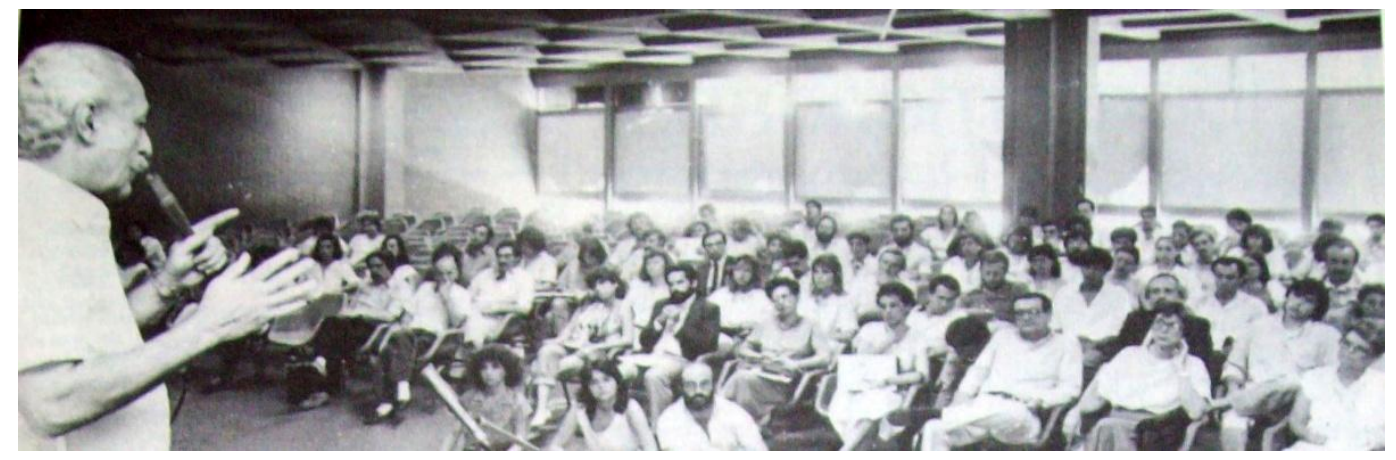

Figura 13: Palestra de Severiano Porto no II SAL, em 1986. Fonte: Revista Projeto, n. 96, jan. 1987.

Apesar de a proposta para o evento buscar uma continuidade ao Primeiro Seminário ${ }^{120}$, dentre os arquitetos estrangeiros convidados para expor sua obra, apenas os dois supracitados também o foram no I SAL. O chileno Edward Rojas não participara deste primeiro evento, nem assinara a Carta de Buenos Aires, no entanto, participara do encontro de revistas realizado no Chile - representando a CA, periódico oficial do Colégio de Arquitetos do Chile. Por outro lado, sobre o boliviano Gustavo Medeiros

\footnotetext{
117 Realizaram-se três mostras - "Arquitetura vernácula do Caribe", "História da Arquitetura Colombiana" e "Arquitetura Contemporânea em Chiloé" - e foram exibidos dois Audiovisuais "Uso popular de tijolos na Colômbia", do arquiteto Sergio Trujillo, e "Tecnicas construtivas para América Latina", realizado pela Associação de Moradia Econômica de Córdoba. Cf. Nota de divulgação do II SAL, publicada na revista Summa n. 231, de novembro de 1986.

118 Trata-se de arquitetos recorrentes nas edições da Summa: Eduardo Sacriste, José Inácio Diaz, César Luís Carli e Giancarlo Puppo. Todos estes assinaram a Carta de Buenos Aires.

${ }^{119}$ Cf. Nota de divulgação do II SAL, publicada na revista Summa n. 231, de novembro de 1986.

${ }^{120}$ Cf. Nota de divulgação do II SAL, publicada na revista Summa n. 231, de novembro de 1986.
} 
Anaya - assim como sobre os demais arquitetos previstos na programação ${ }^{121}$-, não há registro de sua participação em nenhum destes eventos anteriores, sua introdução ao público argentino deu-se através no número preparatório ao evento, nomeado Arquitectura Iberoamericana $\|^{122}$.

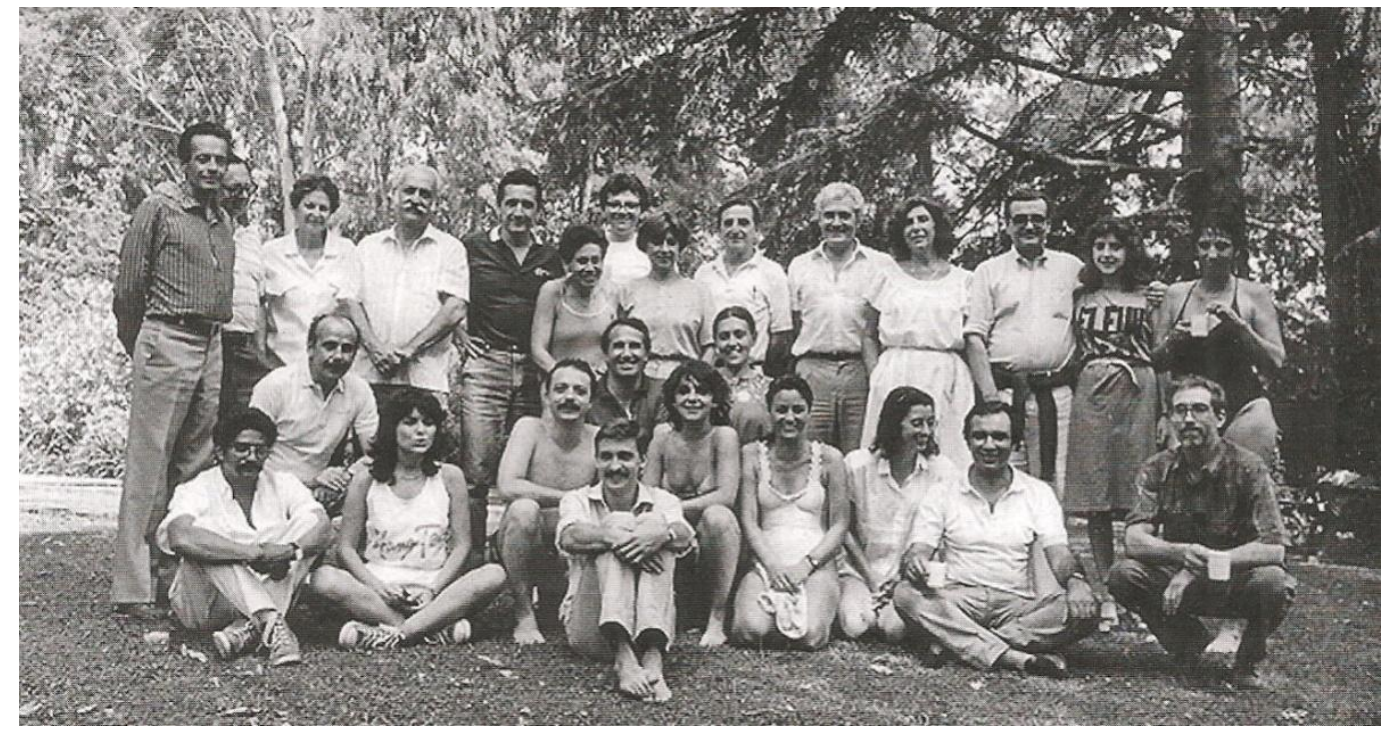

Figura 14: Participantes das mesas redondas do II SAL, realizadas na chácara de Lala Méndez, em dezembro de 1986. Fonte: GUTIÉRREZ, R.; MÉNDEZ, P. (org). Seminario de Arquitetura Latinoamericana (SAL). Haciendo el Camino al andar 1985-2011. Buenos Aires: CEDODAL, 2011.

Se, entre os arquitetos estrangeiros expositores, uma parte significativa iniciava seus primeiros contatos com o SAL, a mesma situação não se repete em meio aos críticos convidados. Apenas Willian Niño, da Venezuela, tomou contato com o debate a partir de sua participação neste evento; Ruth Verde Zein compusera a mesa redonda do primeiro seminário e Silvia Arango assinara a Carta de Buenos Aires ${ }^{123}$, além de ter representado a revista Proa no encontro do Chile. A abertura e o encerramento das seções destinadas a críticos ficaram por conta dos anfitriões: Ramón Gutiérrez

\footnotetext{
${ }^{121}$ Juan Espinosa Paez, do Equador, e Carlos Gómez de Llarena, da Venezuela, tinham apresentações previstas na programação do II SAL divulgada em novembro de 1987. Entretanto, tanto na crônica do evento, quanto na mesa redonda compostas por arquitetos práticos não há qualquer menção a estes.

${ }^{122}$ Trata-se do número 232 da Summa, de dezembro de 1986. Neste número, além das obras de Gustavo Medeiros (Bolívia) e de Diego Banderas Vela e Juan Espinosa Paez (Equador), foram publicadas também obras representativas de outros países e/ou realizadas por arquitetos que acabaram por não participar do evento: Bruno Stagno (Costa Rica); Silvio Feliciangeli (Paraguai) e José Miguel Gália (Venezuela).

${ }^{123}$ Na ocasião ela representou as revistas PROA e Escala, apesar de não possuir vínculo profissional com as mesmas. Cf. ARANGO, Silvia. Depoimento. [11 de novembro de 2011]. Campinas: Arquivo digital da gravação (1hora e $11 \mathrm{~min}$.). Entrevista concedida a Gisela Barcellos de Souza.
} 
apresentou no primeiro dia uma palestra sobre a Ibero América até 1930 e Marina Waisman encerrou o evento com uma reflexão "sobre as ferramentas e os caminhos possíveis na arquitetura latino-americana"124.

Segundo a crônica publicada sobre este evento ${ }^{125}$, a discussão gerada a partir das seções de palestras desenvolveu-se sobre em torno dos seguintes temas: análise e reedição das arquiteturas vernácula e popular; estudo da arquitetura de personagens paradigmáticas da região; a história da arquitetura latino-americana como base para a crítica da produção contemporânea e, por último, a elaboração de "ideias e propostas para o desenvolvimento de um pensamento arquitetônico latino-americano"126.

No ímpeto de finalizar o seminário de forma semelhante ao anterior, a revista Summa organizou duas mesas redondas: uma de arquitetos, outra entre críticos. Desta forma, arquitetos que expuseram reflexões sobre suas obras nas seções do II SAL - oS argentinos José Inácio Diaz, César Luís Carli e Giancarlo Puppo ${ }^{127}$ e os estrangeiros Rogelio Salmona, Severiano Porto, Gustavo Medeiros e Edward Rojas - participaram de um debate que foi conduzido por Juan Manuel Borthagaray, decano da FAU/UNBA. Paralelamente, acontecia outra mesa redonda, com as mesmas questões a serem refletidas, destinada somente aos críticos. Apesar de ambas as discussões terem sido registradas, somente esta última teve sua transcrição divulgada na revista Summa ${ }^{128}$.

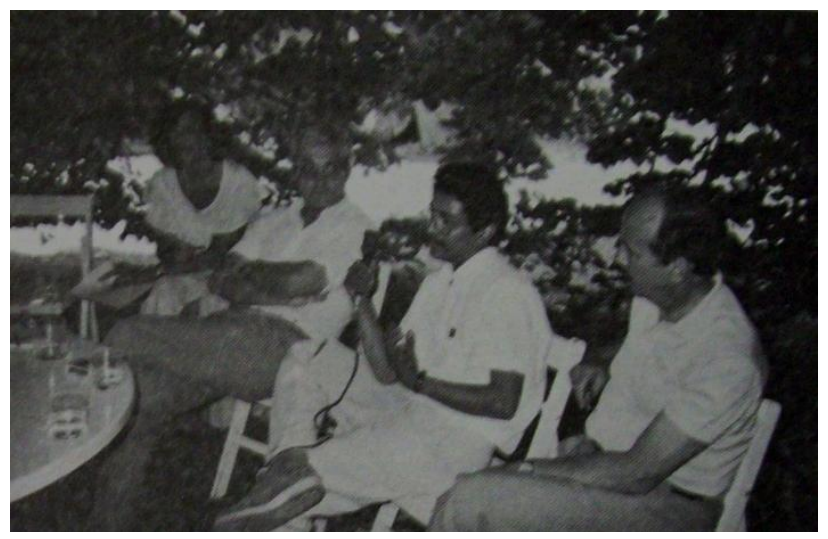

Figura 15: Exposição de Edward Rojas em mesa redonda do II SAL. Fonte: Revista Projeto, n.96, jan. 1987.

\footnotetext{
${ }^{124}$ Nota de divulgação do II SAL, publicada na revista Summa n. 231, de novembro de 1986.

${ }^{125}$ Crónica de SAL II. Latinoamérica: balance y prospectiva. In: Summa. Buenos Aires: Ediciones Summa, n. 235, março de 1987.

${ }^{126}$ Crónica de SAL II. Latinoamérica: balance y prospectiva. In: Summa. Buenos Aires: Ediciones Summa, n. 235, março de 1987.

${ }^{127}$ Eduardo Sacriste também apresentou suas obras no evento, porém não participou do debate.

${ }^{128}$ SAL II: Seminarios de Arquitectura Latinoamericana. In: Summa. Buenos Aires: Ediciones Summa, n.236, abril de 1987, p. 24-34.
} 
Assim como se constatou na análise do debate do I SAL, a mesa composta por Silvia Arango, Willian Niño, Ruth Verde Zein, Ramón Gutiérrez e Marina Waisman foi marcada pelo confronto de opiniões distintas. Os temas de reflexão mantiveram a mesma linha do evento anterior; as questões conduziram à definição do que seria uma identidade latino-americana, das repercussões da incidência de estilos internacionais na América Latina, da relação entre modernidade e identidade e de tecnologias apropriadas. O debate iniciou com a exposição de Willian Niño que assumiu seu distanciamento frente às questões postuladas:

Devo reconhecer, antes de tudo, que todos estes pontos levantados como tema de reflexão, sintetizados na busca de uma identidade latinoamericana, trazem um tópico que, assombrosamente, até agora nunca havia me interessado [...]. ${ }^{129}$

Apesar de recém-introduzido ao debate, Willian Niño justificou seu desconhecimento em relação a esse devido ao isolamento da Venezuela e esforçou-se para tentar acompanhá-lo. Entretanto, ao mesmo tempo em que admitia a possibilidade da existência de uma identidade latino-americana baseada na forma de produzir cultura, afirmava que "as obras mais transcendentes da América Latina não nascem de uma preocupação ou de uma ênfase em estar estreitamente relacionadas com a região" ${ }^{130} \mathrm{e}$ que justamente essa seria a característica que Ihes garantia uma maior projeção internacional.

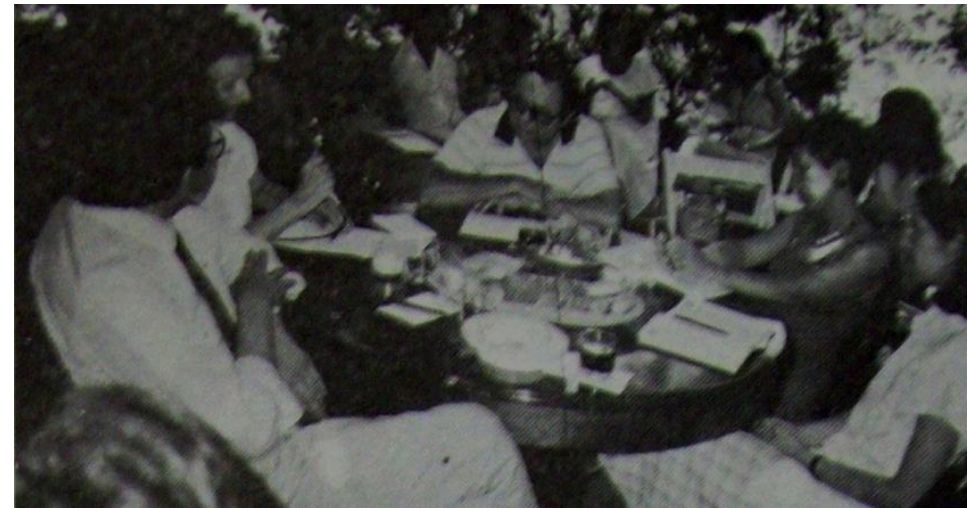

Figura 16: Mesa redonda de críticos no II SAL. Da esquera para a direita: Willian Niño, Marina Waisman, Ramón Gutiérrez, Silvia Arango e Ruth Verde Zein. Fonte: Revista Projeto, n.96, jan. 1987

Ocupando a posição de centro das argumentações e polarizando as demais questões, a existência ou não de uma identidade latino-americana continuava a gerar

\footnotetext{
${ }^{129}$ SAL II: Seminarios de Arquitectura Latinoamericana. Mesa Redonda In: Summa. Buenos Aires: Ediciones Summa, n.236, abril de 1987, p. 28.

${ }^{130}$ SAL II..., loc. cit., abril de 1987, p. 28.
} 
polêmica mesmo entre os habitués do debate. Para Ramón Gutiérrez, a identidade latino-americana seria um fato tangível, colocado, porém, em risco pela desintegração e pelo isolamento entre os países da América Latina ${ }^{131}$. Em contraponto, Silvia Arango descartava a ideia de uma identidade patente e originária e a afirmava "como uma vontade cultural de construção para o futuro, algo que pode chegar a ser, mas que não parece existir tão claramente no passado"132. Marina Waisman já alertava para a possibilidade de a ênfase demasiada na unidade latino-americana tornar-se apenas uma ligeira retórica, visto que "a identidade como convicção se encontra entre poucas pessoas, especialmente em áreas afastadas das metrópoles” ${ }^{\text {"133 }}$. Para Ruth Verde Zein, a identidade latino-americana e de sua arquitetura seria um processo em desenvolvimento contínuo; sempre por se modificar e se refazer, sem regras ou modelos definidos - e admitindo grande diversidade em seu interior ${ }^{134}$.

Dissonâncias semelhantes verificam-se nos outros temas de discussão. Sobre a questão da modernidade, houve tanto posturas que se afirmaram num plano mais teórico - como a de Marina Waisman ao propor uma reformulação do conceito de modernidade de forma a adequá-lo a realidade latino-americana - , como outras, mais frequentes, que ambientaram a discussão dentro das cidades do subcontinente. Arango e Gutiérrez associaram a crise da modernidade à crise das grandes cidades latinoamericanas. Já Willian Niño defendeu a cidade do Movimento Moderno, afirmando que os problemas apontados não eram pertinentes a este projeto. Ao introduzir a temática da tecnologia apropriada, Silvia Arango contrapunha-se a Ruth Verde Zein, afirmando que a ênfase na diversidade era demasiada, que havia uma série de pontos comuns, entre eles, a busca de formas de construção adequadas - citava, para tanto, o uso de tijolos na Colômbia e de concreto armado no Brasil ${ }^{135}$. Por sua vez, a crítica brasileira, em réplica, apontava para o perigo de se enumerar e definir tecnologias apropriadas “seria ditar sobre o autêntico"136.

\footnotetext{
${ }^{131}$ SAL II..., loc. cit., abril de 1987, p. 29.

${ }^{132}$ SAL II..., loc. cit., abril de 1987, p. 29.

${ }^{133}$ SAL II..., loc. cit., abril de 1987, p. 29.

${ }^{134}$ SAL II..., loc. cit., abril de 1987, p. 30.

${ }^{135}$ SAL II..., loc. cit., abril de 1987, p. 32-33.

${ }^{136}$ SAL II..., loc. cit., abril de 1987, p. 32-33.
} 
Diferentemente do primeiro seminário, no entanto, observa-se no II SAL uma maior matização do debate. Frequentemente procurou-se diferenciar a situação dos pequenos povoados latino-americanos - nos quais haveria um maior arraigamento da cultura regional - da das grandes metrópoles do subcontinente - que estariam mais próximas da cultura ocidental, nas quais, para resgatar o exemplo dado por Waisman, o uso de High Tech poderia ser aceitável. Esta questão foi introduzida por Marina Waisman na mesa redonda e acabou sendo desenvolvida pelos outros debatedores tornando-se a chave para um maior entendimento entre olhares metropolitanos, como o de Arango, e outros mais voltados aos pequenos povoados, como o de Gutiérrez.

\section{Diáfanas representações da cidade latino-americana em meio ao debate}

Apesar de não ter sido tema de debate no primeiro e no segundo SAL, representações da cidade latino-americana estiveram presentes, como pano de fundo para a discussão, em ambos os eventos. No primeiro, essa é representada, de modo geral, como um espaço urbano de crescimento acelerado. Marina Waisman, em meio a argumentações sobre o ensino de arquitetura no continente, refere-se a esta cidade como distinta da europeia. Para Salmona, havia uma estrutura urbana consolidada até década de 1950, mas, a partir de então, esta teria passado por um processo de destruição pela ação combinada da especulação imobiliária e das propostas do Movimento Moderno. Mariano Arana, por outro lado, chama a atenção para a armadilha das generalizações afirmando que as "cidades brasileiras, colombianas e peruanas cresc[iam] num ritmo desconhecido em outras partes do mundo"137, enquanto as uruguaias, porém, não cresciam. De modo geral, pode-se afirmar que estas representações coincidem em parte com a imagem de caos urbano que é afirmada como uma espécie de desafio na Carta de Buenos Aires, na qual se postula através de uma busca pela identidade e de uma modernidade própria definir "os eixos diretores de uma nova proposta que não teme à aparente desordem" ${ }^{138}$.

\footnotetext{
${ }^{137}$ Primer Seminario de Arquitectura Latinoamericana. In: Summa, Buenos Aires: Ediciones Summa, 214, de julho de 1985, p.24.

${ }^{138}$ MOSQUERA MENDEZ, Lala. Editorial. In: Summa, Buenos Aires: Ediciones Summa, n. 218, outubro de 1985, p. 17.
} 
No segundo SAL, algumas destas representações permanecem, porém assumem novas tonalidades. Neste diferencia-se durante a mesa, repetidamente, os pequenos povoados das metrópoles. Estas são representadas como locais de crescimento excessivo, seja este "espontâneo e sem planejamento" ${ }^{139}$, de acordo com Willian Niño; ou fruto "realização da cidade do Movimento Moderno"140 - nas palavras de Silvia Arango e Ruth Verde Zein -, cujo resultado seria, para Ramón Gutiérrez , a produção de espaços a-históricos e sem vínculos com a realidade latino-americana ${ }^{141}$. Aqueles outros núcleos urbanos, por sua vez, são definidos a partir de se contraste às grandes cidades, ou seja, como lugares das pequenas comunidades, nos quais a identidade tornava-se mais patente, segundo as argumentações de Gutiérrez e Marina Waisman. Apesar de agora restringida às metrópoles, a representação da cidade latino-americana associada à ideia de caos permanece, afirmando-a como traço distintivo, como se percebe nas palavras de Arango:

[D]evemos enfrentar a crise do construído, que em nossas cidades se apresenta com maior intensidade que em outras partes. Somente na América somaram-se os problemas do anonimato, da repetição, da poluição e congestão de automóveis, do choque entre infraestruturas históricas e o atropelo das novas construções. ${ }^{142}$

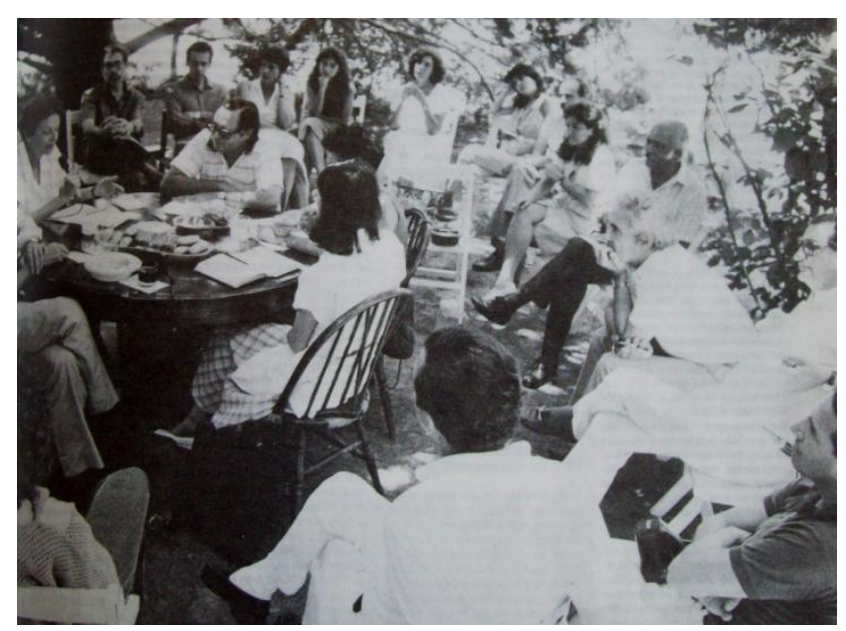

Figura 17: Mesa redonda do II SAL. Em torno da mesa, da esquerda para direitra: Marina Waisman, Ramón Gutiérrez, Silvia Arango e Ruth Verde Zein. Fonte: Summa, n.236, abr. 1987.

\footnotetext{
${ }^{139}$ SAL II: Seminarios de Arquitectura Latinoamericana. Mesa Redonda In: Summa. Buenos Aires: Ediciones Summa, n.236, abril de 1987, p. 28-34.

${ }^{140}$ SAL II..., loc. cit., abril de 1987, p. 33.

${ }^{141}$ SAL II..., loc. cit., abril de 1987, p. 33.

${ }^{142}$ SAL II: Seminarios de Arquitectura Latinoamericana. Mesa Redonda In: Summa. Buenos Aires: Ediciones Summa, n.236, abril de 1987, p. 28-34.
} 
As diferenças entre as cidades latino-americanas e as europeias também são apontadas por Ruth Verde Zein, ao afirmar a inoperância das teorias elaboradas com base nestas para aquelas: "não é que eu não valorize a obra de Rossi ou de outros autores; acontece que somos a modernidade feita em forma de cidades. [...] Cidades modernas onde se apagou todo vestígio do passado e que possuem um nível lamentável de qualidade de vida"143. Introduz-se, a partir desta diferenciação, a temática da periferia das grandes cidades. Descrita por Gutiérrez como o local de maior crescimento descontrolado, a crítica brasileira propunha que os arquitetos assumissem sua parcela de culpa em sua constituição devido ao desinteresse histórico destes profissionais pelo tema ${ }^{144}$.

Não obstante sua condição de fundo sobre o qual se tecem as discussões, estas representações da cidade latino-americana galgariam maior espaço nos dois SAL subsequentes, compondo parte dos temas das seções específicas.

\subsection{Quando a cidade aparece como tema}

Findado o segundo seminário, encerra-se a vinculação dos SAL a Buenos Aires e à organização da Summa; inicia-se, por outro lado, sua longa jornada em busca constante por novos ancoradouros no subcontinente. As viagens trouxeram, para além da ampliação do público, mudanças significativas no formato dos seminários. Deixavamse para trás os tempos heroicos - nos quais os convidados podiam sentar-se informalmente em torno de uma mesa e debater longamente as questões colocadas em pauta -, para assumir o desafio de congregar numerosas apresentações em uma postura que se pretendia mais científica; tanto na criteriosa definição prévia dos temas a serem debatidos em seções temáticas específicas, quanto na publicação posterior das palestras apresentadas em forma de anais. Em meio a estas alterações, a cidade latinoamericana, cujas representações antes transpareciam timidamente em meio de discursos multifacetados, passa a compor os temas de seções específicas do terceiro e no quarto SAL - que tiveram lugar em Manizales (Colômbia) e Tlaxcala (México), respectivamente.

\footnotetext{
${ }^{143}$ SAL II..., loc. cit., abril de 1987, p. 28-34.

${ }^{144}$ SAL II..., loc. cit., abril de 1987, p. 28-34.
} 


\section{Traços distintivos e precisões sobre o recorte}

Antes de passarmos à análise de como a cidade aparece nestas discussões, é necessário precisar e salientar alguns aspectos relativos à organização das jornadas que diferenciam os SAL III e IV de seus antecessores: a solicitação prévia dos textos a serem apresentados; a divisão do debate em seções temáticas específicas e simultâneas e, por último, a proposição de convocatórias de palestras abertas a qualquer interessado.

O primeiro denota uma mudança de postura nos seminários; não havia mais espaço para o improviso, tinha-se desde então a certeza de se produzir história. Tal asserção pode ser verificada nas palavras de Gutiérrez em sua conferência de abertura no III SAL, no qual afirma antever que este evento seria histórico ${ }^{145}$, ou em seu relatório sobre o seminário subsequente no qual declara:

O documento das conclusões de Manizales, que prepararam nossos companheiros da Universidade Nacional da Colômbia, reúne não somente nossa tarefa naquelas jornadas, como também nossos pronunciamentos anteriores, convertendo-se em embasamento de nossa "memória" como movimento. ${ }^{146}$

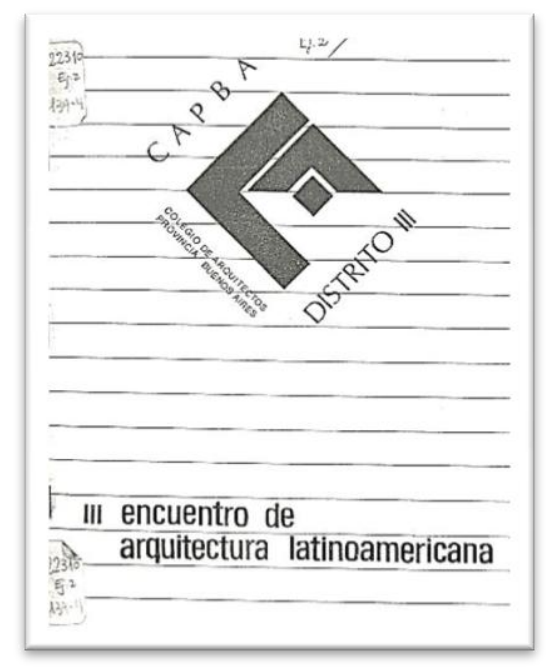

Figura 18: Capa dos Anais do III SAL, realizado em Manizales, em 1987. Fonte: Fotografia da autora.

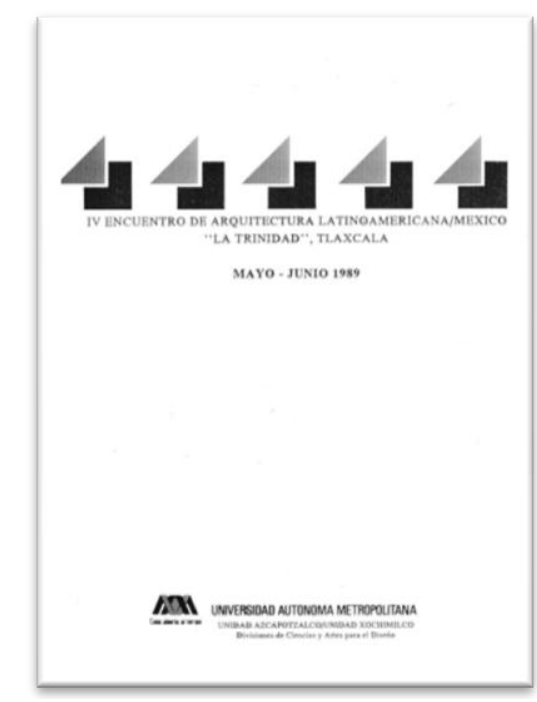

Figura 19: Capa dos Anais do IV SAL, realizado em Tlaxcala, em 1989. Fonte: Fotografia da autora.

\footnotetext{
145 “A convicção da necessidade de uma teoria própria (...) nos trouxe para Manizales para estas jornadas que já prevemos como históricas e densas em conteúdo". GUTIÉRREZ, R. Intervención del Arq. Ramón Gutiérrez en la inauguración del III Encuentro de Arquitectura Latinoamericana. In: III Encuentro de Arquitectura Latinoamericana. Buenos Aires: CAPBA D III, 1988, p.2.

146 GUTIÉRREZ, Ramón, Relatoria General del IV Encuentro de Arquitectura Latinoamericana /México. "La Trinidad", Tlaxcala. In: IV Encuentro de Arquitectura Latinoamericana. Conclusiones. México: Universidad Autónoma Metropolitana, 1991. Grifo no original.
} 
O segundo traço distintivo, ou seja, a definição das seções por temas e não mais por tipo de reflexão - pautada na apresentação de suas próprias obras ou puramente teórica, tal qual ocorrera no II SAL - acabou por ampliar ainda mais o espaço da crítica nesses dois seminários. Rompia-se, desta forma, com o fio condutor que vinculara e caracterizara os dois primeiros SAL, a saber, o debate aberto a partir da exposição de trabalhos de arquitetos latino-americanos. A discussão teórica ganhara tamanho espaço no III e no IV SAL, que Rogelio Salmona, ao apresentar sua conferência em Tlaxcala, afirma expor suas reflexões "como arquiteto latino-americano" e, modestamente, parece prevenir a plateia: "não sou um teórico da arquitetura, muito menos um crítico" ${ }^{147}$. Neste evento, aliás, buscou-se recuperar a discussão a partir de projetos de alguns arquitetos - fato que se apreende através do relato de Gutiérrez ${ }^{148}$-, entretanto, esta não fora a tônica do evento.

Outro aspecto relacionado à inclusão seções de temas específicos nos SAL devese à simultaneidade de sua ocorrência. Esta marcaria o início da existência de discussões paralelas nos SAL: a partir do terceiro seminário, não seria mais permitida a onisciência a um observador qualquer. Logo, as narrativas do evento que se dispusessem a resgatar seus distintos debates, só poderiam fazê-lo a partir dos textos publicados - fato como, aliás, se comprova ao observar as crônicas que foram elaboradas destes eventos ${ }^{149}$. As impressões pessoais sobre as interações e reflexões ocorridas durante as apresentações estariam, por ora, restritas à participação em um dos distintos grupos temáticos ${ }^{150}$.

${ }^{147}$ SALMONA, Rogelio, Una Reflexión como Arquitecto Latinoamericano. In: IV Encuentro de Arquitectura Latinoamericana. Conclusiones. México: Universidad Autónoma Metropolitana, 1991, p.13.

${ }^{148}$ GUTIÉRREZ, Ramón, Relatoria General del IV Encuentro de Arquitectura Latinoamericana /México. "La Trinidad", Tlaxcala. In: IV Encuentro de Arquitectura Latinoamericana. Conclusiones. México: Universidad Autónoma Metropolitana, 1991, p.35.

${ }^{149}$ A crônica publicada na Summa - n.238, em junho de 1987 - sobre o III SAL, por exemplo, é extremamente marcada pelo conjunto de textos que logo seria publicado pelo Colégio de Arquitetos da Província de Buenos Aires, chegando a citar parágrafos inteiros deste e mencionar o texto de Ceça Guimarães que foi enviado, porém não apresentado.

${ }^{150}$ A partir deste aspecto pode-se compreender que participantes de um mesmo seminário possam conceber avaliações muito díspares deste. Tome-se como exemplo algumas que foram ensejadas sobre o encontro de Tlaxcala: Nas palavras de Silvia Arango (loc. cit, 1995), este evento seria "o mais frutífero", pois nele se teria chegado a alguns consensos, como a compreensão da "identidade como atitude", proposta por Waisman, e a preferência pela utilização da "noção 'modernidade apropriada', já afinada e refinada por Cristián Fernández" em detrimento de outras como "arquitetura divergente". Já para Rangel (1990), neste mesmo evento ter-se-ia apresentado "com mais força o processo do qual não se pode esquivar: o massivo deterioramento urbano". 
Por último, a proposição de convocatórias abertas amplia expressivamente o número de palestrantes nos eventos. Esta abertura, todavia, coloca em xeque a própria afirmação - que pode ser constatada no supracitado relatório de Gutiérrez do VI SAL ${ }^{151}$ -, dos seminários como um "movimento". Oriundos de filiações distintas, a cada novo evento uma leva de palestrantes ingressa no debate. Dentre estes, o número que de fato permanece, ou seja, que passa envolver-se nos encontros subsequentes, é significativamente restrito. De tal sorte que, a um grupo inicialmente coeso, que se engajou e idealizou os eventos, agregaram-se debatedores flutuantes, que não possuíam vínculos com sua história e ultrapassaram em número àqueles. Em Manizales, por exemplo, tem-se o registro de uma atuação prévia ativa junto aos SAL de apenas 16 palestrantes dos 33 totais - os 17 restantes não compuseram debates anteriores, nem assinaram acordos. Dentre os iniciantes, somente cinco participariam de pelo menos um outro seminário ${ }^{152}$. Esta situação acentuar-se-ia ainda mais em Tlaxcala. Neste evento, dentre os 58 expositores divididos nas quatro seções temáticas, apenas 21 já tinham debatido em algum evento anterior e/ou assumido um engajamento público com os SAL. Entre os 37 debutantes, somente sete envolver-se-iam com seu debate, seja apresentando trabalhos no seminário seguinte, seja organizando algum de seus próximos eventos $^{153}$, seja participando de publicações conjuntas ${ }^{154}$.

Diante deste número significativo de apresentadores que não estabelece vínculos com os SAL, há de se perguntar sobre a pertinência de uma análise que, como afirmamos em nossas considerações iniciais, pretende se pautar nos vestígios remanescentes destes eventos, no caso, seus anais. Quais textos, dentre os textos apresentados nestas compilações, representariam de fato o debate dos SAL sobre a

\footnotetext{
${ }^{151}$ GUTIÉRREZ, Ramón, loc. cit, 1989.
}

152 Referimo-nos a: Antonio Toca, que foi responsável pela organização do quarto encontro; a Carlos Eduardo Dias Comas, que participaria de todos os eventos entre 1987 e 1995, e aos colombianos Carlos Niño Murica e Alberto Saldarriaga - ver Apêncide B. Consideramos dentro deste dado de ingressantes, Eduardo San Martín - um dos responsáveis pela organização do $\mathrm{V}$ $\mathrm{SAL}-$, visto que não encontramos registro de sua participação ativa em encontros anteriores, entretanto, é certo que, na condição de sócio de Browne e participante do Taller América, este já estava devidamente inteirado do debate.

153 Este é o caso de Hugo Segawa, o organizador do VII SAL, cuja primeira apresentação de trabalho no SAL ocorrera em 1989 - ver Apêndice B.

${ }^{154}$ Refere-se aqui a Ada Dewes, que não apresentou nenhum trabalho no $\mathrm{V}$ SAL, porém o texto que apresentou no quarto seminário, após revisto e ampliado, fora publicado em livro organizado por Silvia Arango sobre a modernidade e a pós-modernidade na América Latina - cf. ARANGO, S. Modernidad y Postmodernidad en América latina. Bogotá: Escala, 1991. 
cidade latino-americana? A existência de reflexões sobre esta seria um desdobramento das questões lançadas nos primeiros encontros ou simplesmente fruto de contribuições ocasionais, que não encontrariam ecos entre aqueles que de fato estavam engajados com estes eventos?

Ao analisarmos o conjunto dos textos publicados nos anais do terceiro e do quarto seminário, vemos que ambas as situações ocorrem simultaneamente, ou seja: tanto há intervenções, escritas por iniciados ou iniciantes, que ressoam inquietações semelhantes às esboçadas nos primeiros encontros e se desdobram em eventos subsequentes; quanto há outras que, fortuitas, causam pouco efeito junto às personagens que ajudaram a construir os SAL. Para efeito de maior acuidade na caracterização deste debate, adotaram-se dois critérios para o estabelecimento do recorte de textos para a análise: o primeiro é o engajamento do palestrante na história dos SAL - caracterizado, no caso, por sua participação ativa em pelo menos três dos cinco eventos analisados ${ }^{155}$-, o segundo seria a ressonância em relação a outros debates do SAL e a continuidade de determinadas abordagens - aplicada em casos em que o apresentador só participara em dois eventos.

A partir destes dois critérios, pode-se afirmar que a discussão sobre a cidade latino-americana no III e IV SAL oscilou entre dois polos: de um lado a questão da periferia e da "cidade de massas" - como fora chamada por Gonzáles Lobo em Tlaxcala -; de outro, a dos centros históricos e do patrimônio. Apesar de ambos os debates transparecerem frequentemente alguns aspectos comuns, como inquietações sobre uma cidade que cresce em ritmo vertiginoso - cuja representação já fora identificada nos primeiros SAL - e, portanto, distinta da europeia; estes ocorreram em seções temáticas distintas, tanto em Manizales, quanto em Tlaxcala. Frente a esses - e, reiteradamente, ditando o rumo das discussões - encontram-se personagens cuja vinculação aos SAL pode ser verificada desde os primeiros eventos. Dentre os engajados no primeiro, constata-se a presença de Jorge Moscato, Cristian Boza e Humberto Eliash; enquanto no segundo, agregam-se Marina Waisman, Ramón Gutiérrez e Mariano Arana.

${ }^{155}$ Incluímos, neste trabalho de caracterização das personagens, a participação ativa destes no $\mathrm{V}$ SAL, justamente por esta ser fundamental para o reconhecimento dos desdobramentos das contribuições individuais no debate sobre a cidade. Consideraram-se como "ativas" apenas as participações como palestrantes, visto que, a afirmação de possíveis vinculações aos SAL a partir da condição de espectador seria dificilmente passível de comprovação - ver Apêncide B. 
Para além da discussão em seções temáticas específicas, representações sobre a cidade latino-americana transpareceram também em algumas das conferências magistrais ou em meio a outros debates. Neste último caso, interessam-nos, particularmente, aquelas que se entreveem em discursos que obtiveram alguma projeção junto aos SAL — sendo sua citação por outros participantes o fundamento para sua escolha.

Ao analisar como a questão da cidade latino-americana aparece nestes dois seminários, não se pretende, obviamente, construir uma história fictícia e lacunar que transforme esta temática no centro de interesse dos debates fomentados nestes. Antes de caracterizar os diferentes matizes perceptíveis na discussão da periferia urbana e dos centros históricos, é necessário que se enquadrem estas reflexões dentro do contexto geral e amplo destes seminários, que, à semelhança dos portenhos, fora marcado pela diversidade. Logo, buscaremos, na sequência, desenhar um breve panorama dos III e IV SAL.

\section{O contexto: ampliação do debate e busca por novos paradeiros}

Antes mesmo de o segundo SAL ocorrer, já estava decidido que o terceiro seminário ocorreria em Manizales ${ }^{156}$, entre 9 e 11 de abril de 1987. A opção por realizáIo na Colômbia, distante do público argentino, não foi, certamente, fortuita. Como vimos, os colombianos já haviam organizado um encontro para discussão da arquitetura latino-americana em 1980, na cidade de Cali. Ensejava-se, portanto, um clima propício para a recepção deste debate. Soma-se a este ambiente pré-disposto o fato de Rogelio Salmona, em particular, ter assumido uma posição de reconhecido destaque em meio ao debate do primeiro SAL. Como desdobramento deste, o arquiteto colombiano encabeçou a criação de um grupo latino-americano que então visava "reunir-se periodicamente para estudar as possibilidades de uma arquitetura genuína e

\footnotetext{
${ }^{156}$ Segundo Jaramillo, decano da Universidad Nacional de Manizales, a idealização de tornar Manizales a sede deste evento deu-se durante a inauguração da exposição "Historia de la Arquitectura en Colômbia", em 1985, segundo Jaramillo Jimenez, da qual participaram "Rogelio Salmona, Laureano Forero, Sergio Trujillo e Silvia Arango, de Bogotá; Ramón Gutiérrez, da Argentina; Hernán Giraldo e Glória Inês Arias, de Manizales". Ver: JARAMILLO JIMENEZ, Jose Oscar. Intervención del Ing. José Oscar Jaramillo en la inauguración del III Encuentro de Arquitectura Latinoamericana. In: III Encuentro de Arquitectura Latinoamericana. Buenos Aires: CAPBA D III, 1988, p.1.
} 
modernamente latino-americana" ${ }^{157}$ e responsabilizou-se por recolher assinaturas para a "Carta de Buenos Aires", debatida em maio de $1985^{158}$.

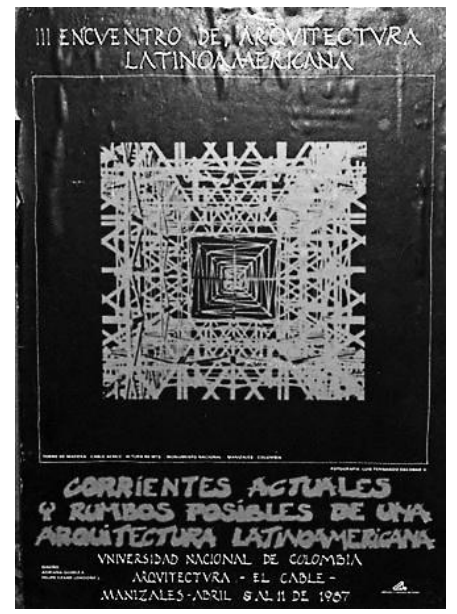

Figura 20: Cartaz do III SAL, realizado em Manizales, em 1987. Fonte: Acervo pessoal de Enrique Browne.

Destarte, não é de se estranhar que alguns meses antes do segundo seminário, em julho de 1986, tenham-se reunido, em Bogotá, Rogelio Salmona, Silvia Arango, Sergio Trujillo e Ramón Gutiérrez para definir a forma definitiva do III SAL ${ }^{159}$ - que fora nomeado pelos colombianos, em referência direta ao evento que ocorrera em Cali, como o "III Encuentro de Arquitectura Latinoamericana" ${ }^{160}$. Definiram-se, nesta ocasião, os agrupamentos de temas para discussão nas três seções que comporiam esse evento ${ }^{161 .}$ A primeira seção destinar-se-ia ao debate de questões relativas à história e historiografia da arquitetura latino-americana, ao patrimônio, aos centros históricos e, grosso modo, à teoria e crítica arquitetônica. A segunda discutiria aspectos concernentes tanto às tendências contemporâneas da arquitetura - latino-americana, de modo geral, e de cada país, em específico -, quanto às relações entre internacionalidade e identidade latino-americana e sua interface com o uso de novas

157 WAISMAN, M. "Primero Seminario de Arquitectura Latinoamericana. Un auspicioso comienzo". In: Summa, Buenos Aires: Ediciones Summa, 217, set 1985, p.26-27

158 MOSQUERA MENDEZ, Lala. Editorial. In: Summa, Buenos Aires: Ediciones Summa, n. 218, outubro de 1985, p. 17.

${ }^{159}$ GUTIÉRREZ, Ramón. Convocatoria para una propuesta iberoamericana en arquitectura. In: III Encuentro de Arquitectura Latinoamericana. Buenos Aires: CAPBA D III, 1988, p.108.

160 No encerramento do evento, Salmona recordou que, para os colombianos, aquele encontro era, na verdade o quarto, referindo-se ao que fora organizado pela Universidad Nacional de Cali sete anos antes, do qual participaram: Mariano Arana (Uruguai), Fernando Salinas (Cuba), Juvenal Baracco (Peru), e Ernesto Alba (México). Cf. SALMONA, R. Clausura al III Encuentro de Arquitectura Latinoamericana. In: III Encuentro de Arquitectura Latinoamericana. Buenos Aires: CAPBA D III, 1988, p.111.

${ }^{161}$ Cf. GUTIÉRREZ, Ramón. Convocatoria para una propuesta iberoamericana en arquitectura. In: III Encuentro de Arquitectura Latinoamericana. Buenos Aires: CAPBA D III, 1988, p.108. 
técnicas e materiais. Já a terceira, e última, abordaria a problemática da periferia e dos espaços públicos, sob o ponto de vista arquitetônico e urbano.

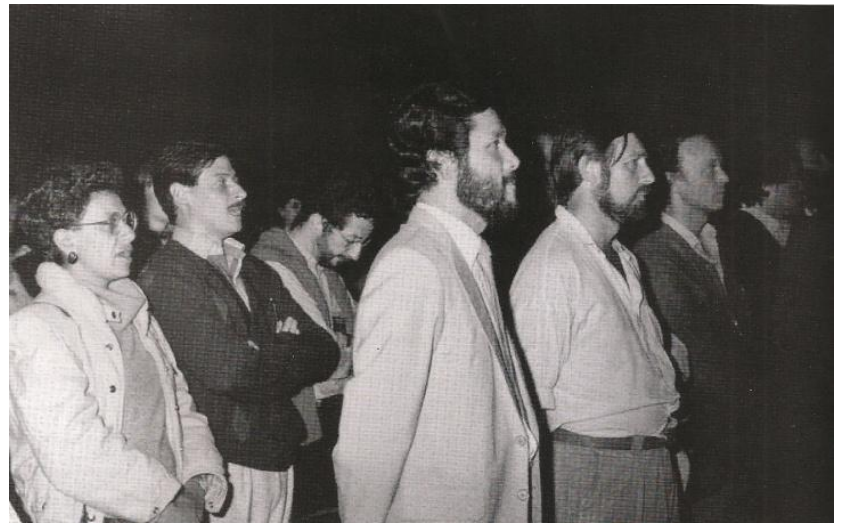

Figura 21: Inauguração do III SAL: Silvia Arango, Humberto Eliash, Jorge Moscato, Enrique Browne e Alberto Saldarriaga. Fonte: GUTIÉRREZ, R.; MÉNDEZ, P. (org). Seminario de Arquitetura Latinoamericana (SAL). Haciendo el Camino al andar 19852011. Buenos Aires: CEDODAL, 2011.

Não obstante a diferenciação inicial, a análise das palestras que compuseram as duas primeiras seções, bem como o relato do debate que estas geraram - cuja responsabilidade ficou a cargo de Gutiérrez, para o primeiro grupo, e de Arango, para o segundo ${ }^{162}-$, revela que as discussões estabelecidas nestas foram significativamente semelhantes. Presente em ambas, e contrariando a programação inicial, as inquietações sobre a identidade e a modernidade latino-americanas compuseram o objeto de maior reflexão e interação entre os participantes ${ }^{163}$. Os principais traços distintivos entre estas duas seções esboçados na programação geral, por outro lado, foram esmaecidos. No primeiro grupo, por exemplo, à temática do patrimônio, destinaram-se somente duas das exposições ${ }^{164}$; já a abordagem da questão dos centros urbanos, por sua vez, não foi objeto central de nenhuma dentre estas - transparecera, no entanto, em diversas ocasiões. No segundo grupo, o tema da contribuição do uso de determinadas

\footnotetext{
${ }^{162}$ Além das palestras proferidas no evento, foram publicados, também, no corpo dos anais do evento - III Encuentro de Arquitectura Latinoamericana. Buenos Aires: CAPBA D III, 1988 relatos gerais dos debates em cada seção $O$ relato da seção relativa à periferia e aos espaços públicos foi incumbido a Humberto Eliash.

${ }^{163}$ Neste sentido, concordamos com Rangel (1990), quando este afirma que "as discussões de Manizales giraram em torno de dois polos: a) a periferia urbana, os bairros e a autoconstrução, b) a identidade de nossos países ligada à da modernidade". RANGEL. Rafael López. El pensamiento arquitectónico latinoamericano. La polémica de los ochenta a través de los encuentros internacionales. In: Cuadernos de Arquitectura Latinoamericana. Universidad Autónoma Metropolitana/Universidad Autónoma de Puebla/Universidad Autónoma MetropolitanaAzcapotzalco. Número 2, dez.1990.

${ }^{164}$ Referimo-nos aqui às apresentações de German Tellez - intitulada "Teoria conservacionista y realidad urbana: el caso excepcional de Popayán" - e de Lorenzo Fonseca - "Inventario de património urbanístico e arquitectónico" -, publicadas em: III Encuentro de Arquitectura Latinoamericana. Buenos Aires: CAPBA D III, 1988.
} 
tecnologias para a formação da identidade fora o foco apenas da palestra de Sérgio Trujillo Jaramillo ${ }^{165}$.

Malgrado o fato de ter contado com número de apresentações semelhante ao das demais seções ${ }^{166}$ - e dentre estas contribuições, cinco foram realizadas por membros já engajados nos SAL ou que o fariam a partir deste evento ${ }^{167}$ - o debate sobre a periferia urbana foi, frequentemente, abordado pela crítica como uma dentre as "outras aberturas" temáticas possibilitadas pelo evento ${ }^{168}$. Logo, o trabalho de toda uma seção - e de um terço dos participantes - fora elencado em meio a questões que tiveram uma importância relativa dentro do contexto geral do evento, como, a título de exemplo, a concernente ao patrimônio ${ }^{169}$.

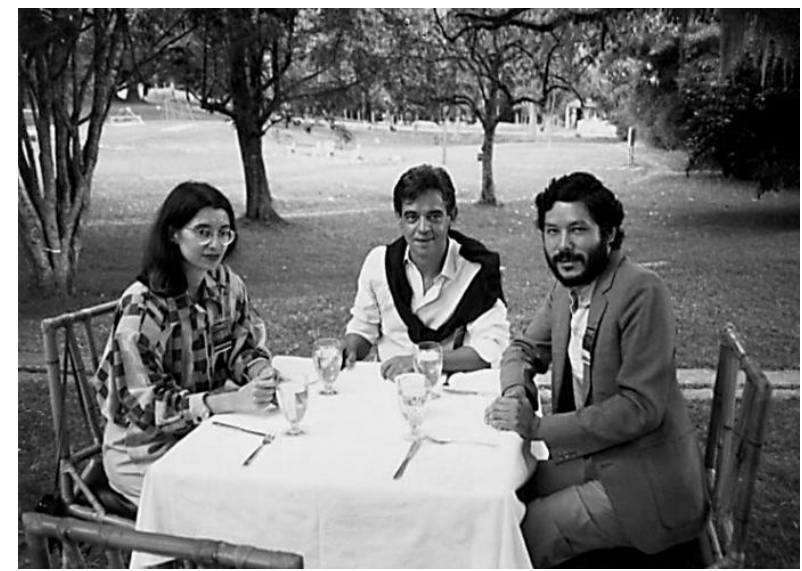

22: Ruth Verde Zein, Carlos Eduardo Comas e Humberto Eliash em conversa informal durante o III SAL. Fonte: Acervo pessoal de Humberto Eliash.

Outras contribuições, no entanto, obtiveram maior destaque na crítica. Dentre elas encontra-se a apresentação sobre a arquitetura moderna brasileira de Carlos Eduardo Comas, estreante no debate dos SAL, que foi recebida como um "aporte

165 TUJILLO JARAMILLO, Sergio. "La arquitectura del ladrillo en Colombia" In: III Encuentro de Arquitectura Latinoamericana. Buenos Aires: CAPBA D III, 1988, p.66-67.

${ }^{166}$ Dez apresentações que compuseram cada uma das duas primeiras seções, na terceira e última foram nove exposições.

${ }^{167}$ Cristián Boza, Humberto Eliash, Jorge Moscato e Juvenal Baracco encontram-se no primeiro caso e Eduardo San Martín no segundo.

${ }^{168}$ Cf. III Encuentro de Arquitectura Latinoamericana, Manizales, Colombia Memoria, continuidad y nuevos propósitos. In: Summa. Buenos Aires: Ediciones Summa. n.238, jun. de 1987; ARANGO, Silvia. Diez años de los "SAL" en América latina. In: PROA, Bogotá: Ediciones PROA, 425, jun.1995, p. 18-21.

169 Referimo-nos aqui a avaliação de Arango (1995) deste seminário - ARANGO, Silvia. loc. cit.1995, p.18-2. Acreditamos que esta lacuna identificada deva-se à dificuldade de domínio da totalidade do evento por seus participantes, já abordada por nós, devido a sua divisão em distintas seções. 
revelador" ${ }^{\prime 170}$. Destacou-se, sobretudo, a exposição de Fernandez Cox de uma das primeiras versões de seu texto "Hacia una modernidad apropiada: factores y desafíos internos" - cujas ideias centrais já vinham sendo desenvolvidas por este desde $1983^{171}$ -, que fora descrita como uma das contribuições mais importantes do evento ${ }^{172}$. Junto às palestras apontadas, salientou-se, também, a de Enrique Browne ${ }^{173}$, devido ao seu êxito em situar no debate "um público amplo e desinformado que se incorporava com surpresa" 174 - esta fora baseada no trabalho de pesquisa que resultou em seu livro "Otra Arquitectura" que em breve seria editado.

O terceiro SAL não se resumiu, contudo, ao trabalho realizado nos distintos grupos. Além dos discursos de inauguração de Gutiérrez, de Salmona e do decano Jaramillo Jimenez, quatro conferências destinadas a todos os participantes precederam o trabalho destes grupos. Proferidas por Marina Waisman, Ruth Verde Zein, Enrique Browne e Antonio Toca, estas tinham por objetivo preparar observadores e interventores para o trabalho que se daria na sequência.

A presença, dentre personagens que, neste momento, já eram identificados à história dos seminários, de Antonio Toca - quem até então não havia participado ativamente de nenhum dos eventos anteriores e, após este, tornara-se o primeiro mexicano a engajar-se publicamente nos SAL - merece ser analisada. Apesar de estreante junto aos Seminários de Arquitetura Latino-americana, Toca não era, obviamente, desconhecido. Seu livro "Más allá del Postmoderno ${ }^{175 " ~ h a v i a ~ s i d o ~ p r e m i a d o ~}$ na $V$ Bienal do Equador, em $1986^{176}$ - ocasião na qual ocorria, simultaneamente, em Quito o segundo encontro de revistas de arquitetura latino-americanas. Além disso, suas

\footnotetext{
${ }^{170}$ Cf. III Encuentro de Arquitectura Latinoamericana, Manizales, Colombia Memoria, continuidad y nuevos propósitos. In: Summa. Buenos Aires: Ediciones Summa. n.238, jun. de 1987.

${ }^{171}$ Referimo-nos ao discurso de Fernandez Cox proferido por ocasião da IV Bienal de Santiago do Chile, publicado posteriormente nas revistas CA e na PROA. Cf. FERNÁNDEZ COX, Cristián. Recado a los arquitectos de Hispanoamérica. In: PROA, Bogotá: Ediciones Proa, n. 337, dez 1984, p. 53.

${ }^{172}$ Cf. III Encuentro de Arquitectura Latinoamericana, Manizales, Colombia Memoria, continuidad y nuevos propósitos. In: Summa. Buenos Aires: Ediciones Summa. n.238, jun. de 1987.

${ }^{173}$ ARANGO, Silvia. loc. cit.1995, p.20.

${ }^{174}$ ARANGO, Silvia. loc. cit.1995, p.20.

${ }^{175}$ TOCA, Antonio. Más allá del postmoderno, Ediciones G. Pili, 1986.

${ }^{176}$ TOCA, Antonio (org). Nueva Arquitectura en América Latina: Presente y Futuro. México: GG, 1990.
} 
contribuições para a revista Proa eram frequentes, sobretudo durante o ano $1986^{177}$, o que demonstra que este autor era bem divulgado entre os colombianos.

Dando sequência à posição de destaque que assumiu em Manizales, Toca ofereceu-se, por conseguinte, para organizar o próximo encontro ${ }^{178}$ - que ocorreu em Tlaxcala, no retiro nomeado "La Trinidad", entre 29 de maio e 2 de junho de 1989. Na comissão que este encabeça para definir a organização do IV SAL, pela primeira vez os argentinos, bem como outros latino-americanos que haviam participado dos seminários em Buenos Aires, desapareceram da cena. Dentre os novos organizadores, somente Toca já havia participado do debate - e, curiosamente, para além deste, apenas outro membro desta comissão, González Lobo, permaneceria em seminários subsequentes.

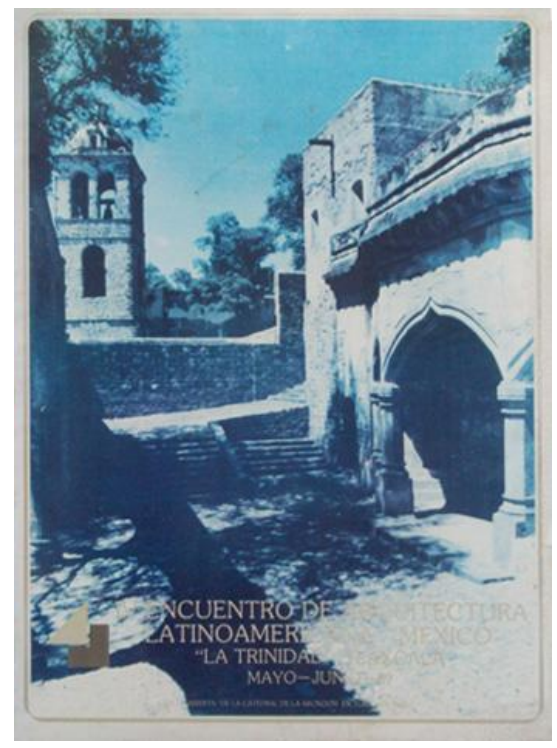

Figura 23: Cartaz do IV SAL, realizado em Tlaxcala, em 1989. Fonte: Acervo pessoal de Enrique Browne.

Portanto, sem contar com a colaboração direta de arquitetos que estiveram à frente das organizações dos encontros anteriores, verifica-se que a nova comissão organizadora, ao definir o formato do quarto seminário, acabou por propor uma reinterpretação dos temas e dos debates do anterior. Este vínculo foi fundamental para que se estabelecesse, a despeito da inclusão, já mencionada, de um significativo número de novos participantes, uma continuidade e um amadurecimento das discussões lançadas em Manizales. Definiram-se, portanto, quatro mesas para este evento, assim especificadas: "características da arquitetura latino-americana"; "dualidade entre

${ }^{177}$ Ao longo do ano de 1986, localizamos três publicações de Toca na Proa: "Origines del moderno en la arquitectura", no no 348; "Más allá del postmoderno", no no 351, e "El ornamento es un crimen", no no355.

${ }^{178}$ SALMONA, R. Clausura al III Encuentro de arquitectura latinoamericana. In: III Encuentro de Arquitectura Latinoamericana. Buenos Aires: CAPBA D III, 1988, p.111. 
declaração teórica expressa e a obra"; "a construção da cidade a partir das necessidades da sociedade de massas" e, por último, "a recuperação e renovação da cidade histórica".

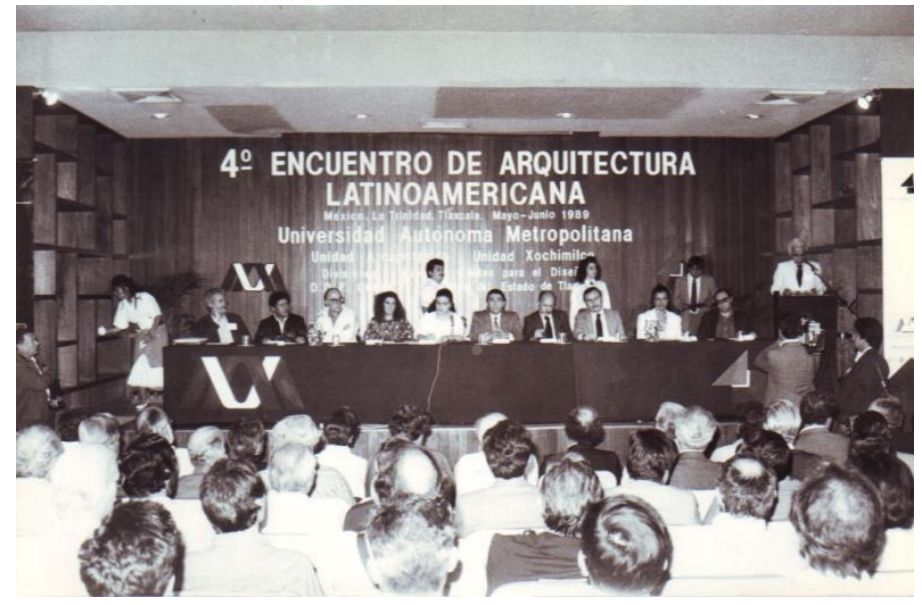

Figura 24: IV SAL, realizado em Tlaxcala, em 1989. Fonte: Acervo pessoal de Humberto Eliash.

As tentativas de amarrar o IV SAL com os debates que já vinham ocorrendo no âmbito dos encontros anteriores não se restringiram à proposição de temas que fossem desdobramentos destes. Além dos discursos de abertura do evento - proferidos por Salmona, Gutiérrez, Mijares Bracho e Dussel -, para cada seção temática fora estabelecida uma conferência de base, com o claro intuito de imprimir o tom ao debate. Desta forma, Marina Waisman abrira a primeira seção com a palestra nomeada "Para una caracterización de la arquitectura latinoamericana"179, na qual dera continuidade ao trabalho, iniciado em uma de suas intervenções no III SAL, de análise dos distintos conceitos manejados nos discursos apresentados nos seminários anteriores e de tentativa de cingi-los uns aos outros. Enrique Browne ficara a cargo da seção incumbida do desenvolvimento de uma das questões apontadas por aquela, ou seja, a "dualidade entre declaração teórica expressa e a obra", a qual fora iniciada com sua palestra "Precisiones Latinoamericanas"180, que ensejara, também, outra avaliação sobre o estado do debate. A partir de suas experiências em Montevidéu, Mariano Arana profere a conferência de base da seção "a recuperação e renovação da cidade histórica", na qual problematiza a temática da preservação do patrimônio arquitetônico e urbano na

179 WAISMAN, Marina, Para una caracterización de la arquitectura latinoamericana. In: IV Encuentro de Arquitectura Latinoamericana. Conclusiones. México: Universidad Autónoma Metropolitana, 1991, p.27-32.

180 BROWNE, Enrique. Precisiones Latinoamericanas. In: IV Encuentro de Arquitectura Latinoamericana/ México. "La Trindad", Tlaxcala. México: Universidad Autónoma Metropolitana, 1989. 
América Latina ${ }^{181}$. Uma única abertura de seção - "a construção da cidade latinoamericana a partir das necessidades da sociedade de massas" - ficara a cargo de um dos anfitriões, González Lobo. Em sua conferência, de título homônimo ${ }^{182}$, este arquiteto mexicano, como veremos no próximo subcapítulo, busca uma hibridação entre o debate sobre a cidade latino-americana construído no III SAL e a definição utópica de Angel Mercado de uma "cidade de massas" associada ao surgimento de uma nova cultura democrática ${ }^{183}$.

A despeito da definição das quatro seções temáticas supracitadas, os expositores não se dividem igualmente entre elas. A primeira seção - e, talvez, a mais aberta dentre as propostas - congrega o maior público de interessados, vinte e um palestrantes, enquanto as demais contam com um número que varia entre quinze a dez apresentadores. A diferença torna-se ainda mais significativa quanto se percebe que o somatório das palestras que compuseram as mesas relativas à cidade latino-americana - seja sob o ponto de vista da sociedade de massas ou do patrimônio histórico - é apenas ligeiramente superior ao número da primeira ${ }^{184}$.

\footnotetext{
${ }^{181}$ ARANA, Mariano. De la recuperación y la renovación de la ciudad histórica. In: IV Encuentro de Arquitectura Latinoamericana. Conclusiones. México: Universidad Autónoma Metropolitana, 1991, p.19-25.

${ }^{182}$ GONZÁLEZ LOBO, Carlos. La construcción de la ciudad latinoamericana, desde las necesidades de masas. In: IV Encuentro de Arquitectura Latinoamericana/ México. "La Trindad", Tlaxcala. México: Universidad Autónoma Metropolitana, 1989.

${ }^{183}$ Angel Mercado é arquiteto mexicano e professor, desde 1980, da Unidade de Xochimilco da Universidad Autónoma Metropolitana, instituição organizadora do evento. Fora responsável, em meados dos anos 1980, pela definição, a partir da caracterização da Cidade do México, do conceito de "cidade de massas" - significativamente influente no meio mexicano -, que seria, sumariamente, uma urbanização pobre, produto da autoconstrução, na qual a edificação a partir de organizações de bases iniciaria o desenvolvimento de novas formas de cultura política (cf. DÍAZ BARRIGA, 1996, p. 292). Segundo Mercado, as massas desarticuladas teriam gestado um ideal de democracia distinto da representativa: "A noção de democracia direta emergiu tanto da 'massificação' do processo social, quanto do incremento da autogestão (...) destes processos devido à crise econômica. (...) As massas aprenderam, por si mesmas, a ideologia coletiva, através da participação na organização de um processo social fundamental (como a construção de suas próprias habitações), privilegiando o valor de uso sobre o valor de troca." (MERCADO, 1985, apud, DÍAZ BARRIGA, loc. cit., 1996, p.292).

${ }^{184}$ A seção intitulada "a construção da cidade latino-americana a partir das necessidades da sociedade de massas" contou com treze intervenções e a nomeada "a recuperação e renovação da cidade histórica" com dez - cf. IV Encuentro de Arquitectura Latinoamericana/ México. "La Trindad", Tlaxcala. México: Universidad Autónoma Metropolitana, 1989.
} 
De forma semelhante ao que ocorrera no terceiro SAL, as narrativas gerais do quarto evento tenderam, salvo algumas exceções ${ }^{185}$, a minimizar ou mesmo a omitir a importância do debate sobre a cidade latino-americana. Em uma crônica sobre do evento de Tlaxcala publicada na revista Summa, Adriana Irigoyen, por exemplo, propondo-se apontar os pontos comuns entre os distintos grupos de debates ali realizados, enfoca apenas os pontos que permitiriam ao leitor a percepção deste seminário como uma continuidade em relação a seus portenhos antecessores - como se pode constatar a partir do excerto a seguir:

Questões tais como as falsas antíteses entre tradição e modernidade, centro e periferia [...] começaram a ser desmontadas em forma sistemática e a partir das mais diversas aproximações. Mas, sobretudo, se evidenciou uma atitude comum: a intenção de construir um conjunto de ideias para servir de sustentação teórica a uma produção arquitetônica realizada sobre a base de óticas, categorias e valores próprios; uma produção que recriasse nossos segredos e nossos sonhos, nossas razões e nossas paixões. ${ }^{186}$

\section{A periferia urbana, o centro histórico e o avesso à cidade europeia}

Reduzida ao papel de coadjuvante na maior parte das crônicas realizadas sobre os seminários realizados na Colômbia e no México, a discussão sobre a cidade latinoamericana não fora, de fato, o objeto de interesse direto do maior número de seus participantes. Todavia, esta correspondeu ao tema central de uma porcentagem significativa das apresentações realizadas nestes eventos - em torno de trinta por cento no terceiro SAL e de quarenta por cento no quarto ${ }^{187}$. Além disso, como já

\footnotetext{
185 Insere-se, neste caso, o relato de Gutiérrez - publicado inicialmente em 1989, na Summa 265 , sob o título "Testimonio y conclusiones" e, posteriormente no volume relativo às conclusões do IV SAL - , no qual este busca costurar os distintos debates presentes não apenas no IV SAL, como também no terceiro seminário bem como nos encontros de revistas realizados no Chile e em Lima. Trata-se de uma tentativa de dar coerência ao todo e vincular as diferentes posturas para afirmá-las na sequência, como de fato o autor o faz neste texto, como pertinentes a um movimento. Cf. GUTIÉRREZ, R. Testimonio y Conclusiones. In: Summa, Buenos Aires: Ediciones Summa, 265, set 1989, p 58-59.

${ }^{186}$ IRIGOYEN, Adriana. Encuentro en Tlaxcala o como los arquitectos latinoamericanos consolidan sus lazos de amistad, compromiso y solidaridad In: Summa, Buenos Aires: Ediciones Summa, 265, set 1989, p 54-55.

${ }^{187}$ Considerou-se neste número apenas as apresentações realizadas dentro das seções temáticas especificamente voltadas para a discussão da cidade - $31 \%$ no III SAL e $39 \%$ no IV SAL. Cf. III Encuentro de Arquitectura Latinoamericana. Buenos Aires: CAPBA D III, 1988 e IV Encuentro de Arquitectura Latinoamericana/ México. "La Trindad", Tlaxcala. México: Universidad Autônoma
} 
salientamos, em ambas as ocasiões, as seções temáticas específicas sobre a cidade contaram com a participação de personagens de reconhecida atuação junto à história destes seminários. Logo, nem o número de contribuições, nem a ausência de participantes ilustres justificariam a corrente omissão da relevância dessa discussão que teve lugar nos III e IV SAL.

Ao se analisar a composição das mesas destes eventos, no entanto, percebe-se a existência de certa oscilação dos habitués entre os distintos grupos temáticos. Participantes fervorosos do debate sobre a periferia urbana no III SAL, a contribuições de Cristián Boza, Jorge Moscato ${ }^{188}$ e Humberto Eliash dispersaram-se em outras seções em Tlaxcala ${ }^{189}$. Já Marina Waisman e Ramón Gutiérrez, os quais ditaram os rumos das discussões sobre os centros históricos no IV SAL, compuseram a seção sobre historiografia e patrimônio em Manizales - e, em ambos os eventos, não tiveram a sua participação restrita à exposição em uma única mesa ${ }^{190}$. Nos dois exemplos aqui elencados não se observa, portanto, a filiação estrita a um debate específico - nem mesmo, em determinados casos, sua percepção como distinto dos demais.

Dentre os polos de debate a partir dos quais a cidade latino-americana fora abordada nos III e IV SAL, o relativo à periferia urbana - ou sobre a cidade de massas, como fora chamado no quarto encontro -, parece constituir em torno de si um grupo mais coeso. De fato, verifica-se, já no seminário de Manizales, certa ressonância entre as exposições relativas a esta temática realizadas por Cristián Boza, Humberto Eliash, Jorge Moscato, Juvenal Baracco e Eduardo San Martín. Estas similitudes de interesse e de forma de abordagem, no entanto, não parecem ser obra do acaso.

Metropolitana, 1989. Ver Apêndice B.

188 Jorge Moscato não pode ir ao evento de Tlaxcala, porém, o artigo que escreveu junto com seu sócio, Rolando Schere, para este seminário foi lido durante em sua seção - cf. MOSCATO, Jorge. Depoimento. [25 de agosto de 2011]. Buenos Aires: Arquivo digital da gravação (2horas $e$ 25min.). Entrevista concedida a Gisela Barcellos de Souza. Consideramos, portanto, que o mesmo foi apresentado, ainda que seus autores não tenham participado diretamente.

${ }^{189}$ Os dois primeiros contribuíram para a discussão sobre as "características da arquitetura latino-americana" e o terceiro para a relativa à "dualidade entre declaração teórica expressa e a obra". Cf. IV Encuentro de Arquitectura Latinoamericana/ México. "La Trindad", Tlaxcala. México: Universidad Autônoma Metropolitana, 1989.

${ }^{190}$ Gutiérrez fora responsável por proferir palestras de abertura em ambos os eventos. Marina Waisman, por outro lado, ministrou conferências magistrais do III SAL e a conferência de abertura da mesa "Características da Arquitetura Latino-americana" no IV SAL. 
O evento colombiano não fora a primeiro encontro entre esses arquitetos; laços anteriores a este episódio - alguns estreitos, outros mais frouxos - são passíveis de serem identificados entre estes arquitetos. Boza e Eliash, por exemplo, participavam desde 1977 do Centro de Estudios de la Arquitectura (CEDLA), responsável, entre outros, pela edição da revista ARS. Entre Jorge Moscato e Cristián Boza verifica-se a contribuição através de experiências docentes: em maio de 1986, ou seja, antes mesmo do segundo SAL, o arquiteto chileno fora convidado por aquele para participar, como crítico, do exercício didático em seu atelier na Escola de Arquitetura da Universidade Nacional de Buenos Aires - cujos resultados foram publicados na revista do CEDLA ${ }^{191}$. Juvenal Barraco iniciara seus contatos com o grupo CEDLA na IV Bienal do Chile, de 1983, e fortalecera-os no Encontro de Caburga, em 1984. San Martín participara, em 1986, juntamente com os arquitetos supracitados, dos debates ensejados pela $V$ Bienal do Chile - intitulada Vivienda y Calidad de Vida - que, nas palavras deste último, fora "um dos primeiros passos em direção ao tratamento do tema [da periferia urbana] com maior profundidade"192.

A partir destes pontos de contato anteriores parece construir-se um interesse comum pela abordagem da periferia e da autoconstrução sob o enfoque arquitetônico. Para além de ter sido o objeto do intercâmbio didático entre Boza e Moscato, esta temática fora, também, amplamente analisada em dois números monográficos da revista ARS, de 1985 e de 1986, os quais logo se tornaram referência no assunto como nos confirma sua menção na palestra de San Martín ${ }^{193}$.

Se a ressonância de ideias é passível de identificação entre os cinco participantes destacados; por outro lado, ecos de um debate anterior, cujos vestígios são testemunhados nos dois números da ARS supracitados, são mais perceptíveis entre as exposições de Jorge Moscato e Humberto Eliash, proporcionando a verificação de grande similitude na argumentação que apresentam. Ambos perfazem um apanhado geral daquele debate e o desenvolvem; um sob a perspectiva portenha, o outro visando torná-la genericamente latino-americana. Contudo, enquanto em sua palestra Moscato

\footnotetext{
${ }^{191}$ Cf. BOZA, Cristián; MOSCATO, Jorge. Dos experiencias académicas sobre la periferia. In: ARS, Santiago do Chile: CEDLA, n7, nov. 1986 p. 58-77.

192 SAN MARTIN, Eduardo. Ponencia sobre la Periferia. In: III Encuentro de Arquitectura Latinoamericana. Buenos Aires: CAPBA D III, 1988, p.94.

${ }^{193}$ Cf. SAN MARTIN, loc. cit. 1988, p.94.
} 
busca explicitar sua vinculação ao debate chileno, ao citar, por exemplo, Cristián Boza para afirmar que a periferia urbana "constitui [...] o maior desafio da arquitetura latinoamericana das próximas décadas" ${ }^{194}$; o mesmo não ocorre na comunicação de Eliash. Este último apenas menciona existência de estudos anteriores que visaram a “caracterização física e sociológica do subúrbio latino-americano"195 - dentre os quais poderíamos incluir seus próprios trabalhos publicados naquele periódico ${ }^{196}$, do qual era o editor responsável.

Tanto o arquiteto argentino, quanto o chileno iniciam suas exposições a partir da afirmação de que há uma "orfandade teórica" - expressão que se repete em ambos os textos - em relação à periferia das cidades latino-americanas. Trata-se, segundo Moscato, do local "onde nossa arquitetura naufraga irremediavelmente" ${ }^{197}$ e de um "problema que não é importante para as cidades europeias"198. Humberto Eliash avança um pouco mais nesta questão e chega a listar os autores cujas asserções tornam-se inoperantes no contexto latino-americano:

Desde os irmãos Krier ou Maurice Culot, até Aldo Rossi e a Tendenza, passando pelo trabalho de Colin Rowe e Alan Colquhoun, todos eles estruturam seu pensamento sobre um modelo urbano que pouca relação tem com a periferia latino-americana. Portanto, as práticas contextuais, ad hocistas, e historicistas são de duvidosa utilidade no caso que nos ocupa. ${ }^{199}$

As dimensões desta omissão teórica são salientadas em números: trata-se, segundo o arquiteto argentino, do local de moradia de milhões de habitantes e de "milhões de metros quadrados sem teoria arquitetônica" ${ }^{200}$, segundo o chileno. Estes buscam contribuir para reversão desta lacuna, caracterizando-a, primeiramente, e apontando alternativas para intervenção na sequência. Neste contexto, Moscato apoia

194 MOSCATO, Jorge. Arquitectura de la Periferia. In: III Encuentro de Arquitectura Latinoamericana. Buenos Aires: CAPBA D III, 1988, p.83.

195 ELIASH, Humberto. Dimensión Arquitectónica de la Periferia Urbana. In: III Encuentro de Arquitectura Latinoamericana. Buenos Aires: CAPBA D III, 1988, p.86.

${ }^{196}$ Cf. ELIASH, Humberto. Periferia Dibujada. In: ARS, Santiago do Chile: CEDLA, n. 7, ago. 1986.

197 MOSCATO, loc. cit., 1988, p. 82.

198 MOSCATO, loc. cit., 1988, p. 82.

199 ELIASH, Humberto. Dimensión Arquitectónica de la Periferia Urbana. In: III Encuentro de Arquitectura Latinoamericana. Buenos Aires: CAPBA D III, 1988, p.86.

${ }^{200}$ ELIASH, loc. cit, 1988, p.85. 
sua argumentação no trabalho que desenvolve em seu atelier na Faculdade de Arquitetura e Urbanismo da UBA:

Nós temos insistido a partir do atelier que a periferia não está desestruturada, porque isto implicaria em lhe dar um caráter de assentamento casual ou temporário. [...] O que pensamos é que sim está estruturad[a], porém segundo uma ordem que não conseguimos compreender, que está ligada ao modo de ocupação do território pelos diversos atores sociais. ${ }^{201}$

Ao apontar possíveis soluções para intervenção na periferia urbana, ambos recorrem à tipo-morfologia, indicando a utilização de padrões identificados e/ou reconhecidos como caminho adequado. Entretanto, enquanto Eliash enumera, ao final de seu texto, cinco itens a serem respeitados na prática arquitetônica como forma de "amenizar os problemas mencionados"202; Moscato aponta somente dois princípios gerais: intensificar utilização da tipologia - entendida aqui como o estudo dos tipos como forma de afirmar o "regional" e o "próprio" e aproveitar o potencial significativo que os edifícios de serviços públicos exercem em tecidos habitacionais de "crescimento contínuo e indiscriminado" ${ }^{203}$.

Diferentemente do que ocorrera nos discursos de Moscato e de Eliash, a palestra de Boza não se preocupou em recuperar elementos do debate anterior ou mesmo em situar rapidamente neste o espectador iniciante - ou mesmo o leitor futuro. Ao contrário, partiu-se diretamente para a asserção de seu postulado sobre "bairro" como o ponto de partida para a intervenção nas cidades do subcontinente "tanto na recuperação de seus centros históricos, como na construção da periferia" ${ }^{204}$ e para a afirmação do objetivo de sua exposição; ou seja, a "definição física dos elementos" 205 que constituiriam àquele. A existência de uma cidade específica latinoamericana aparece, por conseguinte, como inquestionável; sua caracterização prévia, ou mesmo justificativa, torna-se, portanto, desnecessária. Esta ocorreria, contudo, nas linhas subsequentes, tecida em meio à argumentação textual.

${ }^{201}$ MOSCATO, J. loc. cit., 1988, p.83-84.

${ }^{202}$ ELIASH, loc. cit, 1988, p.87.

203 MOSCATO, J. loc. cit., 1988, p.84.

${ }^{204}$ BOZA, Cristián. El Barrio: Punto de partida para reurbanizar la ciudad latinoamericana. In: III Encuentro de Arquitectura Latinoamericana. Buenos Aires: CAPBA D III, 1988, p.78.

${ }^{205}$ BOZA, C., loc. cit., 1988, p.78 
Destarte, após a definição geral de bairro como "instância socioespacial que forma a cidade" ${ }^{206}$ e cenário físico "capaz de alojar os atos da comunidade"207, Boza passa a destacar e caracterizar os pontos que constituiriam sua forma urbana. Ao fazêlo, todavia, preocupa-se repetidamente em afirmar que estes princípios seriam verificáveis em bairros latino-americanos com “qualidade urbana" ${ }^{208}$ - e para tal, são convocados com frequência exemplos de Santiago, Buenos Aires e Bogotá. Na definição destes elementos, Boza esmiúça, descreve-os num nível de detalhamento e condicionamento superior ao verificado as proposições nas comunicações de Moscato e Eliash - chega-se ao ponto de definir tamanhos em hectares e número máximo de habitantes. Percebe-se, em sua proposta e sua caracterização dos "bairros latinoamericanos", certa reverberação do debate de Léon Krier e de Maurice Culot sobre a "reconstrução da cidade europeia"209, contrariando as afirmações de Eliash de inoperância de teorias estrangeiras na cidade latino-americana.

Contudo, não obstante a existência das divergências aqui apontadas, reconhecese muitas similitudes entre os pontos elencados por Boza e os princípios definidos por Eliash e por Moscato. Estas se verificam tanto pontualmente - na afirmação, por exemplo, da importância simbólica dos edifícios públicos, presente nos textos do primeiro e do último, ou a conveniência de se projetar de tipos conhecidos de espaços públicos, proclamada pelos dois integrantes do CEDLA -, quanto em termos gerais. Nestes três arquitetos reconhece-se a mesma discussão de fundo sobre a necessidade de voltar à atenção para a arquitetura das periferias da cidade latino-americana e o reconhecimento desta como uma questão própria ao subcontinente.

Ecos deste mesmo debate imprimem-se também nas contribuições de San Martín e de Juvenal Baracco. Todavia, nestes seus efeitos na argumentação parecem menos perceptíveis, plasmam-se no discurso junto a ideias provenientes de outras matrizes intelectuais, tornando-se numa espécie de híbrido, com maior ou menor intensidade. Percebe-se, em ambos, um duplo esforço em recuperar o debate chileno

\footnotetext{
${ }^{206}$ BOZA, C., loc. cit., 1988, p.78.

207 BOZA, C., loc. cit., 1988, p.78.

${ }^{208}$ BOZA, C., loc. cit., 1988, p.79.

${ }^{209}$ Esta questão, assim como as demais traduções culturais que aparecerão ao longo deste texto, será objeto de análise em maior profundidade no capítulo 4.
} 
sobre arquitetura da periferia urbana e de buscar inserir-se neste - sobretudo no caso de San Martín.

Ao apresentar sua comunicação sobre a periferia em Manizales, o arquiteto chileno, então sócio de Browne, já possuía uma ampla experiência prática, bem como de gestão, no que concerne o desenvolvimento de projetos de habitação de interesse social. Além de ter participado do projeto de "Villa La Reina", iniciado nos anos 1960 e construído por meio de mutirão na gestão municipal Fernando Castilho, ele próprio fora prefeito de Santiago do Chile durante os anos de 1969-1973 ${ }^{210}$. Sua palestra foi amplamente pautada por sua experiência prévia, teórica e profissional. A partir deste lastro, entretanto, amalgamou-se a abordagem da periferia sob a ótica de sua arquitetura. Segundo este autor, até então, "o problema da periferia t[eria] sido tratado mais como um problema de construção de habitações que como uma forma de fazer cidade $^{\prime 211}$ - grifo nosso.

O texto apresentado organiza-se basicamente em duas partes: na primeira, San Martín dedica-se à sua inserção no debate sobre a arquitetura da periferia; na segunda, hibrida-o com questões e ideias de origens diversas. Logo, dentro deste contexto, o autor inicia sua argumentação com afirmação semelhante à de Moscato e de Eliash, ou seja, a de que há "quase uma ausência total de proposições teóricas para a periferia urbana" $^{212}$. No sentido de contribuir para a formação destas, apresenta uma versão preliminar de teses que seriam - num futuro próximo - ampliadas e desdobradas, tais como a diferenciação entre as arquiteturas que julga como responsáveis pela conformação da periferia das cidades chilenas - no caso as quais nomeia como a "oficial" e a "espontânea". Na segunda parte, como já dito, observa-se a ressonância de notas, oriundas das ciências sociais ${ }^{213}$, notadamente das asserções de Castells sobre a

210 SAN MARTIN, Eduardo. Ponencia sobre la Periferia. In: III Encuentro de Arquitectura Latinoamericana. Buenos Aires: CAPBA D III, 1988, p.94.

${ }^{211}$ SAN MARTIN, E. loc. cit., 1988, p.94.

${ }^{212}$ SAN MARTIN, E. loc. cit., 1988, p.94.

${ }^{213}$ Percebe-se também em Moscato e Eliash certa ressonância de uma caracterização da cidade latino-americana a partir da sociologia. Entretanto, nestes há, já neste momento, uma relativização maior desta em prol de um enfoque a partir da arquitetura. Tal questão fica clara nas conclusões que Eliash apresenta sobre o debate realizado na terceira seção do III SAL: "Mitos tais como 'tudo é resultado da dominação e da dependência'; ou 'é necessário revolucionar primeiramente a sociedade, depois a arquitetura'; ou 'os grandes males da periferia são causados somente pela especulação privada e pelo lucro' deverão ser revistos antes de se estruturar seriamente uma teoria". ELIASH, Humberto. Conclusiones. Grupo C. In: III Encuentro de 
urbanização dependente latino-americana ${ }^{214}$, as quais se mesclam às apresentadas anteriormente. Criam-se, desta forma, argumentos mistos. O surgimento, por exemplo, de uma nova sociedade urbana dentro da sociedade, a partir dos fluxos migratórios dos anos 1950, - "com suas próprias formas de organização, novos valores culturais e uma forte economia informal”215 - é utilizado para afirmar a impossibilidade de transcrição de padrões de espaços públicos da cidade formal para dentro destas novas comunidades e a necessidade, portanto, de definição de uma arquitetura apropriada a esta ${ }^{216}$.

O emprego da expressão "arquitetura apropriada" por San Martín merece um pequeno parêntese. Se, por um lado, seu texto estrutura-se a partir da tessitura entre seu interesse longínquo pela habitação de interesse social e sua inserção recente no debate sobre a arquitetura da periferia urbana; por outro, o emprego desta expressão mostra seu enraizamento, também, no debate geral dos SAL - aquele que fora amplamente divulgado pelas revistas de arquitetura e urbanismo. Ao fazê-lo, todavia, San Martín não estava sozinho.

Com efeito, malgrado o fato de não recorrerem ao emprego da expressão "arquitetura apropriada" percebe-se também nos textos de Moscato e de Eliash esta mesma vinculação do debate sobre a periferia urbana à busca de teorias próprias, as quais deveriam alimentar a prática profissional no subcontinente. Inclusive, o estudo desta temática aparece, nestes três autores, como um caminho para a identificação do que seria específico da região, visto que, como afirma Eliash, o problema da periferia urbana seria próprio à América Latina ${ }^{217}$. Ou seja, esse debate não era identificado como paralelo às questões lançadas nos seminários portenhos, mas sim como um desdobramento destas - devemos lembrar que a especificidade da periferia das grandes cidades latino-americanas já podia ser entrevista no debate do II SAL. Aliás, um dos pontos do acordo aprovado no Primeiro Encontro de Revistas de Arquitetura e Urbanismo, realizado em durante a $V$ Bienal de Santiago do Chile, foi justamente o compromisso - motivado pela temática daquela exposição - de que cada um dos

\footnotetext{
Arquitectura Latinoamericana. Buenos Aires: CAPBA D III, 1988, p.103.

214 Cf. CASTELLS, Manoel. Urbanización Dependiente en América latina. In: Castells (org) Imperialismo y Urbanizacíon en América latina. Barcelona: Gili, 1973, p7-26.

${ }^{215}$ SAN MARTIN, E. loc. cit., 1988, p.94.

${ }^{216}$ SAN MARTIN, E. loc. cit., 1988, p.94-95, passim.

${ }^{217}$ ELIASH, Humberto. Dimensión Arquitectónica de la Periferia Urbana. In: III Encuentro de
} Arquitectura Latinoamericana. Buenos Aires: CAPBA D III, 1988, p.85. 
periódicos ali representados contribuiria para a elaboração conjunta de um número monográfico sobre a habitação de interesse social na região, no período compreendido entre 1950 e 1985, o qual deveria ser editado pela Trama (Equador) ${ }^{218}$.

Apesar de não haver uma distinção, para os participantes da seção relativa à "Periferia Urbana", entre a temática nesta desenvolvida e as demais abordadas no evento de Manizales; o pequeno texto de Juvenal Baracco talvez seja, dentre os ali apresentados, o que estabelece uma maior conexão com o debate dos dois primeiros SAL. Efetivamente, tratava-se do único arquiteto ali presente que integrara a mesa redonda do primeiro seminário. Em sua comunicação, reaparecem as representações da urbanização acelerada latino-americana e do caos urbano dela resultante - além de certa preocupação com a recuperação de técnicas tradicionais de construção no provimento de habitação de interesse social. Reafirma-se, também, a necessidade de “enfrentar a arquitetura e a cidade a partir de outro ponto de vista" ${ }^{219}$. Entretanto, sua exposição não se resume a retomar o debate anterior; assim como nas demais exposições aqui elencadas, Baracco também aponta a "irrupção da edilícia funcionalista"220 como responsável pela deterioração da estrutura urbana latinoamericana e indica, como caminho para uma possível reversão, "reconhecer a cidade como estrutura histórica, descobrir a tipologia original da cidade, suas características arquitetônicas e sua evolução" 221 .

A verificação de ecos e ressonâncias neste debate, bem como os encontros informais fora deste - possibilitados, segundo Ruth Verde Zein, pela própria cidade de Manizales, visto que esta "não [era] grande a ponto de dificult[á-los]"222 - permitiu o estabelecimento de novos laços e outros frutos. Após este evento, a edição da revista ARS, de setembro de 1987, passou a contar com a colaboração de correspondentes

${ }^{218}$ Cf. GUTIÉRREZ, Ramón et al (org). Arquitectura Latinoamericana. Pensamiento y Propuesta. México: UAM/Unidad de Xochimilco. 1991.

${ }^{219}$ BARACCO, Juvenal. La Recomposición de la Ciudad Perdida. In: III Encuentro de Arquitectura Latinoamericana. Buenos Aires: CAPBA D III, 1988. 100.

${ }^{220}$ BARACCO, J., loc. cit, p.100.

${ }^{221}$ BARACCO, J., loc. cit, p.100.

${ }^{222}$ ZEIN, Ruth Verde. SAL I, II, III... Um hábito salutar. In: Projeto. São Paulo, n.100, jun., 1987, p.39. 
latino-americanos e a edição seguinte, de maio de 1988, marcaria uma reviravolta ainda maior no seio desta revista com sua vinculação direta aos $\mathrm{SAL}^{223}$.

Fato digno de nota é que, justamente no momento em que os elos parecem se definir com maior intensidade, as contribuições de Boza, Eliash e Moscato se enquadrariam em outras seções temáticas no IV SAL. Dentre os participantes do debate sobre a Periferia Urbana em Manizales, apenas San Martín permaneceu na mesa intitulada "Construção da cidade latino-americana a partir das necessidades da sociedade de massas".

Malgrado a ausência daqueles primeiros, a continuidade com o debate sobre a periferia - tal qual se o abordara no III SAL - fora possibilitada não apenas pela presença de San Martín, mas também, pelo empenho nítido de outros participantes, que, assim como este, conduziram esta mesa, em resgatá-lo e em procurar inserir-se neste. Este é o caso de Gonzalez Lobo, a quem já nos referimos no subcapítulo anterior. As ressonâncias daquele debate, porém, não se resumem ao discurso deste novo debatedor; revelam-se, também, em certa medida, na busca de uma definição de monumento adequada ao contexto latino-americano ${ }^{224}$, de Jorge Ramírez Nieto - o qual acompanhara o III SAL a partir da condição de plateia ${ }^{225}-$ e, com menor intensidade, na asseveração de Rafael Iglesia da necessidade de pensar a cidade como espaço vivido ${ }^{226}$.

A existência de anais, no qual todas as palestras do seminário anterior foram transcritas, desempenha um papel decisivo neste resgate das discussões anteriores. Poupam-se, agora, os novos palestrantes da árdua tarefa de tentar recompor o debate a partir de seus indícios publicados nas revistas de arquitetura ou de tentar rememorá-lo entre lapsos de lembranças pessoais. Significativamente, o texto de Gonzalez Lobo

\footnotetext{
${ }^{223}$ Esta questão é analisada no capítulo 3 desta tese.

${ }^{224}$ RAMIREZ NIETO, Jorge. Los monumentos y la ciudad latinoamericana. In: IV Encuentro de Arquitectura Latinoamericana/ México. "La Trindad”, Tlaxcala. México: Universidad Autônoma Metropolitana, 1989.

${ }^{225}$ Cf. ZEIN, Ruth Verde. SAL I, II, III... um hábito salutar. In: Projeto. São Paulo, n.100, jun., 1987, p.39.

${ }^{226}$ Rafael E. J. Iglesia fora um dos subscritores da Carta de Buenos Aires. Em sua palestra recupera a "Declaración de San Juan y Boedos", firmada 1983 - a qual fora também mencionada por Moscato e Schere, neste mesmo evento - afirmando a partir desta a necessidade de construção de uma "poética urbana respeitosa aos sítios e a seus habitantes". IGLESIA, Rafael, La construcción de la ciudad latinoamericana. In: IV Encuentro de Arquitectura Latinoamericana/ México. “La Trindad”, Tlaxcala. México: Universidad Autónoma Metropolitana, 1989.
} 
apresentado em Tlaxcala é pontuado por citações ipsis litteris dos anais do III SAL. O recurso a este documento - síntese da história dos SAL até então, nas palavras de Gutiérrez $^{227}$ - permitiu, portanto, o logro dos empreendimentos que buscaram promover uma hibridação entre aqueles debates e outros de origens mais ou menos distintas. A ratificação de ecos dos seminários anteriores, mesmo quando apenas parciais, parece, neste momento, constituir-se como condição para fazer avançar as discussões sobre outras frentes, bem como para garantir uma maior inserção dos iniciantes nos seminários.

Dentro deste quadro geral, insere-se a fusão, proposta por Gonzalez Lobo, entre a definição de Angel Mercado de "cidade de massas" - ver nota 171 - e o debate sobre a arquitetura da periferia urbana. Sua argumentação inicia-se com sua vinculação prévia às ideias de importantes personagens dos SAL, realizada por meio de citações diretas a Gutiérrez - e assunção da tarefa de elaboração de uma teoria própria - e a Salmona, especificamente no concernente às suas asserções sobre a necessidade de repensar as cidades latino-americanas. Na sequência, após breve caracterização das teses de Mercado - ao qual se refere como "autoridade relevante neste assunto"228 —, o arquiteto mexicano passa à constituição de uma urdidura entre estas e o debate iniciado em Manizales; de tal sorte que propõe, como objetivo de sua arguição, a delimitação de conceitos para entender a forma urbana da "cidade de massas".

Assim, ao descrever esta cidade que, segundo sua observação, já estaria em processo de constituição 229 - e que propiciaria "o surgimento e a reprodução de novas formas de organização social [...] baseadas em comportamentos coletivos e solidários”230 - Gonzalez Lobo procura simultaneamente caracterizar sua morfologia e indicar caminhos para a intervenção nesta. Na condição de resultante da urbanização acelerada latino-americana e de práticas de autogestão, a "cidade de massas" geraria, em suas palavras, inevitavelmente, tecidos urbanos "polimórficos, caóticos,

227 GUTIÉRREZ, Ramón, Relatoria General del IV Encuentro de Arquitectura Latinoamericana /México. "La Trinidad", Tlaxcala. In: IV Encuentro de Arquitectura Latinoamericana. Conclusiones. México: Universidad Autónoma Metropolitana, 1991.

${ }^{228}$ GONZÁLEZ LOBO, Carlos. La construcción de la ciudad latinoamericana, desde las necesidades de masas. In: IV Encuentro de Arquitectura Latinoamericana/ México. "La Trindad", Tlaxcala. México: Universidad Autónoma Metropolitana, 1989.

${ }^{229}$ GONZALEZ LOBO, C. loc. cit, 1989.

${ }^{230}$ GONZALEZ LOBO, C. loc. cit, 1989. 
catastróficos e desordenados"231. O que, a princípio, poderia parecer um recuo em relação às discussões do III SAL - visto que naquela ocasião afirmou-se que a periferia urbana tinha uma estrutura própria, a despeito de seu desconhecimento ${ }^{232}-$, revela-se, na sequência, como seu desdobramento e sua ampliação. Trata-se, agora, de reconhecer os valores positivos do caos: "convido à reflexão de como é na desordem polimórfica aonde de dão os maiores níveis de agudeza de percepção, [...] a multiplicação polivalente de experiência de índole cultural, social e corporal”233. Dentro deste contexto, Gonzalez Lobo propõe duas posturas de projeto em sua construção: urdir, ou reconstituir o tecido, e bordar, entendido como o ato de "criar variações multiformes [...], porém sujeitas ao ritmo e à ordem da trama"234. Percebe-se, tanto em sua interpretação sobre a forma urbana da cidade de massas, quanto na proposta de forma de intervenção nesta, certa ressonância em relação à apresentação de Moscato, durante o III SAL. De fato, o "urdir" e o "bordar" de Gonzalez Lobo assemelham-se tanto em termos de imagem metafórica, quanto em termos de definição - à sugestão daquele arquiteto argentino de que a estrutura morfológica da periferia fosse compreendida a partir das noções de "tecido", a base caótica e, ao mesmo tempo, monótona da periferia, e de "nós", locais que, contrapostos ao tecido, são capazes de distinção e de identificação ${ }^{235}$.

Ao contrário do percebido em Gonzalez Lobo, a hibridação entre discursos distintos torna-se, desta vez, menos patente na exposição de San Martín. Na condição de único representante do debate realizado em Manizales, este arquiteto desenvolveu em Tlaxcala algumas questões que já estavam esboçadas naquele seminário anterior. Outras, no entanto, como a discussão sobre o surgimento de uma nova sociedade urbana a partir do processo de urbanização latino-americano, acabaram por desvanecer. Esmaecem-se os empréstimos à sociologia para suscitar um destaque maior ao enfoque sob o olhar arquitetônico.

Neste contexto, o arquiteto chileno prosseguiu, em sua nova contribuição, somente com a busca pela definição de uma "Arquitetura Apropriada para a

\footnotetext{
${ }^{231}$ GONZALEZ LOBO, C. loc. cit, 1989.

${ }^{232}$ Cf. MOSCATO, Jorge. Arquitectura de la Periferia. In: III Encuentro de Arquitectura Latinoamericana. Buenos Aires: CAPBA D III, 1988, p.82-84.

${ }^{233}$ GONZALEZ LOBO, C. loc. cit, 1989.

${ }^{234}$ GONZALEZ LOBO, C. loc. cit, 1989.

${ }^{235}$ MOSCATO, Jorge, loc. cit., 1988.
} 
Periferia" ${ }^{236}$. Utilizou-se, para tanto, do resgate histórico das arquiteturas que construíram a periferia em Santiago do Chile, assim como da análise de três projetos que, sob seu ponto de vista pessoal, "reafirma[riam] nossa identidade latinoamericana"237. A diferenciação entre os tipos de arquiteturas da periferia fora iniciada por ocasião do III SAL. Entretanto, a classificação daquele momento - a oficial, realizada pelo Estado, e a espontânea, dita agora popular, fruto da autoconstrução - foi ampliada a fim de destacar justamente àquela que San Martín apontará, ao longo de sua argumentação, como um possível caminho para a aplicação da "Modernidade Apropriada" de Cox à periferia; a saber, as arquiteturas de autogestão. Assim, ao definir estas arquiteturas como "produto do esforço coletivo entre comunidades e arquitetos e reação à massificação e à segregação urbana"238 e distingui-las das demais edificadas pelo Estado, o autor possibilita tanto a crítica destas ditas oficiais - que, quando sob a inspiração do Movimento Moderno, propuseram "edifícios objetos, isolados do contexto [...] produzindo uma ruptura com o tecido tradicional" ${ }^{239}$-, quanto a defesa daquelas primeiras. Na segunda parte do texto descrevem-se de três experiências de autogestão, que são indicadas como exemplares: a Villa La Reina, 1965-1973; as comunidades de Fernando Castilho, de 1975, e o projeto Los Sauces, de 1983.

Este texto, apresentado em Tlaxcala, constituir-se-ia como o embrião de um livro que, posteriormente, seria escrito por San Martín: “A Arquitetura da Periferia de Santiago". A dívida a este escrito inicial seria reconhecida pelo autor em sua apresentação:

Este trabalho é [...] um esforço de recopilação dos projetos mais significativos desenvolvidos na periferia de Santiago, que comecei com a apresentação de uma palestra sobre a arquitetura da periferia no IV Seminário de Arquitetura Latino-americana de Tlaxcala, México, em maio de 1989. O texto definitivo foi terminado no final de $1990 .{ }^{240}$

\footnotetext{
${ }^{236}$ SAN MARTIN, Eduardo. Hacia una Arquitectura Apropiada para la Periferia de Santiago. Tres proyectos, tres propuestas. In: IV Encuentro de Arquitectura Latinoamericana/ México. "La Trindad", Tlaxcala. México: Universidad Autónoma Metropolitana, 1989.

${ }^{237}$ SAN MARTIN, E. loc. cit, 1989.

${ }^{238}$ SAN MARTIN, E. loc. cit, 1989.

239 SAN MARTIN, E. loc. cit, 1989.

${ }^{240}$ SAN MARTIN, E. La Arquitectura de la Periferia de Santiago: Experiencias y propuestas. Santiago: Editorial Andrés Bello. 1992, p. 9.
} 
Para este arquiteto chileno, a motivação para a elaboração deste livro teria advindo de conversas com Cristián Fernández Cox, Humberto Eliash e Cristián Boza, os quais "leram os primeiros esboços e [o] impulsionaram a desenvolver o tema" ${ }^{241}$. Além destes, San Martín agradece também as contribuições de "Ramón Gutiérrez , Adriana Irigoyen e Jorge Moscato, que revisaram a versão final e [...] fizeram importantes comentários sobre seu conteúdo" ${ }^{242}$. A vinculação deste livro aos debates realizados junto aos SAL também é afirmada por Ramón Gutiérrez, no prefácio que escreveu para este: “A análise e a proposta de Eduardo San Martín são [...] um testemunho da tarefa que desenvolvem os Seminários de Arquitetura Latino-americana"243. Em suma, tanto da inserção em um debate maior quanto da existência de relações interpessoais são declaradas como legitimadoras das ideias defendidas pelo autor.

Apesar de não terem composto a mesma mesa de San Martín no IV SAL, Moscato, Boza e Eliash, ao se dispersarem em outras seções temáticas, carregaram consigo um pouco do debate outrora ensejado no âmbito da discussão sobre a periferia urbana. Em sua palestra intitulada "Hacer Arquitectura en la Argentina", Moscato e seu sócio, Rolando Schere, afirmam, novamente, a ignorância latino-americana sobre seus próprios problemas urbanos e a necessidade de buscar uma resposta a estes ao se construir uma teoria própria: "sabemos algumas coisas sobre o centro e os bairros, porque outros pensaram a respeito nos países centrais, porém a periferia é um problema nosso que estes não conhecem" ${ }^{244}$. Na sequência, os autores afirmam que este trabalho já estaria em processo de conformação "há alguns anos, [...] na Argentina e na América latina," ${ }^{245}$ e que este reuniria os "aportes disciplinares mais rigorosos a fim de estruturar uma disciplina urbana latino-americana" ${ }^{246}$. Sem listar os arquitetos envolvidos nesta empreitada, Moscato e Schere fazem ecoar o debate de Manizales propondo refletir sobre "o bairro o ponto de partida para reurbanizar a cidade latino

\footnotetext{
${ }^{241}$ SAN MARTIN, op. cit., 1992, p.9.

${ }^{242}$ SAN MARTIN, op. cit., 1992, p.9.

243 GUTIÉRREZ, R. Prefacio. In: SAN MARTIN, E. La Arquitectura de la Periferia de Santiago: Experiencias y propuestas. Santiago: Editorial Andrés Bello. 1992, p.12.

${ }^{244}$ MOSCATO, J.; SCHERE, R. Hacer Arquitectura en Argentina. In: IV Encuentro de Arquitectura Latinoamericana/ México. "La Trindad", Tlaxcala. México: Universidad Autónoma Metropolitana, 1989.

245 MOSCATO, J.; SCHERE, R, loc. cit., 1989.

${ }^{246}$ MOSCATO, J.; SCHERE, R, loc. cit., 1989.
} 
americana, tal como o escrevera Cristián Boza”247. Este último arquiteto, por sua vez, presente, assim como os dois argentinos na mesa relativa às "Características da Arquitetura Latino-americana", resgatava apenas os aspectos relativos à tipo-morfologia daquele debate, defendo a análise tipológica e formal como caminho para "uma identidade arquitetônica própria, singular e peculiar"248. Em outra mesa de debate, Humberto Eliash apoiava-se também no vocabulário tipo-morfológico para desenvolver, no âmbito da arquitetura, a afirmação do sociólogo chileno Pedro Morandé integrante do Taller América - de que a "cultura latino-americana carrega em si, de forma congênita, o germe da contradição entre o pensar e o fazer" ${ }^{249}$.

A reverberação de ideias entre estes arquitetos, além de transparecerem nos seminários, permitiram, ainda, a organização posterior de um livro intitulado "Architettura e società", prefaciado por Gutiérrez e publicado na Itália em 1996. Para a composição deste, Eliash e San Martín escreveram, juntos, um capítulo sobre a construção da periferia na América Latina; Moscato fez um apanhado geral sobre a atuação dos arquitetos latino-americanos no século vinte e sua relação com a sociedade; já Gonzalez Lobo tratou especificamente da relação entre arquitetura e participação social no subcontinente ${ }^{250}$.

A discussão sobre as cidades latino-americana nos Seminários de Arquitetura Latino-americana realizados na Colômbia e no México, como já mencionamos, não se deu somente a partir da análise de suas margens. Representada frequentemente por seu crescimento acelerado e pela produção de tecidos aparentemente caóticos, os seminários possibilitaram a manifestação de debates que visaram à análise desta urbanização em curso no subcontinente e de suas consequências - tanto no âmbito de suas periferias, quanto de seus centros históricos. Se, por um lado, a problemática relativa aos centros históricos, apesar de prevista na agenda de programação, não chegou a congregar palestras destinadas exclusivamente a seu estudo no III SAL; por

\footnotetext{
${ }^{247}$ MOSCATO, J.; SCHERE, R, loc. cit., 1989.

${ }^{248}$ BOZA, C. Identidad Arquitectónica: Un análisis tipológico y formal en Santiago de Chile. In: IV Encuentro de Arquitectura Latinoamericana/ México. "La Trindad", Tlaxcala. México: Universidad Autónoma Metropolitana, 1989.

${ }^{249}$ ELIASH, Humberto. Esquizofrenia Arquitectónica. El desencuentro entre la ética y la estética. In: IV Encuentro de Arquitectura Latinoamericana/ México. "La Trindad", Tlaxcala. México: Universidad Autónoma Metropolitana, 1989.

${ }^{250}$ GUTIÉRREZ, Ramón (org). Architettura e Società. L’América Latina nel XX secolo. Milão: Jaca Book, 1996.
} 
outro, esta se manteve no debate de forma latente desde que se apresentara no primeiro seminário, trazida à mesa redonda por Mariano Arana e seu relato de sua atuação em Montevidéu. Logo, a delimitação de uma seção temática sobre a recuperação e renovação da cidade histórica no evento de Tlaxcala representou menos a proposição de uma nova abertura do debate, que a assunção de sua autonomia relativa em relação às demais questões entre as quais costumeiramente amalgamavase.

Dentre os debatedores desta mesa, encontravam-se personagens ilustres, que estiveram à frente destes encontros latino-americanos desde suas primeiras realizações: Marina Waisman, Ramón Gutiérrez e Mariano Arana. Responsável pela palestra de abertura desta seção, Arana ${ }^{251}$ enfocou questionamentos sobre a preservação do patrimônio no âmbito latino-americano ${ }^{252}$, sem transparecer representações ou preocupações diretas sobre os centros históricos inseridos neste contexto.

Ao contrário do arquiteto uruguaio, ambos os argentinos trataram de compreender o significado dos centros históricos dentro da cidade contemporânea e de apontar perspectivas para sua recuperação. Curiosamente, ao se analisar as posturas destes dois conterrâneos, percebe-se que, a despeito da frequência com que estes se encontram e do interesse comum que demonstram pelos centros históricos e pela questão da preservação do patrimônio, o nível de divergência entre estas parece maior que o identificado nas discussões sobre a periferia urbana. De certa forma, esta dissonância se manifestara já nos primeiros seminários, quando Ramón Gutiérrez defendia - apoiando-se em suas pesquisas históricas sobre a urbanização na América Latina - a existência de uma identidade regional nata e Marina Waisman, por outro lado, afirmava esta como algo a ser construído.

Outro fato digno de nota é que, apesar de os debates sobre a periferia e o centro histórico se darem em seções distintas nos III e IV SAL, se verifica certa reverberação entre o discurso de algumas das personagens que estiveram em suas frentes. Dentro deste quadro insere-se a semelhança entre a proposta de Marina

\footnotetext{
${ }^{251}$ Esta palestra de Arana em Tlaxcala representou seu retorno à posição de debatedor ativo nos SAL, a qual não exercia desde o primeiro seminário portenho.

${ }^{252}$ ARANA, Mariano. De la recuperación y la renovación de la ciudad histórica. In: IV Encuentro de Arquitectura Latinoamericana. Conclusiones. México: Universidad Autónoma Metropolitana, 1991, p.19-25.
} 
Waisman, apresentada no III SAL, de utilização dos instrumentos aplicados no conhecimento e na preservação do patrimônio - no caso a tipo-morfologia - para a identificação de traços regionais comuns ${ }^{253}$ e a sugestão de Cristián Boza no IV SAL do emprego destes mesmos métodos na construção de uma identidade latino-americana. A exposição do arquiteto chileno parece, dentro do contexto dos seminários, ressoar aquela que lhe precedeu.

O interesse de Waisman pela tipo-morfologia bem como sua proposição como forma de buscar desvelar elementos para construção de uma identidade regional não datam daquele evento em Manizales. Pelo contrário, a defesa do recurso à tipificação como analisaremos melhor no capítulo relativo às traduções e encontros culturais - é recorrente nos textos desta arquiteta argentina, cujas primeiras manifestações são passíveis de reconhecimento já em seu livro “La estructura histórica del entorno"254, publicado em 1972. A proposição da utilização de seus métodos como auxílio para a definição de uma arquitetura própria ao subcontinente, por sua vez, já transparecia no texto desta arquiteta apresentado no primeiro dossiê da revista Summa nomeado “Arquitectura Iberoamericana" ${ }^{255}$. Por ocasião do III SAL, no entanto, Waisman enfatiza a necessidade de se empreender um estudo comparativo dos núcleos urbanos latinoamericanos - chegando a sugerir categorias de análise para tal ${ }^{256}$ - como forma de reconhecimento dos traços comuns à região ${ }^{257}$.

Em sua exposição à mesa relativa aos centros históricos no IV SAL, entretanto, Waisman parece um pouco reticente quanto à afirmação de uma urbanização recente genuinamente latino-americana. Apoiando-se em ciclos temporais de longa duração, afirma que até o final do século XIX as cidades latino-americanas cresceram através de

${ }^{253}$ WAISMAN, Marina. Contribución de las disciplinas históricas y de preservación del patrimonio a la definición de una arquitectura regional. In: III Encuentro de Arquitectura Latinoamericana. Buenos Aires: CAPBA D III, 1988, p.7-8.

${ }^{254}$ WAISMAN, Marina. La estructura histórica del entorno. Buenos Aires: Ediciones Nueva Visión, 1972.

255 WAISMAN, Marina. Alineación e integración en el traspaso de las ideologías. In: Summa. Buenos Aires: Ediciones Summa, n²12, maio de 1985.

${ }^{256}$ No caso, a autora elenca o traçado, o tecido edilício, a tecnologia construtiva, as respostas ambientais, os espaços urbanos, os mobiliários urbanos e o patrimônio cultural imaterial. Cf. WAISMAN, M. loc. cit. 1988.

${ }^{257}$ Waisman justifica sua proposta da seguinte forma: “é de sua função urbano-regional, do processo de ocupação do território, dos modos de desenvolvimento da urbanização, que derivam os traços comuns susceptíveis de permitir a identificação entre o entorno construído da região." Cf. WAISMAN, M. loc. cit., 1988. 
um direcionamento centrípeto - "tendente à consolidação do tecido urbano [...] [e com] a integração das margens ao centro" 258 -, processo este que se teria invertido no século XX por um crescimento centrífugo - "tendente ao enfraquecimento do tecido, [...] [à] perda de força do centro" 259 , cuja aceitação seria equivalente a "decretar a morte da cidade como entidade social e cultural ${ }^{\prime 260}$. Este processo recente, que conduziria à descentralização e à dispersão no território, não representaria, no entanto, uma forma de expansão exclusiva à América Latina, ao contrário, seria característico às "grandes cidades da era pós-moderna"261, de modo geral.

Segundo Marina Waisman, objetivo de sua exposição seria analisar os efeitos que a expansão centrífuga e as operações de estruturação/desestruturação do tecido existente - que se colocaram em prática a partir do final do século $\mathrm{XIX}^{262}$ - geraram nos centros históricos. Ao fazê-lo, no entanto, não se limita à caracterização destes núcleos urbanos originais na contemporaneidade; descreve, também, o processo de marginalização - diferenciando a periferia popular da burguesa - e o enfraquecimento da identidade dos antigos bairros. Como forma de reversão deste processo, propõe a realização de intervenções pontuais que possibilitariam "dar um centro significativo a um material urbano amorfo e indefinido" ${ }^{263}$, afirmando, com esta, certa autonomia na escala do bairro - princípio reiterado correntemente no debate específico sobre a periferia.

O diálogo com aquele debate iniciado em Manizales sobre as margens da cidade latino-americana também parece transparecer na palestra de Ramón Gutiérrez preparada para compor a mesa sobre os centros históricos no IV SAL. Nesta, o autor desdobra e desenvolve a ideia - já lançada no texto que fora inicialmente publicado na Summa ${ }^{264}$, em 1986, e, posteriormente, apresentado em Manizales - que a recuperação dos centros históricos latino-americanos degradados por, entre outros, seu processo esvaziamento poderia se dar através de políticas de promoção de habitação de

\footnotetext{
${ }^{258}$ WAISMAN, Marina. loc. cit., 1989.

${ }^{259}$ WAISMAN, Marina. loc. cit., 1989.

${ }^{260}$ WAISMAN, Marina. loc. cit., 1989.

${ }^{261}$ WAISMAN, Marina. loc. cit., 1989.

262 WAISMAN, Marina. loc. cit., 1989.

${ }^{263}$ WAISMAN, Marina. loc. cit., 1989. Grifo no original.

${ }^{264}$ GUTIÉRREZ, Ramón. Identidad en la Arquitectura Latinoamericana. In: Summa. Buenos Aires: Ediciones Summa, no 224, maio de 1986. Republicado nos anais do SAL III
} 
interesse social. Se, naquele texto exposto no evento colombiano - cujo foco era a afirmação da identidade na arquitetura através do compromisso para com as heranças e os aportes temporais -, esta sugestão era apenas uma indicação de uma das ações que identificariam a política de preservação do "patrimônio como resposta social"265; no evento mexicano esta se torna a base da argumentação do arquiteto argentino e de sua proposta de "vinte pontos para atuar nos centros históricos americanos" ${ }^{266}$. Nesta ocasião, o autor afirma que, dentro do contexto de postergação econômica da América Latina, "é impossível assegurar a preservação de um centro histórico sem resolver simultaneamente problemáticas de índole social”267. Esta asseveração é justificada, por um lado, pela necessidade da coexistência de diferentes usos a fim de garantir a manutenção da vida urbana nos centros e, por outro, pela possibilidade de se congregar sua recuperação com provimento de habitação de interesse social. A inexistência de uma convergência entre as políticas de preservação e de habitação seria, para o autor argentino, inconcebível no contexto latino-americano:

O que se torna incompreensível é que a maioria de nossos países, acossados por problemas econômicos, prossiga, todavia, demolindo um patrimônio econômico edilício existente [...]. Também se torna paradoxal que países que proclamam centenas de milhares ou milhões de unidades habitacionais de déficit não aproveitem este patrimônio construído ${ }^{268}$

A construção desta proposta, vista como adequada à realidade do subcontinente, apoia-se na diferenciação prévia entre as cidades inseridas neste e as europeias. Neste ponto, evidencia-se a divergência entre as asserções de Gutiérrez e aquelas de sua conterrânea, apresentadas na mesma mesa. Ao contrário da semelhança, apontada por Waisman, entre o processo de urbanização difusa presente nas grandes cidades, de modo geral; Gutiérrez reitera que a existência de "cidades de enormes carências sociais [...] em rápido processo de expansão e de renovação edilícia

\footnotetext{
${ }^{265}$ GUTIÉRREZ, R. loc. cit., 1986.

${ }^{266}$ GUTIÉRREZ, Ramón. Los centros históricos de América Latina. Un desafío a la creatividad. In: IV Encuentro de Arquitectura Latinoamericana/ México. "La Trindad", Tlaxcala. México: Universidad Autónoma Metropolitana, 1989.

${ }^{267}$ GUTIÉRREZ, Ramón. loc. cit., 1989.

${ }^{268}$ GUTIÉRREZ, Ramón. loc. cit., 1989.
} 
sem consolidação" constituiriam uma realidade própria urbana à América Latina e oposta à europeia $^{269}$.

Não obstante o fato ter sido ponderada na apresentação de Marina Waisman no IV SAL, a definição da cidade latino-americana a partir de sua oposição à europeia afigura-se como um dentre os elementos mais recorrentes nos discursos proferidos por habitués em Manizales e Tlaxcala, bem como um corolário das representações entrevistas nos primeiros seminários. Efetivamente, esta afirmação transparece nas mais distintas seções temáticas, não sendo, portanto, exclusiva àquelas que se destinaram ao debate de questões específicas relativas às cidades latino-americanas. Seu emprego usual se dá como asserção inicial, e supostamente óbvia, que permite o encadeamento e a justificação das demais. Afirma-se que a cidade latino-americana é distinta da europeia como ponto de partida para os mais diversos fins: desde a defesa da diversidade arquitetônica, no caso de Ruth Verde Zein ${ }^{270}$; à proposição de um olhar arquitetônico sobre a periferia urbana, como Eliash, Moscato e San Martín.

A convocação desta imagem em meio argumentação ocorrera com tamanha frequência nestes eventos, que não parece ter suscitado polêmica o fato de Comas, em sua tentativa de identificar os aspectos que levaram à "corrente preocupação com a caracterização latino-americana"271, ter apontado, dentre os pontos que elenca, a perplexidade em relação à "cidade iluminista europeia encampada como modelo de validade universal”272. Pelo contrário, foi justamente este o fragmento da palestra do arquiteto brasileiro em Tlaxcala - que versava sobre a questão do caráter na arquitetura moderna brasileira - que Gutiérrez escolheu para transcrever na abertura

\footnotetext{
${ }^{269}$ Segundo o autor, na Europa "as grandes cidades perdem habitantes" - cf. GUTIÉRREZ, R. loc. cit., 1989. Esta afirmação é, no entanto, válida se consideradas apenas as taxas de variação populacional entre os anos 1980-90 nos núcleos históricos, descartando-se o crescimento populacional apresentado neste mesmo período nos aglomerados e regiões metropolitanas.

${ }^{270}$ ZEIN, Ruth Verde. Arquitectura en el siglo XXI: ¿Fin de las utopías o su realización? In: III Encuentro de Arquitectura Latinoamericana. Buenos Aires: CAPBA D III, 1988. p.12

271 COMAS, C. E, Identidade Nacional, caracterização arquitetônica. In: IV Encuentro de Arquitectura Latinoamericana/ México. "La Trindad", Tlaxcala, Tlaxcala (México): Universidad Autónoma Metropolitana, 1989.

${ }^{272}$ Cf. COMAS, C. E. loc. cit., 1989. Comas refere-se aqui ao debate relativo à "reconstrução da cidade europeia" do qual fizeram parte - com graus de adesão distintos - arquitetos europeus de diferentes países, entre o final dos anos 1970 e meados da década de 1980.Esta questão e os problemas de tradução cultural que ela engendra serão abordados nesta tese no capítulo 4.
} 
de seu texto sobre as conclusões e sobre seu testemunho pessoal deste evento ${ }^{273}$, publicado originalmente na Summa.

Problemas de tradução cultural de um debate estrangeiro, tal qual o indicado por Comas, são frequentemente apontados. A diferença de origem impede qualquer empréstimo - "importar soluções é estar em falta com a história e com nossos povos", dizia Salmona em sua conferência em Manizales. Muitas contribuições buscam precisar os motivos para a impossibilidade de transcrições. Ruth Verde Zein, por exemplo, afirma que a coerência em relação ao entorno é distinta na América Latina: "em nossos contextos latino-americanos, os arquitetos, em geral, não têm que adotá-los, mas sim dotá-los"274.

Algumas dentre as expressões utilizadas para descrever desta cidade específica acabam por atingir grande fortuna crítica, sendo repetidas em palestras posteriores. Insere-se neste contexto a caracterização, lançada no segundo seminário, de Silvia Arango das cidades latino-americanas como "construídas sob os desígnios do Movimento Moderno"275, nas quais "praticamente se apagaram as frágeis marcas de seus passados" ${ }^{276}$. Além de frequentemente transparecer nos discursos mais diversos, esta mesma definição fora retomada por sua autora em suas contribuições no terceiro e no quarto SAL. Neste último evento, a autora colombiana chegou a asseverar que esta particularidade em relação às cidades europeias e às norte-americanas - "onde o moderno não avassalou os tecidos urbanos históricos mais sólidos" ${ }^{277}$ - teria gerado uma reação própria da América Latina ao Movimento Moderno:

Quando nas últimas décadas o Movimento Moderno foi questionado a partir de múltiplos flancos, nós latino-americanos marcamos uma ênfase na crítica de caráter urbana, com uma arquitetura que busca imbricar-se com a

${ }^{273}$ GUTIÉRREZ, R. Testimonio y Conclusiones. In: Summa, Buenos Aires: Ediciones Summa, 265, set 1989, p 58-59.

${ }^{274}$ ZEIN, Ruth Verde. loc. cit., 1988, p.12

${ }^{275}$ ARANGO, Silvia. Estrutura Essencial y Estrutura Contingente. In: IV Encuentro de Arquitectura Latinoamericana/ México. "La Trindad", Tlaxcala, Tlaxcala (México): Universidad Autónoma Metropolitana, 1989.

276 ARANGO, Silvia. Siete anotaciones para pensar la arquitectura latinoamericana. In: III Encuentro de Arquitectura Latinoamericana. Buenos Aires: CAPBA D III, 1988. p.68-69.

${ }^{277}$ ARANGO. Silvia. loc. cit., 1988. p.69. 
cidade tradicional, recuperando valores urbanos que ameaçavam desaparecer. $^{278}$

Dentro deste âmbito, é possível se entender, segundo Arango, a ressonância determinados arquitetos estrangeiros - entre os quais cita Rossi e os irmãos Krier $^{279}$ nos países do subcontinente: "apesar das evidentes diferenças de contexto físico e cultural, [...] estes afirmam como primeiro termo os temas do espaço público, da memória coletiva e das tipologias urbanas e arquitetônicas" ${ }^{280}$. Ou seja, algumas traduções culturais seriam compreensíveis - e talvez até mesmo permitidas - devido ao seu emprego para reflexão sobre problemáticas específicas, como à do deterioramento dos espaços públicos.

Entretanto, ao escrever estas linhas, a crítica colombiana não parece referir-se apenas à recorrência com que o vocabulário tipo-morfológico transparece em meio aos discursos latino-americanos - apontada também por Waisman, em Manizales ${ }^{281}$-, nem mesmo somente ao trabalho empenhado, desde a década de 1970, por esta arquiteta argentina no sentido de construir uma tipologia específica para a região. Arango parece trazer à memória os eventos concretos que ocorreram em seu país e marcaram sua cultura arquitetônico-urbanística no início dos anos 1980. Dentre estes, um, especificamente, obtivera grande cobertura pela revista Proa e abordara justamente questões relativas ao "espaço urbano" e a necessidade de matização de debates estrangeiros para o contexto latino-americano. Referimo-nos aqui ao encontro "Espacio Urbano" organizado pela Universidad de los Andes, em agosto de 1982, para o qual foram convidados Oriol Bohigas, Álvaro Siza, Fernando Montés e Aldo Rossi ${ }^{282}$. Dentre as conclusões suscitadas por este debate entre os arquitetos colombianos, o

\footnotetext{
${ }^{278}$ ARANGO, Silvia. Estrutura Essencial y Estrutura Contingente. In: IV Encuentro de Arquitectura Latinoamericana/ México. "La Trindad”, Tlaxcala, Tlaxcala (México): Universidad Autônoma Metropolitana, 1989.

${ }^{279}$ ARANGO. Silvia. loc. cit., 1988. p.69.

${ }^{280}$ ARANGO. Silvia. loc. cit., 1988. p.69.

281 A recorrência às técnicas e ao vocabulário da tipo-morfologia também é postulada por Waisman como um traço comum no debate dos SAL - em seu "dicionário do regionalista comprometido", apresentado em Manizales. WAISMAN. Marina. Breve Diccionario del Regionalista Comprometido. In: III Encuentro de Arquitectura Latinoamericana. Buenos Aires: CAPBA D III, 1988. p.68-69.

${ }^{282}$ Ver SALDARRIAGA. Alberto. Arquitetura, Espacio Urbano y Latinoamérica. In: Proa. Bogotá: Ed. Proa, n. 305 abril 1982; bem como a transcrição da mesa redonda deste evento em: "Espacio Público. Mesa Redonda" - Proa. Bogotá: Ed. Proa, n. 321 ago. 1983.
} 
chileno e os europeus, a mais patente talvez tenha sido, justamente, a afirmação da diferença entre suas cidades.

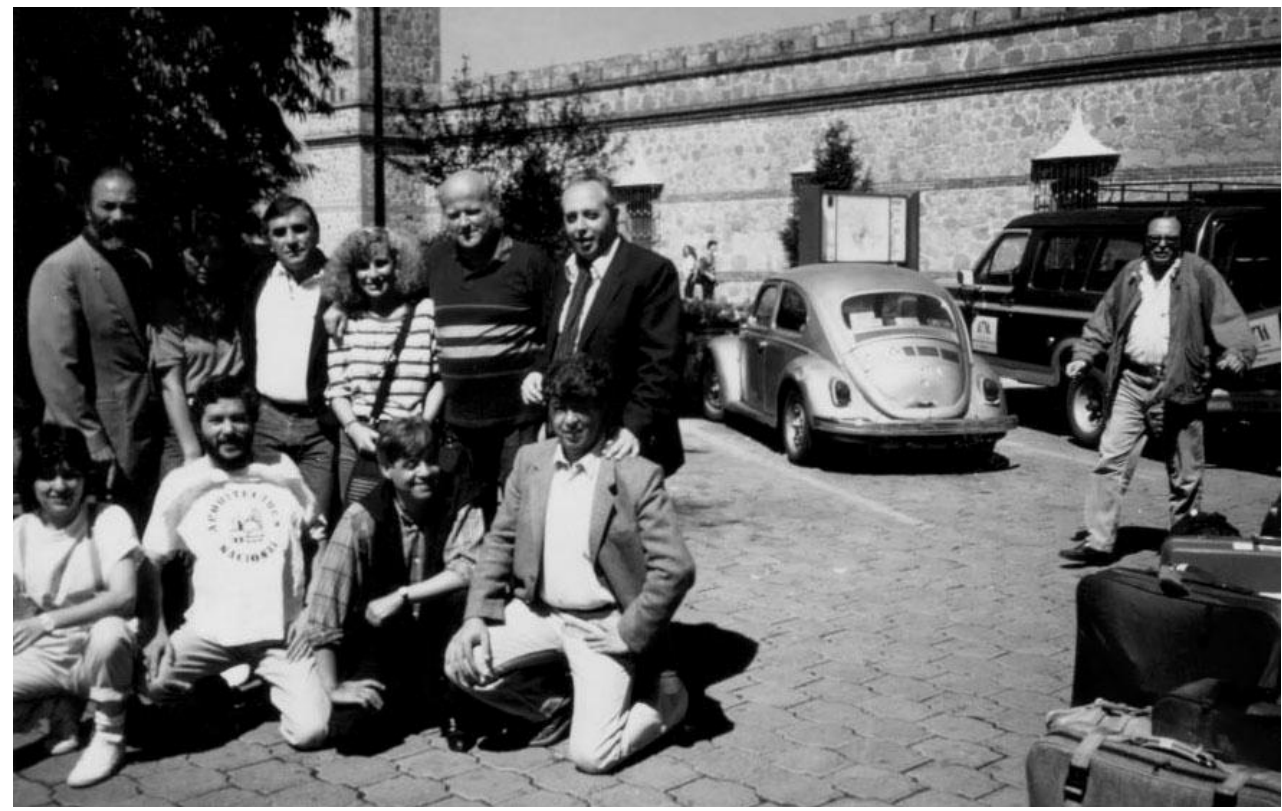

Figura 25: Cristián Boza, Eduardo San Martín, Cristián Fernández Cox, Alberto Petrina, Humberto Eliash e Carlos Eduardo Comas no IV SAL. Fonte: Acervo pessoal de Humberto Eliash.

\section{Prelúdio do V SAL}

Este percurso - ora linear, ora transversal e temático - através das representações sobre a cidade latino-americanas junto aos SAL anteriores ao evento de Santiago, permite-nos, primeiramente, comprovar a inexistência de um discurso unívoco nestes seminários. Ao contrário do que fora correntemente afirmado, as dissonâncias manifestam-se desde as realizações portenhas e não parecem dirimir nas posteriores. Não obstante, observa-se - em diferentes ocasiões do período áureo destes eventos, 1985-1995 - um cuidadoso trabalho, empenhado por críticos que ansiavam sua institucionalização, ou mesmo sua afirmação como movimento, no sentido de buscar urdir um consenso em sua diversidade.

Dentro deste contexto, revela-se o debate sobre a cidade latino-americana como um dentre os distintos centros de interesse dos participantes dos SAL, cuja importância fora, em diversas oportunidades, minorada. Seu enraizamento nestes eventos, contudo, é passível de reconhecimento já em seus primeiros debates. Tênues e ainda latentes naqueles, as representações da cidade latino-americana tornam-se objeto de seções temáticas específicas nos III e IV SAL. Sob olhares distintos e em meio a 
contribuições de participantes de origens diversas, algumas ideias ressoam e solidificamse; outras, por sua vez, escoam.

Na permanência ou no esmaecimento de determinadas abordagens da cidade latino-americana, a reverberação de debates anteriores parece desempenhar um papel determinante. Observa-se, sobretudo no quarto SAL, que a maior ou menor inserção de novos participantes depende, em grande parte, da constituição de dispositivos que lhes permitam hibridar as matrizes originais de suas ideias aos debates realizados em seminários anteriores.

Em meio às discussões sobre a cidade latino-americana, dois olhares - já perceptíveis nos I e II SAL - codificam-se claramente a partir de Manizales: um voltado à periferia urbana e outro aos centros históricos. Em ambos, nota-se a abordagem, com graus de adesão distintos, do tema através do vocabulário tipo-morfológico. A oposição entre a cidade europeia e a latino-americana, no entanto, é frequentemente convocada para afirmar a impossibilidade de transcrição literal de instrumentos elaborados para aquele contexto. Enseja-se, portanto, a proposição de categorias de análise e de projeto próprias ao contexto regional. Entre sugestões novas e precedentes, testemunham-se correntemente reverberações. Estas não se restringem aos debates fomentados em uma mesma seção temática, transpassam por diversos temas e olhares.

As personagens, assim como as ressonâncias, oscilam por seções distintas. Não se percebe, salvo algumas exceções, a vinculação estrita a um único debate. Em meio a esta alternância, no entanto, permanece o interesse pela abordagem tipo-morfológica, bem como a representação da cidade latino-americana a partir de seu contraste em relação à europeia. A recorrência com que estas questões transpareceram em meio às arguições, mesmo que, em sua maior parte, apenas ligeiramente, fez com que Arango e Waisman destacassem-nas como um dos pontos de convergência no debate.

Comprova-se, por conseguinte, que, neste contexto, a realização de um seminário específico sobre a morfologia dos espaços públicos latino-americanos não representava uma ruptura nos rumos dos SAL ou mesmo um hiato. Pelo contrário, esta se afigura como o desdobramento de debates específicos que ganharam maior espaço entre os eventos de 1987 e de 1989. Não é de se estranhar, portanto, que as cidades antigas e a periferia urbana tenham constado dentre os quatro temas de debate propostos para V SAL, em 1991. Entretanto, se por um lado a realização deste evento se 
enraíza na história dos SAL, por outro, diversas inovações neste inseridas - as quais analisaremos no próximo capítulo - não permitem a afirmação desta como sua única origem. 



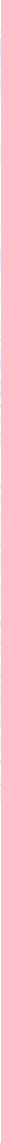


132 Tessituras híbridas ou o duplo regresso: Encontros latino-americanos e traduções culturais do debate sobre o Retorno à Cidade

Fragmento da Carta Isométrica de Santiago do Chile - Boza et. al., 1989 - com a sobreposição da logo do V SAL.

Fonte: manipulação de imagem desenvolvida pela autora. 
Podemos concluir que as contribuições sucessivas nesta perspectiva [cultural] de P. Morandé, C. Fernández Cox, P. Murtinho y E. Browne definem o problema e que, com a análise do "Próprio e estrangeiro" de R. Fernández, fecham o ciclo com êxito e mérito. Corresponde, então, aos SAL nos anos 90 o dever de continuar com a elaboração dos capítulos seguintes que já serão especificamente disciplinares neste processo de acumulação intelectual no qual embarcamos rumo à obtenção de uma teoria adequada que sustente nossa prática ${ }^{1}$.

Através destas palavras Jorge Moscato introduzia - em texto escrito para compor parte do enquadramento teórico da VIII Bienal de Arquitetura chilena², de 1991 - a ideia de que os SAL iniciavam uma nova etapa através da realização de seu quinto seminário, que ocorria simultaneamente àquele evento. Visto que as questões iniciais relativas à identidade cultural na arquitetura estavam, a seu ver, consolidadas; pareciaIhe inevitável assumir o desafio da construção de uma "teoria da Cidade Latinoamericana” ${ }^{3}$. Afirmava, também, que as contribuições no sentido da elaboração desta teoria - ainda que fossem numerosas e variadas - não haviam sido, no entanto, processadas e ordenadas de modo sistemático até então. Neste sentido, propunha abordar esta empreitada a partir da exposição de "grandes problemáticas nas quais há acumulação intelectual” ${ }^{4}$ : a periferia urbana e o centro histórico. Manifestava, assim, o desejo de que se instaurasse o processo de costura entre os debates que haviam tido lugares distintos em Manizales e Tlaxcala.

Ao escrever tais asserções, Moscato, no entanto, não estava sozinho; ecoava diretamente a proposta temática do V SAL. O evento de Santiago do Chile propôs, pela primeira vez, um tema que deveria ser debatido pelo conjunto dos participantes: a

\footnotetext{
${ }^{1}$ MOSCATO, Jorge. El Movimiento de arquitectura Latinoamericana para los años 90. In: CA, Santiago do Chile: Colegio de Arquitectos, n. 65, jul./ago./set 1991, p.26.

${ }^{2}$ Referimo-nos aqui aos textos que foram solicitados pelo presidente da VIII Bienal, José Iglesis, para constituir a seção Documentos do catálogo da Bienal e embasar as atividades pertinentes a esta mostra intitulada "Arquitectura Latinoamericana. Un camino para lo próprio". Cf. MÁRQUEZ, Jaime. El Camino de lo Propio. In: CA, Santiago do Chile: Colegio de Arquitectos, n. 65, jul./ago./set 1991, p.16.

${ }^{3}$ MOSCATO, J. loc. cit, 1991, p.26.

${ }^{4}$ MOSCATO, J. loc. cit, 1991, p.26.
} 
forma dos espaços urbanos latino-americanos. Logo, assim como o texto de Moscato, a proposta do evento também buscava tecer os dois polos sob os quais a cidade latinoamericana havia sido debatida nos eventos precedentes.

A metáfora do "tecer" empregada neste capítulo pode ser estendida a dois de seus sentidos figurados, ou seja: tanto como a costura entre elementos distintos; como, também, a possibilidade de "criar com a imaginação". Ressonando a definição rossiana do projeto como "capacidade de imaginação nascida do concreto" ${ }^{5}$, os organizadores do seminário de Santiago do Chile inovaram, também, ao postular que o debate no evento fosse pautado pela apresentação propostas para cidades latino-americanas. Compreendidos como reflexões elaboradas a partir de situações existentes, estimava-se que planos e projetos constituíssem o cerne do evento, tão ou mais importantes que as apresentações teóricas - as quais nem mesmo haviam sido previstas na proposta inicial de convocatória ${ }^{6}$.

\subsection{O preparo da trama}

O percurso que levou à realização do seminário em Santiago não fora tão retilíneo e claro quanto foi a definição dos paradeiros anteriores. Alguns percalços foram encontrados no caminho. Ao final do evento em Tlaxcala, definira-se - e divulgara-se ${ }^{7}$ - que o próximo SAL ocorreria no Brasil, em Porto Alegre. A proposição de um evento no Brasil partira de Ramón Gutiérrez e Carlos Eduardo Comas - na condição de arquiteto vinculado a uma instituição pública - aceitou ser seu organizador ${ }^{8}$.

\footnotetext{
${ }^{5}$ ROSSI, Aldo. The Analogus City: panel. In: Lotus International. Milão: Indutrie Grafiche Editorial S.p.A., n. 13, 1976, p.6

6 "Posteriormente se agregou à convocatória original a possibilidade de que participem 6 apresentações por país" - cf. BROWNE, Enrique; FERNANDEZ COX, Cristián; MURTINHO, Pedro. Convocatoria del $V$ Seminario de Arquitectura Latinoamericana. Nuestro Espacio Urbano: Propuestas Morfológicas. In: V Seminario de Arquitectura Latinoamericana. Nuestro Espacio Urbano: Propuestas Morfológicas. Santiago de Chile. 1991, p.4.

${ }^{7}$ Cf. GUTIÉRREZ, R. Testimonios y Conclusiones. In: Summa. Buenos Aires: Summa, n. 265, set. 1989, p.58-59, assim como na revista ARS número 11, jul. 1989, p6.

${ }^{8}$ Nas palavras de Comas: "O Ramón queria que [o próximo SAL] ocorresse no Brasil, queira mais participação brasileira. Eu era o arquiteto brasileiro com âncora institucional e, enfim, acertamos de fazê-Io" - COMAS, Carlos Eduardo Dias. Depoimento. [01 de abril de 2011]. Porto Alegre: Arquivo digital da gravação (4horas e 37min.). Entrevista concedida a Gisela Barcellos de Souza.
} 
Contudo, logo houve mudanças nos planos iniciais ${ }^{9}$ e os chilenos, aproveitando-se da possibilidade de fazer coincidir as datas do SAL e da VIII Bienal, assumiram o encargo de organizar o quinto seminário:

Nós tínhamos muita vontade de fazer um SAL, acreditávamos ter uma grande capacidade de organização. $O$ argumento que pesou para que fosse [realizado] no Chile foi que fizemos coincidir com a Bienal. Então, assim, pudemos trazer várias pessoas que vinham ao SAL e que, simultaneamente, vinham à Bienal. Pudemos compartilhar convidados e gastos ${ }^{10}$.

A troca de sede parece ter ocorrido sem grandes transtornos. Na nova equipe organizadora, encontravam-se tanto os nomes dos que estiveram presentes já no primeiro seminário em Buenos Aires - Pedro Murtinho, Enrique Browne, Cristián Boza, Humberto Eliash, e Manuel Moreno ${ }^{11}$ - quanto daqueles cujo engajamento deu-se a partir de Manizales, porém que foram prontamente assimilados ao círculo de participantes assíduos dos SAL - Cristián Fernández Cox e Eduardo San Martín. Portanto, tudo levaria a crer que o seminário seria pautado pelas contribuições chilenas amplamente veiculadas pelos periódicos do subcontinente: o conceito de "modernidade apropriada", de Fernández Cox, e a ideia da busca da identidade através da relação entre o "espírito do tempo e o espírito do lugar" proposta por Browne. A convocatória para o V SAL, no entanto, surpreende ao posicionar-se no sentido contrário: não há sequer uma única menção a estas construções teóricas ao longo do texto.

\section{A escolha dos fios}

Comparada às sumárias divulgações dos seminários anteriores - ou, simplesmente, à estrutura corrente de chamadas de eventos -, a convocatória do V SAL

\footnotetext{
${ }^{9}$ Segundo Carlos E. D. Comas, houve um desentendimento com Ramón Gutiérrez sobre a forma com que se estava conduzindo o planejamento do evento. Diante desta discordância, os chilenos se ofereceram para organizá-lo e Cristián Boza teria ligado a Comas para perguntar pessoalmente se haveria algum problema na troca da sede de Porto Alegre para Santiago. Cf. COMAS, Carlos Eduardo Dias. Depoimento. [01 de abril de 2011].

${ }^{10}$ ELIASH, Humberto. Depoimento. [18 de julho de 2011]. Santiago do Chile: Arquivo digital da gravação (2horas e 13min.). Entrevista concedida a Gisela Barcellos de Souza.

${ }^{11}$ Os dois primeiros como palestrantes e os três últimos como assistentes. Cristián Boza foi convidado pela Bienal de Buenos Aires para participar de outro evento que também ocorreu na sede da FADU/UBA: o colóquio "Identidad y Región” - Cf. EL PROGRAMA definitivo. Bienal Internacional de Arquitectura de Buenos Aires 85. In: Clarín Arquitectura, Ingenieria, Planeamiento y Diseño. Buenos Aires, Edición Especial. mai 1985,p.16.
} 
parece transcender seu papel de publicação de datas e descrição das mesas temáticas e dos formatos para apresentações. De fato, ao longo de suas quatro páginas, apenas uma é destinada ao que normalmente corresponderia ao enquadramento de uma chamada de evento.

A leitura do texto revela que este foi cuidadosamente redigido: como quem pondera exatamente o peso destinado a cada parte do texto, sua estrutura, além de destacada, é enumerada. Na primeira parte, apresentam-se os SAL, seus feitos e sua importância, destacando que haviam possibilitado "conhecer o que cada qual estava pensando e fazendo em termos de arquitetura" e constituir em poucos anos um "movimento informal"12. Na segunda, afirma-se que, concluída esta etapa inicial, deflagra-se a necessidade de avançar a uma nova etapa dos SAL, justificando, desta forma, a necessidade de os participantes elaborarem projetos especificamente para a temática do evento. Na terceira parte, a qual ocupa a maior parte do texto - duas páginas e meia -, apresenta-se o tema do evento e expõe-se a importância de seu debate para as cidades da América Latina. As quarta, quinta e sexta partes são aquelas que apresentam os elementos operacionais na organização do evento, sendo destinadas, respectivamente: à exposição das situações urbanas a serem abordadas pelos projetos, os requerimentos mínimos para elaboração destes e os procedimentos para sua seleção; à forma de divulgação prevista para o material produzido; às responsabilidades do chamado "coordenador crítico" de cada país.

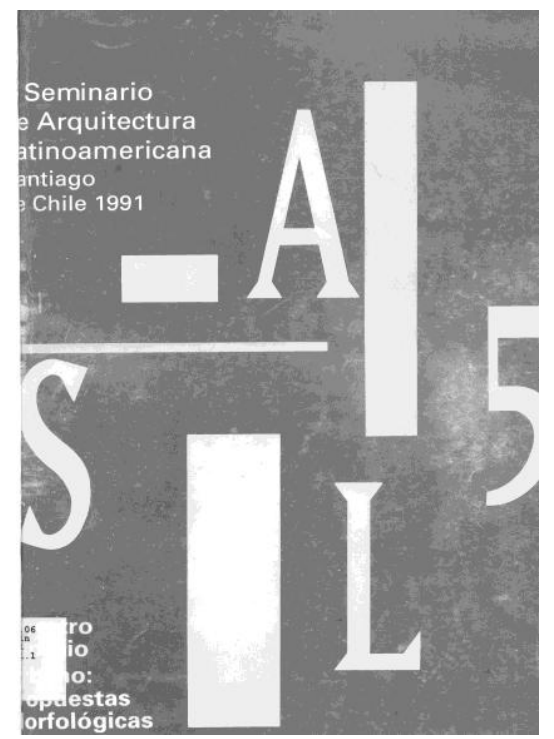

Figura 26: Capa dos Anais do V SAL. Fonte: Fotografia da autora.

\footnotetext{
${ }^{12}$ BROWNE, E.; FERNANDEZ COX, C.; MURTINHO, P. loc. cit. 1991, p.1.
} 
Ao analisar sequência argumentativa do texto, percebe-se que a convocatória para o evento de Santiago do Chile amalgama em sua estrutura elementos que a aproximam do manifesto como gênero literário. A presença desta formação literária é observável, sobretudo, na terceira parte da convocatória, ou seja, na justificativa da temática do evento. Nesta, verificam-se claramente as regras formais dos textos de manifestos descritas por Marcel Burger: denuncia-se um contexto de crise - há, portanto, uma referência em um "real" identificável e pontual fora do texto -, para, na sequência, fazer-se o apelo direto à ação e apresentar a solução julgada verdadeira e eficaz pela identidade coletiva de seus signatários ${ }^{13}$.

A crise que justifica a escolha do tema - e que sustenta a estrutura de manifesto - é apontada logo ao início da terceira parte do texto: "É ostensível o deterioramento da qualidade do espaço urbano em nossas cidades no último meio século [...]"14. Sem fazer menção direta ao que haveria mudado neste período, o texto trata este assunto como algo já amplamente debatido pela cultura arquitetônica - "[...] a tomada de consciência deste assunto nas recentes décadas torna desnecessário justificar a seleção do tema"15 , deixando a cargo do leitor sua interpretação ${ }^{16}$. Na sequência, a tradição cepalina do planejamento multidisciplinar transparece no aparente receio em apresentar uma explicação conclusiva para o deterioramento apontado:

Os temas urbanos - essencialmente multidisciplinares - requerem ser abordados a partir de pontos de vista muito diversos [...]. Logo, tentar realizar um diagnóstico que realmente dos inclua principais fatores que incidiram na decadência do espaço urbano [...] superaria muito as possibilidades de um seminário de uma semana como é o SAL. ${ }^{17}$

\footnotetext{
${ }^{13}$ BURGER, M. op. cit., 2002, passim.

${ }^{14}$ BROWNE, E.; FERNANDEZ COX, C.; MURTINHO, P. loc. cit. 1991, p.1.

${ }^{15}$ BROWNE, E.; FERNANDEZ COX, C.; MURTINHO, P. loc. cit. 1991, p.1.

${ }^{16}$ Este parágrafo do texto reverbera em sua redação e em seu destaque temporal da destruição do espaço urbano a estrutura argumentativa da "Carta de Reconstrução da Cidade" Léon Krier publicada pela primeira vez em 1980 e reescrita por diversas vezes ao longo da década de 1980 (cf. SOUZA, G. B. Re-dire et dé-dire: le nouvel urbanisme en Europe. Dissertação. Université de Paris VIII, Paris, 2004). Deve-se salientar que Cristián Boza e Léon Krier mantiveram correspondência durante este período - BOZA, Cristián. Depoimento. [10 de agosto de 2011]. Santiago do Chile: Arquivo digital da gravação (23min.). Entrevista concedida a Gisela Barcellos de Souza.

${ }^{17}$ BROWNE, E.; FERNANDEZ COX, C.; MURTINHO, P. loc. cit. 1991, p.1.
} 
Contudo, esta ressalva inicial cumpre apenas a função de evitar oposições diretas à abordagem escolhida ao expor, a priori, seus limites. Afirma-se que esta é mais modesta, porém "possivelmente mais útil"18, visto que: "a melhor ou pior qualidade de um determinado espaço é sempre em si mesma uma questão morfológica" ${ }^{19}$. Sem negar as variáveis de outra natureza, defende-se - indicando uma possível ressonância de Rob Krier $^{20}$ ou de releituras de Camilo Sitte ${ }^{21}$ na associação entre qualidade e forma do espaço urbano ${ }^{22}$ - que "as questões morfológicas constituem a variável principal do problema" $^{23}$.

Desta forma, abre-se caminho para a solução para a crise defendida ao longo texto-manifesto: centrar-se na análise das "variáveis propriamente morfológicas da arquitetura do espaço urbano em nossas cidades" ${ }^{24}$ para fins de definição de um acordo coletivo que direcione a prática dos arquitetos. Neste sentido, afirma-se que se pretende constituir, através de reflexões "sobre casos reais e áreas temáticas [...] um recipiente organizado de experiências, opiniões e propostas", um mosaico construído a partir de "visões concretas da realidade, que permita no futuro a inferência em um panorama mais decantado e geral”25. A possibilidade de interferir nos rumos das cidades latino-americanas não estava presente apenas na ideia de construção de um possível acordo coletivo; havia também um componente de imediatismo subliminar a proposta do evento. Como revelou Humberto Eliash em entrevista, havia por parte da comissão de organização do evento a ambição de que o SAL servisse também para validar, após o debate em profundidade, algumas das propostas apresentadas e para "articular algo com algum governo ou algum prefeito" ${ }^{26}$ para que estas fossem colocadas em prática:

\footnotetext{
${ }^{18}$ BROWNE, E.; FERNANDEZ COX, C.; MURTINHO, P. loc. cit. 1991, p.2.

${ }^{19}$ BROWNE, E.; FERNANDEZ COX, C.; MURTINHO, P. loc. cit. 1991, p.2.

${ }^{20}$ Cf. KRIER, Rob. Urban Space. New York: Rizzoli.1979. Rob Krier era uma das principais referências teóricas de Cristián Boza no início dos anos 1980, como se percebe nas revistas ARS e ele mesmo o confirma - cf. BOZA, C. Depoimento [10 de outubro de 2011]. Santiago do Chile: Arquivo digital da gravação (1hora e 12min.). Entrevista concedida a Gisela Barcellos de Souza.

${ }^{21}$ Cf. SITTE, C. A Construção das Cidades segundo seus Princípios Artísticos. São Paulo: editora Ática, 1992.

${ }^{22}$ Não há, no entanto, qualquer menção a estes autores no texto da convocatória.

${ }^{23}$ BROWNE, E.; FERNANDEZ COX, C.; MURTINHO, P. loc. cit. 1991, p.2.

${ }^{24}$ BROWNE, E.; FERNANDEZ COX, C.; MURTINHO, P. loc. cit. 1991, p.2.

${ }^{25}$ BROWNE, E.; FERNANDEZ COX, C.; MURTINHO, P. loc. cit. 1991, p.2.

${ }^{26}$ ELIASH, Humberto. Depoimento. [02 de agosto de 2011]. Santiago do Chile: Arquivo digital da gravação (56min.). Entrevista concedida a Gisela Barcellos de Souza.
} 
"Efetivamente, nosso discurso aspirava transformar a cidade, não era somente com um objetivo de conhecimento erudito ou puramente acadêmico [...]. Aspirávamos introduzir com isto mudanças na maneira que se fazia a cidade"27.

A identidade do grupo a partir do qual se fala varia ao longo do texto. Em determinados momentos o emprego da segunda pessoa do plural se refere aos organizadores do evento - "o tema que nós, organizadores do SAL V, escolhemos [...]"28 -, em outros parece se referir aos Seminários de Arquitetura Latino-americanos como um todo, como entidade capaz de legitimar a construção de acordos coletivos: "Não pode deixar de nos inquietar o fato que, ainda que no plano da obra arquitetônica em si mesma alcançamos algumas atitudes e critérios comuns, estamos muito longe de que ocorra algo análogo no plano do espaço urbano" ${ }^{29}$.

Esperava-se, portanto, estender o campo de atuação e o poder de influência dos SAL. Assim como através destes seminários pode-se difundir e assimilar noções que tiveram forte poder de penetração na crítica arquitetônica do subcontinente - como a "modernidade apropriada" -, almejava-se que através do SAL V se fosse possível construir "acordos morfológicos coletivos [...] para melhorar as normativas e [...] a qualidade do espaço urbano"30.

Na busca de referências para construção destes acordos coletivos a convocatória remete à simplicidade e à potência de "propostas tão básicas como os 'Cinco Pontos' em arquitetura e a 'Carta de Atenas' em urbanismo" que, no passado, obtiveram grande pungência na América Latina ${ }^{31}$. Aparentemente contraditória dentro do contexto do histórico dos $\mathrm{SAL}^{32}$, as referências ao Movimento Moderno e às, em específico, regras sintetizadas por Le Corbusier não parecem inócuas dentro da sequência argumentativa da convocatória. Esta reverbera não apenas na simplicidade dos acordos coletivos

\footnotetext{
${ }^{27}$ ELIASH, Humberto. Depoimento. [02 de agosto de 2011]. Loc. cit.

${ }^{28}$ BROWNE, E.; FERNANDEZ COX, C.; MURTINHO, P. loc. cit. 1991, p.1.

${ }^{29}$ BROWNE, E.; FERNANDEZ COX, C.; MURTINHO, P. loc. cit. 1991, p.3.

${ }^{30}$ BROWNE, E.; FERNANDEZ COX, C.; MURTINHO, P. loc. cit. 1991, p.3.

${ }^{31}$ BROWNE, E.; FERNANDEZ COX, C.; MURTINHO, P. loc. cit. 1991, p.3.

${ }^{32}$ Deve-se, no entanto, ter em mente que os debates em si são sempre mais complexos que suas generalizações reducionistas. Humberto Eliash e Manuel Moreno - ambos organizadores do V SAL -, por exemplo, foram responsáveis pela primeira revisão histórica do Movimento Moderno no Chile - cf. MORENO G., Manuel; ELIASH, Humberto. Arquitectura y Modernidad en Chile/1925-1965. Una Realidad Múltiple. Santiago: Ed. Universidad Católica de Chile. 1989.
} 
buscados, mas também na forma de construí-los, notadamente, na proposição da análise comparada:

Existem muitos modos possíveis, porém, para organizar o trabalho comum de modo que as diversas situações e propostas sejam comparáveis e coerentemente discutíveis entre si, é indispensável que todos nos guiemos por uma pauta muito precisa ${ }^{33}$.

Ora, como se sabe, a prática de solicitar às delegações nacionais a elaboração trabalhos prévios com o objetivo de desvelar regras através de sua análise comparada não era alheia aos CIAM. Se durante os trabalhos de preparação do IV CIAM esta análise aparece como um método, o "urbanismo comparado", defendido - e testado no Plano de Amsterdã - pelo presidente deste congresso, Van Eesteren; procedimentos semelhantes, no entanto, já haviam sido experimentados anteriormente nos eventos de Frankfurt e de Bruxelas ${ }^{34}$. Para o congresso Frankfurt de 1929, presidido por Ernest May, os representantes de cada país organizaram uma "coletânea de planos realizados dentro de seus países, apresentados à mesma escala e seguindo regras de representação gráficas únicas" ${ }^{\prime 35}$. Na preparação do evento de Bruxelas, de 1930, Hans Schmidt, na condição de membro do comitê de organização da exposição "Loteamento Racional", sugeriu ampliar este trabalho prévio: além da comparação entre análises de loteamentos e de normas existentes nos diversos países, já prevista para a mostra, propôs que fosse realizada, também, uma enquete urbana na escala internacional ${ }^{36} \mathrm{e}$ sintetizada na forma de esquemas gráficos - com base nos parâmetros que ele próprio havia desenvolvido para Genebra, Zurique e Basileia ${ }^{37}$. Segundo Enrico Chapel, Le Corbusier não somente apoiara a proposta de Hans Schmidt durante a reunião preparatória do III CIAM, como, também, desvelou o potencial da "comparação visual

\footnotetext{
${ }^{33}$ BROWNE, E.; FERNANDEZ COX, C.; MURTINHO, P. loc. cit. 1991, p.3, grifo nosso.

${ }^{34} \mathrm{Cf}$. KOPP, Anatole. Quand le Moderne n'était pas un style, mais une cause. Paris: ENSBA, 1988 e CHAPEL, Enrico. L'œil raisonné. L'invention de l'urbanisme para la carte. Genebra : Matis Presses, 2010.

${ }^{35}$ KOPP, Anatole. op cit, 1988, p. 181.

${ }^{36}$ CHAPEL, Enrico. op. cit., 2010, 90-91, passim. A enquete proposta por Hans Schmidt incorporava dados urbanos diversos: de densidade populacional a valor do solo e tempo de deslocamento.

${ }^{37}$ CHAPEL, Enrico. op. cit., 2010.
} 
como meio eficaz para definir de uma vez por todas os princípios gerais da urbanização" ${ }^{38}$.

A comparação visual ensejada na exposição do III CIAM seria aprofundada no "urbanismo comparado" proposto pelo grupo neerlandês para o quarto congresso - cuja referência principal fora a experiência de planejamento de Amsterdã, a qual Van Eesteren passou integrar a partir de $1929^{39}$. Com o objetivo claro "definir as linhas de uma ciência urbana ainda balbuciante e alcançar a síntese da cidade moderna a partir da análise crítica das cidades existentes ${ }^{\prime 40}$, as diretrizes para o IV CIAM afirmavam:

A noção de "cidade funcional" exprime a ideia que as funções são essenciais da cidade - a habitação, a produção (trabalho), o relaxamento como elemento de ligação na circulação - são determinantes para as formas de aglomeração urbana. Nós desejamos estabelecer os princípios da cidade funcional, e as condições que permitem sua realização. Para poder empreender este trabalho seriamente, é necessário reunir documentos antes $^{41}$.

Não se pode deixar de perceber semelhanças entre a proposta de organização dos trabalhos para a o congresso da "cidade funcional" e aquela presente na convocatória do V SAL. Ainda que seus autores não tenham tido acesso direto às diretrizes do IV CIAM, dificilmente eles desconheceriam a exposição "Cidade funcional", e o trabalho que a precedeu, visto que esta a importância desta para a construção da "Carta de Atenas" foi amplamente enfatizada pela historiografia - veja-se, por exemplo, Giedion em "Espaço, tempo e arquitetura", Benevolo em "História da Arquitetura Moderna" e Frampton em "História Crítica da Arquitetura Moderna".

Para a exposição "Cidade Funcional"- que ocorreu na Escola Politécnica de Atenas e possibilitou a análise comparada entre 34 cidades situadas em 18 países do mundo - foram elaboradas três séries de mapas, cujos temas, escalas e legendas deveriam ser unificados $^{42}$ : cartas na $1 / 10.000$ que delimitavam as zonas funcionais das

\footnotetext{
${ }^{38}$ CHAPEL, Enrico. op. cit., 2010, p.91.

${ }^{39}$ CHAPEL, Enrico. op. cit., 2010.

${ }^{40}$ CHAPEL, Enrico. op. cit., 2010, 95-96.

41 VAN EESTEREN, 1932, apud CHAPEL, Enrico. op. cit., 2010, p.96, grifo nosso. Ver também: KOPP, Anatole. op cit, 1988, p. 177.

42 Segundo Chapel, as diretrizes nem sempre foram respeitadas. Cf. CHAPEL, Enrico. op. cit., 2010.
} 
cidades; representações na 1/10.000 mostrando a espacialização dos tipos de circulação e, por último, mapas na 1/50.000 que ilustram a inserção regional da cidade - os usos e as circulações em sua "zona de influência"43.

Contudo, as semelhanças entre o V SAL e o IV CIAM param na definição de parâmetros para organização dos trabalhos a serem visualmente comparados. Ao contrário do IV CIAM, que procurou inventar a "Cidade Moderna" através de sua oposição frente às cidades existentes; o V SAL propõe a reflexão sobre a cidade latinoamericana a partir de intervenções que transformam ou enfatizam sua estrutura urbana. O primeiro olha para cidade existente a fim de justificar a cidade imaginada, o segundo imagina transformações urbanas para entender a cidade existente.

Portanto, as legendas e escalas de representação, unificadas no IV CIAM para facilitar a comparação, são substituídas, no caso do evento de Santiago do Chile, pela tentativa de enquadrar projetos com níveis de complexidade semelhantes: as cidades abordadas deveriam ter mais de um milhão de habitantes e as áreas de intervenção necessariamente existentes e com indicações de sua exequibilidade - deveriam ter entre 4 a 10 hectares. A opção pelas grandes cidades não foi casual, segundo Eliash:

Queríamos justamente distinguir [as intervenções a serem apresentadas] daquelas operações em cidades pequenas que poderiam ter um caráter não digo menos importante, mas menos relevante para o desenvolvimento dos países. Em nosso continente o desenvolvimento se deu com altas taxas de urbanização, cerca de $80 \%$ de urbanização em pouquíssimo tempo, em menos de um século. Portanto, nos parecia que os problemas estavam aí: nas grandes cidades ${ }^{44}$.

O paralelismo e a inversão entre a organização dos trabalhos do IV CIAM e do V SAL não se resumem, no entanto, à unificação da representação buscada em Atenas e à semelhança da problemática de projeto desejada para Santiago do Chile. Por um lado, se o corte de análise na exposição do IV CIAM foram os aspectos funcionais - zonas de uso comum e circulação -; por outro, para compreensão dos aspectos morfológicos da cidade latino-americana o escrutínio se fez "por partes", tecidos urbanos nomeados no texto como "situações urbanas prototípicas":

\footnotetext{
${ }^{43}$ Cf. CHAPEL, Enrico. op. cit., 2010.

${ }^{44}$ ELIASH, Humberto. Depoimento. [02 de agosto de 2011], loc. cit.
} 
Situação A: área de cidade antiga com trama urbana existente e fachada contínua; Situação B: área de cidade existente com trama urbana do tipo cidade-jardim; Situação C: área de cidade existente, com edificação isolada de média altura; Situação D: área de cidade existente, com características de periferia marginal $^{45}$.

Certamente, as "situações urbanas prototípicas" definidas implicam uma leitura já construía sobre as cidades latino-americanas. Primeiramente, não se pode deixar de perceber ressonâncias da noção de "cidade por partes" - tal qual definida por Rossi e Aymonino ${ }^{46}$ e como manifesta no urbanismo catalão dos anos $1980^{47}$. No capítulo de "A Arquitetura da Cidade" que dedica à "estrutura da cidade por partes", Rossi defendia a delimitação de áreas de estudo e intervenção - em detrimento de uma abordagem global e genérica - da seguinte forma:

Do ponto de vista da intervenção, eu creio que hoje é necessário operar sobre uma porção bem delimitada da cidade sem querer excluir a princípio sob o nome de uma planificação abstrata o desenvolvimento de uma cidade a possibilidade de outras experiências, mesmo que totalmente diferentes. Um pedaço da cidade apresenta critérios bem mais concretos do ponto de vista de análise e do ponto de vista da programação (intervenção). [...] A cidade, por sua natureza, não é uma criação que nós possamos identificar a uma única ideia fundamental ${ }^{48}$.

Para além das ressonâncias italianas e catalãs, as situações urbanas prototípicas demostram, sobretudo, leituras sobre a "cidade latino-americana" e sobre Santiago do Chile, em específico, que foram se consolidando ao longo dos anos 1980. Por um lado, a cidade antiga e a periferia marginal foram objeto, também, de debate nos SAL - ainda que tivessem lugares distintos no III e no IV SAL - por outro, as situações urbanas relativas à "trama urbana tipo cidade jardim" e "com média altura e edificação isolada" representam uma inovação no âmbito destes eventos e remetem a debates que tiveram lugar em Santiago ao longo dos anos 1980. Ambas as últimas situações estão, de certa

${ }^{45}$ BROWNE, E.; FERNANDEZ COX, C.; MURTINHO, P. loc. cit. 1991, p.3-4.

${ }^{46}$ Cf. AYMONINO, Carlo. O significado das cidades. Lisboa: Editorial presença, 1984 e ROSSI, Aldo. L'Architecture de la Ville. Paris: InFolio, 2001.

47 SAINZ GUTIÉRREZ, Victoriano. El proyecto urbano en España. Génesis y desarrollo de un urbanismo de los arquitectos. Sevilha: Universidad de Sevilla y Consejería de Obras Públicas y Transportes, 2006.

${ }^{48}$ ROSSI, Aldo. op. cit, 2001.p.74. 
forma, calcadas na análise e no debate sobre a forma urbana da expansão de Santiago e, em específico, da comuna de Providencia: os loteamentos jardim que marcaram sua ocupação entre os anos 1930 e 1960 - os quais foram objeto de estudo tipo-morfológico de Montserrat Palmer Trias ${ }^{49}$ - a sua transformação e verticalização que se deu a partir da implementação do Plano Regulador de 1975 e do projeto de Nueva Providencia $(1975)^{50}$, elaborado Germán Bannen e concluído em $1980^{51}$. Numa espécie de ato falho, Murtinho, ao justificar os temas definidos para o debate, ratifica esta interpretação afirmando que se queria recuperar a experiência local: "escolhemos as nossas amostras: a Providencia, o centro, a periferia" ${ }^{25}$. Contudo, apesar de muitos dos debates nos anos 1980 terem partido de Providencia e sua transformação, ambas as situações urbanas caracterizam, de forma geral, a expansão urbana de Santiago no século XX.

$\mathrm{Na}$ definição destes temas específicos e na proposição de que fossem desenvolvidos através de projetos transparece, sobretudo, uma tentativa de redirecionar o enfoque dos SAL, como admite Eliash:
Isto sempre esteve [em nossas] discussões: seremos mais precisos na definição dos temas, pois achávamos que poderíamos conseguir mais em nos aproximando da realidade. E que poderíamos influir melhor se fizéssemos algo mais específico do que algo genérico. Portanto, aproveitamo-nos - não sei se ingenuamente ou não - do fato que tínhamos o poder de definir a convocatória. ${ }^{53}$

\section{Por trás da agulha}

Explicitados os interesses em direcionar os rumos dos SAL subjacentes à convocatória do quinto seminário, é preciso compreender melhor quem estava por trás de sua urdidura. Embora tenha sido a peça chave na transferência da sede do seminário

\footnotetext{
${ }^{49}$ PALMER TRIAS, Montserrat. La ciudad jardín como modelo de crecimiento urbano: Santiago 1935-1960. El caso de la comuna de Providencia. Santiago: Pontificia Universidad Católica de Chile, 1985.

${ }^{50}$ Cf. PALMER TRIAS, Montserrat. op. cit, 1985 e BANNEN, Germán. Chile, Santiago: Providencia, Ciudad entre. In: CA, n. 58, Santiago do Chile: Colegio de Arquitectos, out-dez 1989, p. 54-59.

${ }^{51}$ Cf. RODRIGUEZ, León. Preambulo Histórico. In: CA, n. 58, Santiago do Chile: Colegio de Arquitectos, out-dez 1989, p. 52-53.

${ }^{52}$ MURTINHO, Pedro. Depoimento. [20 de outubro de 2011]. Santiago do Chile: Arquivo digital da gravação (1hora e 51min.). Entrevista concedida a Gisela Barcellos de Souza.

${ }^{53}$ ELIASH, Humberto. Depoimento. [02 de agosto de 2011]. Santiago do Chile: Arquivo digital da gravação (56min.). Entrevista concedida a Gisela Barcellos de Souza.
} 
de Porto Alegre para Santiago, Ramón Gutiérrez - que, a partir do II SAL, tornou-se uma figura proeminente na organização dos seminários ${ }^{54}$, integrando boa parte das comissões organizadoras (ver anexo B) e responsabilizando-se por redigir conclusões aos eventos ${ }^{55}$ - parece ter contribuído de forma mais distante neste evento. Dentre os organizadores entrevistados, apenas Cristián Boza menciona a troca de correspondência com Gutiérrez durante o preparo do evento - sem se referir, no entanto, a nenhum assunto tratado em específico ${ }^{56}$. Não houve, portanto, participação direta do historiador argentino na organização do $\mathrm{V} \mathrm{SAL}^{57}$, nem na definição dos temas a serem debatidos.

Não menos importante, deve-se destacar, também, que este foi o primeiro seminário - e único no ciclo entre 1985 e 1995, ver Anexo B - a não contar com o apoio direto de algum tipo de instituição acadêmica ou profissional. Apesar de ter sido sediado no Centro de Extensión da Universidad Católica e de seus organizadores já terem tido alguma passagem pela Universidad Católica em algum momento de sua trajetória, seja como aluno ou docente ${ }^{58}$, estes não possuíam vínculo com esta instituição durante a realização do evento ${ }^{59}$. Ou seja, o evento foi realizado por arquitetos que participavam

\footnotetext{
${ }^{54}$ A maioria mencionou espontaneamente a importância de Ramón Gutiérrez na organização dos SAL, seja para definir a partir da mesma a existência de grupos distintos dentre os participantes como presente nos depoimentos de Carlos Eduardo Comas, Ruth Verde Zein, Hugo Segawa e Browne - ou para defender a existência de um grupo coeso, ainda que com diferenças internas depoimentos de Humberto Eliash, Eduardo San Martín, Cristián Boza e Jorge Ramírez.

${ }^{55}$ Ruth Verde Zein, Hugo Segawa e Cristián Boza destacam este aspecto em seus depoimentos. A respeito desta função de redator das conclusões dos seminários, Gutiérrez afirmou: "Creio que este é um papel que me coube durante muitos anos. [... Talvez seja] porque eu tenho facilidade para escrever e, além disso, eu tinha uma enorme virtude de escutar e fazer uma síntese das ideias trocadas" - cf. GUTIÉRREZ, Ramón. Depoimento. [11 de novembro de 2011]. Campinas: Arquivo digital da gravação (1hora e 39min.). Entrevista concedida a Gisela Barcellos de Souza.

${ }^{56}$ BOZA, Cristián. Depoimento. [10 de outubro de 2011]. Santiago do Chile: Arquivo digital da gravação (1hora e 12min.). Entrevista concedida a Gisela Barcellos de Souza.

${ }^{57}$ Ao ser questionado sobre a organização do V SAL, Ramón Gutiérrez afirmou ter poucas lembranças sobre o evento - lembrando-se mais da discussão sobre o Prêmio América nesta ocasião. Cf. GUTIÉRREZ, Ramón. Depoimento. [11 de novembro de 2011]. Campinas: Arquivo digital da gravação (1hora e 39min.). Entrevista concedida a Gisela Barcellos de Souza.

${ }^{58}$ Dentre a comissão organizadora, apenas Manuel Moreno e Humberto Eliash formaram-se na Universidad de Chile - em 1978 e 1975, respectivamente. Todos os demais se graduaram na Universidad Católica: Pedro Murtinho em 1961; Eduardo San Martín (em 1962); Cristián Fernández Cox em 1964; Enrique Browne em 1965; Cristián Boza (em 1968); Pilar García em 1985 e Cecilia Puga em 1990. Manuel Moreno e Humberto Eliash tiveram uma curta experiência docente na Católica - em 1980 e em 1981, respectivamente. Pedro Murtinho, Eduardo San Martín e Cristián Boza voltaram a esta faculdade na condição de docentes e em curtas estadias. Enrique Browne em seus primeiros anos de atuação desenvolveu planos diretores tendo realizado através de vínculo institucional com a Católica.

${ }^{59}$ Note-se que a gestão de Pedro Murtinho como decano desta faculdade (1987 a 1990) havia se
} 
nos SAL e que tinham em seus escritórios a sua atuação profissional principal - ainda que a maioria dentre estes tenha atuado, por algum período, como docente.

Sem apoio institucional direto ${ }^{60}$, a comissão contou somente com os nove arquitetos que integravam a equipe organizadora e com o auxílio de empresas privadas contratadas para fins específicos ${ }^{61}$. Nos anais do evento, indica-se uma função precisa desempenhada por cada membro da comissão organizadora. A coordenação geral do evento ficou a cargo de Cristián Boza. Humberto Eliash fora responsável pela publicação e difusão do evento. Eduardo San Martín teria sido o responsável pelas questões financeiras. Manuel Moreno, auxiliado por suas arquitetas então recém-formadas, Pilar García e Cecilia Puga, fora o responsável pela organização da sede e a acomodação dos convidados. A convocatória do evento, em específico, teria sido redigida por Pedro Murtinho, Enrique Browne e Cristián Fernández Cox.

Não obstante a autoria indicada nos anais do evento, durante a leitura do texto da convocatória tem-se dificuldade de identificar as contribuições das mãos que o assinam. Como destacado anteriormente, observa-se a ausência dos elementos e noções teóricas desenvolvidas por Cristián Fernández Cox e por Enrique Browne. Não se quer afirmar com isto que estes dois arquitetos nunca tenham se interessado pela cidade. Ao contrário, o planejamento e o desenho urbano foram as primeiras áreas de atuação Enrique Browne, nas quais, inclusive, desenvolveu seus títulos de pósgraduação no Chile e nos EUA ${ }^{62}$. Cristián Fernández Cox, por outro lado, apesar de nunca ter se dedicado especificamente a temas urbanos, não era totalmente alheio às discussões sobre urbanismo, envolvendo-se nestas em momentos em que considerava necessário ${ }^{63}$. Contudo, a abordagem sobre a cidade proposta para o V SAL difere em

\footnotetext{
encerrado no ano anterior.

${ }^{60}$ Além do espaço cedido pela Pontifícia Universidad Católica, contou-se com o auxílio financeiro da Municipalidad de Santiago; do Ministerio de la Vivienda y Urbanismo e da Direção de Arquitetura do Ministerio de Obras Públicas. Contou-se também com o apoio da "Comisión Hispanoamericana 500 años: Uma Raíz común"; do Banco Santander; da Revista Diseño; do Metro S.A. e de LADECO. BOZA et al. (org). Seminario de Arquitectura Latinoamericana. Nuestro Espacio Urbano: Propuestas Morfológicas. V, 1991. Santiago do Chile. Anais... Santiago do Chile: s.n. 1991.

${ }^{61}$ Nos anais elencam-se duas: Rivera y Donoso Asociados - responsável pela parte operativa na produção do evento - e Exprinter AS (agência de viagens). Cf. BOZA et al (org), op. cit., 1991.

${ }^{62}$ Browne fez uma pós-graduação em planejamento regional e urbano na FADEU - Facultad de Arquitectura, Diseño y Estudios Urbanos de la Universidad Católica - em 1968 e, na sequência, estudou desenho urbano no MIT em 1969

${ }^{63}$ Vale ressaltar que, em pleno processo de implantação das políticas neoliberais extremas
} 
muito daquela do planejamento urbano multidisciplinar. Ainda que Browne já no início dos anos 1970 se mostrasse crítico ao planejamento tecnocrático que tinha no plano o seu próprio fim, clamando por uma maior capacidade de ação e de transformação social ${ }^{64}$, este arquiteto nunca defendeu uma ênfase morfológica - ao contrário, mostrava-se reticente a esta ${ }^{65}$. Aliás, tanto para Browne, quanto para Cristián Fernández Cox, a forma urbana nunca esteve no âmago do debate.

A compreensão da cidade a partir da chave tipo-morfológica foi, no entanto, a principal bandeira do grupo CEDLA durante grande parte de seu período de atuação do qual Murtinho, Boza e Eliash foram fundadores e ao qual Manuel Moreno se associou a partir de 1978. De fato, questionados sobre o texto da convocatória do V SAL, Fernandez Cox já não lembrava ${ }^{66}$ e Browne afirmou que possivelmente teria apenas assinado, mas que não deve ter contribuído para sua redação ${ }^{67}$. Esta declaração coincide com a de Pedro Murtinho, que afirmou que quem efetivamente colaborou na redação deste texto foram Humberto Eliash - seu sócio naquele momento ${ }^{68}$ - e Cristián Boza ${ }^{69}$. De forma semelhante, Eliash revela que o núcleo duro das discussões de preparação do V SAL foi composto por: “Cristián Boza, Pedro Murtinho, Manuel Moreno, eu [Humberto

durante o Governo do Pinochet, Cristián Fernández Cox teceu críticas à sua extensão aos mais diversos setores e, em específico, às políticas urbanas- neste momento em questão aboliram-se, entre outros, as restrições à urbanização do solo agrícola. Cf. FERNÁNDEZ COX, Cristián. Planificación y Mercadismo. In: ARS, Santiago: CEDLA, n. 3, ago. 1979, p.12-14.

${ }^{64}$ Cf. BROWNE, Enrique; GEISSE, Guillermo. ¿Planificación para los planificadores o para el cambio social? In: Castells (org.) Imperialismo y Urbanización en América latina. Barcelona: Gili, 1973, p.315-338.

${ }^{65}$ Browne, em meados dos anos 1980, tecia críticas à leitura formal da cidade e à assimilação e adoção de correntes neorracionalistas na América Latina que associava à Escuelita argentina e ao grupo CEDLA no Chile. Cf. BROWNE, Enrique. Algunos fenómenos de nuestra arquitectura. In: TALLER AMÉRICA. Contribución al Encuentro Latinoamericano de Revista de Arquitectura. Santiago do Chile: s.n. 1985, p.14-21.

${ }^{66}$ Por motivos de saúde, Cristián Fernández Cox já não se lembrava de alguns episódios a respeito dos quais tratou nossa entrevista. Infelizmente, o V SAL estava entre estes.

${ }^{67}$ BROWNE, Enrique. Depoimento. [13 de setembro de 2011]. Santiago do Chile: Arquivo digital da gravação (2horas e $1 \mathrm{~min}$.). Entrevista concedida a Gisela Barcellos de Souza.

${ }^{68}$ Humberto Eliash foi estagiário no escritório de Larraín Murtinho Arquitetos Associados, entre 1971 e 1975, e foi reincorporado à equipe do escritório em seu regresso ao Chile, em 1977, após estadia na Europa. Permaneceu como sócio de Pedro Murtinho após a saída de Jorge Larraín e a reformulação do escritório, em 1983. Em 1992, saiu deste escritório e passou a ser sócio de Manuel Moreno.

${ }^{69}$ MURTINHO, Pedro. Depoimento. [20 de outubro de 2011]. Santiago do Chile: Arquivo digital da gravação (1hora e 51min.). Entrevista concedida a Gisela Barcellos de Souza. 
Eliash] e Cristián Fernández Cox. Enrique Browne participou menos". ${ }^{70}$ Visto que afirmação de Eliash foi ratificada pelas entrevistas de Enrique Browne e Eduardo San Martín, que declararam em entrevista terem uma postura distante na organização do evento $^{71}$, o V SAL foi conduzido majoritariamente por arquitetos que estiveram envolvidos com o CEDLA - Centro de Estudios de la Arquitectura.

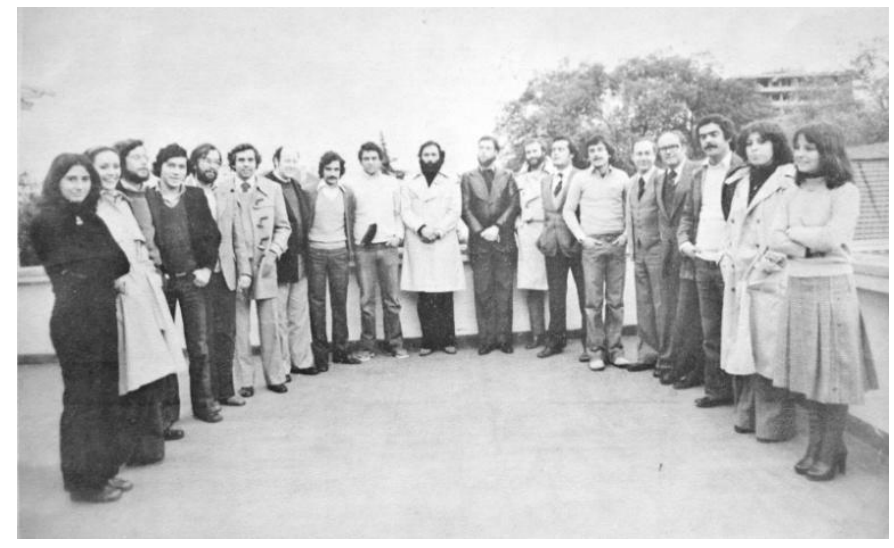

Figura 27: Fotografia dos integrantes do grupo Cedla em 1978. Fonte: ARS, n.1, jul. 1978

Criado no mesmo ano de realização da primeira bienal chilena de arquitetura, em 1977, o CEDLA foi, juntamente com estas mostras bienais, um dos agentes responsáveis pela introdução do debate sobre a revisão da arquitetura e do urbanismo do Movimento Moderno no Chile ${ }^{72}$. Através deste instituto privado de investigações elaboraram-se publicações e projetos e organizaram-se seminários e exposições que permitiram as primeiras aproximações - e traduções culturais - à produção teórica de Aldo Rossi, de Léon e Rob Krier, entre outros. Apesar de não ter tido um marco de encerramento, o CEDLA manteve sua atuação ao longo do período da ditadura de Pinochet, arrefecendo suas atividades ao final da década de 1980. Para Eliash, o centro

\footnotetext{
${ }^{70}$ ELIASH, Humberto. Depoimento. [02 de agosto de 2011]. Santiago do Chile: Arquivo digital da gravação (56min.). Entrevista concedida a Gisela Barcellos de Souza.

${ }^{71}$ Apesar de constarem entre os organizadores do evento, ambos afirmaram ter contribuído pouco para tal. Browne afirma que neste momento já havia começado a se distanciar dos SAL. Além de estar mais envolvido com seu escritório, o arquiteto chileno começava a interessar-se também por um novo tema: as relações entre edifício e natureza - cujo laboratório era o projeto Edifício Consorcio então em desenvolvimento - BROWNE, Enrique. Depoimento. [13 de setembro de 2011]. Loc. cit. San Martín não se lembra por qual motivo, porém afirma que não participou. SAN MARTín, Eduardo. Depoimento. [26 de março de 2012]. Santiago do Chile: Arquivo digital da gravação (22min.). Entrevista concedida a Gisela Barcellos de Souza.

${ }^{72}$ O papel do grupo CEDLA na revisão do Movimento Moderno no Chile é comumente destacado. A respeito, ver os artigos de Jorge Liernur "Portales del Laberinto. Comentarios sobre la Arquitectura em Chile, 1977-2007" e de Fernando Pérez Oyarzun "Arquictectura, cultura y prática professional en Chile" ambos publicados em: LIERNUR (org) Portales del Laberinto. Arquitectura y Ciudad en Chile, 1977-2009. Santiago de Chile: Universidad Andrés Bello, 2009.
} 
de estudos, sua revista ARS e a abertura ao debate internacional e latino-americano que proporcionaram à cultura arquitetônica chilena perderam sua razão de ser no contexto da redemocratização:

O CEDLA, [...] a ARS e as Bienais, constituem de algum modo uma espécie de resistência cultural frente à ditatura. E, ao terminar-se a ditadura, de alguma maneira, abrem-se outras portas de participação cultural. [...] A partir do ano 1990, com a recuperação da democracia, se abrem os canais normais: universidades normais, viagens normais. [...] Nós, de certa maneira, demos um passo assertivo quando decidimos não continuar com a revista. ${ }^{73}$

Durante o período de vigência do CEDLA pode-se reconhecer três momentos distintos. O primeiro constitui-se nos anos iniciais do instituto, caracterizado por grande efervescência cultural e pelo entusiasmo com o debate internacional de revisão do Movimento Moderno e, em específico, sobre a Arquitetura Neorracionalista, cujos ecos foram trazidos por Boza e por Eliash em seu regresso ao Chile. O segundo corresponde ao momento em que se tem a virada latino-americana no grupo e em que se busca claramente traduzir o debate dos anos anteriores para o contexto local. O terceiro período caracteriza-se, por outro lado, pela vinculação direta do trabalho do grupo e de sua revista aos Seminários de Arquitetura Latino-americana.

Os primeiros passos que levariam a criação do CEDLA foram dados em terras estrangeiras. Boza e Eliash conheceram-se casualmente na Inglaterra em $1975^{74}$ e juntos estabeleceram contato com o escritório de Stirling - que experimentava um giro significativo em sua prática projetual após a incorporação de Léon Krier em sua equipe ${ }^{75}$ - e com o ambiente cultural da Architectural Association, no qual Cristián foi assistente do atelier de Sue Rogers por um ano ${ }^{76}$. A viagem de Cristián Boza a Londres fora motivada por questões de trabalho - visto que havia sido contratado para desenvolver

\footnotetext{
${ }^{73}$ ELIASH, Humberto. Depoimento. [02 de agosto de 2011]. Santiago do Chile: Arquivo digital da gravação (56min.). Entrevista concedida a Gisela Barcellos de Souza.

${ }^{74}$ Eliash e Cristián Boza se conheceram em Londres por intermédio de Fernando Boza, irmão Cristián e colega de Humberto. Cf. ELIASH, H. La arquitectura de Cristián Boza : un eclectisismo apasionado. Santiago, Chile : Ediciones ARQ, 1993.

75 MONEO, Rafael. Inquietação teórica e estratégia projetual na obra de oito arquitetos contemporâneos. São Paulo: Cosac Naify, 2008. Léon Krier trabalhou no escritório de Stirling entre 1968 e 1974.

76 BOZA, Cristián. Depoimento. [10 de agosto de 2011]. Santiago do Chile: Arquivo digital da gravação (23min.). Entrevista concedida a Gisela Barcellos de Souza.
} 
projetos para a cidade nova Milton Keynes, logo após o golpe militar no Chile ${ }^{77}$. A estadia de Eliash, no entanto, resultou do prolongamento de uma viagem turística; após um tour pela Europa, o arquiteto chileno, então recém-formado, acabou decidindo permanecer um ano trabalhando em Londres e outro entre Madrid e Barcelona, regressando ao Chile em 1977. O contato com o ambiente cultural e os debates londrinos colocou em cheque a muitos aspectos que pareciam sólidos na formação de ambos os arquitetos chilenos e levou-lhes a "decidir por fazer algo"78 em seu regresso ao Chile. Desta forma, constituiu-se o gérmen que daria lugar à fundação do CEDLA, em 1977, inicialmente a partir de três escritórios de arquitetura: Boza, Lürhs e Muzard; Larraín Murtinho y Asociados, no qual trabalhava Eliash; e Flaño, Nuñez y Tuca - este último abandonou a empreitada pouco tempo depois ${ }^{79}$.

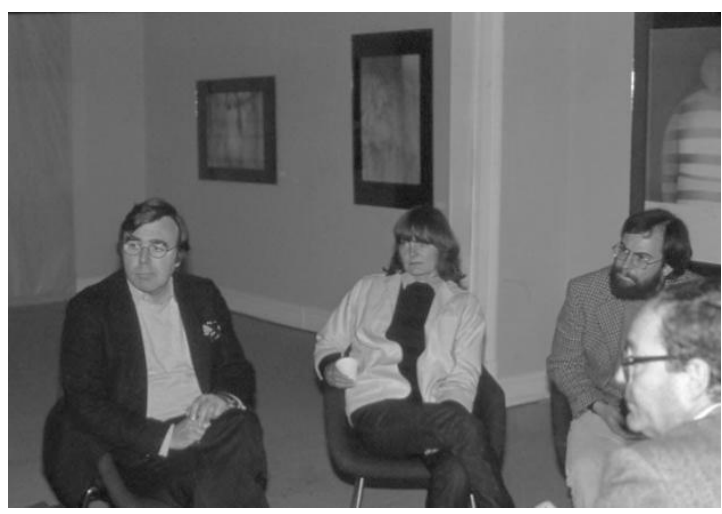

Figura 28: John Muller e Sue Rogers em evento na sede do CEDLA. Fonte: Acervo pessoal de Pedro Murtinho.

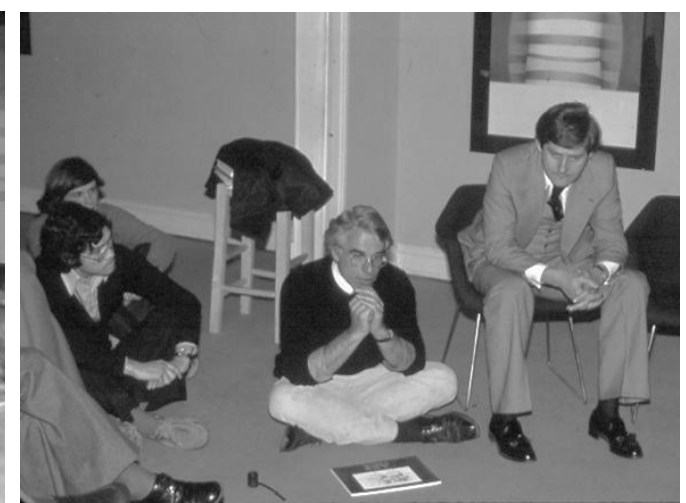

Figura 29: Peter Eisenman na sede do CEDLA em 1979 - ocasião em que foi ao Chile a convite da II Bienal. Fonte: acervo pessoal de Pedro Murtinho

\footnotetext{
${ }^{77}$ Segundo Cristián Boza, James Stirling foi fundamental para a obtenção deste contrato. Durante o período em que esteve desenvolvendo sua pós-graduação em Desenho Urbano em Endiburgo (1968-1971), Cristián Boza foi conhecer o escritório de James Stirling. Em março de 1973, Cristián Boza contratou em seu escritório um arquiteto que fora assistente de Stirling, Robin Nicholson, cujo interesse em trabalhar no Chile era conhecer de perto o governo de Allende - cf. NICHOLSON, Robin. El año en que vivimos en peligro. In: ELIASH, H. La arquitectura de Cristián Boza : un eclectisismo apasionado. Santiago, Chile : Ediciones ARQ, 1993, 149-150. A estadia deste arquiteto britânico foi encurtada devido ao golpe militar em 11 de setembro e, segundo Boza, James Stirling teria ficado agradecido por ter contratado seu assistente e preocupado com sua situação no Chile, conseguindo Ihe um contrato de trabalho na Inglaterra. BOZA, Cristián. Depoimento. [10 de agosto de 2011]. Santiago do Chile: Arquivo digital da gravação (23min.). Entrevista concedida a Gisela Barcellos de Souza.

${ }^{78}$ ELIASH, Humberto. La arquitectura de Cristián Boza : un eclectisismo apasionado. Santiago, Chile : Ediciones ARQ, 1993, p.17.

${ }^{79}$ ELIASH, H., op. cit. 1993.
} 
O CEDLA chegou a contar como uma sede física na Avenida Pedro de Valdivia entre 1978 e $1982^{80}$, que se constituiu em um ponto de encontro no qual se reuniam arquitetos, artistas, historiadores e estudantes. Esta sede serviu tanto como ponto de referência para as conferências e as exposições, como, também, local no qual o grupo se reunia para debater questões teóricas, desenvolver projetos e elaborar as edições da revista $\mathrm{ARS}^{81}$. Entre as produções mais significativas deste período, estão: o projeto para o bairro Santiago Poniente de 1977; a publicação, em 1982, do livro "Inventario de una arquitectura anónima” 82 , de Cristián Boza e Hernán Duval - fruto de quatro anos de investigação em que se realizou um levantamento tipo-morfológico de quarteirões e Cités de bairros de Santiago e Providencia constituídos entre 1850 e $1940^{83}$ - e o seminário de Aldo Rossi, realizado também em $1982^{84}$.

A análise transversal dos textos produzidos pelo grupo neste período publicados nas revistas CEDLA $^{85}$ e ARS - do número 1, de 1978, ao 4, de 1982 - revela um debate sobre a tipo-morfologia era animado principalmente pela produção teórica de Aldo Rossi, Léon Krier e Fernando Montés ${ }^{86}$. Para além destas três principais referências, observam-se citações a Stirling, Moneo, Norbeg-Schulz, Gregotti, e Bohigas. Por outro lado, reconhece-se, também, nas páginas da ARS o valor das contribuições de outros

${ }^{80}$ Durante quatro anos, a sede foi mantida pelos próprios membros do CEDLA, sem contar com o auxílio financeiro de nenhuma instituição - cf. ELIASH, H, op. cit., 1993.

${ }^{81}$ Cf. ELIASH, H., op. cit. 1993. Informação confirmada em depoimento de Humberto Eliash: “Nos encontrávamos, produzíamos as revistas alí. [...] Todas as quartas nos entregávamos aos debates, era muito interessante". Cf. ELIASH, Humberto. Depoimento. [06 de julho de 2011]. Santiago do Chile: Arquivo digital da gravação (58min.). Entrevista concedida a Gisela Barcellos de Souza.

82 BOZA, Cristián; DUVAL, Hernán. Inventario de una arquitectura anónima. Santiago de Chile: Lord Cochrane, 1982.

${ }^{83} \mathrm{O}$ levantamento e a classificação inicial foram feitos informalmente, percorrendo-se a cidade. Em um segundo momento, 400 obras foram fotografadas e desenhadas. Dentre estas, fez-se uma seleção de 133 obras apresentadas no livro e agrupadas em 12 bairros históricos de Santiago e Providencia. Cf. BOZA, C; DUVAL, H. op. cit., 1982.

${ }^{84}$ O seminário de Aldo Rossi será abordado no próximo capítulo.

${ }^{85}$ A revista CEDLA foi um embrião da revista ARS - inclusive foi retomada em forma de resumo na primeira edição desta última - contou apenas com uma única edição, lançada na primeira Bienal de Arquitetura Chile, em 1977. Cf. CEDLA. Santiago: CEDLA, ago. de 1977.

${ }^{86}$ Na revista CEDLA: MURTINHO, P. Conceptos teóricos en Aldo Rossi. In: CEDLA. Santiago: CEDLA, ago. de 1977, p. 8-11; MONTES, F. Santiago Poniente: en torno a su remodelación. In: CEDLA. Santiago: CEDLA, ago. de 1977, 24-25. Na revista ARS: MONTES, F. Modernidad e Inibición. In:ARS. Santiago: CEDLA, n.1, jul. 1978, p.67-69; BOZA, C. Léon Krier: su pensamiento frente a la ciudad. In:ARS. Santiago: CEDLA, n.1, jul. 1978, 35-41; KRIER, L. Carta a Cristián Boza. In:ARS. Santiago: CEDLA, n.1, jul. 1978, 95; MONTES, F. Hacia una arquitectura convencional. . In: ARS. Santiago: CEDLA, n.3, jul. 1979, p.4-9; MONTES, F. 157 Departamentos, Ciudad Nueva de Cergy-Pontoise, Paris, 1980. In: ARS. Santiago: CEDLA, n.4, ago. 1981, p.85-87. 
chilenos em trânsito no exterior, como as Urban Transformations de Rodrigo Perez de Arce - especulação, em forma de desenho, sobre as transformações urbanas através da adição de novas construções publicada em número monográfico da Architectural ${ }^{87}$ - e o estudo tipológico de New York desenvolvido por Luis Alberto Darraidou, durante sua pós-graduação na Cornell University, em $1975^{88}$.

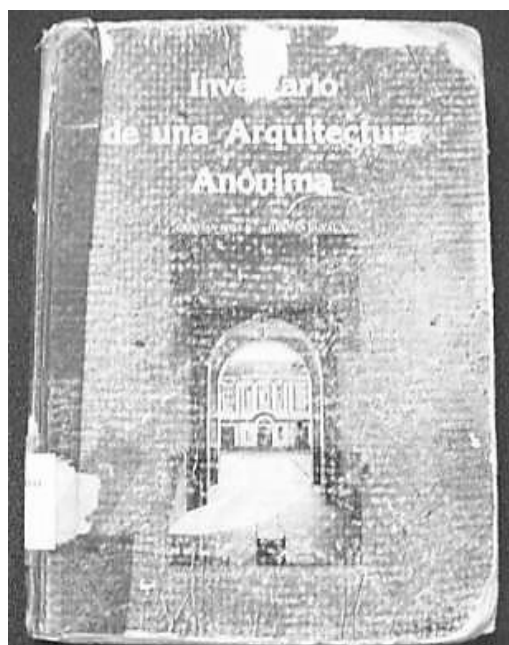

Figura 30: Capa do livro "Inventario de una Arquitectura Anónima" de Boza e Duval, 1982. Fonte: fotografia da autora.

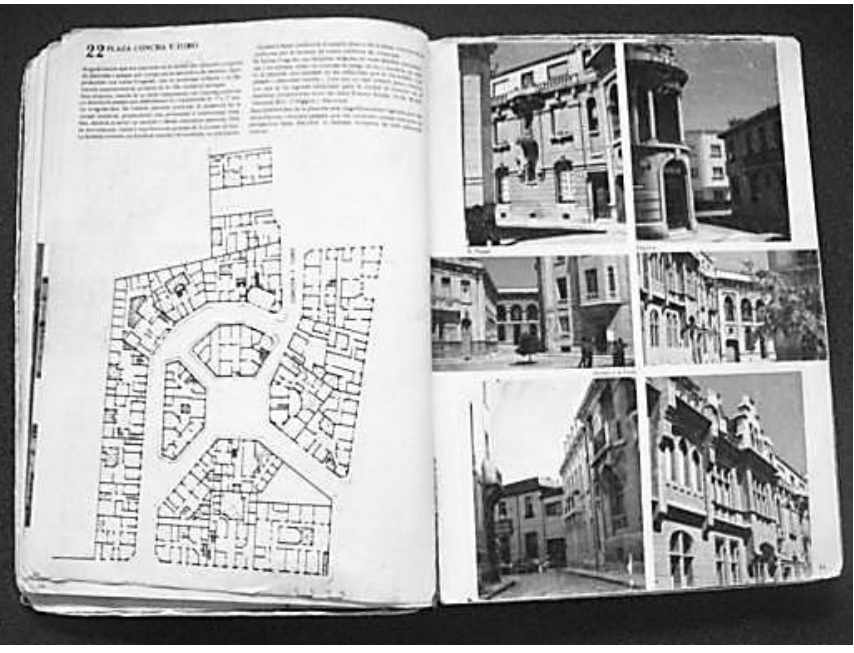

Figura 31: Páginas destinadas à descrição do tecido urbano do setor Concha y Toro, em Santiago Poniente. Fonte: BOZA, C; DUVAL, H., op. cit, 1982.

Em suma, através da revista CEDLA e dos primeiros números da ARS, este grupo de arquitetos chilenos assume o papel de tradutor cultural do Pós-modernismo, em outras palavras, atuam como mediadores entre o debate internacional e o cenário nacional: seja através de textos teóricos que introduzem a produção de determinados $\operatorname{arquitetos}^{89}$, seja através da republicação de manifestos ${ }^{90}$ ou mesmo através da

\footnotetext{
${ }^{87}$ PEREZ DE ARCE, Rodrigo. Urban Transformations \& The Architecture of Additions. In: Architectural Design:AD PROFILE 12. Londres: Architectural Design, jan.1978, p.237-266. A parte deste trabalho relativa às propostas para Dacca e Chandigah é publicada apenas alguns meses depois na ARS número 1: cf. PEREZ DE ARCE, R. Chandigarh y Dacca. La reurbanización de la ciudad moderna. In: ARS. Santiago: CEDLA, n.1, jul. 1978, p.53-61.

${ }^{88}$ DARRAIDOU, Luis. El bloque urbano de Nueva York como un tipo arquitectónico. In: ARS. Santiago: CEDLA, n.1, jul. 1978, p.70-91.

${ }^{89}$ Veja-se: MURTINHO, Pedro. Conceptos teóricos en Aldo Rossi. In: CEDLA. Santiago: CEDLA, ago. de 1977, p. 8-11; CONTRERAS, Ricardo. Vittorio Gregotti, la arquitectura de sus ideas. In: CEDLA. Santiago: CEDLA, ago. de 1977, p. 11-14. BOZA, C. Léon Krier: su pensamiento frente a la ciudad. In:ARS. Santiago: CEDLA, n.1, jul. 1978, 35-41; BOZA, C. James Stirling y la recreación del espacio urbano. In: ARS. Santiago: CEDLA, n.2, dez. 1978, 5-16; NORBERG SCHULZ, C. Genius Loci. In: ARS. Santiago: CEDLA, n.2, dez. 1978, 21-27; CONTRERAS, R. Richard Meier: dos proyectos recientes. In: ARS. Santiago: CEDLA, n.4, ago. 1981, p.75-79.

${ }^{90}$ GOYTISOLO, J. A. Manifiesto del Diablo sobre la Arquitectura y el Urbanismo. In:ARS. Santiago: CEDLA, n.1, jul. 1978, p.96-97. HUET, B. Pequeño Manifesto. In: ARS. Santiago: CEDLA, n.2, dez. 1978, p.98; VENTURI, R. Um suave manifiesto em favor de uma arquitectura equivoca. In: ARS.
} 
simulação de diálogos imaginários ${ }^{91}$. 0 aporte do debate internacional cumpre a função de legitimar as causas defendidas pelo CEDLA: o reconhecimento da especificidade disciplinar; a autonomia da forma, compreendida em suas dimensões semânticas e temporais; a salvaguarda do patrimônio urbano e a revalorização da cidade dita tradicional - com fachadas contínuas exercendo o papel da separação entre os espaços público e privado. Observa-se, neste momento, uma clara defesa dos espaços urbanos de tecidos santiaguinos do século XIX e início do século XX em oposição aos espaços gerados por sua expansão a partir de 1930 sob o ideário da cidade-jardim. Neste sentido, lê-se introdução do livro "Inventario de una Arquitectura Anónima":

Atualmente a imagem ideal de vida do santiaguino alimenta-se do caráter rural ou de cidades jardins onde a continuidade da edificação não existe. A casas são concebidas como elementos arquitetônicos únicos, quase como protótipos, que se inserem em jardins, que é o único elemento que marca sua presença sobre a rua. Conseguiu-se assim uma cidade-campo, na qual desaparece a trama urbana e o muro edificado que conforma o vazio urbano. Não existe a esquina, a praça, nem o armazém, nem o bar; e a rua não se comporta mais como cenário da vida cidadã. A vida social se dá nos interiores dos terrenos e as compras, o passeio e o encontro ocorrem nos grandes supermercados e nos "mall". ${ }^{92}$

As polêmicas geradas pelos debates e projetos desenvolvidos pelo CEDLA, bem como suas repercussões na cultura arquitetônica chilena, logo despertariam o interesse Munizaga ${ }^{93}$ que, uma vez diretor da FADEU da Universidad Católica, convida-os para o

Santiago: CEDLA, n.2, dez. 1978,. p.99. KRIER, L.; CULOT, M. et al. Declaração de Bruxelas, 1978. In: ARS. Santiago: CEDLA, n.3, ago. 1979, p.150;KRIER, L. Manifiesto: Clásico y Vernáculo, Arquitectura y construcción. In: ARS. Santiago: CEDLA, n.4, ago. 1981, p.105.

${ }^{91}$ Cf. ELIASH, H. Encuentro de arquitetos. In: ARS. Santiago: CEDLA, n.3, ago. 1979, p.49-58.

92 BOZA, Cristián; DUVAL, Hernán. Inventario de una arquitectura anónima. Santiago, Chile : Lord Cochrane, 1982, p.X.

${ }^{93}$ Munizaga formou-se em 1963 na Universidad Católica - pertencendo, portanto, à geração de Murtinho, San Martín e Fernándex Cox, formados respectivamente em 1961, 1962 e 1964. Logo após formado, realiza pós-graduação em Desenho Urbano em Harvard (1964-65). A partir de meados da década de 1970 interessa-se por documentar a prática do urbanismo no Chile (ver livro "Cronología sobre urbanismo y diseño urbano en Chile : 1872 - 1977", publicado pela Universidad Católica), bem como por elaborar manuais de desenho urbano - dentre os quais o "Diseño urbano: fundamentos y aplicaciones", publicado também em 1977 pela Universidad Católica, seria o primeiro da série. Parte deste último livro seria publicada no segundo número da ARS, justamente aquela em que Munizaga e José Rosas empreendem a possibilidade de definir tipos de organizações morfológicas em três níveis - setores urbanos, cidades e sistemas urbanos - apoiando-se para tal em Ungers, Rossi, Lynch e Halasz. Cf MUNIZAGA, G.; ROSAS, J. Diseño 
desenvolvimento de experiências didáticas no curso de arquitetura. Desta forma, constituem-se o atelier de projeto de Cristián Boza, Hernán Duval e Manuel Moreno no segundo semestre de 1980, destinado ao quarto ano do curso, e o de Murtinho e Eliash em 1981, destinado ao quinto ano. Os resultados de ambas experiências didáticas, em que se trabalharam com os conceitos de tipo, morfologia urbana, cidade análoga e contrapropostas, seriam publicados em formato de livros editados pela própria Universidad Católica $^{94}$. Entre os alunos destes ateliers, estavam aqueles que formariam do grupo Contrapropuestas e que editariam revista homônima ${ }^{95}$ na qual se discutiam: temas teóricos e projetos relativos ao pós-modernismo; projetos desenvolvidos pelos alunos, bem como a prática de ensino dentro da Universidad Católica. Reconhecendo a importância destes dois ateliers - somada, também, à do atelier de Munizaga e José Rosas ministrado em 1980 - Pilar Garcia ${ }^{96}$ como uma dos fundadores do Contrapropuestas, associa-os à formação do grupo:

No atelier Boza-Duval-Moreno se introduz toda uma nova terminologia arquitetônica [...] todo este enquadramento conceitual que se coloca no atelier nos obriga a estudar, a refletir e a discutir sobre os autores e os projetos citados [...] Discussão esta que se formaliza em reuniões semanais que, em última análise, construíram um projeto para nós mesmos, a revista CONTRAPROPUESTAS ${ }^{97}$.

Figura 32: Capa da publicação referenta aos trabalhos desenvolvidos no atelier de projeto ministrado por Murtinho e Eliash na Universidad Católica em 1981. Fonte: Fotografia da autora.

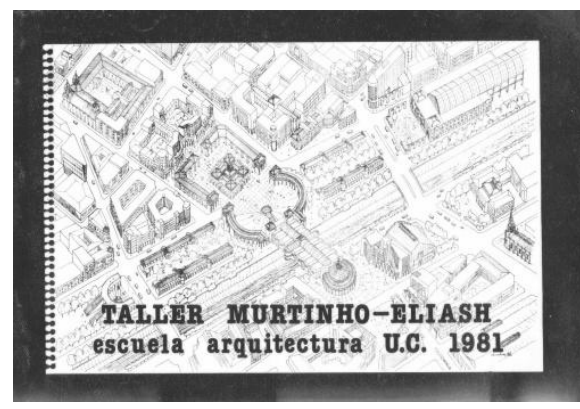

Urbano: tipologias. ARS. Santiago: CEDLA, n.2, dez. 1978, p.79-86.

${ }^{94}$ Ver: BOZA, Cristián; MORENO G., Manuel; DUVAL V., Hernán. Taller Boza-Duval-Moreno: nivel ejercitación. Santiago: Pontificia Universidad Católica de Chile, Escuela de Arquitectura, 1980, e MURTINHO, Pedro; ELIASH, Humberto. Taller Murtinho-Eliash. Santiago, Chile: Pontificia Universidad Católica de Chile. Escuela de Arquitectura. 1981.

95 Referimo-nos a revista Contrapropuestas, confeccionada e editada dentro da Universidad Católica. Fundada em 1980, a revista teve poucos números editados. Atualmente, apenas duas edições da Contrapropuestas permanecem hoje no acervo da biblioteca da FADEU: o número 4 de agosto de 1981 e o número 5 de 1982.

${ }^{96}$ Logo após formada, em 1986, Pilar Garcia passou a integrar a equipe do escritório de Cristián Boza, no qual permaneceu até 1990 - cf. ELIASH, H, op. cit., 1993.

${ }^{97}$ GARCIA, Pilar. Enseñanzas de Cristián. In: ELIASH, H., op. cit. 1993, p.154. 
Este ciclo de euforia combativa dos anos iniciais do CEDLA seria interrompido pela crise econômica de 1982-83 - período em que o Chile, já socialmente assolado pelas medidas dos "Chicago Boys", enfrentou uma significativa redução $\mathrm{PIB}^{98}$ e uma aguda elevação da taxa de desemprego ${ }^{99}$. Sob os impactos desta crise o grupo teve que abrir mão de sua sede ${ }^{100}$ e a edição do quinto número da revista ARS teve que esperar 3 anos. No editorial do supracitado número, Eliash destacava o desavio de produzir a revista neste contexto ${ }^{101}$ e questionava-se: “É válido fazer e pensar arquitetura nestas condições? É correto fazer Bienais, encontros e revistas?"102

Através deste questionamento, Eliash apresentava o Encontro de Caburga - ao qual se dedicou o quinto número da ARS - como resposta do CEDLA ao contexto de crise. De fato, observa-se a partir da organização deste encontro um ponto de virada no grupo, em seus interesses teóricos e em sua forma de atuação. A partir deste evento, realizado em abril de 1984 nas várzeas do lago Caburga, em Pucón ${ }^{103}$, o grupo CEDLA assume publicamente a defesa da necessidade de que os postulados defendidos anos antes como universais fossem adaptados para a realidade ibero-americana e chilena, em particular. Neste sentido, Cristián Boza, Cristián Fernández Cox, Hernán Duval, Manuel Moreno, Humberto Eliash e Pedro Murtinho escreviam na convocatória do evento:

\footnotetext{
98 “Em um pouco mais de doze meses, o 'milagre chileno' se transformou em crise e recessão, um produto interno bruto que em 1983 caiu 14 por cento" - TIRONI, Eugenio. Autoritarismo, modernización y marginalidade: el caso de Chile 1973-1989. Santiago: Sur, 1990, p.143.

${ }^{99} \mathrm{Em} 1980$ a taxa de desemprego era já era de 11,8 \% - cf. GONZÁLEZ, Norberto. Balance preliminar de la economía latinoamericana, 1986. Santiago: CEPAL, 1986. Contudo, a crise financeira torna esta situação ainda mais aguda: ao final de 1983 a taxa de desemprego chegou a mais de $30 \%$ da população economicamente ativa - cf. BARANDIARÁN, Edgardo; HERNÁNDEZ, Leonardo. Origins and Resolutions of a Banking Crisis: Chile 1982-86. In: Banco Central de Chile Documentos de Trabajo, Santiago: Banco Central de Chile, n57, dez 1990.

${ }^{100}$ A crise econômica de 1982 no Chile teria inviabilizado a manutenção do aluguel imóvel, segundo Murtinho - cf. MURTINHO, Pedro. Depoimento. [20 de outubro de 2011]. Santiago do Chile: Arquivo digital da gravação (1hora e $51 \mathrm{~min}$.). Entrevista concedida a Gisela Barcellos de Souza.

101 “[...] foram três anos singulares da história recente do país. Em menos tempo do que duraria um período presidencial, presenciamos uma sacudida do "modelo" parecida às típicas réplicas em torno das mudanças de governo. [...] Em poucos anos vivemos o auge e a decadência de um sistema econômico neoliberal, sustentado pelo aparato criado pelo regime militar, que produziu resultados - sobretudo em arquitetura - estão à vista." ELIASH, H. Editorial. In: ARS. Santiago: CEDLA, n.5, jul. 1984, p.7.

${ }^{102}$ ELIASH, H. loc. cit., 1984, p.8.

${ }^{103} \mathrm{O}$ lago Caburga fica a 22 quilometros de Pucón e a quase $800 \mathrm{~km}$ ao sul de Santiago. O evento foi realizado nas casas que Cristián Boza e Hernán Duval possuíam em torno do lago. Cf. BOZA, Cristián. Depoimento. [17 de agosto de 2011]. Santiago do Chile: Arquivo digital da gravação (1hora e 1min.). Entrevista concedida a Gisela Barcellos de Souza.
} 
Assim, por exemplo, são peculiares nossos problemas urbanos, em cidades que crescem a velocidades muito superiores, e com meios muito inferiores, dos de outras latitudes. São peculiares nossos problemas de significação, não somente pelas peculiaridades de nossa idiossincrasia, mas também pela ostensiva confusão de identidades em que se encontra nossa sociedade, por diversas circunstâncias que requerem esclarecimento. São peculiares nossos problemas de adoção de tipologias ou de estilos importados, cuja coerência com nossa realidade deve ser permanentemente revisada. São peculiares os problemas de nossa explosiva demanda de "habitação econômica", da qual temos consciência, e da demanda de "rua econômica", "bairro econômico" e "cidade econômica", das quais parecemos não ter consciência ${ }^{104}$.

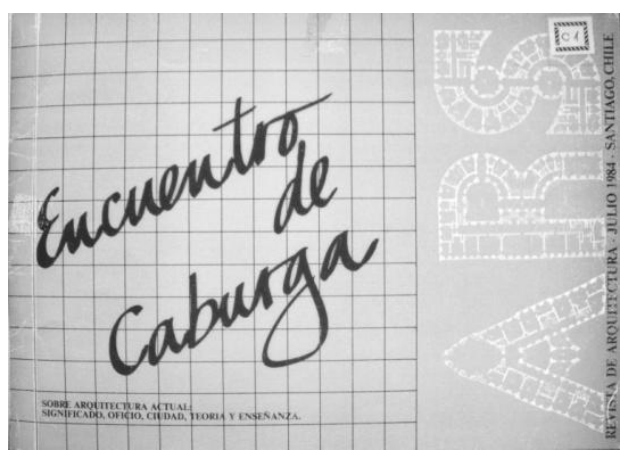

Figura 33: Capa da revisa ARS de julho de 1984, destinada à divulgação das apresentações e debates do Encontro de Caburga. Fonte: fotografia da autora.

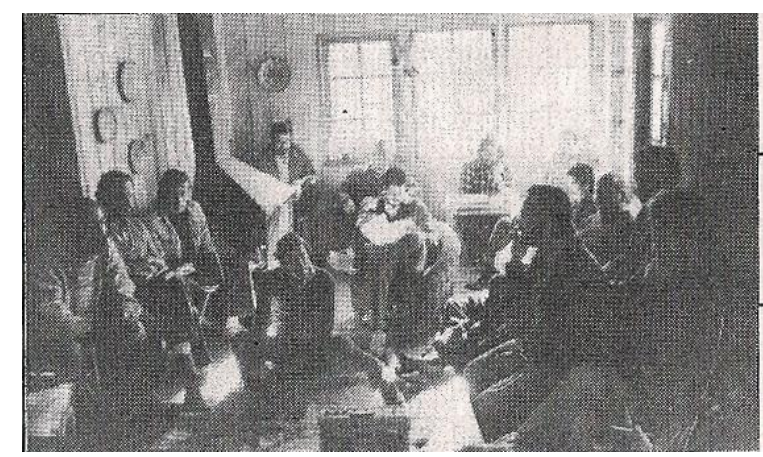

Figura 34: Seção de trabalho no evento de Caburga. Fonte: ARS, n.5, jul. 1984.

Esta virada do CEDLA rumo à reflexão da condição ibero-americana não se deu, certamente de forma repentina. Deve-se salientar que apenas nove meses separam a realização deste evento da IV Bienal de arquitetura do Chile, em agosto 1983, presidida por Pedro Murtinho - e destacada por nós como um dos elementos catalizadores na constituição dos SAL. De fato, dois dos convidados latino-americanos daquela mostra participaram também do Encontro de Caburga: Juvenal Baracco e Roberto Fernández ${ }^{105}$. Outro aspecto que não pode deixar de ser destacado é a participação de Cristián Fernández Cox na redação da convocatória deste evento. Amigo de longa data de Murtinho ${ }^{106}$, Cristián Fernández Cox, como já abordamos, havia sido fundador do Taller América e responsável pelo desenvolvimento das primeiras reflexões sobre o próprio e o

104 BOZA, C.; FERNANDEZ COX, C. et al. Convocatoria Encuentro de Caburga. In: ARS. Santiago: CEDLA, n.5, jul. 1984, p.10.

105 Juvenal Baracco apresentou o texto “La ciudad metasíquica” e Roberto Fernández o texto "Hacia una teoría de la apropriación", ambos publicados no número 5 da revista ARS.

${ }^{106}$ MURTINHO, Pedro. Depoimento. [20 de agosto de 2011]. loc. cit. 
apropriado na arquitetura latino-americana. Sua inserção no comitê organizador do evento denota uma aproximação de interesses entre estes dois grupos.

Logo, durante os três dias do evento, os 27 arquitetos participantes apresentaram trabalhos e participaram de mesas de debate ${ }^{107}$, cujos resultados foram publicados na ARS e agrupados em torno dos seguintes temas: arquitetura e identidade cultural; problemas arquitetônicos de nossas cidades; autonomia disciplinar e ofício no atual momento cultural; e, por último, teoria, crítica e ensino. Para Murtinho e Eliash as contribuições mais importantes do evento foram as de Cristián Fernández Cox e de Roberto Fernández, pois permitiram “um olhar um pouco mais transversal e teórico" ${ }^{108}$. Murtinho destaca o papel que o encontro teve na tradução do tema da identidade cultural para o campo da arquitetura: "todos éramos interessados leitores de Octavio Paz, ele era o guru da identidade cultural latino-americana, porém, como traduzi-lo para arquitetura?"109.

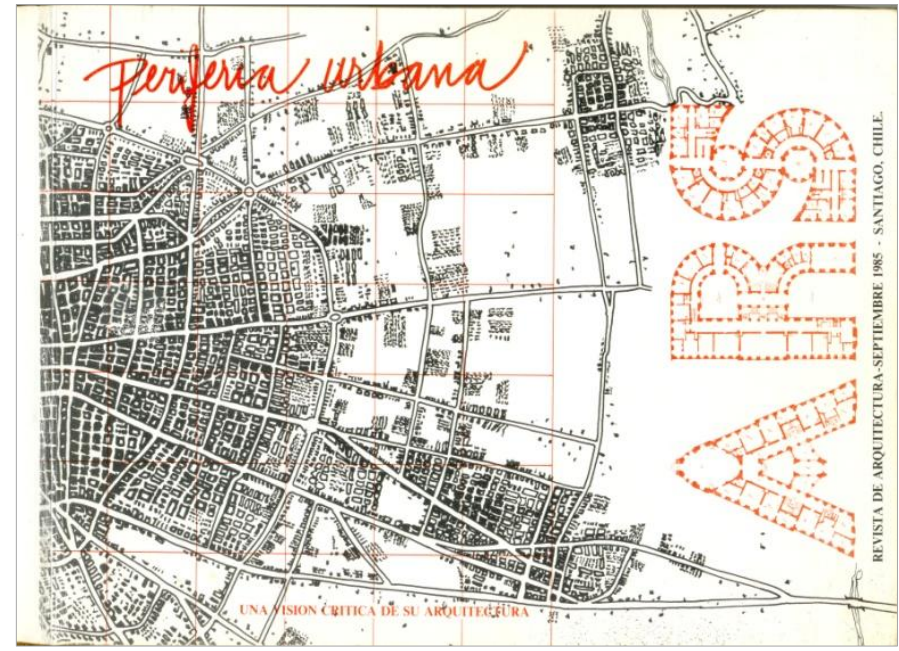

Figura 35: Capa do número 6 da revista ARS, de setembro de 1985 , o primeiro número monográfico sobre a arquitetura da periferia. Fonte: Fotografia da autora.

A partir deste evento, o grupo CEDLA empreende a dupla tarefa de adaptar o debate da identidade cultural para a arquitetura e de traduzir o debate da tipomorfologia para a América Latina. O lócus no qual estes arquitetos vislumbrariam a possibilidade de realizar e experimentar esta empreitada logo se materializaria na periferia urbana - compreendida como o espaço de síntese das problemáticas

\footnotetext{
${ }^{107}$ Ver a descrição geral do evento em: SUAREZ, Isidro. Notas sobre el encuentro de Caburga. In: ARS. Santiago: CEDLA, n.5, jul. 1984, p.137-138.

${ }^{108}$ ELIASH, Humberto. Depoimento. [18 de julho de 2011]. Santiago do Chile: Arquivo digital da gravação (2horas e 13min.). Entrevista concedida a Gisela Barcellos de Souza.

109 MURTINHO, Pedro. Depoimento. [20 de outubro de 2011]. Santiago do Chile: Arquivo digital da gravação (1hora e 51min.). Entrevista concedida a Gisela Barcellos de Souza.
} 
específicas da cidade latino-americana ${ }^{110}$ - e a cuja análise dedicar-se-ia os dois números subsequentes da ARS. Neste segundo momento do grupo, as trocas maiores ocorreriam com Juvenal Baracco e, sobretudo, com Jorge Moscato - a quem membros do CEDLA conheceram durante a exposição "Arquitectura en Chile"111, realizada em Buenos Aires poucos meses após o Encontro de Caburga ${ }^{112}$. O registro dos intercâmbios e debates deste momento constam nas as edições 6 e 7 da revista ARS, de setembro de 1985 e novembro de 1986, respectivamente. No primeiro tema há o lançamento do tema, arquitetos do CEDLA e arquitetos convidados - José Rosas e Fernando Pérez Oyarzun, do Chile, Jorge Moscato, da Argentina, e Juvenal Baracco, do Peru - escrevem sobre o assunto. No segundo número, a análise sob o viés da forma urbana que caracterizou majoritariamente o primeiro foi contrabalanceada com observações oriundas de outras áreas: do sacerdote Derry Healy ${ }^{113}$, do jornalista Pedro Lira ${ }^{114}$ e do advogado Gutenberg Martínez ${ }^{115}$. Este segundo número caracteriza-se também por uma clara tentativa em ampliar os intercâmbios sobre o tema da periferia urbana com países vizinhos. Aproveita-se o contato momentâneo de Murtinho com o ambiente argentino estabelecido através de sua participação em bancas de concurso público para professores da FADU/UBA ${ }^{116}$ - para aumentar o número de contribuições oriundas deste país ${ }^{117}$ publicadas na ARS. Criava-se, desta forma, a impressão de um intercâmbio mais

\footnotetext{
${ }^{110} \mathrm{O}$ debate sobre a periferia urbana será analisado em maior detalhe no capítulo 4 .

${ }^{111}$ Cf. MOSCATO, Jorge. Depoimento. [25 de agosto de 2011]. Buenos Aires: Arquivo digital da gravação (2horas e $25 \mathrm{~min}$.). Entrevista concedida a Gisela Barcellos de Souza. Assim como: ELIASH, Humberto. Depoimento. [06 de julho de 2011]. loc. cit.

${ }^{112}$ Abordamos a respeito da exposição "Arquitectura en Chile", realizada no CAYC entre julho e agosto de 1984, no capítulo 2.

${ }^{113}$ HEALY, Derry. Los arquitectos deben perder el tiempo. In: ARS, Santiago: CEDLA, n. 7, nov 1986, p.26-30.

114 LIRA, Pedro. Erradicación de campamentos. Un éxodo con efectos regressivos. In: ARS, Santiago: CEDLA, n. 7, nov 1986, p.31-32.

${ }^{115}$ MARTínEZ, Gutenberg. El crecimiento de Santiago. ¿Problema técnico o político? In: ARS, Santiago: CEDLA, n. 7, nov 1986, p.38-40.

${ }^{116}$ Murtinho foi convidado durante cinco anos consecutivos para ser banca na UBA, sendo a primeira vez em 1985 - cf. MURTINHO, Pedro. Depoimento. [20 de agosto de 2011]. loc. cit.

${ }^{117}$ Para além da contribuição de Moscato, há duas outras argentinas neste número: "Conjuntos habitacionales. Viviendas de interés social en la periferia", de Alberto Ciocchini, Diana Rosenberg e Laura Sales; e "Periferia y proyectación de la ciudad", de Isabel Martínez de San Vicente e Manuel Fernández Luco - ver ARS, número 7, dezembro de 1986.
} 
amplo que aquele já intimamente estabelecido com Moscato e lançava-se um número que pretendia cobrir o debate no Chile e na Argentina ${ }^{118}$.

A análise comparada entre os textos publicados nestes dois números ARS e as apresentações de Humberto Eliash, Jorge Moscato, Cristián Boza, Juvenal Baracco e Eduardo San Martín no III SAL revela a importância que estas reflexões iniciais tiveram na mesa temática da qual participaram em Manizales, sobretudo no caso específico dos três primeiros. Parte significativa dos argumentos que Eliash e Moscato apresentaram em 1987, por exemplo, já havia sido redigida por eles mesmos na ocasião em que refletiam sobre os resultados do "Taller de Verano do CEDLA" que ministraram juntos em janeiro de 1985 , no qual se abordou a periferia como traço distintivo da forma urbana latino-americana ${ }^{119}$.

Se, por um lado, as apresentações dos arquitetos supracitados no III SAL reverberam fortemente o debate fomentado pelo CEDLA entre 1986 e 1987, por outro, não se pode afirmar que este encontro tenha sido insignificante para os membros deste grupo. Certamente, o engajamento anterior de membros do grupo nos SAL já era patente em maio de 1987: Murtinho, Boza, Eliash e Moreno participaram do primeiro SAL - o primeiro como palestrante e os demais como assistentes - e todos subscreveram à Convocatória de Buenos Aires; apenas quatro meses após estes eventos, em setembro de 1985, Manuel Moreno organizou o Primeiro Encontro Latinoamericana de Revistas de Arquitetura ${ }^{120}$; no ano seguinte, Boza representou a revista ARS no segundo encontro de revistas ${ }^{121}$, em Quito. A despeito destes registros de envolvimento, no entanto, somente depois o evento de Manizales o grupo daria os primeiros passos no sentido de ampliar a abrangência de sua revista, a ARS, a fim de associá-la aos Seminários de Arquitetura Latino-americana.

${ }^{118}$ O número 7 da ARS tinha como título “Periferia Urbana II. Teoría y Proyectos en Chile y Argentina".

${ }^{119}$ Cf. ELIASH, H.; MOSCATO, J. Taller de Verano CEDLA 1985 - Teoría y prática de la ciudad. In: ARS, Santiago de Chile: CEDLA, n.6, set. 1985, p.51-58.

120 Cf. 5a BIENAL de Quito 20 Encuentro de Revistas de Arquitectura. Ecuador 86. In: ARS, Santiago de Chile: CEDLA, n. 7, nov. 1986, 111-113. Além disso, Manuel Moreno, Cristián Fernández Cox e Humberto Eliash atuaram como moderadores no primeiro encontro latinoamericano de revistas de arquitetura, realizado entre 3 e 5 de setembro de 1985. Cf. PRIMER Encuentro de Revistas, In: CA. Santiago de Chile: Colegio de Arquitectos, n.42, dez. 1985, p.16.

${ }^{121}$ Cf. 5a BIENAL de Quito 2o Encuentro de Revistas de Arquitectura. Ecuador 86. In: ARS, Santiago de Chile: CEDLA, n. 7, nov. 1986, 111-113. 
Efetivamente, percebe-se maior alinhamento de membros do CEDLA aos Seminários de Arquitetura Latino-americana após III SAL, referência a partir da qual é possível caracterizar um terceiro período do grupo. Ou seja, se anos antes já havia uma preocupação com a especificidade latino-americana, após o encontro de Manizales esta inquietação se dá diretamente vinculada aos SAL. Neste contexto, o número 8/9 da revista ARS - publicado em setembro de 1987, apenas quatro meses após o evento colombiano - cumpre o papel de peça de transição. Destinada à comemoração do centenário de nascimento de Le Corbusier, nesta edição insere-se a figura de correspondentes estrangeiros - inexistentes nos números antecedentes -, entre os quais a maioria participava dos SAL: Juvenal Baracco (Peru); Jorge Moscato (Argentina); Sergio Trujillo (Colômbia) e Ruth Verde Zein (Brasil) ${ }^{122}$. Para além desta sutil alteração, o comitê editor solicita, também, a diversos arquitetos do subcontinente, o desenvolvimento de um projeto para uma casa-atelier para Le Corbusier, todos publicados na revista ${ }^{123}$.

A ideia de ampliar a abrangência da revista do grupo, contudo, tomaria forma claramente somente a partir do décimo número. Assim, a publicação periódica que havia se mantido desde 1978 com o subtítulo "Revista del Centro de Estudios de la Arquitectura (CEDLA)", passa a se chamar, em 1988, "ARS - Revista Latino-americana de Arquitetura". A própria alteração na sequência da numeração da revista dá indícios de que a mudança no nome já estava programada em 1987, quando se lançou uma edição com dupla numeração de forma a garantir que a próxima - comemorativa dos dez anos da revista e inaugural do novo perfil do periódico - fosse a de número 10. Neste sentido, a celebração da década de existência da revista e o lançamento de sua nova etapa vinculada aos encontros latino-americanos são destacados no editorial deste número:

Ao cumprir uma década, pensamos que era necessário reconsiderar os conteúdos originais e complementá-los com novas tarefas que hão de definir esta nova etapa que começamos a partir do número 10.

\footnotetext{
${ }^{122}$ Também passam a ser correspondentes: Andrea Contardo (Inglaterra), Amando Oyarzún (Espanha) e Renato Vivaldi (Italia) - cf. ARS número 8/9, setembro de 1987.

${ }^{123}$ Dentre os projetos publicados na ARS número $8 / 9$ estão 3 do Brasil (E. Maia, M.J. de Vasconcellos y S.E. de Podestá; Gustavo Pena; E. Mahfuz, A. Machado); 3 da Argentina (Bielus, Goldemberg, Weinstein Krasuk y equipo; J. Moscato y R. Schere; Korn, Lopatin, Rodas, Zylberberg); 1 da Colômbia (M. Pinilla, E. Silva, P.Weiss, H. Silva) e 1 da Bolívia (Gustavo Medeiros). Cf. MORENO, Manuel; ELIASH, Humberto. Una casa taller para Le Corbusier. In: ARS, Santiago de Chile: CEDLA, n. 8/9, set. 1987, p.77-94.
} 
Propusemo-nos realizar uma revista que transcenda o enquadramento nacional e possa ser parte de um interessante processo de encontro que se está produzindo na América Latina. [...] Sem sombra de dúvida no campo do debate arquitetônico, as coisas não voltarão a serem as mesmas depois das Bienais do Chile, dos Seminários de Arquitetura de Buenos Aires e Manizales, da Convocatória de Buenos Aires de 1985 e outros eventos difíceis de enumerar. Estes encontros permitiram ter capacidade e intenção de nos conhecer e projetar novas empreitadas em conjunto ${ }^{124}$.

No novo projeto editorial da ARS, a divulgação do grupo CEDLA aparece minimizada frente à promoção dos encontros latino-americanos. A fim de destacar a relevância destas redes profissionais em consolidação, a responsabilidade da elaboração do periódico foi dividida entre dois grupos: o comitê executivo editorial e o conselho editorial. No primeiro comitê, encontram-se os nomes de membros do CEDLA - Cristián Boza, Ricardo Contreras, Hernán Duval, Humberto Eliash, Manuel Moreno ${ }^{125}$ - agora acrescidos de Carlos Eduardo Comas e Jorge Moscato. Este a ampliação comitê executivo editorial agregava, nas palavras de Eliash, "aqueles que se viam com maior frequência" ${ }^{126}$ : Moscato - com quem o grupo tinha um histórico de trocas - e Comas, a quem membros do CEDLA conheceram em Manizales e cujo nome fora indicado por Boza $^{127}$. Para além deste pequeno comitê, os outros participantes assíduos dos SAL e os demais arquitetos latino-americanos com quem o CEDLA estabeleceu contato durante sua trajetória encontraram lugar no chamado Conselho Editorial da Revista: Mariano Arana (Uruguai), Silvia Arango (Colômbia), Juvenal Barraco (Peru), Pedro Belaúnde (Peru), Guido Díaz (Equador), Tony Díaz (Argentina), Éolo Maia (Brasil), Gustavo Medeiros (Bolívia), Rolando Moya (Equador), Pedro Murtinho (Chile), Augusto Ortiz de Zeballos (Peru), Alberto Petrina (Argentina), Edward Rojas (Chile), José Rosas (Venezuela), Rogelio Salmona (Colômbia), Bruno Stagno (Costa Rica), Antonio Toca

${ }^{124}$ ELIASH, H.; BOZA, C., et al. Una década... Nuevas tareas. In: ARS. Santiago do Chile: CEDLA, n.10, maio 1988, p.1.

125 Pedro Murtinho deixa de aparecer dentre os nomes do Comitê Executivo Editorial a partir do $\mathrm{n}^{\circ} 10$ da revista ARS e passa a compor seu conselho editorial.

${ }^{126}$ ELIASH, Humberto. Depoimento. [18 de julho de 2011]. Santiago do Chile: Arquivo digital da gravação (2horas e 13min.). Entrevista concedida a Gisela Barcellos de Souza.

${ }^{127}$ Informação confirmada pelos depoimentos de Eliash e Boza. Segundo Boza, a incorporação de Comas se justificava pelo fato deste ser "um grande teórico e um grande crítico da arquitetura [... que] contribuiu muito a partir da perspectiva brasileira" - BOZA, Cristián. Depoimento. [10 de outubro de 2011]. Santiago do Chile: Arquivo digital da gravação (1hora e 12min.). Entrevista concedida a Gisela Barcellos de Souza. 
(México), Sérgio Trujillo (Colômbia) e Ruth Verde Zein (Brasil). Neste conselho maior, segundo Eliash, estavam "os amigos, porém já divididos por países, com tarefas concretas e com estrutura de temas"128.

No primeiro número da ARS como revista latino-americana publicam-se textos diversos agrupados em torno da temática "Tradição e Modernidade" e cujos autores e temas testemunham antigos e novos intercâmbios. Entre os primeiros, encontram-se, por exemplo, Roberto Fernández ${ }^{129}$ - que participara da IV Bienal, a convite de Murtinho, e do Encontro de Caburga - e a transcrição de mesa redonda entre Marina Waisman, Moneo, Legorreta e Fernando Pérez que ocorreu na IV Bienal, em 1983, recuperada no texto de Wren Strabucchi ${ }^{130}$. Entre os segundos, encontram-se Ramón Gutiérrez $^{131}$, Antonio Toca ${ }^{132}$, Ruth Verde Zein ${ }^{133}$ e Germán Tellez ${ }^{134}$. Apenas um único texto da edição foi escrito por membro do chamado comitê executivo: o de Cristián Boza, "Arquitectura Latinoamericana: Tradición y Modernidad". Redigido especialmente para a revista, o texto de Boza abordava a tradição e a modernidade em uma seleção de obras arquitetônicas latino-americanas produzidas entre 1978 e 1988 e apoiava-se para tal, principalmente nos registros impressos do I e do III SAL ${ }^{135}$.

As páginas do número seguinte da ARS foram impressas em um cenário político bem distinto daquele em que se elaboraram todas as publicações precedentes do CEDLA. Cumprindo com o referendo previsto pela constituição chilena de 1980, Pinochet organizou o plebiscito em outubro 1988 e, ao ser convocada às urnas, a maioria da

\footnotetext{
${ }^{128}$ ELIASH, Humberto. Depoimento. [18 de julho de 2011]. loc. cit.

${ }^{129}$ FERNÁNDEZ, Roberto. Propiedad y ajenidad en la Arquitectura Latinoamericana. In: ARS, Santiago: CEDLA, n.10, mai 1988, p.18-23.

${ }^{130}$ STRABUCCHI,Wren. El Silencio Latinoamericano. A propósito de una Mesa Redonda en la IV Bienal de Chile (1983). In: ARS. Santiago de Chile: CEDLA, n.10, mai 1988, p41-43.

${ }^{131}$ GUTIÉRREZ, Ramón, Una aproximación a la arquitectura ibero-americana. In: ARS. Santiago de Chile: CEDLA, n.10, mai 1988, p.7-9. Além deste texto, publica-se também entrevista realizada com Ramón Gutiérrez em outubro de 1987 - cf. GUTIERREZ, R.; ELIASH, H. Entrevista al arquitecto Ramón Gutiérrez. In: ARS. Santiago de Chile: CEDLA, n.10, p.72-73.

${ }^{132}$ TOCA, Una arquitectuta alternativa para latinoamérica. In: ARS. Santiago de Chile: CEDLA, n.10, mai 1988, p.24-28.

${ }^{133}$ ZEIN, Ruth Verde. Arquitectura en el siglo XXI. Fin de las utopías o su realización. In: ARS. Santiago de Chile: CEDLA, n.10, mai 1988, p. 29-31.

${ }^{134}$ TELLEZ, Germán. Manual Práctico de Latinoamericanidad. In: ARS. Santiago de Chile: CEDLA, n.10, mai 1988, p.74.

${ }^{135}$ No total, há 6 referências no artigo aos anais do III SAL e 3 aos textos publicados na Summa 212, número preparatório ao I SAL. Cf. BOZA, Cristián. Arquitectura Latinoamericana: Tradición y Modernidad. In: ARS. Santiago de Chile: CEDLA, n.10, mai 1988, p. 44-71.
} 
população votou contra a continuidade do ditador no poder - ou seja, pelo "no" ${ }^{136}$. O retorno à democracia tornava-se finalmente um horizonte concreto. Com as eleições diretas para o novo presidente chileno marcadas para dezembro de 1989, o otimismo marcava o editorial da revista:

Após dezesseis anos de ditatura, nosso país se encaminha à recuperação de sua democracia. [...] Estamos certos que este retorno generalizado à democracia em nosso continente, unido aos avanços produzidos nos últimos anos na discussão e difusão de nossa arquitetura, gera uma concentração positiva de vontades e de energias de fecundas consequências ${ }^{137}$.

A despeito do clima festivo, este viria a ser, no entanto, o último número da ARS. Manifestava-se mais claramente neste o recuo de cena tomado pelo CEDLA na edição anterior - e que marcou esta terceira e última fase do grupo. Afirmava-se, portanto, que a revista estava "a serviço do estabelecimento e manutenção das relações culturais internacionais" ${ }^{138}$ e que se constituía "em porta-voz do grupo de arquitetos latino-americanos" ${ }^{\prime 139}$ participantes dos SAL e de encontros diversos. O número se propunha como uma contribuição para a discussão sobre a arquitetura latino-americana prevista para a VII Bienal ${ }^{140}$, que ocorreria no mês seguinte à sua edição, ou seja, em agosto de 1989. Logo, reuniam-se os textos e a seleção de obras recentes por países que seriam apresentados no Encontro Crítico de Arquitetura Latino-americana ${ }^{141}$.

Sem qualquer evento específico que selasse seu encerramento, o paulatino recuo do CEDLA em prol dos Seminários Latino-americanos, iniciado a partir de Manizales, daria lugar ao seu desaparecimento completo após a retomada dos canais democráticos. Com a grande expansão da economia chilena nos anos 1990, os arquitetos do grupo passariam a se dedicar com maior intensidade aos seus respectivos escritórios. Menções ulteriores aos feitos do CEDLA apareceriam no início do período democrático, em dois livros sobre a produção dos dois escritórios cujos arquitetos

\footnotetext{
${ }^{136}$ O resultado do plebiscito foi $55,99 \%$ para o "no" e 44,01\% para o "si".

${ }^{137}$ ELIASH, H.; BOZA, C. et al. Arquitectura Latinoamericana en tempos de democracia: un desafio. In: ARS. Santiago do Chile: CEDLA, n.11, jul 1989, p.7.

${ }^{138}$ ELIASH, H.; BOZA, C. et al. loc. cit. 1989, p.7.

${ }^{139}$ ELIASH, H.; BOZA, C. et al. loc. cit. 1989, p.7.

${ }^{140}$ SAN MARTín, Eduardo. Arquitectura y Crítica: Un Encuentro Necesario. In: ARS. Santiago do Chile, n.11, jul 1989, p.5.

${ }^{141}$ SAN MARTíN, E. loc. cit., 1989, p.5.
} 
estiveram intimamente envolvidos com a história deste centro de estudos: o Murtinho \& Asociados $^{142}$ e o de Cristián Boza ${ }^{143}$.

\section{Santiagos Ponientes}

No momento da realização do V SAL, a revista ARS já não exista há três anos e o período de grande efervescência cultural junto ao CEDLA era uma lembrança associada à primeira metade da década de 1980. Logo, não se pode afirmar que este seminário tenha sido concebido por seus organizadores como o marco do encerramento das atividades daquele grupo do qual outrora participaram ativamente. De fato, não há, em documento algum pertinente à organização do evento de Santiago, qualquer menção ao antigo CEDLA. Entretanto, não somente na temática geral do evento e nos subtemas definidos para o debate, o V SAL permitia vislumbrar algumas das discussões que foram caras ao grupo CEDLA: o primeiro projeto apresentado no seminário - desenvolvido especificamente para representar o Chile na problemática relativa à "cidade antiga com fachada contínua" - ecoava diretamente o período inicial daquele grupo.

No ano de 1977, durante a primeira bienal de arquitetura do Chile - evento em que se deu a aparição pública do CEDLA - seus arquitetos apresentaram uma proposta de intervenção urbana para o bairro Santiago Poniente, na qual sintetizavam as ideias que defendiam. A constituição da identidade do grupo em si se deu a partir da elaboração deste projeto ${ }^{144}$. Quatorze anos depois, ao procurar definir os projetos chilenos a serem apresentados no V SAL, parte da comissão organizadora - Pedro Murtinho, Cristián Fernández Cox e Humberto Eliash - decidiu por armar uma equipe e desenvolver uma nova proposta para o bairro Santiago Poniente especificamente para ser apresentada no V SAL. A retomada desta área de estudo e de sua problemática de projeto é justificada por Eliash como um compromisso:

Havíamos levantado [o questionamento sobre Santiago Poniente] na primeira bienal e sentíamos que devíamos nos encarregar do filho que havia ficado ali. Por isto resolvemos postulá-lo novamente. Havia outra equipe

\footnotetext{
142 FERNÁNDEZ LARRAÑAGA, Teodoro. Murtinho \& Asociados. Santiago do Chile: Publicaciones ARQ, 1991.

${ }^{143}$ ELIASH, H. La arquitectura de Cristián Boza : un eclectisismo apasionado. Santiago, Chile : Ediciones ARQ, 1993.

${ }^{144}$ ELIASH, H. op. cit, 1993. Informação confirmada em depoimento: cf. ELIASH, H. Depoimento. [06 de julho de 2011]. loc. cit.
} 


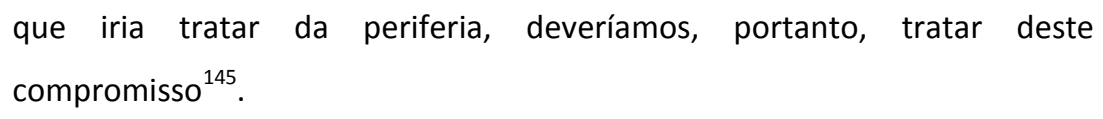

O bairro Santiago Poniente guarda em seu tecido, segundo Murtinho, marcas da hibridação entre a quadrícula espanhola e as influências europeias diversas que marcaram a arquitetura chilena do século $\mathrm{XIX}^{146}$. Seu nome faz menção a própria história do bairro, visto que corresponde à área de expansão urbana a oeste do antigo núcleo colonial de Santiago, para além do chamado canal García Cárceres - que corresponde ao atual traçado da Avenida Brasil ${ }^{147}$. Santiago Poniente permaneceu como área de chácaras até meados do século XIX, quando o primeiro loteamento ao poente foi aberto, a chamada Vila Yungay ${ }^{148}$. A vinculação desta vila à área urbana do núcleo original se daria com a extensão da malha urbana colonial a oeste, promovida por Benjamin Vicuña Mackenna $^{149}$ na década de $1870^{150}$. Ao longo do século $X X$, dois fatores viriam a modificar o cenário deste bairro e contribuir para decadência de sua vitalidade urbana: de um lado, a crescente expansão urbana a leste do núcleo original, em direção à cordilheira - local em que se estabelecem as classes abastadas a partir dos anos 1930 -; por outro, a implantação durante a década de 1970 da Avenida Norte-Sur - projeto desenvolvido em 1965 por Juan Parrochia ${ }^{151}$ - que rompeu com a estrutura viária colonial e que veio a configurar um novo limite ao centro metropolitano e isolar, desta forma, o bairro a oeste deste.

O primeiro projeto que o CEDLA elaborou para o bairro Santiago Poniente apoiava-se entre outros, em um parecer técnico encomendado em 1976 por Patrício Mekis - então prefeito de Santiago - sobre como promover a renovação das áreas

\footnotetext{
${ }^{145}$ ELIASH, Humberto. Depoimento. [02 de agosto de 2011]. Santiago do Chile: Arquivo digital da gravação (56min.). Entrevista concedida a Gisela Barcellos de Souza.

${ }^{146}$ MURTINHO, Pedro. Depoimento. [20 de agosto de 2011]. Santiago do Chile: Arquivo digital da gravação (1hora e 57min.). Entrevista concedida a Gisela Barcellos de Souza.

${ }^{147}$ O canal García Cárceres ligava o rio Mapocho ao que se chamava La Cañada, ou seja, antiga bifurcação do Mapocho que existia onde hoje está a Alameda Bernardo O’Higgins . Cf. RAMÓN, Armando de. Santiago de Chile (1541-1991). História de una Sociedad Urbana. Providencia: Editorial Sudamérica, 2000.

${ }^{148}$ RAMÓN, A. op. cit., 2000.

${ }^{149}$ Benjamín Vicuña Mackenna foi prefeito de Santiago entre 1872 e 1875.

${ }^{150}$ RAMÓN, A. op. cit., 2000.

${ }^{151}$ Ver a respeito: PAVEZ REYES, María Isabel. En la ruta de Juan Parrochia Beguin - Premio Nacional de Urbanismo Chile 1996. Santiago: Facultad de Arquitectura y Urbanismo, Universidad de Chile, 2003.
} 
urbanas deterioradas do centro da cidade ${ }^{152}$. Neste parecer, definia-se como área prioritária de intervenção aquela na qual se insere a proposta desenvolvida pelo CEDLA em 1977, ou seja: a área compreendida entre a Av. Norte-Sul (atual Autopista Central), a Alameda Bernardo O'Higgins, a Av. Brasil e o rio Mapocho ${ }^{153}$. O interesse por Santiago Poniente, no entanto, remonta ao início da década de 1970 e fora despertado pelos estudos que o arquiteto Fernando Domeyko realizou, com o auxílio de seus alunos da Universidad de Chile - entre os quais estava Humberto Eliash - sobre o espaço urbano deste bairro. Em seu levantamento sobre as cités e os antigos cortiços localizados no setor Mapocho-Bulnes, cujos desenhos resultantes foram expostos pela primeira vez em $1972^{154}$ e, posteriormente, publicados na Bélgica ${ }^{155}$, revelava-se a qualidade de espaços esquecidos no passado e até então desconhecidos para grande parte dos arquitetos ${ }^{156}$.
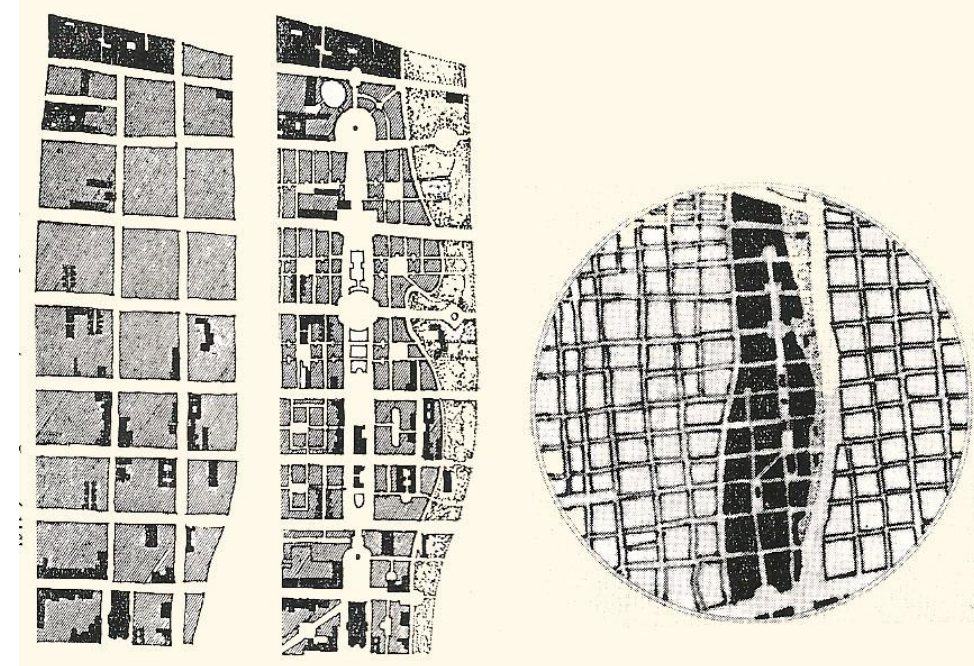

Figura 36: Projeto para Santiago Poniente desenvolvido pelo CEDLA, em 1977. Da esquerda para a direita: (a) situação existente no momento da realização da proposta, com destaque para os edifícios mantidos na proposta; (b) estrutura de espaços públicos do projeto, com destaque em preto para os edifícios conservados na proposta; (c) inserção do projeto em seu entorno. Fonte: ARS, n.1, jul. 1978.

${ }^{152}$ CEDLA. Antreproyecto Santiago Poniente. In: CEDLA, Santiago do Chile: CEDLA, ago. de 1977, p.35.

${ }^{153}$ CEDLA, loc. cit., 1977, p.35. O recorte do projeto desenvolvido em 1977 pelo CEDLA difere um pouco do indicado pela comissão: o limite ao sul foi definido pela Rua Moneda.

${ }^{154}$ FERNÁNDEZ LARRAÑAGA, T. loc. cit., 1991.

155 DOMEYKO, F. Tissu Urbain San Pablo / Santiago du Chili. Exposé du Problème et des Conclusions. Cf. In: A+, Bruxelas: CIAUD, n.7, abr. 1974, p.22-40.

${ }^{156}$ Cf. ELIASH, H. Depoimento. [02 de agosto de 2011]. Santiago do Chile: Arquivo digital da gravação (56min.). Entrevista concedida a Gisela Barcellos de Souza. 


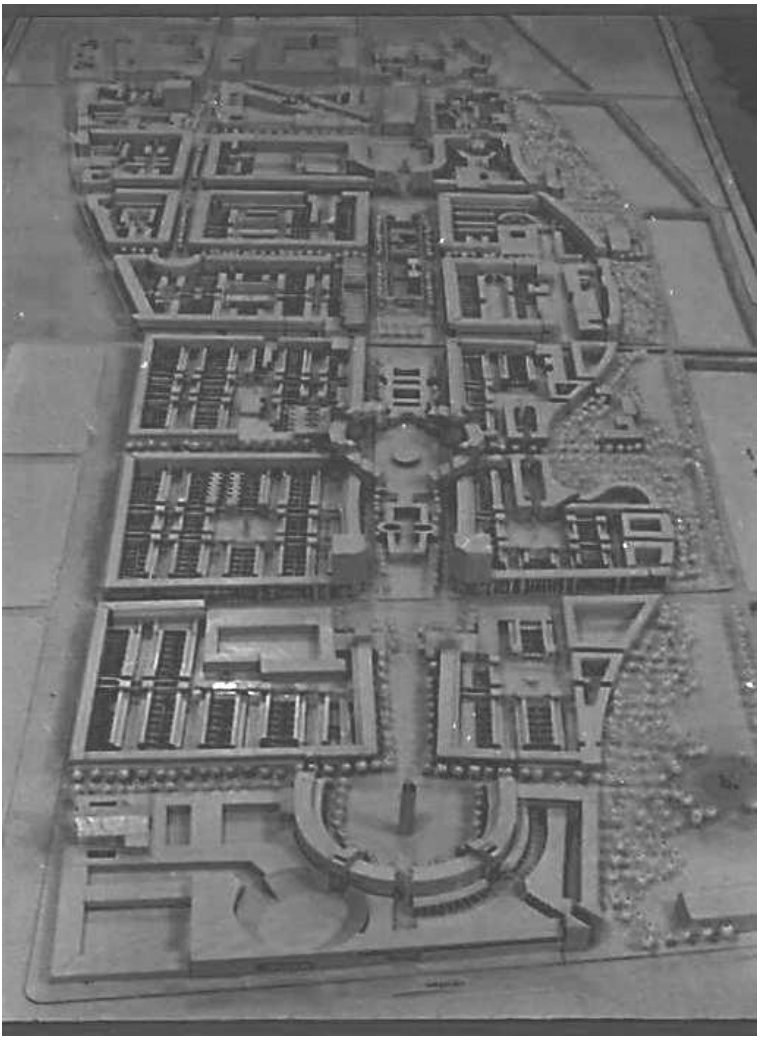

Figura 37: Maquete do projeto para Santiago Poniente desenvolvido pelo CEDLA, em 1977. Fonte: Acervo pessoal de Pedro Murtinho.

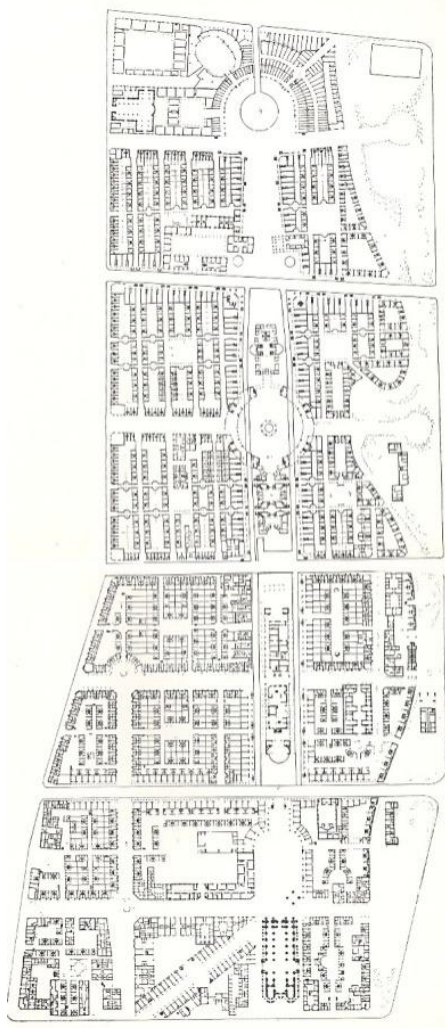

Figura 38: Planta do térreo do projeto urbano para Santiago Poniente. Fonte: ARS, n. 1, jul. 1978.

Somava-se ainda a este contexto, segundo Eliash, a oposição do CEDLA a duas grandes intervenções propostas para áreas históricas de Santiago no final dos anos 1960 e início dos anos 1970: a renovação de San Borja (1968-1970) ${ }^{157}$, amplamente criticada pelo grupo - "era a implantação de torres sobre uma cidade do passado arrasada, torres no parque"158 -, e o projeto para Santiago Poniente ganhador do concurso que se realizou durante a Unidade Popular, em 1972, elaborado por uma equipe de La Plata, que não se chegou a ser executado, pois logo se instaurou a ditadura militar ${ }^{159}$. 0 projeto desenvolvido pelo CEDLA visava mostrar ser possível uma solução com alta

\footnotetext{
${ }^{157}$ O projeto de renovação de San Borja foi coordenado pelo arquiteto Ernesto Labbé Achondo, durante o governo de Frei. Encontra-se parcialmente executado e deve seu nome ao antigo Hospital San Borja que se encontrava no local de sua implantação, entre a Alameda Bernardo O'Higgins e a Diagonal Paraguay. Trata-se de um projeto de torres articuladas por passagens de pedestres cobertas e centros comerciais, com estacionamentos subterrâneos e densidade habitacional líquida de 1042 hab/há e bruta 872 hab/há. Cf. LABBÉ A., Ernesto; MIRANDA R., Sergio; et al. Remodelación de San Borja. Santiago: MINVU/CORMU. 197-?.

${ }^{158}$ ELIASH, H. Depoimento. [02 de agosto de 2011]. loc. cit.

${ }^{159}$ ELIASH, H. Depoimento. [02 de agosto de 2011]. loc. cit.
} 
densidade bruta - entre 550 a 600 habitantes por hectare -, baixa altura e buscando "uma continuidade tipológica à área existente"160.

Desta forma, com os ânimos inflados pelas novidades trazidas do exterior por Boza e Eliash, as equipes de dois escritórios de arquitetura ${ }^{161}$ se reuniram para desenvolver o projeto para Santiago Poniente ${ }^{162}$. A despeito da ideia de continuidade com o tecido urbano adjacente, o projeto tratava a área de 69 hectares na qual se inseria como um setor autônomo, no qual, além de habitação, propunha-se, também, comércio, serviços, escritórios e equipamentos básicos. Embora alguns edifícios existentes tenham sido mantidos na proposta, para parte significativa apenas as fachadas ou os primeiros compartimentos eram conservados. O projeto desenvolvido se estruturava a partir de três ideias essenciais: quarteirões penetrados por uma trama secundária de espaços públicos que constituíam o elemento de base do projeto; uma sequência de espaços públicos monumentais em seu centro; e, por último, um parque linear que protegeria o interior do setor urbano do impacto da Av. Norte-Sur ${ }^{163}$.

Nestes aspectos supracitados do projeto revelam-se ressonâncias de propostas de intervenção urbana que eram coetaneamente desenvolvidas na Europa. Algumas referências são declaradas no memorial, como o projeto para New Castle de Ralph Erskine, que servira de inspiração para a proposição de um edifício de altura variáveis frente ao parque linear "que protege[ria] a interioridade do bairro"164. Na sequência de espaços públicos monumentais, constituída por uma rambla na qual se inseriam três grandes praças arrematadas ao sul pela Basílica del Salvador existente e ao norte por um mercado e um colégio propostos, reverberações dos projetos que eram então desenvolvidos pelos irmãos Krier, revelam-se no desenho de gosto neoclássico. Mais especificamente, percebem-se semelhanças entre a rambla - conformada por um

\footnotetext{
${ }^{160}$ CEDLA, loc. cit. 1978, p.15.

${ }^{161}$ Inicialmente, o escritório de Flaño, Nuñes e Tuca também integrava a equipe, porém estes arquitetos saíram da equipe antes mesmo de se iniciar o projeto - cf. ELIASH, H. La arquitectura de Cristián Boza : un eclectisismo apasionado. Santiago, Chile : Ediciones ARQ, 1993.

162 Participaram na elaboração do anteprojeto para Santiago Poniente: Pablo Asttaburuaga, Cristián Boza, Ricardo Contreras, Miguel Castillo, Hernán Duval, Humberto Eliash, Luís González, Eugenio Guzmán, Guillermo Hevia, José Larraín, Roberto López, Teresa Lima Campos, Jorge Lührs, Pedro Murtinho, José Muzard, Ignacio Martínez, Santiago Raby e Eduardo Walker - CEDLA, Remodelación de Santiago Poniente 2. In: ARS, Santiago de Chile: CEDLA, n.1, jul. 1978, p.15-26.

${ }^{163}$ A Av. Norte-Sur ainda não havia sido concluída, porém é tomada como um condicionante do projeto. Cf. CEDLA, loc. cit., 1978.

${ }^{164}$ CEDLA, loc. cit., 1978, p.25.
} 
edifício contínuo com galerias cobertas e atividades comerciais no térreo no projeto do CEDLA - e aquela da proposta de Léon Krier desenvolvida para o concurso de La Villette, em 1976.
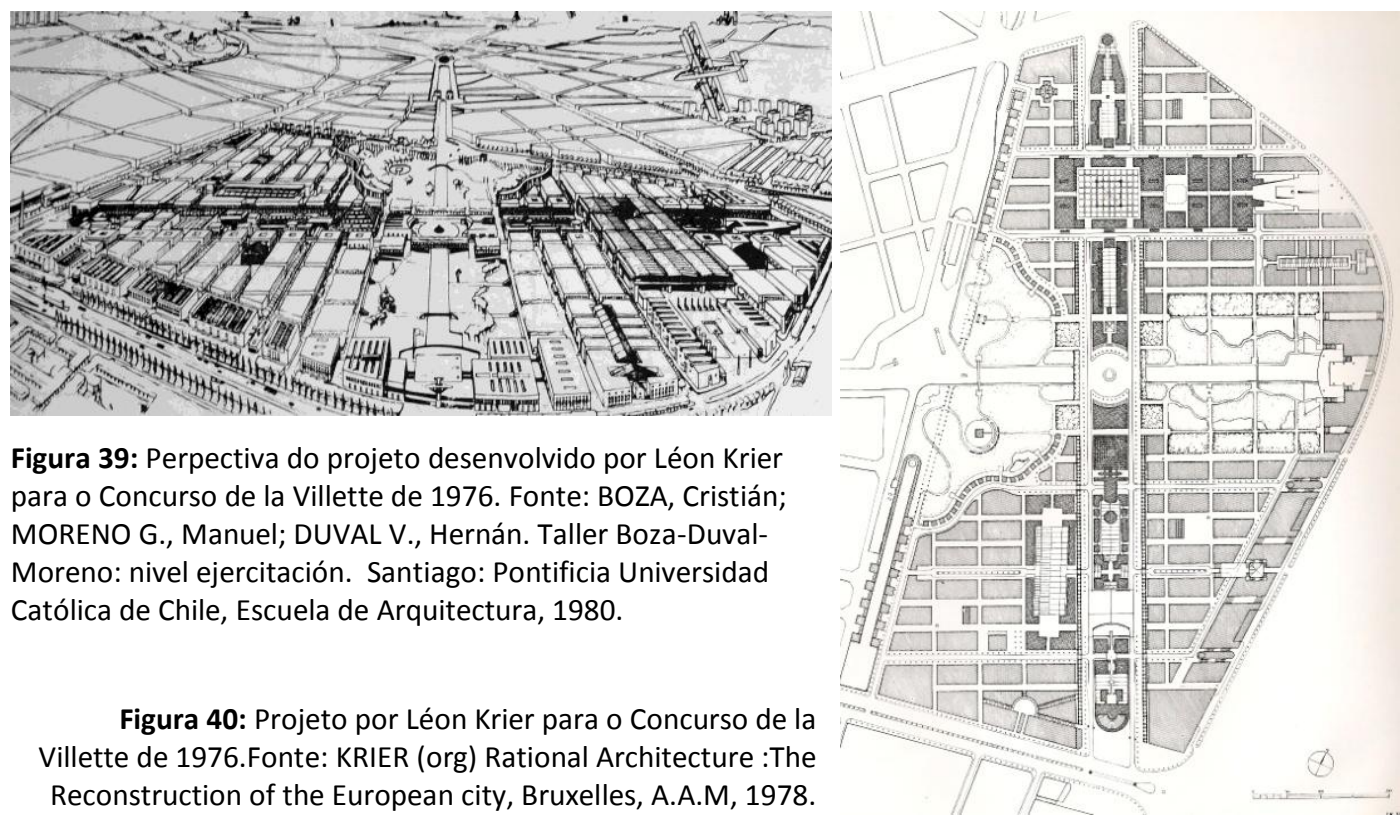

Figura 40: Projeto por Léon Krier para o Concurso de la Villette de 1976.Fonte: KRIER (org) Rational Architecture :The Reconstruction of the European city, Bruxelles, A.A.M, 1978.

Contudo, é no elemento-base do projeto, a chamada "manzana-block"165, que se revelam traços interessantes de uma mescla entre elementos trazidos da leitura do tecido urbano de Santiago Poniente - a ideia de recuperar o espaço urbano das cités e travessas do entorno - e outros que reverberam o debate internacional. Não se pode deixar de notar, no uso da expressão "manzana-block", o interesse em remeter ao debate sobre a tipo-morfologia tal qual ele foi propagado no ambiente anglófono e a definição de "building-block" de Léon Krier que afirmava que "o grau de urbanidade (sic) de uma trama espacial pode ser avaliado na frequência de ruas e praças" ${ }^{166}$. Neste sentido, no projeto do CEDLA a quadrícula espanhola é rompida por uma série de ruelas e pequenas praças que criavam uma segunda trama de espaços públicos no interior do quarteirão. Deve-se ressaltar a semelhança deste procedimento àquele da revisão do quarteirão de Cerdá que Krier havia proposto como exercício didático um ano antes ${ }^{167}$.

\footnotetext{
${ }^{165}$ CEDLA, loc. cit., 1978.

${ }^{166}$ KRIER, Léon (org). Rational Architecture :The Reconstruction of the European city, Bruxelles, A.A.M, 1978, p.74.

167 Cf. KRIER, Léon (org)., op.cit., 1978, p.75-82. Krier justificava-o da seguinte forma: "Se nós subdividirmos o quarteirão de Cerdá $(113 \times 113 \mathrm{~m})$ por duas ou três vias de pedestres, nos recriamos no Ensanche uma densidade estrutural similar a do centro histórico" - cf. KRIER, Léon; SOLÁ-MORALES, Manuel. Ensache Cerdá. A project and a debate. In: Lotus, Milão: Electra, n.19, jun 1978, p.33
} 
Contudo, ao contrário do arquiteto luxemburguês, o CEDLA não rompia por completo com a estrutura da quadrícula espanhola, criando uma miríade de pequenos quarteirões. No projeto para Santiago Poniente, uma fachada perimetral contínua - de seis pavimentos - recuperava a geometria da quadrícula e protegia as cités e as travessas, conformadas por residências de 2 a 3 pavimentos ${ }^{168}$.

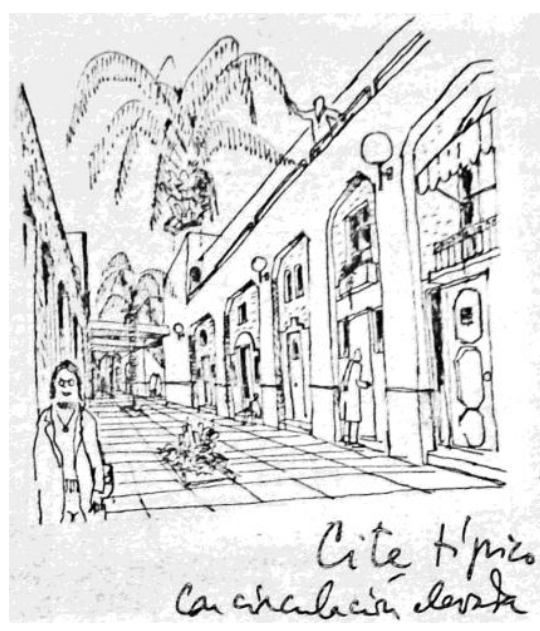

Figura 41: O espaço típico de uma Cité, croqui do processo de elaboração do projeto para Santiago Poniente elaborado em 1977 pelo CEDLA. Fonte: CEDLA, n.1, ago.1977

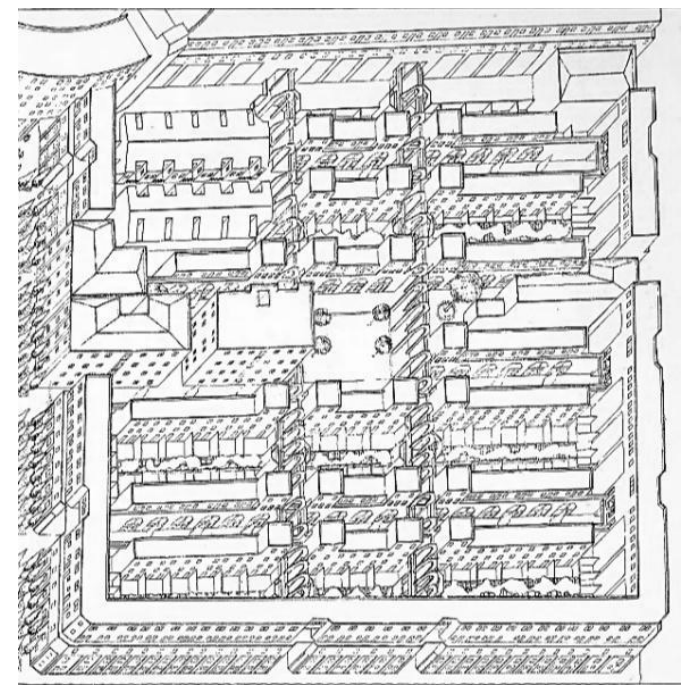

Figura 42: Quarteirão do projeto para Santiago Poniente elaborado em 1977, a borda edificada e a estrutura interna de cités e travessas. Fonte: ARS, n.1, jul. 1978.

A apresentação do projeto na primeira bienal do Chile causou grande furor entre a plateia ${ }^{169}$. Contudo, apesar da polêmica gerada pelo projeto, passados quatorze anos, nada havia ocorrido no sentido de executá-lo e o processo de deterioramento do patrimônio urbano e arquitetônico de Santiago Poniente só havia se agravado ${ }^{170}$.

[...] Nós sentíamos que o [projeto para "Santiago Poniente"] que havíamos desenvolvido no ano de 1977 - um pouco panfletário, quase um manifesto [...] - tinha que ser superado agora e nós deveríamos lhe introduzir elementos de gestão e de planejamento contemporâneo que pudessem aproximá-lo da realidade ${ }^{171}$

\footnotetext{
${ }^{168}$ CEDLA, loc. cit., 1978.

${ }^{169}$ A respeito, Murtinho afirmou em depoimento: "Foi algo iconoclasta. Decidimos: vamos apresentar um projeto clássico [na bienal]. Foi um escândalo completo. Fomos tratados de conservadores." Cf. MURTINHO, Pedro. Depoimento. [20 de agosto de 2011]. loc. cit.

${ }^{170}$ MURTINHO, Pedro. Depoimento. [20 de outubro de 2011]. Santiago do Chile: Arquivo digital da gravação (56min.). Entrevista concedida a Gisela Barcellos de Souza.

${ }^{171}$ ELIASH, Humberto. Depoimento. [02 de agosto de 2011]. Santiago do Chile: Arquivo digital da gravação (56min.). Entrevista concedida a Gisela Barcellos de Souza.
} 
A busca por uma maior possibilidade de concretude e de consecução na transformação urbana, destacada por Eliash em seu depoimento, é, certamente, uma das principais tônicas que diferenciam o ambicioso projeto de 1977 para 69 hectares e a moderada proposição de revisão das normas edilícias em 1991 experimentada em apenas seis hectares. Estas diferentes posturas marcam momentos distintos na carreira destes arquitetos: em 1977 interessava mais a efervescência do debate de revisão do Movimento Moderno, em 1991, no entanto, estes arquitetos entravam em um ciclo de grande produção em seus escritórios e as questões pragmáticas pareciam ter maior apelo.

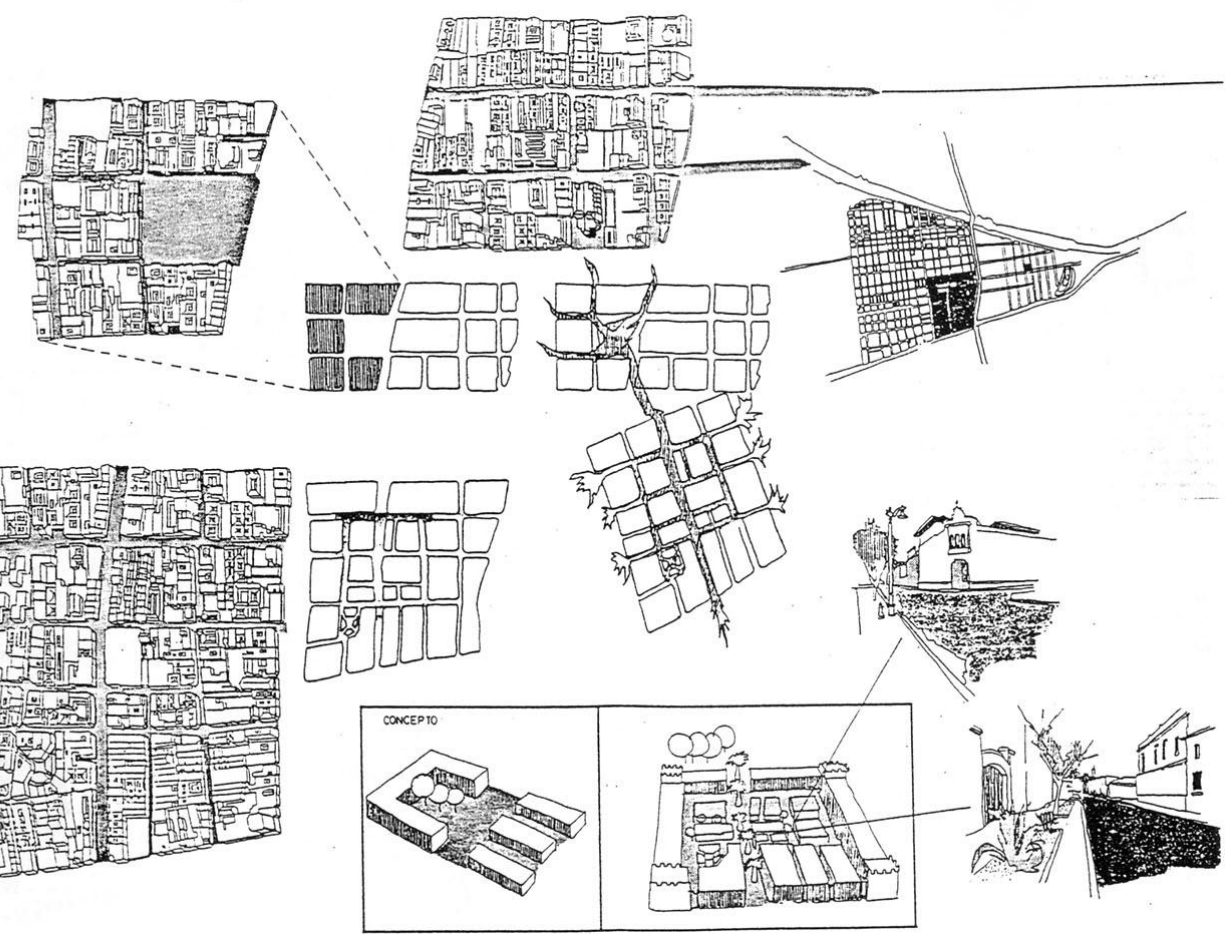

Figura 43: Croquis que sintetizam a leitura e o conceito da proposta de revisão de normas para Santiago Poniente desenvolvida em 1991. Fonte: MURTINHO, P.; FERNÁNDEZ, C. et al. Proposición de normativa urbana para Santiago Poniente. In: BOZA et al, 1991.

O interesse renovado pelo pragmatismo das normativas e a necessidade de que os arquitetos dedicassem atenção a estas ${ }^{172}$ eram inclusive defendidos na convocatória do V SAL como um substituto contemporâneo aos antigos acordos coletivos que garantiam no passado a qualidade do espaço urbano:

172 "É surpreendente a pouca atenção que nós arquitetos demos a estas normativas tão decisivas" - BROWNE, E.; FERNANDEZ COX, C.; MURTINHO, P. loc. cit. 1991, p. 3. 
Desaparecidos ou muito enfraquecidos, os antigos acordos culturais tácitos do passado - que constituíam os "genius loci" urbanos - restam hoje principalmente os acordos racionalmente explícitos, constituídos pelas normativas morfológicas que conformam ou desconformam a cidade ${ }^{173}$.

Logo, a equipe composta pelos escritórios Murtinho \& Asociados $^{174}$; Cristián Fernández \& Asociados $^{175}$ e Manuel Fernández ${ }^{176}$ - que participou como consultor ${ }^{177}$ trabalhou com afinco durante três meses na elaboração da proposta que foi apresentada no V SAL. O pragmatismo estendia-se para além do fato de buscar uma fácil viabilização da execução da proposta; pretendia-se, também, que houvesse interesse por parte do setor imobiliário em fazê-lo. Logo, a revisão de normativas propostas para Santiago Poniente não deveria reduzir a possibilidade de lucro imobiliário na área: "A ideia é que se construísse o mesmo, porém com uma normativa que permitisse não destruir Santiago Poniente" ${ }^{178}$.

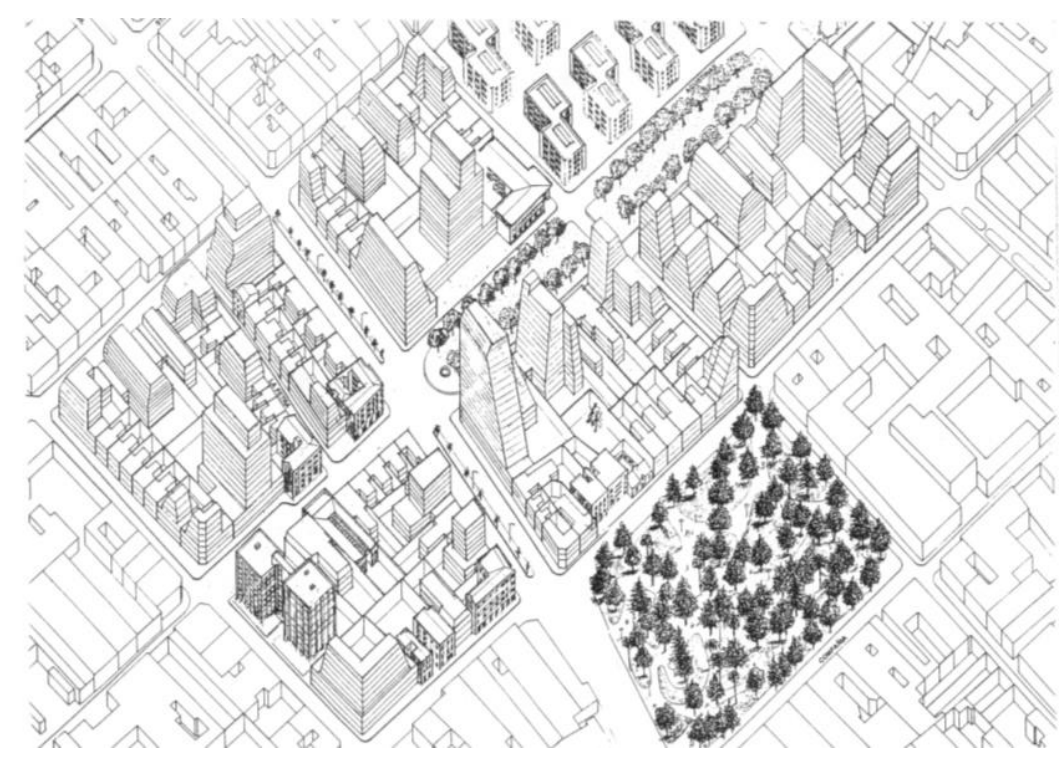

Figura 44: Simulação da aplicação das normas vigentes para Santiago Poniente em 1991. Fonte: MURTINHO, P.; FERNÁNDEZ, C. et al. Proposición de normativa urbana para Santiago Poniente. In: BOZA et al, 1991.

\footnotetext{
${ }^{173}$ BROWNE, E.; FERNANDEZ COX, C.; MURTINHO, P. loc. cit. 1991, p.2-3.

${ }^{174}$ Pedro Murtinho; Ricardo Contreras; Luis González M.; Humberto Eliash D. e Santiago Raby P.

${ }^{175}$ Cristián Fernández Cox e Cristián Fernández Eyzaguirre.

${ }^{176}$ Manuel Fernández, doutor pela Universidade Técnica de Munique, era então decano da Facultad de Arquitectura y Urbanismo da Universidad de Chile.

177 Cf. ELIASH, Humberto. Depoimento. [18 de julho de 2011]. Santiago do Chile: Arquivo digital da gravação (56min.). Entrevista concedida a Gisela Barcellos de Souza.

${ }^{178}$ MURTINHO, Pedro. Depoimento. [20 de outubro de 2011]. loc. cit.
} 


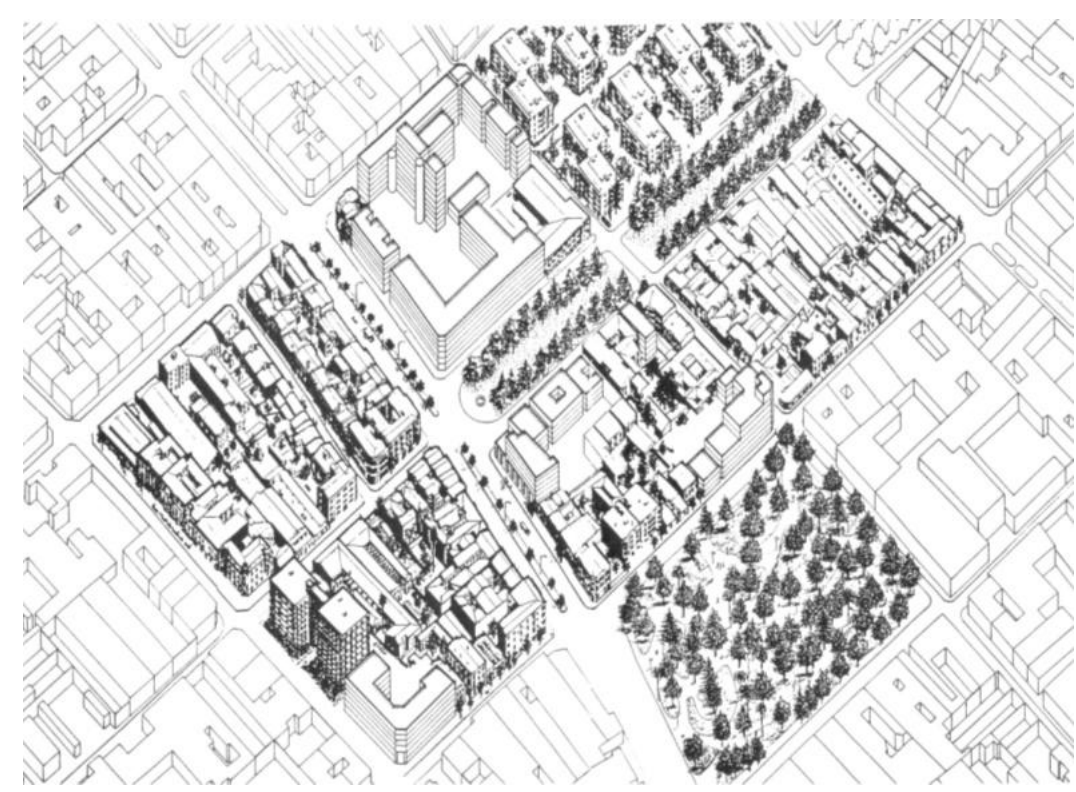

Para tanto, a equipe apoiava-se em estudo tipo-morfológico simplificado ${ }^{179}$, porém metódico, que buscava compreender área do entorno da Praça Brasil" ${ }^{180}$ "como arremate da continuidade da área central e como um setor interno protegido por bordas" $^{\prime 181}$. A caracterização dos principais traços da relação entre os tipos edilícios e a morfologia urbana - apoiada em estudos que estavam sendo realizados junto a Universidad de Chile ${ }^{182}$ e apresentada nas pranchas expostas no V SAL - contrastava com a informalidade do levantamento que apoiava a proposta desenvolvida em $1977^{183}$.

Ao se comparar o projeto de 1977 com as normativas de 1991, no entanto, observa-se que não somente o tom pragmático distancia as duas propostas: do debate

\footnotetext{
${ }^{179}$ Abordam-se de forma esquemática os seguintes aspectos: relação entre o todo e suas partes, tipos de quarteirões, estrutura do parcelamento, caracterização volumétrica e de fachadas dos tipos edilícios. Estas análises gráficas são antecedidas por breve caracterização histórica da constituição da área de estudo. Cf. MURTINHO \& ASOC.; CRISTIÁN FERNÁNDEZ \& ASOC; FERNÁNDEZ, Manuel. Proposición Normativa Urbana - Barrio Santiago Poniente. In: Seminario de Arquitectura Latinoamericana. Nuestro Espacio Urbano: Propuestas Morfológicas. V, Santiago do Chile. Anais... Santiago do Chile : s.n. 1991.

${ }^{180}$ Foi utilizado como recorte para análise tipo-morfológica a área delimitada pelos seguintes arruamentos: a avenida Norte-Sur a leste, a alameda Bernardo O'Higgins ao sul, a rua Catedral ao norte e a rua Ricardo Cumming a oeste - Cf. MURTINHO \& ASOC.; CRISTIÁN FERNÁNDEZ \& ASOC; FERNÁNDEZ, Manuel. loc. cit. 1991.

${ }^{181}$ MURTINHO \& ASOC.; CRISTIÁN FERNÁNDEZ \& ASOC; FERNÁNDEZ, Manuel. loc. cit. 1991, p.3.

182 Os desenhos de análise tipo-moforlógica apresentados nas pranchas foram elaborados por Pablo de la Llera, então aluno de mestrado, orientado por Manuel Fernández, na Universidad de Chile- cf. MURTINHO \& ASOC.; CRISTIÁN FERNÁNDEZ \& ASOC; FERNÁNDEZ, Manuel. loc. cit. 1991.

${ }^{183}$ Cf. CEDLA, loc. cit., 1977 e CEDLA, loc. cit., 1978.
} 
que havia motivado a "manzana-block" no final dos anos setenta, apenas a ideia de definir claramente a forma da quadrícula através do conjunto edificado permanece. Desta forma, como alternativa as leis então vigentes que permitiam a construção de torres de até trinta pavimentos com tangentes em Santiago Poniente ${ }^{184}$, a proposta dos escritórios Murtinho \& Asociados e Cristián Fernández \& Asociados propunha a construção contínua junto ao alinhamento da rua com seis pavimentos, tal qual a proposta de 1977. A estrutura do parcelamento e dos quarteirões, no entanto, permanecia agora inalterada, nenhuma proposta foi feita no sentido de incorporar as cités e as travessas que outrora constituíam elementos essenciais no quarteirão do projeto do CEDLA.

\subsection{O tecido e sua distensão}

Exposto o preparo da trama que permitiria entrelaçar aqueles debates que haviam tido locais distintos nos SAL anteriores - e reveladas as expectativas e citações ao passado que se imiscuíam entre seus fios -, deve-se passar a exposição do evento em si, dos projetos e textos que foram apresentados neste e da continuidade ou não das discussões ali fomentadas nos dois eventos posteriores que completam o ciclo entre 1985 e 1995.

Como se mostrou no subcapítulo anterior, houve um grande cuidado na concepção e no planejamento deste evento; imaginava-se, de fato, que este iniciaria uma nova etapa nestes seminários. Havia, certamente, um clima de grande otimismo na organização do V SAL, como o confirma Eliash em seu depoimento:

À diferença dos demais que foram especulativos, nós queríamos fazer um SAL propositivo: que as pessoas viessem com projetos sobre bairros, sobre lugares, sobre periferia, sobre praças e que fosse sobre isto que nós discutíssemos ${ }^{185}$.

Poder-se-ia imaginar que especificidade temática do evento - frente à abertura dos eventos anteriores - e, mais precisamente, a exigência de projetos para

\footnotetext{
${ }^{184}$ MURTINHO, Pedro. Depoimento. [20 de outubro de 2011]. loc. cit.

${ }^{185}$ ELIASH, Humberto. Depoimento. [18 de julho de 2011]. Santiago do Chile: Arquivo digital da gravação (2horas e 13min.). Entrevista concedida a Gisela Barcellos de Souza.
} 
embasamento de debates que, nas edições anteriores, haviam sido pautados por importantes contribui de críticos - como se demonstrou no segundo capítulo - poderia ter causado problemas de adesão ao seminário. Entretanto, esta suposição inicial não confirma quando se observam os dados do evento: em seus anais há registro ${ }^{186} \mathrm{da}$ apresentação de 32 projetos - dentre os quais 26 tiveram suas pranchas incluídas nos anais - e de 30 exposições teóricas, das quais 18 foram publicadas nos anais ${ }^{187}$. Estes números eram destacados logo no início da apresentação dos anais do evento, como uma afirmação antecipada de seu sucesso:

Quando, em 1985, a revista SUMMA organizou o 10 SAL em Buenos Aires, ninguém imaginava que aquele evento chegaria, em apenas 6 anos, a convocar mais de 200 arquitetos, provenientes de 11 países da América Latina, que trabalharam durante meses para enviar mais de 50 apresentações a serem discutidas em Santiago do Chile ${ }^{188}$.

Efetivamente, para além do significativo número de apresentações previstas e da incorporação de dois novos países aos SAL - Cuba e Curaçao, ver Apêndice B -, observa-se grande adesão de arquitetos de países que haviam contribuído de forma errática nos seminários - pouco frequente e sem nenhum personagem assíduo antes deste evento -, bem como a ampliação do número de contribuições daqueles outros países cuja participação até então havia ficado restrita aos habitués do debate. No primeiro caso, inserem-se a Venezuela - que envia sete textos e três projetos para apresentação e que havia sido representada somente por Willian Niño, no II SAL, e por Eligia Calderón, no IV SAL ${ }^{189}$ - e o Equador, que contribui com três projetos e uma exposição teórica - a única apresentação equatoriana anterior ao quinto seminário havia sido a de Guido Díaz, no III SAL ${ }^{190}$. No segundo caso, encontra-se o Peru, que havia tido sua representação apenas através de suas personagens assíduas aos SAL - Juvenal Baracco e Pedro Belaúnde - e que, na ocasião do evento de Santiago do Chile,

\footnotetext{
${ }^{186}$ Consideram-se neste dado tanto os projetos e os textos que foram publicados nos anais, quanto aqueles cujos títulos apenas constam na grade de programação - ver Apêndice $C$, bem como: BOZA et al. (org). Seminario de Arquitectura Latinoamericana. Nuestro Espacio Urbano: Propuestas Morfológicas. V, 1991. Santiago do Chile. Anais... Santiago do Chile: s.n. 1991.

${ }^{187}$ BOZA et al. (org). op. cit., 1991.

${ }^{188}$ BOZA, C. et al. Presentación. In: Seminario de Arquitectura Latinoamericana. Nuestro Espacio Urbano: Propuestas Morfológicas. V, Santiago do Chile. Anais... Santiago do Chile : s.n. 1991.

${ }^{189}$ Ver registros das apresentações no II e no IV SAL no Apêndice B.

${ }^{190}$ Ver registros das apresentações no III SAL no Apêndice B.
} 
apresentou cinco projetos e três textos; assim como, também, o Brasil, que, apesar compor o seleto grupo dos países que foram representados em todos os seminários entre 1985 e 1995, as contribuições haviam sido restritas aos nomes de Ruth Verde Zein, Carlos Eduardo Comas e Hugo Segawa - no V SAL participaram também Álvaro Hardy e, segundo fontes orais ${ }^{191}$, Éolo Maia ${ }^{192}$.

De acordo com a crônica do evento publicada na revista Projeto, participaram do evento que ocorreu no Centro de Extensión da Universidad Católica de Chile 320 arquitetos oriundos de 14 países distintos ${ }^{193}$. De fato, para além dos 11 países que mandaram os projetos e textos que foram incluídos nos anais e/ou no programa, verifica-se que, durante a realização do evento, arquitetos de outros países juntaram-se ao debate. Os dados publicados na Projeto são confirmados pela reportagem publicada no jornal El Mercurio, que acrescenta à lista inicialmente prevista ${ }^{194}$ o Uruguai, o Paraguai e a Costa Rica ${ }^{195}$, sem, no entanto, especificar quem seriam os arquitetos representantes de cada um destes países ${ }^{196}$.

$\mathrm{Na}$ avaliação pessoal de Humberto Eliash, a convocatória do V SAL foi bem acolhida - como indicam os números - e este evento viria a se diferenciar dos seminários anteriores - e posteriores - como aquele em que houve maior participação de arquitetos que se interessavam por projetar ${ }^{197}$. Esta perspectiva poderia levar a

\footnotetext{
${ }^{191}$ Tanto Cristián Boza - em depoimento do dia 10 de outubro de 2011 - quanto Hugo Segawa confirmariam a presença de Éolo Maia e Álvaro Hardy (Veveco) no evento: "Mas esse encontro foi curioso, foi o meu segundo e quem estava lá foi um grupo de mineiros [...] O Éolo já era um "habitué" de Buenos Aires e essa turma foi pela primeira vez num SAL. Ele, o Veveco... [...] Houve uma palestra do Éolo. O Veveco não me recordo se apresentou" - SEGAWA, Hugo Massaki. Depoimento. [06 de abril de 2011]. São Paulo: Arquivo digital da gravação (1hora e 34min.). Entrevista concedida a Gisela Barcellos de Souza.

${ }^{192}$ Como se observa, no caso brasileiro, não houve uma ampliação significativa de novos participantes. Apenas Álvaro Hardy (Veveco) enviou projeto desenvolvido para o centro de Belo Horizonte, do qual Éolo Maia também participou - ver Apêndice $C$.

${ }^{193}$ SAL: Em busca de uma modernidade latino-americana. In: Projeto. São Paulo: Projeto, n. 148, dez 1991.

${ }^{194}$ De acordo com os Anais e o programa do evento, estavam previstas a participação de arquitetos dos seguintes países: Argentina, Brasil, Chile, Colômbia, Costa Rica, Cuba, Curaçao, Equador, México, Peru e Venezuela. Cf. BOZA, C. et al.(org), op. cit.,1991.

${ }^{195}$ MONTERO WARD, Beatriz. Propuestas Concretas para la Ciudad. El Mercúrio, Santiago do Chile, Vivienda y Decoración p. 6, 12 de out. de 1991.

${ }^{196}$ Encontrou-se apenas registro impresso da participação de Mariano Arana (Uruguai) na VIII Bienal de Arquitetura do Chile, evento que ocorria em paralelo.

${ }^{197}$ ELIASH, Humberto. Depoimento. [02 de agosto de 2011]. Santiago do Chile: Arquivo digital da gravação (56min.). Entrevista concedida a Gisela Barcellos de Souza.
} 
pensar que, neste seminário, teria ocorrido uma menor participação dos habitués dos SAL - visto que parte significativa era constituída por críticos ou historiadores, ou por aqueles que tinham a prática do projeto como atividade secundária ${ }^{198}$ - ou mesmo uma renovação dos nomes a frente do debate. Contudo, verifica-se justamente o oposto: a realização conjunta do V SAL com a VIII Bienal possibilitou a participação de grande número de habitués e iniciados no evento de Santiago do Chile. Encontraram-se, nos registros impressos, os nomes de 36 arquitetos que já haviam participado anteriormente em algum evento vinculado à história dos SAL - frente aos 22 observados no IV SAL e os 16 no III SAL (ver Apêndice B) -, além destes, outros três profissionais viriam a se engajar nesta rede após o evento, auxiliando na organização de sua próxima edição ${ }^{199}$.

Esta primeira aproximação aos registros impressos da participação de iniciados e da afluência do público conduz à pressuposição de que o evento de Santiago do Chile teria conseguido criar as condições necessárias para atingir as expectativas de debate que transpareciam em sua convocatória. No entanto, esta não condiz com a impressão que alguns dentre os habitués dos SAL entrevistados revelaram sobre este evento. Silvia Arango, por exemplo, afirmou não se lembrar de discussões muito aprofundadas na ocasião ${ }^{200}$. Ramón Gutiérrez disse lembrar pouco do seminário, recordando-se mais da discussão em torno do Prêmio América ${ }^{201}$. Dentre os organizadores do V SAL, Enrique Browne e Eduardo San Martín revelaram que se envolveram pouco com o evento de fato $^{202}$ e Cristián Fernández Cox - que não apenas se engajou na orquestração do seminário, como, também, desenvolveu a proposta para Santiago Poniente em conjunto

\footnotetext{
${ }^{198}$ Esta afirmação vale, sobretudo, para o contexto argentino - ver Apêndice B, "Personagens assíduas nos SAK entre 1985 e 1995, segundo os registros impressos" - que, além de contar com o maior número de personagens assíduas (onze, no total, dentre quais apenas dois tinham em seus escritórios sua primeira área de atuação), contribuía, também, com uma quantidade significativa de apresentações nos eventos entre 1985 e 1995, sendo, de modo geral, o segundo país mais numerosamente representado nestes eventos - ver Apêndice B, "Total de apresentações e palestras nos SAL entre 1985 e 1995, de acordo com os registros impressos dos eventos".

${ }^{199}$ Referimo-nos a Martín Padrón, Alberto Sato e Oscar Tenreiro, que organizaram o IV SAL em Caracas - Cf. PADRÓN, Martín J et al. (org). Seminario de Arquitectura Latinoamericana. Nuestro arquitectura reciente: conceptos y realizaciones. VI, 1993. Caracas. Ponencias generales... Caracas: Ediciones Fundación Museo de Arquitectura. 1993.

200 ARANGO, Silvia. Depoimento. [11 de novembro de 2011]. Campinas: Arquivo digital da gravação (1hora e 11min.). Entrevista concedida a Gisela Barcellos de Souza.

${ }^{201}$ GUTIÉRREZ, Ramón. Depoimento. [11 de novembro de 2011]. Campinas: Arquivo digital da gravação (1hora e 39min.). Entrevista concedida a Gisela Barcellos de Souza.

202 Cf. BROWNE, Enrique. Depoimento. [13 de setembro de 2011]. loc. cit. e SAN MARTín, Eduardo. Depoimento. [26 de março de 2012]. loc. cit.
} 
com o escritório de Pedro Murtinho - afirmou que ao final deste ficou com a impressão de que não o haviam preparado de maneira satisfatória ${ }^{203}$. Por outro lado, Eliash, Boza e Murtinho coincidiram na afirmação de que, na condição de anfitriões, assumiram uma posição de segundo plano, não se envolvendo diretamente nos debates, pois preferiram “deixar espaço para aos estrangeiros" 204.

Disjunção entre as amplas expectativas que se manifestavam na convocatória do V SAL e a aparente falta de memória que habitués dos seminários manifestam sobre os debates que ocorreram efetivamente naquela ocasião merece ser mais bem analisada. Teriam os projetos e textos apresentados correspondido ao enquadramento temático definido para o evento? Em que medida? Visto que muitas das personagens assíduas parecem ter assumido uma postura mais distante, qual teria sido o papel desempenhado por estes durante o V SAL?

Na sequência buscaremos analisar de perto as peças que compunham o tecido que se pretendia construir através do V SAL - os projetos e textos apresentados -, assim como a relação que este seminário estabeleceu com a VIII Bienal, que ocorria simultaneamente. Por último, abordaremos o esmaecimento da temática da morfologia das cidades latino-americanas nos seminários subsequentes juntamente com o desengajamento progressivo de algumas das personagens que estavam vinculados à história dos seminários desde seu início. Em outras palavras, buscaremos analisar o tecido construído e vislumbrar seu processo de distensão.

\footnotetext{
${ }^{203}$ No momento em que realizamos a entrevista, Cristián Fernández Cox encontrava-se com sua saúde debilitada e, a despeito desta condição, recebeu-nos gentilmente, respondendo muito bem a diversas perguntas que foram realizadas, apresentando, porém, alguns lapsos de memória em alguns temas. Infelizmente, o V SAL era um deles, do qual Fernández Cox afirmou não se recordar de "praticamente nada": "Somente lembro que fiquei com o sentimento de que não havíamos feito bem as coisas" Cf. FERNÁNDEZ COX, Cristián. Depoimento. [31 de setembro de 2011]. Santiago do Chile: Arquivo digital da gravação (1hora e 56min.). Entrevista concedida a Gisela Barcellos de Souza.

204 Esta frase é de Pedro Murtinho - cf. MURTINHO, Pedro. Depoimento. [20 de outubro de 2011]. loc. cit. -, porém, afirmações semelhantes foram declaradas por Boza e Eliash em seus depoimentos. BOZA, Cristián. Depoimento. [10 de outubro de 2011]. Santiago do Chile: Arquivo digital da gravação (1hora e $12 \mathrm{~min}$.). Entrevista concedida a Gisela Barcellos de Souza. e ELIASH, Humberto. Depoimento. [02 de agosto de 2011]. Santiago do Chile: Arquivo digital da gravação (56min.). Entrevista concedida a Gisela Barcellos de Souza.
} 


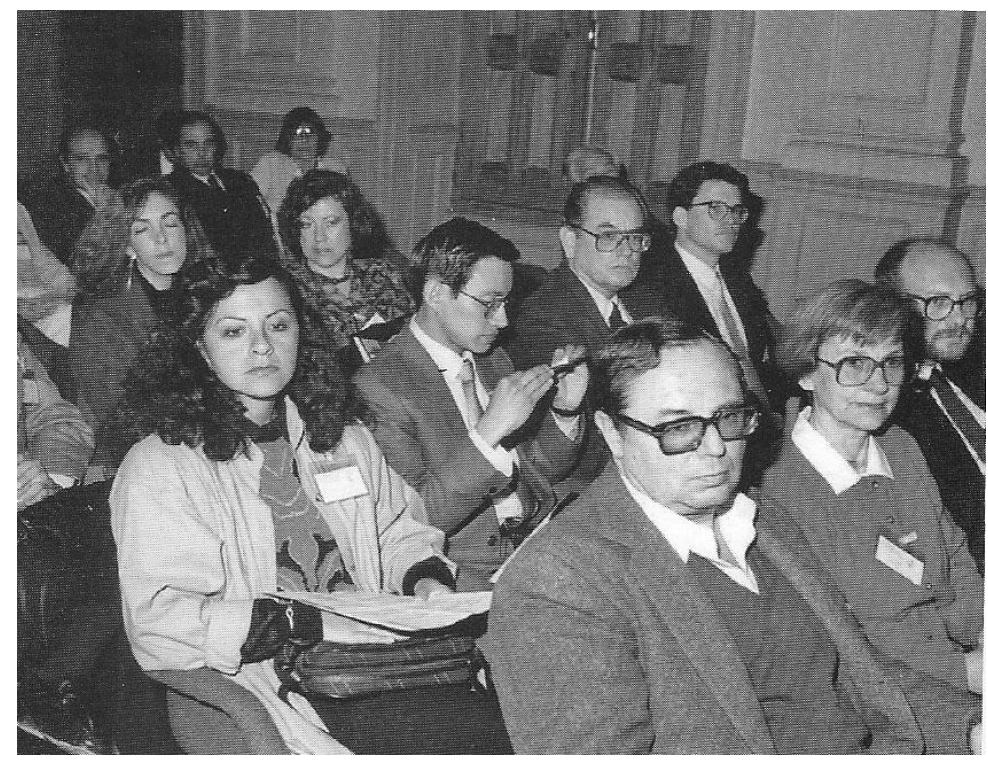

Figura 46: Ramón Gutiérrez, Lala Méndez Mosquera e Pedro Belaúnde no V SAL. Fonte: GUTIÉRREZ, R.; MÉNDEZ, P. (org). Seminario de Arquitetura Latinoamericana (SAL). Haciendo el Camino al andar 1985-2011. Buenos Aires: CEDODAL, 2011.

\section{Nós e pontos lassos}

Ainda que não fosse amplamente difundido e aplicado na prática do urbanismo corrente na América Latina, pensar a "cidade por partes" não era, certamente, uma proposta nova no início dos anos 1990. Décadas haviam permitido, por um lado, a ampla circulação - e assimilação - aos escritos de Rossi ${ }^{205}$ e Aymonino ${ }^{206}$ que teorizavam sobre este tema, assim como à ideia da Collage City proposta por Rowe ${ }^{207}$, que também conduzia à abordagem fragmentária da cidade. Estas referências, entre outras, serviram de base para a afirmação de uma prática do urbanismo por arquitetos que preteria a escala global e a abstração do plano, optando pelo desenvolvimento de peças urbanas arquitetonicamente definidas.

Na ocasião da organização do V SAL, diversos concursos internacionais haviam experimentado esta nova forma de pensar a cidade ${ }^{208}$ e muitos dos projetos urbanos já estavam concluídos ou em vias de conclusão - veja-se, entre outros: o IBA Berlim, as reconversões das áreas de docas de Londres e as de Amsterdã, os grandes projetos de

\footnotetext{
205 Referimo-nos aqui ao segundo capítulo de "L'architettura de la città" (1966) em que Aldo Rossi se dedica ao estudo da estrutura da cidade por partes - cf. ROSSI, A. L'Architecture de la Ville. Trad. Françoise Brun. Paris: InFolio, 2001.

${ }^{206}$ Ver, mais especificamente os capítulos "Arquitetura como fenômeno urbano" e "Partes da cidade e a dimensão arquitetônica" em: AYMONINO, Carlo. O significado das cidades. Lisboa: Editorial presença, 1984.

${ }^{207}$ ROWE, Colin ; KOETTER Fred. Collage City. Infolio editions, Paris, 2002.

${ }^{208}$ Citamos, somente a título de exemplo, o concurso de La Villete (Paris) em 1978, e Bicocca (Milão) em 1986.
} 
Mitterrand e os projetos urbanos de Barcelona, dentre os quais a Vila Olímpica estava em execução naquele momento ${ }^{209}$. Havia, portanto, um cenário de fundo denso de projetos, debates e proposições teóricas, de tal sorte que a proposição, ensejada por Aymonino em 1975, da abordagem da problemática da cidade por partes, ou seja, através de "novas intervenções pensadas e realizadas à escala arquitetônicas, [...voltadas] no entanto para a estrutura urbana no seu conjunto, modificando-a substancialmente" ${ }^{210}$ já contava, no início dos anos 1990, com diversos experimentos internacionais que interpretavam formas de concretizá-la.

No contexto regional, não se poderia deixar de incluir entre aqueles ensaios o concurso para "20 ideias para Buenos Aires", de 1986, que, inspirado no "Plano para as 50 ideias de Madri" de Eduardo Leira ${ }^{211}$ - e contando com a colaboração deste arquiteto através de um convênio de cooperação entre a Municipalidade de Buenos Aires e a Espanha, firmado no contexto das atividades preparatórias da comemoração do quinto centenário da chegada de Colombo à América -, solicitava propostas urbanoarquitetônicas para fragmentos da cidade, no caso, vazios urbanos no centro e na periferia $^{212}$. Para Gorelik este concurso não representa um fato isolado, mais sim uma peça chave ao longo de um percurso - cujos primeiros passos foram dados ainda sob o período ditatorial $\left.\right|^{213}$ - que se manifesta na transformação da cultura arquitetônica e urbana argentina no contexto da retomada da democracia e da crise econômica:

${ }^{209}$ Não caberia aqui fazer uma relação da bibliografia sobre o assunto, já amplamente estudado. A título de referência, no entanto, remetemos a abordagem panorâmica de: ORDEIG CORSINI, José María. Diseño Urbano y pensiamento contemporáneo. Barcelona: Instituto Monsa de Ediciones, 2004.

${ }^{210}$ AYMONINO, C. op. cit., 1984, p.136.

${ }^{211}$ Para compreensão das "50 ideias para Madri" e sua inserção contexto da cultura arquitetônica e urbanística espanhola dos anos 1980, ver: SAINZ GUTIÉRREZ, Victoriano. El proyecto urbano en España. Génesis y desarrollo de un urbanismo de los arquitectos. Sevilha: Universidad de Sevilla y Consejería de Obras Públicas y Transportes, 2006.

${ }^{212}$ Ao contrário do exemplo madrileno, cujo plano precedeu os projetos - cf. SAINZ GUTIÉRREZ, V. op. cit., 2006 -, no caso portenho não havia um plano por trás do concurso. O concurso para as 20 ideias foi organizado quando Dardo Cúneo e Alberto Varas ingressaram no Consejo de Planificación Urbana de la Municipalidad de Buenos Aires (CPU), um como presidente, o outro como conselheiro, respectivamente. Os números 119 e 120 da Summarios, de 1987, foram dedicados ao concurso das 20 ideias - cf. SPINADEL, Laura; BLAZICA, Claudio (org) 20 ideas para Buenos Aires - Summarios. Buenos Aires: Ed. Summa, n.119, nov 1987, e SPINADEL, Laura; BLAZICA, Claudio. 20 ideas para Buenos Aires II - Summarios. Buenos Aires: Ed. Summa, n.120, dez 1987. Ver também a respeito: JAJAMOVICH, Guilhermo, Arquitectos proyectistas y transición democrática. El concurso de las 20 ideas. In: Anales del IAA. Buenos Aires:FADU/UBA, n.41, 2011,p.203-212.

${ }^{213}$ Gorelik se refere aos trabalhos desenvolvidos junto a La Escuelita, sobre a qual discorreremos 
[Neste contexto,] o que se tornou fundamental era de ideia da "cidade por partes", que permitiu o despojamento em relação às ambições estruturais dos planos tradicionais: a nova visão da cidade, como um mosaico de diferentes situações, oferecia não apenas a perspectiva pluralista em termos de romper com ilusões totalizantes (leia-se: totalitárias) de modernização da cidade, mas também uma leitura realista na medida em que apoiou a execução de projetos pequenos e fragmentários ${ }^{214}$.

Este concurso e a agitação cultural que proporcionou no meio profissional argentino não eram, obviamente, ignorados pelos arquitetos do outro lado da cordilheira dos Andes. Mais além, este debate encontrava eco direto nas propostas que, historicamente, o grupo de arquitetos do CEDLA havia procurado colocar em pauta. Logo, não por acaso, se republicou, no número 10 da revista ARS, a introdução do artigo de reflexão sobre este concurso que Laura Spinadel e Claudio Blazica escreveram originalmente para a Summarios, no ano anterior ${ }^{215}$. Ao final do texto, afirmava-se o engajamento do corpo editorial da ARS em publicar com maiores detalhes os projetos selecionados pelo concurso na próxima edição $0^{216}$ - o que não acabou se efetivando.

O concurso das "20 ideias para Buenos Aires" e o interesse por seus resultados não demostra apenas o grau de enraizamento que a ideia da "cidade por partes" encontrava na cultura arquitetônica e urbanística do Cone Sul. Observa-se nesse, também, outro aspecto que parece crucial na convocatória do V SAL: a ideia do projeto como reflexão. Ao contrário das "50 ideias para Madri", as propostas desenvolvidas para a convocatória das "20 ideias para Buenos Aires" não contaram com um diagnóstico geral da cidade ${ }^{217}$. $\mathrm{O}$ ato de prescindir de uma diagnose, neste momento, não era gratuito, mas sim uma tomada de postura. Transparece em ambas as convocatórias - a do seminário de Santiago do Chile e a do concurso de Buenos Aires - a concepção de que o ato de projetar implica em si a existência de uma análise, ou uma investigação,

no capítulo 4.

214 GORELIK, Adrián. The Puerto Madero Competition and Urban Ideas in Buenos Aires in the 1980. In: LIERNUR, J. F. Puerto Madero Waterfront. Munique: Prestal Verlag, 2007, p.67

215 Referimo-nos ao artigo: SPINADEL, Laura; BLAZICA, Claudio. Reflexión crítica sobre las 20 ideas. In: Summarios. Buenos Aires: Ed. Summa, n.120, dez 1987, p.3-13. Publicado na ARS número 10 (de maio de 1988) sob o título "Concurso 20 ideas para Buenos Aires", p.75.

${ }^{216}$ Cf. "Concurso 20 ideas para Buenos Aires" In: ARS. Santiago do Chile: CEDLA, n.10, mai 1988, p.75

${ }^{217}$ Cf. GORELIK, Adrián. loc. cit., 2007. 
sobre a situação em que se intervém. Ressoava-se, portanto os debates dos arquitetos da Tendenza e o que postulavam Gregotti - em "Território da Arquitetura"218 - e Grassi em "A construção lógica da arquitetura": "Não se pode [...] falar de projeto sem falar das técnicas com as quais este se inicia, [...] sem falar de análise (na condição de dirigida ao conhecimento da matéria mesma do projeto) ${ }^{219 \prime \prime}$.

Logo, para o contexto do Cone Sul, a convocatória do V SAL não inovava nem na ideia de pensar a cidade latino-americana por partes, nem na proposição de que a reflexão se desse através de projetos. A novidade estava em propô-lo dentro do espaço dos Seminários Latino-Americanos de Arquitetura, os quais haviam se mantido até então um pouco à margem destes debates, visto que buscavam definir instrumentos próprios e apropriados ao contexto regional.

$O$ ato de definir novos parâmetros para apoiar o debate através da convocatória, contudo, seria completamente inócuo no seminário se não houvesse a adesão de arquitetos interessados em discutir a pauta proposta dentro dos moldes estabelecidos. Em um primeiro - e genérico - olhar os números nos revelaram que não apenas o evento conseguiu atrair apresentações de projetos e de textos, como o número destas ultrapassou aquele dos verificado nos seminários anteriores. Ao aproximarmos a lente do tecido urdido no evento, entretanto, revelam-se diversos pontos distendidos.

Deve-se lembrar que o evento propunha como seu foco principal a elaboração de projetos sob um enquadramento de situações urbanas específicas. Este é o primeiro lapso que se revela entre a convocatória e o programa do seminário: observa-se, neste segundo, peso equivalente entre apresentações de textos e projetos, o que não estava previsto naquela primeira. Malgrado o fato de em seus anais terem sido incluídos 18 textos e 26 projetos, no programa constam 30 apresentações teóricas e 32 exposições de intervenções urbanas. Para cada um destes aspectos do evento se destinam espaços temporais semelhantes: três manhãs para as reflexões teóricas e três tardes para aquelas que se apoiavam na prática. Em ambos os casos, foi necessário realizar duas seções simultâneas devido à quantidade de propostas recebidas ${ }^{220}$. Na organização e

\footnotetext{
${ }^{218}$ GREGOTTI, Vittorio. Território da Arquitetura. São Paulo: Perspectiva, 2001.

${ }^{219}$ GRASSI, Giorgio. La construcción lógica de la arquitectura. Barcelona: Colegio Oficial de Arquitectos de Cataluña y Baleares 1973.

${ }^{220}$ Cf. BOZA, C. et al. (org.) Instrucciones generales a los participantes. In: BOZA et al. (org).
} 
distribuição das apresentações não se buscou definir temáticas transversais que permitissem a leitura conjunta de textos e projetos: tratados como entidades distintas, estes últimos foram agrupados por país, enquanto os primeiros foram agrupados por proximidades não explicitadas no programa que apenas os identificava genericamente como "Bloco A" e "Bloco B"221.

Textos e projetos obedecem, obviamente, a lógicas distintas; não podem, portanto, ser analisados sob os mesmos aspectos. Se, por um lado, é possível, de modo geral, analisar os projetos a partir de seu enquadramento das situações urbanas propostas pela convocatória - com raras exceções ${ }^{222}$, ver Apêndice C -; por outro, o mesmo não ocorre com os textos. Ao contrário do que ocorrera nos seminários anteriores, no evento do V SAL a maior parte dos textos incluídos nos anais não tratou de reflexões a partir situações urbanas específicas: somente três textos abordavam a questão dos centros históricos - seja de forma abstrata ou a partir de casos concretos ${ }^{223}$ -; nenhum tratou especificamente da periferia marginal ou de qualquer outra das partes da cidade propostas para o debate.

Soma-se a este quadro o fato que em sete dos dezoito artigos publicados a temática geral do evento não consta ou, se abordada, aparece de forma marginal como

Seminario de Arquitectura Latinoamericana. Nuestro Espacio Urbano: Propuestas Morfológicas. V, 1991. Santiago do Chile. Anais... Santiago do Chile: s.n. 1991.

${ }^{221}$ Os temas por trás dos agrupamentos não são claros, pois coexistem abordagens muito distintas em um mesmo "bloco", e nem mesmo verificáveis - levando-se em consideração de 12 dos 30 textos listados não constam nos anais.

222 Dentre os projetos previstos para apresentação no V SAL, apenas 3 não se enquadravam em nenhuma das situações urbanas específicas propostas pela convocatória. Duas delas extrapolavam a ideia da cidade por partes e abrangiam a sua totalidade: as ordenanças para o parcelamento e a ocupação do solo de Córdoba e a renovação de Caracas através do metrô (projeto de Max Pedemonte que recebeu, aliás, grande fortuna no período - cf. PEDEMONTE, Max. Venezuela Caracas. Una Ciudad Recobrada. In: CA. Santiago de Chile: Colegio de Arquitectos, n. 58, out/dez 1989, p.36-43; PEDEMONTE, Max. Caracas: la ciudad y el metro. In: PROA. Bogotá: Ed. Proa, n.422, jun 1995, p.16-22). Outra intervenção destinava-se apenas ao redesenho de uma praça em área verticalizada de Caracas, junto à UCV - ver Apêndice C.

${ }^{223}$ Inserem-se neste enquadramento temático: o estudo tipológico de quarteirões residenciais de Santiago Poniente, de autoria de Patricia Valenzuela (Chile); as reflexões sobre as formas de intervenção nos centros históricos latino-americanos, de Pedro Villa-Córdova (Peru); a avaliação dos efeitos do projeto de proteção e conservação do bairro histórico Barranco em Lima, de autoria de Jorge Balerdi (Peru). Cf. VALENZUELA, Patricia. Estudio tipológico de la manzana. Bloque de viviendas en Santiago de Chile. In: BOZA et al. (org) op. cit, 1991. VILLAR-CORDOVA, Pedro. En torno de los Cascos Históricos: una aproximación morfológica. In: BOZA et al. (org) op. cit, 1991. BALERDI A., Jorge. Proyecto Barranco: la transformación morfológica de un barrio histórico. In: BOZA et al. (org) op. cit, 1991. 
uma breve menção à especificidade da cidade latino-americana; enfocam-se apenas aspectos arquitetônicos e/ou os diálogos que estes estabelecem com as questões relativas à identidade e ao regionalismo. Trata-se de textos que, em sua maioria, buscam dar continuidade a debates iniciados em seminários anteriores. Ao contrário do que se poderia imaginar a partir do que se percebeu no seminário de Tlaxcala, não se trata de uma postura assumida apenas por iniciantes que buscavam se inserir no debate que acompanhavam através de publicações diversas. Curiosamente, dentre os supracitados textos, quatro são de autoria de arquitetos argentinos que eram habitués do debate: Alberto Petrina, Rafael Iglesia, Adriana Irigoyen e Maria Isabel Larrañaga. Seja por confusão em relação à convocatória, seja por uma demarcação de postura frente àquela, na condição de responsável pela seleção das apresentações teóricas da Argentina, Alberto Petrina introduzia o conjunto de textos que representava este país afirmando que se destinavam à seção de "Teoria, História e Crítica de Arquitetura do V SAL"224, inexistente no evento de Santiago do Chile.

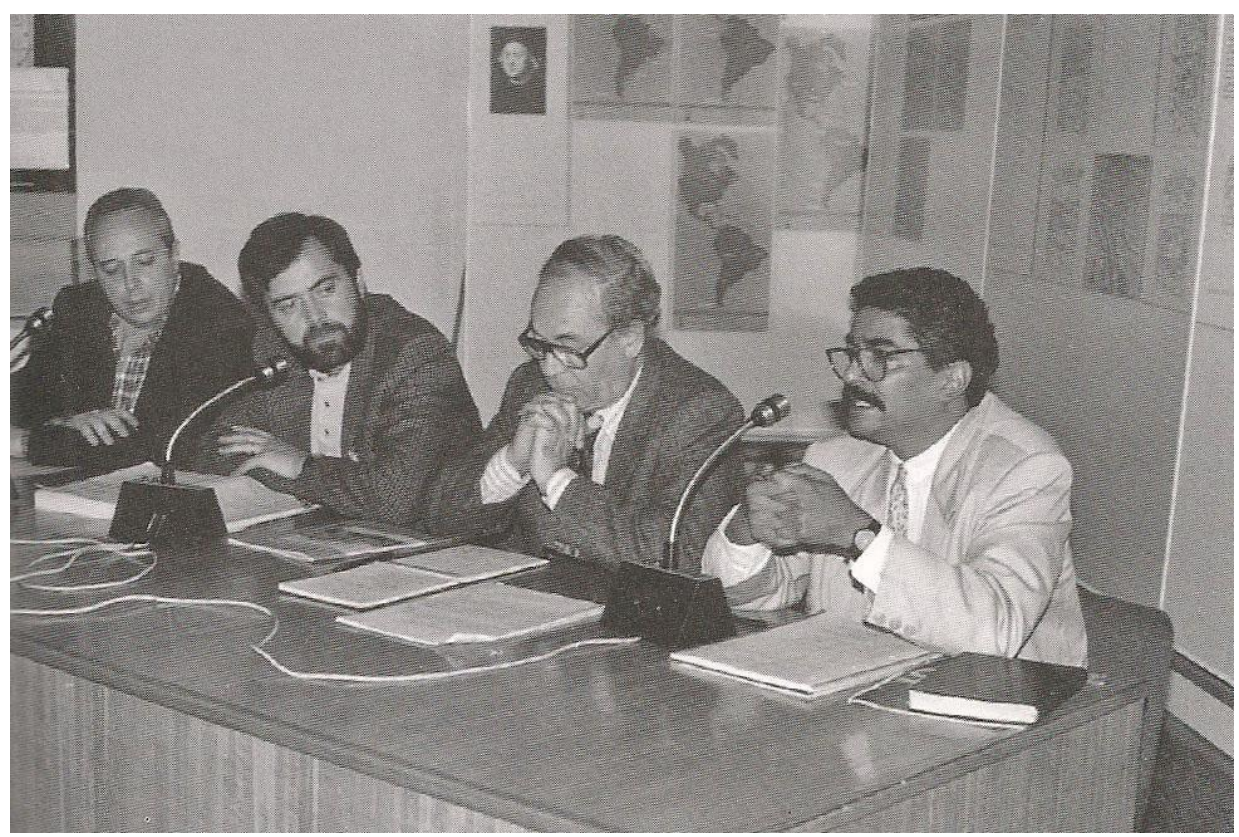

Figura 47: Alberto Petrina, Manuel Moreno, Pedro Murtinho e Edward Rojas em mesa de apresentação de trabalhos no V SAL. Fonte: GUTIÉRREZ, R.; MÉNDEZ, P. (org). Seminario de Arquitetura Latinoamericana (SAL). Haciendo el Camino al andar 1985-2011. Buenos Aires: CEDODAL, 2011.

Se, por um lado, uns buscam dar continuidade a debates que marcaram os seminários anteriores; outros - ainda que abraçando o enfoque urbano do evento procuraram avançar sobre novos temas, cujas primeiras reflexões começavam a

${ }^{224}$ PETRINA, Alberto. Introducción a una continuidad. In: BOZA et al. (org) op. cit, 1991, p.1. 
despontar naquele momento: a urbanização difusa e a privatização dos espaços urbanos de uso coletivo. Esta foi a orientação da exposição de Marina Waisman e daquelas de dois arquitetos que pela primeira vez apresentavam contribuições orais em um SAL, Francisco Liernur e Alberto Sato.

Marina Waisman, desenvolvendo inquietações que já transpareciam em sua apresentação em Tlaxcala - quando abordou a questão da dispersão através da caracterização do crescimento centrífugo 225 - e que culminariam em seu livro "La Arquitectura Descentrada" de $1995^{226}$, enfatizou, nesta nova ocasião, o fenômeno mundial da privatização dos espaços coletivos, analisando os aspectos relativos à modificação da vida urbana e do significado dos espaços coletivos tradicionais a partir da avaliação da implantação de dois Shoppings Center em Córdoba, Argentina ${ }^{227}$. A progressiva substituição do papel que era exercido pelos espaços públicos urbanos por espaços privados uni-significativos e unidirecionais - visto que são voltados ao consumo - representaria, para Waisman, uma das etapas para a "desurbanização, último extremo da descentralização, [que] conduz também à perda da sociabilização e da liberdade"228. A urbanização difusa como fenômeno das metrópoles mundiais também seria objeto do artigo apresentado por Liernur, quem, partindo da observação de que, desde a década de 1970, as "metrópoles europeias foram adquirindo traços das grandes concentrações latino-americanas [...tornando] difícil detectar particularidades regionais do fenômeno"229, procurou diferenciar as situações através das urgências das sociedades nas quais estas urbanizações se inserem ${ }^{230}$.

Alberto Sato, por outro lado, partiu da análise da inserção dos Shoppings Centers e das grandes torres de escritórios no tecido urbano caótico de Caracas. Apesar de reconhecer estes tipos edilícios como fenômeno internacional, para Sato sua inserção

\footnotetext{
${ }^{225}$ WAISMAN, M. La Recuperación de la Sociedad Urbana. La recuperación y renovación de la ciudad histórica. In: IV Encuentro de Arquitectura Latinoamericana/ México. "La Trindad", Tlaxcala. IV, Anais...México: Universidad Autónoma Metropolitana, 1989.

226 Vejam-se mais especifcamente os capítulos: "Descentramientos, fragmentaciones, marginalidades" e "La crisis: apocalípticos o integrados". Inclusive, as reflexões apresentadas por Marina Waisman no V SAL integram o primeiro capítulo supracitado. Cf. WAISMAN, M. La arquitectura Decentrada. Bogotá: Escala, 1995.

${ }^{227}$ WAISMAN, M. Espacio público - Espacio privado. In: In: BOZA et al. (org) op. cit, 1991.

${ }^{228}$ WAISMAN, M. loc. cit. 1991.

229 LIERNUR, Jorge Francisco. Requién para la plaza y la fábrica: notas sobre la metrópolis contemporánea en América Latina. In: BOZA et al. (org) op. cit, 1991, p.1.

${ }^{230}$ LIERNUR, Jorge Francisco. loc. cit, 1991
} 
no contexto venezuelano nega a cidade, visa substituí-la, sem chegar a constituir "uma cidade dentro da cidade, como ocorre na metrópole norte-americana” ${ }^{231}$ - uma clara referência do autor venezuelano ao livro Delirious New York de Koolhaas ${ }^{232}$.

Outros textos, apesar de demonstrarem conhecimento da convocatória, desenvolvem certas críticas ou restrições a aspectos desta. Neste contexto insere-se a contribuição de Villar-Cordova que aponta suas restrições ao difundido emprego de estudos tipológicos em projetos para centros históricos, defendendo leituras urbanas perceptivas e cognitivas ${ }^{233}$, tal qual a proposta por Lynch, em “A imagem da Cidade"234. Outra crítica viria de Cesar Naselli quem, anos antes, havia não apenas se envolvido no a tipo-morfologia como, também, desenvolvido exercícios que buscavam traduzi-lo ao contexto local ${ }^{235}$. Familiarizado com a questão, o arquiteto argentino alertava em sua apresentação para o aspecto restritivo e superficial das situações urbanas definidas e para os riscos do papel de destaque dado à morfologia urbana:

A suposição de um papel preponderante da forma urbana, tanto no deterioramento da qualidade de vida de nossas cidades, quanto como base primordial para a solução de suas consequências sociais, pode conter uma perigosa simplificação da questão proposta para este Encontro, a ponto de esterilizar suas contribuições prática ${ }^{236}$.

Em suma, os textos publicados nos permitem perceber que o debate sobre a tipo-morfologia, ao contrário do que se poderia imaginar, não era novidade para muitos dos arquitetos que apresentaram no evento. Contudo, a despeito do fato de que oito dos dezoito artigos publicados terem desenvolvido reflexões sobre aspectos tipomorfológicos junto a seu tema principal - seja utilizando seu vocabulário para o desenvolvimento da estrutura argumentativa ou criticando esta abordagem, ver Apêndice $\mathrm{C}-$, observa-se que, ao final, a convocatória mostrou-se pouco operativa nas

\footnotetext{
${ }^{231}$ SATO, Albero. Caos y Utopia em Caracas Moderna. In: BOZA et al. (org) op. cit, 1991, p.9.

${ }^{232}$ Neste livro, publicado originalmente em 1978, Koolhaas define o arranha-céu de New York como uma "cidade dentro da cidade" - Cf. KOOLHAAS, R. Delírio de Nueva York. Barcelona: Gustavo Gili, 2004.

${ }^{233}$ VILLAR-CORDOVA, Pedro. loc. cit., 1991.

${ }^{234}$ LYNCH, Kevin. A Imagem da Cidade. Edições 70, Lisboa, Portugal, 1982.

235 Cf. NASELLI, César. La tipología como instrumento proyectual. In: Summarios. Buenos Aires: Ed. Summa, fev/mar 1985, p.22-34.

${ }^{236}$ NASELLI, César. La forma urbana de nuestras ciudades. In: BOZA et al. (org) op. cit, 1991, p.1.
} 
exposições teóricas. De modo geral, esta falhou, sobretudo, em buscar tecer debates que acabaram não sendo abordados no evento ou que seguiram outros rumos.

Os pontos distensos que se observam no conjunto de textos apresentados não se verificam com a mesma intensidade quando se analisam os projetos expostos no $\mathrm{V}$ SAL. De fato, neste componente do evento, as definições da convocatória parecem ter sido mais efetivas. Ainda que nem todos os projetos tenham seguido por completo os parâmetros indicados por aquela, observa-se que houve, de modo geral, uma adequação à proposta do evento. Entre os vinte e oito projetos publicados, apenas dois não se enquadravam nas quatro situações urbanas estabelecidas: um por não abordar apenas uma parte da cidade, mas sim sua totalidade ${ }^{237}$; outro por restringir-se ao projeto de uma praça inscrita em área verticalizada e com complexidade não prevista pela convocatória ${ }^{238}$. De forma semelhante, aspectos relativos à tipo-morfologia transpareciam na maioria dos projetos publicados - vinte e um no total - seja através do simples emprego de vocábulos relacionados a este debate ou, até mesmo, por meio de leituras meticulosas e ensaios de tipificação. O requisito de que os projetos se destinassem a cidades com mais de um milhão de habitantes também foi respeitado por quase todas as propostas enviadas, exceto em quatro: duas que se voltavam a povoados $^{239}$ e outras duas que se inseriam em cidades menores que o piso estipulado na ocasião ${ }^{240}$

O escrutínio do total das contribuições publicadas e aquelas cuja apresentação estava prevista no programa ${ }^{241}$ revela que entre os países que estiveram representados por habitués desde os primeiros seminários - Argentina, Brasil, Chile, Colômbia e Peru ${ }^{242}$ -, ou entre aqueles que sediaram algum dos anteriores - soma-se, no caso, o México -,

${ }^{237}$ Referimo-nos à revisão das normas de parcelamento e ocupação de Córdoba (Argentina), realizada pela Municipalidade de Córdoba em 1985 - ver Apêndice C.

${ }^{238}$ Trata-se do projeto da "Praça Venezuela" junto à UCV, que busca articular e compatibilizar diferentes tipos de transportes. desenvolvido por Domenico Silvestro, Sansone, Lobato, Mariani, Vera e Ojeda - ver Apêndice C.

239 Trata-se de duas propostas que representavam a Argentina no evento, uma tratava de pequenos povoados históricos na província de Buenos Aires e outra abordava situação análoga na província de Córdoba.

${ }^{240}$ Referimo-nos aqui às propostas para Willemstad (Curaçao), que possuía menos de 100 mil habitantes em 1991 e para San José da Costa Rica, que, na ocasião, ainda não contava com 1 milhão de habitantes - ver apêndice $C$.

${ }^{241}$ Ver Apêndice B - "Registro de Apresentações no V SAL".

${ }^{242}$ Ver Apêndice B: “Personagens assíduas nos SAL entre 1985 e 1995" e "Total de apresentações por país entre 1985 e 1995". 
houve a preocupação em apresentar, pelo menos, projetos que abarcassem aquelas partes da cidade que polarizaram os debates anteriores, ou seja: o centro histórico - ou a cidade antiga - e para a periferia urbana. Para os demais países - sejam aqueles que se juntavam pela primeira vez aos seminários, ou aqueles cujas contribuições anteriores nos SAL haviam sido intermitentes e sem continuidade de personagens entre os seminários $^{243}$ - esta aparente regra de apresentar propostas para os dois polos da cidade não foi seguido.

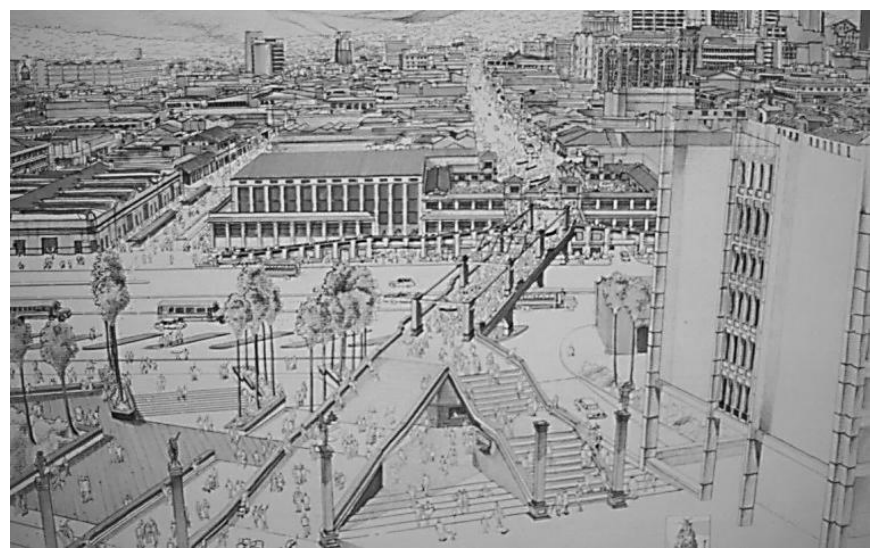

Figura 48: Sequencia de espaços públicos no setor Guayaquil do centro histórico Medellín, proposta de Ramiro Henao V., apresentada no V SAL. Fonte: Acervo pessoal de Humberto Eliash.

As entrevistas realizadas com os responsáveis pelas escolhas dos projetos que representaram a Argentina, o Brasil e a Colômbia - Jorge Moscato ${ }^{244}$, Carlos Eduardo Comas $^{245}$ e Silvia Arango ${ }^{246}$, respectivamente - confirmam a existência de um padrão subjacente entre aqueles países que sempre participaram dos SAL. Os discursos dos entrevistados revelam que houve uma atenção cuidadosa na definição das propostas a serem apresentadas, procurando compreender como estas se encaixavam nas situações urbanas definidas do evento e quais questões que levantavam. Moscato, ao listar os projetos que escolhera, chegou a afirmar que nesta seleção "havia uma relação direta entre a obra que se produz e a teoria urbana [que se construía junto aos SAL]"247.

\footnotetext{
${ }^{243}$ Conferir no Apêndice B: "Personagens assíduas nos SAL entre 1985 e 1995" e "Total de apresentações por país entre 1985 e 1995".

${ }^{244}$ Moscato não foi responsável definição da totalidade dos projetos apresentados, mas sim por todos aqueles de Buenos Aires, que constituem 6 do total de previstos e/ou publicados nos anais do evento - cf. MOSCATO, Jorge. Depoimento. [25 de agosto de 2011]. Buenos Aires: Arquivo digital da gravação (2horas e 25min.). Entrevista concedida a Gisela Barcellos de Souza. Os projetos da região de Córdoba foram escolhidos e apresentados por César Naselli.

${ }^{245}$ COMAS, Carlos Eduardo Dias. Depoimento. [01 de abril de 2011]. Porto Alegre: Arquivo digital da gravação (4horas e 37min.). Entrevista concedida a Gisela Barcellos de Souza.

${ }^{246}$ ARANGO, Silvia. Depoimento. [11 de novembro de 2011]. Campinas: Arquivo digital da gravação (1hora e 11min.). Entrevista concedida a Gisela Barcellos de Souza.

${ }^{247}$ MOSCATO, Jorge. Depoimento. [25 de agosto de 2011], loc. cit. Moscato sempre defendeu a
} 
Arango, por outro lado, escolheu três projetos que tinham em comum a proposição de sequências de espaços públicos e indica que chegou a realizar uma pequena investigação sobre estas propostas: buscou conhecer pessoalmente os arquitetos responsáveis, recolheu e organizou as informações sobre os projetos e visitou as obras da única proposta cuja execução havia sido iniciada ${ }^{248}$. A fim de representar o Brasil no evento, Comas levou um projeto para a periferia que representava a orientação dos trabalhos que vinha desenvolvendo junto ao PROPAR e convidou Álvaro Hardy para apresentar o projeto que desenvolvera para o concurso para o centro de Belo Horizonte $^{249}$.

Portanto, não por acaso, entre estes países que estiveram representados por habitués em todos os seminários anteriores ao de Santiago, as situações intermediárias entre o centro histórico e a periferia foram pouco exploradas. Entre esses países apenas duas propostas que se enquadravam em tecidos urbanos situados entre o centro e a periferia marginal: a Colômbia apresentou uma alternativa de normativa para um setor de Ciudad Salitre ${ }^{250}$ que conformava um tecido urbano de altura edilícia mediana; e o Chile foi representado pelo projeto de Nueva Providencia que transformava a estrutura urbana de uma comuna constituída por loteamentos jardins.

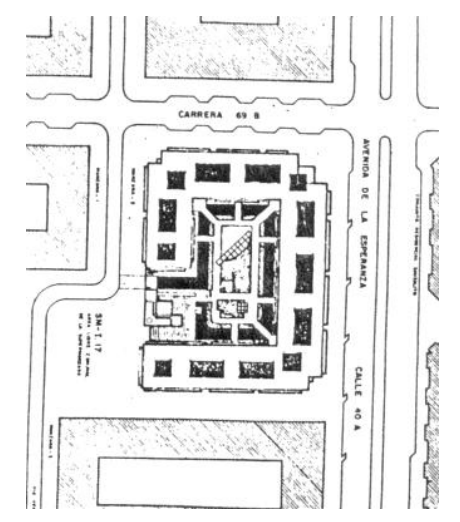

Figura 49: Detalhe de quarteirão que sintetiza a proposta de revisão de normativas em Ciudad Salitre elaborada por Sérgio Trujillo Jaramillo e Juan Manuel Gutierrez Alvarez. BOZA et al. (org). Seminario de Arquitectura Latinoamericana. Nuestro Espacio Urbano: Propuestas Morfológicas. V, 1991. Santiago do Chile. Anais... Santiago do Chile: s.n. 1991

ideia de que os SAL constituíram uma teoria urbana entre os eventos de Manizales e de Santiago - cf. MOSCATO, J. Gli Architetti in America Latina. In: GUTIÉRREZ, Ramón (org). Architettura e Società. L'América Latina nel XX secolo. Milão: Jaca Book, 1996.

${ }^{248}$ Referimo-nos aqui ao projeto "Gérmenes de la Ciudad" o único dos projetos apresentados cuja execução havia sido iniciada. Cf. ARANGO, Silvia. Depoimento. [11 de novembro de 2011], loc. cit.

${ }^{249}$ COMAS, Carlos Eduardo Dias. Depoimento. [01 de abril de 2011], loc. cit. A respeito do concurso para o centro de Belo Horizonte, ver a reportagem: MARINHO, Gabriela. Propostas em convergência: BH Centro. In: AU, São Paulo: Pini, n. 28, jan/fev 1990, p. 75-85.

${ }^{250}$ Ciudad Salitre, em Bogotá, era, segundo Arango, uma urbanização à la CIAM, com torres isoladas nos terrenos. - cf. ARANGO, Silvia. Depoimento. [11 de novembro de 2011], loc. cit. 
Todos os países participantes, no entanto, apresentaram projetos para centros históricos. De fato, as propostas para esta parte da cidade representam a maior parte do que foi publicado nos anais: dezoito sobre o total de vinte e oito projetos. Certamente, tais números não são apenas uma coincidência de interesses; eles testemunham que, ainda no início dos anos 1990, o vocabulário referente à tipo-morfologia estava associado às intervenções em centros históricos e em áreas de interesse patrimonial ${ }^{251}$. Entre os projetos publicados que se destinavam a esta situação urbana, treze apresentavam algum nível de preocupação com o patrimônio arquitetônico-urbano; seja através da definição de princípios para restauração e reabilitação, seja através de normas edilícias que procuravam articular tecidos do século XVIII e XIX às novas intervenções - ver Apêndice C.

Outro fato digno de nota é que, neste momento, aqueles que fomentaram o debate sobre a periferia urbana em Manizales ou apresentaram projetos que se destinavam para o centro histórico, ou, simplesmente, não expuseram projeto algum. 0 primeiro caso não é apenas o de Eliash que, junto com parte da comissão organizadora, desenvolvera a proposta de revisão de normas para Santiago Poniente. Inserem-se, também, nesta circunstância os sócios Moscato e Schere que, neste momento, estavam envolvidos com cargos de administração pública ${ }^{252}$ e, sob esta condição, desenvolviam propostas de significativa importância para o centro de Buenos Aires que foram levadas para discussão no V SAL: o projeto de Puerto Madero - em sua primeira versão, ou seja, aquela desenvolvida com a consultoria dos espanhóis Joan Busquets, Jordi Borja e Joan Alemagni $^{253}$ - e o Programa de Revitalização da Avenida de Mayo (PRAM), cuja

\footnotetext{
${ }^{251}$ Esta questão será mais bem desenvolvida no capítulo 4.

252 Durante o período em que o peronista Carlos Grosso foi prefeito de Buenos Aires, ou seja, entre 1989 e 1992, Moscato e Schere assumiram cargos junto à municipalidade. Moscato foi entre 1989 e 1992 conselheiro de planejamento urbano na Secretaría de Planeamiento do município de Buenos Aires e participa, neste momento, do desenvolvimento do projeto de Puerto Madero. Rolando Schere, por outro lado, assumiu entre 1991 e 1993 o cargo de gerente de projetos do Programa de Revitalização da Avenida de Mayo. cf. MOSCATO, J; SCHERE, R. Arquitectura e ideología. México: Menhir Libros. 2000.

${ }^{253}$ Salienta-se o fato de já havia sido lançado, em junho de 1991, o concurso elaborado pela Sociedad Central de Arquitetos (SCA) e pela administração municipal como resposta à polêmica gerada entre o meio profissional após a apresentação do "Plan Estratégico Antiguo Puerto Madero" em julho de 1990 - cf. GOLERIK, A. loc. cit., 2007. Ou seja, o projeto apresentado no V SAL não encontrava amplo apoio entre os arquitetos argentinos neste momento. Para maiores informações sobre o Puerto Madero ver: LIERNUR, J. F. (org). Puerto Madero Waterfront. Munique: Prestal Verlag, 2007; bem como LIERNUR, J. F. Buenos Aires e seu rio: de porto de barro ao bairro globalizado. Arquitextos, São Paulo, 54.03, nov. $2004 .<$
} 
viabilização se deu através de convênio entre a municipalidade de Buenos Aires e a Sociedad Quinto Centenario da Espanha ${ }^{254}$. A despeito da grande fortuna crítica que o projeto para o Puerto Madeiro obteria nos anos subsequentes, na ocasião do V SAL o PRAM - que se inseria entre as atividades comemorativas do quinto centenário da chegada de Colombo à América ${ }^{255}$ - parece ter despertado maior interesse, tendo sido a única das propostas para os centros históricos a ser destacada pela crônica publicada em El Mercúrio ${ }^{256}$.

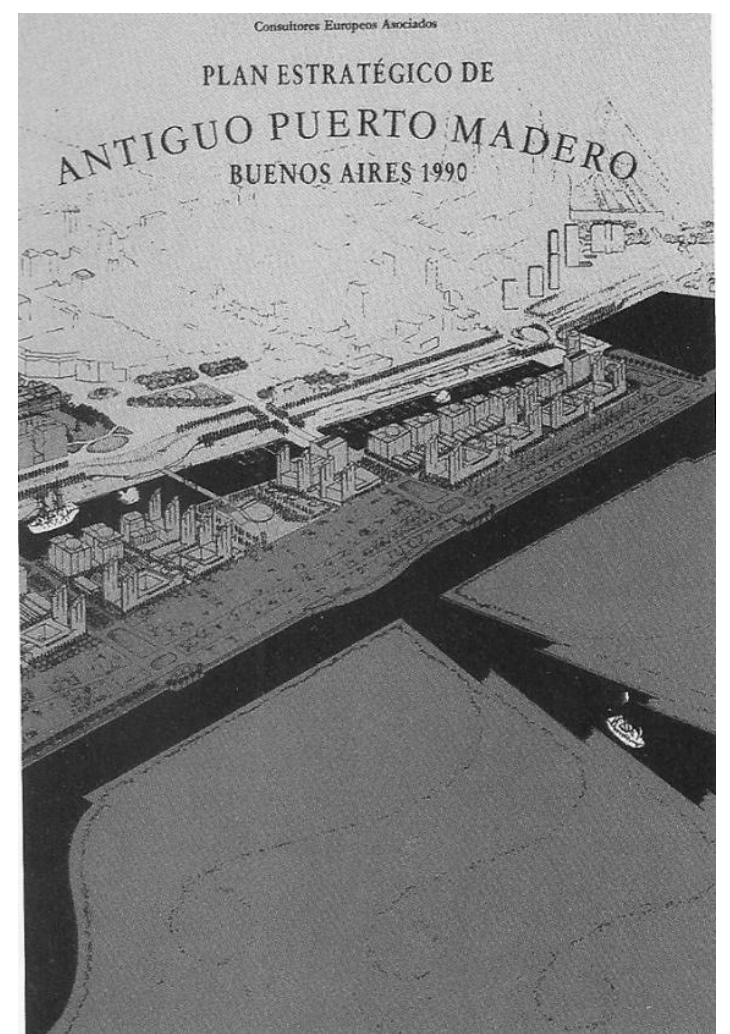

Figura 50: Plano Estratégico para o Antigo Porto Madero, concluído em 1990, com a consultoria de Joan Busquets, Jordi Borja e Joan Alemagni e apresentado em 1991 no V SAL. Fonte: LIERNUR, J. F. (org). Puerto Madero Waterfront. Munique: Prestal Verlag, 2007.

Se, por um lado, aqueles que, em Manizales, haviam levantado a necessidade de refletir sobre a arquitetura da periferia assumiam agora outros rumos, por outro, este

http://www.vitruvius.com.br/revistas/read/arquitextos/05.054/526/pt> Acesso em: 10 de jun. 2012.

254 Através desta cooperação criou-se um escritório municipal que foi responsável pela intermediação entre os diversos agentes interessados - proprietários, habitantes, agentes imobiliários - a fim de promover novos investimentos na área e a recuperação da avenida que se encontrava em processo de degradação. Segundo Garay, "em três anos este programa conseguiu alcançar a renovação de vinte e cinco edifícios e quarenta e cinco intervenções no pavimento térreo" - GARAY, Alfredo. On the Administration of Urban Projects: The lessons of Puerto Madero. In: LIERNUR, J. F. (org). Puerto Madero Waterfront. Munique: Prestal Verlag, 2007, p.82.

${ }^{255}$ GARAY, Alfredo. loc. cit., 1991.

${ }^{256}$ MONTERO WARD, Beatriz. Propuestas Concretas para la Ciudad. El Mercúrio, Santiago do Chile, Vivienda y Decoración p. 6, 12 de out. de 1991, p.6 
tema continuou a motivar interessados; este congregou o segundo maior número de projetos - um total de sete projetos apresentados, dos quais cinco foram publicados ${ }^{257}$. Entre os projetos apresentados, dois transformavam grandes glebas periféricas - uma sede de antiga fábrica e outra de propriedade uma sociedade de transporte urbano em bairros de uso mistos, porém com propostas morfológicas distintas: o projeto para a antiga sede da SNIAFA ${ }^{258}$, entre Buenos Aires e La Plata, e a proposta para a gleba SOPAL, no bairro Parque dos Maias, em Porto Alegre ${ }^{259}$. O primeiro fora desenvolvido pela direção de obras da província de Buenos Aires e, para além de promover a reciclagem de alguns edifícios, buscava, também, recuperar a quadrícula nos tecidos residenciais novos, como forma de se assemelhar à forma urbana da repetição, típica das cidades coloniais hispano-americanas. O segundo projeto, desenvolvido por Comas junto ao PROPAR/UFRGS ${ }^{260}$, assumia o desafio oposto: o de se destacar figurativamente em relação ao entorno. Inserido em uma área em processo de consolidação ${ }^{261}$, no novo bairro proposto utilizavam-se tipos edilícios inexistentes no tecido do entorno - edifícios com implantação em "redents", "em U", que definiam os novos espaços públicos, sem delimitá-los por completo - como forma de garantir sua identidade morfológica em face do tecido existente. Apesar de Comas ter afirmado que o projeto apresentado não despertou muito interesse no $\mathrm{VSAL}^{262}$, esta proposta para o Parque dos Maias foi uma das três destacadas pela reportagem de El Mercúrio sobre o evento ${ }^{263}$.

\footnotetext{
${ }^{257}$ Ver Apêndice C.

${ }^{258}$ Projeto publicado nos anais - cf. BOZA et al. (org) op. cit, 1991.

${ }^{259}$ Este projeto não foi publicado nos anais, porém há menções a respeito dele em: IRIGOYEN, Adriana. V SAL, Santiago, Chile Passado, Presente e Futuro. In: AU. São Paulo: Pini, n.39, dez/jan 1992, p.20-21; bem como em MONTERO WARD, Beatriz. loc. cit., 1991, p.6

${ }^{260}$ Participaram também da equipe de desenvolvimento deste projeto: Glenio Boher, Marta Peixoto e Roni Anzolch. Cf. COMAS, C. E. et al. Uma superquadra periférica de Porto Alegre. Relatório de estudo de desenho urbano. [memorial do projeto apresentado no V SAL]. Porto Alegre: s.n., 1991.

${ }^{261}$ A gleba SOPAL encontrava-se junto a invasões regularizadas, loteamentos de classe média baixa e área industrial. Cf. COMAS, C. E. et al, loc. cit.,1991.

${ }^{262}$ COMAS, Carlos Eduardo Dias. Depoimento. [01 de abril de 2011]. loc. cit.

${ }^{263}$ Cf. MONTERO WARD, Beatriz. Propuestas Concretas para la Ciudad. El Mercúrio, Santiago do Chile, Vivienda y Decoración p. 6, 12 de out. de 1991, p.6.
} 


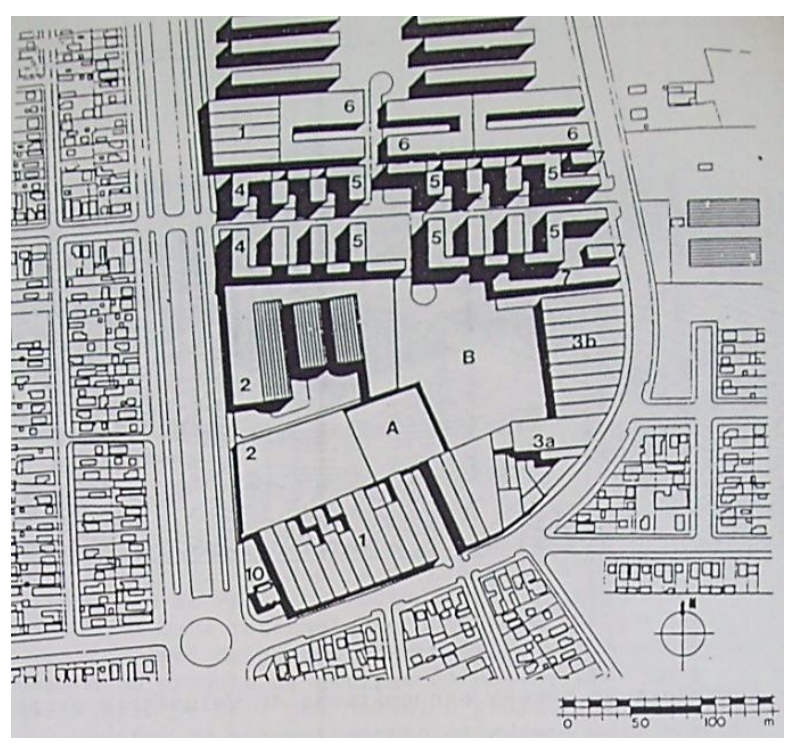

Figura 51: Projeto para a Gleba SOPAL no Parque dos Maias, Porto Alegre, desenvolvido junto ao PROPAR e apresentado por Comas no V SAL. COMAS, C. E. et al. Uma superquadra periférica de Porto Alegre. Relatório de estudo de desenho urbano. [memorial do projeto apresentado no V SAL]. Porto Alegre: s.n., 1991.

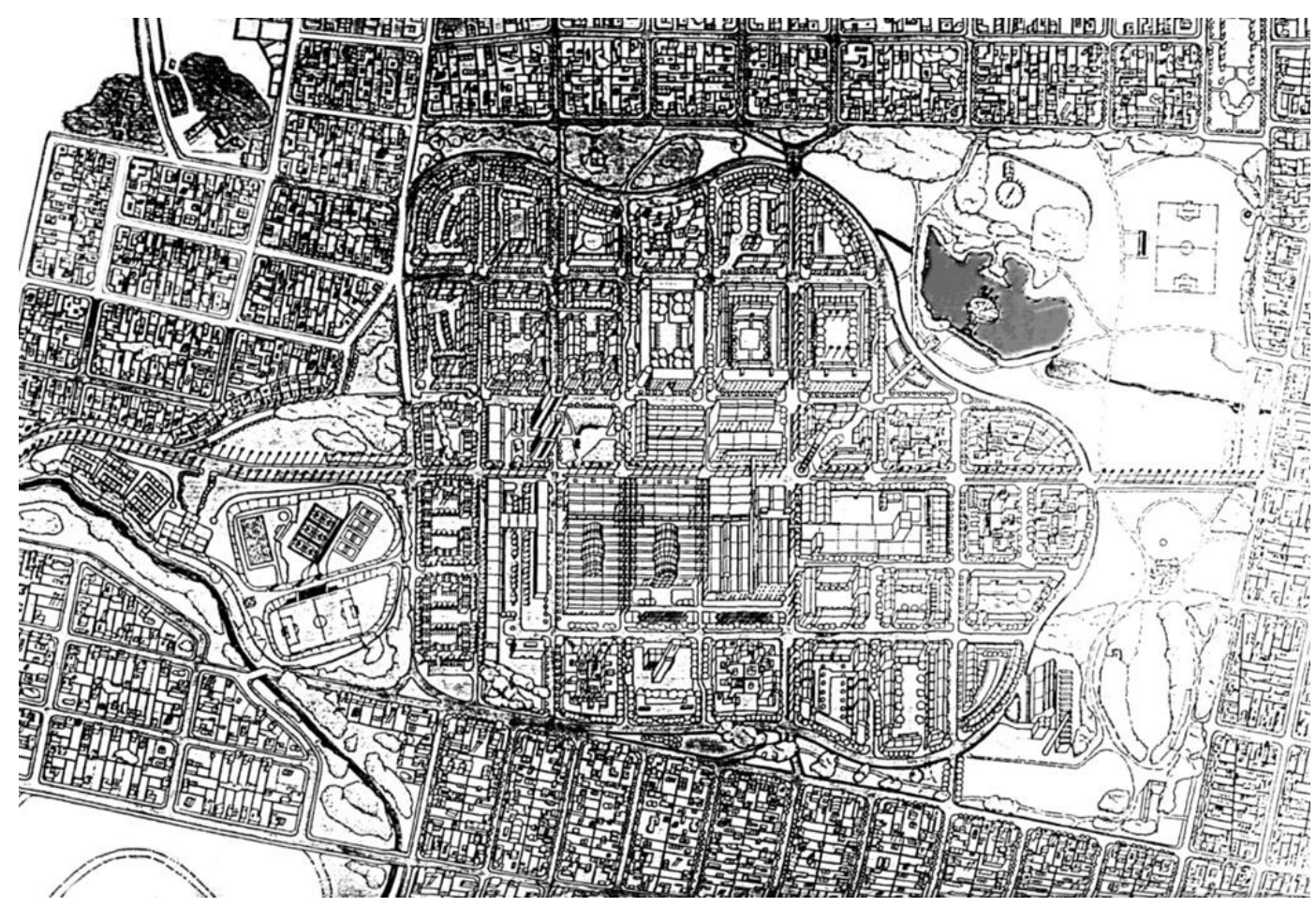

Figura 52: Projeto SINAFA desenvolvido pela Província de Buenos Aires e coordenado por Carlos A Dodero. Fonte: BOZA et al. (org). Seminario de Arquitectura Latinoamericana. Nuestro Espacio Urbano:

Propuestas Morfológicas. V, 1991. Santiago do Chile. Anais... Santiago do Chile: s.n. 1991.

As demais situações urbanas definidas pela convocatória não foram capazes de motivar número significativo de projetos. Os tecidos urbanos com edificação isolada de média altura foram abordados por apenas dois projetos, enquanto a trama urbana tipo cidade-jardim contou com somente três projetos apresentados - dos quais dois foram publicados. Não por acaso, a supracitada reportagem publicada em El Mercurio, que 
procurou distinguir um projeto de cada situação urbana e entrevistar os arquitetos responsáveis por sua elaboração - tendo entrevistado, portanto, Rolando Schere, Carlos Eduardo Comas e Sergio Trujillo, responsável pelas normas para Ciudad Salitre -, não apontou nenhum projeto para os loteamentos tipo cidade-jardim ${ }^{264}$. Nesta situação urbana, não havia somente poucos interessados, como, também, não houve nenhum habitué dos SAL que tenha se motivado em desenvolvê-lo em forma de proposta de intervenção.

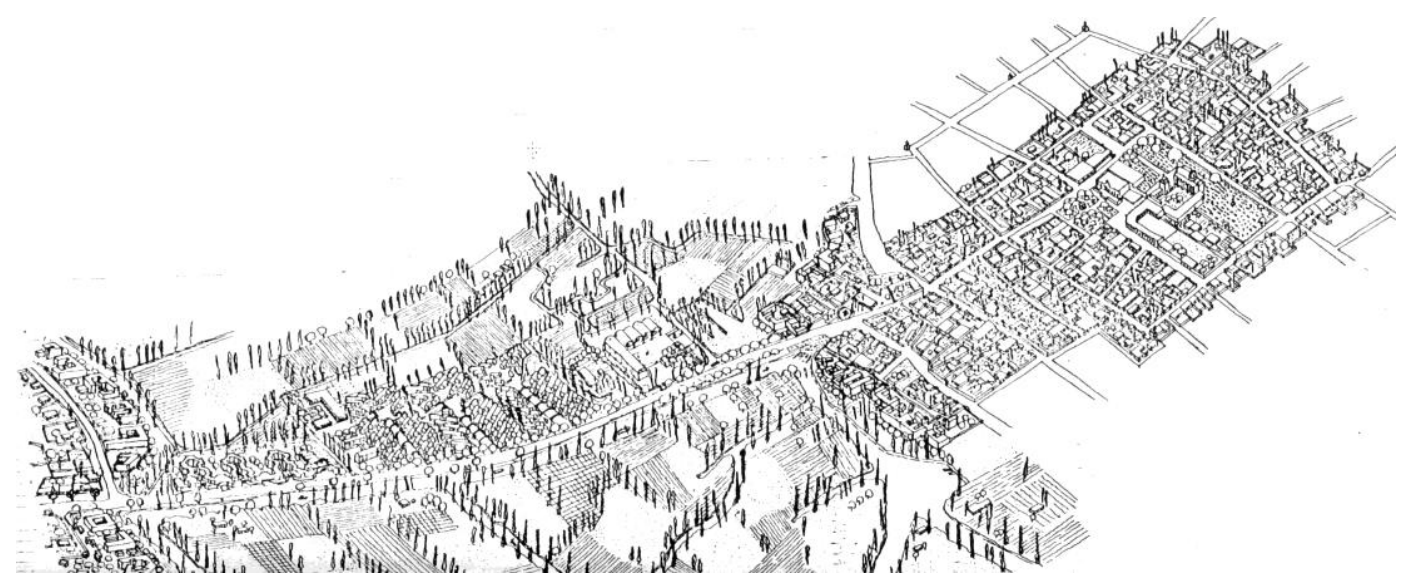

Figura 53: Projeto para Mixquic, cidade incorporada à periferia da Cidade do México, elaborado para o $\mathrm{V}$ SAL sob a coordenação de González Lobo. Fonte: BOZA et al. (org). Seminario de Arquitectura Latinoamericana. Nuestro Espacio Urbano: Propuestas Morfológicas. V, 1991. Santiago do Chile. Anais... Santiago do Chile: s.n. 1991

Os projetos que obtiveram maior destaque na mídia, no entanto, não foram aqueles que demonstraram o desenvolvimento e a continuidade de aspectos que haviam sido debatidos nas mesas relativas à cidade latino-americana nos seminários anteriores. Dois projetos que representaram o México parecem ter cumprido esta função: um, coordenado por Carlos González Lobo, abordava o tema da periferia urbana; o outro, realizado por Rafael Rangel Lopez, voltava-se para situação em centro histórico. O projeto de González Lobo chegou a ter sua qualidade destacada no discurso de Eliash. Segundo o arquiteto chileno, "foi uma pena não poder discuti-lo em profundidade ${ }^{\prime 265}$. Neste projeto para a cidade de Mixquic - povoado histórico que foi incorporado pelo crescimento da periferia da Cidade do México -, González Lobo, que havia participado na mesa relativa à cidade de massas do IV SAL, buscou avançar em sua contribuição para a construção de teoria da arquitetura da cidade da periferia, buscando

\footnotetext{
${ }^{264}$ Cf. MONTERO WARD, Beatriz. loc. cit. 1991, p.6.

${ }^{265}$ ELIASH, Humberto. Depoimento. [02 de agosto de 2011]. Santiago do Chile: Arquivo digital da gravação (56min.). Entrevista concedida a Gisela Barcellos de Souza.
} 
caracterizar, para além dos tipos edilícios e da morfologia urbana, os tipos de crescimentos $^{266}$. Rafael Rangel Lopez, por outro lado, retomou a proposta de Boza, apresentada no III SAL, do bairro como ponto de partida para intervenção da cidade latino-americana, para, a partir da aplicação deste princípio, propor a intervenção em bairro histórico da Cidade do México ${ }^{267}$.
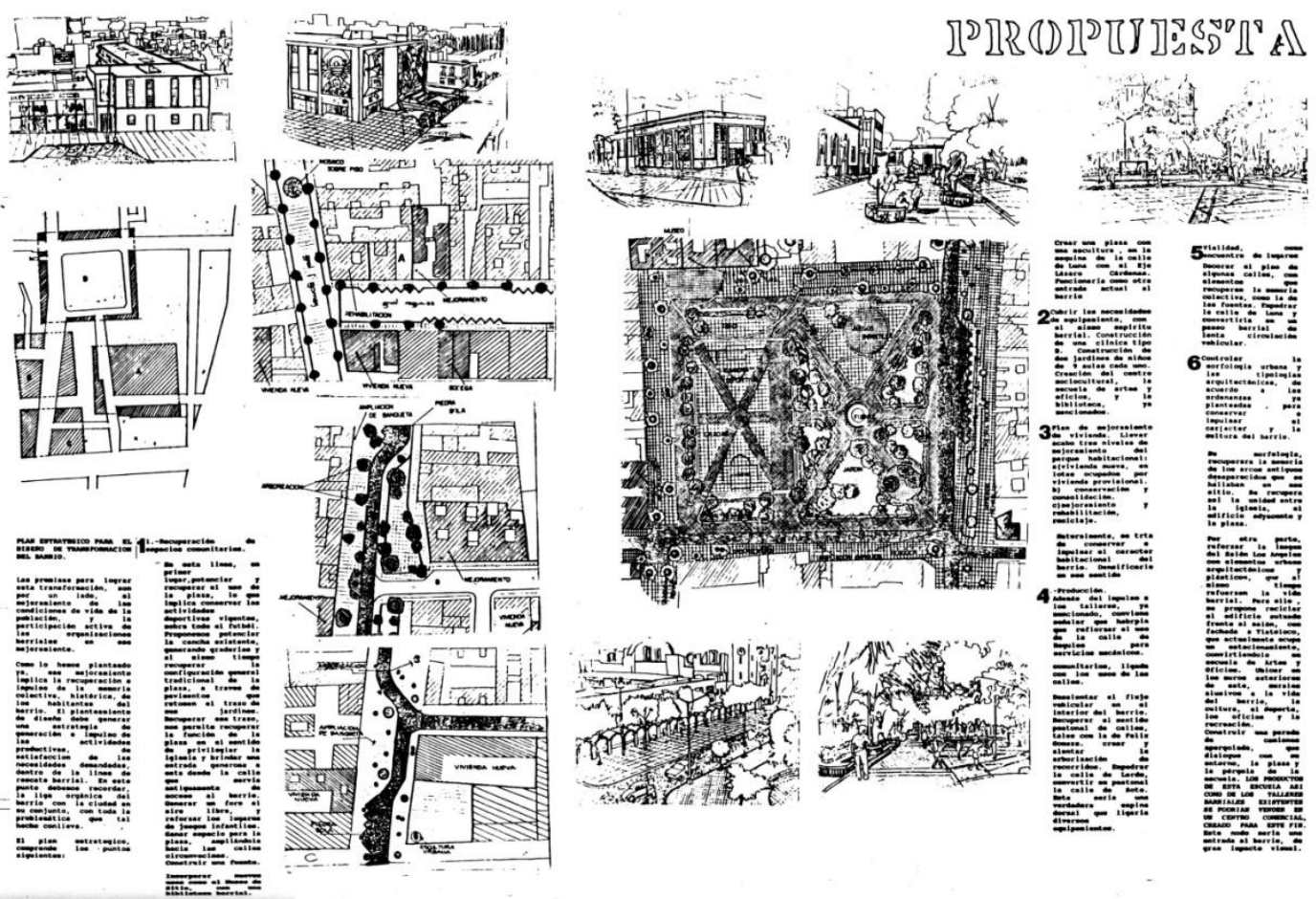

Figura 54: Prancha do projeto desenvolvido por Rafael Rangel Lopez para o V SAL "Rescatar la identidad Barrial de la Ciudad" Fonte: BOZA et al. (org). Seminario de Arquitectura Latinoamericana. Nuestro Espacio Urbano: Propuestas Morfológicas. V, 1991. Santiago do Chile. Anais... Santiago do Chile: s.n. 1991

A despeito das divergências em relação à convocatória que parte das apresentações teóricas apontava, ou da falta de interesse que aqueles que optaram pela elaboração de projetos demostraram por algumas das situações urbanas propostas, a restinção de tempo para o debate parece ter sido o ponto crucial que impediu que as expectativas de legitimação de projetos e de estabelecimento de pactos coletivos, que transpareciam no planejamento do evento, fossem desenvolvidas em qualquer nível. Devido à quantidade de propostas de apresentação recebidas, a comissão organizadora introduzia o programa com a ressalva de que os participantes deveriam se ater a vinte

\footnotetext{
${ }^{266}$ GONZÁLEZ LOBO, Carlos. La Ciudad de la Periferia: Mixquic. In: BOZA et al. (org) op. cit, 1991.

${ }^{267}$ RANGEL LOPEZ, Rafael. Rescatar la identidad Barrial de la Ciudad. In: BOZA et al. (org) op. cit, 1991.
} 
minutos de exposição oral ${ }^{268}$. A falta de tempo para a compreensão e debate adequados dos projetos foi destacada nos depoimentos de Arango, Comas, Eliash e Moscato ${ }^{269}$. Logo após o seminário, Irigoyen destacava este aspecto em sua crônica: "A quantidade e a qualidade dos trabalhos apresentados e a falta de tempo impediram, porém, que a discussão se aprofundasse sobre cada obra, para a frustração de todos" ${ }^{270}$. Anos mais tarde, Eliash avaliaria a falta de tempo previsto para o debate como uma falha na concepção do evento:

Debatemos projetos sem o conhecimento exato desta realidade, isto é pouco consistente. [...] Tamanhas eram as complexidades, as particularidades de cada projeto, que era muito difícil envolver-se em pouco tempo. Mais ainda, [equivocamo-nos] porque tínhamos a expectativa que isto [o seminário] servisse para que depois este projeto se canalizasse na realidade. Era algo muito mais complexo e nós nem sequer manejávamos as estruturas de poder e de financiamento para que estes projetos avaliados por nós pudessem ser concretizados ${ }^{271}$.

Logo, o V SAL encerrava-se sem alcançar seus objetivos. Por um lado, foram inócuos os esforços no sentido de criar um quadro que legitimasse as propostas apresentadas. Malgrado o fato do então prefeito de Santiago, Jaime Ravinet, ter sido chamado para proferir o discurso de abertura do seminário, nenhum projeto teve sua execução viabilizada a partir do evento ${ }^{272}$. A proposição de normas para Santiago Poniente fora apresentada, porém, assim como as demais, não foi devidamente debatida. De forma semelhante, frustrou-se, também, o objetivo de definir diretrizes comuns para as intervenções em cidades latino-americanas. A ausência de um debate intenso impediu qualquer análise comparativa do conjunto de projetos apresentados, condição sine qua non para que se revelassem e avaliassem aspectos comuns a estes. As ambições de aproximar os Seminários de Arquitetura Latino-americana a uma abordagem mais operativa, tal qual a que se identificava nos CIAM, encerrava-se,

\footnotetext{
${ }^{268}$ BOZA et al. Instrucciones Generales a los participantes. In: BOZA et al. (org) op. cit, 1991.

${ }^{269}$ ARANGO, Silvia. Depoimento. [11 de novembro de 2011], loc. cit.; COMAS, Carlos Eduardo Dias. Depoimento. [01 de abril de 2011], loc. cit.; ELIASH, Humberto. Depoimento. [18 de julho de 2011], loc. cit.; MOSCATO, Jorge. Depoimento. [25 de agosto de 2011], loc. cit.

${ }^{270}$ IRIGOYEN, Adriana. V SAL, Santiago, Chile Passado, Presente e Futuro. In: AU. São Paulo: Pini, n.39, dez/jan 1992, p.20.

${ }^{271}$ ELIASH, Humberto. Depoimento. [18 de julho de 2011], loc. cit.

${ }^{272}$ ELIASH, Humberto. Depoimento. [18 de julho de 2011], loc. cit.
} 
portanto, na convocatória. O tecido, cujos fios haviam sido meticulosamente escolhidos, mostrava-se, ao final do evento, irregular e lasso.

\section{Trama complexa ou dupla urdidura}

A compreensão do que foi o V SAL, e do debate que teve lugar neste seminário, seria lacunar caso não se considerasse que este não foi um evento isolado. Repetia-se, em Santiago do Chile, um cenário semelhante ao que se configurou seis anos antes, quando organizou-se o primeiro SAL junto à Bienal de Buenos Aires. Apesar de terem sido organizados como eventos distintos, houve um intenso diálogo entre a programação da VIII Bienal de Arquitetura do Chile e a do V SAL. Realizados simultaneamente - a bienal ocorreu de 28 de setembro a 14 de outubro no Museu de Belas Artes, enquanto o SAL foi realizado de 7 a 11 de outubro -, para alguns dos participantes houve a impressão de que o SAL constituía parte dos eventos que compunham a VIII Bienal ${ }^{273}$. Tal impressão não era gratuita, arquitetos latinoamericanos convidados circulavam entre ambos os eventos e, além disso, nas instruções aos participantes, a comissão organizadora do V SAL estipulava um horário para o encerramento das seções vespertinas de apresentação de projetos "para permitir que os participantes assistam às conferências da VIII Bienal de Arquitetura"274

A proximidade entre os dois eventos iniciava-se no tema escolhido para a VIII Bienal de Arquitetura do Chile. Aproveitando-se do clima preparativo da comemoração dos quinhentos anos da chegada dos espanhóis à América, a oitava bienal, presidida por Jorge Iglesis - arquiteto que nunca havia apresentado algo nos SAL -, tomava "como referência teórica e fundamento o desafio de decifrar um Caminho Próprio para a arquitetura latino-americana" ${ }^{275}$. O título da bienal - Arquitetura Latino-americana, um caminho para o próprio - teria sido sugerido por Ramón Gutiérrez, em ocasião em que Iglesis foi visitá-lo e explicar-Ihe sua proposta para o evento ${ }^{276}$. Os convidados latinoamericanos da bienal foram compartilhados com o V SAL. Logo, habitués dos SAL como Silvia Arango, Ramón Gutierrez, Antonio Toca, Ernesto Alba, Jorge Moscato e Rogelio

\footnotetext{
${ }^{273}$ Cf. IRIGOYEN, Adriana, loc. cit.,1991

${ }^{274}$ BOZA et al. Instrucciones Generales a los participantes. In: BOZA et al. (org) op. cit, 1991.

${ }^{275}$ IGLESIS, Jorge. La VIII Bienal de Arquitectura. In: CA. Santiago de Chile: Colegio de Arquitectos, n.65, jul/ago/set 1991, p.15.

${ }^{276}$ GUTIÉRREZ, Ramón. Depoimento. [11 de novembro de 2011]. Campinas: Arquivo digital da gravação (1hora e 39min.). Entrevista concedida a Gisela Barcellos de Souza.
} 
Salmona ${ }^{277}$ tiveram que dividir o seu tempo entre as duas programações. 0 mesmo ocorreu com convidados como Carlos Morales - que apesar de não contar com registros de apresentações nos SAL, na condição de editor da Escala, teve importância fundamental na constituição desta rede viabilizado a publicação da coleção SomoSur - e Max Pedemonte. Avaliando a relação entre o SAL e a bienal, Eliash afirmaria:

Produziu-se uma grande confluência entre a Bienal e o SAL porque o presidente da Bienal, Jorge Iglesis, [...] compartilhava de muitas destas ideias de alguma maneira e propôs o tema de Arquitetura Latino-americana $-[\ldots]$ influenciado por todo este movimento que se estava gerando ${ }^{278}$.

Tal qual reconhecia Jorge Iglesis, a aproximação a temas latino-americanos não era uma novidade às bienais chilenas ${ }^{279}$. Como demonstramos no capítulo 2 , a IV Bienal de Arquitetura do Chilena havia se constituído como um dos elementos catalisadores para o estabelecimento de intercâmbios entre arquitetos latino-americanos. A quinta bienal, por sua vez, havia inserido em sua programação o Primeiro Encontro de Revistas Latino-americanas e havia convidado Ramón Gutierrez, Alberto Petrina e Eladio Dieste para a seção encontro. Na bienal seguinte, críticos latino-americanos foram novamente convidados a contribuir na seção encontro - no caso, foram Ruth Verde Zein, Carlos Eduardo Comas, Edson Mahfuz, Alfredo Gastal, Jaime Lerner, Alberto Petrina, Ramón Gutiérrez, e Eduardo Neira Alva ${ }^{280}$ - e se organizou o simpósio "Espacio Urbano: acciones posibles" no qual arquitetos do subcontinente foram chamados a expor intervenções urbanas representativas de seus países - participaram deste simpósio: Miguel Angel Roca, Max Pedemonte, Claudio Caveri e Fernando Castillo ${ }^{281}$.

Não obstante o fato de que as bienais chilenas anteriores constituíram-se como um foro de encontro entre arquitetos latino-americanos, foi a VII Bienal - presidida por Eduardo San Martín e realizada em agosto de 1989 - aquela de abriu efetivamente o

277 Cf. SWIBURN, Daniel. VIII Bienal de Arquitectura. En Búsqueda de lo próprio. El Mercúrio, Santiago do Chile, p. E10, 22 de set. de 1991; assim como PROGRAMA SAL V. In: BOZA et al. (org) op. cit, 1991.

${ }^{278}$ ELIASH, Humberto. Depoimento. [02 de agosto de 2011]. Santiago do Chile: Arquivo digital da gravação (56min.). Entrevista concedida a Gisela Barcellos de Souza.

${ }^{279}$ SWIBURN, Daniel. loc. cit. 1991.

${ }^{280}$ Cf. JORDAN, Ricardo. Sección encuentro. In: CA. Santiago de Chile: Colegio de Arquitectos, n. 48, jun 1987, p.16-23.

${ }^{281}$ Cf. BROWNE, Enrique. Gérmenes Positivos en las ciudades latino-americanas. In: CA. Santiago de Chile: Colegio de Arquitectos, n.52, jun 1988, p.44-45. 
precedente para a abordagem temática da oitava mostra. Nesta bienal, San Martín propôs que se organizasse um encontro exclusivo de críticos latino-americanos ${ }^{282}$ para o qual foram convidados: Marina Waisman (Argentina), Ruth Verde Zein e Carlos Eduardo Comas (Brasil), Silvia Arango (Colômbia), Ernesto Alva (México) e Pedro Belaúnde $(\text { Peru })^{283}$. Os críticos deviam escolher sete obras que fossem representativas da produção arquitetônica de seu país nos anos 1980, as quais foram apresentadas e debatidas durante a mostra ${ }^{284}$. Na ocasião, San Martín justificava a existência deste encontro de críticos latino-americanos da seguinte forma:

Nos últimos anos, os esforços de Amereida e do Taller América, as últimas três Bienais de Arquitetura Chilena e os Seminários de Arquitetura Latinoamericana (SAL), foram abrindo um caminho mais claro na teoria e uma nova sensibilidade nas obras. Com o trabalho do arquiteto Cristián Fernández Cox sobre a "Modernidade Apropriada" evidentemente nos encaminhamos a uma mudança de ótica, fundamentos e obras ${ }^{285}$.

Portanto, compreende-se que, dentro desta sequência, o próximo passo seria a realização de uma bienal chilena específica sobre a arquitetura latino-americana. Em seu texto de apresentação da mostra, Jorge Iglesis tornava patente seu interesse em dar continuidade ao debate ensejado pela mostra organizada por San Martín ${ }^{286}$. Tal motivação teria levado ao presidente da oitava bienal a encomendar a San Martín a redação do texto de abertura da seção Documento Bienal cujo objetivo era "servir de marco teórico a todas as atividades" 287 do evento. Este texto encomendado à San Martín - cujo título era "Arquitectura latino-americana: Los desafios para la década de los noventa"288 - foi, segundo Jaime Marquez ${ }^{289}$, enviado aos arquitetos Jorge Moscato

${ }^{282}$ Cf. SAN MARTín, Eduardo. Depoimento. [14 de março de 2012]. Santiago do Chile: Arquivo digital da gravação (1hora e 4min.). Entrevista concedida a Gisela Barcellos de Souza.

${ }^{283}$ Os textos de análise crítica deste conjunto, bem como a descrição destas obras, foram publicados na revista ARS número 11, de julho de 1989.

${ }^{284}$ A apresentação ocorreu durante as manhãs ao longo de uma semana e, segundo San Martín, "o debate foi muito sério, havia grande rigor". SAN MARTín, Eduardo. Depoimento. [14 de março de 2012], loc. cit.

${ }^{285}$ SAN MARTín, Eduardo. Presentación. Arquitetura y Crítica. In: CA. Santiago de Chile: Colegio de Arquitectos, n. 57, jul/ago/set 1989, p.15

${ }^{286}$ IGLESIS, Jorge. loc. cit., 1991.

${ }^{287}$ MARQUEZ, Jaime. El Camino Próprio. In: CA. Santiago de Chile: Colegio de Arquitectos, n. 65, jul/ago/set 1991, p.16.

${ }^{288}$ SAN MARTín, Eduardo. Arquitectura latino-americana: Los desafios para la década de los noventa In: CA. Santiago de Chile: Colegio de Arquitectos, n. 65, jul/ago/set 1991, p.18-21. 
(Argentina), Carlos Morales (Colômbia), Antonio Toca (México) e Mariano Arana (Uruguai) que, com base nesse, desenvolveram os demais textos que compunham esta seção.

Os nomes dos autores cujos textos compunham a seção documento correspondiam, portanto, a personagens íntimas dos SAL. Apesar de a bienal não ter abarcado a questão da cidade latino-americana ${ }^{290}$, no texto de base de Eduardo San Martín pairavam temas e críticas de origem urbana. Neste sentido, sua argumentação iniciava-se com crítica a adoção indiscriminada do Movimento Moderno nos países latino-americanos, cujas "piores consequências terminaram arrasando nossas cidades, modificando sua morfologia, destruindo importantes obras do patrimônio arquitetônico e transformando definitivamente a paisagem da cidade" ${ }^{291}$. Entre os nove desafios que definira para a arquitetura latino-americana nos anos 1990, um era a recuperação dos centros históricos e outro era a conformação da periferia. Estes dois desafios, não por casualidade, foram reafirmados nos demais textos que compunham a seção documento ${ }^{292}$.

O tema da VIII Bienal, sua seção documento e os arquitetos latino-americanos compartilhados com o V SAL, tudo levaria a crer que haveria o diálogo entre o seminário e a mostra chilena seria intenso e, inclusive, testemunhado por debates semelhantes. Contudo, na prática não foi exatamente o que ocorreu. Ao contrário do que ocorreu na bienal anterior, na mostra presidida por Jorge Iglesis não houve um encontro exclusivo a arquitetos latino-americanos. Curiosamente, demonstrando uma orientação um pouco distinta da que se poderia supor ao ler os textos que compunham o documento da

\footnotetext{
${ }^{289}$ MARQUEZ, Jaime, loc. cit., 1991.
}

${ }^{290}$ Cf. SWIBURN, Daniel. VIII Bienal de Arquitectura. En Búsqueda de lo próprio. El Mercúrio, Santiago do Chile, p. E10, 22 de set. de 1991; PIDERIT, Gabriela; SANTIS, Ernesto. Crear, Compartir, Analizar, los verbos que se conjugan en la VIII Bienal. El Mercúrio, Santiago do Chile, Cuaderno VIII Bienal p. 2, 26 de set. de 1991; PIDERIT, Gabriela; SANTIS, Ernesto. Encuentro retrospectivo para proyectar el futuro. El Mercúrio, Santiago do Chile, Cuaderno VIII Bienal p. 34, 26 de set. de 1991; PIDERIT, Gabriela; SANTIS, Ernesto. Montaje abierto a todas percepciones culturales. El Mercúrio, Santiago do Chile, Cuaderno VIII Bienal p. 3-4, 26 de set. de 1991.

${ }^{291}$ SAN MARTín, Eduardo. loc. cit., 1991, p.18.

${ }^{292}$ Ver: TOCA, Antonio. Desafios para una Nueva Arquitectura en Latinoamerica. In: CA. Santiago de Chile: Colegio de Arquitectos, n. 65, jul/ago/set 1991, p.22-25; MOSCATO, Jorge. El Movimiento de arquitectura Latinoamericana para los años 90. In: CA. Santiago de Chile: Colegio de Arquitectos, n. 65, jul/ago/set 1991, p.26-28; MORALES, Carlos. Reflexiones para Iniciar una Discusión. In: CA. Santiago de Chile: Colegio de Arquitectos, n. 65, jul/ago/set 1991, p.29-31; ARANA, Mariano. La Arquitectura en los Tiempos del Cólera In: CA. Santiago de Chile: Colegio de Arquitectos, n. 65, jul/ago/set 1991, p.32-33. 
bienal, na seção Encontro, arquitetos latino-americanos, europeus e asiáticos debateram sobre a obra do arquiteto e a cidade, "entendendo que esta relação se dá de maneira criativa somente quando, ao fazer sua obra, o arquiteto pensa também a

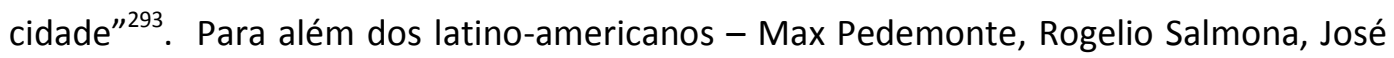
Ignacio Díaz, Roberto Burle Max e Guillermo Jullian de la Fuente - participaram, também, desta discussão: Guillermo Vásquez Consuegra (Espanha); Enric Miralles (Espanha); Zaha Hadid (Iraque), Daniele Vitale (Itália) e Kenneth Frampton (Inglaterra). A inserção de Zaha Hadid na programação da bienal que buscava "um caminho para o próprio" era destacada por Iglesis como um contraponto no debate: "Zaha Hadid, que realiza o contrário do que os arquitetos latino-americanos estão fazendo, vem dar o contraponto, pois o desconstrutivismo é a tendência em voga no mundo desenvolvido"294.

O contraponto, no entanto, acabou tomando conta do debate. A grande afluência de pessoas para assistir a palestra de Zaha Hadid foi descrita inclusive por aqueles que não puderam comparecer ao evento. San Martín afirma, em seu depoimento, que "todos os estudantes queriam ver a Zaha Hadid" ${ }^{295}$ e que, inclusive, a fim de garantir seu lugar na plateia "alguns dormiram na rua um dia antes" ${ }^{296}$. Silvia Arango relata que estava em meio a um debate no SAL, quando alguém lhes avisou da palestra da iraquiana e todos abandonaram a seção para ir assisti-la ${ }^{297}$. Segawa recorda que não era possível entrar para assistir a palestra, pois o auditório estava muito cheio $^{298}$. Face ao furor que a presença da arquiteta iraquiana causou na ocasião, compreende-se a avaliação que Arango fazia do V SAL quatro anos mais tarde: "A poucas quadras, no Palácio de Bellas Artes, apresentavam-se os convidados internacionais da bienal. Competia-se com Zaha Hadid"299.

293 Cf. FERNANDEZ, Teodoro; PEREZ DE ARCE, Rodrigo. Los arquitectos y su Ciudad. In: CA. Santiago de Chile: Colegio de Arquitectos, n. 65, jul/ago/set 1991, p.118.

${ }^{294}$ IGLESIS apud SWIBURN, Daniel, loc. cit., 1991, p.22.

${ }^{295}$ SAN MARTín, Eduardo. Depoimento. [26 de março de 2012]. Santiago do Chile: Arquivo digital da gravação (22min.). Entrevista concedida a Gisela Barcellos de Souza.

${ }^{296}$ SAN MARTíN, Eduardo. Depoimento. [26 de março de 2012]. loc. cit.

${ }^{297}$ ARANGO, Silvia. Depoimento. [11 de novembro de 2011]. loc. cit.

298 SEGAWA, Hugo Massaki. Depoimento. [06 de abril de 2011]. São Paulo: Arquivo digital da gravação (1hora e 34min.). Entrevista concedida a Gisela Barcellos de Souza.

${ }^{299}$ ARANGO, Silvia. Diez años de los "SAL" en América latina. In: PROA, Bogotá: Ediciones PROA, 425, jun.1995, p.19. 
Diante deste cenário, qualquer similaridade entre os debates da seção Encontro da bienal e aqueles que ocorriam nas seções do V SAL parecem improváveis. O encerramento do seminário de Santiago do Chile, contudo, havia sido concebido como uma seção comum entre ambos os eventos que ocorriam simultaneamente. Logo, a mesa redonda que ocorreu no dia 11 de outubro, no Museu de Belas Artes, e que deveria tecer considerações comuns à VIII Bienal e ao V SAL, revelava ainda mais os ruídos entre os debates de ambos os eventos. Composta por Antonio Toca (México) ${ }^{300}$, Silvia Arango (Colômbia), Ramón Gutiérrez (Argentina), Victor Pérez Escolano $(\text { Espanha })^{301}$, a transcrição parcial desta mesa permite entrever a dificuldade dos participantes em se posicionar sobre ambos os eventos. A primeira questão que se percebe é que a temática do V SAL, ou seja, a abordagem da forma das cidades latinoamericanas, desapareceu neste contexo. As questões específicas do SAL foram ofuscadas pelo dilema entre a temática da bienal - Um caminho para o próprio - e a dimensão espetacular que a presença de Zaha Hadid obteve neste evento. O SAL, quando citado, acabou tendo seu debate tratado como se fosse coincidente com o tema proposto para a bienal.

Desta forma, Silvia Arango iniciava seu discurso buscando refletir sobre "inquietudes que deixaram Zaha Hadid e o Seminário de Arquitetura Latinoamericana" ${ }^{302}$ e propondo, a partir deste confronto entre posturas distintas, um novo desafio para a América Latina:

Parece-me um desafio importante, para América Latina, tentarmos, daqui adiante, estabelecer uma forma de pensar, unida a novas formas de expressão. Assim como, ocuparmo-nos do interstício que relaciona a pintura, a escultura, a arquitetura e as distintas formas de expressão artísticas, que dão uma dimensão cultural a criação arquitetônica e a aproximam de outras manifestações ${ }^{303}$.

\footnotetext{
${ }^{300}$ No programa do SAL estava previsto o nome de González Lobo como representante do México. No entanto, como se observa na revista CA número 69 (jul/ago/set 1992), a participação deste arquiteto nesta mesa foi substituída pela de Antonio Toca.

${ }^{301}$ Cf. PROGRAMA SAL V. In: BOZA et al. (org) op. cit, 1991.

${ }^{302}$ Transcrição da contribuição de Silvia Arango em: ARANGO, Silvia; PEREZ ESCOLANO, Victor et. al. El Camino Propio. Fragmentos del Foro Panel realizado en la VIII Bienal de Arquitectura. In: CA. Santiago de Chile: Colegio de Arquitectos. Jul/ago/set 1992, capa.

${ }^{303}$ Transcrição da contribuição de Silvia Arango em: ARANGO, Silvia; PEREZ ESCOLANO, Victor et. al., loc. cit., 1992, capa.
} 
Seguindo outra direção os arquitetos europeus, Victor Pérez Escolano e Daniele Vitale, pareciam partilhar certo incômodo em relação aos debates expressos no documento da bienal e à ideia da arquitetura latino-americana como específica e resistente às influências forâneas. Pérez Escolano afirmava que, na condição de espanhol, sentia-se ao mesmo tempo próximo e distante da América do Sul e alertava para o fato de que, em um mundo tendente à integração, as diferenças e especificidades regionais se inclinavam à minimização: "Há processos que não são exclusivos de um momento e de uma região do mundo [...]. Por tanto, seria um erro crer que a América Latina tem uma via marcada pela divisão, pela absoluta especificidade em relação aos problemas gerais" ${ }^{\prime 304}$. Daniele Vitale, avançando um pouco mais na questão, afirmava que não havia sentido em conceber a arquitetura latino-americana tomando-se como ponto de partida a defesa às influências estrangeiras:

Se olharmos a realidade e a história destas cidades, veremos que sempre se construíram referenciando-se ou imitando-se e síto apesar das distâncias e dos mares. Isso não concerne somente à América Latina, concerne também à Europa, e, em geral, à história da cidade. [...] Então, a arquitetura é um sistema de referências, de analogias. [...] A América Latina se propõe [hoje] o regionalismo como uma atitude quase minimalista; como defesa de uma origem que se está perdendo; como recuperação da marginalidade. Esta é uma postura frágil ${ }^{305}$.

Antonio Toca, por outro lado, encerrava a mesa defendendo a postura latinoamericanista, afirmando que: "Olhar para fora é imprescindível, se o fez, se o seguirá fazendo e tem uma série de vantagens. Porém, perdemos tempo demais esperando de fora o que não havíamos conseguido olhar e realizar dentro" ${ }^{306}$. 0 arquiteto mexicano defendia que a atuação na América Latina exigia; estar informado sobre o que ocorre no mundo; ter uma reflexão sobre a América e ter conhecimento da região à qual se pertence $^{307}$.

\footnotetext{
${ }^{304}$ Transcrição da contribuição de Victor Pérez Escolano em: ARANGO, Silvia; PEREZ ESCOLANO, Victor et. al., loc. cit., 1992, capa.

${ }^{305}$ Transcrição da contribuição de Daniele Vitale em: ARANGO, Silvia; PEREZ ESCOLANO, Victor et. al., loc. cit., 1992, capa.

${ }^{306}$ Transcrição da contribuição de Antonio Toca em: ARANGO, Silvia; PEREZ ESCOLANO, Victor et. al., loc. cit., 1992, capa.

${ }^{307}$ Transcrição da contribuição de Antonio Toca em: ARANGO, Silvia; PEREZ ESCOLANO, Victor et. al., loc. cit., 1992.
} 
A partir da síntese do debate acima, observa-se que, após ter-se passado cinco dias debatendo sobre projetos e textos que analisavam e refletiam distintos aspectos sobre a cidade latino-americana e sua morfologia, o encerramento do seminário parecia desconexo. O confronto entre arquitetos atuantes na Europa e a proposta latinoamericanista da bienal ofuscou por totalmente o trabalho desenvolvido junto ao V SAL e trouxe novamente à baila a discussão sobre as influências estrangeiras que havia motivado os primeiros SAL - sobretudo aqueles de Buenos Aires. A despeito do fato de a estrutura do seminário de Santiago não ter permitido vínculos transversais entre textos e projetos, nada parece ter contribuído tanto para a ausência de conclusões ${ }^{308}$ do evento quanto o compartilhamento de sua mesa de encerramento com o programa de atividades da VIII Bienal, bem como sua realização no espaço que sediava esta mostra.

\section{Distensão e esmaecimento}

Sob a perspectiva histórica, o episódio da palestra de Zaha Hadid e o ofuscamento parcial que este causou ao V SAL parecem constituir, juntamente a uma miríade de outros pequenos fatos, um daqueles eventos que viriam a testemunhar, na sequência, uma mudança na cultura arquitetônica. Apenas seis anos antes, uma multidão de estudantes argentinos havia afluído às palestras de arquitetos latinoamericanos durante o I SAL ${ }^{309}$; agora, estudantes chilenos recebiam de forma semelhante uma arquiteta que, na ocasião, ainda não tinha obras construídas. Obviamente, por mais que se tenham estabelecido fortes intercâmbios, não se pode tratar de forma semelhante o que ocorre de um lado e de outro da cordilheira. No entanto, deve-se salientar que, apenas dois anos antes, Santiago do Chile havia sido o palco no qual críticos da região expuseram e debateram - ao longo de uma semana,

\footnotetext{
${ }^{308}$ Há um texto que circulou como uma espécie de release do evento - provavelmente escrito por Ramón Gutiérrez -, que foi integralmente publicado na PROA n. 409 e que parece ter servido de base para o texto publicado na Projeto - V SEMINARIO de Arquitectura Latinoameriana, SAL. Informe del encuentro. In: PROA. Bogotá: Ed. Proa, n.409, abr 1992, p.58; SAL: Em busca da modernidade latino-americana. In: Projeto. São Paulo: Projeto, n.148, dez 1991, p.79. Contudo, como destacava Irigoyen em seu texto "não houve conclusões oficiais" do evento - Cf. IRIGOYEN, A. loc. cit., 1991, p.20.

${ }^{309}$ WAISMAN, Marina. Primer Seminario de Arquitectura Latinoamericana. Un auspicioso comienzo. In: Summa, Buenos Aires: Ediciones Summa, 217, set 1985, p.26-27. Segundo Gutiérrez, foram 2 mil estudantes - GUTIERREZ, R. Seminarios de arquitectura latino-americana. Uma experiencia de reflexión (1985-2009) In: GUTIÉRREZ, R.; MÉNDEZ, P. (org). Seminario de Arquitetura Latinoamericana (SAL). Haciendo el Camino al andar 1985-2011. Buenos Aires: CEDODAL, 2011.
} 
dentro do quadro da VII Bienal, e contando com uma plateia numerosa ${ }^{310}$ - as obras que caracterizavam arquitetura latino-americana dos anos 1980.

Efetivamente, diversos autores coincidem com a identificação de uma mudança na cultura arquitetônica chilena no início dos anos 1990. O processo de redemocratização teria sido, segundo Liernur ${ }^{311}$, acompanhado pela recuperação de um sentimento de autoestima e de celebração da modernização. A economia neoliberal encontrava, ao virar da década, eco e apoio na abertura política; buscava-se, neste contexto, "um modelo cultural mais adequado a um país exportável"312. No âmbito da arquitetura, dois fatos são apontados frequentemente como indicativos desta mudança na cultura disciplinar: o prêmio Andrea Palladio que Cristián Undurraga e Ana Luisa Déves receberam em 1991 - e cujo júri foi composto por Rafael Moneo James Stirling, Francesco Dal Co e Manfredo Tafuri - e o pavilhão, projetado por Jose Cruz e Germán del Sol, que representou o Chile na Feira Internacional do Quinto Centenário em Sevilha, em $1992^{313}$. Esta última obra, mais especificamente, seria utilizada por Liernur como marco de uma nova etapa na cultura arquitetônica daquele país:

Foi a primeira grande vitrine na qual se pode apresentar a novidade do estilo democrático da modernização. Por este motivo, o pavilhão projetado por Jose Cruz e Germán del Sol pode ser considerado como a obra que em nosso campo marca o início desta nova etapa ${ }^{314}$.

Mudanças na cultura arquitetônica, no entanto, não ocorrem de forma subitamente. Frequentemente, camadas de debates distintos se sobrepõem e coexistem até que um - ou mesmo um conjunto dentre estes - se sobressai, enquanto outros esmaecem paulatinamente. Esta é a situação que se observa na cultura arquitetônica chilena do início dos anos 1990. A redemocratização e a ampliação do crescimento econômico, como já abordado, modificaram os parâmetros dentro dos quais se

\footnotetext{
${ }^{310}$ Cf. SAN MARTíN, Eduardo. Depoimento. [14 de março de 2012]. Santiago do Chile: Arquivo digital da gravação (1hora e 4min.). Entrevista concedida a Gisela Barcellos de Souza.

311 LIERNUR, Jorge F. Portales del Laberinto. Comentarios sobre la Arquitectura em Chile, 19772007. In: LIERNUR (org). Portales del Laberinto. Arquitectura y Ciudad en Chile, 1977-2009. Santiago de Chile: Universidad Andrés Bello, 2009

312 MACHUCA, GULLERMO et. al. apud LIERNUR, loc. cit, 2009, p.21.

${ }^{313}$ Cf. LIERNUR, Jorge F., loc. cit., 2009, assim como : DEAMBROSIS, Federico. El lugar de Chile en el imaginário arquitectónico del siglo XIX. In: LIERNUR (org). Portales del Laberinto. Arquitectura y Ciudad en Chile, 1977-2009. Santiago de Chile: Universidad Andrés Bello, 2009, p.121-172,

${ }^{314}$ LIERNUR, Jorge F., loc. cit., 2009, p.21.
} 
configurava a prática arquitetônica da década anterior. Novos interesses surgem neste novo cenário em que a arquitetura chilena contemporânea rumava a encontrar seu lugar no debate internacional ${ }^{315}$; no entanto, vestígios do que caracterizou a cultura arquitetônica sob o regime militar ainda são perceptíveis no início dos anos 1990.

Por um lado, os arquitetos se voltam para seus escritórios e os espaços que outrora se destinavam à discussão teórica e a sua divulgação - como o Taller América, o CEDLA e a revista ARS - perdem sua razão de ser face à retomada das esferas democráticas. Por outro, os temas latino-americanos continuam a motivar debates, apesar de demonstrarem seu enfraquecimento junto ao ambiente chileno. Observa-se que alguns dos chilenos habitués dos SAL passam a frequentá-los de forma intermitente: Browne e San Martín, que já haviam assumido uma posição distante no V SAL e prosseguem com esta postura no VI SAL, realizado na Venezuela ${ }^{316}$; este evento de 1993 seria, por outro lado, o último seminário do qual Boza participou ${ }^{317}$. As casas-parrón de Browne, que demonstravam sua interpretação pessoal de como conciliar o espírito do tempo e o do lugar ${ }^{318}$ - e que haviam marcado o debate dos SAL portenhos ${ }^{319}$-, dão lugar agora ao Edificio Consorcio e às reflexões sobre a relação entre a arquitetura e a natureza ${ }^{320}$ - na qual o edifício serve de suporte à vegetação. Ainda mais significativo seria o fato de que o ciclo das Bienais de Arquitetura do Chile como foro de encontro entre arquitetos e críticos latino-americanos foi interrompido em 1993, com a IX Bienal - cujo tema era "Arquitetura, Cidade e Meio Ambiente" -, quando não foram convidados representantes do subcontinente para a seção Encuentro da mostra ${ }^{321}$.

\footnotetext{
${ }^{315}$ DEAMBROSIS, Federico. loc. cit., 2009.

${ }^{316}$ Cf. BROWNE, Enrique. Depoimento. [13 de setembro de 2011]. Santiago do Chile: Arquivo digital da gravação (2horas e 1min.). Entrevista concedida a Gisela Barcellos de Souza. e cf. SAN MARTín, Eduardo. Depoimento. [26 de março de 2012]. Santiago do Chile: Arquivo digital da gravação (22min.). Entrevista concedida a Gisela Barcellos de Souza.

${ }^{317}$ Cf. BOZA, Cristián. Depoimento. [10 de outubro de 2011]. Santiago do Chile: Arquivo digital da gravação (1hora e 12min.). Entrevista concedida a Gisela Barcellos de Souza.

${ }^{318}$ Cf. BROWNE , Enrique (org). Casas y escritos. Santiago de Chile: Taller América, 1989.

${ }^{319}$ Cf. ZEIN, Ruth Verde. Las casas-parrón de Enrique Browne: en el espíritu de la época y del lugar. In: Summa. Buenos Aires: Ed. Summa, n. 232, dez 1986, p.32; bem como WAISMAN. Primer Seminario de Arquitectura Latinoamericana. Un auspicioso comienzo. In: Summa, Buenos Aires: Ediciones Summa, 217, set 1985, p.26-27

${ }^{320}$ Cf. BROWNE, Enrique. Enrique Browne arquitecto : obras 1974-1994. Santiago de Chile: ARQ 1995.

${ }^{321}$ Os estrangeiros convidados para esta mostra são: Giancarlo de Carlo, Philippe Samyn, Jean Remy, Anders Dragheim, Steward Page, Francesco di Castri e Trieb Schmidt - ver revista CA, número 76, Abril/Maio/Junho 1994.
} 
Contudo, não é apenas a diminuição do interesse na cultura arquitetônica chilena - nacionalidade que representou o segundo maior número entre os habitués nos $\mathrm{SAL}^{322}$ - pelo debate de temas latino-americanistas caracterizaria os dois SAL posteriores ao seminário de Santiago do Chile, que completam o ciclo de 1985 a 1995. Como demonstramos ao longo desta tese, entre o terceiro, o quarto e o quinto seminário houve uma preocupação, por parte das equipes organizadoras e de alguns participantes - citavam apresentações de seminários anteriores -, em constituir elos e, desta forma, garantir a persistência de alguns temas e debates entre os eventos. Ainda que, como destacaram Arango, Gutiérrez e Segawa em seus depoimentos ${ }^{323}$, os interesses locais sempre primavam na definição dos temários, observa-se, nos seminários entre 1987 e 1991, a permanência de alguns debates que esmaeceriam nos dois subsequentes. A continuidade entre estes três eventos se deu, especificamente, na discussão sobre o centro histórico e a periferia urbana a partir de enfoques morfológicos - tratados no debate como aqueles específicos à disciplina arquitetônica. Silvia Arango ratificaria o desvanecimento deste debate após Santiago do Chile, afirmando que "este tema da forma da cidade latino-americana não teve lugar, nem em Caracas, nem em São Paulo" ${ }^{324}$. Não se afirma, com isto, que não se tenham discutidos temas urbanos nestes eventos, mas sim que o enfoque dado a estes foi outro, demonstrando novas preocupações.

O evento de Caracas teve como tema central a arquitetura recente latinoamericana, em cuja abordagem se privilegiou a apresentação de panoramas da produção da última década por país pelos chamados coordenadores nacionais ${ }^{325}$. A Venezuela, como já mencionado, havia contribuído de forma intermitente nos

\footnotetext{
${ }^{322}$ A Argentina teve o maior número de habitués nos SAL entre 1985 e 1995 - ver Apêndice B, “Personagens assíduas nos SAL entre 1985-1995".

${ }^{323}$ ARANGO, Silvia. Depoimento. [11 de novembro de 2011]. Campinas: Arquivo digital da gravação (1hora e 11min.). Entrevista concedida a Gisela Barcellos de Souza; GUTIÉRREZ, Ramón. Depoimento. [11 de novembro de 2011]. Campinas: Arquivo digital da gravação (1hora e 39min.). Entrevista concedida a Gisela Barcellos de Souza; SEGAWA, Hugo Massaki. Depoimento. [06 de abril de 2011]. São Paulo: Arquivo digital da gravação (1hora e 34min.). Entrevista concedida a Gisela Barcellos de Souza.

${ }^{324}$ ARANGO, Silvia. Depoimento. [11 de novembro de 2011], loc. cit.

${ }^{325}$ A saber: Alberto Petrina (Argentina), Carlos Eduardo Comas (Brasil), Gustavo Medeiros (Bolívia); Silvia Arango (Colombia); Humberto Eliash, Cristián Boza e Manuel Moreno (Chile); Jorge Grané del Castillo (Costa Rica); Roberto Segre (Cuba); Juvenal Baracco e Pedro Belaúnde (Peru), Andrés Mignucci (Porto Rico), Rubém Moreira (Equador), Antonio Toca (México) e Juan Pedro Margenat (Uruguay).
} 
seminários anteriores ao de Santiago do Chile, sem chegar a constituir personagens assíduas ao debate ${ }^{326}$. Soma-se, a esta participação descontínua, o fato de que neste país "as revistas e publicações de arquitetura não passa[vam] nunca dos quatro primeiros números ${ }^{\prime 327}$ e, portanto, não havia, do mesmo modo, uma representação efetiva de venezuelanos nos encontros de revistas. Logo, neste contexto, a recorrência à exposição de panoramas parece uma solução encontrada para a falta de intimidade do grande público com os debates ensejados junto aos SAL. Estes panoramas não apenas constituíram o cerne do evento, como foram, também, as únicas contribuições registradas ${ }^{328}$. Ao contrário dos eventos anteriores, neste seminário não houve a publicação, ou mesmo o registro, das demais apresentações orais que o compuseram.

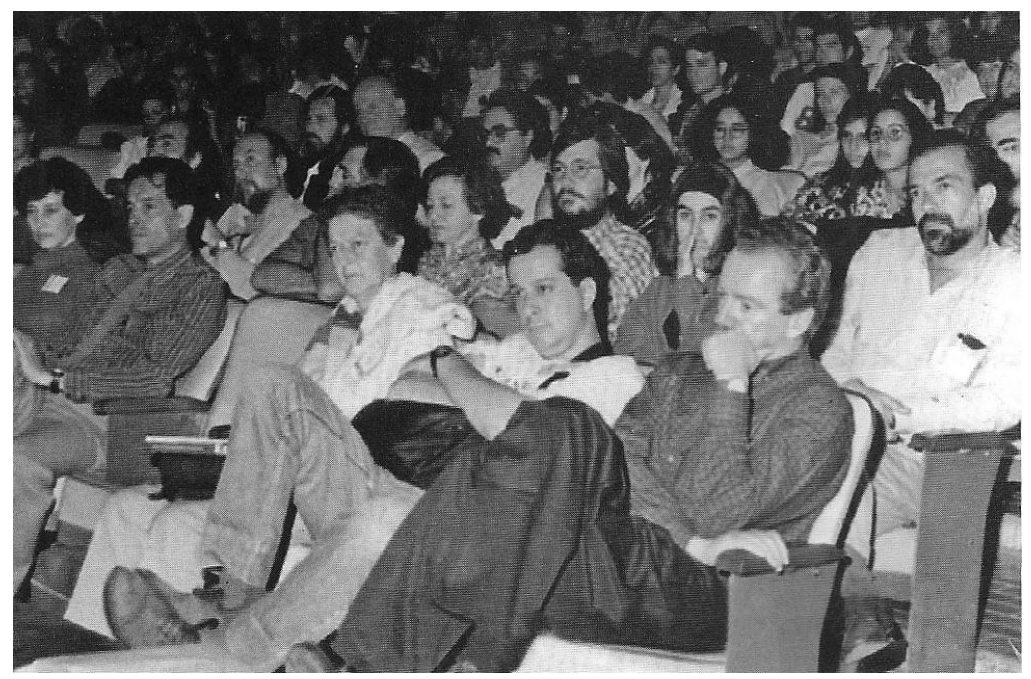

Figura 55: Marina Waisman, Jorge Zingoni e Sergio Trujillo no VI SAL em Caracacas, 1993. Fonte: Fonte: GUTIÉRREZ, R.; MÉNDEZ, P. (org). Seminario de Arquitetura Latinoamericana (SAL). Haciendo el Camino al andar 1985-2011. Buenos Aires: CEDODAL, 2011.

Desta forma, dos quatro temas que compunham o temário do evento "arquitetura recente na América Latina", "arquitetura e docência na América Latina", "a arquitetura como objeto museográfico" e, por último, "teoria e pensamento" ${ }^{329}$, apenas as apresentações do primeiro foram parcialmente registradas - visto que as comunicações que se enquadravam neste não foram publicadas. Justamente neste primeiro tema, estava prevista sua divisão em quatro subtemas, dentre os quais um era

\footnotetext{
${ }^{326}$ Ver Apêndice B, "personagens assíduas nos SAL entre 1985 e 1995".

${ }^{327}$ POSANI, Juan Pedro. A pesar de todo... Economia HOY. Caracas, Arquitectura HOY, p.2, 2 de mai. de 1992.

${ }^{328}$ Os panoramas por países foram publicados pela revista venezuelana Immuebles - NEGRÓN, Marco et al (org). Edición Especial del Sexto SAL: Arquitectura Latino-Americana de los años 80/90. In: Immuebles. Caracas: JMBC Grupo Editor Immobiliário, n.9, mar 1993, p.65-88 - bem como, pela Fundación Museo de Arquitectura - PADRÓN, Martín J et al. (org). Seminario de Arquitectura Latinoamericana. Nuestro arquitectura reciente: conceptos y realizaciones. $\mathrm{VI}$, 1993. Caracas. Ponencias generales... Caracas: Ediciones Fundación Museo de Arquitectura. 1993. ${ }^{329}$ Cf. NEGRÓN, M. et al, loc. cit., 1993.
} 
a abordagem de "reabilitações urbanas" no contexto da produção contemporânea definidas como propostas de desenho urbano em centros urbanos históricos ou tradicionais ${ }^{330}$. Ao se analisar as apresentações publicadas, no entanto, observa-se que este subtema constou apenas marginalmente nas apresentações de Alberto Petrina ${ }^{331}$, Gustavo Medeiros ${ }^{332}$, Silvia Arango ${ }^{333}$ e de Willian Niño ${ }^{334}$. Por outro lado, alguns panoramas apoiavam suas análises das obras - mesmo que brevemente - em vocabulário relacionado à tipo-morfologia, como se observa nas contribuições de Comas $^{335}$, Willian Niño ${ }^{336}$ e Eliash, Boza e Moreno ${ }^{337}$. Nesta ocasião, Silvia Arango, ao analisar a produção recente de seu país - realizada por uma geração que tinha entre quarenta e sessenta anos e que se havia formado nos anos 1960 e $1970-$, justificava o número diminuto de intervenções urbanas mencionadas da seguinte forma: "Apesar da enorme vigência do discurso sobre a cidade entre os membros desta geração, as realizações neste sentido são menos contundentes" ${ }^{\prime 338}$.

No seminário que ocorreu parte em São Carlos e parte em São Paulo - de 21 a 25 de agosto de 1995, sendo os dois primeiros dias realizados na primeira cidade e os três últimos na segunda -, os temas urbanos apareceram sob enfoques distintos do que vinha sendo desenvolvido nos seminários anteriores - a gestão urbana e a provisão de moradia popular. Para tanto, constituíram-se duas das quatro seções temáticas previstas para o evento: "Arquitetura e Experiências de Gestão das Cidades Latinoamericanas", por um lado, e "Habitação Social e Cidade na América Latina”339, por outro.

\footnotetext{
${ }^{330}$ PADRÓN, M. et al. Convocatoria del VI SAL: Aclaratoira de los temas. Caracas: s.n., 1992.

${ }^{331}$ PETRINA, Alberto. Genealogía razonada de la actual arquitectura argentina In: Immuebles. Caracas: JMBC Grupo Editor Immobiliário, n.9, mar 1993, p.68-69.

332 MEDEIROS, Gustavo. Nuestra arquitectura reciente: 1982 a 1992. In: Immuebles. Caracas: JMBC Grupo Editor Immobiliário, n.9, mar 1993, p.70-71.

${ }^{333}$ ARANGO, Silvia. Arquitectura de los años 80 en Colombia. In: Immuebles. Caracas: JMBC Grupo Editor Immobiliário, n.9, mar 1993, p.74-75.

${ }^{334}$ NIÑO, Willian. La escuela de Caracas. Reflexiones breve para una primera aproximación a la arquitectura contemporánea en Venezuela. In: Immuebles. Caracas: JMBC Grupo Editor Immobiliário, n.9, mar 1993, p.86-87.

${ }^{335}$ COMAS, Carlos E. D. Arquitectura Brasileña: 1989 a 1992. In: Immuebles. Caracas: JMBC Grupo Editor Immobiliário, n.9, mar 1993, p.72-73.

${ }^{336}$ NIÑO, W., loc. cit., 1993.

${ }^{337}$ ELIASH, H.;BOZA, C.; MORENO, M. Arquitectura chilena en el laberinto de la prosperidad In: Immuebles. Caracas: JMBC Grupo Editor Immobiliário, n.9, mar 1993, p.78-79.

${ }^{338}$ ARANGO, S. loc. cit.,1993, p.74.

${ }^{339}$ SEGAWA, H. et al. 70 SAL - Cidade e arquitetura: Construindo o amanhã [convocatória]. São Paulo: s.n, 1995.
} 
Nesta última seção a comissão organizadora conseguiu reunir iniciados e iniciantes que demonstravam certa afinidade de abordagens ${ }^{340}$, o que possibilitaria que alguns paralelos fossem traçados entre as "arquiteturas da periferia" ${ }^{341}$ de Eduardo San Martín e de Joan Villà ${ }^{342}$, por exemplo. Contudo, como, neste momento, San Martín já não estava mais tão envolvido com os SAL - e com estas questões -, este encontro aconteceu apenas de forma circunstancial, sem maior profundidade ${ }^{343}$. Na outra seção, a relativa à gestão urbana, havia apenas iniciantes no debate dos SAL: Cássio Taniguchi (Curitiba), Luiz Paulo Conde (Rio de Janeiro), Dora Arizaga Guzmán (Quito) e Jorge Gamboa (Cidade do México) $)^{344}$.

Apesar de serem dois SAL distintos em termos de temática e de estrutura do evento - ao contrário dos panoramas de Caracas, cada tema do seminário brasileiro foi pautado por conferências e mesas redondas que complementavam as sessões de comunicação ${ }^{345}$-, ambos aproximam-se em uma questão em específico: a grande afluência do público. Em Caracas, segundo crônica do evento redigida por Comas, havia em torno de seiscentas pessoas na plateia da Aula Magna de Carlos Villanueva ${ }^{346}$. Segawa destacava, também, o número de participantes no evento, alertando para seus possíveis efeitos; seria difícil "avaliar com precisão o quanto do conjunto de reflexões promovidas numa oportunidade se transferiu para o seminário seguinte ${ }^{1347}$ - tal qual um ascensorista, corria-se o risco de "ouvir fragmentos de conversa de quem entra e sai sem nunca apreender o sentido completo da conversação" ${ }^{348}$. De forma semelhante, o seminário realizado no Brasil também contou com um número significativo de

\footnotetext{
${ }^{340}$ Ver Apêndice B, "registros de apresentações no VII SAL".

${ }^{341}$ Referimo-nos aqui ao título do livro de San Martín - SAN MARTíN, E. La Arquitectura de la Periferia de Santiago: Experiencias y propuestas. Santiago: Editorial Andrés Bello. 1992 -, assim como ao título do artigo que Joan Villà publicou sobre a habitação de interesse social na revista AU - cf. VILLÀ, Joan, Projetar a Periferia. In: AU. São Paulo: Pini, n.56, out/nov 1994, p.116-117.

342 Joan Villà esteve no VI SAL, segundo a crônica do evento realizada por Comas - cf. COMAS, Carlos Eduardo. O esgotamento do regionalismo. In: AU. São Paulo: Pini, n. 48, jun/jul 1993, p.25.

${ }^{343}$ SAN MARTín, Eduardo. Depoimento. [26 de março de 2012]. Santiago do Chile: Arquivo digital da gravação (22min.). Entrevista concedida a Gisela Barcellos de Souza.

344 SEGAWA, H. et al. 70 SAL - Cidade e arquitetura: Construindo o amanhã [convocatória]. São Paulo: s.n, 1995.

${ }^{345}$ Ver Apêndice B, "registros de apresentação no VII SAL".

${ }^{346}$ COMAS, Carlos Eduardo. O esgotamento do regionalismo. In: AU. São Paulo: Pini, n. 48, jun/jul 1993, p.25.

${ }^{347}$ SEGAWA, H. Ascensoristas do 6o SAL. In: Projeto. São Paulo: Projeto, n. 166, ago. 1993, p.104.

${ }^{348}$ SEGAWA, H., loc cit, p.104.
} 
participantes, tanto na plateia ${ }^{349}$, quanto através de exposições orais - para além das palestras e das participações em mesas redondas, houve noventa e cinco trabalhos apresentados nas seções de comunicações ${ }^{350}$. Para alguém que, como Jorge Ramirez, esteve no SAL de Manizales e voltou a participar diretamente ${ }^{351}$ destes eventos a partir de 1993, estes dois eventos - o venezuelano e o brasileiro - representavam um salto de escala:

Em 1993, em Caracas [...] o formato era diferente. Talvez tenha sido o grande SAL de multidões. Não foi nem em Manizales, nem no Chile, mas sim foi em Caracas que o SAL se tornou um grande espetáculo. A Aula Magna da Universidad Central estava cheia de gente na plateia, escutando as apresentações. Esta explosão da escala do SAL chegou a gerar muitas complicações, observavam-se diferenças em relação ao que havia ocorrido em Manizales. Para mim, estávamos diante de outro tipo de reunião. [0 evento de] Caracas, portanto, representou um momento de crise em termos do que era o SAL. E o [seminário] do Brasil, dois anos depois, significou um momento de crise em termos de conceitos ${ }^{352}$.

Efetivamente, grande expansão do número de participantes parece ter trazido consigo fissuras na definição dos debates que eram associados a estes seminários e, por extensão, na própria identidade do grupo que participava assiduamente dos SAL. Logo após o seminário de Caracas, Comas apontava o esgotamento do debate:

As discussões formais e informais apontaram o esgotamento das bandeiras do regionalismo e da identidade, se correlacionas com a ideia de única arquitetura latino-americana. [...] Cresce a convicção de que a noção de contextualismo precisa se redefinir; mais que adotar um contexto, o

\footnotetext{
${ }^{349}$ Cf. SEGAWA, Hugo Massaki. Depoimento. [06 de abril de 2011]. São Paulo: Arquivo digital da gravação (1hora e $34 \mathrm{~min}$.). Entrevista concedida a Gisela Barcellos de Souza; COMAS, Carlos Eduardo Dias. Depoimento. [01 de abril de 2011]. Porto Alegre: Arquivo digital da gravação (4horas e 37min.). Entrevista concedida a Gisela Barcellos de Souza.

${ }^{350}$ SEGAWA, H.; BRUNA, P. J. V. et all (org). $7^{\circ}$ SAL - Seminário de Arquitetura Latino-americana. Cidade e Arquitetura: Construindo o amanhã, 7, 1995. Rio de Janeiro. Resumos de Comunicações Científicas. São Paulo: FAU/USP, 1995.

${ }^{351}$ Jorge Ramirez não participou diretamente do quarto e do quinto SAL, pois estava na Alemanha desenvolvendo seu doutorado. Contudo, sempre manteve contato estreito com o grupo colombiano que frequentava os SAL. RAMíREZ, Jorge. Depoimento. [05 de abril de 2011]. São Paulo: Arquivo digital da gravação (1hora e $45 \mathrm{~min}$.). Entrevista concedida a Gisela Barcellos de Souza.

${ }^{352}$ RAMÍREZ, Jorge. Depoimento. [05 de abril de 2011]. loc. cit.
} 
arquiteto latino-americano frequentemente chamado a criar um contexto inovador ${ }^{353}$.

De forma semelhante, Joaquim Guedes que também esteve no VI SAL - oito anos depois que participou do primeiro evento em Buenos Aires - tecia, em 1993, duras críticas a estes eventos: "Persiste a retórica terceiro-mundista ingênua e inconsequente, mas sempre aplaudida. Há um ranço elitista-populista (ou peronista) travestido de culto $[\ldots]^{354}$. Portanto, o esgotamento do debate anunciado ao fim do VII SAL pela crítica de Ruth Verde Zein ${ }^{355}$ e observado na crônica de José Wolf ${ }^{356}$, já vinha se materializando desde Caracas.

O evento brasileiro, no entanto, adicionou alguns componentes à equação. Além de ter sido marcado pela apresentação de um número significativo de novatos - ver Apêndice B -, não se pode deixar de destacar que, entre as setenta e seis apresentações brasileiras no evento, dezenove eram vinculadas a programas de pós-graduação stritu senso $^{357}$ - e somente dezenove dos responsáveis pelas noventa e cinco comunicações apresentadas não possuíam vínculo com alguma universidade. A mistura entre o ambiente dos SAL, que almejavam um debate com orientação ideológica - e se caracterizavam pela mescla entre historiadores, críticos e arquitetos atuantes no mercado 358 -, e o rigor exigido ao pensamento científico e ao ambiente acadêmico talvez tenha contribuído para identificação de um desgaste. Outrossim, havia indícios, na própria estrutura do evento, de que os SAL deixavam de ser o local privilegiado para o debate teórico da arquitetura latino-americana e começavam a dar lugar a instâncias de orientações distintas: o primeiro seminário do DOCOMOMO brasileiro - e,

\footnotetext{
${ }^{353}$ COMAS, C. E. D. loc. cit.,1993, p.25.

354 GUEDES, Joaquim. “Arquitetura é construção” In: AU. São Paulo: Pini, n. 48, jun/jul 1993, p.25. ${ }^{355}$ ZEIN, Ruth Verde. Revistas \& Revistas. In: Projeto. São Paulo: Projeto, no 190, out. 1995, p.90.

${ }^{356}$ Ao escrever sobre o evento, Wolf afirmava: "realizado pela primeira vez no Brasil, deixou claro que vive uma fase de transição, de uma desejável renovação". WOLF, José. Ser (ou não ser) América Latina. In: AU. São Paulo: Pini, n. 62, out/nov 1995, p.77.

${ }^{357}$ As contribuições são oriundas de cursos de pós-graduação da FAU/USP, da FFLCH/USP, da UFBA, da UFMG e da PUC/SP - ver Apêndice B, "registros de apresentações no VII SAL

${ }^{358}$ Característica frequentemente destacada nos SAL do período 1985 a 1995 . Ver a título de exemplo: ELIASH,H. Reflexiones desde Chile sobre los 25 años de los Seminarios de Arquitectura Latinoamericana. In: GUTIÉRREZ, R.; MÉNDEZ, P. (org) Seminarios de Arquitectura Latinoamericana (SAL). Haciendo camino al andar. Buenos Aires: CEDODAL, 2011, p.45-48.
} 
igualmente, o primeiro no âmbito latino-americano - ocorreu durante a realização do VII SAL e constituiu uma das atividades de sua programação ${ }^{359}$.

Seja uma observação motivada pelo ambiente brasileiro $^{360}$, seja um esgotamento efetivo do debate, fato é que a percepção de um arrefecimento das discussões latino-americanistas não foi exclusiva aos brasileiros; este já vinha sendo observado por habitués de outras nacionalidades, como Boza ${ }^{361}$, Browne ${ }^{362}$ e Moscato $^{363}$. Para Jorge Moscato, que esteve no evento de São Paulo - e que compartilhou com a impressão de esgotamento do debate naquele momento -, o ponto de virada ocorrido logo após as comemorações do Quinto Centenário, em 1992: "após esta data, cada grupo nacional já vinha desenvolvendo outros programas" ${ }^{364}$. Mesmo entre aqueles que defendem a existência de uma continuidade entre os seminários do período de 1985 a 1995 e aqueles retomados a partir de 1999, intervalo de quatro anos entre o SAL de São Paulo e o realizado em Lima ${ }^{365}$ é frequentemente apontado como incômodo:

Um dos intervalos críticos, pela incômoda sensação de vazio, foi o transcorrido entre o SAL do Brasil e do Peru (1995-1999). No Brasil havia se assumido a superação de elementos que haviam inspirado inicialmente o encontro em torno da arquitetura continental. O ambiente geral ficou carregado de desencanto ${ }^{366}$.

359 Cf. COSTA, Xavier. Da Margem e do Centro. O Docomomo e a valorização da arquitetura moderna. In: Projeto. São Paulo: Projeto, n.191, nov 1995, p.71-72.

360 Deve-se manter em vista que os SAL foram retomados em 1999 e que a impressão de esgotamento no VII SAL não é unânime. Entre os entrevistados, Ramón Gutiérrez, Silvia Arango, Jorge Ramírez e Humberto Eliash defenderam em seus depoimentos a existência de uma continuidade na realização dos seminários desde 1985 - ainda que, para este último, seja necessário revisar sua estrutura. Cf. ELIASH,H. loc. cit., 2011.

${ }^{361}$ BOZA, Cristián. Depoimento. [10 de outubro de 2011]. Santiago do Chile: Arquivo digital da gravação (1hora e 12min.). Entrevista concedida a Gisela Barcellos de Souza.

362 BROWNE, Enrique. Depoimento. [13 de setembro de 2011]. Santiago do Chile: Arquivo digital da gravação (2horas e $1 \mathrm{~min}$.). Entrevista concedida a Gisela Barcellos de Souza.

363 MOSCATO, Jorge. Depoimento. [25 de agosto de 2011]. Buenos Aires: Arquivo digital da gravação (2horas e $25 \mathrm{~min}$.). Entrevista concedida a Gisela Barcellos de Souza.

${ }^{364}$ MOSCATO, Jorge. Depoimento. [25 de agosto de 2011]. loc. cit.

${ }^{365}$ Ao final do VII SAL, já estava previsto que o próximo, que deveria ocorrer em 1997, seria em Lima - cf. WOLF, J. loc.cit, 1995. Contudo, este prazo acabou não sendo cumprido e o seminário foi realizado com dois anos de atraso.

366 RAMÍREZ NIETO, Jorge. Refexiones en torno de los Seminarios de Arquitectura Latinoamericana. In: GUTIÉRREZ, R.; MÉNDEZ, P. (org) Seminarios de Arquitectura Latinoamericana (SAL). Haciendo camino al andar. Buenos Aires: CEDODAL, 2011, p.42. 
Talvez, ainda mais significativo que o lapso temporal entre o sétimo e o oitavo SAL, seja a interrupção dos encontros de revistas latino-americanas em $1995^{367}$ - os quais seguiam a numeração dos SAL e ocorriam no espaço desde o evento de Manizales. Retomados somente em 2009 - e com um formato distinto daquele de meados dos 1980 a meados dos $1990^{368}$-, a interrupção destas reuniões indica o desengajamento das revistas latino-americanas ao âmbito dos SAL. O desgaste destes encontros de revistas já era apontado por Segawa, em 1991, quando descrevia as discrepâncias entre as edições periódicas do subcontinente e a repetição de rotinas e de acordos entre os eventos $^{369}$.

A análise serial das revistas de arquitetura ${ }^{370}$ neste período confirma, por um lado o desengajamento progressivo das revistas, por outro, indica também o arrefecimento do debate latino-americanista na primeira metade dos anos 1990 . No contexto chileno, a revista ARS havia sido extinguida com a virada da década e, na revista $C A$, as publicações de artigos com ênfase latino-americanista e de projetos de profissionais do subcontinente decai significativamente após a conclusão da cobertura da VIII Bienal, em 1992. No outro lado da cordilheira, a Summa e a Summarios - edições que, historicamente, estiveram vinculadas aos SAL - tiveram seus últimos números editados em 1992 e 1990, respectivamente. A nova revista, a Summa+ - iniciada em 1993 -, apesar de ter comprado a antiga revista de Lala Méndez Mosquera e de ter permanecido com sua equipe, demostra, logo em seus primeiros anos, uma orientação editorial distinta, abrindo espaço para uma série de textos que, ainda que escritos por latino-americanos, possuíam pontos de vista internacionalistas ou críticos aos SAL ${ }^{371}$. No

\footnotetext{
${ }^{367}$ Ver Apêndice A.

${ }^{368}$ Recentemente retomados - ver Apêndice A -, os novos encontros de revistas têm assumido um caráter de trocas entre revistas acadêmicas, sem contar com revistas comerciais como a Projeto e a Summa que participaram destas reuniões, de 1985 a 1995, para a primeira, e de 1985 a 1992, para a segunda.

${ }^{369}$ SEGAWA,Hugo. A pobreza Latino-americana. In: Projeto. São Paulo: Projeto, n. 148, dez 1991, p. 20.

${ }^{370}$ Ver Apêndice $D$.

${ }^{371}$ A nova orientação da Summa+ fica clara em sua quarta edição no artigo em que Adriana Irigoyen, ao apresentar o Centro Cultural da Espanha projetoado pelos chilenos San Martín, Wrenborne e Gaston Pascal, afirma que "havia deixado de crer na sacralidade de determinados conceitos" referindo-se à questão da identidade - cf. IRIGOYEN, Adriana. Cortar por lo sano. In: Summat. Buenos Aires: Donn S. A., n.4, dez 1993, p.18. A resposta a este artigo, defendendo a importância da identidade na arquitetura latino-americana, seriaredigida por Fernándex Cox e publicada na edição número sete - cf. FERNÁNDEZ COX, Cristián. Aviso de retorno In: Summa+. Buenos Aires: Donn S. A., n.7, jun/jul 1994, p.88-89.
} 
Brasil, observa-se uma redução no número de textos de enfoque latino-americanistas a partir dos anos 1990, tanto na AU, quanto na Projeto ${ }^{372}$. Constituem-se como exceções a esta tendência na revista Projeto o número comemorativo do Quinto Centenário ${ }^{373}$ e os artigos publicados em função da realização do $\mathrm{V} \mathrm{SAL}^{374}$. Na AU, por outro lado, observase, a partir de 1995, um maior número de artigos escritos por latino-americanos com perspectiva internacionalista - notadamente, na coluna CAYC, de Glusberg e nas contribuições de Corona Martinez. Contudo, apesar da diminuição do interesse por olhares latino-americanistas observada, o número de projetos de arquitetos latinoamericanos manteve-se, no entanto, relativamente estável em ambas as revistas brasileiras na primeira metade dos anos $1990^{375}$. Apenas na Colômbia, as revistas PROA e Escala configurariam um cenário um pouco distinto dos demais países. Por um lado, o projeto editorial da revista Escala era mais de divulgação de projetos e comportava poucos textos teóricos ${ }^{376}$. A revista PROA, por outro, demonstra um número crescente de textos latino-americanistas até 1988 - um ano após o seminário em Manizales - e retoma um volume significativo de publicações com esta perspectiva em $1995^{377}$, quando se completavam dez anos dos SAL.

Ao serem retomados em Lima, os SAL, em 1999, não se constituíam mais como um foro latino-americano privilegiado que possibilitava o encontro entre arquitetos atuantes no mercado, críticos e historiadores; outra série de eventos de abrangência ibero-americana - com uma estrutura e uma orientação distintas - surgiria neste período: as Bienais Ibero-americanas de Arquitetura e Urbanismo, cuja primeira realização ocorreu em Madri, em $1998^{378}$. Contudo, talvez a maior diferença entre os SAL do período de 1985 a 1995 e aqueles retomados em 1999 esteja na perda de Marina Waisman - que faleceu em fevereiro de 1997.

\footnotetext{
${ }^{372}$ Ver Apêndice D.

${ }^{373}$ Cf Projeto, número 156, de setembro de 1992.

${ }^{374}$ No ano de 1995, em função da realização do VII SAL no Brasil, há a publicação de artigos e entrevistas com habitués destes debates, ver: n. 186 (mar 1995); n.187 (jul 1995) e n. 188 (ago 1995).

${ }^{375}$ A exceção do ano de 1992 para a projeto, em que há um aumento significativo no volume de obras publicadas, devido à edição 156, dedicada a comemoração do Quinto centenário - ver Apêndice $D$.

${ }^{376}$ Ver Apêndice D.

${ }^{377}$ Ver Apêndice D.

${ }^{378}$ Ver Apêndice A.
} 
Sem Marina Waisman, os SAL deixaram de contar não apenas com sua grande intelectual ${ }^{379}$, como, também, com uma figura essencial nos debates. Como afirmou Arango, "Marina tinha uma vantagem: ela ouvia e analisava.[...] Não é que fosse mediadora, mas ela escrevia e estruturava o que muita gente dizia" ${ }^{380}$. Esta tarefa era empreendida não apenas através dos editoriais dos Cadernos Summarios dedicados à arquitetura latino-americana ${ }^{381}$, como também através de textos que buscavam aprofundar a análise de conceitos que eram empregados nos Seminários de Arquitetura Latino-americana ${ }^{382}$. Além disso, sem Marina Waisman para ponderar, os SAL passaram a pender para a orientação de Ramón Gutiérrez. Para Ruth Verde Zein, havia uma grande diferença entre estes dois arquitetos argentinos: "O Ramón sempre teve uma postura mais dogmática sobre o que era o SAL. A Marina tinha uma postura mais aberta, sensível aos tempos" ${ }^{\prime 383}$. De forma semelhante, Segawa também diferenciava a ambos em seu depoimento:

[...] Ramón Gutiérrez, [...] eu diria, é um pouco mais conservador, latinoamericanista, com conteúdos nacionalistas, e a questão da identidade parte um pouco de ideários dos anos 1960, de nacionalismos. [...] Marina era uma mulher extraordinária por seu conhecimento e sua abertura para com a

\footnotetext{
${ }^{379}$ ARANGO, Sílvia. Introducción. In: WAISMAN. El Interior de la Historia. Bogotá: Escala, 1990.

380 ARANGO, Silvia. Depoimento. [11 de novembro de 2011]. Campinas: Arquivo digital da gravação (1hora e 11min.). Entrevista concedida a Gisela Barcellos de Souza.

${ }^{381}$ Dos 135 números editados dos Cadernos Summarios - entre novembro de 1976 e junho de1990 - quatorze foram dedicados à arquitetura latino-americana ou àquela referente a algum de seus países em específico. Deve-se ressaltar que, antes da realização do primeiro SAL a abordagem se dava por países e que, a partir de 1986, surgem números com abrangência de temáticas latino-americanas. Nas últimas treze edições da Summarios há uma clara orientação latino-americanista por parte de sua editora, Marina Waisman: verificam-se seis números publicados entre 1988 e 1990 - ou seja, quase a metade do total - voltados à questões latinoamericanas. Listamos na sequência os números que compõem o corpus aqui analisado: Espacio Peruano (n. 15, 1978); Enfoques Mexicanos (n.39, 1980); Eladio Dieste (n.45, 1980); Arquitectura en Bogotá (n.55, 1981); Brasilia (n.97/98, 1986); Latinoamérica: Utopías y Mitos (n.100/101, 1986); Bienal de Venecia - los latinoamericanos (n.104, 1986); Ciudad y Vida (n.116, 1987); América Latina el Pensamiento Joven (n.122, 1988); Arquitectos de Caracas (n.124, 1988); Lo general y lo particular (n.126, 1988); Arquitectura y Proyecto Nacional - Los siglos XIX y XX en los países andinos (n. 129/130, 1989); Esas Arquitecturas Im-Pertinentes (n.131, 1989); Identidad y Modernidad (n.134, 1990).

${ }^{382}$ Veja-se a título de exemplo: WAISMAN, Marina. Un proyecto de Modernidad. In: Summarios. Buenos Aires: Ed. Summa, n.134, mar/abr 1990, p.18-26. Este artigo foi republicado em: ARANGO, Silvia (org). Modernidad y Postmodernidad en América latina. Bogotá: Escala, 1991.

${ }^{383}$ ZEIN, Ruth Verde. Depoimento. [05 de abril de 2011]. São Paulo: Arquivo digital da gravação (1hora e 57min.). Entrevista concedida a Gisela Barcellos de Souza.
} 
arquitetura mundial - que não era o caso do Ramón. Ramón era um estudioso que se dedicava a articular um mundo latino-americano ${ }^{384}$.

${ }^{384}$ SEGAWA, Hugo Massaki. Depoimento. [06 de abril de 2011]. São Paulo: Arquivo digital da gravação (1hora e 34min.). Entrevista concedida a Gisela Barcellos de Souza. 
218 Tessituras híbridas ou o duplo regresso: Encontros latino-americanos e traduções culturais do debate sobre o Retorno à Cidade 


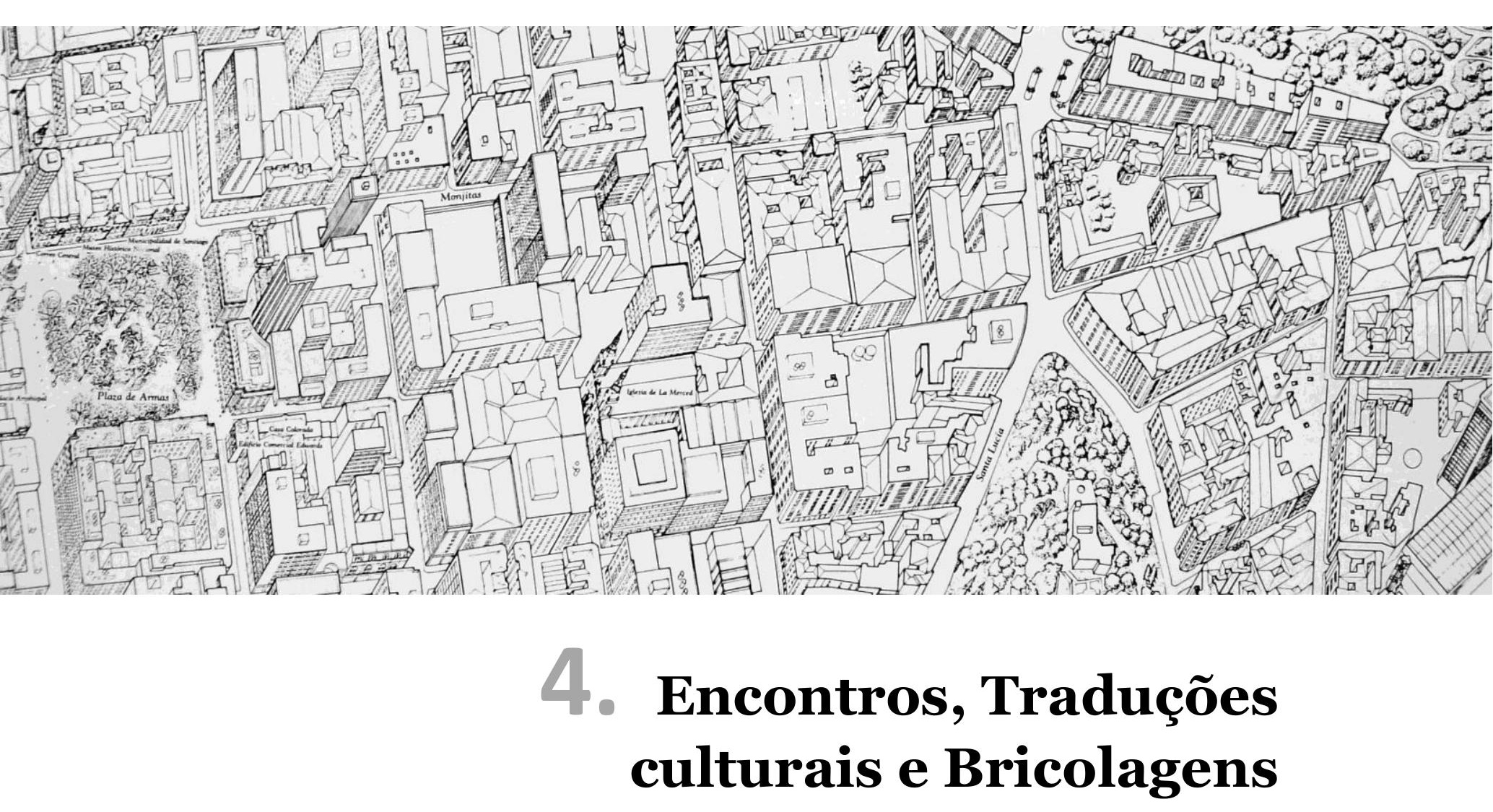


220 Tessituras híbridas ou o duplo regresso: Encontros latino-americanos e traduções culturais do debate sobre o Retorno à Cidade

Fragmento da Carta Isométrica de Santiago do Chile, desenvolvida por Cristián Boza et.

al., em 1989.

Fonte: Acervo pessoal de Cristián Boza. 
A forma pela qual determinadas ideias são trazidas à discussão no âmbito da cultura arquitetônica não se dá, certamente, de forma autônoma aos lugares sociais em que estas ocorrem e, menos ainda, em relação à atuação das personagens e dos grupos que a fomentam. A travessia de distintas fronteiras por um debate envolve a agregação de novos significados, bem como a perda e o esmaecimento de outros. Ao longo desta tese, abordamos nossa problemática mantendo como fio condudor a análise cronológica dos SAL. Neste capítulo, no entato, analisamo-a de forma mais difusa, sob a ótica da circulação das idéias.

Ao longo do percuso que realisamos até o presente capítulo demonstrou-se como, por um lado, a realização de um SAL específico sobre a morfologia dos espaços urbanos latino-americanos inseria-se dentro da perpectiva do desdobramento de debates ensejados nos primerios seminários e, por outro, transcendia os limites destes próprios seminários, remetendo a encontros e traduções culturais sobre a tipomorfologia que ocorriam simultaneamente. A fim de concluir a demonstração de nossas segunda e terceira hipóteses, o presente capítulo visa, portanto, dar continuidade ao que foi apenas iniciado pelo anterior, ou seja, a análise da conjuntura de realização do seminário de Santiago do Chile através de sua tessitura em um conjunto de encontros, de traduções culturais e de bricolagens.

Para tanto, busca-se, primeriramente, identificar quais foram os percursos o debate sobre a relação entre os tipos edilícios e a morfologia urbana no continente europeu e sob quais as possíveis vias este penetrou na cultura latino-americana. $\mathrm{Na}$ sequência, analisam-se de perto os encontros e as traduções culturais iniciais em torno daqueles personagens cujas proposições teóricas tiveram maior penetração no subcontinente. Por último, procurou-se demonstrar a conformação de hibridações de conceitos e recombinações de significados nos debates originais e a construção de representações comuns sobre a morfologia de uma "cidade latino-americana" e a forma de se intervir nela, cujos vestígios transparecem nos debates dos SAL. 


\subsection{A Cidade Redescoberta: o debate no contexto europeu através dos pontos de contato iniciais}

Antes de buscar compreender como ocorreu a tradução cultural da tipomorfologia e sua hibridação à questão da construção de uma identidade latinoamericana, é preciso reconhecer a trajetória anterior daquele debate. Através de alguns dos debates iniciais dos SAL é possível desvelar alguns autores que obtiveram maior ressonância na América Latina. Arango ${ }^{1}$, por exemplo, explicava a maior penetração de autores como Rossi e os irmãos Krier - e de suas teorizações sobre espaços públicos e a tipo-morfologia - devido à ênfase urbana que a crítica ao Movimento Moderno assumiu na América Latina. Por outro lado, alguns apresentavam suas ressalvas e destacavam que aqueles arquitetos - assim como Culot, outros da Tendenza e Rowe - organizavam seu pensamento sobre uma realidade urbana dissonante à latino-americana ${ }^{2}$.

De qualquer sorte, independentemente da inadequação, constantemente reafirmada nos seminários, da aplicação direta de teorias forâneas no contexto regional, constata-se que os diálogos com autores ligados ao debate europeus sobre a tipomorfologia foram frequentes no contexto regional no final dos anos 1970 e na primeira metade da década de 1980 - ou seja, antes mesmo que fossem firmadas as cooperações entre a Espanha e países hispano-americanos inseridas no contexto das comemorações do Quinto Centenário ${ }^{3}$. Em distintas ocasiões, arquitetos europeus visitaram países do subcontinente e participaram de eventos latino-americanos. Ainda em 1978, Aldo Rossi esteve pela primeira vez na América Latina, ocasião em que ministrou um seminário em Buenos Aires. No ano seguinte, participavam da II Bienal de Arquitetura do Chile, intitulada "Hacer Ciudad" os catalães Oriol Bohigas ${ }^{4}$ e Salvador Tarragó ${ }^{5}$, o português

\footnotetext{
${ }^{1}$ ARANGO, Silvia. Siete anotaciones para pensar la arquitectura latinoamericana. In: III Encuentro de Arquitectura Latinoamericana. Buenos Aires: CAPBA D III, 1988. p.68-69.

2 Cf. ELIASH, Humberto. Dimensión Arquitectónica de la Periferia Urbana. In: III Encuentro de Arquitectura Latinoamericana. Buenos Aires: CAPBA D III, 1988; MOSCATO, Jorge. Arquitectura de la Periferia. In: III Encuentro de Arquitectura Latinoamericana. Buenos Aires: CAPBA D III, 1988, p.82-84.

${ }^{3}$ Sobre os intercâmbios entre profissionais argentinos e espanhóis constituídos neste contexto, ver: JAJAMOVICH, Guilhermo., loc. cit., 2011.

${ }^{4}$ MARQUEZ, Jaime. Oriol Bohigas. In: CA. Santiago de Chile: Colegio de Arquitectos, n.25, dez 1979, p. 66.

${ }^{5}$ MARQUEZ, Jaime; RODRIGUEZ, León. Salvador Tarragó. . In: CA. Santiago de Chile: Colegio de
} 
Nuno Portas ${ }^{6}$ - que meses havia ministrado palestras no Brasil $^{7}$ - e o chileno atuante em Londres Rodrigo Perez de $\operatorname{Arce}^{8}$. Na Bienal seguinte, realizada em 1981, Fernando Montes ${ }^{9}$ participou do encontro de arquitetos estrangeiros. No contexto colombiano, em 1982, Oriol Bohigas, Fernando Montes e Aldo Rossi participaram do evento "Espacio Público Urbano" realizado em Bogotá e organizado pela Universidad de Los Andes ${ }^{10}$. No ano seguinte, a IV Bienal de Santiago do Chile - cujo subtítulo "A recuperação crítica do passado" deixava entreouvir as exposições de Kleihues e de Portoghesi ${ }^{11}$ - contou com a presença, entre os palestrantes convidados, de Rafael Moneo ${ }^{12}$ e Manuel de SolàMorales $^{13}$. Em 1984, Glusberg organizou, através do CAYC, palestras de Kleihues ${ }^{14}$ e de Rob Krier em Buenos Aires.

Por outro lado, alguns dos arquitetos latino-americanos que participariam dos SAL estabeleceram contato com o debate sobre a tipo-morfologia não somente através de publicações diversas, mas também em curtas estadias em países europeus, a trabalho ou estudos, entre meados dos anos 1970 e início dos anos 1980. Este não fora somente o caso de Boza e Eliash, fundadores do CEDLA, que após contato com o ambiente londrino em meados dos anos 1970, mantiveram diálogo frequente com Léon

Arquitectos, n.25, dez 1979, p. 63.

${ }^{6}$ Cf. NARAMOnTO, E. Nuno Portas. In: CA. Santiago de Chile: Colegio de Arquitectos, n.25, dez 1979 , p. 61.

${ }^{7}$ PORTAS, Nuno. A Revolução portuguesa e a política de habitação e urbanismo. In: Projeto. São Paulo: Projeto, n.13, jun/jul 1979, p.5-6. e PORTAS, Nuno. A arquitetura sob os regimes militares na Argentina e Chile. In: Projeto. São Paulo: Projeto, n.15, set/out 1979, p.8.

${ }^{8}$ PEREZ DE ARCE, Rodrigo. "Estudio histórico de las transformaciones urbanas" y "Propuestas em Chandigarh, Dacca, Paris, Londres y Runcorn". . In: CA. Santiago de Chile: Colegio de Arquitectos, n.25, dez 1979, p. 64.

${ }^{9}$ MONTES, Fernando. Charlas. In: CA. Santiago de Chile: Colegio de Arquitectos, n.31, dez 1981, p. 39.

${ }^{10}$ Ver SALDARRIAGA. Alberto. Arquitetura, Espacio Urbano y Latinoamérica. In: Proa. Bogotá: Ed. Proa, n. 305 abril 1982. e a transcrição da mesa redonda deste evento em "Espacio Público. Mesa Redonda" - Proa. Bogotá: Ed. Proa, n. 321 ago. 1983.

11 Referimo-nos à "Presença do Passado" da Strada Novíssima organizada por Portoghesi na Bienal de Veneza e à "reconstrução crítica" defendida por Kleihues na IBA Berlim. A IV Bienal de Arquitetura do Chile foi abordada no capítulo 2.

${ }^{12}$ Cf. MONEO, Rafael. De la tipologia. In: CA. Santiago de Chile: Colegio de Arquitectos, n.35, ago 1983, p. 18-27.

${ }^{13}$ Ver: PEREZ OYARZUN, Fernando. El futuro del pasado - sección encuentro. In: CA. Santiago de Chile: Colegio de Arquitectos, n.35, ago 1983, p. 110-131.

${ }^{14}$ Cf. PETRINA, A. El Racionalismo Poético de Josef Paul Kleihues. In: Summa. Buenos Aires: Ed. Summa, n.202, jul 1984, p. 36-41. 
Krier por correspondência ${ }^{15}$. Silvia Arango, por exemplo, após concluir uma especialização em Oxford em 1975, foi para Paris, onde morou entre 1975 e 1979 a fim de desenvolver seu mestrado e iniciar seu doutorado ${ }^{16}$. Carlos Eduardo Dias Comas estabeleceu seu primeiro contato com o ambiente da Architectural Association em uma curta estadia em Londres, no final dos anos 1970 - momento em que conheceu o trabalho de Rodrigo Perez de Arce -, e viria a realizar um estágio de curta duração nesta escola no ano de $1983^{17}$. Inclusive Ramón Gutiérrez, em suas viagens a congressos de conservação do patrimônio, estabeleceu laços de amizade com Salvador Tarragó ${ }^{18}$, o que o levaria a colaborar na edição número 19 da revista 2c, de novembro de 1981, dedicado à colonização do interior da Argentina entre o final do século XIX e início do século $X X^{19}$.

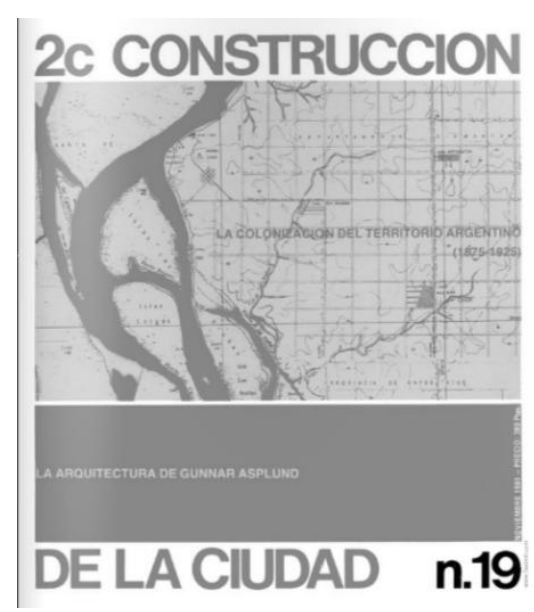

Figura 56: Capa do número 19 da revista 2c-Construcción de la Ciudad, de novembro de 1981, em que foi publicado dossiê sobre a colonização do interior da Argentina a partir da colaboração de Ramón Gutiérrez. Através deste número, o editor da revista - Salvador Tarragó - afirmava buscar a aproximação com o público latino-americano. Fonte: fotografia da autora.

A recorrência à figura do "retorno à cidade" na cultura arquitetônico-urbanística europeia dos anos 1970 fora, por diversas vezes, afirmada como um movimento associado à difusão e aos desdobramentos dos estudos italianos sobre a tipo-

${ }^{15}$ BOZA, C., KRIER, L. Léon Krier: su pensamiento frente a la ciudad. In: ARS, n.1, 1978, p.35.

16 ARANGO, Silvia. Depoimento. [11 de novembro de 2011]. Campinas: Arquivo digital da gravação (1hora e 11min.). Entrevista concedida a Gisela Barcellos de Souza.

17 Trata-se de um intercâmbio com a Architectural Association viabilizado através do CNPq, do qual Comas e outros professores brasileiros participaram em seu período exploratório. Após esta curta estadia, firmou-se um convênio que, entre 1983 e 1986, permitiu que docentes da UFRGS realizassem estágios de três meses na AA. COMAS, Carlos Eduardo Dias. Depoimento. [01 de abril de 2011]. Porto Alegre: Arquivo digital da gravação (4horas e 37min.). Entrevista concedida a Gisela Barcellos de Souza.

18 GUTIÉRREZ, Ramón. Depoimento. [11 de novembro de 2011]. Campinas: Arquivo digital da gravação (1hora e 39min.). Entrevista concedida a Gisela Barcellos de Souza.

${ }^{19}$ Ver: TARRAGÓ, Salvador. Editorial. In: 2c. Barcelona: 2c, n.19, nov. 1981, p.3; assim como: GUTIÉRREZ, Ramón. Política fundacional y ampliación de fronteras. In: 2c. Barcelona: 2c, n.19, nov. 1981, p.9-20. 
morfologia $^{20}$. De modo geral, as revisões de língua inglesa enfatizaram a existência de dois grandes meios culturais: o anglófono - composto pelos EUA e a Grã-Bretanha - e aquele relativo aos demais países europeus - referindo-se, em geral, apenas à França, à Itália e à Bélgica ${ }^{21}$. Se, por um lado, esta grande diferenciação permite compreender o desenvolvimento tardio do interesse pela relação entre os tipos edilícios e a forma urbana em países anglófonos ${ }^{22}$ - e o espaço que determinadas personagens acabam conquistando por transitarem nestes dois meios ${ }^{23}$-; por outro, acaba-se por minimizar a importância dos percursos e dos percalços específicos ao contexto heterogêneo da Europa continental.

Dentre as revisões existentes sobre a construção teórica em torno da relação entre tipos edilícios e a morfologia urbana, diversas são aquelas que enfatizam seus aspectos acadêmicos, que a situam como linha de pesquisa ou método de investigação ${ }^{24}$, traço que talvez só se possa afirmar nos anos 1980 . Todavia, no surgimento destes estudos, bem como em seu desenrolar nos anos 1970, sempre esteve presente e fora ratificada a indissolubilidade da relação entre análise e projeto. A trajetória destas posturas que objetivavam definir caminhos para a prática, mais do que definir teorias científicas, é o enfoque preciso deste trabalho.

Nas páginas que seguem, buscaremos reinserir as personagens que estabeleceram contatos com arquitetos da América Latina em seus lugares sociais; ou seja, verificar sua contribuição à cultura arquitetônica em seus países e a forma como se apropriaram da reflexão sobre a tipo-morfologia. Trata-se de uma abordagem fragmentária e aparentemente arbitrária, visto que as personagens narradas não são escolhidas devido ao reconhecimento de sua importância hierárquica em seus contextos originais ou mesmo no âmbito internacional; a eleição pelo enfoque maior em uma ou

\footnotetext{
${ }^{20}$ Veja-se, por exemplo, DEVILLARD; JANNIÈRE. loc. cit., 1977.

${ }^{21}$ Cf. ELLIN, Nan. Postmodern Urbanism. New York, Princeton Architectural Press, 1996; assim como, SAMUELS, Ivor. Urban Morphology in design. Research Note 19, Oxford: Joint Centre for Urban Design, 1985.

${ }^{22}$ Trata-se de uma afirmação recorrente: Cf. SAMUELS, loc. cit, 1985; assim como PANERAI, Ph. , MANGIN, D. Projet Urbain. Paris: Éditions Paranthèses, 2005

${ }^{23}$ Este é o caso de Léon Krier, por exemplo, que pelo fato de dominar o inglês, o francês, o alemão e o luxemburguês, teve facilidade em transitar entre a Grã Bretanha e a Europa continetal - assim como entre o norte e o sul da Europa. Cf.ELLIN, N. op. cit., 1996; SAMUELS, I. loc. cit.,1985.

${ }^{24}$ Ver, neste sentido: SAMUELS, Ivor. Urban Morfology in design. Research Note 19, Oxford: Joint Centre for Urban Design, 1985; ou, mais recentemente, PEREIRA COSTA, Stael de Alvarenga . Brazilain Urban Morphology. In: Urban morphology, Birmingham, v. 10, n. 02, 2006, p. 142-144.
} 
outra se dá pela existência ou não de contatos com arquitetos latino-americanos. Outrossim, pontuaremos alguns dos elos que permitiram o encontro interpessoal entre essas distintas personagens e procuraremos analisar algumas matizações deste debate. Em outras palavras, apontaremos, por um lado, quais foram os seus núcleos duros e, por outro, ressaltaremos as noções que foram passíveis de diferentes interpretações. 0 recorte temporal aqui analisado prioriza os anos 1970, período em que os postulados construídos na Itália a partir dos anos 1950 encontraram maior capacidade de ressonância na cultura arquitetônica do restante da Europa.

\section{O debate sobre a tipo-morfologia no contexto europeu}

Não obstante as diferenças que possam existir entre as ênfases dos estudos sobre a tipo-morfologia e de suas revisões, alguns pontos comuns são correntemente reafirmados. Assume-se, em geral, a dívida original às investigações italianas, cujos primeiros passos foram motivados pelas críticas ao urbanismo positivista, realizadas por Samonà, e firmaram-se através dos trabalhos de Muratori ${ }^{25}$. Este último, com seu extenso levantamento sobre a cidade histórica de Veneza - publicado em 1959, sob o nome "Studi per un'operante Storia urbana di Venezia" - fora responsável pelo desenvolvimento de postulados que se tornariam pontos-chave nas abordagens da tipomorfologia nas décadas seguintes: a definição do estudo do tecido urbano como elemento concreto para relacionar arquitetura e cidade e a afirmação de que a estrutura urbana só poderia ser compreendida através da história.

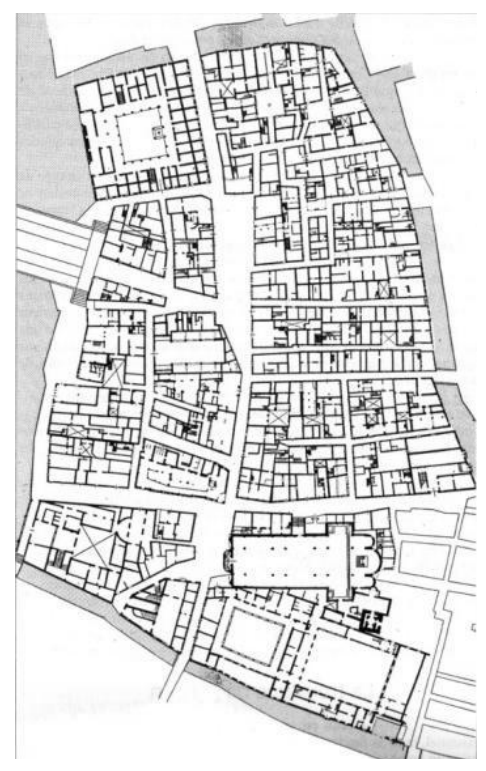

Figura 57: Tecido urbano do quarteirão de São Bartolomeu em Veneza, em 1950, por Saverio Muratori, em Studi per un' operante storia di Venezia, 1959. Fonte: Panerai et al. Analyse Urbaine. Marseille: Paranthèses, 1999.

\footnotetext{
${ }^{25}$ Cf. PANERAI et al. Analyse Urbaine. Paris: Éditions Paranthèses, 1999.; SAMUELS, loc. cit.,1985.
} 
Distante dos grandes debates da cultura arquitetônica italiana da época, com uma atuação "restrita à sala de aula, sem [...] contar com uma revista como portavoz $^{\prime 26}$, Muratori conseguira, com a disseminação de seus estudos através de seus exalunos, ultrapassar os limites da academia que the pareciam destinados. Dentre os discentes que tivera durante sua curta estadia em Veneza ${ }^{27}$, estava Gianugo Polesello ${ }^{28}$ amigo de Aldo Rossi e seu colaborador nos primeiros anos de sua carreira ${ }^{29}$. Segundo Saint Gutierrez, fora através deste ex-aluno de Muratori que Rossi entrou em contato com os estudos tipológicos desenvolvidos em Veneza ${ }^{30}$.

Inserindo-se no contexto do questionamento, que se deu no âmbito italiano entre o fim década de 1950 e o início dos anos 1960, sobre a pertinência ou não do urbanismo à prática dos arquitetos - e marcando a posição daqueles que defendiam a união entre estas disciplinas -; o primeiro trabalho em que Rossi analisa as relações entre a morfologia urbana e a tipologia edilícia fora realizado em Milão, em 1963, sob coordenação de De Carlo ${ }^{31}$. Neste mesmo ano, iniciar-se-ia, também, a colaboração acadêmica entre Rossi e Aymonino, cuja importância fora fundamental para a definição dos contornos que futuros estudos tipo-morfológicos assumiriam sob o Tendenza.

Trata-se do período de apenas três anos em que Aymonino, convidado por Samonà para assumir a antiga disciplina de Muratori no IUAV, chama a Rossi - de quem era amigo há mais de dez anos - para ser seu ajudante no curso ${ }^{32}$. Anos mais tarde, o arquiteto romano reconheceria a contribuição de Rossi como determinante "para precisar as relações entre morfologia e tipologia", devido a sua experiência prévia com estudos deste gênero em Milão ${ }^{33}$. Através desta parceria, e dos estudos realizados sobre a cidade de Pádua, editaram-se pequenos volumes que se constituíram nas bases para

\footnotetext{
${ }^{26}$ PORTOGHESI, Paolo. Depois da Arquitetura Moderna. São Paulo: Martins Fontes, 2002, p.82.

${ }^{27}$ No ano 1954, Muratori fora convidado a voltar para Roma, para suceder Armando Foschini na cadeira de "Composição Arquitetônica" - cf. CATALDI, C., MAFFEI, G. L., VACCARO, P. Saverio Muratori and the Italian school of planning typology. In: Urban Morphology, 6(1), p.3-14, 2002.

${ }^{28}$ SAINZ GUTIÉRREZ, op. cit., 2006, p.29-30

${ }^{29}$ Veja-se, a título de exemplo, os escritos de Rossi em colaboração com Polesello em: ROSSI, A. Para una Arquitectura de Tendencia. Escritos 1956-1972. Barcelona: GG, 1977a.

${ }^{30}$ SAINZ GUTIÉRREZ, op. cit., 2006.

${ }^{31}$ Uma parte introdutória deste estudo pode ser encontrada no capítulo "Contribución al problema de las relaciones entre tipología construtiva y la morfología urbana" de "Para una Arquitectura de Tendeza" (Rossi, op. cit., 1977a)

${ }^{32}$ SAINZ GUTIÉRREZ, op. cit., 2006.

${ }^{33}$ AYMONINO, 1980, apud SAINZ GUTIÉRREZ, 2006.
} 
análise tipo-morfológica ${ }^{34}$. Entretanto, a colaboração entre estes arquitetos encerra-se em 1966, com a contratação de Rossi pelo Politécnico de Milão, no mesmo ano em que se publica a primeira edição de "L'Architettura della città".

Retomando o objeto de interesse, não se trata de abordar aqui, uma vez mais, as distintas influências manifestas naquele livro que - juntamente com "Complexity and Contradition in Architecture" de Venturi - se tornaria uma das referências mais importantes na revisão do movimento moderno ${ }^{35}$. Ao contrário, interessa-nos compreender até que ponto o Aldo Rossi que visitou a América Latina pode ser compreendido a partir da leitura deste livro. Segundo Saint Gutierrez, Rossi e o grupo milanês - assim como Aymonino e os venezianos - iriam, progressivamente deslocar seu centro de interesse do urbanismo para a arquitetura ${ }^{36}$. Neste sentido, o autor espanhol destaca o fato de que no epílogo da edição alemã de "Arquitetura da Cidade", de 1973, Rossi tenha escrito que este livro era "um projeto de arquitetura", sem qualquer modificação no texto original que fora apresentado em 1966 como um "esboço de uma teoria urbana fundamentada" ${ }^{37}$. As asserções às quais se dedicava o último capítulo daquele livro já pareciam, portanto, um pouco distantes em meados dos anos 1970. Um deslocamento semelhante do olhar para cidade através da arquitetura também poderia ser comprovado por meio do capítulo "Projeto arquitetônico e formação da cidade" que compõe o livro "O significado das Cidades" de Aymonino, publicado originalmente em $1975^{38}$.

Para além dos estudos dos arquitetos da Tendenza, a publicação do texto de Argan "On the Typology of de Architecture" na Architectural Design, em 1963, é correntemente afirmada como o marco da renovação do interesse pela tipologia ${ }^{39}$. Contudo, foi o Plano para o Centro Histórico de Bolonha o responsável por revelar internacionalmente as possibilidades de aplicação dos estudos tipo-morfológicos.

\footnotetext{
${ }^{34}$ Cf. CASTEX, J. Histoire de la forme urbaine. In : Castex et al. Histoire Urbaine, antropologie de I'espace. Paris : CNRS Editions, 1995.

${ }^{35}$ Ver, entre outros, MARTIN, Reinhold. Utopia's Ghost. Architecture and Postmodernism, again. London/Minneapolis: University of Minnesota Press, 2010.

${ }^{36}$ SAINZ GUTIÉRREZ, op. cit., 2006.

${ }^{37}$ SAINZ GUTIÉRREZ, op. cit., 2006, p.38.

${ }^{38}$ AYMONINO, Carlo. O significado das cidades. Lisboa: Editorial presença, 1984.

${ }^{39}$ Trata-se de uma afirmação corrente, para tanto, verificar em: ELLIN, op. cit., 1996 e NESBITT, Kate. Uma nova Agenda para a Arquitetura. Antologia Teórica 1965-1995. São Paulo: Cosac Naify, 2006.
} 
Desenvolvido em 1969, sob a coordenação de Cervellati e Scannavini, este plano logo se converteu em ícone e foco dos debates, pois permitia a aproximação entre as posturas políticas do Partido Comunista Italiano e os postulados arquitetônicos do grupo de Veneza ${ }^{40}$. Segundo Lucan ${ }^{41}$ e Cohen ${ }^{42}$, as excursões de estudantes e arquitetos franceses à Bolonha tornam-se numerosas e frequentes no início da década de 1970, igualando-se às com destino para as cidades novas britânicas ${ }^{43}$.

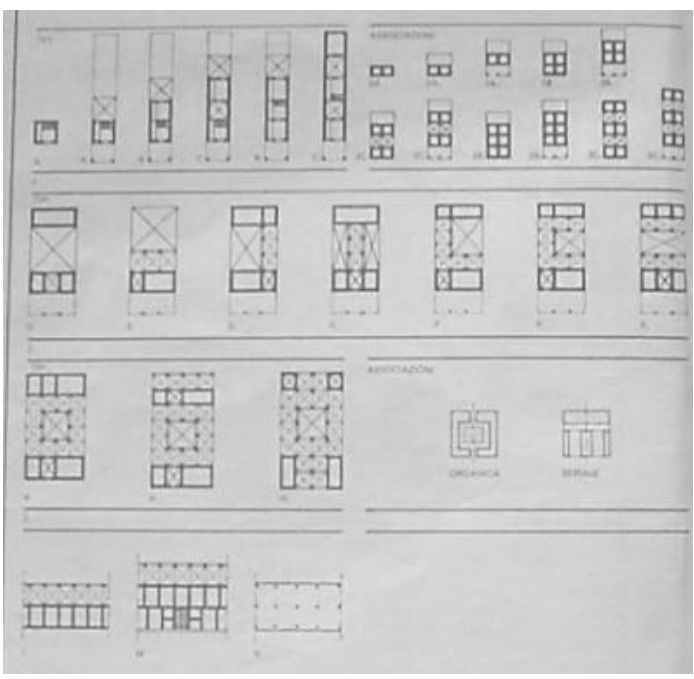

Figura 58: Estudos dos tipos edilícios encontrados em Bolonha. Fonte: CERVALLATI, P. L. Bolonia : política y metodología de la restauración de centros históricos. Barcelona: GG, 1976

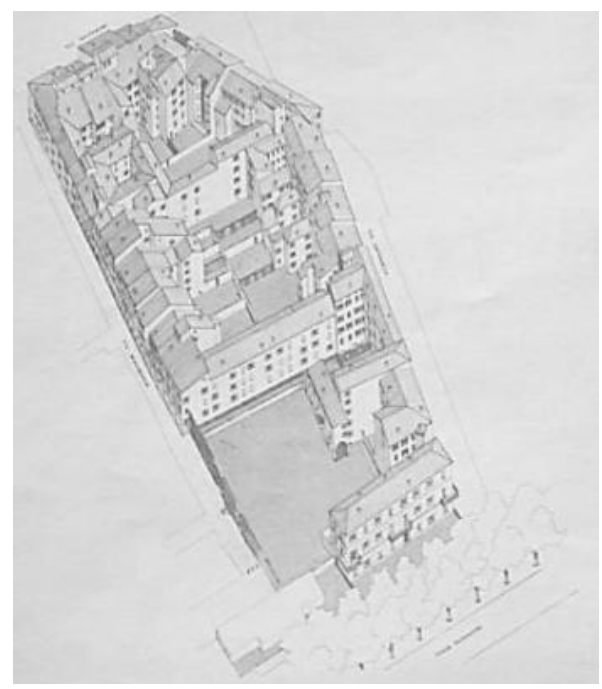

Figura 59: Perspectiva de quarteirão no bairro Solferino após restauração. Fonte: CERVALLATI, P. L., op. cit, 1976.

As viagens foram logo acompanhadas por publicações sobre processo de planejamento de Bolonha nas revistas francesas da primeira metade da década de 1970, entre as quais se destaca a edição especial da Architecture d'Aujourd'hui - de agosto de 1975, n.180 - dedicada aos centros históricos. Entretanto, Cohen salienta que mesmo "antes que as ideias dos teóricos italianos fossem publicadas em periódicos ou estudos, elas foram cristalizadas nas aulas e em exercícios pedagógicos" ${ }^{\prime 4}$.

A inserção das teorias italianas nas práticas dos ateliês deu-se em um contexto específico de renovação do ensino de arquitetura na França, que até o ano de 1968 ocorria dentro da Escola de Belas Artes. Os primeiros alicerces da reforma se

\footnotetext{
${ }^{40}$ Ver a este respeito: COHEN, J-L The italiophiles at Work. In: Hays (org). Architecture theory since 1968. Nova York : MIT Press, 1998.

${ }^{41}$ LUCAN, Jacques. Architecture en France (1940-2000). Paris : Le Moniteur, 2001.

${ }^{42}$ COHEN, J-L. loc. cit., 1998.

${ }^{43}$ COHEN, J-L. loc. cit., 1998.

${ }^{44}$ COHEN, J-L. loc. cit., 1998.
} 
manifestaram em $1963^{45}$, contudo, as manifestações de maio de 1968 acabaram por promover aceleração deste processo: ao final daquele mesmo ano decretava-se a extinção da seção "Arquitetura" da Escola de Belas Artes e criavam-se as chamadas "Unidades Pedagógicas" independentes que passariam a ser responsáveis pelo ensino daquela disciplina ${ }^{46}$. É dentro destas Unidades Pedagógicas (UP) recém-criadas que se dá a experimentação das teorias não somente advindas de Veneza e Milão, como também aquelas oriundas de Louis Kahn e da sociologia ${ }^{47}$.

Organizada por Bernard Huet, Devillers e Laisney, a UP 8 seria uma entre estas escolas. Não obstante sua institucionalização recente, o grupo que a compunha esboçara sua formação em 1966, quando Bernard Huet voltou de sua estadia nos EUA período em que fora aluno de Kahn - e criara um ateliê inicialmente independente da Escola de Belas Artes, o “Colégial 1"48. O interesse pela sociologia urbana e a divulgação dos estudos de Henri Lefebvre em Nanterre ${ }^{49}$ delineariam um importante papel às questões urbanas durante os anos de fundação da UP $8^{50}$. Dentro deste âmbito, a experiência de Bolonha aparecia como chave para a conciliação entre política e arquitetura.

Se, no entanto, a combinação entre a referência italiana, a sociologia urbana e os ensinamentos de Kahn caracterizaria, de modo geral, a prática pedagógica inicial na UP 8; seria a atuação de Bernard Huet como editor da revista Architecture d'Aujourd'hui, entre 1974 e 1977, que permitiria a ampliação da esfera de atuação dos debates nos quais seu corpo docente estava engajado. A primeira edição sob a nova coordenação na qual, por exemplo, publicou-se o artigo "Typologie de l'habitat et morphologie urbaine" de Christian Devillers - configuraria, segundo Cohen, "um ponto de virada da cultura arquitetônica francesa" ${ }^{51}$; nesta, a afirmação da ideia de urbanidade era

\footnotetext{
${ }^{45}$ cf. LUCAN, op.cit., 2001

${ }^{46}$ Ver: LUCAN, op. cit., 2001 e PORTOGHESI, Paolo. Depois da Arquitetura Moderna. São Paulo: Martins Fontes, 2002.

${ }^{47}$ MONTES, Fernando. Depoimento. [20 de dezembro de 2011]. Santiago do Chile: Arquivo digital da gravação (58min.). Entrevista concedida a Gisela Barcellos de Souza.

${ }^{48}$ Ver: LUCAN, op. cit. 2001 e PORTOGHESI, op.cit. 2002.

${ }^{49}$ Referimo-nos aqui à investigação que Lefebvre coordenou entre 1966 e 1973 sobre os conjuntos habitacionais de Nanterre, cujos primeiros resultados foram publicados em 1967, na Architecture d'Aujourd'hui n.132.

${ }^{50}$ COHEN, J-L. loc. cit., 1998.

${ }^{51}$ COHEN, J-L. loc. cit., 1998.
} 
associada à divulgação de postulados tipo-morfológicos. A passagem de Huet pela Architecture d'Aujourd'hui marcou, também, a ampliação do conhecimento dos autores italianos ${ }^{52}$ na França e o estabelecimento paulatino de um intercâmbio entre estes dois países. Neste contexto, a edição de números especiais daquela revista - como o "Italie $75^{\prime \prime}$ - se constituiria em apenas um dentre os diversos testemunhos existentes desta rede de $\operatorname{trocas}^{53}$. Se este encontro cultural poderia, inicialmente, parecer desigual, logo contribuições francesas também surgiriam em revistas italianas - Grumbach, por exemplo, passa a ser oficialmente colaborador da Lotus, a partir de 1978.

Malgrado a importância do debate fomentado por Bernard Huet e seu grupo - e a atenção internacional, graças a sua veiculação na Architecture d'Aujourd'hui, que este recebeu -, foi na Unidade Pedagógica estabelecida em Versalhes (UP 3) que foram realizados as primeiras pesquisas sobre tipo-morfologia que alcançariam uma maior projeção para além das fronteiras francesas. Publicadas pela primeira vez em 1975, as investigações realizadas pelo grupo de Panerai e Castex "Formes Urbaines: de l'îlot à la Barre" e "Principes d'Anlyse Urbaine" seriam percebidos, segundo Manuel de SolàMorales, como a "pedra angular" da abordagem da cidade partir da arquitetura ${ }^{54}$. Através destes trabalhos, como viria a destacar Panerai, diversos intercâmbios internacionais foram estabelecidos, inclusive com alguns latino-americanos: Carlos Eduardo Comas e Sílvia Fischer, o Brasil; Alfonso Corona Martinez, na Argentina, Fernando Perez Oyarzun, no Chile, e Tomas Sprechmann, no Uruguai ${ }^{55}$.

Junto à outra Unidade Pedagógica que demonstraria uma orientação semelhante, encontrava-se uma das personagens que estabeleceria pontos contatos, em diferentes ocasiões, entre o debate europeu e aquele que se iniciava na América Latina no final dos anos 1970 e princípio dos anos 1980: trata-se do chileno Fernando Montes, que emigrara para França em meados dos anos $1960^{56}$. Organizada pelo grupo

52 O livro "Arquitetura da Cidade" só foi traduzido para o francês em 1981, porém este fato não impediu seu conhecimento antes desta data.

${ }^{53}$ Sobre estes intercâmbios, ver: COHEN, J-L. loc. cit., 1998.

${ }^{54}$ Referimo-nos aqui ao prefácio escrito por Solà-Morales à edição espanhola de 1986 do livro "Formes Urbaines: de l'îlot à la Barre", republicado na edição francesa de 1997.

$55 \mathrm{Na}$ apresentação à edição de 1999 de "Analyse Urbaine ", Panerai agradece às trocas frutuosas estabelecidas com colegas de diferentes escolas, dos quais destacamos os latinoamericanos. cf. PANERAl et al. Analyse Urbaine. Paris: Éditions Paranthèses, 1999.

${ }^{56}$ Fernando Montes formou-se na Universidad Católica de Chile em 1962 e, logo em seguida, foi para Europa a fim de complementar seus estudos. Trabalhou um tempo na Inglaterra e, em 1964, 
de Grumbach, Montes e Castro, a chamada UP 6 esta foi, segundo Fernando Montes, a escola de arquitetura que possuiu maior engajamento político em seus primeiros anos de funcionamento ${ }^{57}$. Os vínculos estreitos com maio de 68 foram decisivos para que se postulasse a ausência de projeto nas séries inicias de formação do arquiteto. Entretanto, este direcionamento inicial foi logo revisto pelos supracitados professores nos anos seguintes e o retorno ao projeto foi proposto vinculado ao "Retorno à Cidade" ${ }^{58}$. Montes, aliás, um dos responsáveis por organizar a retomada da exposição da Bienal de Veneza de 1980 - "Strada Novissima" - no ano seguinte em Paris, na capela Salpêtrière, sob o título "La présence de I'histoire. L'après-modernisme" ${ }^{\prime 59}$. Juntas, as UP 6, UP 8 e UP 3 estabeleceriam intercâmbios com profissionais e instituições em outros países europeus.

Entre estes, salienta-se o desenvolvido ao longo dos anos 1970, com Escola de Arquitetura La Cambre (em Bruxelas) e com movimento fomentado pela ação direta de Maurice Culot e Léon Krier - a chamada "Resistência Antiindustrial". As diferenças existentes entre o debate francês sobre o "Retorno à Cidade" e o movimento de resistência bruxelense são agudas e dificilmente menosprezáveis. Entretanto, a proximidade facilitada pela língua e pela atuação propagandística de Culot através do Archives d'Architecture Moderne (AAM) ${ }^{60}$ permitiu o estabelecimento de contatos e trocas no âmbito acadêmico. Ao longo dos anos 1970, Huet, Devillers, Montes, Panerai e Castex foram à Bruxelas, em distintas ocasiões, a fim de participar das bancas de avaliação trabalhos em La Cambre ${ }^{61}$ - ocasiões nas quais se associavam também Scolari e Léon Krier.

foi desenvolver estudos de pós-graduação em Karlsruhe, sob a orientação de Egon Eiermann. Em 1965, começa a trabalhar com Candilis na França, país no qual se estabeleceu desde então. Cf.MONTES, Fernando. Depoimento. [24 de novembro de 2011]. Santiago do Chile: Arquivo digital da gravação (2hora e $8 \mathrm{~min}$.). Entrevista concedida a Gisela Barcellos de Souza.

${ }^{57}$ MONTES, Fernando. Depoimento. [24 de novembro de 2011]. loc. cit.

${ }^{58}$ MONTES, Fernando. Depoimento. [24 de novembro de 2011]. loc. cit.

59 JENCKS, Charles et al. Presents of the past - revisiting the 1980 Venice Biennale. In: Architectural Design. Londres: Architectural Design, vol. 52, no. 1/2, 1982, p. 2-24.

60 Referimo-nos tanto à casa editorial como à revista homônima. Sobre a Resistência Antiindustrial de sua atuação, ver: SOUZA, G. B. Re-Dizer e Des-dizer: o Novo Urbanismo Europeu in: Topos (Belo Horizonte), v. 4, pp. 113-123, 2005.

${ }^{61}$ Informação presente em Ellin (op. cit., 1996) e confirmada em entrevista com Fernando Montes: MONTES, Fernando. Depoimento. [20 de dezembro de 2011]. loc. cit. 
Vinculada à atuação da militância esquerdista belga, a "Resistência Antiindustrial" teve como um de seus grandes feitos - amplamente divulgado através da revista AAM a mobilização dos habitantes do bairro de Marolles, em Bruxelas, contra a renovação urbana que the era proposta pela municipalidade - episódio que ficou conhecido como a "Batalha de Marolles", de 1969. Este movimento apoiava-se em leituras das relações tipo-morfológicas a fim de denunciar a destruição, promovida pela expansão capitalista, dos aspectos físicos e sociais que caracterizavam os tecidos urbanos constituídos anteriormente à revolução industrial ${ }^{62}$. Para os arquitetos engajados neste movimento havia apenas duas alternativas possíveis: ou o engajamento nas lutas urbanas, a fim de retardar o processo de destruição; ou o desenvolvimento de um trabalho teórico que servisse de apoio estratégico àquelas ${ }^{63}$. A vinculação de Léon Krier - professor da Architectural Association entre 1974 e 1977 - à Resistência Antiindustrial deu-se ao longo da década de 1970, entre suas visitas frequentes à Escola La Cambre. Nestas, Krier participou diretamente da elaboração das chamadas "contrapropostas" - propostas de intervenções alternativas às da municipalidade a fim de motivar o engajamento da população. Segundo Montes, a escola bruxelense era aberta à população e ao restante da Europa:

La Cambre, imediatamente, encontrou algumas frentes de batalha. Neste momento, se estava construindo o primeiro edifício da União Europeia, feito de uma forma muito cosmopolita, muito burocrática em uma cidade que não tinha este caráter. [...] Todos os temas como este [ou seja, as batalhas da escola], se plasmavam em todos os programas de La Cambre e na produção de projetos de estudantes, inclusive nos projetos de conclusão de curso, [... que tinham uma] qualidade extraordinária. [...] Quem era o motor disto tudo era Léon Krier. Léon estava sempre muito presente em La Cambre, ele passava muito tempo lá. ${ }^{64}$

Frequentemente associadas às de Rob $\mathrm{Krier}^{65}$, as ideias de Léon diferem daquelas de seu irmão justamente em sua vinculação a um projeto ideológico que o leva

\footnotetext{
${ }^{62}$ BAREY, André. Propos sur la reconstruction de la ville européenne : Déclaration de Bruxelles. Bruxelas: Archives d'Architecture Moderne, 1980.

${ }^{63}$ CULOT, Maurice; KRIER, Léon. The Only Path for Architecture. Oppositions, New York: MIT Press, n.14, fall 1978. p.39-53

${ }^{64}$ MONTES, Fernando. Depoimento. [20 de dezembro de 2011]. loc. cit.

${ }^{65}$ Cf. PORTOGHESI, op. cit, 2002, e GRUMBACH, Antoine. I fratelli Krier/The Krier Brothes. In:
} 
a afirmar a impossibilidade de construir sem contribuir para o sistema capitalista e o processo de destruição das cidades ${ }^{66}$. Para o autor de Stadtraum o engajamento político não é tão evidente; ainda que seja possível entrever em suas páginas uma "conexão romanticamente marxista de corte italiano" ${ }^{67}$, Rob Krier expõe uma "indignação controlada e canalizada na publicação de uma Enciclopédia espaços urbanos [...] [e] opera com aparente ingenuidade" ${ }^{\prime 68}$. Ao invés de responsabilizar o modo de produção capitalista, Rob Krier vislumbra na própria história da arquitetura o enraizamento da perda do espaço urbano que identifica no urbanismo moderno:

Eu quero demonstrar, dentro deste histórico, que a evolução que viria a influenciar fortemente o urbanismo moderno, não foi iniciada sem preparo: ela se funda dentro de um longo prelúdio de teorias arquitetônicas, cuja origem remonta provavelmente à arquitetura das villas dos séculos XVI e XVII. Não é por acaso que nós consideramos ainda que a villa isolada é, em geral, o tipo ideal de residência. O único problema é que nós não poderemos jamais construir uma cidade contentando-se em adicionar este tipo de habitação ${ }^{69}$.

Apesar das diferenças na forma de compreender as causas do que ambos definiam como a destruição da cidade e como em que contexto sua reconstrução seria possível, a associação entre os irmãos Krier não foi fortuita. De fato, ela foi, por diversas vezes buscada como forma de retroalimentação. Veja-se, a título de exemplo menção a Léon nas palavras finais do livro de Rob sobre o espaço urbano: "Meu irmão, que leciona em Londres, me ajudou a esclarecer estas noções teóricas essenciais" ${ }^{\prime 70}$

Se, por um lado, a associação entre as ideias de ambos os irmãos também se verifica no contexto latino-americano ${ }^{71}$; por outro, para o grupo de arquitetos chilenos do CEDLA não apenas reconheciam a diferença entre ambos, como buscava, em seus

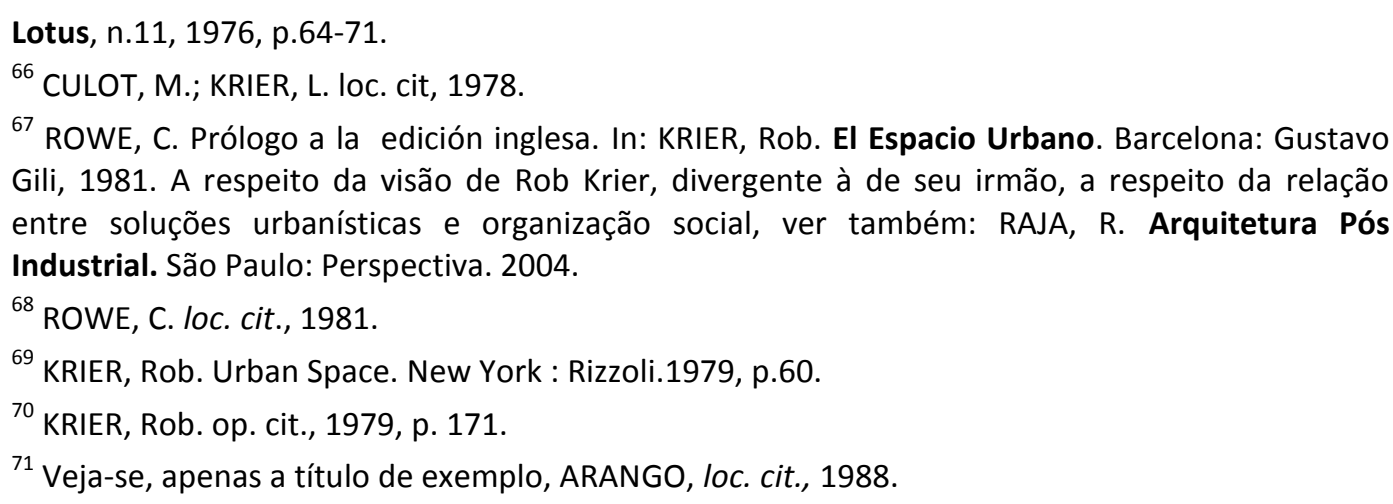
Gili, 1981. A respeito da visão de Rob Krier, divergente à de seu irmão, a respeito da relação entre soluções urbanísticas e organização social, ver também: RAJA, R. Arquitetura Pós Industrial. São Paulo: Perspectiva. 2004.

${ }^{68}$ ROWE, C. loc. cit., 1981.

${ }^{69}$ KRIER, Rob. Urban Space. New York : Rizzoli.1979, p.60.

${ }^{70}$ KRIER, Rob. op. cit., 1979, p. 171.

${ }^{71}$ Veja-se, apenas a título de exemplo, ARANGO, loc. cit., 1988. 
primeiros anos de atuação, explicitar o contato direto que Boza e Eliash tinham com Léon $\mathrm{Krier}^{72}$. Neste contexto, três chilenos parecem ampliar a possibilidade de diálogo entre estes dois mundos: Fernando Montes - em cujos artigos publicados nos primeiros números da revista $A R S$ verificam-se sempre referências ao grupo de Léon Krier e Culot $^{73}$ -; Rodrigo Perez de $\operatorname{Arce}^{74}$ e, em menor intensidade, René Davids ${ }^{75}$.

Rodrigo Perez de Arce e René Davids graduaram-se pela Universidad Católica de Chile, em 1972 - ou seja alguns anos antes de Humberto Eliash - e ambos foram a Londres complementar sua formação, o primeiro logo após a graduação e o segundo em 1976. Rodrigo Peréz de Arce fez uma pós-graduação de dois anos na Architectural Association (AA), onde fora aluno de Léon Krier. No ano letivo de 1978/79, começou a lecionar nesta mesma escola, dividindo a disciplina com René Davids - que acabava sua pós-graduação na Royal College of $\mathrm{Arts}^{76}$. A disciplina ministrada por Pérez de Arce e Davids buscou dar continuidade ao programa neorracionalista - "A Cidade Possível" - e a abordagem didática ${ }^{77}$ que caracterizou $\mathrm{o}$ atelier que fora coordenado por Krier durante os três anos em que este lecionou na $\mathrm{AA}^{78}$.

A relação com o mestre luxemburguês permitiu, também, que os trabalhos de Rodrigo Pérez de Arce fossem publicados na edição da AD Profiles organizada por Léon

${ }^{72}$ Cf. BOZA, C., KRIER, L. Léon Krier: su pensamiento frente a la ciudad. In: ARS, n.1, 1978, p.3541.

${ }^{73}$ Cf. MONTES, Fernando. Santiago Poniente: en torno a su remodelación. In: CEDLA. Santiago: CEDLA, ago. de 1977, 24-25.; MONTES, F. Modernidad e Inhibicion. In: ARS. Santiago do Chile: CEDLA, n.1, jul 1978 p.67-69; MONTES, F. Hacia uma arquitectura convencional. In: ARS, n.3, 1979, p.4-8.

74 Devido a maior proximidade com ambiente londrino de muitos dos latino-americanos que buscaram formações complementares no período, assim como pelo fato de ser um chileno na prestigiosa Architectural Association, Rodrigo Perez de Arce acaba assumindo uma importância maior no subcontinente. Tal asserção pode ser verificada em textos que, como o de Vicente del Rio (1992), dão grande destaque a Perez de Arce neste debate.

75 Há apenas uma única menção à René Davids na ARS - OYARZÚN K., Armando. Arquitectos chilenos extramuros: Dos Proyectos de René Davids. In: ARS, Santiago de Chile: CEDLA, n.4, ago 1981, p.80-84.

${ }^{76}$ OYARZÚN K., A. loc. cit,1981.

${ }^{77}$ Esta seria a orientação inicial do atelier de Perez de Arce e Davis, porém estes modificam um pouco sua posição nos programas posteriores. A respeito da atuação docente de Perez de Arce pela Architectural Association, ver: HIGGOTT, Andrew. Mediating Modernism. Architectural cultures in Britain. Nova York: Routledge. 2007.

78 Léon Krier fora professor da Architectural Association, entre 1974 e 1977, no contexto de fomento à diversidade de opiniões que caracterizou o período em que esta esteve sob a direção de Boyarsky - cf. HIGGOTT, op. cit., 2007. Diversos autores, além de Higgott, destacam o aspecto didático de Léon Krier, a respeito, ver também: LUCAN, op.cit, 2002. 
Krier em 1978, intitulada "Urban Transformations"79. Na introdução que escreveu para esta edição, Krier associava o trabalho docente que desenvolvera junto à AA às críticas da Resistência Antiindustrial, apontava Rodrigo Perez de Arce como parte da nova geração que buscava uma alternativa para a destruição das cidades e afirmava que seus desenhos analíticos permitiam a formulação de poderosos manifestos ${ }^{80}$. Não obstante seu caráter amplamente didático e o respaldo do antigo mestre, as formulações de Perez de Arce não parecem ter encontrado nos países anglo-saxões a mesma aceitação que demonstraram ter na América Latina. Deve-se pontuar que, naqueles países, o debate sobre a tipo-morfologia se afirmaria somente na década seguinte e dentro do enquadramento universitário ${ }^{81}$.

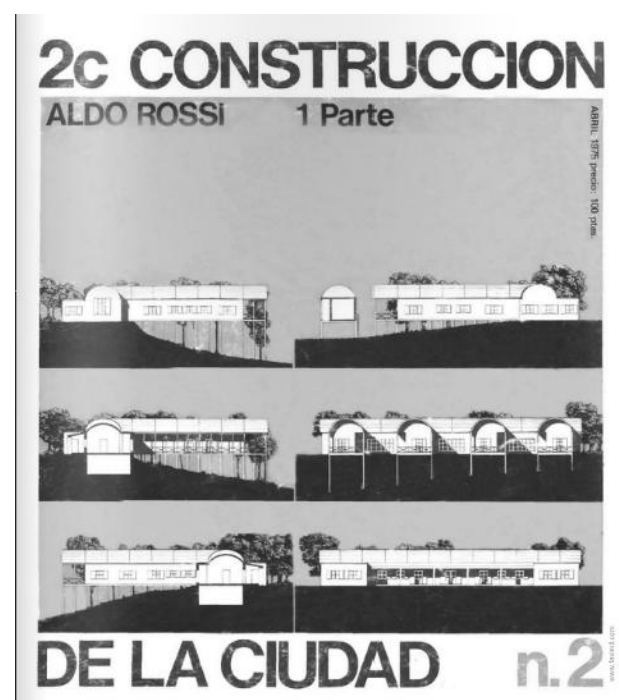

Figura 60: Capa da edição número 2 de abril de 1975 da revista 2c Construcción de la Ciudad -, revista catalã vigente entre 1972 e 1985 . Fonte: fotografia da autora.

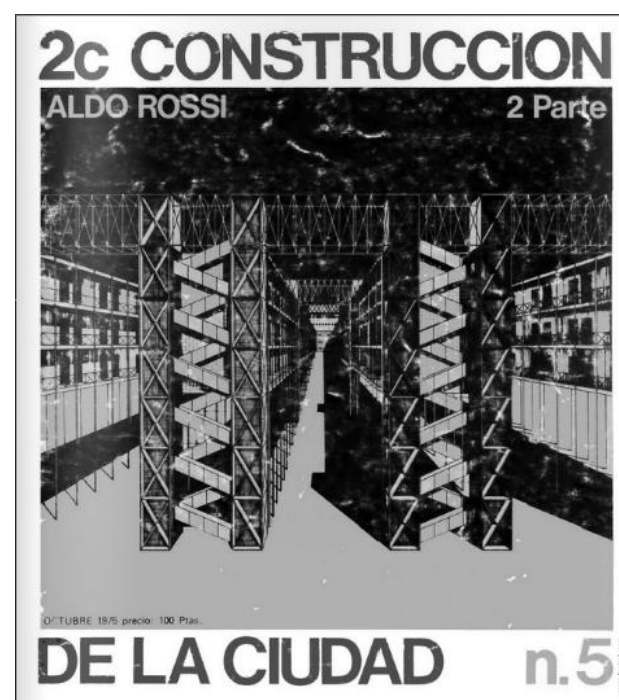

Figura 61: Capa da edição número 5 de outubro de 1975 da revista 2c Construcción de la Ciudad. Fonte: fotografia da autora.

Ao contrário do que se observava nos países anglo-saxões, no sul da Europa manifestaram-se intercâmbios profícuos em torno da tipo-morfologia ao longo da década de 1970. Entre a Espanha e a Itália do Pós-guerra - e, mais especificamente, entre Milão e a região da Catalunha - estabeleceu-se um diálogo assíduo que permitiu o florescimento do interesse pela tipo-morfologia em terras espanholas já no final dos anos 1960. A primeira tradução do livro "A Arquitetura da Cidade" de Rossi, por exemplo, foi para a língua espanhola, publicada pela editora Gustavo Gili, em 1971, e

\footnotetext{
${ }^{79}$ KRIER, Léon (ed.) Urban Transformation. AD Profiles. v.48, n.4, 1978, p.119-221.

${ }^{80}$ KRIER, Léon. The Blind Spot. In: KRIER, Léon (ed.) Urban Transformation. AD Profiles. v.48, n.4, 1978, p.119-221.

${ }^{81}$ Cf. PANERAI, Ph. , MANGIN, D. op. cit., 2005
} 
elaborada por Salvador Tarragó - quem, na condição de editor da revista 2c, organizou três números monográficos sobre o arquiteto italiano entre 1975 e $1979^{82}$.

Como afirmava Bohigas, em 1978, o impacto que a arquitetura italiana do Pósguerra obteve na Europa "afetou de maneira particular a Catalunha, onde, por assim dizer, se cristalizou" ${ }^{\prime 33}$. Nos anos 1950, a revista Casabella, sob direção de Ernesto Rogers, se convertera na revista mais influente entre os arquitetos catalães ${ }^{84}$. Na década seguinte, repercussões dos debates italianos fizeram-se também presentes no urbanismo catalão e serviram de base a muitas das críticas que foram feitas aos "polígonos" 85 - forma como foram chamados na Espanha os conjuntos habitacionais desconectados do tecido urbano. Neste contexto, destacaram-se Bohigas e Tusquets como os responsáveis pelas críticas mais contundentes.

O protagonismo de Bohigas na cultura arquitetônica catalã se afirmara ainda no final anos 1950 - mesmo período em que se dá a dissolução do Grup $R$ do qual fora um dos fundadores. Em meados da década de 1960, na condição de colaborador da revista Serra d'Or, Bohigas fora um dos primeiros catalães a apontar as limitações do urbanismo concebido dentro dos parâmetros da Carta de Atenas como um dos problemas que se manifestava nos "polígonos" ${ }^{86}$. A projeção internacional de Bohigas viria antes mesmo do período em que este esteve à frente do departamento de urbanismo de Barcelona (1980-84). Ainda nos anos 1970, esta pode ser testemunhada em exemplos tão distintos quando o fato de este arquiteto catalão passar a compor a equipe de colaboradores da revista italiana Lotus a partir de seu número 8, de setembro de 1974 - momento em que esta publicação da Electa, buscando maior projeção internacional, passa a se chamar Lotus International e a assumir o formato bilíngue -, como, também, o desenvolvimento de projetos para além das fronteiras ibéricas, como o Parque España, em Rosário (Argentina) em $1979^{87}$.

${ }^{82}$ A revista 2c. Construcción de la Ciudad, coordenada por Salvador Tarragó e Carlos Martí, teve vigência entre 1972 e 1985 e contou com 22 números publicados nestes período.

83 BOHIGAS, Oriol. Casabella e la cultura architettonica spagnola negli anni 50. In: Casabella, Milão: Electa. n.440-441, 1978, p.87.

${ }^{84}$ SAINZ GUTIÉRREZ, op. cit, 2006.

${ }^{85}$ SAINZ GUTIÉRREZ, op. cit, 2006.

${ }^{86}$ SAINZ GUTIÉRREZ, op. cit, 2006, p.72.

${ }^{87}$ Ver a respeito: JAJAMOVICH, Guillermo. Rosario y sus vínculos con el debate internacional: un análisis del Parque España (1979-1993). In: Arquitextos, n. 115.06, dez 2009 < http://www.vitruvius.com.br/revistas/read/arquitextos/10.115/7/es> acessado em: 12 out 2011. 
Se, por um lado, as críticas aos polígonos constituíram o meio propício ao eco das teses rossianas entre os arquitetos catalães; por outro, a contribuição espanhola efetiva para a compreensão das relações entre tipos edilícios e morfologia urbana deuse através do Laboratório de Urbanismo de Barcelona (LUB) e da figura de Manuel de Solà-Morales, seu coordenador a partir de 1968. Ao assumir, neste mesmo ano, a disciplina de urbanismo na Escola de Arquitetura de Barcelona, Solà-Morales empreendeu o projeto de ensinar um "urbanismo para arquitetos" 88 - expressão que viria caracterizar o interesse pela tipo-morfologia na Espanha. $\mathrm{Na}$ busca pela especificidade disciplinar, o LUB foi responsável pelas primeiras traduções para o espanhol de textos de Gregotti, Rossi e Aymonino ${ }^{89}$. Contudo, ao contrário daqueles, os trabalhos desenvolvidos junto ao LUB deram maior ênfase à forma urbana como processo e à contribuição das redes de infraestrutura ${ }^{90}$.

Para completar nosso percurso falta-nos ainda discorrer sobre as figuras de Kleihues - coordenador da Neubau da IBA - e Ungers. Segundo Bronstein, ao final dos anos 1970, "juntamente com Oswald Mathias Ungers, Kleihues é tido como personagem central do cenário alemão no que diz respeito à crítica mais operativa aos planejamentos urbanos do segundo pós-guerra" ${ }^{\prime 11}$.

No contexto de fechamento ao debate internacional da Alemanha do segundo pós-guerra, estes dois arquitetos foram responsáveis pelos primeiros pontos de conexão que permitiram trocas para além das fronteiras germânicas. Ungers estabelecera seus primeiros contatos com Rossi, Colin Rowe e Frampton ainda no final dos anos 1960, o que Ihe permitiu, entre outros, sua inserção na Trienal de Milão de 1973 e a publicação de alguns de seus projetos nos anos seguintes na Casabella e na Controspazio ${ }^{92}$. Kleihues, por sua vez, com uma atuação e uma trajetória majoritariamente acadêmica, fora responsável pela curadoria da primeira "Exposição de Arquitetura de Dortmund"

\footnotetext{
${ }^{88}$ SAINZ GUTIÉRREZ, op. cit, 2006.

${ }^{89}$ SAINZ GUTIÉRREZ, op. cit, 2006.

${ }^{90}$ SOLÀ-MORALES, Manuel. Las formas de crecimiento urbano. Barcelona: Ediciones UPC, 1997.

91 BRONSTEIN, L. Fragmentos de uma crítica : Revisando a IBA de Berlim. Tese de Doutorado. Universitat Politecnica de Catalunya, 2002, p.45;

92 BRONSTEIN, L., op. cit. 2002.
} 
em 1976, na qual foram exibidas obras de Aldo van Eyck, Hans Hollein, Isozaki, Charles Moore, Aldo Rossi, Oswald Mathias Ungers, James Stirling e Robert Venturi ${ }^{93}$.

Apesar de assumirem papel semelhante de mediadores entre 0 debate internacional e a cultura arquitetônica alemã dos 1970, ambos, Ungers e Kleihues, se apropriaram do debate sobre a tipo-morfologia de modos distintos. Enquanto para o primeiro a morfologia é um entre os seus temas de investigação arquitetônica, aquele que "permite reunir opostos aparentemente irreconciliáveis" ${ }^{14}$ através do princípio da transformação; para o segundo, a referência àquela fundamenta suas críticas ao planejamento urbano desvinculado da arquitetura e a proposição do "redescobrimento da história da cidade como precondição de projeto" e do traçado existente como base constante para intervenções futuras ${ }^{95}$.

\section{Encontros e leitmotiven}

A despeito da considerável distância entre os debates locais acima descritos, tentativas de reconhecimento e de afirmação de traços comuns internacionais foram colocadas em pauta logo nos primeiros anos da década de 1970. Esta prática teria continuidade ao longo desta década, em uma série de eventos que visaram estabelecer vínculos.

O primeiro dentre estes foi a Mostra Internacional de Arquitetura, organizada por Aldo Rossi, junto à XV Trienal de Milão em 1973, que viria a ser conhecida pelo título do livro que a compunha: "Architettura Razionale". Em texto introdutório a este livro, Rossi reconhecia a importância das exposições na cultura arquitetônica e afirmava buscar repetir os efeitos de trienais milanesas anteriores ${ }^{96}$ através da exposição de projetos "estreitamente relacionados com a cidade, que afrontam através do projeto os problemas urbanos" ${ }^{\prime 97}$. Sob esta perspectiva, enquadraram-se arquitetos tão distintos quanto Aldo Rossi, Massimo Scolari, Enzo Bonfanti, James Stirling, Ungers, Venturi, Rob

\footnotetext{
${ }^{93}$ BRONSTEIN, L., op. cit. 2002.

${ }^{94}$ UNGERS, O. M. Architecture come theme/ Die Thematisierung der Architektur. Paris: Electra Moniteur, 1983.

${ }^{95}$ BRONSTEIN, L., op. cit. 2002.

${ }^{96}$ Rossi destaca na introdução ao catálogo da exposição o papel das V, VI e VII Trienais de Milão para a arquitetura racionalista italiana - ROSSI, A. Introducción. In: BONFANTI, E. et al. Arquitectura racional. Madri: Alianza Editorial, 1979, p.11-22.

${ }^{97}$ ROSSI, A. Introducción. In: BONFANTI, E. et al. Arquitectura racional. Madri: Alianza Editorial, 1979, p.20.
} 
e Léon Krier, os então chamados de New York Five - Peter Eisenman, Michael Graves, Charles Gwathmey, John Hejduk e Richard Meier -, dentre outros ${ }^{98}$. Rossi afirmava na ocasião que a seção de arquitetura da Trienal era "o marco de uma nova situação que há tempo estava amadurecendo na Europa e no mundo e que permitiu (...) fixar algumas posturas" ${ }^{\prime \prime 9}$.

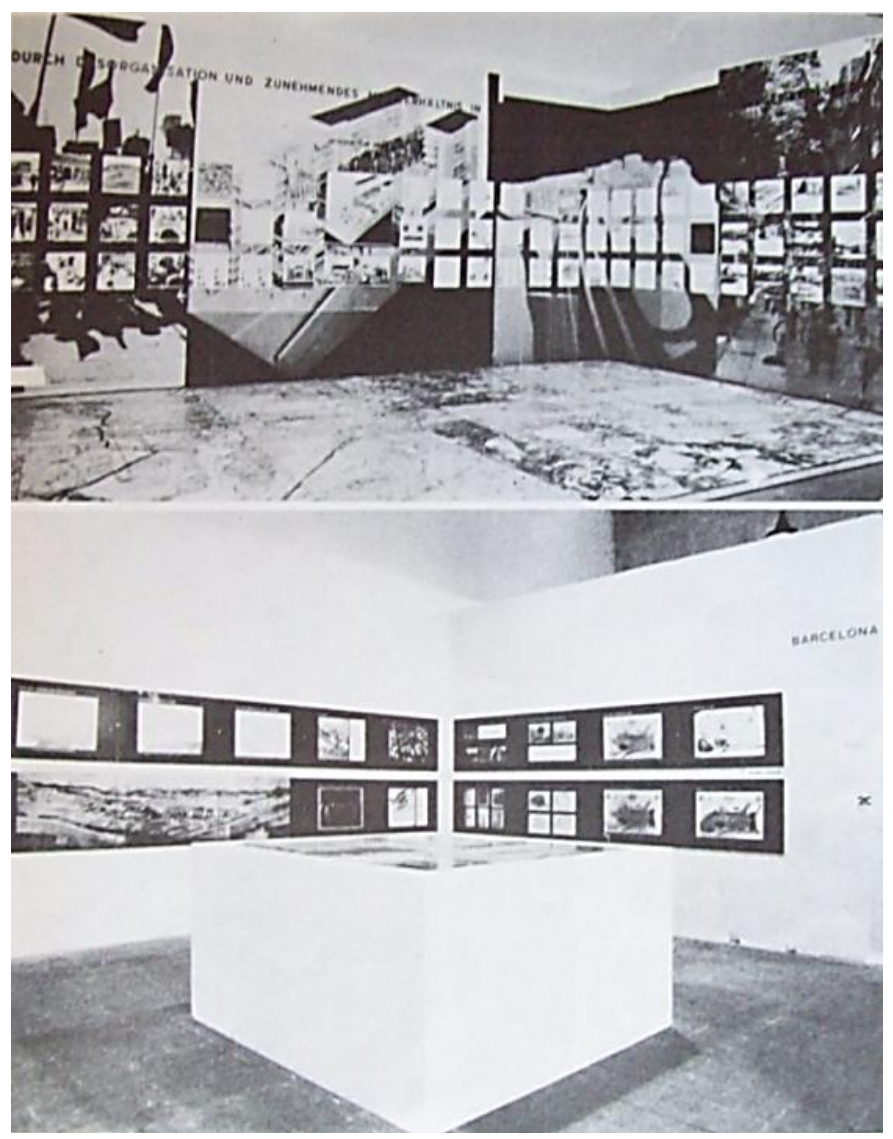

Figura 62: Fotografia dos trabalhos sobre Berlim apresentados na exposição de arquitetura organizada por Aldo Rossi junto à XV Trienal de Milão de 1973. Abaixo: análise da história urbana de Barcelona elaborada pelo grupo 2c Fonte: Revista 2C, n.2, 1975, p.15.
Figura 63: Análise da história urbana de Barcelona elaborada pelo grupo 2c exposta na mostra de arquitetura organizada por Aldo Rossi junto à XV Trienal de Milão de 1973. Abaixo: Fonte: Revista 2C, n.2, 1975, p.15.

Esta mesma estratégia seria repetida e ampliada em outro contexto, apenas dois anos depois. Referimo-nos a exposição Rational Architecture, organizada por Léon Krier em Londres no ano de 1975. A retomada da exposição italiana em contexto londrino não foi, certamente, desinteressada; pretendia-se, através dela, afirmar a existência de um movimento. Como afirmaria Ellin, "quando o neorracionalismo migrou para o norte da Europa, seus componentes urbanísticos envolveram-se no Movimento para Reconstrução da Cidade Europeia" ${ }^{100}$. Nesta exposição, portanto, foram apresentados como representantes a um mesmo movimento: Aymonino, Rossi, Scolari, Stirling,

\footnotetext{
${ }^{98}$ GRUMBACH, Antoine. I fratelli Krier/The Krier Brothes. Lotus, n.11, pp.64-71, 1976.

${ }^{99}$ ROSSI, A. Sección de Arquitectura de la XV Trienal. 2C, n.2, pp.12-15, 1975.

${ }^{100}$ ELLI,N., op. cit., 1996, p.27.
} 
Ungers, Koolhaas, Zenghelis, Kleihues, Huet, Montes, Grassi, Gregotti, Léon Krier, Rob Krier, Perez de Arce, Portzamparc, Manuel de Solà-Morales, entre outros.

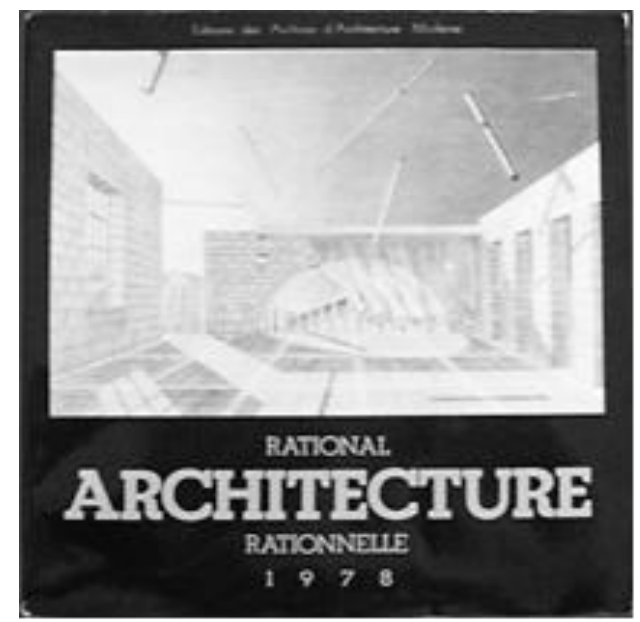

Figura 64: Capa do catálogo bilíngüe "Rational Architecture/Architecture Rationnelle", publicado em 1978 pela AAM, referente à exposição homônima realizada em Londres, em 1975. Fonte: Fotografia da autora.

No texto que escreveu para o catálogo da exposição, Léon Krier procurou explicar os critérios para inclusão de novos arquitetos na mostra e a exclusão de outros. Tratava-se de selecionar os projetos representativos de um "novo movimento arquitetônico, uma nova aproximação crítica face à renovação da Cidade Europeia" ${ }^{101}$. Por este motivo teria excluído arquitetos como Venturi e os New York Five que, segundo o curador, iriam "confundir os grandes temas anunciados pela Arquitetura Racional"102. Entre os projetos arquitetônicos reunidos na mostra, Krier asseverava existir uma mesma "reflexão sobre a cidade e sua história, sobre seu emprego e seu conteúdo social" e uma preocupação comum para com a "recriação do espaço público"103. Na introdução ao catálogo, Robert Delevoy - então diretor da Escola de Arquitetura La Cambre - procurava ampliar o contexto do movimento bruxelense para os demais países do continente; "o futuro se anunciaria somente no passado perdido" e a tipologia seria o instrumento para o seu resgate ${ }^{104}$.

101 KRIER, Léon. La Reconstruction de la ville. In: Krier (org) Rational Architecture: The Reconstruction of the European city/Architecture Rationnelle: La Reconstruction de la Ville Européenne, Bruxelles : A.A.M, 1978, p.34

${ }^{102}$ KRIER, Léon., op. cit., 1978, p.34.

${ }^{103}$ KRIER, Léon., op. cit., 1978, p.35.

104 DELEVOY, Robert L. Vers une Architecture. In : Krier (org) Rational Architecture :The Reconstruction of the European city/Architecture Rationnelle: La Reconstruction de la Ville Européenne, Bruxelles : A.A.M,, 1978, p.8. 


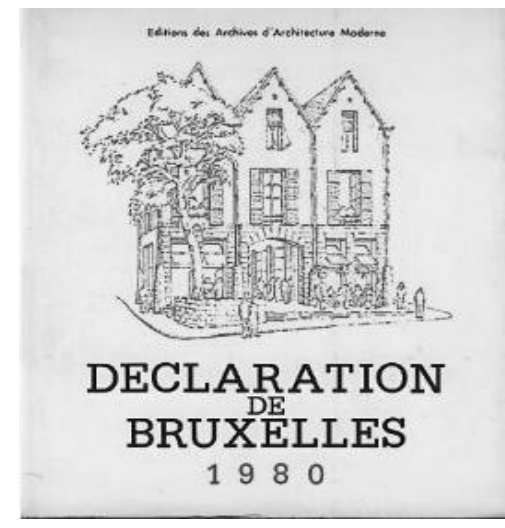

Figura 65: Capa do livro "Propos sur la reconstruction de la ville européenne : Déclaration de Bruxelles", organizado por Barey e publicado em 1980 pela AAM. Fonte: Fotografia do autor.

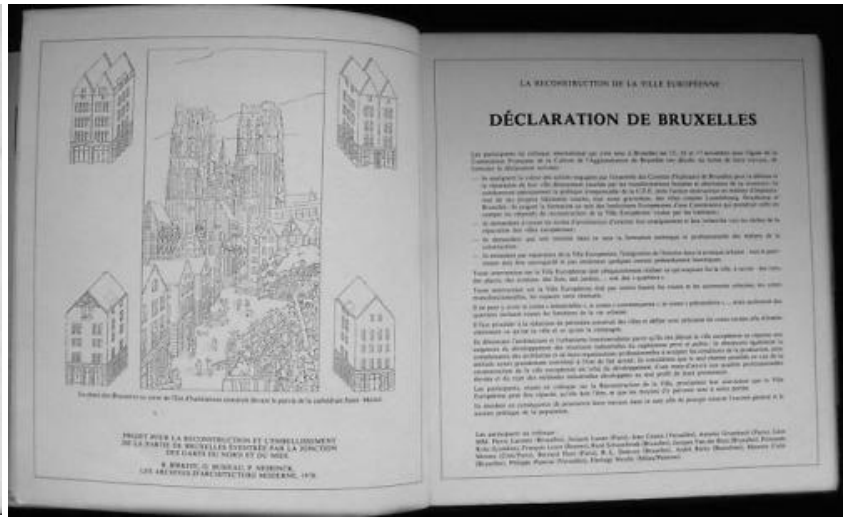

Figura 66: Publicação da Declaração de Bruxelas no livro "Propos sur la reconstruction de la ville européenne : Déclaration de Bruxelles", referente ao Colóquio "A Reconstrução da Cidade Europeia". Fonte: BAREY, A., op. cit., 1980.

Como desdobramento desta tentativa de afirmação de um movimento internacional, a Escola de La Cambre organizou um colóquio, em 1978, nomeado "A Reconstrução da Cidade Europeia". Participaram deste evento - além de Léon Krier, Culot e Delevoy - arquitetos da França, Bélgica, Espanha e Itália que já haviam estabelecido contato com esta escola durante os anos 1970 . Como resultado final deste colóquio, houve a assinatura da "Declaração de Bruxelas"105 na qual os subscritores afirmavam seu apoio às lutas urbanas bruxelenses ${ }^{106}$ e ratificavam, entre outros aspectos, a necessidade de retomada dos espaços públicos tradicionais da cidade europeia: "Toda intervenção na Cidade Europeia deve obrigatoriamente realizar aquilo que sempre foi a cidade, a saber: ruas, praças, avenidas, quarteirões, jardins, ... ou seja 'bairros'”107.

Aldo Rossi, por sua vez, organizou junto com Tarragó e três anos após a XV Trienal, o primeiro Seminário Internacional de Arquitetura em Compostela (SIAC) realizado em outubro de 1976. Este evento reuniu arquitetos espanhóis com Rossi,

\footnotetext{
${ }^{105}$ Os signatários desta declaração eram: "MM. Pierre Laconte (Bruxelas), Jacques Lucan (Paris), Jean Castex (Versailles), Antoine Grumbach (Paris), Léon Krier (Londres), François Loyer (Rennes), René Schoonbrodt (Bruxelas), Jacques Van der Biest (Bruxelas), Fernando Montes (Chile/Paris), Bernard Huet (Paris), R-L Delevoy (Bruxelles), André Barey (Barcelona), Maurice Culot (Bruxellas), Philippe Panerai (Versailles), Pierluigi Nicolin (Milão/Palermo)". - BAREY, André. Propos sur la reconstruction de la ville européenne: Déclaration de Bruxelles. Bruxelas: Archives d'Architecture Moderne, 1980, p.21

${ }^{106}$ BAREY, A., op. cit. 1980, p.21.

${ }^{107}$ BAREY, A., op. cit. 1980, p.21.
} 
Aymonino, Vitale, Ungers, Keihues, Stirling e Siza. O debate focou-se nas possibilidades de intervenção em cidades históricas europeias, tendo Santiago de Compostela como objeto para especulação através de projetos desenvolvidos durante o evento. Neste seminário, o vínculo com a exposição de arquitetura da XV Trienal de Milão fora buscado através de seção de projeção de suas filmagens. Em sua conferência introdutória ao evento, Rossi destacava como bases teóricas compartilhadas pela maioria dos presentes o estudo analítico da cidade e o estudo da tipologia "como a parte central das decisões globais de um projeto" ${ }^{108}$.

Figura 67: Capa da publicação "Proyecto y Ciudad Histórica", organizada por Tarragó e Beramendi em 1977 e decorrente . I Seminario Internacional de Arquitectura de Compostela realizado em 1976. Fonte: Fotografia do autor

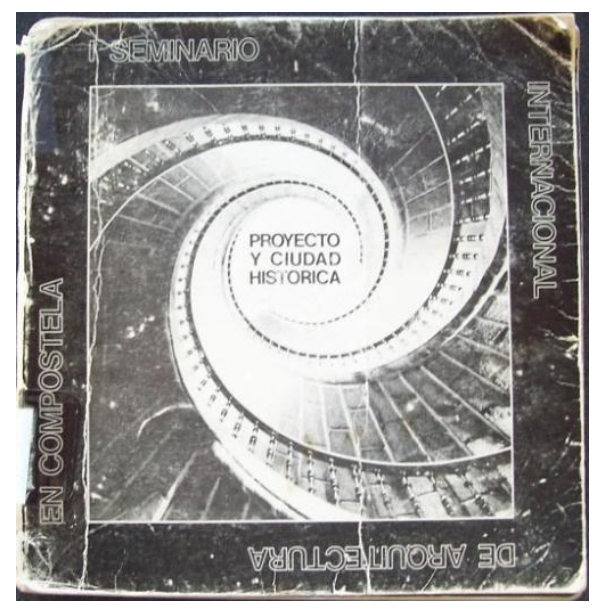

As reflexões através do projeto sobre as especificidades de uma "cidade europeia" do passado também seriam motivadas pela exposição "Roma Interrotta", organizada em 1977 pelos Incontri Internazionali D'Arte. Para esta mostra, arquitetos europeus e americanos - Piero Sartogo, Constantino Dardi, Grumbach, Stirling, Romaldo Giurgola, Venturi, Rowe, Graves, Léon Krier, Rossi e Robert Krier - foram convidados a desenvolver hipóteses de intervenção para a cidade de Roma representada no plano Giambattista Nolli de $1748^{109}$. Através do trabalho sobre as pranchas de Nolli, a exposição tinha o duplo objetivo de prover um exame crítico do processo de mudança no tecido urbano e de buscar alternativas para a cidade e seu centro histórico ${ }^{110}$. 0 resultado da exposição é apresentado por Argan como um "conjunto de aventuras,

108 ROSSI, A. Introducción. In: TARRAGO e BERAMENDI (org.). Proyecto y Ciudad Histórica. I Seminario Internacional de Arquitectura de Compostela. Santiago de compostela: COAG, 1977b, p.15.

${ }^{109}$ SARTOGO, P. et al., Roma Interrotta. Roma: Incontri Internazionali D’Arte, 1979.

${ }^{110}$ SARTOGO, P. et al., op. cit., 1979. 
pesquisas fantásticas sobre o ventre urbanístico de Roma", e como utopias, contraposições estéticas a um plano de desenvolvimento ${ }^{111}$.

De modo geral, percebem-se nestes pontos de encontro alguns conceitos e postulados frequentemente reafirmados - as definições de tipo por Quatremère de Quincy ou por Durand e algumas asserções resultantes dos estudos de Muratori e Aymonino, por exemplo. As interpretações dissonantes mostram-se, contudo, quando se trata de definir diretrizes para a prática. Neste momento, propõem-se alguns leitmotiven - como a "cidade por partes", cara aos arquitetos da Tendenza, sobre a qual discorremos no capítulo anterior - que, apesar de repetidos em contextos distintos, variam substancialmente em seus significados. Abordaremos, na sequência, dois dentre aqueles que leitmotiven não apenas são representativos destas dissonâncias, como, também, sua compreensão é importante para avaliar sua posterior derivação e/ou contraposição em bricolagens latino-americanas: as noções de "reconstrução da cidade" e de "cidades dentro de cidades".

A expressão "reconstrução da cidade" - assim como algumas de suas variantes, como a "recomposição da cidade"112 - foi empregada amplamente na Europa entre os anos 1970 e 1980. Dentro deste contexto, reconstruir significava opor-se a uma série de demolições recentes - e, então, frequentes em diversas cidades europeias - para dar lugar às renovações urbanas. $O$ desolamento coletivo face à destruição de tecidos do passado permitiu a organização de movimentos populares diversos que se opunha a este tipo de intervenção ${ }^{113}$. Ao se empregar o termo "reconstrução" nos anos 1970 e 1980, portanto, possibilitava-se ecoar a filiação a estes movimentos.

Por outro lado, o emprego da palavra "reconstrução" evocava, também, o próprio plano de Bolonha que, ao promover a restauração do centro histórico, propôs intervenções em alguns quarteirões a partir da repetição dos tipos edilícios identificados no levantamento que Ihe precedeu. Quase uma década depois deste plano, Cervellati escreveria na Casabella: “O centro histórico não nos interessa porque é belo ou antigo,

\footnotetext{
${ }^{111}$ SARTOGO, P. et al., op. cit., 1979.

112 Expressão recorrente em planos e projetos urbanos espanhóis nos anos 1980 - cf. SAINZ GUTIERREZ, op. cit., 2006.

113 Como, por exemplo, a chamada Batalha de Marolles, em 1969, em Bruxelas, ou os movimentos organizados por estudantes de arquitetura para parar obras em Berlim, na década de 1960 - cf. BRONSTEIN,op. cit. 2002.
} 
mas porque (...) representa o modelo, o exemplo que se deve seguir para modificar, para demolir e reconstruir a cidade emergente ${ }^{\prime 114}$.

Apesar destas possíveis motivações comuns para a sua utilização, verifica-se que nunca existiu uma definição unívoca para a chamada "reconstrução": diferentes grupos empregaram-na com conotações próprias. Versaremos aqui sobre três que ensejaram definições precisas: a "reconstrução da cidade europeia", pregada por Léon Krier e Culot; a "reconstrução crítica" formulada por Kleihues, durante o processo de organização da IBA; e, por último a "reconstrução da cidade" defendida por Bohigas, também em meados dos anos 1980.

No catálogo da supracitada exposição Rational Architecture, Léon Krier, escreveu uma das primeiras formulações a respeito da "reconstrução da cidade". Tratava-se, neste momento, de uma vaga alternativa à destruição das cidades pelos grandes trabalhos de renovação: "Nós podemos dizer que nos anos do pós-guerra, as cidades europeias foram mais destruídas fisicamente e socialmente do que em qualquer outro período de sua história, inclusive as duas guerras mundiais"115. A estratégia para alcançar esta reconstrução tornar-se-á mais clara e incisiva em publicações seguintes, nas quais seria definida como a imitação exata das formas urbanas e arquitetônicas da cidade do século XVIIII1. A "reconstrução da cidade europeia" era entendida como parte de uma proposta mais ampla e incompatível com o sistema capitalista. Negava-se, portanto, tudo o que ocorrera após a Revolução Industrial; dever-se-ia, impreterivelmente, retornar ao passado.

Face à defesa de imitação do passado de Krier, a ideia de Kleihues de manifesto em prol da pluralidade em sua concepção para a "reconstrução crítica" de Berlim não poderia ser mais dissonante. $\mathrm{O}$ arquiteto alemão propunha, portanto, a coexistência e a experimentação de diferentes arquitetos sobre a base comum da recuperação do traçado histórico; a busca de um diálogo entre o tradicional e o moderno. A orientação de Kleihues priorizava, portanto, definições para a inserção na estrutura urbana,

\footnotetext{
${ }^{114}$ CERVAlLATTI, P. L. Un avenire per nuestro passado. In: Casabella. Milão: Electa. n.428, set. 1977, p.11.

${ }^{115}$ KRIER, L., loc. cit., 1978, p.34.

${ }^{116}$ CULOT, M.; KRIER,L., loc. cit., 1978.
} 
colocando em segundo plano a "experimentação a partir do objeto arquitetônico individual” ${ }^{\prime 117}$.

A noção de "reconstrução da cidade" de Bohigas seria explicitada de forma mais clara em seu livro, "Reconstrució de Barcelona", cuja primeira edição data de 1985. Sob a pena de Bohigas, este leitmotiv assume caráter mais genérico: trata-se da reconstrução da cidade por partes que, ligadas umas as outras, formariam um contínuo urbano $^{118}$; ou seja, uma postura oposta àquela que caracterizou os "polígonos". A "cidade feita por partes" objetivaria, portanto, recuperar o sentido dos espaços coletivos e de sua relação com estrutura geral e com a hierarquia ${ }^{119}$.

Ao optar por esta definição mais aberta, Bohigas, no entanto, procurou caracterizá-la como tendência amplamente difundida no planejamento europeu: "O retorno à ideia de rua, de praça e de jardim urbano definidos com a linguagem arquitetônica e com o projeto do solo (...) representa o esforço principal de um planejamento mais iluminado"120. Anos depois, Bohigas inseriria a ênfase na escala do bairro na "reconstrução de Barcelona" dentro no contexto sociopolítico da Espanha após o fim da ditadura de Franco; esta corresponderia, portanto, a um "significado político e (...) à criação de instrumentos de descentralização administrativa”"121.

A ênfase no bairro como escala de intervenção não fora, todavia, privilégio do pós-franquismo espanhol; esta esteve também subjacente à compreensão da noção de "cidade dentro da cidade". Uma de suas definições foi ensejada durante a Sommerakademie de arquitetura realizada em Berlim pela Cornell University em 1977. Apresentada e discutida por Ungers, Rem Koolhaas, Peter Riemann, Hans Kollhof e Arthur Ovaska, a "cidade dentro de cidade" por eles proposta era um conceito para a leitura e o planejamento de Berlim como uma cidade-arquipélago ${ }^{122}$. Propunha-se, através desta, um projeto pluralista, no qual Berlim era abordada "como uma federação de cidades individuais com distintas estruturas, organizadas a partir de uma lógica

\footnotetext{
${ }^{117}$ BRONSTEIN, L., op. cit., 2002, p.45.

${ }^{118}$ BOHIGAS, Oriol. Ricostruire de Barcellona. Milão: Etas libri. 1992.

${ }^{119}$ BOHIGAS, O. op. cit. 1992.

${ }^{120}$ BOHIGAS, O. op. cit. 1992, p.11

${ }^{121}$ BOHIGAS, Oriol. Ten points on an Urbanistic Methodology. The Journal of Architecture, v. 4, outono,, 1999, p.240.

122 UNGERS, O. M., KOOLHAAS, M., KOLLHOFF, H., OVASKA, A. A., RIEMANN, P. Cities within the city. in: Lotus International. L'isolato urbano /The urban block, no 19, pp.82-97, 1978.
} 
deliberadamente antitética"123, como um sistema de ilhas arquitetônicas autônomas separadas por lagos e florestas.

Ao contrário da definição de "cidade dentro da cidade" definida na Sommerakademie, a de Léon Krier opunha-se à ideia de pluralidade. A "cidade dentro da cidade" de Krier ${ }^{124}$ corresponderia aos bairros de cidades europeias consolidadas e seria o fundamento para a "reconstrução da cidade". As características destes bairros seriam, segundo Krier, verificáveis através de análise tipo-morfológica. Em sua definição das características bairro europeu, no entanto, Krier acaba por aproximá-los dos parâmetros da Unidade de Vizinhança ${ }^{125}$. Assim como esta última, aquele possuiria: tamanhos máximos definidos em população e em superfície com distância confortável para uma caminhada, atividades urbanas locais periódicas e limites definidos por avenidas nas quais se concentram as atividades "que poderiam sobrecarregar ou superlotar um simples bairro"126.

\subsection{Entre dois mundos: encontros e traduções culturais iniciais}

[...] devemos lembrar que não existe texto fora do suporte que o dá a ler (ou escutar) e que não há compreensão de um escrito que não dependa das formas nas quais ele chega a seu leitor ${ }^{127}$.

A história da arquitetura e do urbanismo é pontuada por viagens diversas e pelos encontros culturais que estas proporcionaram. Frequentemente, através do diálogo entre profissionais de diferentes contextos constroem-se trocas e sintetizam-se ideias, que, ao ganharem corpo e perdurarem temporalmente, costumam ser associadas a mudanças na cultura arquitetônica. A experiência da viagem, neste caso, ocorre em

\footnotetext{
${ }^{123}$ UNGERS et al., loc. cit., 1978, p.86

$124 \mathrm{O}$ texto "A cidade dentro da Cidade" de Krier foi originalmente publicado na revista $A+U$, em novembro de 1977 - mês antecedente à Sommerakademie - e republicado, porteriormente, no catálogo de Rational Architecture.

${ }^{125}$ cf. SOUZA, G. B. De los desdoblamientos de la Unidad de Vecindad. El espacio comunitário en la Ciudad Policéntrica de Léon Krier. in: Revista Bitácora Urbano-Territorial (Bogotá), v. 10, pp. 8-16, 2006.

${ }^{126}$ KRIER, L., loc. cit.1978, p.34.

${ }^{127}$ CHARTIER, Roger. El mundo como representación. Estudios sobre história cultural. Barcelona: Gedisa, 1992, p.55.
} 
ambos os sentidos: tanto o viajante quanto o seu destino modificam-se após o encontro estabelecido. Em outros casos, no entanto, o contato não encontra a mesma ressonância, ocorre de forma efêmera ou seus efeitos verificam-se apenas unilateralmente.

Certamente, nem todos os encontros com os personagens e lugares sociais supracitados proporcionaram a mesma intensidade de trocas; alguns encontraram maior eco na cultura arquitetônica local que os outros. A frequência com que determinados autores são citados é indicativa de sua maior ou menor penetração. $\mathrm{Na}$ sequência, abordaremos dois encontros através dos quais os diálogos entre os dois mundos - o novo e o velho - sobre a tipo-morfologia parece ter sido mais pungente, ou seja, as relações com Aldo Rossi e as conexões estabelecidas via Léon Krier. A escolha destes dois casos não se deu apenas pela frequência aparecem com que estes autores aparecem em textos latino-americanos; como também, pelo fato de que estes encontros e traduções culturais iniciais revelam aspectos importantes sobre o grupo de arquitetos que viria a organizar o V SAL.

\section{Viagens de Rossi à América Latina: entre resistências e redes de leitores}

Entre os textos que abordavam as ressonâncias estrangeiras na cultura arquitetônica de países latino-americanos, dificilmente se escapou de Aldo Rossi. De fato, não apenas o arquiteto italiano era apontado nos debates dos SAL, como também foi amplamente citado em artigos e ensaios diversos - ainda que o número de publicações sobre sua obra em revistas latino-americanas pareça desproporcional face à sua penetração na cultura arquitetônica regional ${ }^{128}$. A fim de compreender como se deu a penetração das ideias de Rossi no subcontinente, resolvemos acompanhar o contexto

\footnotetext{
${ }^{128}$ De modo geral, a publicação de obras arquitetônicas de Rossi em revistas locais acompanhou o período de maior produção do arquiteto. Analisando-se o período de 1979 a 1995 em revistas do subcontinente, observaram-se os seguintes dados: na AU, publicam-se 4 obras de Rossi entre 1991 e 1995 e uma entrevista em 1987; na Projeto, há 5 artigos publicados sobre Rossi entre 1989 e 1992 e a Summa publicou somente uma entrevista em 1979 e dois textos críticos sobre a obra de Rossi, um em 1989 e outro em 1992. Em duas outras revistas argentinas, os textos sobre a obra de Rossi acompanham suas visitas a este país: a Dos Puntos publica um artigo sobre Rossi em 1982/83 e, na revista A/Ambiente, dois artigos sobre Rossi foram publicados entre 1981 e 1982. Na Summarios, apenas se publicou um dossiê que apresentava textos e obras de Rossi aos argentinos, no número 22 de 1978. Na Proa apenas se publicou a contribuição de Rossi na mesa redonda do evento "Espacio Público Urbano", em edição de 1983. Não se observou publicação de nenhuma obra de Rossi na Escala (Colombia), na CA (Chile), na AUCA (Chile) e na ARQ (Chile) no período analisado.
} 
de suas primeiras viagens à América Latina realizadas entre 1978 e 1982. Ao longo destas, revelar-se-á as reações de resistência, por um lado, e, por outro, a constituição de redes de leitores através destas visitas.

Apenas cinco anos após a primeira edição italiana, a tradução do livro "Arquitetura da Cidade" já havia sido publicada em território espanhol. A disponibilidade da edição espanhola de 1971 - e de suas numerosas reedições nos anos subsequentes -, permitiu que este livro fosse lido por latino-americanos antes mesmo que ele viesse a contar com suas edições em língua francesa e em língua inglesa - as quais ocorreriam em 1981 e 1982, respectivamente. Contudo, apesar da facilidade linguística, a maior difusão das ideias de Rossi na América Latina deu-se a partir de meados dos anos 1970, acompanhando, portanto, suas primeiras viagens a este subcontinente.

Hispanófilo declarado, o Aldo Rossi que visitou pela primeira vez a América Latina, em 1978, intuía já conhecer o paradeiro que o esperava: “A América Latina sempre foi para mim uma fonte de inspirações fantásticas, ao ponto que eu me considero, como orgulho e presunção, um hispanista" ${ }^{129}$. O interesse pela língua espanhola e pela cultura hispano-americana não garantiu, no entanto, sua adesão imediata ao convite para ministrar um seminário em Buenos Aires. Enviado por um arquiteto argentino que então lhe era desconhecido, Antonio Díaz del Bo (Tony Díaz) ${ }^{130}$, e proveniente de um país que se encontrava sob governo ditatorial, a supracitada proposta causou-Ihe inicialmente certo receio ${ }^{131}$. Esta hesitação inicial fora dissipada após a recomendação de Antonio Díaz, e do grupo de docentes vinculados ao que se nomeou como La Escuelita, por parte de Diana Agrest e Mario Gandelsonas - arquitetos argentinos a quem Rossi conhecera, e logo se tornara amigo, em sua primeira conferência no IAUS, em $1975^{132}$. Através deste percurso, Aldo Rossi desembarcava em Buenos Aires, em novembro de 1978, a fim de contribuir com uma experiência de

\footnotetext{
${ }^{129}$ ROSSI, A. Autobiografía Científica. Barcelona: Gustavo Gili, 1984, p.90.

${ }^{130}$ Tony Díaz afirma ter tomado conhecimento sobre o trabalho de Rossi através de seus artigos publicados no número 2 da Revista $2 \mathrm{C}$, a qual teve acesso durante uma viagem de turismo em Madri realizada em 1975 - Cf.DÍAZ DEL BO, Antonio. Depoimento. [02 de fevereiro de 2012]. Madrid: Texto em arquivo digital (14 páginas). Entrevista concedida a Gisela Barcellos de Souza.

${ }^{131}$ AGREST, Diana. Para Aldo, con cariño de una argentina. In: Block. Buenos Aires: Instituto Torcuato di Tella. n.3, dec.1998, p.32-41.

${ }^{132}$ AGREST, Diana. loc. cit., 1998.
} 
ensino de arquitetura desvinculada de qualquer universidade ou instituição - $L a$ Escuelita - que, em sua condição incipiente e marginal, não the garantia qualquer possibilidade de prestígio acadêmico.

Organizada por um grupo de docentes que havia sido rechaçado de suas cátedras na Universidade de Buenos Aires após intervenção política realizada em $1975^{133}$ ainda sob o governo de Isabel Perón - em ação de purgação ideológica que foi chamada "La Misión Ivanissevich"-, a série de "Cursos de Arquitetura" começou suas atividades no ano anterior à vinda de Aldo Rossi. Este conjunto de cursos, que logo seriam nomeados como "La Escuelita", iniciou suas atividades na forma de quatro ateliers autônomos que ocorriam paralelamente ${ }^{134}$. Ao longo do ano de 1976, conceberam-se as linhas gerais do que viria a marcar a forma de atuação através destes cursos. O terror da ditadura e a possibilidade de censura estiveram presentes no momento de abertura das primeiras inscrições; entretanto, após um incidente inicial que indicava a possibilidade de intervenção militar nesta experiência de ensino ${ }^{135}$, obteve-se a autorização para sua realização, sob a condição de que os cursos tratariam apenas de arquitetura ${ }^{136}$.

Apaziguadas as desconfianças iniciais, La Escuelita pôde atuar ao longo dos anos de terror sem ser a vir alvo da censura ${ }^{137}$ e logo se converteria em porta de entrada para elementos e questões que se debatiam internacionalmente na cultura arquitetônica. A abertura ao debate internacional seria buscada, entre outros, através de palestrantes

\footnotetext{
${ }^{133}$ DÍAZ DEL BO, Antonio. Depoimento. [02 de fevereiro de 2012]. loc. cit.

${ }^{134}$ DÍAZ; SOLSONA et. al. La Escuelita. 5 años de enseñanza de alternativa de arquitectura en la Argentina, 1976/1981. Buenos Aires: Espacio Editora, 1981.

135 “Cuando estábamos haciendo la primera inscripción para los Cursos de Arquitectura (...), la secretaria que realizaba la inscripción nos llamó para decirnos que se habían presentado dos personas interesadas en inscribirse y que pertenecían a Fabricaciones Militares. Mantuvimos la calma." DíAZ, Antonio. Posmodernismo y dictadura. In: Block. Buenos Aires: Instituto Torcuato di Tella. n.5, dec. 2000, p.52

${ }^{136}$ DÍAZ, Antonio. loc. cit., 2000, p.51-53.

${ }^{137}$ A respeito desta questão, Tony Díaz afirmaria: "De cualquier manera, me parece que la Dictadura en la Argentina no fue, por suerte, tan "perfecta" ni estuvo tan interesada en controlar al detalle fenómenos como este.(...) En esa época, tampoco los debates referidos a la arquitectura eran tan políticos como a fines de los 60 y comienzos de los 70 , así que, en principio, nos conformábamos con poder discutir acerca de los problemas de "nuestra disciplina" (expresión muy en boga en aquella época). Esto no quiere decir que no hubiera un fondo político, en el sentido más generoso y general de la palabra, detrás de toda esta experiencia. La Escuelita era una forma, consciente o inconsciente, de resistencia" - DÍAZ DEL BO, Antonio. Depoimento. [02 de fevereiro de 2012]. loc. cit.
} 
convidados, residentes no exterior ou estrangeiros. Para tal, enfrentava-se, contudo, as dificuldades intrínsecas ao contexto de clausura da ditadura militar. Como destacou Díaz, "não foram poucos intelectuais, políticos, etc. que demonstravam restrições (e com razão) de ir até aí [na Argentina] por rechaço ao regime militar"138. Os primeiros visitantes em La Escuelita foram arquitetos argentinos que estavam radicados nos EUA: Diana Agrest, Jorge Silvetti e Mario Gandelsonas - com quem Tony Díaz e Rafael Viñoly mantinham contato desde que se conheceram na Faculdade de Arquitetura da Univesidad de Buenos Aires, entre 1956 e $1966^{139}$. Com o aval inicial destes arquitetos inseridos no debate internacional, logo se possibilitariam outros contatos. Neste contexto, Aldo Rossi seria o primeiro arquiteto estrangeiro a colaborar com La Escuelita $^{140}$.

A contribuição de Rossi se constituiu na forma de três seminários noturnos, nos quais apresentou e discutiu questões relativas tipo-morfologia e ao conceito de "cidade análoga". Para tanto, o arquiteto italiano utilizou-se de exemplos históricos e de outros oriundos de seus próprios projetos e da discussão sobre os trabalhos que, na ocasião, eram desenvolvidos pelos alunos de La Escuelita ${ }^{141}$. Durante sua estadia, Rossi procurou conhecer Buenos Aires tanto em caminhadas solitárias ${ }^{142}$, como em outras guiadas por seus anfitriões ${ }^{143}$, tendo sido notavelmente impressionado pelas chamadas "casas

${ }^{138}$ DíAZ, Antonio. Aldo Rossi y Buenos Aires. 1914-1997. In: 47 al fondo. Revista de la Facultad de Arquitectura y Urbanismo de la Universidad Nacional de la Plata. La Plata: Univ. Nacional de la Plata, n.3, oct. 1998, p.52.

${ }^{139}$ A relação com estes arquitetos é ratificada por Díaz: “Apesar de que eles viviam nos EUA, há muito tempo, continuávamos tendo uma estreita relação intelectual, profissional e pessoal. Por conseguinte, sua participação em La Escuelita dando aulas, etc. era lógica e obrigatória" - cf. DÍAZ DEL BO, Antonio. Depoimento. [02 de fevereiro de 2012]. loc. cit.

140 Ao longo de seus oito anos de atuação, La Escuelita receberia também a visita dos seguintes arquitetos estrangeiros: Salvador Tarragó; Rafael Moneo; Álvaro Siza; Fernando Montes - cf. DÍAZ; SOLSONA e KATZENSTEIN. Declaración acerca de la suspensión de las actividades de La Escuelita. Buenos Aires: s.n., 1984 - e Manfredo Tafuri - cf. LIERNUR, J. F. Arquitectura en la Argentina del siglo XX : la construcción de la modernidad. Buenos Aires : Fondo Nacional de las Artes, 2001. Segundo Tony Díaz, durante a primeira estadia de Rossi em Buenos Aires, discutiu-se sobre os possíveis próximos convidados estrangeiros - a sugestão do nome de Salvador Tarragó teria partido do arquiteto italiano - cf. DÍAZ DEL BO, Antonio. Depoimento. [02 de fevereiro de 2012]. loc. cit.

141 ROSSI, A. Seminario dictado en diciembre de 1978. In: DÍAZ, SOLSONA, et. al. (org.). La Escuelita. 5 años de enseñanza de alternativa de arquitectura en la Argentina, 1976/1981. Buenos Aires: Espacio Editora, 1981.

142 DÍAZ, Antonio. loc. cit., 1998.

${ }^{143}$ ROSSI, A. loc. cit., 1981 
chorizo" ${ }^{\prime 14}$ e pelo antigo Asilo de Anciões do bairro Recoleta - que hoje abriga o Centro Cultural Recoleta e naquele momento ainda estava desocupado -, cujas referências foram incorporadas em suas conferências ${ }^{145}$.

A realização destes seminários coincidiu com o início da divulgação dos trabalhos teóricos de Rossi no meio arquitetônico argentino - a primeira publicação argentina dedicada à apresentação de seu trabalho teórico e de seus projetos antecedeu apenas em três meses à sua chegada neste país ${ }^{146}$. Neste contexto, o discurso apresentado foi "em grande medida inesperado" para o público ${ }^{147}$. A novidade do debate, não minimizou, no entanto, a pungência do encontro: este contato inicial permitiria não apenas o estabelecimento de uma amizade entre Tony Díaz e Aldo Rossi, como também, o desenvolvimento posterior, por parte do arquiteto argentino, de uma série de exercícios didáticos que traduziam e adaptavam livremente teorias rossianas ao contexto local. Para Justo Solsona, a experiência de La Escuelita ficaria, doravante, marcada por esta visita inicial de Rossi ${ }^{148}$.

Rossi, por outro lado, recordar-se-ia desta estadia em Buenos Aires, em algumas passagens de sua "Autobiografia Científica". Dentre suas imagens recorrentes, surgem das margens do Paraná que conhecera em $1978^{149}$, cuja paisagem parece ter-se fixado em sua memória. Além destas passagens, Rossi afirmaria diretamente, também neste mesmo texto, a importância que teve esta viagem à Argentina - a qual coloca ao lado da experiência de ensino nos EUA e, curiosamente, de sua breve passagem pelo Brasil:

Estas experiências [de ensino en la Cooper Union], assim como minhas estadias na Argentina ou no Brasil, foram pouco a pouco dissolvendo, por

\footnotetext{
${ }^{144}$ Forma como são chamados em Buenos Aires e Montevidéu os tipos edilícios que se desenvolvem em torno de um pátio lateral e ocupam a profundidade da parcela e cujos compartimentos organizam-se em forma sequencial.

${ }^{145}$ ROSSI, A. loc. cit., 1981

${ }^{146}$ Trata-se da edição número 22 dos Cadernos Summarios, de agosto de 1978, a qual será abordada na sequência.

147 SOLSONA, Justo; CIPRIANI, Alejandro. Justo Solsona : entrevistas, apuntes para una autobiografía. Buenos Aires: Ed. Infinito, 1997, p.105.

${ }^{148}$ SOLSONA, Justo; CIPRIANI, Alejandro. op. cit. 1997, p.105.

149 "Durante su primera visita a Buenos Aires, Rossi pasó una parte de un fin de semana en una casa que Solsona todavía tiene en el Delta del Paraná y otra parte en una casa de fin de semana que yo tenía en la ciudad de Ing. Maschwitz, a 40/50 kilómetros de Buenos Aires, y también cerca del río Paraná. Solsona fue el que le hizo conocer el Paraná, el Hotel del "italiano" donde se suicidó el poeta Lugones, etc." - cf. DÍAZ DEL BO, Antonio. Depoimento. [02 de fevereiro de 2012]. loc. cit.
} 
um lado, minha dedicação à arquitetura, porém, por outro, contribuíram para tratar com precisão os objetos, as formas, as criações ${ }^{150}$.

Ao contrário das estadias nos EUA e na Argentina, a passagem de Rossi pelo Brasil, mencionada no excerto acima, estaria entre suas raras experiências de turismo ${ }^{151}$. Quando voltava a Milão, vindo de sua estadia em Buenos Aires, passou pelo Brasil ${ }^{152} \mathrm{a}$ fim de visitar as obras de Niemeyer ${ }^{153}$. Nesta breve viagem conheceu também algumas cidades de Minas Gerais - entre as quais destacou Ouro Preto e Belo Horizonte em "Autobiografia Científica". Nove anos mais tarde, ainda recordaria esta viagem e sua importância: "Fiquei dois ou três dias em Ouro Preto [...]. Creio que seja um dos lugares mais lindos e ricos que eu tenha visto, e é suficiente pensar nestas imagens para enriquecer a própria arquitetura"154. O número de citações a paisagens e a cidades brasileiras na "Autobiografia Científica" ratificaria a importância desta viagem para Rossi ${ }^{155}$. Este encontro seria, no entanto, um dentre aqueles encontros unilaterais: Rossi ainda era pouco lido no Brasil no final dos anos 1970 e assim o seria ainda no início dos anos $1980^{156}$. Sua viagem se deu em âmbito privado e ninguém nunca a comentou. A

${ }^{150}$ ROSSI, A. op. cit., 1984, p.93.

${ }^{151}$ ROSSI, A. Entrevista a Marisa Barda. In: Arquitetura e Urbanismo. São Paulo: Editora Pini, n.10, fev./mar. 1987, p.90-97.

152 DÍAZ, Antonio. loc. cit., 1998.

153 "Regresando a Europa pasó por Brasil (en su retorno a Italia esta parada no estaba prevista y él nos pidió pasar por Brasil porque tenía interés especial en ver las obras de Niemeyer)" - cf. DÍAZ DEL BO, Antonio. Depoimento. [02 de fevereiro de 2012]. loc. cit.

${ }^{154}$ ROSSI, A. loc. cit., 1987, p.93.

155 Neste livro, testemunha-se que algumas imagens então experimentadas povoavam as memórias de Rossi naquele momento e constituíam-se como nós reincidentes entre as analogias que urdia: as igrejas de Ouro Preto; o tênue destaque de teatros em cidades do interior reduzido à clareza de seus tímpanos -; a visão de um bloco que identifica como racionalista em Belo Horizonte ou a vida de um bairro residencial que encontrou nesta mesma cidade - ROSSI, A. op. cit., 1984.

${ }^{156}$ A título de exemplo, veja-se o número de citações a Rossi nos Anais do Seminário de Desenho Urbano (SEDUR), marco inicial da introdução do debate sobre o projeto urbano no Brasil. No I SEDUR, realizado em 1984, apenas 2 dentre as 29 apresentações publicadas citavam Rossi em suas referências, ambas vinha de profissionais gaúchos: uma de Mário Júlio Teixeira Krüger, intitulada "Descrição Taxonômica e Morfogenética das Tipologias Arquitetônicas" e outra de Rômulo Krafta e Douglas Aguiar, cujo título era "Projeto de Reabilitação Urbana da Avenida Voluntários da Pátria, Porto Alegre. Cf. TUKIENICZ, Benamy (org). Desenho Urbano II - Anais do I Seminario sobre Desenho Urbano no Brasil. São Paulo: Ed. Projeto, 1984; e TUKIENICZ, Benamy (org). Desenho Urbano III - Anais do I Seminario sobre Desenho Urbano no Brasil. São Paulo: Ed. Projeto, 1984. 
única menção a esta passagem em publicação brasileira seria feita pelo próprio Rossi, em uma entrevista realizada nove anos mais tarde pela revista $\mathrm{AU}^{157}$.

Entre 1978 e 1982, Rossi esteve na América Latina em duas ocasiões: um seminário na Venezuela em 1980 e um evento na Colômbia no início de 1982. O evento em Caracas teve lugar na Universidad Central de Venezuela e foi organizado pelo Instituto de Arquitectura Urbana - associação de arquitetos que, entre 1978 e 1985, desenvolveu uma série de estudos e projetos para Caracas $^{158}$. Nesta ocasião, organizouse tanto uma conferência de Rossi, como uma exposição de seus trabalhos. Na Colômbia, no entanto, o evento que trouxe Rossi em março de 1982 não lhe era dedicado exclusivamente. $\mathrm{O}$ arquiteto italiano esteve presente dentre os quatro convidados para o evento nomeado "Espacio Público Urbano", dividindo a cena com outros três arquitetos com atividade profissional no continente europeu: Oriol Bohigas, Fernando Montes e Álvaro Siza.

Organizado pela Universidad de Los Andes e pela Revista PROA, encontro "El Espacio Público Urbano"159 envolvia, além da realização de conferências, a coordenação de workshops ${ }^{160}$. Sua realização deu-se no contexto de diversos eventos colombianos que, no início dos anos 1980, procuraram abordar o debate sobre a definição de "arquitetura pós-moderna" e buscar significados locais para a revisão da arquitetura moderna que se verificava no âmbito internacional ${ }^{161}$. Ao contrário do evento que o precedeu - o “Panorama de la Arquitectura anos 1960-1980", organizado, em 1980, pela Universidad Nacional de Colombia ${ }^{162}$ - os eventos fomentados por Carlos Morales, então editor da PROA e diretor da Facultad de Arquitectura de la Universidad de Los Andes,

\footnotetext{
157 Aldo Rossi fala em entrevista cedida à Marisa Barda, em 1987, que esteve duas vezes a turismo no Brasil. Cf. ROSSI, Aldo. Entrevista a Marisa Barda. In: Arquitetura e Urbanismo. São Paulo: Editora Pini, n.10, fev./mar. 1987, p.90-97.

158 NOVOA, Maria Teresa. Willian Niño Araque. In: Revista CAV. Caracas: Colegio de Arquitectos de Venezuela, n.57, jun. 2011, p.22-29.

${ }^{159}$ A divulgação do evento, bem como um dossiê preparatório a este, foram publicadas na revista PROA número 305, de 1982.

160 MONTES, Fernando. Depoimento. [24 de novembro de 2011]. Santiago do Chile: Arquivo digital da gravação (2hora e $8 \mathrm{~min}$.). Entrevista concedida a Gisela Barcellos de Souza.

${ }^{161}$ RAMíREZ, Jorge. El pensamiento a través de los Seminarios de Arquitectura latinoamericana. In: XI Seminario de Arquitectura Latinoamericana. Oaxtepec (México), 2005.

${ }^{162}$ RAMÍREZ, Jorge. loc. cit., 2005.
} 
buscaram a reflexão sobre o tema através de encontros com arquitetos internacionais ${ }^{163}$.

Segundo Fernando Montes ${ }^{164}$, o workshop para o qual ele e os demais arquitetos europeus foram convidados foi motivado pelo interesse em definir projetos para "La Candelaria" - núcleo histórico de Bogotá que se encontrava deteriorado neste período. O evento se estruturava, portanto, no interesse comum pela recuperação deste bairro e a inexistência de um consenso de como fazê-lo. Contudo, a despeito de se pautar em uma problemática local e concreta, a proposição deste evento se deu somente através da articulação de Carlos Morales, sem contar com nenhuma demanda oficial por parte da prefeitura - contrariando, neste aspecto, a expectativa dos palestrantes convidados ${ }^{165}$.

Nem as palestras ministradas, nem os resultados dos workshops foram publicados - destes restam apenas lembranças resgatáveis através de fontes orais. Contudo, uma mesa redonda conduzida pela Revista PROA - transcrita e publicada em sua edição número 321 - permite entrever que os rumos tomados pelo debate durante o evento e perceber certa resistência às propostas de Rossi, bem como uma compreensão parcial de sua obra teórica na Colômbia naquele momento ${ }^{166}$. Esta impressão de desconhecimento do público e de novidade em relação aos assuntos debatidos transparecia, também, aos arquitetos convidados, como relembra Fernando Montes ${ }^{167}$. Apesar da plateia numerosa que assistia ao evento - havia, de acordo com o arquiteto franco-chileno, em torno de mil pessoas nas conferências realizadas em Bogotá -, as discussões ali travadas pareciam distantes e inauditas:

Eles não sabiam muito bem o que fazer [com a Candelaria]. [A postura que defendíamos é que ] não se tratava de restaurar algumas casas antigas, mas de incorporar este quarteirão abandonado à cidade. (...) Nós discutíamos justamente esta transformação da cidade, que não significava mais apagar a

\footnotetext{
${ }^{163}$ RAMÍREZ, Jorge. Depoimento. [05 de abril de 2011]. São Paulo: Arquivo digital da gravação (1hora e 45min.). Entrevista concedida a Gisela Barcellos de Souza.

${ }^{164}$ MONTES, Fernando. Depoimento. [24 de novembro de 2011]. loc. cit.

165 Rossi e Montes chegaram a ir juntos para apresentar uma proposta ao prefeito, mas perceberam que não havia nenhuma abertura ou interesse de sua parte - cf. MONTES, Fernando. Depoimento. [24 de novembro de 2011]. loc. cit.

${ }^{166}$ Cf. Revista PROA, número 321, 1983.

${ }^{167}$ MONTES, Fernando. Depoimento. [24 de novembro de 2011]. loc. cit.
} 
cidade para construir a cidade moderna, mas que significava construir a "cidade sobre a cidade" ou a "cidade entre a cidade" ou a "cidade com a cidade", etc. E isto, para os estudantes e professores presentes era surpreendente [...], eles nunca haviam pensado nisto. Eles pensavam que a arquitetura era a primazia do novo, ou seja, para que haja algo que apareça, é preciso que outras desapareçam ${ }^{168}$.

Por outro lado, Silvia Arango - que participou como debatedora na mesa organizada pela PROA - descreve, a respeito deste evento, a existência de certa resistência de parte do público presente às ideias ali expostas e, sobretudo, às teses rossianas: "Nós vivíamos uma situação ambígua, por um lado, considerávamos que no fundamental [Rossi] tinha razão. Porém não somos a Itália. O que é tipologia na América Latina?"169. De fato, o interesse pelo espaço público não era novo para a historiadora colombiana, visto que havia sido abordado esta temática em seu doutorado - sob a chave da semiótica - e em sua monografia de conclusão de curso, em 1972, que analisara a rua como espaço social ${ }^{170}$. Transparece, portanto, neste evento certo conflito entre os conceitos universais da tipo-morfologia de matriz italiana e o interesse pelos aspectos latino-americanos que já começavam a se manifestar na Colômbia no início dos anos 1980 - deve-se lembrar que o Encontro de Cali, organizado por Salmona, ocorreu no mesmo ano, em $1982^{171}$.

Em 1982, o Aldo Rossi regressara à Argentina era muito distinto daquele de 1978. No período de quatro anos, Rossi havia consolidado sua importância no cenário internacional: já havia passado por sua estadia de ensino no IAUS - entre 1979 e 1981 -; as versões de "A Arquitetura da Cidade" em língua francesa e língua inglesa acabavam de ser publicadas - e garantiram sua grande difusão internacional -; sua participação de destaque na Bienal de Veneza de 1980 com o "Teatro del Mondo" o tornara uma figura incontornável na cultura arquitetônica coetânea. Segundo Tony Díaz, apesar de terem mantido os laços de amizade desde que se conheceram em 1978, a vinda de Rossi a La

\footnotetext{
${ }^{168}$ MONTES, Fernando. Depoimento. [24 de novembro de 2011]. loc. cit.

169 ARANGO, Silvia. Depoimento. [11 de novembro de 2011]. Campinas: Arquivo digital da gravação (1hora e 11min.). Entrevista concedida a Gisela Barcellos de Souza.

${ }^{170}$ ARANGO, Silvia. Depoimento. [11 de novembro de 2011]., loc. cit.

${ }^{171}$ Ver "Múltiplas origens" no segundo capítulo.
} 
Escuelita em outubro de 1982 ocorreu somente devido a sua insistência pessoal, visto que "Aldo já tinha muitos compromissos internacionais" ${ }^{172}$.

Se, em sua primeira estadia à Argentina, Rossi pôde desfrutar de uma curta experiência de turismo - e mesmo de anonimato - no Brasil, a situação em sua segunda visita a este país não poderia ser mais oposta. Por um lado, Rossi teria solicitado que sua passagem não se restringisse à Buenos Aires ${ }^{173}$. Por outro, ao saber da vinda deste arquiteto à América do Sul, outros grupos de arquitetos se organizam para poder recebê-lo também:

\begin{abstract}
Havíamos organizado, também, uma viagem ao Uruguai, Chile e Peru para ministrar seminários e conferências e um encontro na cidade argentina de Córdoba. O único lugar ao qual não pôde ir foi Lima, já que teve que regressar imprevistamente aos Estados Unidos ${ }^{174}$.
\end{abstract}

Explicitava-se, em seu roteiro de viagem, a existência contatos entre leitores de diferentes nacionalidades - dentre estes, alguns viriam, anos mais tarde a se engajar nos SAL. Desta forma, Cristián Boza, em Santiago do Chile; Jorge Morini, em Córdoba; Mariano Arana, em Montevidéu, e Juvenal Baracco, em Lima, buscaram organizar a vinda de Rossi em suas respectivas cidades ${ }^{175}$. Segundo Tony Díaz, com todos estes arquitetos já havia um diálogo - de intensidade variável, no entanto - estabelecido por distintos motivos: "com alguns havia mais afinidades políticas com outros menos; com alguns havia mais afinidades no campo da arquitetura com outros menos" ${ }^{\prime 176}$.

As cidades de Buenos Aires, Córdoba e Santiago - destacadas na carta de Rossi $^{177}$ a Tony Díaz - foram aquelas nas quais suas conferências foram recebidas por uma grande multidão de arquitetos e estudantes. Rossi se refere, no entanto, a Montevidéu como uma desilusão ${ }^{178}$. Segundo Tony Díaz, "sua decepção esteve

${ }^{172}$ DÍAZ, Antonio. loc. cit., 1998, p.54.

${ }^{173}$ DÍAZ DEL BO, Antonio. Depoimento. [02 de fevereiro de 2012]. loc. cit.

${ }^{174}$ DÍAZ, Antonio. loc. cit., 1998, p.53.

${ }^{175}$ DÍAZ DEL BO, Antonio. Depoimento. [02 de fevereiro de 2012]. loc. cit.

${ }^{176}$ DÍAZ DEL BO, Antonio. Depoimento. [02 de fevereiro de 2012]. loc. cit.

177 “[...] depois da desilusão de Montevideo, a viagem a Santiago foi inesquecível. Gostei de tudo no Chile: a paisagem, as pessoas, a arquitetura [...]. Na realidade, creio que em Córdoba e Buenos Aires meu encontro com as pessoas foi positivo e, para mim, importante" - ROSSI apud DÍAZ, Antonio. loc. cit., 1998, p. 54.

${ }^{178}$ ROSSI apud DÍAZ, Antonio. loc. cit., 1998, p. 54. 
relacionada, principalmente, com um intercâmbio de ideias um pouco esquemático e deslocado que teve com algumas pessoas em um encontro depois da conferência" ${ }^{179}$.

Sua nova estadia na capital da Argentina não foi, desta vez, restrita apenas a $L a$ Escuelita. Além de sua participação naquela escola, Rossi deu também uma conferência no Colegio de Escribanos e participou de uma reunião com a imprensa especializada. Entretanto, face ao grande interesse que a vinda de Rossi despertou na comunidade arquitetônica local, é possível compreender que, os alunos de La Escuelita tenham passado, neste momento, por um grupo de privilegiados que pôde gozar de um contato mais próximo e profundo com Rossi ${ }^{180}$.

Como o reconhece o arquiteto chileno Cristián Boza, a figura de Tony Díaz foi fundamental para articulação da visita de Rossi a outros países da América do Sul que, assim como a Argentina, encontravam-se sob regimes ditatoriais. Segundo Boza, foram várias tentativas anteriores de trazer Rossi ao Chile; todas frustradas. Somente com o auxílio de Tony Díaz que se conseguiu convencer Rossi:

Tentamos contatá-lo durante muito tempo e ele sempre nos dizia que não, que tinha horror em vir ao país governado por Pinochet. Além de não gostar deste governo, Aldo Rossi era comunista, não Ihe agradava a ideia. Então, (...) conseguimos convencer Aldo Rossi a vir ao Chile através do Tony ${ }^{181}$.

Em Santiago, Rossi ficou apenas um dia e meio ${ }^{182}$. Convidado pelo grupo CEDLA - que, neste momento, já não contava mais com sua sede própria ${ }^{183}$-, sua palestra ocorreu na sede do Colegio de Arquitectos, em um evento que ocorreu fora do circuito das bienais. A numerosa acolhida do público chileno a este evento demostrava o interesse, neste momento, em conhecer um pouco mais as ideias do arquiteto italiano. Como recordaria Humberto Eliash: "Foi uma conferência multitudinária"184. A conferência, segundo Pedro Murtinho, tratou sobre temas que já eram conhecidos do

\footnotetext{
${ }^{179}$ DÍAZ DEL BO, Antonio. Depoimento. [02 de fevereiro de 2012]. loc. cit.

${ }^{180}$ ELGUEZABAL, Eduardo. Aldo Rossi en Buenos Aires. In: SCA. Buenos Aires: Sociedad Central de Arquitectos, n.123, dec. 1982, p.61.

${ }^{181}$ BOZA, Cristián. Depoimento. [17 de agosto de 2011]. Santiago do Chile: Arquivo digital da gravação (1hora e $1 \mathrm{~min}$.). Entrevista concedida a Gisela Barcellos de Souza.

182 Informação confirmada pelas entrevistas aos arquitetos Humberto Eliash (em 6 julho de 2011) e a Cristián Boza (em 17 de agosto de 2011) realizadas pela autora.

${ }^{183}$ Ver capítulo 3, "O preparo da trama"

${ }^{184}$ ELIASH, Humberto. Depoimento. [06 de julho de 2011]. Santiago do Chile: Arquivo digital da gravação (58min.). Entrevista concedida a Gisela Barcellos de Souza.
} 
grupo CEDLA, ou seja: "a postura que [Rossi] tinha sobre os monumentos; a ideia que tinha sobre a cidade; a ideia que tinha da história; o que era tipologia e que importância tinha a tipologia como instrumento de projeto arquitetônico?"185.

Neste breve excursus empreendido através das viagens de Rossi pela América Latina, é possível perceber como, em determinados contextos, a visita deste arquiteto revestiu-se de representações e significados que transcendiam os limites semânticos do evento em si. Ao contrário do que ocorreu em Colômbia e Venezuela, no âmbito das ditaduras do sul da América Latina a visita de Rossi parece coincidir com a afirmação de uma rede de contatos entre seus leitores. Em meio à clausura do ambiente cultural destes países, algumas instituições e personagens parecem condensar as possibilidades de abertura ao debate internacional; como, neste caso, afigura-se La Escuelita e o papel desempenhado por Antonio Díaz.

As redes de leitores, no entanto, cumprem outras funções no cenário acima descrito: elas servem, também, para a legitimação da forma de atuação dos arquitetos nelas evolvidos. A afirmação de semelhanças entre grupos de diferentes países do Cone Sul é, portanto, buscada como forma de conquistar espaço e maior respeitabilidade aos leitores de Rossi no âmbito nacional. Entre as redes que se entreveem nos destinos e nas conferências de Rossi em sua segunda viagem à Argentina, uma parece ter acontecido com maior frequência - e interessa a esta pesquisa por revelar novas facetas do grupo que viria a organizar o V SAL: o intercâmbio que se estabeleceu entre arquitetos de La Escuelita e do grupo CEDLA.

O CEDLA, como já vimos, desempenhou no contexto da cultura arquitetônica chilena, inicialmente, função similar à da Escuelita, auxiliando na revisão da arquitetura e do urbanismo do Movimento Moderno naquele país - apesar de nunca ter se proposto a ministrar cursos. Dentro deste contexto, o CEDLA realizou a primeira publicação de um compêndio de "A Arquitetura da Cidade" no Chile. Trata-se do artigo "Conceptos teóricos en Aldo Rossi" de autoria de Pedro Murtinho, publicado em agosto de 1977, no encarte nomeado CEDLA 1 - que viria a tornar-se, posteriormente, o embrião da Revista ARS. O texto de Murtinho focava-se nos 3 primeiros capítulos do livro, abordando as questões relativas à definição de tipo, aos fatos urbanos e à cidade como artefato

\footnotetext{
${ }^{185}$ MURTINHO, Pedro. Depoimento. [20 de outubro de 2011]. Santiago do Chile: Arquivo digital da gravação (1hora e 51min.). Entrevista concedida a Gisela Barcellos de Souza.
} 
construído no tempo ${ }^{186}$. Segundo Murtinho, a figura de Rossi foi muito importante nos primeiros anos de atuação do grupo:

Nós nos tornamos grandes leitores e admiradores da obra de Rossi, porque pensávamos que incorporando a tipologia que construíra a história - no caso de Santiago, as passagens internas - era uma forma de estar sendo fiel ao legado histórico-arquitetônico. (...) A figura de Rossi neste sentido como que nos ilustrou, nos indicou um caminho ${ }^{187}$.

Apesar do reconhecimento de Murtinho da importância de Rossi para o CEDLA, é preciso salientar que nunca houve uma filiação estritamente rossiana por parte destes arquitetos. Rossi foi uma das referências, dentre as quais orbitavam Léon Krier, Fernando Montes, entre outros. O contato com as teorias de Rossi se deu, tanto para Boza, como para Eliash, através do contato com o ambiente londrino e intermediado pela interlocução frequente com Léon $\operatorname{Krier}^{188}$.

Nos primeiros anos de sua atuação, o CEDLA encontrou uma grande resistência por parte do público local ${ }^{189}$, recebendo diversas críticas que afirmavam a inadequação das ideias fomentadas por estes arquitetos aos problemas urbanos latino-americanos. Analisados sob esta perspectiva, alguns de seus críticos reconheciam a qualidade dos desenhos - divulgados pelo CEDLA - de Krier e Rossi, porém denunciavam que, ao serem trazidos ao contexto local, estes perdiam matéria e concretude; pareceriam "com um ambiente quase fantasmagórico, de ar parado, irreal, sem tempo"190. O interesse, por outro lado, em promover suas teorias no Chile era acusado de repetir as relações de dependência e colonialismo ${ }^{191}$.

Compreende-se, neste cenário, que a busca da afirmação semelhanças com grupos de países vizinhos permita legitimar a atuação local do grupo. A primeira demonstração de interesse do grupo CEDLA por La Escuelita transparece na publicação

\footnotetext{
${ }^{186}$ MURTINHO, Pedro. Conceptos teóricos en Aldo Rossi. In: CEDLA. Santiago: CEDLA, ago. de 1977 , p. 8-11.

${ }^{187}$ MURTINHO, Pedro. Depoimento. [20 de outubro de 2011]. loc. cit.

${ }^{188}$ ELIASH, H. La arquitectura de Cristián Boza : un eclectisismo apasionado. Santiago, Chile : Ediciones ARQ, 1993.

${ }^{189}$ ELIASH, H. op. cit., 1993.

${ }^{190}$ PALMER TRIAS, Montserrat. Urbanismo, Ideologías y Dependencia. In: CA. Santiago: Colegio de Arquitectos. dec. 1978, p.III.

${ }^{191}$ PALMER TRIAS, M. loc. cit., 1978.
} 
na Revista ARS, de dezembro de 1978, de um artigo escrito a partir do catálogo da exposição realizada no CAYC - Centro de Artes y Comunicación, em Buenos Aires - a respeito dos trabalhos desenvolvidos por aquela escola no ano de $1977^{192}$. Se, nesta reportagem, já se percebem alguns vieses semelhantes - como a revisão da prática profissional e a recuperação "do interesse pela elaboração ideológica dentro do campo da Arquitetura"193 -, seria somente após a primeira visita de Aldo Rossi que maior contato com a experiência que ocorria do outro lado dos Andes seria viabilizado ${ }^{194}$. As Bienais de Arquitetura do Chile seriam, neste contexto, o elemento mediador que tornaria esta troca possível.

$\mathrm{Na}$ definição dos convidados estrangeiros para as II e III Bienais do Chile os arquitetos do CEDLA trataram de propor nomes de arquitetos vinculados à La Escuelita. Logo, Antonio Díaz e Justo Solsona vieram à II Bienal, no ano de 1979. Em 1981, seria a vez de Ernesto Katzenstein que veio através da III Bienal. Rafael Viñoly fora o único fundador de La Escuelita que nunca veio ao Chile, visto que em 1978 já havia emigrado aos EUA. Em texto que introduzia o resumo das palestras ministradas por Antonio Díaz e Justo Solsona na II Bienal, publicado em 1979 pela revista CA, Humberto Eliash apresentava La Escuelita como uma experiência intimamente ligada ao debate internacional. Neste sentido, destacava a visita de Aldo Rossi a esta escola, em 1978, e a importância que suas conferências haviam representado na cultura arquitetônica $\operatorname{argentina}^{195}$. Ao concluir seu texto de apresentação, Eliash buscava vincular simultaneamente o trabalho de La Escuelita ao debate internacional e àquele fomentado pelo CEDLA:

A organização da Escuelita é muito adaptável aos resultados que se vão obtendo e aos requerimentos dos pensamento arquitetônico mundial. Relações internacionais estão sendo estabelecidas não apenas com a Europa

\footnotetext{
${ }^{192}$ GONZÁLEZ, Luis. Cayc: la función sigue la forma. In: ARS. Santiago: CEDLA, n.2, dec. 1978. ${ }^{193}$ GONZÁLEZ, Luis. loc cit. 1978, p.57.

${ }^{194}$ Cristián Boza e Tony Díaz conheceram-se pessoalmente nos EUA, em 1977, durante evento organizado pelo IAUS - cf. BOZA (2011) e DÍAZ DEL BO, Antonio. Depoimento. [02 de fevereiro de 2012]. loc. cit.. Ainda no ano de 1978, anuncia-se uma palestra de Tony Díaz na sede do CEDLA em um folder de divulgação, todavia, esta não chegou a realizar-se.

195 ELIASH, H. Encuentro de Arquitectos Extranjeros. Antonio Díaz y Justo Solsona. In: CA. Santiago: Colegio de Arquitectos, n. 25, dec. 1979b.
} 
e os EUA, mas, também, com instituições como o CEDLA (Centro de Estudios de Arquitectura) de Santiago de Chile ${ }^{196}$.

A partir deste contato inicial, os diálogos com arquitetos de La Escuelita e, sobretudo, com Antonio Díaz se tornariam constantes até a primeira metade da década de 1980, quando grupo CEDLA tomaria outros rumos, engajando-se na busca de afirmação de uma identidade latino-americana. A importância que esta troca com a experiência argentina teve para o CEDLA seria, no entanto, constantemente reafirmada. Neste contexto, a curta estadia de Aldo Rossi, somada aos diálogos frequentes com Antonio Díaz e La Escuelita, serviu para legitimar a trajetória inicial do grupo CEDLA. De tal sorte que Cristián Boza chega a admiti-lo ao falar sobre as relações entre o CEDLA e La Escuelita:
A importância que teve é que nos apoiou. Nós nos convencemos que o que estávamos dizendo era válido. Poderíamos ter tido dúvidas... [...] A conferência [de Aldo Rossi] veio a consolidar o movimento que havíamos iniciado em 1977 e que havia proporcionado uma reviravolta no ensino de arquitetura en Chile ${ }^{197}$.

Se, desde a perspectiva chilena, a experiência de La Escuelita, avalizada por Aldo Rossi, parecia um porto seguro no qual se ancorar - e cuja credibilidade poderia permitir sua extensão ao CEDLA -, tal situação não se verifica no contexto argentino, sobretudo, em seus primeiros anos de atuação daquela escola. Tal qual se observava no contexto chileno, as fontes utilizadas para renovação profissional seriam objeto de questionamento inicial. Neste contexto, encontra-se a recepção inicial do trabalho de Rossi.

Como já mencionado, a primeira publicação sobre este arquiteto italiano na Argentina antecedeu apenas em alguns meses a sua chegada. Trata-se da edição número 22 dos Cadernos Summarios ${ }^{198}$, de agosto de 1978 - nomeada "Racionalismo a tres voces" - na qual se introduzia ao público local um resumo das ideias de Rossi, de Léon Krier e de Ungers. Organizada por Marina Waisman - e baseada em material

\footnotetext{
${ }^{196}$ ELIASH, H. loc cit., 1979b, p.60.

197 BOZA, Cristián. Depoimento. [17 de agosto de 2011]. loc. cit.

198 Coleção dirigida pela historiadora e crítica de arquitetura Marina Waisman que visava, justamente, apresentar ao público argentino compêndios periódicos do debate internacional.
} 
publicado nas revistas Lotus, Controspazio, Architecture d'Aujourd'hui, Arquitectural Design e $2 C$-, na supracitada edição sugeriam-se ao leitor, para além do compêndio, “algumas chaves críticas para empreender o redimensionamento destas propostas" 199 . As críticas tecidas ao trabalho de Rossi apontavam suas preferências por "tipologias burocráticas" e por "uma linguagem que na história contemporânea está ligada às diversas expressões dos regimes totalitários" ${ }^{\prime 200}$. Marina Waisman concluía seu editorial afirmando que "nos trabalhos teóricos de Rossi abundam ideias ricas e positivas", mas que era necessário manter "alerta a atitude crítica frente a sua produção projetual"201. Vale ressaltar que a historiadora argentina reconhecia o valor da obra teórica de Rossi seis anos após de ter publicado o livro "La estrutura histórica del entorno", no qual Waisman apoiava-se no conceito de tipo tal qual definido no texto de Argan "Sobre a tipologia" para propor cinco séries tipológicas - tipologias estruturais, funcionais, formais, de relação obra/ entorno, de modos de emprego das técnicas ambientais - que permitiriam uma abordagem estruturalista da arquitetura e de sua história ${ }^{202}$.

Ainda que destacasse em seu texto o interesse dos trabalhos teóricos de Rossi, as ressalvas de Marina Waisman à sua produção projetual viriam apenas a ilustrar algumas dentre as críticas que posteriormente seriam direcionadas a exercícios de inspiração rossiana que foram desenvolvidos junto à La Escuelita. Mais correntes, no entanto, foram aquelas críticas que - de forma semelhante ao cenário já apontado para o Chile, neste mesmo período - construíam-se sobre a oposição à utilização de conceitos e teorias construídos em países estrangeiros. Estruturavam-se, portanto, como indica Silvestri, através do endosso às "hipóteses dependentistas elementares" ${ }^{203}$.

Entre aqueles que se enquadravam nesta abordagem, encontra-se Ramón Gutierrez. Fundador do Instituto Argentino de Historia de la Arquitectura y el Urbanismo (IAHAU), em 1972, o interesse de Ramón Gutiérrez pelas questões específicas à América

\footnotetext{
${ }^{199}$ WAISMAN, M. Editorial. In: Summarios. Buenos Aires: Ed. Summa, n.22, ago. 1978, p.126.

${ }^{200}$ WAISMAN, M., loc. cit., 1978, p.127.

${ }^{201}$ WAISMAN, M., loc. cit., 1978, p.127.

202 Cf. WAISMAN, Marina. La estructura histórica del entorno. Buenos Aires: Ediciones Nueva Visión, 1972.

203 SILVESTRI, Graciela. Aparencia y Verdad. Reflexiones sobre obras y documentos de arquitectura producidos durante la dictadura militar en la Argentina. In: Block. Buenos Aires: Instituto Torcuato di Tella. n.5, dec. 2000, p.46.
} 
Latina surgiu "quase naturalmente" ${ }^{204}$, motivado por seus trabalhos de investigação e por sua experiência docente em Resistencia (Argentina) - através da qual estabeleceu contato com diversos estudantes paraguaios ${ }^{205}$. Logo, a despeito de ser colega de faculdade de Tony Díaz ${ }^{206}$, Gutiérrez já não via com bons olhos a abertura a teorias e modelos forâneos que representava La Escuelita. Poucos anos após ter ministrado um seminário intitulado "Aproximaciones a la arquitectura americana" em outubro de 1980 naquela escola autônoma, Ramón Gutierrez publicava duras críticas a esta experiência ao escrever sobre a situação da arquitetura argentina sob a ditatura militar:

A decadência do ensino oficial da arquitetura gera sistemas paralelos ('La Escuelita') nos quais se tenta recuperar o ofício, porém sob um nível de abstrações e de vigência de modelos formais externos que coincidem no fundo com a própria carência de um cordão umbilical das faculdades em relação à definição de em que deve atuar o arquiteto $^{207}$.

Os fatos, no entanto, demonstram a existência de uma maior gama de matizes nas relações que se estabeleciam entre distintos grupos. A despeito das acusações de posicionamento e interesses alheios à realidade local, os motivos que levaram ao convite de Ramón Gutierrez, assim como de Jorge Enrique Hardoy, a contribuir com La Escuelita firmavam-se justamente no sentido oposto: o interesse em compreender a “cidade latino-americana". Segundo Díaz ${ }^{208}$, apesar das divergências que possuíam no campo da arquitetura e da política - a exceção da oposição à ditatura -, "o convite teve a ver com nosso interesse em conhecer com maior profundidade estes temas sobre os quais eles eram especialistas".

Justamente nestes anos, Díaz procurava desenvolver em seu atelier em La Escuelita reflexões sobre o que nomeava como a "arquitectura de la manzana" e a "ciudad de la repetición" que associava às cidades latino americanas. Os resultados parciais deste trabalho foram apresentados no III SIAC, em 1980 - evento que dava

\footnotetext{
${ }^{204}$ GUTIÉRREZ, Ramón. Depoimento. [11 de novembro de 2011]. Campinas: Arquivo digital da gravação (1hora e 39min.). Entrevista concedida a Gisela Barcellos de Souza.

${ }^{205}$ GUTIÉRREZ, Ramón. Depoimento. [11 de novembro de 2011]. loc. cit.

${ }^{206}$ GUTIÉRREZ, Ramón. Depoimento. [11 de novembro de 2011]. loc. cit.

${ }^{207}$ GUTIÉRREZ, R. Arquitectura y Urbanismo en Iberoamérica. Madrid: Cátedra, 1983, p.660.

${ }^{208}$ DÍAZ DEL BO, Antonio. Depoimento. [02 de fevereiro de 2012]. loc. cit.
} 
continuidade ao I SIAC e que foi organizado em Barcelona por Salvador Tarragó ${ }^{209}$. No texto que resume a apresentação de Díaz naquele evento, percebe-se claramente quais eram as suas preocupações naquele momento:

Quase todas as leituras de cidades e quase todas as teorias urbanas foram realizadas com base na experiência dos países centrais. Na maioria dos casos elas não levaram em conta uma realidade como a nossa porque, obviamente, era uma realidade que não pertencia a seus autores.(...) [A cidade da repetição em forma de xadrez] para nós, por outro lado, é um fato indiscutível de todos os dias e o mais surpreendente é, em todo caso, que esta estrutura urbana e sua arquitetura possam ser contestadas ${ }^{210}$.

As diferenças de posturas, no entanto, afirmavam-se na forma de realizar esta leitura desta cidade e de seus fins. Neste sentido, Díaz buscava destacá-lo em seu artigo:

Significa [...] ter clareza que não se trata de encontrar uma "expressão própria" abstratamente e menos ainda um estilo particular meramente folclórico. Trata-se de algo mais importante: de reconhecer as leis essenciais de um fenômeno e saber como convertê-las em elementos úteis para a discussão de seu desenvolvimento e/ou transformação ${ }^{211}$.

Este texto de Díaz, não apenas era conhecido de Gutierrez, como ele utilizaria a leitura de Buenos Aires a partir dos projetos que lhe foram destinados como exemplo de uma prática pós-modernista e "irresponsável” da arquitetura na América Latina entre os anos 1970 e 1990, em seu texto "Arquitectura Latinoaméricana: haciendo caminho al andar" $^{212}$, dez anos mais tarde.

\footnotetext{
${ }^{209}$ Ramón Gutierrez também foi convidado para este evento - era amigo pessoal de Tarragó - e chegou a enviar um texto que foi incluído nos Anais, porém não pôde ir. Cf. GUTIÉRREZ, Ramón. Depoimento. [11 de novembro de 2011]. Campinas: Arquivo digital da gravação (1hora e $39 \mathrm{~min}$.). Entrevista concedida a Gisela Barcellos de Souza.

${ }^{210}$ DÍAZ, Antonio. Buenos Aires: La arquitectura de la "manzana". In: La Manzana como Idea de Ciudad. Elementos teóricos y propuestas para Buenos Aires. III SIAC. Barcelona: $2 \mathrm{C}$ ediciones, 1980, p.39

${ }^{211}$ DÍAZ, A. loc. cit., 1980, p.39.

212 "A ironia de sociedades satisfeitas e sofisticadas transposta a sociedades carentes e plenas de expectativas é uma zombaria insustentável que os pós-modernistas utilizam orgulhosamente em sua irresponsável prática profissional. Assim, as ideas diretrizes de um edifício podem ser as de um 'cubo virtual' sem compromisso algum com funções ou usuários, enquanto a megalomania de algum colega nos oferece uma 'leitura' de uma cidade como Buenos Aires a partir de três obras inconclusas. Vale tudo, e o cinismo também." Cf. GUTIÉRREZ, "Architettura latinoamericana. Strada faceno" In: GUTIÉRREZ, R. (org). Architettura e Società", Milão: Jaca Books, 1996., p.30.
} 
Logo, entende-se que, neste contexto, o convite de membros de La Escuelita para participar das bienais chilenas venha a condensar as possibilidades de afirmar a validade no âmbito regional dos exercícios e das reflexões que ensejavam. Mesmo após a primeira visita de Rossi, La Escuelita ainda era tida como uma experiência marginal na Argentina - ainda que não isolada ${ }^{213}$. As participações nos debates das mostras chilenas, não apenas demonstraram, momentaneamente, sua projeção para além da cordilheira, como seriam, também, posteriormente destacadas entre as atividades desempenhadas por La Escuelita na publicação que resumia suas atividades entre 1976 e $1981^{214}$.

\section{Conexões via Londres: as relações entre Léon Krier, Fernando Montes e o CEDLA}

Grande parte dos projetos arquitetônicos recentes possuem uma cuidadosa aproximação às características do contexto urbano. É frequente que os projetos se expliquem a partir de análises dos traçados convencionais, da importância social de certos espaços tradicionais (como a rua, a praça, o parque ou a travessa), das características do ambiente físico circundante ou ainda da paisagem urbana de modo geral. [...] É incontestável que tanto no discurso teórico como na prática, a temática do respeito ao entorno foi abrindo caminho como um aspecto de importância primordial na nossa arquitetura $^{215}$.

O excerto acima, retirado do texto de Silvia Arango "Estrutura Essencial e Estrutura Contingente" - apresentado originalmente no IV SAL - era ilustrado em sua republicação nos Cadernos Summarios pelas elevações urbanas de Rob Krier, que compunham seu livro Stadtraum - ou "espaço urbano" ${ }^{\prime 216}$. A escolha da ilustração não era gratuita, fazia menção direta a umas das principais fontes dos arquitetos latinoamericanos na abordagem da relação edifício-cidade e ecoava, igualmente, a exposição

\footnotetext{
${ }^{213}$ SILVESTRI, G. loc. cit., 2000.

${ }^{214}$ DÍAZ; SOLSONA et. al., op.cit., 1981.

215 ARANGO, S. Estrutura Essencial y Estrutura Contingente. In: IV Encuentro de Arquitectura Latinoamericana/ México. "La Trindad", Tlaxcala, IV, Anais...Tlaxcala (México): Universidad Autónoma Metropolitana, 1989. Republicado em: Summarios. Buenos Aires: Ed. Summa, n.134, mar/abr 1990, p.4-7.

${ }^{216}$ Cf. ARANGO, S. Estrutura Essencial y Estrutura Contingente. In: Summarios. Buenos Aires: Ed. Summa, n.134, mar/abr 1990, p.4-7.
} 
de Arango no III SAL, na qual a arquiteta colombiana destacava a significativa penetração das contribuições de Rossi, de Léon e Rob Krier no subcontinente.

Efetivamente, se, por um lado, as ideias e propostas dos irmãos luxemburgueses não parecem ressoar com a intensidade descrita por Arango em revistas brasileiras ${ }^{217}$ no período entre 1977 e $1997^{218}$; por outro, verifica-se que o número de reportagens de cobertura da atuação de Rob e de Léon Krier - bem como das iniciativas motivadas pela associação entre este último e Maurice Culot, tal qual a "Reconstrução da Cidade Europeia" ou os chamados "contrapropostas" - em revistas da Argentina ${ }^{219}$ e da Colômbia ${ }^{220}$ foi semelhante ao espaço destinados a textos sobre Rossi ${ }^{221}$. Apesar da discrepância na cobertura similar a personagens que possuem uma importância distinta na revisão do Movimento Moderno e na construção do debate sobre a tipo-morfologia, a frequência com que os irmãos Krier constaram em revistas analisadas não é exclusiva ao subcontinente.

Ambos luxemburgueses tiveram uma penetração significativa na cultura arquitetônica europeia entre os meados dos 1970 e início dos anos 1980. Para além do fato de dominarem diferentes línguas - o que facilitou, de fato, seu trânsito por diferentes países europeus -, a grande difusão das ideias dos irmãos Krier explica-se,

${ }^{217}$ De fato, não se encontrou nenhum artigo dedicado à exposição da obra ou da teoria de Rob ou Léon Krier. Contudo, deve-se destacar que nos anais do primeiro SEDUR, Rob Krier foi mais citado que Aldo Rossi, ainda que de forma pouco expressiva como aquele italiano - o luxemburguês consta nas referências de três artigos, enquanto Rossi consta em dois - cf. TUKIENICZ, Benamy (org)., op. cit, 1984a; TUKIENICZ, Benamy (org)., op. cit, 1984b; TUKIENICZ, Benamy (org)., op. cit, 1984c;

${ }^{218}$ Este foi o recorte, de modo geral, que se utilizou para analisar as revistas latino-americanas, à excessão daquelas que se extinguiram antes, bem como de outras nas quais se verificou intercâmbios latino-americanos anteriores a 1977 - ver Apêndice D.

${ }^{219}$ Entre 1982 e 1987, observam-se na revista Summa três reportagens que se enquadram na situação descrita: uma reportagem sobre a "Reconstrução da Cidade Europeia", em 1982 (n.181); uma entrevista com Léon Krier, em 1983 (n. 187) e outra com Rob Krier em 1987 (n.244). A mesma entrevista publicada na Summa com Léon Krier, compôs também a edição número 35 da revista argentina A/ambiente, de dezembro de 1983. Na Summarios, além do número "Racionalismo a tres voces" (n.22, de 1978), que apresentava ao público argentino as obras dos irmãos Krier junto às de Ungers e de Rossi, publicou também uma matéria específica sobre a "Campanha Europeia para o Renascimento da Cidade" - motivada e fomentada por Culot e Léon Krier - no número 65, de 1983.

${ }^{220} \mathrm{Na}$ Colômbia, a revista Proa dedica uma reportagem sobre os contra-projetos em 1990 (n.389) e a Escala publica um texto no número 123 (1992) sobre a polêmica exposição que Léon Krier organizou sobre a obra de Albert Speer, arquiteto de Hitler, em 1992.

${ }^{221}$ Comparando-se com as publicações de Rossi no período analisado, verifica-se que o número de referências nas revistas argentinas analisadas no período entre 1977 e 1997 é o mesmo, e que, caso colombiano, é ligeiramente inferior. 
também, pela habilidade que possuíam em expressá-las em forma de desenho e pelo nível de simplificação das noções e conceitos da tipo-morfologia que se verifica nessas. De um lado, o catálogo de espaços urbanos de Rob Krier, de outro, nas lições e receitas - como as definiu Fernando Montes ${ }^{222}$ - que Léon divulgava em publicações diversas; as ideias de ambos, representadas em forma de desenhos, viajavam sem sofrer as barreiras das traduções e tornavam-se mais passíveis de assimilação que debates aprofundados sobre noções e conceitos. A qualidade do desenho destes arquitetos era frequentemente destacada em textos da época, sejam escritos por Marina Waisman ${ }^{223}$ ou por Antoine Grumbach:

[...] os irmãos Krier transformam violentamente a repressão da arquitetura em vontade de reutilizar a autonomia dos desenhos, prática mágica, figuras sempre escondidas, desmaterializadas pelo construído. Os desenhos de arquitetos e, em particular, de Robert e Léon Krier, se desprendem dos tabus morais nos quais os havia encerrado o Movimento Moderno, ao condenar o prazer da figuração [...]. ${ }^{224}$

Neste contexto de difusão das ideias dos irmãos luxemburgueses, deve-se salientar que o livro "Stadtraum in Theorie und Praxis" de Rob Krier, publicado originalmente em alemão em 1975, foi traduzido logo no ano seguinte para o espanhol publicado pela Gustavo Gili em $1976^{225}$ - e que suas versões para o inglês e para o francês antecipam em poucos anos a tradução de "Arquitetura da Cidade" para estes mesmos idiomas - edição em inglês foi publicada em 1979, simultaneamente pela Rizzoli (EUA) e pela Academy Editions (Grã Bretanha), enquanto que a versão francesa

\footnotetext{
${ }^{222}$ Fernando Montes, em seu depoimento, explicou o sucesso que Léon Krier obteve nesse período da seguinte forma: "Léon tinha algo farmacêutico, ou seja, ele tinha receitas magistrais: 'para as ruas, deve-se fazer isto...'. Logo, ele dava receitas e mais receitas ... E para os estudantes receita é a palavra sagrada. O que os estudantes mais querem são as receitas" - MONTES, Fernando. Depoimento. [20 de dezembro de 2011]. Santiago do Chile: Arquivo digital da gravação (1hora e $28 \mathrm{~min}$.). Entrevista concedida a Gisela Barcellos de Souza.

${ }^{223}$ Marina Waisman escrevia, em no editorial dos Cadernos Summarios 22, que os desenhos de Léon Krier eram "belíssimos" - cf. WAISMAN, M. Editorial. In: Summarios. Buenos Aires: Ed. Summa, n.22, ago. 1978, p.126.

${ }^{224}$ GRUMBACH, Antoine. I fratelli Krier/The Krier Brothes. Lotus, n.11, 1976, p.64.

${ }^{225}$ A primeira edição em espanhol foi publicada na coleção "Materiales de la Ciudad" sob o título "Stuttgart. Teoria y práctica de los espacios urbanos. Isto explica, portanto, que alguns latinoamericanos, como Cristián Boza em seu depoimento, se refiram a este livro como "Stuttgart". Uma nova edição espanhola, também da Gustavo Gili, foi editada em 1981, com o título "El espacio urbano".
} 
foi publicada em 1980 pela AAM, editora de Maurice Culot $^{226}$. A capacidade de Léon Krier de congregar arquitetos no Norte e no Sul da Europa e de motivar eventos e publicações, por outro lado, não deve ser menosprezada. Ademais de suas contribuições, já descritas, na no debate arquitetônico da Inglaterra, Bélgica e França; Léon Krier transitava, também, na Itália e nos EUA. A título de exemplo, veja-se sua contribuição na elaboração da "Declaração de Palermo" ${ }^{227}$ - manifesto considerado o embrião da "Declaração de Bruxelas", redigido e firmado em evento organizado por Pierluigi Nicolin, então editor da revista Lotus International, em abril de $1978^{228}$-; bem como a realização de exposições retrospectivas de seus desenhos em Verona ${ }^{229}$, em 1980, e em Nova York ${ }^{230}$, no ano seguinte.

Logo, compreende-se, através da descrição deste cenário, a importância que a amizade entre Léon Krier e Cristián Boza teve para a legitimação da atuação inicial do grupo CEDLA. Segundo, Cristián Boza, o contato com Léon Krier se estabeleceu através da Architectural Association, durante o período em que o arquiteto chileno foi assistente do atelier Sue Rogers ${ }^{231}$. Logo se tornaram amigos próximos e frequentavam o círculo de arquitetos semelhantes, no qual estavam James Stirling, Robin Nicholson ${ }^{232}$, Rodrigo Perez de Arce, e outros ${ }^{233}$. Devido à proximidade entre ambos, quando Léon Krier viajava, costumava emprestar sua residência em Londres para que Boza a utilizasse como atelier temporário. Desta forma, Boza e Eliash trabalharam esporadicamente na casa-atelier de Krier, local onde desenvolveram o projeto arquitetônico para uma residência de idosos na cidade de Milton Keynes ${ }^{234}$. Na ocasião da realização da

\footnotetext{
${ }^{226}$ SOUZA, G. B. Re-dire et dé-dire: le nouvel urbanisme en Europe. Dissertação. Université de Paris VIII, Paris, 2004.

${ }^{227}$ A Declaração de Palermo foi escrita por Léon Krier, Pierluigi Nicolin, Villa, Maurice Culot e Antoine Grumbach. Ver a respeito: BAREY, A. op. cit. 1980.

${ }^{228}$ BAREY, A. op. cit. 1980.

${ }^{229}$ A exposição ocorreu no Museo di Castelvecchio, em Verona. Ver: PAVAN, Vicenzo; KRIER, L. Léon Krier. La ricostruzione della Città Europea, Veneza: Cluvea, 1980.

${ }^{230}$ A exposição em Nova York ocorreu nos meses de janeiro e fevereiro de 1981, no Max Protetch Gallery - CULOT, M; KRIER, L. Léon Krier: Drawings 1967-1980, Bruxelas: AAM, 1980.

${ }^{231}$ BOZA, Cristián. Depoimento. [10 de agosto de 2011]. Santiago do Chile: Arquivo digital da gravação (23min.). Entrevista concedida a Gisela Barcellos de Souza.

${ }^{232}$ Ver nota 77, capítulo 3.

${ }^{233}$ Cf.ELIASH, H. La arquitectura de Cristián Boza : un eclectisismo apasionado. Santiago, Chile : Ediciones ARQ, 1993.

${ }^{234}$ ELIASH, H. op. cit., 1993.
} 
exposição Rational Architecture, organizada por Léon Krier na ART-NET ${ }^{235}$, Eliash ainda não havia chegado a Londres; Boza, no entanto, não somente estava presente, como, também, auxiliou em sua montagem ${ }^{236}$. Mesmo após o foi mantido através de cartas e reafirmado em viagens curtas posteriores de Boza à Inglaterra ${ }^{237}$.

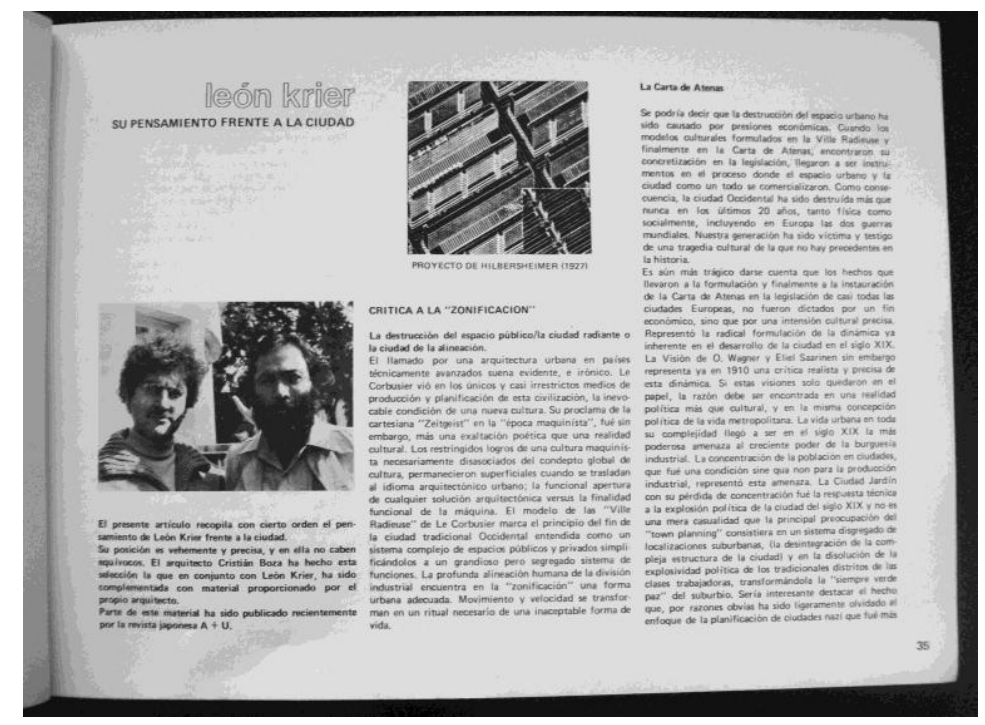

Figura 68: Foto de Léon Krier e Cristián Boza na página da revisa ARS número 1 que introduz o texto de Léon Krier. Fonte: ARS, n.1, jul. 1978.

Este contato direto com Léon Krier seria destacado logo nas primeiras aparições do grupo CEDLA. Na primeira edição da revista ARS - julho de 1978 -, publicou-se um artigo que resumia as ideias de Léon Krier. Destacava-se que o material apresentado havia sido selecionado em conjunto por Boza e Krier $^{238}$ - tratava-se da tradução de excertos de texto publicado na revista $\mathrm{A}+\mathrm{U}$ complementada pelo arquiteto luxemburguês ${ }^{239}$. A introdução ao artigo vinha acompanhada de uma fotografia de Cristián Boza ao lado de Léon Krier - sem especificação de data e local - e da seguinte apresentação do arquiteto luxemburguês: "Sua posição é veemente e precisa, nela não cabem equívocos" ${ }^{240}$.

A proximidade entre 0 arquiteto luxemburguês e Boza, testemunhada pela fotografia, somada a afirmação assertiva da importância e do valor de suas posturas

\footnotetext{
${ }^{235}$ ELIASH, H. op. cit., 1993.

${ }^{236}$ BOZA, Cristián. Depoimento. [10 de agosto de 2011]. loc. cit.

${ }^{237}$ BOZA, Cristián. Depoimento. [10 de agosto de 2011]. loc.cit.

${ }^{238}$ ELIASH, H.; BOZA, C., et al. Léon Krier. Su pensamiento frente a la ciudad [introdução ao artigo de Krier]. In: ARS. Santiago de Chile: CEDLA, n.1, julho 1978, p.35.

${ }^{239}$ ELIASH, H.; BOZA, C., et al. loc. cit. 1978.

${ }^{240}$ ELIASH, H.; BOZA, C., et al. loc. cit.,1978, p.35.
} 
defendidas, cumpria um papel distinto dos compêndios da obra de Rossi ${ }^{241}$ e de Gregotti $^{242}$ que haviam composto o encarte nomeado CEDLA, a primeira publicação do grupo. Naquele momento, tratava-se de introduzir um debate à cultura arquitetônica chilena. Na nova edição, no entanto, busca-se afirmar que a filiação direta do CEDLA. Neste sentido, neste mesmo número, publicava-se também um trecho de uma carta de Léon Krier a Boza, no qual o luxemburguês agradecia a publicação e os desenhos do grupo recebidos ${ }^{243}$. O contato direto com Léon Krier, portanto, servia para ratificar que o grupo chileno não estava sozinho nas ideias que defendia e que seu trabalho era conhecido por um arquiteto com projeção no continente europeu.

Esta estratégia, no entanto, ocorria nos dois sentidos; para Krier, o grupo chileno representava a repercussão de suas ideias na América Latina. Compreende-se neste contexto que, apesar de o projeto para "Santiago Poniente"244 tenha sido elaborado em 1977 - portanto, após a exposição organizada por Krier em Londres -, Léon tenha decidido incluir seus desenhos ${ }^{245}$ no catálogo Rational Architecture, publicado em $1978^{246}$. Com efeito, no desenvolvimento deste projeto o diálogo com Krier foi fundamental, como o confessa Eliash ${ }^{247}$. Ademais das proximidades já apontadas com o projeto de Léon Krier para La Villette, a proposta desenvolvida pelo CEDLA foi submetida, também, à avalição de Léon ${ }^{248}$. No catálogo, Krier o apresentava entre os exemplos de proposta estruturada a partir do conceito de "building-block" - ou seja, do quarteirão como elemento base da composição urbana - complementava o memorial do projeto com sua interpretação pessoal sobre seu significado, destacando a recuperação de aspectos que caracterizavam a cidade tradicional:

Nos últimos 150 anos, o interior das manzanas foi explorado por um sistema de passagens, de galerias, de mews e de pátios públicos, etc. A continuidade

\footnotetext{
${ }^{241}$ MURTINHO, Pedro. Conceptos teóricos en Aldo Rossi. In: CEDLA. Santiago: CEDLA, ago. de 1977, p. 8-11.

${ }^{242}$ CONTRERAS, Ricardo. Vittorio Gregotti, la arquitectura de sus ideas. In: CEDLA. Santiago: CEDLA, ago. de 1977, p. 11-14.

${ }^{243}$ Ver seção Cartas na ARS número 1, julho de 1978.

${ }^{244}$ Ver capítulo 3, Santiagos Ponientes.

${ }^{245}$ BOZA, Cristián. Depoimento. [10 de agosto de 2011]. loc.cit.

${ }^{246}$ Krier (org). Rational Architecture :The Reconstruction of the European city/Architecture Rationnelle: La Reconstruction de la Ville Européenne, Bruxelles, A.A.M, 1978

${ }^{247}$ ELIASH, H. op. cit, 1993.

${ }^{248}$ BOZA, Cristián. Depoimento. [10 de agosto de 2011]. loc.cit. Verificar, também, referência ao mesmo em excerto de carta de Krier a Boza, publicada na revista ARS número 1, julho 1978.
} 
das construções permitia uma solução coerente e econômica para as habitações populares, nas quais a principal preocupação era a conformação do espaço público. [...] Este sistema foi abalado pela importação do bungalow norte americano bem como das ideias do CIAM, que se tornaram influentes a partir dos anos $1930^{249}$.

Para além desta legitimação da atuação inicial do grupo e do projeto que o lançou publicamente, através Léon Krier estabeleceu-se, igualmente, o contato com outro arquiteto chileno que seria fundamental para a concepção do CEDLA. Trata-se de Fernando Montes que, no momento, estava envolvido com o debate do "retorno à cidade" na França e conheceu Léon Krier em suas participações frequentes nas bancas de conclusão de curso em La Cambre ${ }^{250}$. Assim, sem conhecer Cristián Boza, Montes aproveitou uma visita particular que fazia ao Chile em 1976, para encontrá-lo, visto que havia sido indicado por Krier ${ }^{251}$. Boza afirma que não esperava por sua visita, no entanto, quando o conheceu "começa[ram] a conversar e não para[ram] de fazê-lo por dois dias" $^{\prime 252}$. Na ocasião, combinaram que Fernando Montes faria duas conferências no escritório de Boza a fim de introduzir a revisão do Movimento Moderno no Chile ${ }^{253} . \mathrm{Em}$ sua revisão sobre a cultura e a prática profissional no Chile nos anos 1970, Perez Oyarzun destacaria a importância destas conferências de Montes:

Em 1976, o escritório de Boza, Lührs e Muzard, considerada entre as de vanguarda no meio local, convidou um conjunto de profissionais e acadêmicos para assistir duas conferências do arquiteto chileno residente na França, Fernando Montes. [...] Em suas conferências, Montes propôs apresentar algumas das novas tendências que desde meados dos anos sessenta estavam se desenvolvendo na Europa e nos Estados Unidos. Foi assim que aproximadamente uns cinquenta assistentes puderam se

\footnotetext{
${ }^{249}$ Krier (org). op. cit., 1978, p.83 (grifo nosso para destacar palavras que estavam em inglês e em espanhol no original).

250 MONTES, Fernando. Depoimento. [20 de dezembro de 2011]. Santiago do Chile: Arquivo digital da gravação (1hora e $28 \mathrm{~min}$.). Entrevista concedida a Gisela Barcellos de Souza.

${ }^{251}$ MONTES, Fernando. Depoimento. [20 de dezembro de 2011], loc. cit.

252 BOZA, Cristián. Depoimento. [17 de agosto de 2011]. Santiago do Chile: Arquivo digital da gravação (1hora e 1min.). Entrevista concedida a Gisela Barcellos de Souza.

253 BOZA, Cristián. Depoimento. [17 de agosto de 2011], loc. cit.
} 
aproximar à obra de Rossi ou dos irmãos Krier na Europa e de Robert Venturi nos EUA ${ }^{254}$.

Segundo Boza, o número de assistentes ultrapassou, em muito, o que se esperava inicialmente e, como resultado, “as pessoas se penduravam nas janelas" ${ }^{255} \mathrm{da}$ casa que servia como escritório. Após este evento, "Montes se transformou em uma espécie de guru para este grupo [que viria a fundar o CEDLA] e passou a vir seguidamente ao Chile ${ }^{256}$. Este papel exercido por Montes é verificável através da análise longitudinal do encarte CEDLA e dos primeiros números da revista ARS. Entre 1977 e 1984, há apenas um único número - o de dezembro de 1978 - em que não foi publicado nenhum texto de sua autoria ${ }^{257}$. No terceiro número da ARS, Montes chegou a constar entre os colaboradores permanentes da revista, ao lado de membros do CEDLA.

As citações a Montes eram frequentes e o diálogo que este arquiteto estabeleceu com o grupo o motivou em diferentes empreitadas. Dentre estas, a que obteria maior fortuna crítica seria a elaboração da investigação sobre a arquitetura anônima de Santiago - que, ao fundo, ressonava no Chile as polêmicas geradas na cultura arquitetônica francesa pelos textos em que de Bernard Huet defendia a prática ordinária e denunciava o "mito da criatividade" ${ }^{258}$. Segundo Boza, a pesquisa que resultou no livro "Inventario de Arquitectura Anónima", publicado em 1982, teria sido sugerida por Montes:

Durante uma estadia de Fernando Montes, ele nos disse: o que vocês têm que fazer é demonstrar aos arquitetos chilenos o que estamos transmitindo.

\footnotetext{
${ }^{254}$ PÉREZ OYARZUN, Fernando. Arquitectura, cultura y práctica profesional en Chile 1930-1980. In: LIERNUR (org). Portales del Laberinto. Arquitectura y Ciudad en Chile, 1977-2009. Santiago de Chile: Universidad Andrés Bello, 2009. p.116-117.

255 BOZA, Cristián. Depoimento. [17 de agosto de 2011], loc. cit.

${ }^{256}$ BOZA, Cristián. Depoimento. [17 de agosto de 2011], loc. cit.

${ }^{257}$ Conferir: MONTES, Fernando. Santiago Poniente: en torno a su remodelación. In: CEDLA. Santiago: CEDLA, ago. de 1977, 24-25; MONTES, F. Modernidad e Inibición. In: ARS. Santiago: CEDLA, n.1, jul. 1978, p.67-69; MONTES, F. Hacia una arquitectura convencional. . In: ARS. Santiago: CEDLA, n.3, jul. 1979, p.4-9; MONTES, F. 157 Departamentos, Ciudad Nueva de CergyPontoise, Paris, 1980. In: ARS. Santiago: CEDLA, n.4, ago 1981, p.85-87; MONTES. F. Santiago no es una ciudad fácil. In: ARS. Santiago: CEDLA, n.5, jul. 1984, p.59-61.

258 Referimo-nos aos textos em que Bernard Huet retoma o conceito de "imitação", tal qual definido por Quatremère de Quincy, e opõe-se à ideia da necessidade da originalidade - Cf. HUET, Bernard. Anachroniques d'architecture. Bruxelles : Editions des Archives d'architecture moderne, 1981.
} 
[Ao iniciar a investigação,] nós mesmos nos surpreendemos, porque nos demos conta que não conhecíamos Santiago da Praça Itália para baixo. [...] Ninguém nos havia recomendado ir à Praça Brasil ou à Praça Yungay, ir ao Bairro da Av. Matta. Entender o tecido urbano, a trama urbana, entender as cités, as travessas, a arquitetura eclética, ninguém nos havia ensinado nada disto $^{259}$.

O diálogo com Fernando Montes, no entanto, parece ter esmaecido a partir de meados dos anos $1980^{260}$. Suas contribuições na ARS praticamente desaparecem ${ }^{261}$ quando o CEDLA passa a se engajar no debate sobre a identidade latino-americana. Neste momento, contatos com países vizinhos parecem mais importantes que aqueles com a Europa e a construção de bricolagens é procurada do que a realização de traduções e compêndios.

\subsection{A construção de bricolagens ou a impossibilidade da cidade europeia}

[...] a poesia da bricolagem vem também, e sobretudo, do fato que ela não se limita à alcançar ou executar [...]. Sem nunca finalizar seu projeto, o bricoleur sempre coloca algo de si nele ${ }^{262}$.

Entre os diferentes encontros que acabamos de narrar, verificam-se, grosso modo, semelhanças na busca do estabelecimento de vínculos com a cultura arquitetônica europeia. $\mathrm{O}$ contato com o debate sobre a tipo-morfologia em sua "origem" aparecia, naquele momento, como possibilidade de certificação da genuinidade das traduções culturais ensejadas. Podia-se traduzir ou porque se presenciou o discurso no momento em que este nascia, ou porque se tinha contato direto com uma de suas fontes. Neste sentido, ainda que alguns latino-americanos se

\footnotetext{
${ }^{259}$ BOZA, Cristián. Depoimento. [17 de agosto de 2011], loc. cit.

${ }^{260}$ Fernando Montes confirma a existência de um distanciamento a partir de meados dos anos 1980. MONTES, Fernando. Depoimento. [27 de dezembro de 2011]. Santiago do Chile: Arquivo digital da gravação (58min.). Entrevista concedida a Gisela Barcellos de Souza.

${ }^{261}$ Há apenas um projeto de Montes para a Casa-atelier de Le Corbusier, na ARS número 8, de setembro de 1987.

${ }^{262}$ LEVI-STRAUSS, Claude. La pensée sauvage. Paris: Plon, 1962,p.32
} 
aventurassem em tecer reflexões que se distanciavam das matrizes originais, a presença deste diálogo com o continente europeu parecia condição fundamental para a validade ou não do que estavam produzindo.

Os encontros e traduções culturais iniciais acima descritos diferem em muito, portanto, de um segundo momento, em que se verifica a construção de bricolagens. Ao contrário do que se observou no subcapítulo precedente, não há neste contexto uma preocupação com o reconhecimento de uma filiação. Se a tradução cultural tinha sua validade reconhecida pela proximidade com o debate ultramarino, a estratégia que marca o que nomeamos nesta tese como bricolagens é justamente a oposta: parte-se da afirmação da distância, da impossibilidade de transposição ao contexto regional de debates e conceitos gestados em contextos forâneos, para, na sequência, recortar, sobrepor, combinar e adaptar discursos de origens diversas na constituição de representações que transcendem suas origens, perpassam por variados meios e manifestam-se nos SAL - entre o terceiro e o quinto, mais especificamente. Nas traduções a legitimação - de leitores e de tradutores - era dada pelo reconhecimento estrangeiro; na bricolagem ela surge como um a priori. Ou seja, trata-se de uma construção legítima pelo simples fato de ser produzida a partir da realidade e das questões locais.

Não se trata, certamente, de momentos que se encadeiam linearmente, ou, menos ainda, de etapas condicionadas. Em alguns núcleos, por exemplo, o concurso dos vínculos com latino-americanos e com o ambiente europeu se dá de forma quase simultânea e, nesse sentido, parecem cumprir papeis semelhantes ${ }^{263}$. Por outro lado,

${ }^{263}$ Este é o caso dos intercâmbios estabelecidos através do PROPAR/UFRGS, que quase simultaneamente a realização de um convênio através do qual professores da UFRGS realizavam um estágio na Architectural Association, busca-se o estabelecimento de contatos com arquitetos latino-americanos. Entre 1985 e 1989, arquitetos latino-americanos e europeus frequentaram o programa de pós-graduação, dos quais se localizou nos arquivos do PROPAR/UFRGS os seguintes registros: Alfonso Corona Martinez (em 1985, 1986, 1987 e 1989); Fernando Diez (1986); Marina Waisman (1986 e 1987); Marcelo Trabuco (1986, 1987 e 1988); Miguel Angel Roca (1987); Jorge Liernur (1987); José Rosas Vera (1986); Enrique Browne (1987); Pedro Murtinho (1989); Rodrigo Pérez de Arce (1986); Fernando Pérez Oyarzún (1986 e 1987); Eladio Dieste (1987 e 1989); Juvenal Baracco (1989); Philippe Panerai (1987); Ignasi de Solà-Morales (1989). Para tanto, os encontros de quatros Encontros de Ensino de Projeto (realizados em 1985, 1986, 1987 e 1989) e o curso de especialização “Pensamento Arquitetônico Moderno e Contemporâneo" (de 1986 a 1988) servem como forma de viabilizar estes intercâmbios - cf. COMAS, C. E.D.. Depoimento. [01 de abril de 2011]. loc. cit., bem como OLIVEIRA, R. Depoimento. [30 de março de 2011]. Porto Alegre: Arquivo digital da gravação (1hora e 9min.). Entrevista concedida a Gisela Barcellos de Souza. 
como já destacado no capítulo "Ecos e escoamentos", observa-se que, de modo geral, na primeira metade dos anos 1980, multiplicam-se os contatos entre arquitetos latinoamericanos - sobretudo entre aqueles que viriam a engajar-se nos $\mathrm{SAL}-\mathrm{e}$, a partir de meados da década, a afirmação destes encontros regionais parece ser tão importante quanto foram, na virada dos anos 1970 aos 1980, aqueles contatos com arquitetos europeus.

Abordaremos, na sequência, a construção - através de encontros diversos que transcendem os limites dos SAL e, em parte, os antecipam - de algumas bricolagens que se manifestaram nos debates dos terceiro, quarto e quinto seminário: a periferia como própria e o centro histórico latino-americano, os dois polos sob os quais a cidade foi debatida ao longo destes seminários. Buscar-se-á demonstrar como permanecem nestas bricolagens partes reconhecíveis de debates anteriores e de origens distintas que, ao serem recombinadas, adquirem novos significados. Não se observa, portanto, a dívida a um único debate, que caracterizaria a tradução cultural, mas sim a hibridação entre diversos.

A compreensão da cidade latino-americana através de dois polos - o centro histórico e a periferia urbana -, como vimos, já se manifesta evento de Manizales. Esta construção foi ganhando corpo ao longo dos anos ao ponto de que fora, no momento em que se preparava o V SAL, apresentada por Moscato como a base de uma teoria urbana da cidade latino-americana ${ }^{264}$. A necessidade de "estruturar uma disciplina urbana latino-americana" já era apontada por Moscato e Schere, em 1989, em contribuição apresentada no evento de Tlaxcala ${ }^{265}$. Ainda que esta dita teoria nunca tenha sido sistematizada de forma aprofundada pelos autores que se declaravam engajados em sua construção, sua reafirmação foi constante.

Após o evento de Caracas $^{266}$, Moscato afirmava que a estrutura urbana de nossas cidades havia permanecido "praticamente desconhecida" até o estudo da

\footnotetext{
${ }^{264}$ Ver a introdução ao capítulo "Tecendo as partes da cidade latino-americana". Cf. MOSCATO, J. El Movimiento de arquitectura Latinoamericana para los años 90. In: CA, Santiago do Chile: Colegio de Arquitectos, n. 65, jul./ago./set 1991, p.26-28.

${ }^{265}$ MOSCATO, J.; SCHERE, R. Hacer Arquitectura en Argentina. In: IV Encuentro de Arquitectura Latinoamericana/ México. "La Trindad", Tlaxcala. IV, Anais...México: Universidad Autónoma Metropolitana, 1989.

${ }^{266}$ Apesar de ter sido publicado em 1996, o texto "Gli Architetti in America Latina" se refere ao evento de Caracas, de 1993, como o último seminário. Cf. MOSCATO, J. Gli Architetti in America Latina. In: GUTIÉRREZ, Ramón (org). Architettura e Società. L'América Latina nel XX secolo.
} 
periferia urbana nos eventos de Manizales e Tlaxcala, e "do centro da cidade e os bairros em Santiago" 267 . Neste sentido, retomava o texto escrito para a seção "Documento" da VIII Bienal de Arquitetura do Chile, afirmando:

Se hoje parece inevitável a construção de uma teoria sobre a cidade na América Latina, é graças à aceitação de um substrato comum e ao fato que, depois de tanto esforço, ao final do século XX quase desapareceram os opositores ao projeto. [...] Devemos rever a definição de algumas grandes problemáticas que têm feito parte de nossa bagagem intelectual: a teoria da periferia urbana (continuidade da problemática de nossos bairros já consolidados, e traço específico de nossa realidade que caracteriza e define nossa cidade); e a teoria do centro ou, melhor, a absoluta necessidade de manter a primazia do centro na cidade latinoamericana ${ }^{268}$.

Antes de passarmos à exposição da construção das bricolagens nas quais Moscato se apoiava ao escrever estas linhas, deve-se destacar que o simples fato de pensar a cidade a partir destes dois polos já era, em si, uma tomada de posição frente ao debate europeu que servira de referência inicial para parte daqueles que se engajavam neste debate, mais especificamente, para aqueles que fundaram o grupo CEDLA. Assumir estas duas partes da cidade como distintas era opor-se ao que a Declaração de Palermo - redigida e assinada por Léon Krier, Pierluigi Nicolin, Angelo Villa, Maurice Culot, Antoine Grumbach em abril de 1978 - afirmava, ou seja: "A reconstrução da cidade em múltiplos bairros complexos não deve[ria] diferenciar funcional ou culturalmente Centro e Periferia" ${ }^{269}$.

\section{A periferia como própria}

Dentre as bricolagens que transpareceram nos debates abordados ao longo da tese, a periferia urbana aparece como aquela que conseguiu constituir nos SAL um grupo mais coeso em torno de si. Quando, no capítulo "Ecos e escoamentos", analisavam-se as apresentações relativas à periferia urbana no III SAL, destacava-se a

\footnotetext{
Milão: Jaca Book, 1996

${ }^{267}$ MOSCATO, J., loc. cit., 1996, p.73.

268 MOSTATO, J. loc. cit., 1996, p.74.

269 BAREY, op. cit, 1980, p.23
} 
existência de reverberações entre as apresentações de Boza, Eliash, Moscato, Juvenal Baracco e San Martín. Esta ressonância, contudo, não foi casual ou fruto, somente, de uma confluência de interesses geracionais; ao se analisar o processo de constituição desta bricolagem, verifica-se esta testemunha encontros e trocas que antecedem a própria realização do primeiro SAL.

A periferia urbana não foi, certamente, uma temática presente entre os interesses iniciais do grupo CEDLA - do qual participavam Eliash e Boza. Nos primeiros anos de atuação do grupo, como já vimos, inquietações relativas ao patrimônio urbanoarquitetônico e, por extensão, ao tecido urbano do centro histórico revelavam-se entre as traduções culturais iniciais do debate sobre a tipo-morfologia. A periferia surge em um segundo momento, após o giro latino-americanista do grupo, cujo marco fora o Encontro de Caburga, realizado em 1984.

Esse evento, no entanto, foi antecedido por outro que viria a contribuir tanto para o supracitado giro no foco de interesse do grupo, quanto para a construção posterior de bricolagens em torno da morfologia da periferia urbana de cidades latinoamericanas: a IV Bienal de Arquitetura chilena, em 1983, a qual fora presidida por Pedro Murtinho. Como já abordamos no capítulo "Ecos e escoamentos" esta mostra em específico constituiu um dos primeiros foros de encontro entre arquitetos que participariam da mesa de debate do I SAL. Todavia, para além deste aspecto, as contribuições de Marina Waisman ${ }^{270}$, Roberto Fernández ${ }^{271}$, Mariano Arana ${ }^{272}$ e Juvenal Baracco $^{273}$ neste evento deixavam claro, em meio a argumentações que abordavam diferentes assuntos, a necessidade de traduzir e adaptar elementos do debate sobre a tipo-morfologia para questões pertinentes ao contexto latino-americano como condição para garantir sua validade local. Marina Waisman, em específico, em uma palestra que tratava dos desafios para a crítica de arquitetura na América Latina, afirmava:

\footnotetext{
${ }^{270}$ WAISMAN, M. Reivindicación Mundial de la Crítica. In: CA. Santiago de Chile: Colegio de Arquitectos, n. 36, dez. 1983, p. 30-31.

271 FERNÁNDEZ, Roberto. Modernidad Perisférica. In: CA. Santiago de Chile: Colegio de Arquitectos, n. 36, dez. 1983, p. 34-35.

${ }^{272}$ ARANA, Mariano. Patrimonio Urbano en Latinoamérica. In: CA. Santiago de Chile: Colegio de Arquitectos, n. 36, dez. 1983, p. 32-33.

273 BARACCO, Juvenal. Arquitectura y contexto urbano. In: CA. Santiago de Chile: Colegio de Arquitectos, n. 36, dez. 1983, p. 36.
} 
O tema das tipologias, ou talvez o que se deveria chamar "tipologismo", que tem se proliferado a partir de considerações surgidas das cidades europeias, requer também uma "tradução", se se quer que tenha sentido para as arquiteturas da América Latina. Exceto para alguns poucos centros históricos consolidados, as cidades do continente não possuem uma variedade de tipos arraigados através de séculos de desenvolvimento, nem tecidos urbanos coerentes em sua totalidade. É mais especificamente a fragmentação e, ainda, a confusão que os caracteriza. De modo que o ideal de construir "cidades análogas" como propõe Aldo Rossi, não tem o menor sentido entre nós ${ }^{274}$.

Se algumas das representações sobre a cidade latino-americana que transpareceriam nos debates dos primeiros SAL já estavam presentes na palestra de Marina Waisman, seria, no entanto, a palestra de Roberto Fernández aquela que sistematizaria o argumento que se tornaria central na compreensão da periferia como o traço distintivo da cidade latino-americana. Ao destacar algumas características comuns na prática da arquitetura na América Latina, Roberto Fernández afirmava:

[...] na América Latina se dá a situação prevalecente da geração de um habitat urbano marcado pela questão quantitativa [...]: com efeito, a acelerada urbanização concentrada em um número relativamente escasso de cidades [...] gera um tipo de habitat definido por parâmetros alheios ou marginais à disciplina arquitetônica. A presença maciça de uma "edilícia" de tipo popular inclui não somente o habitat encortiçado, de autoconstrução e decididamente marginal no aspecto sócio-produtivo - as "villas de miséria", "poblaciones", "callampas", "favelas", o "cantegriles" - mas também o extenso tecido suburbano da ampla camada de setores médios [...]. Todas estas questões dão lugar a uma classe de relações entre arquitetura (como atividade disciplinar) e cidade, que na América Latina é decididamente diferente de certa contemporânea preocupação na Europa e nos EUA ${ }^{275}$.

Observam-se, no excerto acima, componentes que, somados aos preceitos da tipo-morfologia, constituiriam a base da busca pela definição do que, posteriormente,

\footnotetext{
${ }^{274}$ WAISMAN, M. loc. cit., 1983, p. 31.

275 FERNÁNDEZ, Roberto. Modernidad Perisférica. In: CA. Santiago de Chile: Colegio de Arquitectos, n. 36, dez. 1983, p. 34.
} 
seria chamado como "Arquitetura da Periferia": de um lado a representação da cidade latino-americana como a metrópole de crescimento acelerado; de outro, ideia de que este tipo de urbanização geraria um habitat específico que se revelaria na periferia e que seria elemento de distinção em relação às cidades da Europa e dos EUA. O primeiro remete, de modo geral, ao conjunto de representações sobre a "cidade latinoamericana" que Adrián Golelik descreveu como "uma categoria do pensamento social, uma figura no imaginário intelectual e político em vastas regiões do continente" ${ }^{276}$ no período de 1950 a 1970 - ou seja, o conjunto de representações associados à "cidade latino-americana" que exerceu um papel chave desde as teorias do desenvolvimento às teorias da dependência ${ }^{277}$. Mais especificamente, ecoava a vasta produção intelectual de instituições como a Cepal (Comissão Econômica para a América Latina) e da Siap (Sociedade Interamericana de Planejamento) que costumavam destacar as cifras relativas à explosão urbana de países do subcontinente ${ }^{278}$, assim como o debate relativo à “urbanização dependente" ${ }^{279}$.

O segundo componente revelava traços do interesse em relação aos tecidos urbanos marginalizados que havia despertado sido pela atuação de personagens como John Turner, com seu trabalho nas barriadas de Lima, Peru, entre 1957 e 1965. Entre o final dos anos os 1960 e meados dos 1970, as ideias de John Turner sobre a autoconstrução e a constituição dos tecidos marginalizados pelos próprios moradores como uma alternativa e não um problema ${ }^{280}$ foram amplamente divulgadas através dos livros que publicou ${ }^{281}$ e de revistas especializadas ${ }^{282}$. No caso específico do Brasil, soma-

${ }^{276}$ GORELIK, Adrián. A produção da "cidade latino-americana". In: Tempo Social, São Paulo, v. 17 , n. 1 , jun 2005, p.112.

${ }^{277}$ Cf. GORELIK, A., loc. cit., 2005.

278 A título de exemplo, em 1940 , somente $37,7 \%$ da população do subcontinente vivia em cidades, em 1980 este número passou para a ser 69,4\%. Além disso, atente-se ao fato de que até 1970-1980 este crescimento foi altamente polarizado por metrópoles. Cf. OLIVEIRA, Orlandina de. O crescimento urbano e a estrutura urbana na América Latina, 1930-1990. In: BETHELL, L. A América Latina após 1930. São Paulo: Edusp, 2005.

${ }^{279}$ Trata-se de uma construção intelectual que se apoiava na urbanização acelerada de países latino-americanos, formadora de um tecido urbano truncado, desvinculada de um processo de industrialização e um aumento da capacidade produtiva para caracterizar uma situação específica ao subcontinente. Cf. CASTELLS, Manuel. Urbanización Dependiente en América latina. In: Castells (org.) Imperialismo y Urbanización en América latina. Barcelona: Gili, 1973, p7-26.

${ }^{280}$ Cf. TURNER, John F. C. Vivienda, todo el poder para los usuarios : hacia la economía en la construcción del entorno. Madrid Blume, 1977.

281 Após sua experiência no Peru, John Turner publicou dois livros: "Urban Dwelling Environments. An Elementary survey of Settlements for the Study of Design Determinants" (1969) 
se também o trabalho de Carlos Nelson Ferreira dos Santos ${ }^{283}$ que contribuiu amplamente para o desenvolvimento desta temática, desde sua experiência como um dos assessores na reurbanização da Favela de Brás de Pina, ainda em $1964^{284}$ - e cujo trabalho era devidamente reconhecido em outros países da América Latina ${ }^{285}$.

Não se pode esquecer, dentro da descrição destes elementos de debates que seriam amalgamados às questões da tipo-morfologias, que o crescimento vertiginoso das cidades latino-americanas não era um conhecimento abstrato, apreendido através de números, para esta geração. Os arquitetos que viriam a participar dos SAL, presenciaram, de modo geral, a grande expansão demográfica de suas cidades. A respeito desta questão, Juvenal Baracco refletia: "Quando eu nasci, Lima tinha 400 mil habitantes, quando concluí o curso de graduação, tinha dois milhões de habitantes; deixou de ser a pérola do Pacífico para converter-se, progressivamente, cada vez mais na barriada do Pacífico" ${ }^{286}$.

Realizado este breve excurso sobre os elementos que seriam combinados na bricolagem relativa à periferia, deve-se retomar o percurso que permitiu sua construção. Apenas sete meses após a IV Bienal de Arquitetura do Chile, o grupo CEDLA associava-se à Cristián Fernández e assumia o desafio de pensar a arquitetura a partir da realidade ibero-americana na convocatória para o Encontro de Caburga ${ }^{287}$. Participaram deste

e "Housing by People" (1976). Um breve resumo sobre o percurso acadêmico e profissional de John Turner pode ser encontrado em: BENVOLO, L. O último capítulo da Arquitetura Moderna. Lisboa: Edições 70, 1997.

${ }^{282}$ Para além dos livros que publicou a partir desta experiência, o trabalho de Turner também contou com ampla divulgação em revistas, notadamente, na Architectural Design sob direção da chilena Monica Piegion - de 1946 a 1975. Cf. HIGGOTT, Andrew. Mediating Modernism. Architectural cultures in Britain. Nova York: Routledge. 2007.

${ }^{283}$ Segundo Abrahão, Carlos Nelson Ferreira dos Santos chegou a estabelecer contato com John Turner quando este visitou o Brasil em 1968. Cf. ABRAHÃO, Sérgio Luís. Espaço Público: Do urbano ao político. São Paulo : Annablume, 2008.

${ }^{284}$ Ver a respeito: ABRAHÃO, Sérgio Luís. op. cit., 2008.

${ }^{285}$ Deve-se lembrar que Carlos Nelson Ferreira dos Santos ministrou um seminário no CAYC, em Buenos Aires, em 1983 e foi um dos convidados para a V Bienal de Arquitetura chilena - cf. CA 41, setembro de 1985. Além disso, a Summa lhe entrevistou em 1983 - "Carlos Nelson dos Santos: la ciudad es una Fiesta, o la orgía permanente", no número 193, de novembro de $1983-$ e publicou texto de sua autoria em um dos números ibero-americanos. Cf. SANTOS, Carlos Nelson Ferreira. Las ciudades enormes, o como aprendí a gustar de ellas con el doctor Strangelove. In: Summa. Buenos Aires: Ed. Summa, n. 254, set 1983, p. 41-45.

${ }^{286}$ BARACCO apud BELAUNDE, Pedro. Juvenal Baracco : un universo en casa. Bogotá : Escala, 1988, p.41-42.

${ }^{287}$ A convocatoria de Caburga foi escrita em março de 1984 - cf. BOZA, Cristián; FERNÁNDEZ 
evento, como já se destacou no capítulo "Tecendo as partes da cidade latinoamericana", os arquitetos Roberto Fernández e Juvenal Baracco. Nesta ocasião, as contribuições destes arquitetos estrangeiros em meio ao evento chileno indicavam que algumas contribuições oriundas do debate da tipo-morfologia poderiam auxiliar neste processo. Roberto Fernández desenvolveu uma reflexão sobre a "apropriação" na qual destacava, dentre as "três lições recentes da Europa" que deveriam ser consideradas pelos latino-americanos, as questões sobre a autonomia disciplinar, levantadas por Rossi, Culot e $\mathrm{Krier}^{288}$. Juvenal Baracco, por outro lado, afirmava que o tipo poderia auxiliar o arquiteto na interpretação modelos culturais e inconscientes coletivos ${ }^{289}$.

Observa-se, portanto, que os elementos que transpareceriam no debate sobre a periferia urbana como própria já estavam constituídos anos antes da realização do SAL de Manizales. No entanto, seria somente através do intercâmbio estabelecido com Jorge Moscato que esta questão seria operacionalizada na busca de uma teoria urbanoarquitetônica específica à cidade latina-americana. $\mathrm{O}$ encontro entre este arquiteto argentino e os chilenos do grupo CEDLA ocorreu em julho de 1984, durante os seminários que acompanhavam a exposição "Arquitectura en Chile" realizada no Cayc ${ }^{290}$, momento em que se revelou um grande afinamento de ideias, segundo Eliash ${ }^{291}$.

Apesar de ter sido leitor de Rossi, ainda que dentro do âmbito privado ${ }^{292}$, sempre teve a preocupação com os aspectos do que seria apropriado ao contexto local motivada, em parte, por seu engajamento político no peronismo ${ }^{293}$. Neste contexto, Moscato já se mostrava crítico ao emprego de soluções arquitetônicas identificadas como rossianas no contexto argentino que, como o Conjunto Centenario de Tony Díaz, repetiam a ideia do quarteirão com a borda edificada e o miolo de apropriação semipúblico. Paradigmático nesta tomada de posição foi o projeto que Moscato e Schere

COX, Cristián. et al. Convocatoria Encuentro de Caburga. In: ARS. Santiago de Chile: CEDLA, n.5, jul. 1984, p.9-10.

${ }^{288}$ FERNÁNDEZ, Roberto. Hacia una teoría de la "Apropriación". In: ARS. Santiago de Chile: CEDLA, n.5, jul. 1984, p.20.

${ }^{289}$ BARACCO, Juvenal. La ciudad Metasíquica. In: ARS. Santiago de Chile: CEDLA, n.5, jul. 1984, p.76.

${ }^{290}$ Ver "Múltiplas origens" no capítulo "Ecos e escomentos".

${ }^{291}$ ELIASH, Humberto. Depoimento. [06 de julho de 2011]. Santiago do Chile: Arquivo digital da gravação ( $58 \mathrm{~min}$.). Entrevista concedida a Gisela Barcellos de Souza.

292 MOSCATO, Jorge. Depoimento. [25 de agosto de 2011]. Buenos Aires: Arquivo digital da gravação (2horas e $25 \mathrm{~min}$.). Entrevista concedida a Gisela Barcellos de Souza.

${ }^{293}$ Cf. MOSCATO, J.; SCHERE, R. Arquitectura e ideología. México: Menhir Libros. 2000. 
desenvolveram entre 1979 e 1980 para um conjunto habitacional vizinho à cidade de Posadas, junto ao rio Paraná. Neste projeto, os sócios justificavam o fato de que, apesar de terem recuperado a quadrícula do traçado original, haviam preferido uma solução de baixa densidade de residências unifamiliares em lotes privados, pois: "o esquema 'rossiano' de agrupações de habitação então em voga, informação 'culta' segundo o ideário da equipe, não servia como moradia para o clima subtropical, caloroso, úmido e muito chuvoso do lugar"294.

Percebe-se, portanto, que o intercâmbio que se configuraria entre grupo CEDLA e Jorge Moscato, tomaria rumos distintos daquele que se havia estabelecido anos antes com Tony Díaz. Apenas sete meses após o contato inicial ocorrido na mostra em Buenos Aires, o CEDLA convidou Jorge Moscato para conduzir, junto com Humberto Eliash, um atelier de curta duração que o grupo organizou na sede do Colégio de Arquitetos do Chile, chamado "Taller de Verano". Este atelier, realizado em janeiro de 1985, destinavase a arquitetos recém-formados e tinha como objetivo desenvolver projetos para o concurso da $\mathrm{V}$ Bienal de Arquitetura - que ocorreria em agosto daquele mesmo ano cujo tema era a habitação de interesse social ${ }^{295}$. Desenvolveram-se dois projetos na ocasião: um para uma área central de Santiago - a remodelação do entorno da Praça Yungay, situada em Santiago Poniente -, outro em área periférica na comuna de Pudahuel da região metropolitana de Santiago ${ }^{296}$. Significativamente, apenas o projeto desenvolvido para a Pudahuel teve seu memorial publicado na revista ARS $^{297}$.

\footnotetext{
${ }^{294}$ WAISMAN, Marina; NASELI, César. 10 Arquitectos Latinoamericanos. Sevilha: Junta de Andalucía, 1989, p.125.

${ }^{295}$ ELIASH, H.; MOSCATO, J. Taller de Verano CEDLA 1985 - Teoría y prática de la ciudad. In: ARS, Santiago de Chile: CEDLA, n.6, set. 1985, p.51-55.

${ }^{296}$ Cf. ELIASH, H.; MOSCATO, J., loc. cit., 1985.

${ }^{297}$ BAROS, M. ; CASTRO, O. et al. Anteproyecto Conjunto Vivienda Social en Pundahuel. In: ARS, Santiago de Chile: CEDLA, n.6, set. 1985, p.56-58.
} 


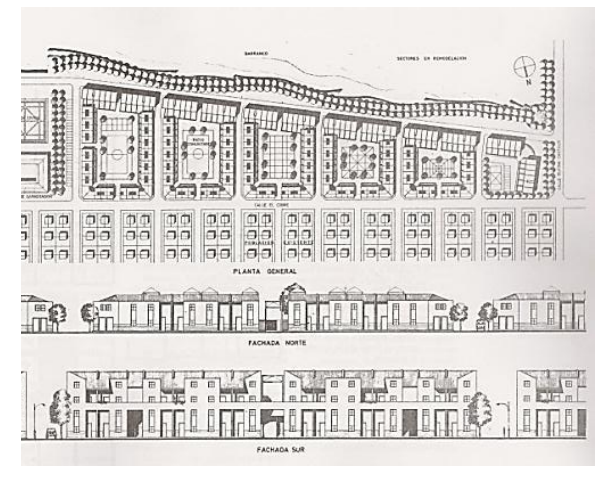

Figura 69: Plantas e elevações do projeto desenvolvido para Pudahuel (Chile) durante o Taller de Verano, coordenado por Moscato e Eliash, em 1985. Fonte: ARS, n.6, set. 1985.

Nesse mesmo ano, a revista ARS lançaria seu primeiro número dedicado ao tema da periferia urbana - o número 6 de setembro de 1985. Nesta edição, a narrativa dos resultados do "Taller de verano" era acompanhada por reflexões de Moscato e Eliash sobre a "teoria e o projeto na periferia urbana" ${ }^{298}$. Sua leitura revela que os argumentos que seriam repetidos em Manizales pelo argentino e pelo chileno - neste último caso, exatamente com as mesmas palavras - haviam sido constituídos na redação deste texto:

Desde os irmãos Krier ou Maurice Culot, até Aldo Rossi e a Tendenza, passando pelo trabalho de Colin Rowe e Alan Colqhoun, todos eles estruturam seu pensamento sobre um modelo urbano que pouca relação tem com a periferia latino-americana. [...] Portanto, as práticas contextuais, ad hocistas e historicistas são de duvidosa utilidade no caso que nos ocupa ${ }^{299}$.

Através desta asserção, reafirmada diversas vezes nos anos subsequentes, deixava-se clara a nova postura frente às traduções que haviam sido tão importantes no início dos anos 1980, especialmente para o CEDLA. A ideia de que a periferia latinoamericana estaria desprovida de teorias urbano-arquitetônicas - expressa na frase de efeito "nos encontramos órfãos de teoria" ${ }^{300}$-, de que as contribuições sobre a tipomorfologia desenvolvidas na Europa teriam sua validade apenas para alguns centros históricos latino-americanos, enfim, todas as questões que seriam posteriormente

\footnotetext{
${ }^{298}$ ELIASH, H.; MOSCATO, J., loc. cit., 1985.

${ }^{299}$ ELIASH, H.; MOSCATO, J., loc. cit., 1985, p.52.

${ }^{300}$ ELIASH, H.; MOSCATO, J., loc. cit., 1985, p.52.
} 
debatidas em Manizales, já haviam sido lançadas dois anos antes, neste atelier realizado em Santiago.

De fato, após o Plano para o Centro Histórico de Bolonha de 1969, como vimos, a construção teórica sobre as relações entre tipos edilícios e a forma urbana ficou associada a intervenções em áreas de patrimônio histórico urbano e arquitetônico relevante. Esta vinculação não se deu somente pela divulgação deste plano em si, mas também, por publicações posteriores que, ao apresentar intervenções em centros históricos, descreviam a tipo-morfologia como instrumento para a reabilitação do patrimônio urbano e arquitetônico. À discussão da temática do centro histórico destinaram-se os dois primeiros SIAC (Seminario Internacional de Arquitectura Contemporánea), o de Santiago de Compostela e o de Sevilha ${ }^{301}$ - realizados em 1976 e em 1978, respectivamente - e publicações de números especiais de revistas europeias de ampla circulação, como a Casabella e a Architecture d'Aujourd'hui ${ }^{302}$.

Contudo, apesar do debate da tipo-morfologia ter contribuído amplamente para intervenções em centros históricos, a afirmação de que não havia, dentro do debate europeu, nenhuma contribuição teórica sobre a periferia não era inteiramente verdadeira. Ainda que não tenha constituído o foco do que, em sua obra teórica, receberia grande fortuna crítica, Rossi, por exemplo, havia escrito no início dos anos 1960 três artigos que tratavam do tema da periferia : "Il problema della periferia nella città moderna", de 1960; "La città e la periferia", de 1961; e "Nuovi problemi", de $1963^{303}$. Publicados originalmente na revista Casabella Continuità e, posteriormente, republicados no livro "Para una arquitectura de tendencia" ${ }^{304}$, profusamente difundido entre os arquitetos do subcontinente, estes textos não eram desconhecidos por aqueles que a afirmavam a necessidade de uma teoria para a periferia das cidades latinoamericanas. Moscato, chegava a pontuar, em sua apresentação em Manizales, uma citação ao texto "La ciudad y la periferia" republicado no supracitado livro ${ }^{305}$, ratificando

${ }^{301}$ GRUPO 2C. Presentación. In: La Manzana como Idea de Ciudad. Elementos teóricos y propuestas para Buenos Aires. III SIAC. Barcelona: 2C ediciones, 1980.

302 Veja-se, a título de exemplo, os dossiês centrais dos números 185 da Architecture d'Aujourd'hui (de 1975) e 428 da revista Casabella (de 1977) destinados à questão do centro histórico.

${ }^{303}$ Ver Casabella Continuità números 241 (1960), 253 (1961) e 277 (1963), respectivamente.

${ }^{304}$ ROSSI, A. Para una Arquitectura de Tendencia. Escritos 1956-1972. Barcelona: GG, 1977a.

${ }^{305}$ Ver capítulo “La ciudad y la periferia”, páginas 97-106, em: ROSSI, A., op. cit., 1977a 
a passagem em que Rossi afirma que "para o habitante da periferia a cidade passa a ser somente uma referencia na parada de ônibus" ${ }^{306}$ - referência também presente em textos publicados na ARS número 6 , de $1985^{307}$.

Se, para Rossi, a periferia urbana foi um tema lateral, o mesmo não o foi para o LUB (Laboratório de Urbanismo) da ETSAB em seus primeiros anos de atuação. $\mathrm{Na}$ primeira década deste laboratório, este tema foi seminal para grande parte das investigações desenvolvidas sob a orientação de Manuel de Solà-Morales - e contatou com uma bolsa do Colégio de Arquitetos, obtida em 1969, destinada a financiar o estudo este tipo de urbanização ${ }^{308}$. A análise das "formas de crescimento urbano", método que caracterizou as contribuições do LUB, teria sido, segundo Busquets, cunhada a partir destes estudos sobre a urbanização marginal ${ }^{309}$. As investigações iniciais do LUB sobre a urbanização marginal foram publicadas em 1976 em três cadernos do Laboratório de Urbanismo - números 13, 14 e 15. No primeiro, divulgavam-se artigos de Manuel de Solà-Morales e Joan Busquets, em colaboração com outros autores. Os dois últimos destinavam-se a cobrir partes da tese que Joan Busquets desenvolveu sobre as coreas de Barcelona ${ }^{310}$, sob a orientação de Manuel de Solà-Morales, entre 1971 e $1974^{311}$.

Não obstante o fato de que as contribuiç̧̃̃es do LUB não conheceram a mesma fortuna crítica que as publicações de Aldo Rossi, dificilmente os arquitetos que, no Chile e na Argentina, estavam engajados na construção de uma teoria para a periferia urbana as desconheceriam por completo. Por um lado, as questões pertinentes à urbanização marginal faziam parte do conteúdo programático da disciplina "Urbanística I" ministrada por Manuel de Solà Morales na Politécnica da Catalunha ${ }^{312}$, instituição na qual Fernando

306 MOSCATO, Jorge. Arquitectura de la Periferia. In: III Encuentro de Arquitectura Latinoamericana. III, Anais...Buenos Aires: CAPBA D III, 1988, p.83.

${ }^{307}$ Cf. DUVAL, Ciudad y periferia. In: ARS, Santiago de Chile: CEDLA, n.6, set. 1985, p.37-41; bem como, ROSAS VERA, José. Hispanoamérica : ¿Periferia física o... periferia cultural? In: ARS, Santiago de Chile: CEDLA, n.6, set. 1985, p.9-14.

${ }^{308}$ BUSQUETS, Joan. La urbanización marginal. Barcelona : Edicions UPC, 1999.

${ }^{309}$ BUSQUETS, Joan, op. cit., 1999.

${ }^{310}$ A tese de Joan Busquets, intitulada "Las Coreas de Barcelona : Estudio sobre la Urbanización Marginal" abordou o processo de constituição dos tecidos periféricos em Barcelona ao longo do século $X X$, desenvolvendo a análise de diversos aspectos tipo-morfológicos. Esta tese foi reeditada na forma do livro "La urbanización marginal” - Cf. BUSQUETS, J, op. cit., 1999.

${ }^{311}$ Cf. BUSQUET, Joan. La urbanización marginal en Barcelona (II). In: Laboratorio de Urbanismo. Barcelona: Ed. ETSAB, n.14, 1976 ; e BUSQUET, Joan. La urbanización marginal en Barcelona (III) In: Laboratorio de Urbanismo. Barcelona: Ed. ETSAB, n.15, 1976.

${ }^{312}$ Cf. SOLÀ-MORALES, Manuel. Las Formas de crecimiento urbano. Barcelona: Edicions UPC, 
Pérez Oyarzún e José Rosas Vera - que contribuíram em eventos organizados por arquitetos do CEDLA, inclusive do "Taller de Verano" ${ }^{313}$ - desenvolveram seus doutorados. Mais especificamente, nos textos que José Rosas ${ }^{314}$ e Ricardo Contreras ${ }^{315}$ um dos fundadores do CEDLA - escreveram para o primeiro número da ARS sobre a periferia urbana, há uma menção aos métodos propostos por Manuel de Solà-Morales e a um seminário que este ministrou na Faculdade de Arquitectura da Universidad Católica, em junho de 1985. Por outro lado, ainda que a investigação dos aspectos tipomorfológicos das coreas de Barcelona, realizada por Busquets, não fosse conhecida, este arquiteto esteve como convidado na $\vee$ Bienal chilena, em agosto de 1985, ocasião em que ministrou uma palestra intitulada "Arquitectura y Asentamientos Precarios" e apresentou o Plano Especial de Reforma Interior que desenvolveu para o bairro SaintJosep $^{316}$, em 1979, no qual aplicava os conhecimentos sobre a urbanização marginal que desenvolvera em sua tese ${ }^{317}$.

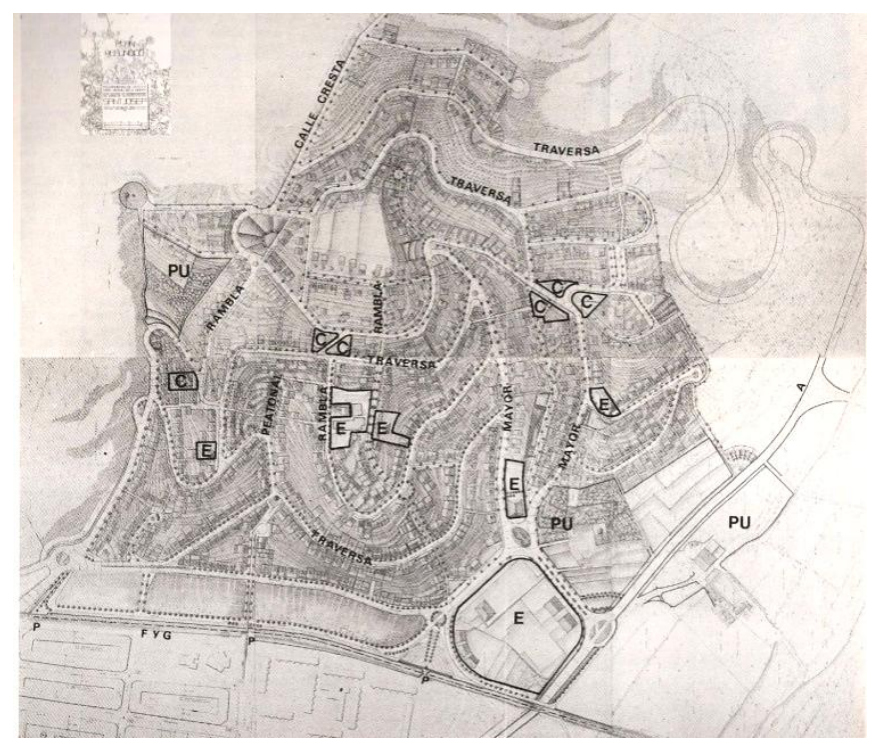

Figura 70: Plano Especial de Reforma Interior para o bairro SaintJosep, desenvolvido por Busquet em 1979 e apresentado na V Bienal de Arquitetura do Chile. Fonte: $\mathrm{CA}$, n.44, jun. 1986.

1997.

313 José Rosas Vera colaborou na orientação dos projetos do atelier e Fernando Pérez participou da seção de correção e crítica dos projetos. Cf. ELIASH, H.; MOSCATO, J. Taller de Verano CEDLA 1985 - Teoría y prática de la ciudad. In: ARS, Santiago de Chile: CEDLA, n.6, set. 1985, p.51-55.

314 Na ocasião, José Rosas era orientando de Manuel de Solà-Morales. ROSAS VERA, José. Hispanoamérica : ¿Periferia física o... periferia cultural? In: ARS, Santiago de Chile: CEDLA, n.6, set. 1985, p.9-14.

${ }^{315}$ CONTRERAS, Ricardo. Indagaciones sobre la periferia. In: ARS, Santiago de Chile: CEDLA, n.6, set. 1985, p.43-44.

${ }^{316}$ BUSQUETS, Joan. Arquitectura y Asentamientos Precarios. In: CA. Santiago de Chile: Colegio de Arquitectos, n. 44, jun 1986, p.52-53.

${ }^{317}$ BUSQUETS, Joan. La urbanización marginal. Barcelona : Edicions UPC, 1999. 
Logo, ao lançar o primeiro número sobre a periferia urbana, em setembro de 1985, o corpo editorial da ARS sabia da existência das contribuições de Rossi e do LUB sobre a temática. A opção por não reconhecer ou minimizar sua validade ao contexto latino-americano insere-se, portanto, dentro do âmbito da estratégia de afirmar a autenticidade da bricolagem ensaiada: a priori, nenhuma daquelas contribuições poderia servir para as cidades do subcontinente, pois foram produzidas a partir de observações de cidades europeias, nas quais, supostamente, o problema da periferia não seria relevante ${ }^{318}$. Obviamente, ao se construir este argumento, não se estava considerando as cidades do continente europeu caso a caso; mas sim uma representação genérica do que seria a cidade europeia aventada, de modo geral, pelo movimento pela "Reconstrução da Cidade Europeia". A respeito desta representação, Panerai afirmava: "Desagradando somente à Léon Krier, $A$ cidade europeia não existe. Londres ou Madri têm histórias distintas. Veneza possui poucos pontos em comum com Briminghan"319.

A bricolagem sobre a periferia urbana como traço distintivo e específico à América Latina, portanto, deveria ter sua origem na observação direta das cidades do subcontinente. Três diretrizes foram tomadas pelos arquitetos engajados na compreensão da "arquitetura da periferia": a crítica à produção oficial de habitação de interesse social, a leitura expedita da periferia e a experimentação de propostas, profissionalmente e através de exercícios didáticos. No primeiro caso, insere-se a crítica que Boza apresentou na mesa redonda da V Bienal - cujo título era "Vivienda Social" -, às restrições morfológicas impostas pelos concursos de projetos de habitação de interesse social organizados pelo Ministerio de la Vivienda, demonstrando como este condicionava a apresentação de propostas de baixa densidade, com edificações unifamiliares isoladas no lote, que tornariam, em suas palavras, impossível "pensar em criar de uma cidade coerente, contínua e harmônica" ${ }^{320}$.

Embora nunca tenham realizado uma leitura tipo-morfológica detalhada da periferia, alguns ensaios expeditos foram realizados. Ainda no primeiro número da ARS

\footnotetext{
318 MOSCATO, Jorge. Arquitectura de la Periferia. In: III Encuentro de Arquitectura Latinoamericana. III, Anais...Buenos Aires: CAPBA D III, 1988, p.82-84.

319 PANERAI, Ph. Croissances. In : PANERAI et al. Analyse Urbaine. Paris: Éditions Paranthèses, 1999, p.52 (grifo no original).

${ }^{320}$ BOZA, C. Evaluación cualitativa de la arquitectura periférica: concursos oferta 83-84 Serviu. In: ARS, Santiago de Chile: CEDLA, n.6, set. 1985, p.17-36.
} 
sobre a periferia urbana, Hernán Duval apoiava suas considerações na comparação de representações de cheios e vazios de diferentes partes da cidade, demonstrado como na periferia a se perdia por completo a continuidade urbana:

São zonas em que o espaço público por excelência, no qual se sustenta e se expressa a comunidade, são os caminhos que foram concebidos como soluções viárias intercomunais ou interurbanas, em torno das quais se instalam áreas de dormitório que se implantam como unidades independentes umas das outras sem existir espaço cívico que as relacione e que thes dê o sentido da cidade ${ }^{321}$.

O recurso às representações de cheios e vazios, ensaiados no artigo de Duval, seriam retomados e ampliados por Boza e Moscato na sequência. O desafio de construir um mapa de cheios e vazios da cidade por inteiro foi tomado inicialmente por Boza que o elaborou em 1985 para Santiago, na escala 1:20.000, com o auxílio dos alunos da Universidad Católica ${ }^{322}$. O mapa "blanco y negro" resultante - cujas dimensões eram de aproximadamente 2,5 por 2,5 metros ${ }^{323}$ - seria apresentado a Moscato que replicaria a experiência, na mesma escala, com seus alunos em Buenos Aires, em 1986, resultando em um mapa de dois metros por três ${ }^{324}$. Ambos os mapas "blanco y negro" foram levados à Manizales e apoiaram o debate naquela ocasião ${ }^{325}$. Ainda que tenha servido de apoio ao debate, estes mapas eram, em essência, descritivos, ou seja, não se ensaiava, através destas representações, análises e classificações que pudessem transcender os casos estudados e servir de base para a compreensão maior de cidades latino-americanas. Esta seria a motivação de base, no entanto, da leitura da periferia de Humberto Eliash, que com seus alunos da Universidad del Norte, buscou desvelar a "ordem" subjacente à periferia urbana e definir um esquema a partir do qual fosse possível "analisar outras cidades chilenas ou latino-americanas"326. Na prática, a

\footnotetext{
${ }^{321}$ DUVAL, Ciudad y periferia. In: ARS, Santiago de Chile: CEDLA, n.6, set. 1985, p.40.

322 BOZA, Cristián. Depoimento. [17 de agosto de 2011]. Santiago do Chile: Arquivo digital da gravação (1hora e $1 \mathrm{~min}$.). Entrevista concedida a Gisela Barcellos de Souza.

${ }^{323}$ BOZA, Cristián. Depoimento. [17 de agosto de 2011]. Santiago do Chile: Arquivo digital da gravação (1hora e 1min.). Entrevista concedida a Gisela Barcellos de Souza.

324 MOSCATO, Jorge. Depoimento. [25 de agosto de 2011]. Buenos Aires: Arquivo digital da gravação (2horas e $25 \mathrm{~min}$.). Entrevista concedida a Gisela Barcellos de Souza.

${ }^{325}$ BOZA, Cristián. Depoimento. [17 de agosto de 2011]. loc. cit.; e MOSCATO, Jorge. Depoimento. [25 de agosto de 2011]., loc. cit.

${ }^{326}$ ELIASH, H. La periferia dibujada. In: ARS. Santiago de Chile: CEDLA, n.7, nov. 1986, p.12.
} 
estrutura analítica proposta amalgamava vocabulários oriundos da tipo-morfologia à elementos da estrutura imagética de Lynch $^{327}$ : tipos de tecidos (espontâneos e planificados), tipos de nós (na escala metropolitana e do bairro); tipos de ruas (na escala metropolitana e do bairro); tipos edilícios (residências uni e multifamiliares); tipos de marcos (naturais e edificados) ${ }^{328}$.

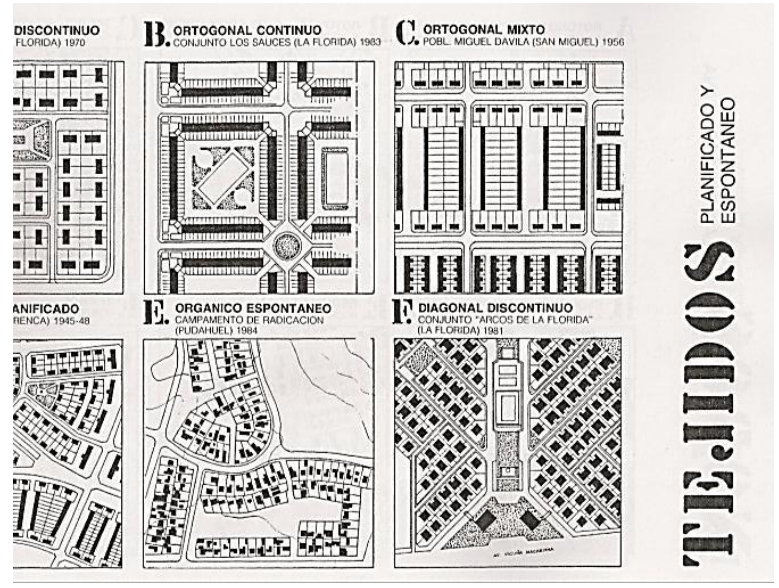

Figura 71: Ensaio, desenvolvido por Eliash, de classificação de tipos de tecidos da periferia. Fonte: ELIASH, H. La periferia dibujada. In: ARS. Santiago de Chile: CEDLA, n.7, nov. 1986

Somavam-se a estas leituras simplificadas, a proposição da construção da periferia urbana como tema de projeto e como objeto de intercâmbios didáticos os ateliers conduzidos por estes arquitetos-docentes. Neste sentido, o segundo número da ARS dedicado à periferia urbana buscava divulgar tanto projetos profissionais como experiências didáticas que demonstrassem afinidades com as ideias e interpretações defendidas para este traço distintivo da cidade latino-americana. No primeiro caso, enquadravam-se os projetos urbanos "Villa Boulevard Seguí" e a "Reabilitação urbana da Isla de Saladillo" em áreas periféricas de Rosário, dos argentinos Isabel Martínez de San Vicente e Manuel Fernández de Luco $^{329}$, ao lado de projetos de conjuntos habitacionais chilenos que buscam formas de definir o espaço urbano através do

\footnotetext{
${ }^{327}$ LYNCH, Kevin. A Imagem da Cidade. Edições 70, Lisboa, Portugal, 1982.

${ }^{328}$ ELIASH, H. La periferia dibujada. In: ARS. Santiago de Chile: CEDLA, n.7, nov. 1986, p.11-21.

${ }^{329}$ MARTÍNEZ DE SAN VICENTE, Isabel; FERNÁNDEZ LUCO, Manuel .Periferia y proyectación de la ciudad. In: ARS. Santiago de Chile: CEDLA, n.7, nov. 1986, p.42-47.
} 
conjunto edificado ${ }^{330}$. No segundo caso, divulgavam-se os resultados da experiência de intercâmbio didático entre Boza e Moscato - comparando-se os resultados do atelier que Boza ministrou em 1985 na Universidad Católica àqueles obtidos no atelier de Moscato na UBA, do qual o arquiteto chileno participou como convidado em maio de $1986^{331}$-, bem como do atelier do chileno Francisco Vergara, realizado em 1986, também na Universidad Católica. A despeito de que nunca tivesse estabelecido contato maior com o grupo CEDLA, Vergara ratificava, na conclusão do texto sobre sua experiência didática, as premissas defendidas pelo corpo editorial: as propostas nasciam da "observação complexa da realidade habitacional de Santiago" e configuravam "uma realidade que nos é própria", forma de "ir avançando com o conhecimento e afirmação de nossa identidade" ${ }^{332}$.

Apesar das afirmações constantes de que as teorias desenvolvidas na Europa e nos Estados Unidos não teriam validade para a cidade latino-americana, ainda se observam, na segunda metade dos anos 1980, algumas traduções em meio ao debate sobre periferia urbana. Este é o caso do texto de Boza, "El Barrio: Punto de partida para reurbanizar la ciudad latino-americana", apresentado inicialmente no III SAL, que se tornou uma referência no debate, sendo citado por Moscato, em sua contribuição para o quarto seminário ${ }^{333}$, e por Eduardo San Martín, em seu livro "La Arquitectura de la Periferia de Santiago" ${ }^{\prime 334}$. A despeito de Boza apresentar sua proposta de estruturação da cidade latino-americana como resultado da leitura e reconhecimento dos aspectos que caracterizam os bairros latino-americanos com "qualidade urbana" ${ }^{335}$, a semelhança entre os parâmetros que apresenta ao descrevê-los e aqueles utilizados por Léon Krier para definir o bairro europeu em sua "Carta para a Reconstrução da Cidade Europeia"³36,

\footnotetext{
${ }^{330}$ Constam no número 7 da ARS: o projeto de habitação para Santo Domingo, de Ana Luisa Devés, Cristián Undurraga e Patrícia Valenzuela; o projeto para Pudahuel, de Jorge Iglesis e Leopoldo Prat; e o Parque Santa Elvira de Murtinho y associados - Ver: ARS. Santiago de Chile: CEDLA, n.7, nov. 1986.

${ }^{331}$ BOZA, C. ; MOSCATO, J. Dos experiencias acadêmicas sobre la periferia. In : : ARS. Santiago de Chile: CEDLA, n.7, nov. 1986, p.58-76.

332 VERgARA, Francisco. Viviendas para Santiago. Experiencias del Taller en la Universidad Católica. : ARS. Santiago de Chile: CEDLA, n.7, nov. 1986, p.85.

${ }^{333}$ Ver capítulo « Ecos e escoamentos ».

${ }^{334}$ Cf. SAN MARTIN, E. La Arquitectura de la Periferia de Santiago: Experiencias y propuestas. Santiago: Editorial Andrés Bello. 1992.

${ }^{335}$ BOZA, Cristián. El Barrio: Punto de partida para reurbanizar la ciudad latinoamericana. In: III Encuentro de Arquitectura Latinoamericana. Buenos Aires: CAPBA D III, 1988, p.79.

${ }^{336}$ KRIER, Léon. Charte de la reconstruction de la ville européenne. in : Leon Krier: Drawings
} 
de 1981, não é desprezável. Na descrição do bairro latino-americano, Boza repete exatamente os mesmos parâmetros e argumentos que Léon Krier utiliza para descrever o bairro europeu em sua definição da "cidade dentro da cidade" ${ }^{337}$. Em ambos os textos, afirma-se que a população máxima do bairro "não deve exceder a 15.000 habitantes" ${ }^{338}$ e que sua área é definida pela distância equivalente a no máximo dez minutos de caminhada - ou seja, 35 hectares ${ }^{339}$. Boza chega a afirmar em seu texto a importância de se "entender que o bairro é como uma pequena cidade dentro da cidade" ${ }^{340}$. $O$ trabalho de tradução cultural, neste caso, revela-se na busca de exemplos santiaguinos e latinoamericanos para comprovar os argumentos. Entretanto, a ausência de qualquer referência ao texto original de Léon Krier acaba induzindo à sua percepção como mais uma bricolagem em torno da cidade latino-americana e, desta forma, facilitando sua difusão entre os demais arquitetos que participavam do debate.

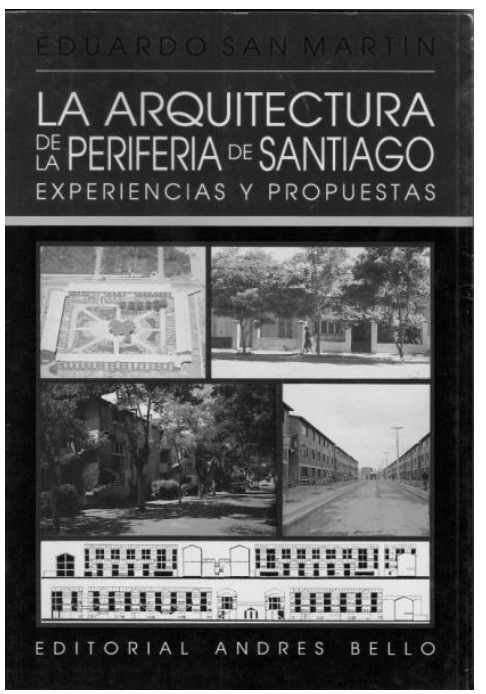

Figura 72: Livro de San Martín, publicado em 1992 e desenvolvido a partir da versão preliminar apresentada no IV SAL. Fonte: Fotografia da autora.

As bricolagens, por outro lado, evoluiriam por conta própria ao serem retomas pelas mãos de autores distintos, seus vínculos com os debates originais vão paulatinamente se perdendo, ao ponto de se tornarem quase irreconhecíveis. Um exemplo que se enquadra nesta situação é o livro de San Martín "La arquitectura de la Periferia de Santiago". Antes de San Martín, o título "A arquitetura da Periferia" já havia

\footnotetext{
1967-1980, Bruxelles, A.A.M, 1981.

${ }^{337}$ Ver "a cidade redescoberta", neste mesmo capítulo.

${ }^{338}$ BOZA, Cristián. El Barrio: Punto de partida para reurbanizar la ciudad latinoamericana. In: III Encuentro de Arquitectura Latinoamericana. III, Anais...Buenos Aires: CAPBA D III, 1988, p.79.

${ }^{339}$ BOZA, C., loc. cit, 1988 e KRIER, L., loc. cit., 1981.

340 BOZA, C., loc. cit, 1988, p. 79.
} 
sido utilizado em um artigo de Juvenal Baracco, publicado na ARS número seis, de $1985^{341}$, e por Jorge Moscato, em sua apresentação no III SAL, em uma clara tentativa de resposta à "Arquitetura da Cidade" de Aldo Rossi ${ }^{342}$. No entanto, San Martín, em sua bricolagem, perde-se por completo esta referência, ao ponto de não reconhecê-la ${ }^{343}$. Em seu texto, cujo esboço foi apresentado no IV SAL, o arquiteto chileno procura compreender a construção da periferia através da habitação popular - pelo estado, por iniciativa popular e em gestão mista - no Chile ao longo do século XX e apontar diretrizes para uma "arquitetura apropriada" neste contexto. O texto se estrutura através da amálgama de diferentes aportes do debate sobre a periferia urbana e de outros que foram associados aos SAL. Neste sentido, San Martín emprega o conceito de "modernidade apropriada" Fernández Cox. Ao buscar classificar as arquiteturas que analisa, adapta o método utilizado por Browne em "Otra Arquitectura" ${ }^{344}$ para definir os períodos e as linhas arquitetônicas ${ }^{345}$. Os argumentos que enfatizavam os aspectos quantitativos da periferia urbana permanecem. O catálogo da $\vee$ Bienal, no qual constava uma análise da habitação de interesse social no Chile entre 1900 e $1985^{346}$, é constantemente citado ao longo do livro. De forma semelhante, as descrições de aspectos da relação edifício-cidade vêm sempre acompanhada de citações à produções do CEDLA: os dois números da ARS sobre a periferia e os livros "Inventario de la arquitectura anónima", de Boza e Duval, e "Arquitectura y Modernidad en Chile/19251965 " de Eliash e Moreno ${ }^{347}$.

\footnotetext{
${ }^{341}$ BARACCO, J. La arquitectura de la periferia. In: ARS, Santiago de Chile: CEDLA, n.6, set. 1985, p.42.

${ }^{342}$ Moscato o confirmou em seu depoimento. Cf. MOSCATO, Jorge. Depoimento. [25 de agosto de 2011]. Buenos Aires: Arquivo digital da gravação (2horas e 25min.). Entrevista concedida a Gisela Barcellos de Souza.

${ }^{343}$ SAN MARTín, Eduardo. Depoimento. [14 de março de 2012]. Santiago do Chile: Arquivo digital da gravação (1hora e 4min.). Entrevista concedida a Gisela Barcellos de Souza.

${ }^{344}$ BROWNE, Enrique. Otra Arquitetura en América latina. Barcelona: Gustavo Gili, 1988.

${ }^{345}$ San Martin confirmou, em depoimento, a inspiração no gráfico elaborado por Browne em "Otra Arquitectura". Cf. SAN MARTín, Eduardo. Depoimento. [26 de março de 2012]. Santiago do Chile: Arquivo digital da gravação (22min.). Entrevista concedida a Gisela Barcellos de Souza.

${ }^{346}$ Cf. Revista CA, número 41, setembro de 1985.

${ }^{347}$ MORENO, Manuel; ELIASH, Humberto. Arquitectura y Modernidad en Chile/1925-1965. Una Realidad Múltiple. Santiago: Ed. Universidad Católica de Chile. 1989.
} 


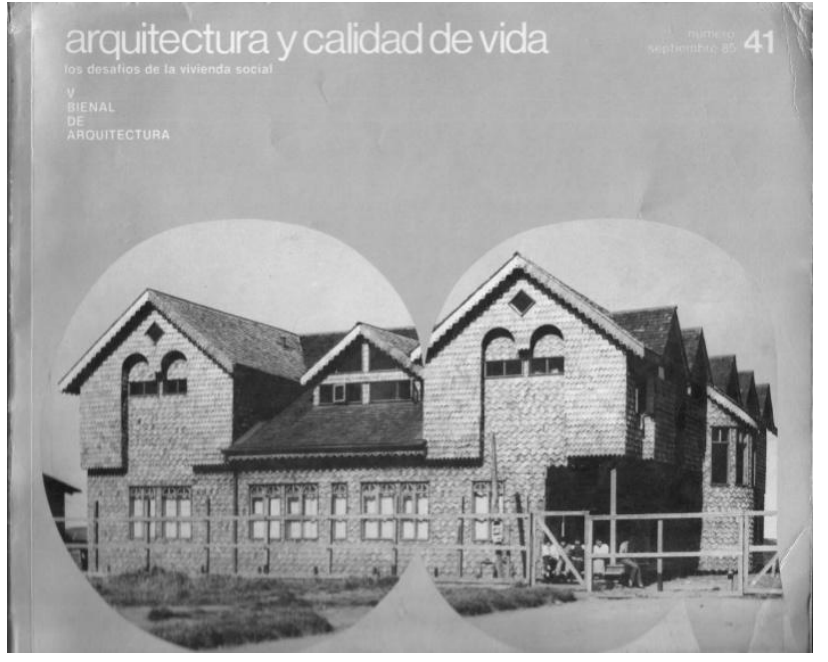

Figura 73: Catálogo da V Bienal do Chile, de 1985. Fonte: Fotografia da autora.

Este texto de Eduardo San Martín serviria, posteriormente, de base para aquele que escreveu, em 1993, conjunto com Humberto Eliash: "L'abitazione sociale e la costruzione della periferia urbana in America Latina", publicado no livro "Architettura e società". Neste artigo, propunha-se estender para a América Latina a classificação que San Martin havia feito para o Chile, através de exemplos oriundos da Argentina, Chile, Colômbia, Cuba, Peru e Uruguai ${ }^{348}$.

\section{O centro histórico latino-americano}

Contrariamente ao que se verificou no caso da periferia urbana, as bricolagens sobre o centro histórico não foram construídas por meio de um intercâmbio frequente entre um número restrito de arquitetos. Não obstante a tentativa de Moscato de incluir a reflexão sobre os centros históricos como parte de uma "teoria urbana" em construção junto aos SAL, o que de fato se percebe é que estes seminários talvez tenham contribuído pouco para a evolução desta discussão.

O debate sobre a especificidade do centro histórico no subcontinente não surge, como se percebeu nas bricolagens para periferia urbana, de uma indagação do que seria específico à forma da cidade latino-americana. Verifica-se justamente o oposto: as reflexões que the são urdidas apoiam-se em uma série de experiências de intervenções

${ }^{348}$ SAN MARTíN, E., ELIASH, H. L'abitazione sociale e la costruzione della periferia urbana in America Latina. In: GUTIÉRREZ, Ramón (org). Architettura e Società. L'América Latina nel XX secolo. Milão: Jaca Book, 1996, p.53-64. 
restauro e reabilitação urbana em cidades latino-americanas ainda dos anos 1970, bem como em eventos ibero-americanos sobre patrimônio histórico - como aqueles convocados pela OEA (Organização dos Estados Americanos), pelo PNDU (Programa das Nações Unidas para o Desenvolvimento) e pela UNESCO - nos quais se estabeleceram acordos coletivos e normas que antecedem a existência dos SAL.

Neste contexto, deve-se lembrar que, apenas três anos após a Carta de Veneza (1964) e a criação do ICOMOS, ocorria em Quito a "Reunião sobre conservação e utilização de monumentos e lugares de interesses históricos e artísticos", promovida pela OEA, na qual se redigiram as chamadas "Normas de Quito"349. Neste documento, adaptavam-se as definições da Carta de Veneza para o contexto ibero-americano e apontava-se o turismo cultural dentre as alternativas econômicas para viabilizar restauração e reabilitação do patrimônio nos países do subcontinente ${ }^{350}$.

Estas disposições - e, sobretudo, o destaque dado ao turismo cultural - seriam revistas em 1977 no "Colóquio Internacional sobre a preservação dos centros históricos frente ao crescimento da cidade contemporânea", convocado pelo PNDU e pela UNESCO, do qual Ramón Gutiérrez participou na condição de membro titular ${ }^{351}$. Nas conclusões deste evento, novamente sediado em Quito, observam-se muitas das ideias que este historiador argentino defenderia nos anos subsequentes para as intervenções em centros históricos da região. Neste sentido, detectava-se que "um dos problemas [...] [dos] centros históricos latino-americanos é o abandono destes por sua população antiga e um subsequente deterioramento da área por um processo de ação especulativa sobre o solo e pelo encortiçamento" ${ }^{\prime 352}$. Revisava-se o caráter turístico de algumas intervenções, que teriam aplicado "critérios limitados que vão desde a conservação de monumentos isolados até 'maquilagens cenográficas" ${ }^{\prime \prime 353}$. Concluía-se que "a tarefa do resgate do patrimônio histórico, cultural e social da América Latina [...deveria ter] como protagonistas prioritários os habitantes dos países interessados" ${ }^{\prime 354}$.

\footnotetext{
349 PAULA, Alberto. Los centros históricos y las ciudades contemporáneas: el Coloquio de Quito, 1977. In: Summa. Buenos Aires: Ed. Summa, n. 114, jul. 1977, p.86-89.

${ }^{350}$ Cf. OEA. Norma de Quito. Quito: s.n. 1967.

${ }^{351}$ PAULA, Alberto. loc. cit, 1977.

352 PAULA, Alberto. loc. cit, 1977, p.86.

353 CONCLUSIONES del Coloquio de Quito. In: Summa. Buenos Aires: Ed. Summa, n. 114, jul. 1977, p.96.

${ }^{354}$ CONCLUSIONES del Coloquio de Quito. loc. cit., 1977, p.96.
} 
Entre as experiências supracitadas de restauro e reabilitação de centros históricos, destacamos duas não apenas por sua importância para o subcontinente, mas, também, pelo fato de terem contado com o engajamento direto de personagens que, posteriormente, vieram a debater esta temática em específico junto aos SAL: a implementação do Plano Copesco, de 1969, no Peru, e a reabilitação da Cidade Velha de Montevidéu, no início dos anos 1980. Pouco mais de uma década separam estas duas experiências que testemunham debates e enfoques distintos acerca do patrimônio histórico.

A primeira corresponde ao desdobramento da assessoria técnica e econômica prestada pela UNESCO ao Governo do Peru a fim desenvolver o turismo cultural na região de Cusco, em $1965^{355}$. Logo, o Plano Copesco (Comisión Especial para coordenar y supervigilar el Plan Turístico y Cultural) possibilitou, inicialmente, "restaurações dos edifícios históricos e sítios arqueológicos da região, e a construção nas instalações turísticas de estabelecimentos hoteleiros"356 e, após 1975, promoveu, também, o melhoramento da rede viária. Ramón Gutiérrez trabalhou diretamente junto à esta experiência, tendo sido convidado a ministrar um curso de formação sobre patrimônio em Cusco, entre 1975 e $1976^{357}$. Durante os dois anos em que viveu no Peru, Gutiérrez pôde acompanhar os impactos das políticas de promoção do turismo cultural nos centros históricos, verificando in situ seu esvaziamento e a perda do caráter residencia $\left.\right|^{358}$. A partir desta experiência, o historiador argentino construiu suas primeiras críticas ao turismo como propulsor do resgate do patrimônio, afirmando que "cidade é para os habitantes e não para o turismo" ${ }^{359}$.

A incorporação dos habitantes na reabilitação do centro histórico, por outro lado, seria uma das bases da proposta para a cidade velha de Montevidéu, viabilizada pela atuação do Grupo de Estudios Urbanos - do qual Mariano Arana foi um dos fundadores, em 1980. Como reação à destruição do patrimônio edilício de Montevidéu pela especulação imobiliária durante o período ditatorial (1973-1985) e à sua aceleração

\footnotetext{
355 BELAÚNDE, P. Cusco. In: GUTIÉRREZ, Ramón (org.). Centros históricos : América Latina., Bogotá: Escala, Colección SomoSur, 1990.

${ }^{356}$ BELAÚNDE, P. loc. cit., 1990, p. 160.

357 GUTIÉRREZ, Ramón. Depoimento. [11 de novembro de 2011]. Campinas: Arquivo digital da gravação (1hora e 39min.). Entrevista concedida a Gisela Barcellos de Souza.

${ }^{358}$ GUTIÉRREZ, Ramón. Depoimento. [11 de novembro de 2011], loc. cit.

359 GUTIÉRREZ, Ramón. Depoimento. [11 de novembro de 2011], loc. cit.
} 
por um decreto de 1979 que retirava da classificação de Monumento Histórico centenas de imóveis, organizou-se a partir de 1980 e da atuação do Grupo de Estudios Urbanos um movimento de conscientização popular ${ }^{360}$. A ampla recepção e divulgação nos meios de comunicação que esta campanha recebeu permitiu a criação, em 1982, da "Comisión Especial Permanente de la Ciudad Vieja" e a realização pela Sociedad de Arquitectos do Uruguai de um inventário patrimonial da Cidade Velha ${ }^{361}$. A conjunção entre a criação da Comissão Especial, com a participação do Banco Hipotecario del Uruguay em sua composição, e o apoio popular permitiu que a reabilitação de edifícios da Cidade Velha saísse do papel. Percebendo o processo de esvaziamento da Cidade Velha, somado a casos imóveis irregularmente ocupados, a proposta do Grupo de Estudios Urbanos buscou garantir a permanência e o engajamento da população residente. Para tanto, "a proposta incluiu o estudo de reformas a realizar (incorporação de banheiro e cozinha em cada unidade, espaço isolável para cada núcleo e a recuperação geral do edifício)”362. A recuperação dos edifícios contou a participação dos habitantes ali alojados "através da modalidade de 'ajuda mútua', incorporando a instrumental experiência da habitação em sistema de cooperativa desenvolvida no país" ${ }^{\prime 363}$.

Obviamente, a experiência do Plano de Bolonha reverbera tanto nas críticas de Gutiérrez ao Plano Copesco, quanto na proposta do Grupo de Estudios Urbanos de engajamento da população local na reabilitação do patrimônio edilício. De fato, ainda que negue a possibilidade desta referência em seu pensamento, Gutiérrez afirmou, em seu depoimento, que nos anos 1970 e início dos 1980, "Bolonha aparece como a panaceia" ${ }^{364}$, sendo defendida como exemplo a seguir por diversos de seus colegas ${ }^{365}$. Por outro lado, devemos lembrar que, mesmo não sendo um rossiano, Mariano Arana organizou a conferência de Aldo Rossi em 1982 e, no ano seguinte, em sua palestra na IV Bienal de Arquitetura do Chile, afirmava: "concordo com a postura teórica de Aldo Rossi, tanto quanto não gosto de sua atuação como projetista" ${ }^{366}$.

\footnotetext{
360 ARANA, M; MAZZINI, A. Montevidéu. In: GUTIÉRREZ, Ramón (org.). Centros históricos : América Latina., Bogotá: Escala, Colección SomoSur, 1990, p.274-281.

${ }^{361}$ ARANA, M; MAZZINI, loc. cit., 1990.

${ }^{362}$ ARANA, M; MAZZINI, loc. cit., 1990, p.280.

${ }^{363}$ ARANA, M; MAZZINI, loc. cit., 1990, p.280.

364 GUTIÉRREZ, Ramón. Depoimento. [11 de novembro de 2011]. Campinas: Arquivo digital da gravação (1hora e 39min.). Entrevista concedida a Gisela Barcellos de Souza.

${ }^{365}$ GUTIÉRREZ, Ramón. Depoimento. [11 de novembro de 2011], loc. cit.

${ }^{366}$ ARANA, Mariano. Patrimonio Urbano en Latinoamérica. In: CA. Santiago de Chile: Colegio de
} 
Outra referência vinculada à difusão do debate sobre a tipo-morfologia, no entanto, aparece transversalmente no início dos anos 1980 nos três habitués dos SAL que debateram nestes a questão do centro histórico: as lutas urbanas organizadas por Culot através do Atelier de Recherches et d'Action Urbaine (ARAU) e da escola de La Cambre. Mariano Arana, encerrava a palestra que proferiu na IV Bienal de Arquitetura do Chile afirmando que era preciso redefinir o papel dos arquitetos latino-americanos e apontando como uma possiblidade a "execução de Contra-projetos alternativos aos projetos devastadores de origem pública ou privada" ${ }^{367}$, em uma clara referência à forma de atuação do grupo de Culot. De forma semelhante, questionando, em 1982, sobre as experiências que considerava próximas ao seu pensamento, Gutiérrez admitia que:

As campanhas do Atelier de Recherches et d'Action Urbaine na Bélgica, para impedir o domínio da especulação imobiliária e a destruição da paisagem urbana, mostram um caminho de ação que é urgente adotar na América Latina, assegurando a participação ativa da população na defesa das nossas cidades. ${ }^{368}$

O interesse pelos contra-projetos realizados na Escola de La Cambre são perceptíveis até mesmo em Marina Waisman que, apesar de interessar-se por questões relativas ao patrimônio e às intervenções em centros históricos desde o início dos anos $1970^{369}$, nunca admitiu “olhar nostálgico" ou historicista ${ }^{370}$. Em 1983, no entanto, quando apresentava, nos cadernos Summarios algumas reconstruções de espaços devastados pela guerra ou pela especulação, parecia abrir uma exceção ao trabalho de La Cambre. Após uma breve introdução sobre o processo de destruição do tecido edilício de Bruxelas por ações de renovação urbana, Waisman afirmava:

Arquitectos, n. 36, dez. 1983, p. 32.

${ }^{367}$ ARANA, M., loc. cit. 1983, p.33.

368 GUTIÉRREZ, R. Falando claro. In: GUTIÉRREZ, R. Arquitetura latino-americana. Textos para reflexão e polêmica. São Paulo: Nobel, 1989, p.25.

${ }^{369}$ Marina Waisman fundou o Instituto de Historia y Presenvación del Patrimonio na Universidad Católica de Córdova durante da ditadura militar argentina - cf. WAISMAN, Marina. Autobiografía. In: DANA. Buenos Aires: Instituto Argentino de Investigaciones en Historia de la Arquitectura. $\mathrm{n}$ 39/40, 1997. No entanto, seu interesse pelas questões de patrimônio já podem ser observados no início dos anos 1970. Ver a título de exemplo : WAISMAN, Marina. Patrimonio histórico, ¿para qué? In: Summa. Buenos Aires: Ed. Summa. n 177, 1974, p.17-20.

370 WAISMAN, Marina. Autobiografía. In: DANA. Buenos Aires: Instituto Argentino de Investigaciones en Historia de la Arquitectura. n 39/40, 1997, p.8. 
Não é de se estranhar, então, que ali tenha surgido um movimento de habitantes e de acadêmicos - incorporado na Escola de La Cambre - de resistência a tais desaforos. Como situações extremas levam a medidas extremas, a Escola de La Cambre se inscreveu em um anti-industrialismo fechado, e proclamou a necessidade de retornar a uma arquitetura artesanal [...]. Porém os alunos da Escola, com a orientação de seus professores, realizaram muitas e valiosas ações, como, por exemplo, os "contra-projetos" que permitiam aos movimentos cidadãos opor-se com os melhores argumentos aos projetos do Estado ou das grandes companhias que pretendiam destruir seu habitat ${ }^{371}$.

Não obstante a presença de referências semelhantes no início dos anos 1980, como já demonstramos no capítulo "Ecos e escoamentos", não se observa no espaço dos seminários ensejados nos SAL uma confluência de representações e bricolagens sobre os centros históricos semelhante à verificada no debate sobre a periferia - e condizente à coerência que Moscato ${ }^{372}$ dá a entrever. Em Tlaxcala, por exemplo, demonstramos que Marina Waisman analisava os efeitos do processo crescimento centrífugo como fenômeno mundial e não específico às cidades latino-americanas; enquanto Ramón Gutiérrez estruturava sua argumentação a partir da asserção de sua especificidade como indubitável $\left.\right|^{373}$.

Através destas referências comuns - e da compreensão da relevância de realizações como a do Plano de Bolonha -, no entanto, pode-se compreender porque alguns dos participantes dos SAL associavam as contribuições sobre a tipo-morfologia às intervenções em centros e núcleos históricos. Marina Waisman, por exemplo, tratava, em 1987, os aspectos tipo-morfológicos como "instrumentos destinados ao conhecimento e proteção do patrimônio" cuja função poderia ser ampliada a fim de contribuir para o estudo sistemático da região e a identificação, desta forma, dos traços comuns à região ${ }^{374}$. Esta representação da existência de uma correspondência entre o

\footnotetext{
${ }^{371}$ WAISMAN, Marina. Volver a vivir. In: Summarios. Buenos Aires: Ediciones Summa, n.64, abr 1983, p.19-31.

372 MOSCATO, J. Gli Architetti in America Latina. In: GUTIÉRREZ, Ramón (org). Architettura e Società. L'América Latina nel XX secolo. Milão: Jaca Book, 1996.

${ }^{373}$ Ver "a periferia urbana, o centro histórico e o avesso da cidade europeia" em "Ecos e escoamentos".

${ }^{374}$ WAISMAN, Marina. Contribución de las disciplinas históricas y de preservación del patrimonio a la definición de una arquitectura regional. In: III Encuentro de Arquitectura Latinoamericana.
} 
resgate do patrimônio e a leitura dos aspectos tipo-morfológicos do espaço urbano também se torna patente ao se comparar o número de intervenções em centros históricos apresentado no V SAL com resultante do somatório do total das propostas que se destinava às demais situações urbanas - vinte para o primeiro caso, contra quinze no segundo ${ }^{375}$.

Ainda que não se verifiquem ressonâncias entre Marina Waisman e Ramón Gutiérrez a respeito dos centros históricos na ocasião em que estiveram juntos debatendo este tema nos SAL, algumas bricolagens comuns se revelam entre ambos em momentos distintos. Uma destas é a concepção da cidade como um conjunto de bairros - com os quais seus habitantes se identificam -, e do centro histórico como um dentre estes. Ora, deve-se atentar, primeiramente, para o fato de que a representação da cidade como um conjunto de bairros difere da leitura e da interpretação da "cidade por partes" tal qual propunham as formulações teóricas de Rossi e Aymonino, por exemplo. Na primeira, existe a noção de um espaço comunitário ${ }^{376}$ e de uma identidade que pode se afirmar a partir de diferentes aspectos - sejam eles sociais, culturais, históricos, imagéticos ou tipo-morfológicos. A segunda refere-se a um fragmento relacionado historicamente a um fato urbano, que serviria tanto como elemento de apoio ao estudo um fenômeno em específico, como recorte concreto para intervenções urbanas ${ }^{377}$. Certamente, a simples predileção pela escala do bairro não permite identificar em si a que definição esta se refere, visto que diferentes autores no pós-guerra trabalharam com esta categoria - veja-se Lynch, Jacobs, Krier e Culot, por exemplo. No entanto, ainda que o vínculo original não esteja claro, a ideia da "identificação do cidadão com seu bairro" transparece em algumas asserções de Marina Waisman e, posteriormente, de Gutiérrez. Em Tlaxcala, Marina Waisman apontava como possível alternativa para reversão dos efeitos do crescimento centrífugo a realização de um conjunto de intervenções que viesse a reconstituir a autonomia na escala do bairro. Em publicação um pouco posterior, Gutiérrez afirmava o centro histórico como um dos bairros da

Buenos Aires: CAPBA D III, 1988, p.7.

${ }^{375}$ Ver Apêncide $B$.

${ }^{376}$ Cf. DEVILLARD, V. ; JANNIÈRE,H. Espaces publics, communauté et voisinage, 1945-1955. In: PICON-LEFBVRE, V.(org). Les espaces publics modernes, situations et propositions. Paris : Groupe Moniteur, 1997, p.15-32; bem como, SOUZA, G.B. De los desdoblamientos de la Unidad de Vecindad. El espacio comunitário en la Ciudad Policéntrica de Léon Krier. in: Revista Bitácora Urbano-Territorial (Bogotá), v. 10, pp. 8-16, 2006.

${ }^{377}$ ROSSI, Aldo. L’Architecture de la Ville. Trad. Françoise Brun. Paris: InFolio, 2001. 
cidade - mostrando, especificamente neste caso, certa proximidade às interpretações de Boza e Moscato a este respeito:

[...] o centro histórico pode ser tratado como um bairro a mais com características especiais que requerem, ao final, normativas específicas. A diferença é que o "centro histórico" confere identidade a toda a cidade, enquanto os bairros - ainda que os tenhamos definidos como áreas histórico-culturais - podem fazê-lo somente a seus próprios habitantes ou aos bairros mais próximos ${ }^{378}$.

\begin{tabular}{|c|c|c|c|c|}
\hline \multirow[t]{2}{*}{$\begin{array}{l}\text { CONCEPTOS } \\
\text { INSTRUMENTALES }\end{array}$} & \multicolumn{2}{|c|}{ PROBLEMATICA } & \multirow{2}{*}{$\begin{array}{l}\text { PAUTAS DE } \\
\text { EUROPA }\end{array}$} & \multirow{2}{*}{$\begin{array}{l}\text { VALORES } \\
\text { AMERICA }\end{array}$} \\
\hline & EUROPA & AMERICA & & \\
\hline $\begin{array}{l}\text { ESTRUCTURAS } \\
\text { URBANAS }\end{array}$ & $\begin{array}{l}\text { CERRADAS } \\
\text { CONTINUAS }\end{array}$ & $\begin{array}{l}\text { ILIMITADAS } \\
\text { DISCONTINUAS } \\
\text { INDIFERENCIADAS }\end{array}$ & REVITALIZAR & $\begin{array}{l}\text { DEFINIR } \\
\text { ORDENAR } \\
\text { CLARIFICAR } \\
\end{array}$ \\
\hline $\begin{array}{l}\text { CENTROS } \\
\text { OAREAS } \\
\text { HISTORICAS }\end{array}$ & CONSOLIDADOS & $\begin{array}{l}\text { NO CONSOLIDADOS } \\
\text { TUGURIZADOS }\end{array}$ & $\begin{array}{l}\text { MANTENER } \\
\text { LA MEMORIA }\end{array}$ & $\begin{array}{l}\text { CREAR MEMORIA } \\
\text { MEJORAR } \\
\text { CALLAD DE VIDA }\end{array}$ \\
\hline $\begin{array}{l}\text { RELACION } \\
\text { CENTRO } \\
\text { PERISFERIA } \\
\end{array}$ & $\begin{array}{l}\text { CENTRAL } \\
\text { COLONIZANTE }\end{array}$ & $\begin{array}{l}\text { DEPENDENCIA } \\
\text { CHAUVINISMO } \\
\end{array}$ & DESCOLONIZAR & $\begin{array}{l}\text { ENCONIRAR Y } \\
\text { AFIRMAR LA } \\
\text { PROPIA IDENTIDAD }\end{array}$ \\
\hline LENQVAJE & ESTILO PROPIO & $\begin{array}{l}\text { ESTTL NO ORIGINAL } \\
\text { ENLARELACION DE } \\
\text { PORMA I TECICA } \\
\text { PORMA I ENTORNO } \\
\end{array}$ & $\begin{array}{l}\text { CIUDAD COMO } \\
\text { MODELO URBANO }\end{array}$ & $\begin{array}{l}\text { HACER } \\
\text { LA CIUDAD }\end{array}$ \\
\hline $\begin{array}{l}\text { DESARROLLO } \\
\text { DE IDEAS } \\
\text { ARQUIIEGTO NIGAS } \\
\end{array}$ & $\begin{array}{l}\text { CONTINUIDAD } \\
\text { DE LNEA }\end{array}$ & $\begin{array}{l}\text { DISCONTINUIDAD } \\
\text { ANTE LO AJENO }\end{array}$ & $\begin{array}{l}\text { EVOLUCIONAR EN } \\
\text { LA CONTINUIDAD }\end{array}$ & $\begin{array}{l}\text { CONSOUDAR UNA } \\
\text { LINEA EN UNA } \\
\text { AFERTURA POSITIVA }\end{array}$ \\
\hline $\begin{array}{l}\text { TPPOLOGIAS } \\
\text { DE } \\
\text { GIUDAD }\end{array}$ & $\begin{array}{l}\text { CIUDAD } \\
\text { EN CAMBIO }\end{array}$ & $\begin{array}{l}\text { TENER } \\
\text { CIUDAD }\end{array}$ & $\begin{array}{l}\text { CIUDAD } \\
\text { ANALOGA }\end{array}$ & $\begin{array}{l}\text { CIUDAD } \\
\text { FUTURA }\end{array}$ \\
\hline
\end{tabular}

Figura 74: Quadro que ilustrava o artigo "Reivindicación mundial de la crítica" de Marina Waisman em sua publicação na revista CA 36. Fonte: WAISMAN. Reivindicación Mundial de la Crítica. In: CA Santiago de Chile: Colegio de Arquitectos, n. 36, dez. 1983, p. 30-31.

Outra bricolagem que aparece com frequência é definição da especificidade do centro histórico latino-americano a partir de sua oposição àqueles europeus. Ainda que em Tlaxcala Marina Waisman começasse a questionar a existência de problemas e aspectos específicos às metrópoles latino-americanas - pensamento que viria a aprofundar em "Arquitetura descentrada", contextualizando-os nos fenômenos de fragmentação e descentralização ${ }^{379}$-, no início dos anos 1980 , a contraposição entre os centros históricos destes dois mundos serviu-lhe de bricolagens e noções iniciais que combinavam elementos da produção intelectual sobre a urbanização acelerada com outros oriundos de construções próprias a respeito das relações tipo-morfológicas. A título de exemplo, em 1983, Marina Waisman diferenciava os desafios a serem enfrentados pelas intervenções em centros históricos europeus daqueles pertinentes

378 GUTIÉRREZ, R. Testimonios de una identidad cultural. In: GUTIÉRREZ, R. (org) Centros históricos : América Latina. Coleção SomoSur, Bogotá: Escala. 1990, p.15.

${ }^{379}$ Cf. WAISMAN, M. La arquitectura Decentrada. Bogotá: Escala, 1995. 
aos latino-americanos: os primeiros deveriam manter a memória, os segundos, criar memória e qualidade de vida ${ }^{380}$ :

A consideração do tipo e do tecido urbano, que na Europa tende a imagem passada; entre nós não tem outra solução que olhar ao futuro, na esperança de criar um entorno mais harmônico que o existente. E é com este futuro em vista que se há de valorizar os tipos existentes ${ }^{381}$.

Esta representação dos centros históricos a partir de sua polarização entre a América Latina e a Europa seria, no entanto, logo revista pela autora argentina que, em "El interior de la história", preteriria esta polarização, propondo a elaboração de categorias e estratégias de intervenção que pudessem dar conta da diversidade do subcontinente - como distinção entre "centros históricos não consolidados" e aqueles ditos tradicionais. À representação unitária da cidade latino-americana e de seus centros históricos, Marina contrapunha, portanto, a necessidade de conhecer caso a caso e de dar conta das diferenças regionais:

Há uma imagem corrente da América Latina, segundo a qual todo o subcontinente constitui uma grande unidade cultural. Suas cidades, seus centros históricos, sua arquitetura assim como os problemas sociais e econômicos com eles relacionados, apareceriam como traços comuns que, apesar da diversidade de origens pré-colombianas, permitiriam entrever soluções semelhantes para as situações de conflito que se advertem em seus centros históricos. Esta imagem unitária provém, em parte, de uma visão eurocêntrica simplificadora, porém também de uma ideologia americanista, que, ao descobrir um destino para América Latina no panorama mundial, estende esta unidade fundamental à consideração de problemas particulares. Ainda que a ideia de uma América Latina unida por ideais e procedimentos compartilhados frente ao resto do mundo seja um objetivo valioso e urgente, pode perder sua eficácia se se embasa na falácia de considerar o subcontinente como uma férrea unidade histórico-cultural ${ }^{382}$.

\footnotetext{
${ }^{380}$ WAISMAN, M. loc. cit.,1983.

${ }^{381}$ WAISMAN, M. loc. cit. 1983, p. 31.

382 WAISMAN, Marina. El Interior de la Historia. Bogotá: Escala, 1990, p.35.
} 
Se, no final dos anos 1980, Waisman revisava a oposição América Latina e Europa como chave para pensar a cidade e os centros históricos regionais, foi constantemente repetida nos textos de Ramón Gutiérrez, como argumento fundamental para afirmar a impossibilidade de transposição de soluções entre estes dois mundos. No mesmo ano em que historiadora argentina publicava as asserções e críticas acima, Gutiérrez lançou um livro sobre os centros históricos da América Latina ${ }^{383}$, no qual introduzia a exposição de diferentes experiências em centros históricos latinoamericanos $^{384}$ pela oposição entre a realidade europeia e a local:

Esta realidade nos desafia com cidades de enormes carências sociais em matéria de habitação, equipamento e infraestrutura, em rápido processo de expansão e de renovação edilícia sem consolidação. Uma circunstância, pois diametralmente oposta à de uma Europa na qual o crescimento populacional está totalmente controlado, as grandes cidades perdem habitantes e está quase totalmente solucionada a demanda de habitação ${ }^{385}$.

Figura 75: Capa do livro "Centros Historicos: América Latina", publicado na coleção SomoSur da Escala e organizado por Ramón Gutiérrez em 1990. Fonte: Fotografia da autora.

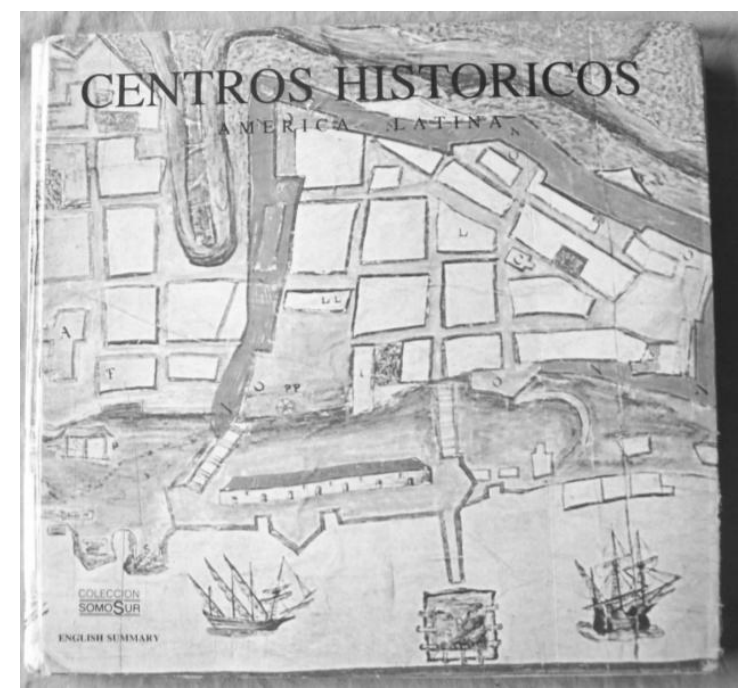

\footnotetext{
${ }^{383}$ GUTIÉRREZ, R. Centros históricos : América Latina. Coleção SomoSur, Bogotá: Escala. 1990.

${ }^{384}$ Neste livro, Gutiérrez recolheu a história e as experiências de intervenções de centros históricos de diversas cidades latino-americanas: Cidade do México, Guanajuato, Santiago de Cuba, Guatemala antiga, Portobelo, Jajo, Santa fé de Antioquia, Quito, Cusco, Arequipa, Sucre, Potosi, Valparaíso, Salvador, Corrientes, Buenos Aires e Montevideu. Cf. GUTIÉRREZ, R. op. cit, 1990.

385 GUTIÉRREZ, R. Testimonios de una identidad cultural. In: GUTIÉRREZ, R. (org) Centros históricos : América Latina. Coleção SomoSur, Bogotá: Escala. 1990, p.15-16.
} 
De fato, através do percurso empreendido pela periferia urbana e pelos centros históricos, observa-se que duas representações manifestam-se com maior frequência e de forma transversal a estes debates: a cidade latino-americana como o avesso da europeia e o bairro como escala de compreensão e de intervenção nesta cidade. Verifica-se, portanto, o que Comas já havia identificado no evento de Tlaxcala, quando elencava os traços comuns que haviam permitido a aproximação entre países do subcontinente e o surgimento do interesse pelas questões latino-americanas: a perplexidade face à apresentação da cidade europeia do século XVIII como modelo universal $^{386}$. O absurdo e a impossibilidade de se pensar a "Reconstrução da Cidade Europeia" no continente Latino-americano levam até mesmo aqueles que sempre se mostraram mais abertos ao debate internacional, como os chilenos do grupo CEDLA, à formulação de bricolagens e à busca noções próprias. Nesta empreitada, as construções intelectuais de décadas anteriores, sejam da ótica do planejamento ou do patrimônio, possibilitam a estes arquitetos e historiadores chaves de interpretação que são descontextualizas, recortadas e recombinadas em bricolagens sobre cidade latinoamericana. A possível teoria sobre esta cidade, sempre em construção segundo os textos de Moscato, nunca chega a ser concluída, visto que, como toda bricolagem, tratase de um processo em constante reconfiguração.

386 COMAS, C. E, Identidade Nacional, caracterização arquitetônica. In: IV Encuentro de Arquitectura Latinoamericana/ México. "La Trindad", Tlaxcala, Tlaxcala (México): Universidad Autónoma Metropolitana, 1989. 
Considerações finais 


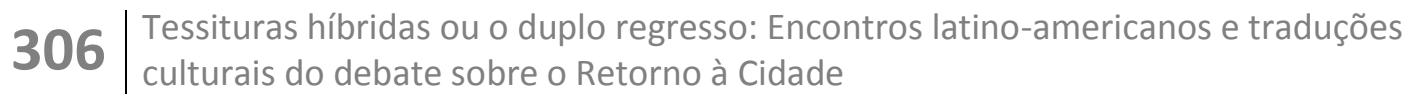


Ao longo desta tese abordou-se a realização do V SAL sob a ótica da microhistória. Ou seja, este curto evento no tempo - cuja duração foi de apenas cinco dias serviu-nos para demonstrar a existência de uma hibridação entre o "voltar-se à América Latina" e o "retorno à cidade" na cultura arquitetônica latino-americana dos anos 1980 a meados dos anos 1990. Para tanto, trabalhou-se com um jogo de escalas que ora enfocava o V SAL a partir da história profissional do pequeno grupo de arquitetos chilenos que foram responsáveis por sua organização, ora afastava-se por completo deste objeto inserindo-o como mais um evento associado à difusão do debate sobre a tipo-morfologia.

Obviamente, nem todos os arquitetos dos países representados nos encontros e debates estudados engajaram-se da mesma forma e com mesmo grau de profundidade. Para tanto, foi fundamental a ponderação realizada através das análises sequenciais dos registros impressos dos seminários, assim como de revistas especializadas do subcontinente entre meados dos anos 1970 e meados dos anos 1990. Os dados sistematizados a partir destes escrutínios seriais foram cotejados aos depoimentos orais, permitindo, desta forma, a verificação da existência de lacunas e a busca novas fontes a fim de minimizá-las.

Através deste percurso, pôde-se demonstrar que o debate sobre a cidade latinoamericana e sua morfologia não era uma novidade no contexto dos SAL quando se realizou o evento de Santiago do Chile, em 1991. Tal qual se demonstrou no capítulo "Ecos e Escoamentos", esta temática já podia ser entrevista nas primeiras realizações em Buenos Aires e sua discussão em seções próprias ocorria no terceiro e no quarto seminário. Seu surgimento corresponde, inicialmente, a um ensaio de matização dos conceitos propostos e de definir convergências em meio à diversidade de opiniões que se verificava naquele momento. Não obstante o fato de que nos terceiro e quarto seminários houve a destinação de mesas específicas para seu debate, a temática da cidade latino-americana ainda podia ser observada em meio aos argumentos expostos 
nas demais seções. Contando com o engajamento direto de personagens vinculadas à história dos SAL, o debate sobre a cidade latino-americana codificou-se na passagem do terceiro ao quarto seminário a partir de dois olhares: o centro histórico e a periferia urbana.

Nos preparativos do V SAL, buscar-se-ia costurar estes dois pólos de debate em uma urdidura que visava ampliar a atuação dos SAL e definir parâmetros para as intervenções na América Latina. Desta forma, buscou-se demonstrar no capítulo "Tecendo as partes da cidade latino-americana" o preparo minucioso da trama que, não apenas unia discussões que haviam ocorrido até então em locais distintos nos SAL, como também imiscuíam entre seus fios elementos e interesses pertinentes à história do grupo de arquitetos que organizava o seminário, bem como dos encontros e debates paralelos nos quais este se havia engajado. Por outro lado, ao abordar a descrição do evento de fato verificou-se que apesar de ter contado com grande afluência de contribuições em forma de projetos e textos - oriundas de diversos países - o V SAL não conseguiu atingir suas expectativas iniciais. $\mathrm{O}$ formato definido para o evento, com restrição do tempo destinado para a exposição das contribuições teóricas e das propostas de intervenção, somado à realização concomitante da VIII Bienal que trazia novos debates na bagagem de seus convidados internacionais, impossibilitou a discussão aprofundada necessária a qualquer tentativa de aproximação aos acordos coletivos almejados pela convocatória. Por outro lado, no momento em que o V SAL teve lugar, vislumbravam-se os primeiros - e ainda ínfimos - sinais do processo que se estabeleceria na sequência e culminaria na afirmação coletiva do desgaste do debate latino-americanista em 1995, no evento de São Paulo/São Carlos.

Por último, em "Encontros, Traduções Culturais e Bricolagens" enfocamos os aspectos que transcendiam a história dos SAL e que eram apenas entrevistos nos capítulos anteriores. Situamos, em forma de panorama as personagens e debates através dos quais arquitetos latino-americanos estabeleceram contato com a construção teórica em torno da tipo-morfologia. Na sequência, ao analisar os contatos diretos com aqueles arquitetos cujas reflexões obtiveram maior penetração na cultura arquitetônica do subcontinente, voltamos a enfocar o grupo CEDLA, mostrando seu envolvimento em intercâmbios e traduções culturais iniciais. Por último, demonstramos como o engajamento no debate sobre a identidade latino-americana viria a transformar os rumos das traduções iniciais, possibilitando o rompimento - ou, em alguns casos, a 
ocultação - dos vínculos originais com o debate europeu e a construção das bricolagens que se revelam em meio aos debates dos SAL analisados.

Uma tese certamente não esgota uma problemática. Ao longo desta pesquisa, verificou-se uma miríade de outros eventos e intercâmbios extremante interessantes que testemunhavam, também, a hibridação da qual trata esta tese. Muitos destes foram estudados ao longo da execução deste trabalho e abordados longamente nas entrevistas realizadas. Infelizmente, a maior parte destes não pode ser incorporada à redação final da tese, pois seu contato com a conjuntura da realização do V SAL mostrou-se demasiadamente tênue para justificá-lo. Ao final desta tese, constitui-se, portanto, um denso material na forma de depoimentos e documentos coletados a ser explorado em investigações futuras. 
$310 \begin{aligned} & \text { Tessituras híbridas ou o duplo regresso: Encontros latino-americanos e traduções } \\ & \text { culturais do debate sobre o Retorno à Cidade }\end{aligned}$ 


\section{Referências bibliográficas}


312 Tessituras híbridas ou o duplo regresso: Encontros latino-americanos e traduções culturais do debate sobre o Retorno à Cidade 


\section{Livros, Artigos, Capítulos de Livros e Teses:}

ABRAHÃO, Sérgio Luís. Espaço Público: Do urbano ao político. São Paulo : Annablume, 2008.

AGREST, Diana. Para Aldo, con cariño de una argentina. In: Block. Buenos Aires: Instituto Torcuato di Tella. n.3, dec.1998, p.32-41.

ALTAMIRANO, Carlos. Ideias para um programa de História intelectual. In: Tempo Social, São Paulo, v. 19, n. 1., jun 2007, p. 9-17

AYMONINO, Carlo. O significado das cidades. Lisboa: Editorial presença, 1984.

ARANA, Mariano. Patrimonio Urbano en Latinoamérica. In: CA. Santiago de Chile: Colegio de Arquitectos, n. 36, dez. 1983, p. 32-33.

De la recuperación y la renovación de la ciudad histórica. In: IV Encuentro de Arquitectura Latinoamericana. Conclusiones. México: Universidad Autónoma Metropolitana, 1991, p.19-25.

La Arquitectura en los Tiempos del Cólera In: CA. Santiago de Chile: Colegio de Arquitectos, n. 65, jul/ago/set 1991, p.32-33.

ARANA, M; MAZZINI, A. Montevidéu. In: GUTIÉRREZ, Ramón (org.). Centros históricos : América Latina., Bogotá: Escala, Colección SomoSur, 1990, p.274-281.

ARANGO, Silvia. Siete anotaciones para pensar la arquitectura latinoamericana. In: III Encuentro de Arquitectura Latinoamericana. Buenos Aires: CAPBA D III, 1988. p.68-69.

. Estrutura Essencial y Estrutura Contingente. In: IV Encuentro de Arquitectura Latinoamericana/ México. "La Trindad”, Tlaxcala, IV, Anais...Tlaxcala (México): Universidad Autónoma Metropolitana, 1989.

Diez años de los "SAL" en América latina. In: PROA, Bogotá: Ediciones PROA, 425, jun.1995, p.19-22.

. Arquitectura de los años 80 en Colombia. In: Immuebles. Caracas: JMBC Grupo Editor Immobiliário, n.9, mar 1993, p.74-75.

ARANGO, Silvia (org). Modernidad y Postmodernidad en América latina. Bogotá: Escala, 1991.

ARANGO, Silvia; PEREZ ESCOLANO, Victor et. al. El Camino Propio. Fragmentos del Foro Panel realizado en la VIII Bienal de Arquitectura. In: CA. Santiago de Chile: Colegio de Arquitectos. Jul/ago/set 1992, capa 
ARGAN, Giulio Carlo. História da arte como história da cidade. São Paulo: Martins Fontes,1993.

Sur le Concept de Typologie Architecturale. In : Projet et Destin. Art, architecture, urbanisme. Chatillon: Editions de la Passion, 1993, p.57-61.

BALERDI A., Jorge. Proyecto Barranco: la transformación morfológica de un barrio histórico. In: V Seminario de Arquitectura Latinoamericana. Nuestro Espacio Urbano: Propuestas Morfológicas. V, 1991. Santiago do Chile. Anais... Santiago do Chile: s.n. 1991.

BANNEN, Germán. Chile, Santiago: Providencia, Ciudad entre. In: CA, n. 58, Santiago do Chile: Colegio de Arquitectos, out-dez 1989, p. 54-59.

BARACCO, Juvenal. La Recomposición de la Ciudad Perdida. In: III Encuentro de Arquitectura Latinoamericana. III, Anais...Buenos Aires: CAPBA D III, 1988. 100.

Arquitectura y contexto urbano. In: CA. Santiago de Chile: Colegio de Arquitectos, n. 36, dez. 1983, p. 36.

. La ciudad Metasíquica. In: ARS. Santiago de Chile: CEDLA, n.5, jul. 1984, p.76.

. La arquitectura de la periferia. In: ARS, Santiago de Chile: CEDLA, n.6, set. 1985, p.42.

BARANDIARÁN, Edgardo; HERNÁNDEZ, Leonardo. Origins and resolutions of a banking crisis: Chile 1982-86. In: Banco Central de Chile - Documentos de Trabajo, Santiago de Chile: Banco Central de Chile, n.57, dez. 1990.

BAREY, André. Propos sur la reconstruction de la ville européenne : Déclaration de Bruxelles. Bruxelles, Archives d'Architecture Moderne, 1980.

BARDIN, Laurence. Análise de Conteúdo. Lisboa: Edições 70, 2009.

BAROS, M. ; CASTRO, O. et al. Anteproyecto Conjunto Vivienda Social en Pundahuel. In: ARS, Santiago de Chile: CEDLA, n.6, set. 1985, p.56-58.

BARROS, José d'Assunção. História das Ideias - em torno de um domínio historigráfico. In: Locus. Revista de história. Juiz de Fora, v.13, n.1, 2007, p. 199-209.

BELAÚNDE, Pedro. Juvenal Baracco: un universo en casa. Bogotá : Escala, Colección SomoSur, 1988.

. Cusco. In: GUTIÉRREZ, Ramón (org.). Centros históricos: América Latina., Bogotá: Escala, Colección SomoSur. 1990, p.146-165.

BENVOLO, L. $O$ último capítulo da Arquitetura Moderna. Lisboa: Edições 70, 1997.

BLAU, Eve. Architectural History 1999/2000: A Special Issue of "JSAH" In: Journal of the Society of Architectural Historians, v. 58, n.3, Architectural History, set., 1999, p.278-280.

BOHIGAS, Oriol. Ten points on an Urbanistic Methodology. The Journal of Architecture, v. 4, outono, pp.240-244, 1999. 
. Ricostruire de Barcellona. Etaslibri. 1992.

. Casabella e la cultura architettonica spagnola negli anni 50. In: Casabella, n.440441,1978, p.87-88.

BOZA, Cristián. El Barrio: Punto de partida para reurbanizar la ciudad latinoamericana. In: III Encuentro de Arquitectura Latinoamericana. III, Anais...Buenos Aires: CAPBA D III, 1988, p.78-79. - Identidad Arquitectónica: Un análisis tipológico y formal en Santiago de Chile. In: IV Encuentro de Arquitectura Latinoamericana/ México. "La Trindad", Tlaxcala. IV, Anais...México: Universidad Autónoma Metropolitana, 1989.

Léon Krier: su pensamiento frente a la ciudad. In: ARS. Santiago: CEDLA, n.1, jul. 1978, 35-41.

. James Stirling y la recreación del espacio urbano. In: ARS. Santiago: CEDLA, n.2, dez. 1978, 5-16.

. Arquitectura Latinoamericana: Tradición y Modernidad. In: ARS. Santiago de Chile: CEDLA, n.10, maio 1988, p. 44-71.

- Evaluación cualitativa de la arquitectura periférica: concursos oferta 83-84 Serviu. In: ARS, Santiago de Chile: CEDLA, n.6, set. 1985, p.17-36.

BOZA, Cristián; DUVAL, Hernán. Inventario de una arquitectura anónima. Santiago, Chile : Lord Cochrane, 1982.

BOZA, Cristián; MOSCATO, Jorge. Dos experiencias académicas sobre la periferia. In: ARS, Santiago do Chile: CEDLA, n7, nov. 1986 p. 58-77.

BOZA, Cristián; MORENO G., Manuel; DUVAL V., Hernán. Taller Boza-Duval-Moreno: nivel ejercitación. Santiago: Pontificia Universidad Católica de Chile, Escuela de Arquitectura, 1980.

BRONSTEIN, Laís. Fragmentos de uma crítica: Revisando a IBA de Berlim. Tese de doutorado. Escola Tècnica Superior d'Arquitectura - Universitat Politècnica de Catalunya, Barcelona, 2001.

BROWNE, Enrique. Otra Arquitetura en América latina. Barcelona: Gustavo Gili, 1988. - Espíritu de la época y espíritu del lugar In: Summa, Buenos Aires: Ediciones Summa, 232, dez 1986.

- Precisiones Latinoamericanas. In: IV Encuentro de Arquitectura Latinoamericana/ México. “La Trindad”, Tlaxcala. México: Universidad Autónoma Metropolitana, 1989.

. Algunos fenómenos de nuestra arquitectura. In: TALLER AMÉRICA. Contribución al Encuentro Latinoamericano de Revista de Arquitectura. Santiago do Chile: s.n. 1985, p.14-21. 
. Gérmenes Positivos en las ciudades latino-americanas. In: CA. Santiago de Chile: Colegio de Arquitectos, n.52, jun 1988, p.44-45.

. Enrique Browne arquitecto : obras 1974-1994. Santiago de Chile: ARQ 1995.

BROWNE, Enrique (org). Casas y escritos. Santiago de Chile: Taller América, 1989.

BROWNE, Enrique; GEISSE, Guillermo. ¿Planificación para los planificadores o para el cambio social? In: Castells (org.) Imperialismo y Urbanización en América latina. Barcelona: Gili, 1973, p.315-338.

BURGER, Marcel. Les manifestes: paroles de combat. De Marx à Breton. Lonay: Delachaux et Nieslé, 2002.

BURKE, Peter. O que é história cultural? Rio de Janeiro: Zahar, 2008.

. Hibridismo cultural. São Leopoldo: UNISINOS, 2003.

BURKE, P.; PO-CHIA HSIA. Introdução. In: BURKE; PO-CHIA HSIA (org.) Tradução Cultural nos primórdios da Europa Moderna. São paulo: Ed. UNESP, 2009, p. 7-10.

BUSQUETS, Joan. La urbanización marginal. Barcelona : Edicions UPC, 1999.

CAMACHO, Luís Eduardo. Sociedade Interamericana de Planificación. SIAP 50 años de vida institucional y Progamática. In: Revista Bitácora Urbano-Territorial, Bogotá: Universidad Nacional de Colombia, vol.1, n 11, 2007, p.268-284.

CANCLINI, Nestor Gracía. Culturas Híbridas. São Paulo : Edusp, 2008.

CARVALHO, José Murilo de. História intelectual no Brasil: a retórica como chave de leitura. In: Topoi, no1, Rio de Janeiro, jan/dez, 2000, p. 123-152

CASTELLS, Manuel. Urbanización Dependiente en América latina. In: Castells (org.) Imperialismo y Urbanización en América latina. Barcelona: Gili, 1973, p7-26.

CASTEX, J. Histoire de la forme urbaine. In : Castex et al. Histoire Urbaine, antropologie de l'espace. Paris : CNRS Editions, 1995.

CEDLA. Antreproyecto Santiago Poniente. In: CEDLA, Santiago do Chile: CEDLA, ago. de 1977, p.35-51.

CEDLA, Remodelación de Santiago Poniente 2. In: ARS, Santiago de Chile: CEDLA, n.1, jul. 1978, p.15-26.

CERTEAU, Michel de. A operação historiográfica. In: A escrita da história. Rio de Janeiro : Forense Universitaria, 2006. 345 p.

CERVALLATTI, Pier Luigi P. L. Un avenire per nuestro passado. Casabella, n.428, set., pp.10-12, 1977.

Bolonia : política y metodología de la restauración de centros históricos. Barcelona : Gustavo Gili, 1976.

CHAPEL, Enrico. L'œil raisonné. L'invention de l'urbanisme para la carte. Genébra: Métis Presses, 2010. 
CHARTIER, Roger. El mundo como representación. Estudios sobre história cultural. Barcelona: Gedisa, 1992.

CHOAY, Françoise. La règle et le modèle: sur la théorie de l'architecture et del'urbanisme. Paris: Seuil, 1986.

COHEN, Jean-Louis. Préface. In: JANNIERE, H., Politiques éditoriales et architecture " moderne " : L'émergence de nouvelles revues en France et en Italie (19231939). Paris, ed. Arguments, 2002.

. The italiophiles at Work. In: Hays (org). Architecture theory since 1968. Nova York : MIT Press, 1998.

. Scènes de la vie future: I'architecture européenne et la tentation de l'Amérique 1893-1960. Paris: Flammarion/Centre Canadien de l'Architecture,1995.

CONTRERAS, Ricardo. Vittorio Gregotti, la arquitectura de sus ideas. In: CEDLA. Santiago: CEDLA, ago. de 1977, p. 11-14.

. Indagaciones sobre la periferia. In: ARS, Santiago de Chile: CEDLA, n.6, set. 1985, p.43-44.

COMAS, C. E, Identidade Nacional, caracterização arquitetônica. In: IV Encuentro de Arquitectura Latinoamericana/ México. "La Trindad", Tlaxcala. IV, Anais... Tlaxcala (México): Universidad Autónoma Metropolitana, 1989.

. Arquitectura Brasileña: 1989 a 1992. In: Immuebles. Caracas: JMBC Grupo Editor Immobiliário, n.9, mar 1993, p.72-73.

. O esgotamento do regionalismo. In: AU. São Paulo: Pini, n. 48, jun/jul 1993, p.25.

COMAS, C. E. et al. Uma superquadra periférica de Porto Alegre. Relatório de estudo de desenho urbano [memorial do projeto apresentado no V SAL]. Porto Alegre: s.n., 1991.

CONFORTI, Claudia. Instruments et méthodes de l'architecture contemporaine. Un parallèle avec l'histoire de l'architecture de la période moderne. In : Les Cahiers de la recherche architecturale et urbaine. Paris : Éditions du Patrimoine, 2002, p.127-132.

COLOMINA, Beatriz. Privacy and Publicity. Modern Architecture as Mass Media. Nova York : MIT Press, 1996.

COSTA, Xavier. Da Margem e do Centro. O Docomomo e a valorização da arquitetura moderna. In: Projeto. São Paulo: Projeto, n.191, nov 1995, p.71-72.

CULOT, Maurice; KRIER, Léon. The Only Path for Architecture. Oppositions, n.14, New York, MIT Press, fall, pp.39-53, 1978.

CULOT, M; KRIER, L. Léon Krier: Drawings 1967-1980, Bruxelas: AAM, 1980. 
DARRAIDOU, Luis. El bloque urbano de Nueva York como un tipo arquitectónico. In: ARS. Santiago: CEDLA, n.1, jul. 1978, p.70-91.

DE FUSCO, Renato de. História y Estructura. Teoría de la historiografía arquitectónica. Madri: Alberto Corazón, 1974.

DEAMBROSIS, Federico. El lugar de Chile en el imaginário arquitectónico del siglo XIX. In: LIERNUR (org). Portales del Laberinto. Arquitectura y Ciudad en Chile, 19772009. Santiago de Chile: Universidad Andrés Bello, 2009, p.121-172.

DELEVOY, Robert L. Vers une Architecture. In : Krier (org) Rational Architecture :The Reconstruction of the European city/Architecture Rationnelle: La Reconstruction de la Ville Européenne, Bruxelles, A.A.M, pp.5-13, 1978.

DEVILLARD, V. ; JANNIÈRE,H. Espaces publics, communauté et voisinage, 1945-1955. In: PICON-LEFBVRE, V.(org). Les espaces publics modernes, situations et propositions. Paris : Groupe Moniteur, 1997, p.15-32.

DíAZ, Antonio. Buenos Aires: La arquitectura de la "manzana". In: La Manzana como Idea de Ciudad. Elementos teóricos y propuestas para Buenos Aires. III SIAC. Barcelona: 2C ediciones, 1980.

. Posmodernismo y dictadura. In: Block. Buenos Aires: Instituto Torcuato di Tella. n.5, dec. 2000, p.51-53.

. Aldo Rossi y Buenos Aires. 1914-1997. In: 47 al fondo. Revista de la Facultad de Arquitectura y Urbanismo de la Universidad Nacional de la Plata. La Plata: Univ. Nacional de la Plata, n.3, oct. 1998, p.52-55.

DÍAZ; SOLSONA et. al. La Escuelita. 5 años de enseñanza de alternativa de arquitectura en la Argentina, 1976/1981. Buenos Aires: Espacio Editora, 1981.

DÍAZ; SOLSONA e KATZENSTEIN. Declaración acerca de la suspensión de las actividades de La Escuelita. Buenos Aires: s.n., 1984.

DÍAZ BARRIGA, Miguel. "Necesidad": Notes on the Discourses of Urban Politics in the Ajusco Foothills of Mexico City. In: American Ethnologist, Vol. 23, №. 2, maio de 1996, p. 291-310.0

DIEZ, Fernando. Buenos Aires y algunas constantes en las transformaciones urbanas. Buenos Aires: Editorial de Belgrano, 1996.

DOMEYKO, F. Tissu Urbain San Pablo / Santiago du Chili. Exposé du Problème et des Conclusions. Cf. In: A+, Bruxelas: CIAUD, n.7, abr. 1974, p.22-40.

DUVAL, Hernán. Ciudad y periferia. In: ARS, Santiago de Chile: CEDLA, n.6, set. 1985, p.37-41.

ELEB, Monique. Généalogie de l'habitation et histoire sociale. In : Les Cahiers de la recherche architecturale et urbaine. Paris : Éditions du Patrimoine, 2002, p.137150. 
ELGUEZABAL, Eduardo. Aldo Rossi en Buenos Aires. In: SCA. Buenos Aires: Sociedad Central de Arquitectos, n.123, dec. 1982, p.61.

. Simposio de la Crítica: crónicas y comentarios. In: Summa. Buenos Aires: Ed. Summa, n.151, julho de 1980.

ELIASH, Humberto. Arquitectura Contemporánea Latinoamericana. In: ARS, Santiago do Chile: CEDLA, n. 3, ago. 1979a. - Encuentro de Arquitectos Extranjeros. Antonio Díaz y Justo Solsona. In: CA. Santiago: Colegio de Arquitectos, n. 25, dec. 1979b.

. La Periferia Dibujada. In: ARS, Santiago do Chile: CEDLA, n. 7, ago. 1986, p. 1121.

- Dimensión Arquitectónica de la Periferia Urbana. In: III Encuentro de Arquitectura Latinoamericana. III, Anais... Buenos Aires: CAPBA D III, 1988, p.8587.

. Conclusiones. Grupo C. In: III Encuentro de Arquitectura Latinoamericana. III, Anais...Buenos Aires: CAPBA D III, 1988, p.103.

. Esquizofrenia Arquitectónica. El desencuentro entre la ética y la estética. In: IV Encuentro de Arquitectura Latinoamericana/ México. "La Trindad", Tlaxcala. IV, Anais...México: Universidad Autónoma Metropolitana, 1989.

. La arquitectura de Cristián Boza : un eclectisismo apasionado. Santiago, Chile : Ediciones ARQ, 1993.

. Encuentro de arquitetos. In:ARS. Santiago: CEDLA, n.3, ago. 1979, p.48-58.

. Editorial. In: ARS. Santiago: CEDLA, n.5, jul. 1984, p.7-8.

- Reflexiones desde Chile sobre los 25 años de los Seminarios de Arquitectura Latinoamericana. In: GUTIÉRREZ, R.; MÉNDEZ, P. (org) Seminarios de Arquitectura Latinoamericana (SAL). Haciendo camino al andar. Buenos Aires: CEDODAL, 2011, p.45-48.

ELIASH, H.; BOZA, C., et al. Uma década... Nuevas tareas. In: ARS. Santiago do Chile: CEDLA, n.10, maio 1988, p.1.

. Arquitectura Latinoamericana en tempos de democracia: un desafio. In: ARS. Santiago do Chile: CEDLA, n.11, jul 1980, p.7-9.

ELIASH, H.; BOZA, C.; MORENO, M. Arquitectura chilena en el laberinto de la prosperidad In: Immuebles. Caracas: JMBC Grupo Editor Immobiliário, n.9, mar 1993, p.78-79.

ELIASH, H.; MOSCATO, J. Taller de Verano CEDLA 1985 - Teoría y prática de la ciudad. In: ARS, Santiago de Chile: CEDLA, n.6, set. 1985, p.51-58.

ELLIN, Nan, Postmodern Urbanism. New York, Princeton Architectural Press, $2^{\mathrm{e}}$ ed (1996), 1999, 399p. 
FERNÁNDEZ, Roberto. Propiedad y ajenidad en la Arquitectura Latinoamericana. In: ARS, Santiago: CEDLA, n.10, mai 1988, p.18-23.

Modernidad Perisférica. In: CA. Santiago de Chile: Colegio de Arquitectos, n. 36, dez. 1983, p. 34-35.

. Hacia una teoría de la "Apropriación". In: ARS. Santiago de Chile: CEDLA, n.5, jul. 1984, p.17-20.

FERNANDEZ, Teodoro; PEREZ DE ARCE, Rodrigo. Los arquitectos y su Ciudad. In: CA. Santiago de Chile: Colegio de Arquitectos, n. 65, jul/ago/set 1991, p.118.

FERNÁNDEZ COX, Cristián. Recado a los arquitectos de Hispanoamérica. In: PROA, Bogotá: Ediciones Proa, n. 337, dez 1984, p. 53.

. Planificación y Mercadismo. In: ARS, Santiago: CEDLA, n. 3, ago. 1979, p.12-14.

- Tres notas para una reflexión sobre las bienales. In: CA. Santiago do Chile: Colégio de Arquitetos do Chile, n. 52, junho de 1988, p.62.

. Modernidad Apropriada, Modernidad Revisada y Modernidad Reecantada. In: Arango (org.). Modernidad y Postmodernidad en América latina. Bogotá: Escala, 1991.

. Aviso de retorno. In: Summa+. Buenos Aires: Donn S. A., n.7, jun/jul 1994, p.8889.

FERNÁNDEZ LARRAÑAGA, Teodoro. Murtinho \& Asociados. Santiago do Chile: Publicaciones ARQ, 1991.

FFRENCH-DAVIS, R.; MUÑOZ, O.; PALMA, J.G. As Economias Latino-americanas, 19501990. In: BETHELL (org) História da América Latina. América Latina após 1930: Economia e Sociedade. São Paulo: Edusp, 2009, p.129-231.

FIORE, Paolo. Recherches en histoire et la formation des architectes. In : Les Cahiers de la recherche architecturale et urbaine. Paris: Éditions du Patrimoine, 2002, p.113-126.

FORTY, Adrian. Words and Building. A vocabulary of Modern Architecture. Londres: Thames \& Hudson, 2000.

FRAMPTON, K. On Reading Heidegger. In : HAYS, K. M. (org) Oppositions Reader. New York : Princenton Architectural Press, 1998, p.3-6. . Perspectivas para um regionalismo crítico. In: NESBITT, K. Uma nova Agenda para a Arquitetura. Antologia Teórica 1965-1995. São Paulo: Cosac Naify, 2006, p.504-520.

FROMMEL, Sabine. Pourquoi s'intéresser aux méthodes? In : Les Cahiers de la recherche architecturale et urbaine. Paris: Éditions du Patrimoine, 2002, p.5-11.

FUENTE, Carlos. Las culturas, portadoras de la vida posible. In: Summa, Buenos Aires: Ediciones Summa, 212, maio 1985. 
GARAY, Alfredo. On the Administration of Urban Projects: The lessons of Puerto Madero. In: LIERNUR, J. F. (org). Puerto Madero Waterfront. Munique: Prestal Verlag, 2007, p.74-83.

GARCÍA ALVARADO, Rodrigo. Esbozos de Teoría de la Arquitectura en Chile. In: Arquitectura del Sur. Concepción: Universidad de Bio-Bio, n. 32, 2005.

GARCÍA MORENO, Beatriz. Región y Lugar. Arquitectura Latinoamericana Contemporánea, Bogotá: Pontificia Universidad Javeriana, 2000.

GHIRARDO, Diane. Arquitetura Contemporânea. Uma História Concisa. São Paulo: Martins Fontes, 2002.

GONZÁLEZ LOBO, Carlos. La construcción de la ciudad latinoamericana, desde las necesidades de masas. In: IV Encuentro de Arquitectura Latinoamericana/ México. "La Trindad", Tlaxcala. IV, Anais...México: Universidad Autónoma Metropolitana, 1989.

La Ciudad de la Periferia: Mixquic. In: BOZA et al. (org). Seminario de Arquitectura Latinoamericana. Nuestro Espacio Urbano: Propuestas Morfológicas. V, 1991. Santiago do Chile. Anais... Santiago do Chile: s.n. 1991.

GORELIK, Adrián. A produção da "cidade latino-americana". In: Tempo Social, São Paulo, v. 17, n. 1, jun 2005, p.111-133.

. The Puerto Madero Competition and Urban Ideas in Buenos Aires in the 1980. In: LIERNUR, J. F. (org.) Puerto Madero Waterfront. Munique: Prestal Verlag, 2007, p.62-73.

GONZÁLEZ, Luis. Cayc: la función sigue la forma. In: ARS. Santiago: CEDLA, n.2, dec. 1978.

GONZÁLEZ, Norberto. Balance preliminar de la economía latinoamericana, 1986. Santiago: CEPAL, 1986.

GLUSBERG, Jorge. Identidad y región: recorrido crítico de la arquitectura en América latina. In: Summa, Buenos Aires: Ediciones Summa, 212, maio 1985.

. Bienal Internacional de Arquitectura de Buenos Aires BA/85. In: Summa. Buenos Aires: Ediciones Summa, n. 217, setembro de 1985, p. 29.

GRASSI, Giorgio. La construcción lógica de la arquitectura. Barcelona: Colegio Oficial de Arquitectos de Cataluña y Baleares 1973.

GREGOTTI, Vittorio. Território da Arquitetura. São Paulo: Perspectiva, 2001.

GROAT, Linda; WANG, David. Architectural Research Methods. New York: John Wiley \& Sons, 2002.

GRUPO 2C. Presentación. In: La Manzana como Idea de Ciudad. Elementos teóricos y propuestas para Buenos Aires. III SIAC. Barcelona: 2C ediciones, 1980.

GRUMBACH, Antoine. I fratelli Krier/The Krier Brothes. Lotus, n.11, 1976, p.64-71. 
GUEDES, Joaquim. Arquitectos sudamericanos, 1985: problemas, preocupaciones, perspectivas y responsabilidades. In: Summa, Buenos Aires: Ediciones Summa, 212, maio 1985.

. “Arquitetura é construção” In: AU. São Paulo: Pini, n. 48, jun/jul 1993, p.25.

GUTIÉRREZ, Ramón. Intervención del Arq. Ramón Gutiérrez en la inauguración del III Encuentro de Arquitectura Latinoamericana. In: III Encuentro de Arquitectura Latinoamericana. III, Anais... Buenos Aires: CAPBA D III, 1988, p.2.

. Relatoría General del IV Encuentro de Arquitectura Latinoamericana /México. "La Trinidad", Tlaxcala. In: IV Encuentro de Arquitectura Latinoamericana. Conclusiones. IV, Anais... México: Universidad Autónoma Metropolitana, 1991.

. Los centros históricos de América Latina. Un desafío a la creatividad. In: IV Encuentro de Arquitectura Latinoamericana/ México. "La Trindad", Tlaxcala. México: Universidad Autónoma Metropolitana, 1989.

, Testimonio y Conclusiones. In: Summa, Buenos Aires: Ediciones Summa, 265, set 1989, p 58-59.

Identidad en la Arquitectura Latinoamericana. In: Summa. Buenos Aires: Ediciones Summa, no 224, maio de 1986.

. Arquitectura y Urbanismo en Iberoamérica. Madrid: Cátedra, 1983.

"Arquitectura Latinoaméricana: haciendo caminho al andar" In: GUTIERREZ (org.) Arquitectura Latinoamericana en el siglo XX. Madrid: Lunwerg Editores, 1998.

Seminarios de arquitectura latino-americana. Uma experiencia de reflexión (1985-2009) In: GUTIÉRREZ, R.; MÉNDEZ, P. (org). Seminario de Arquitetura Latinoamericana (SAL). Haciendo el Camino al andar 1985-2011. Buenos Aires: CEDODAL, 2011.

Una aproximación a la arquitectura ibero-americana. In: ARS. Santiago de Chile: CEDLA, n.10, 1989, p.7-9.

. Política fundacional y ampliación de fronteras. In: 2c. Barcelona: Grupo 2c, n.19, nov. 1981, p.9-20.

. Arquitetura latino-americana. Textos para reflexão e polêmica. São Paulo: Nobel, 1989.

GUTIÉRREZ, Ramón (org). Architettura e Società. L'América Latina nel XX secolo. Milão: Jaca Book, 1996.

Centros históricos : América Latina. Coleção SomoSur, Bogotá: Escala. 1990.

GUTIÉRREZ , Ramón et al (org). Arquitectura Latinoamericana. Pensamiento y Propuesta. México: UAM/Unidad de Xochimilco. 1991.

GUTIÉRREZ, R.; MÉNDEZ, P. (org). Seminario de Arquitetura Latinoamericana (SAL). Haciendo el Camino al andar 1985-2011. Buenos Aires: CEDODAL, 2011. 
GUTIERREZ, Ramón; TARTARINI, Jorge; STAGNO, Bruno. Congressos Panamericanos de Arquitectos, 1920-2000. Aportes para su história. Buenos Aires: CEDODAL e FPAA, 2007.

HARTLYN, J. A democracia na América Latina após 1930. BETHELL (org) História da América Latina. América Latina após 1930: Estado e Política. São Paulo: Edusp, 2009, p.127-197.

HARVEY, David. Condição Pós-Moderna. São Paulo: Ed. Loyola, 1992.

HEALY, Derry. Los arquitectos deben perder el tiempo. In: ARS, Santiago: CEDLA, n. 7, nov 1986, p.26-30.

HEIDEGGER, M. Habitar, contruir, pensar. Trad. Schuback. 1951. Disponível em: http://www.prourb.fau.ufrj.br/jkos/p2/heidegger_construir,\%20habitar,\%20pens ar.pdf. Acesso em: 10/06/2012.

HIGGOTT, Andrew. Mediating Modernism. Architectural cultures in Britain. Nova York: Routledge. 2007.

HUET, Bernard, Anachroniques d'architecture. Bruxelles : Editions des Archives d'architecture moderne, 1981.

IGLESIA, Rafael, La construcción de la ciudad latinoamericana. In: IV Encuentro de Arquitectura Latinoamericana/ México. "La Trindad", Tlaxcala. México: Universidad Autónoma Metropolitana, 1989.

IGLESIS, Jorge. La VIII Bienal de Arquitectura. In: CA. Santiago de Chile: Colegio de Arquitectos, n.65, jul/ago/set 1991, p.15.

IRIGOYEN, Adriana. Encuentro en Tlaxcala o como los arquitectos latinoamericanos consolidan sus lazos de amistad, compromiso y solidaridad In: Summa, Buenos Aires: Ediciones Summa, 265, set 1989, p 54-55.

. V SAL, Santiago, Chile Passado, Presente e Futuro. In: AU. São Paulo: Pini, n.39, dez/jan 1992, p.20-21.

. Cortar por lo sano. In: Summa+. Buenos Aires: Donn S. A., n.4, dez 1993, p.1819.

JANNIERE, H., Politiques éditoriales et architecture " moderne ": L'émergence de nouvelles revues en France et en Italie (1923-1939). Paris, ed. Arguments, 2002.

JAJAMOVICH, Guilhermo, Arquitectos proyectistas y transición democrática. El concurso de las 20 ideas. In: Anales del IAA. Buenos Aires: FADU/UBA, n.41, 2011, p.203212.

. Rosario y sus vínculos con el debate internacional: un análisis del Parque España (1979-1993). In: Arquitextos, n. 115.06, dez 2009 <http://www.vitruvius.com.br/revistas/read/arquitextos/10.115/7/es> acessado em: 12 out 2011. 
JARAMILLO JIMENEZ, José Oscar. Intervención del Ing. José Oscar Jaramillo en la inauguración del III Encuentro de Arquitectura Latinoamericana. In: III Encuentro de Arquitectura Latinoamericana. III, Anais...Buenos Aires: CAPBA D III, 1988, p.1.

JARZOMBEK, Mark. The Cunning of Architecture's Reason. Footprint Delf School of Design Journal, Delft : TU Delft - Techne Press, outono 2007, pp. 31-46.

JENCKS, Charles. The Story of Post-Modernism. West Sussex : John Wiley \& Sons Ltd., 2011.

. The Language of Post-Modern Arquitecture. New Haven : Yale University Press, 1978.

JENCKS, Charles et al. Presents of the past - revisiting the 1980 Venice Biennale. In: Architectural Design. Londres: Architectural Design, vol. 52, no. 1/2, 1982, p. $2-$ 24.

JORDAN, Ricardo. Sección encuentro. In: CA. Santiago de Chile: Colegio de Arquitectos, n. 48, jun 1987, p.16-23.

KOPP, Anatole. Quand le Moderne n'était pas un style, mais une cause. Paris : ENSBA, 1988.

KOOLHAAS, R. Delírio de Nueva York. Barcelona: Gustavo Gili, 2004.

KRIER, Léon. La Reconstruction de la ville. In : KRIER (org) Rational Architecture :The Reconstruction of the European city, Bruxelles, A.A.M, 1978, p.34-35. . The City Within the City. A+U, Tokyo, Special Issue, nov 1977, p.62-152. . Carta a Cristián Boza. In: ARS. Santiago: CEDLA, n.1, jul. 1978, p.95.

KRIER, Léon; SOLÁ-MORALES, Manuel. Ensache Cerdá. A project and a debate. In: Lotus, Milão: Electra, n.19, jun 1978, p.33-41.

KRIER (org) Rational Architecture :The Reconstruction of the European city, Bruxelles, A.A.M, 1978.

KRIER, Rob. Urban Space. New York : Rizzoli.1979.

KSIAZEK, Sarah. Architectural Culture in the Fifties: Louis Kahn and the National Assembly Complex in Dhaka. In: The Journal of the Society of Architectural Historians, Vol. 52, No. 4, Dec., 1993, p. 416-435

LABBÉ A., Ernesto; MIRANDA R., Sergio; et al. Remodelación de San Borja. Santiago: MINVU/CORMU. 197-?.

LEVI, G. Sobre a Micro-história. In : BURKE (org.) A Escrita da História. Novas perspectivas. São Paulo: Ed. UNESP, 1992, p.133-161.

LEVI-STRAUSS, Claude. La pensée sauvage. Paris: Plon, 1962. 
LIERNUR, Jorge F. Portales del Laberinto. Comentarios sobre la Arquitectura em Chile, 1977-2007. In: LIERNUR (org). Portales del Laberinto. Arquitectura y Ciudad en Chile, 1977-2009. Santiago de Chile: Universidad Andrés Bello, 2009. P. 1-58.

. Arquitectura en la Argentina del siglo XX : la construcción de la modernidad. Buenos Aires : Fondo Nacional de las Artes, 2001.

. Requién para la plaza y la fábrica: notas sobre la metrópolis contemporánea en América Latina. In: BOZA et al. (org). Seminario de Arquitectura Latinoamericana. Nuestro Espacio Urbano: Propuestas Morfológicas. V, 1991. Santiago do Chile. Anais... Santiago do Chile: s.n. 1991. . Buenos Aires e seu rio: de porto de barro ao bairro globalizado. Arquitextos, São Paulo, 54.03, nov. 2004. <http://www.vitruvius.com.br/revistas/read/ arquitextos/05.054/526/pt> Acesso em: 10 de jun. 2012.

LIERNUR, J. F. (org). Puerto Madero Waterfront. Munique: Prestal Verlag, 2007.

LIPSTADT, Hélène. Responding to the Postmodern by Reconceptualizing the Modern: "Architectural Culture, 1943-1968". In: Assemblage, No. 39, Aug., 1999, p. 118123.

LIRA, Pedro. Erradicación de campamentos. Um éxodo com efectos regressivos. In: ARS, Santiago: CEDLA, n. 7, nov 1986, p.31-32.

LOVE, Joseph. Ideias e Ideologias Econômicas na América Latina, c.1930-c.1990. In: BETHELL (org.) A América Latina após 1930: Ideiais, Cultura e Sociedade. São Paulo: Edusp, 2011, p.161-242.

LUCAN, Jacques. Quatre points de méthode. In: Les Cahiers de la recherche architecturale et urbaine. Paris : Éditions du Patrimoine, 2002, p.179-181.

. Architecture em France (1940-2000). Paris : Le Moniteur, 2001.

LYNCH, Kevin. A Imagem da Cidade. Edições 70, Lisboa, Portugal, 1982.

MALLGRAVE, H. F.; GOODMAN, D. An Introduction to Architectural Theory. 1968 to the Present. New York: Wiley-Blackwell, 2011.

MARQUES, Sérgio. A Revisão do Movimento Moderno? A arquitetura no Rio Grande do Sul nos anos 80. Porto Alegre: Editora Ritter dos Reis, 2002.

MARQUEZ, Jaime. El Camino de lo Propio. In: CA, Santiago do Chile: Colegio de Arquitectos, n. 65, jul./ago./set 1991, p.16.

. Oriol Bohigas. . In: CA. Santiago de Chile: Colegio de Arquitectos, n.25, dez 1979, p. 66.

MARQUEZ, Jaime; RODRIGUEZ, León. Salvador Tarragó. . In: CA. Santiago de Chile: Colegio de Arquitectos, n.25, dez 1979, p. 63.

MARTÍNEZ, Gutenberg. El crecimiento de Santiago. ¿Problema técnico o político? In: ARS, Santiago: CEDLA, n. 7, nov 1986, p.38-40. 
MARTÍNEZ DE SAN VICENTE, Isabel; FERNÁNDEZ LUCO, Manuel .Periferia y proyectación de la ciudad. In: ARS. Santiago de Chile: CEDLA, n.7, nov. 1986, p.42-47.

MEDEIROS, Gustavo. Nuestra arquitectura reciente: 1982 a 1992. In: Immuebles. Caracas: JMBC Grupo Editor Immobiliário, n.9, mar 1993, p.70-71.

MONEO, Rafael. Inquietação teórica e estratégia projetual na obra de oito arquitetos contemporâneos. São Paulo: Cosac Naify, 2008.

. De la tipologia. In: CA. Santiago de Chile: Colegio de Arquitectos, n.35, ago 1983, p. 18-27.

MONTANER, Josep Maria. Arquitetura e crítica. Barcelona: Gustavo Gili, 2007.

MONTANER, Josep Maria. Después Del movimiento moderno: arquitectura de la segunda mitad del siglo XX. Barcelona: Gustavo Gili, 1993.

MONTANER, Josep Maria. La modernidad superada. Arquitectura, arte y pensamiento Del siglo XX. Barcelona: Editoial Gustavo Gili, 1997.

MONTES, Fernando. Santiago Poniente: en torno a su remodelación. In: CEDLA. Santiago: CEDLA, ago. de 1977, 24-25.

. Modernidad e Inibición. In: ARS. Santiago: CEDLA, n.1, jul. 1978, p.67-69.

. Hacia una arquitectura convencional. . In: ARS. Santiago: CEDLA, n.3, jul. 1979, p.4-9;

157 Departamentos, Ciudad Nueva de Cergy-Pontoise, Paris, 1980. In: ARS. Santiago: CEDLA, n.4, ago 1981, p.85-87.

. Santiago no es una ciudad fácil. In: ARS. Santiago: CEDLA, n.5, jul. 1984, p.59-61

. Charlas. In: CA. Santiago de Chile: Colegio de Arquitectos, n.31, dez 1981, p. 39.

MORANDÉ, Pedro. La cultura latinoamericana ante los desafíos de la modernización. In: Summa, Buenos Aires: Ediciones Summa, 212, maio 1985.

MORENO, Manuel; ELIASH, Humberto. Arquitectura y Modernidad en Chile/1925-1965. Una Realidad Múltiple. Santiago: Ed. Universidad Católica de Chile. 1989. . Una casa taller para Le Corbusier. In: ARS, Santiago de Chile: CEDLA, n. 8/9, set. 1987, p.77-94.

MORENO, Manuel. Identidad y Arquitectura: un tema recurrente en el sur de América. In: Summa. Buenos Aires: Ed. Summa. N.286/287, jun./jul. 1991, p.103-105.

MORALES, Carlos. Reflexiones para Iniciar una Discusión. In: CA. Santiago de Chile: Colegio de Arquitectos, n. 65, jul/ago/set 1991, p.29-31

MOSCATO, Jorge. Arquitectura de la Periferia. In: III Encuentro de Arquitectura Latinoamericana. III, Anais...Buenos Aires: CAPBA D III, 1988, p.82-84.

. El Movimiento de arquitectura Latinoamericana para los años 90. In: CA, Santiago do Chile: Colegio de Arquitectos, n. 65, jul./ago./set 1991, p.26-28. 
Gli Architetti in America Latina. In: GUTIÉRREZ, Ramón (org). Architettura e Società. L'América Latina nel XX secolo. Milão: Jaca Book, 1996.

MOSCATO, J.; SCHERE, R. Hacer Arquitectura en Argentina. In: IV Encuentro de Arquitectura Latinoamericana/ México. "La Trindad", Tlaxcala. IV, Anais...México: Universidad Autónoma Metropolitana, 1989.

Arquitectura e ideología. México: Menhir Libros. 2000.

MOSQUERA MENDEZ, Lala, Editorial. In: Summa, Buenos Aires: Ediciones Summa, n. 180, out. 1982, p.15.

, Editorial. In: Summa, Buenos Aires: Ediciones Summa, n. 182, dez. 1982, p.13.

,Editorial. In: Summa, Buenos Aires: Ediciones Summa, n. 186, abril 1983, p.19.

, Editorial. In: Summa, Buenos Aires: Ediciones Summa, n. 198, abril 1984, p.19.

, Editorial. In: Summa, Buenos Aires: Ediciones Summa, n. 204, set 1984, p.22.

Editorial. In: Summa, Buenos Aires: Ediciones Summa, n. 218, outubro de 1985, p. 17.

MUMFORD, Eric. The CIAM discourse on urbanism, 1928-1960. Cambridge: MIT Press, 2000.

MUNIZAGA, G.; ROSAS, J. Diseño Urbano: tipologias. In: ARS. Santiago: CEDLA, n.2, dez. 1978, p.79-86.

MURTINHO, Pedro. Conceptos teóricos en Aldo Rossi. In: CEDLA. Santiago: CEDLA, ago. de 1977, p. 8-11.

. Nuestra Participación. In: Arquitectura en Chile. Buenos Aires: CAYC, 1984, p.23.

MURTINHO, Pedro; ELIASH, Humberto. Taller Murtinho-Eliash. Santiago, Chile: Pontificia Universidad Católica de Chile/Escuela de Arquitectura, 1981.

MURTINHO \& ASOC.; CRISTIÁN FERNÁNDEZ \& ASOC; FERNÁNDEZ, Manuel. Proposición Normativa Urbana - Barrio Santiago Poniente. In: Seminario de Arquitectura Latinoamericana. Nuestro Espacio Urbano: Propuestas Morfológicas. V, Santiago do Chile. Anais... Santiago do Chile : s.n. 1991.

NARAMONTO, E. Nuno Portas. In: CA. Santiago de Chile: Colegio de Arquitectos, n.25, dez 1979, p. 61.

NASELLI, César. La tipología como instrumento proyectual. In: Summarios. Buenos Aires: Ed. Summa, fev/mar 1985, p.22-34.

La forma urbana de nuestras ciudades. In: BOZA et al. (org). Seminario de Arquitectura Latinoamericana. Nuestro Espacio Urbano: Propuestas Morfológicas. V, 1991. Santiago do Chile. Anais... Santiago do Chile: s.n. 1991. 
NEGRÓN, Marco et al (org). Edición Especial del Sexto SAL: Arquitectura LatinoAmericana de los años 80/90. In: Immuebles. Caracas: JMBC Grupo Editor Immobiliário, n.9, mar 1993, p.65-88.

NESBITT, Kate. Uma nova Agenda para a Arquitetura. Antologia Teórica 1965-1995. São Paulo: Cosac Naify, 2006.

NIÑO, Willian. La escuela de Caracas. Reflexiones breve para una primera aproximación a la arquitectura contemporánea en Venezuela. In: Immuebles. Caracas: JMBC Grupo Editor Immobiliário, n.9, mar 1993, p.86-87.

NOVICK, Alicia. Intercambios Internacionales en construcción de la ciudade. Apuntes para un estado del Arte. In: SALGADO e BERTONI (org.) Da construção do Território ao Planejamento das Cidades. São Calos: Rima, 2010, p. 81-89.

NOVOA, Maria Teresa. Willian Niño Araque. In: Revista CAV. Caracas: Colegio de Arquitectos de Venezuela, n.57, jun. 2011, p.22-29.

OEA. Norma de Quito. Quito: s.n. 1967.

OCKMAN, Joan (org.) Architecture Culture 1943-1968. A Documentary Anthology. New York: Rizzoli, 2007.

ORDEIG CORSINI, José María. Diseño Urbano y pensiamento contemporáneo. Barcelona: Instituto Monsa de Ediciones, 2004.

OLIVEIRA, Orlandina de. O crescimento urbano e a estrutura urbana na América Latina, 1930-1990. In: BETHELL, L. (org.) A América Latina após 1930. São Paulo: Edusp, 2005.

OYARZÚN K., Armando. Arquitectos chilenos extramuros: Dos Proyectos de René Davids. In: ARS, Santiago de Chile: CEDLA, n.4, ago 1981, p.80-84.

PALLARES-BURKE, Maria Lúcia. The Spectator, ou as metamorfoses do periódico: um estudo em tradução cultural. In: BURKE e PO-CHIA HSIA (org.) Tradução Cultural nos primórdios da Europa Moderna. São Paulo: Ed. UNESP, 2009, p. 163-181.

PALMER TRIAS, Montserrat. Urbanismo, Ideologías y Dependencia. In: CA. Santiago: Colegio de Arquitectos. dec. 1978, p.III.

. La ciudad jardín como modelo de crecimiento urbano: Santiago 1935-1960. El caso de la comuna de Providencia. Santiago: Pontificia Universidad Católica de Chile, 1985.

PANERAl et al. Analyse Urbaine. Paris: Éditions Paranthèses, 1999.

PANERAI, Philippe; MANGIN, David. Projet Urbain. Paris: Ed. Parenthèses, 2005.

PANTIN, Isabelle. O papel das traduções culturais nos intercâmbios científicos nos séculos XVI e XVII. In: BURKE e PO-CHIA HSIA (org.) Tradução Cultural nos primórdios da Europa Moderna. São paulo: Ed. UNESP, 2009, p. 185-202. 
PAULA, Alberto. Los centros históricos y las ciudades contemporáneas: el Coloquio de Quito, 1977. In: Summa. Buenos Aires: Ed. Summa, n. 114, jul. 1977, p.86-89.

PAVEZ REYES, María Isabel. En la ruta de Juan Parrochia Beguin - Premio Nacional de Urbanismo Chile 1996. Santiago: Facultad de Arquitectura y Urbanismo, Universidad de Chile, 2003.

PAZ, Octavio. América Latina y la democracia moderna. La tradición antimoderna. In: Summa, Buenos Aires: Ediciones Summa, 212, maio 1985.

PEDEMONTE, Max. Venezuela Caracas. Una Ciudad Recobrada. In: CA. Santiago de Chile: Colegio de Arquitectos, n. 58, out/dez 1989, p.36-43.

. Caracas: la ciudad y el metro. In: PROA. Bogotá: Ed. Proa, n.422, jun 1995, p.1622.

PAVAN, Vicenzo; KRIER, Léon. Léon Krier. La ricostruzione della Città Europea, Veneza: Cluvea, 1980

PEREIRA, Renata Baesso. Arquitetura, imitação e tipo em Quatremère de Quincy. Tese de doutorado. Faculdade de Arquitetura e Urbanismo, Universidade de São Paulo, São Paulo, 2008.

PEREIRA COSTA, S. A. Brazilain Urban Morphology. In: Urban morphology, Birmingham, v. 10, n. 02, pp. 142-144, 2006.

PEREZ DE ARCE, Rodrigo. Urban Transformations \& the Architecture of Additions. In: Architectural Design: AD PROFILE 12. Londres: Architectural Design, jan.1978, p.237-266.

. Chandigarh y Dacca. La reurbanización de la ciudad moderna. In: ARS. Santiago: CEDLA, n.1, jul. 1978, p.53-61.

. "Estudio histórico de las transformaciones urbanas" y "Propuestas em Chandigarh, Dacca, Paris, Londres y Runcorn". . In: CA. Santiago de Chile: Colegio de Arquitectos, n.25, dez 1979, p. 64.

PÉREZ OYARZUN, Fernando. Arquitectura, cultura y práctica profesional en Chile 19301980. In: LIERNUR (org). Portales del Laberinto. Arquitectura y Ciudad en Chile, 1977-2009. Santiago de Chile: Universidad Andrés Bello, 2009. P.59-120.

. El futuro del pasado - sección encuentro. In: CA. Santiago de Chile: Colegio de Arquitectos, n.35, ago 1983, p. 110-131.

PETRINA, Alberto, 1993. Balance del VI Seminario de Arquitectura Latinoamericana. In: Las Últimas Arquitecturas. Encuentro Reflexión y Crítica. Ponencias y Debates. Buenos Aires: s.n., 1993.

. Introducción a una continuidad. In: BOZA et al. (org). Seminario de Arquitectura Latinoamericana. Nuestro Espacio Urbano: Propuestas Morfológicas. V, 1991. Santiago do Chile. Anais... Santiago do Chile: s.n. 1991. 
- Genealogía razonada de la actual arquitectura argentina In: Immuebles.

Caracas: JMBC Grupo Editor Immobiliário, n.9, mar 1993, p.68-69.

. El Racionalismo Poético de Josef Paul Kleihues. In: Summa. Buenos Aires: Ed. Summa, n.202, jul 1984, p. 36-41.

PINTO, John. Histoire de l'architecture, une discipline des sciences humaines. Les enjeux du rapprochement entre histoiriens de l'art et architectes. In : Les Cahiers de la recherche architecturale et urbaine. Paris : Éditions du Patrimoine, 2002, p.161168.

PICON, Antoine. Architecture, sciences et techniques. Problematiques et méthodes. In : Les Cahiers de la recherche architecturale et urbaine. Paris: Éditions du Patrimoine, 2002, p.151-160.

PORTAS, Nuno. A arquitetura sob os regimes militares na Argentina e Chile. In: Projeto. São Paulo: Projeto, n.15, set/out 1979, p.8.

. A Revolução portuguesa e a política de habitação e urbanismo. In: Projeto. São Paulo: Projeto, n.13, jun/jul 1979, p.5-6.

PORTOGHESI, Paolo. Depois da Arquitetura Moderna. São Paulo: Martins Fontes, 2002.

POSANI, Juan Pedro. A pesar de todo... Economia HOY. Caracas, Arquitectura HOY, p.2, 2 de mai. de 1992.

PRINS, G. História Oral. In : BURGE (org.) A Escrita da História. Novas perspectivas. São Paulo: Ed. UNESP, 1992, p.163-198.

QUATREMÈRE DE QUINCY, A. C. "Type". Encyclopédie Methodique - Architecture. Liège: chez Panckoucke, Tome III, 1825, p. 543-545. Disponível em: <http://catalogue.bnf.fr/ark:/12148/bpt6k85720c >. Acessado em: 02 de outubro de 2011.

RAJA, Raffaele. Arquitetura Pós-industrial. São Paulo: Perspectiva, 2004.

RAMÍREZ NIETO, Jorge. El pensamiento a través de los Seminarios de Arquitectura latinoamericana. In: XI Seminario de Arquitectura Latinoamericana. Oaxtepec (México), 2005.

. Refexiones en torno de los Seminarios de Arquitectura Latinoamericana. In: GUTIÉRREZ, R.; MÉNDEZ, P. (org) Seminarios de Arquitectura Latinoamericana (SAL). Haciendo camino al andar. Buenos Aires: CEDODAL, 2011, p.27-44.

. Los monumentos y la ciudad latinoamericana. In: IV Encuentro de Arquitectura Latinoamericana/ México. "La Trindad”, Tlaxcala. IV, Anais... México: Universidad Autónoma Metropolitana, 1989.

RAMÓN, Armando de. Santiago de Chile (1541-1991). História de una Sociedad Urbana. Providencia: Editorial Sudamérica, 2000. 
RANGEL LOPEZ. Rafael. El pensamiento arquitectónico latinoamericano. La polémica de los ochenta a través de los encuentros internacionales. In:Cuadernos de Arquitectura Latinoamericana. Universidad Autónoma Metropolitana/ Universidad Autónoma de Puebla/Universidad Autónoma MetropolitanaAzcapotzalco, n.2, dez. 1990.

Rescatar la identidad Barrial de la Ciudad. In: BOZA et al. (org). Seminario de Arquitectura Latinoamericana. Nuestro Espacio Urbano: Propuestas Morfológicas. V, 1991. Santiago do Chile. Anais... Santiago do Chile: s.n. 1991.

RICOEUR, Paul. Civilization universelle et cultures nacionales. In: RICOEUR, Paul. Histoire et Verité. Paris: Seuil, 2001, p.286-299.

RODRIGUEZ, León. Preambulo Histórico. In: CA, n. 58, Santiago do Chile: Colegio de Arquitectos, out-dez 1989, p. 52-53.

ROSAS VERA, José. Hispanoamérica : ¿Periferia física o... periferia cultural? In: ARS, Santiago de Chile: CEDLA, n.6, set. 1985, p.9-14.

ROSSI, Aldo. Sección de Arquitectura de la XV Trienal. 2C, n.2, pp.12-15, 1975.

Para una Arquitectura de Tendencia. Escritos 1956-1972. Barcelona: GG, 1977a.

. Introducción. In: TARRAGO e BERAMENDI (org.). Proyecto y Ciudad Histórica. I Seminario Internacional de Arquitectura de Compostela. Santiago de compostela: COAG, 1977b.

. Introducción. In: BONFANTI, E. et al. Arquitectura racional. Madrid Alianza Editorial pp.11-22, 1979.

. L’Architecture de la Ville. Trad. Françoise Brun. Paris: InFolio, 2001.

. Autobiografía Científica. Barcelona: Gustavo Gili, 1984.

Seminario dictado en diciembre de 1978. In: DÍAZ, SOLSONA, et. al. (org.). La Escuelita. 5 años de enseñanza de alternativa de arquitectura en la Argentina, 1976/1981. Buenos Aires: Espacio Editora, 1981.

. Entrevista a Marisa Barda. In: Arquitetura e Urbanismo. São Paulo: Editora Pini, n.10, fev./mar. 1987, p.90-97.

- The Analogus City: panel. In: Lotus International. Milão: Indutrie Grafiche Editorial S.p.A., n. 13, 1976, p.4-7

ROVATI, João Farias. Quem debate o projeto urbano no Brasil? In: Machado (org.) Sobre Urbanismo. Rio de Janeiro: Viana \& Viana: Ed. Prourb, 2006.

ROWE, Colin; KOETTER Fred. Collage City. Infolio editions, Paris, 2002

ROWE, Colin. Prólogo a la edición inglesa. In: KRIER, Rob. El Espacio Urbano. Barcelona: Gustavo Gili, 1981. 
SAINZ GUTIÉRREZ, Victoriano. El proyecto urbano en España. Génesis y desarrollo de un urbanismo de los arquitectos. Sevilha: Universidad de Sevilla y Consejería de Obras Públicas y Transportes, 2006.

SALGUEIRO, H. A. Apresentação. In: LEPETIT, B. Por uma nova história urbana. São Paulo: EDUSP, 2001.

SALMONA, Rogelio, Una Reflexión como Arquitecto Latinoamericano. In: IV Encuentro de Arquitectura Latinoamericana. Conclusiones. IV, Anais...México: Universidad Autónoma Metropolitana, 1991

Clausura al III Encuentro de Arquitectura Latinoamericana. In: III Encuentro de Arquitectura Latinoamericana. III, Anais...Buenos Aires: CAPBA D III, 1988, p.111.

SALMONA, R. Notas II. Entrevista a Salmona. In: A/Ambiente. Buenos Aires: CEPA, n. 36, p.32-36, março 1983.

SAMUELS, I. Urban Morfology in design. Research Note 19, Oxford: Joint Centre for Urban Design, 1985.

SAN MARTIN, Eduardo. Ponencia sobre la Periferia. In: III Encuentro de Arquitectura Latinoamericana. III, Anais...Buenos Aires: CAPBA D III, 1988, p.93-95.

- Hacia una Arquitectura Apropiada para la Periferia de Santiago. Tres proyectos, tres propuestas. In: IV Encuentro de Arquitectura Latinoamericana/ México. "La Trindad", Tlaxcala. IV, Anais...México: Universidad Autónoma Metropolitana, 1989.

La Arquitectura de la Periferia de Santiago: Experiencias y propuestas. Santiago: Editorial Andrés Bello. 1992.

. Arquitectura y Crítica: Un Encuentro Necesario. In: ARS. Santiago do Chile, n.11, jul 1989, p.5.

- Presentación. Arquitetura y Crítica. In: CA. Santiago de Chile: Colegio de Arquitectos, n. 57, jul/ago/set 1989.

. Arquitectura latino-americana: Los desafios para la década de los noventa In: CA. Santiago de Chile: Colegio de Arquitectos, n. 65, jul/ago/set 1991, p.18-21.

SAN MARTÍN, E., ELIASH, H. L'abitazione sociale e la costruzione della periferia urbana in America Latina. In: GUTIÉRREZ, Ramón (org). Architettura e Società. L'América Latina nel XX secolo. Milão: Jaca Book, 1996, p.53-64.

SANTOS, Carlos Nelson Ferreira. Las ciudades enormes, o como aprendí a gustar de ellas con el doctor Strangelove. In: Summa. Buenos Aires: Ed. Summa, n. 254, set 1983, p. 41-45.

SARTOGO, P. et al., Roma Interrotta. Roma: Incontri Internazionali D’Arte, 1979. 
SATO, Albero. Caos y Utopia em Caracas Moderna. In: BOZA et al. (org). Seminario de Arquitectura Latinoamericana. Nuestro Espacio Urbano: Propuestas Morfológicas. V, 1991. Santiago do Chile. Anais... Santiago do Chile: s.n. 1991.

SCHWARZER, Mitchell. History and Theory in architectural periodicals. Assembling Oppositions. In: Journal of the Society of Architectural Historians, v. 58, n.3, Architectural History, set., 1999, p.342-348.

SECCHI, B. Primeira Lição de Urbanismo. São Paulo: Perspectiva, 2006.

SEGAWA, Hugo. Arquiteturas no Brasil 1900-1990. São Paulo : EDUSP, 1998.

. Arquitectura Latinoamericana Contemporanea. Colin Ross, 2005.

. A pobreza Latino-americana. In: Projeto. São Paulo: Projeto, n. 148, dez 1991, p. 20.

. Ascensoristas do 6o SAL. In: Projeto. São Paulo: Projeto, n. 166, ago. 1993, p.104.

SPINADEL, Laura; BLAZICA, Claudio. 20 ideas para Buenos Aires - Summarios. Buenos Aires: Ed. Summa, n.119, nov 1987.

20 ideas para Buenos Aires II - Summarios. Buenos Aires: Ed. Summa, n.120, dez 1987.

SILVESTRI, Graciela. Aparencia y Verdad. Reflexiones sobre obras y documentos de arquitectura producidos durante la dictadura militar en la Argentina. In: Block. Buenos Aires: Instituto Torcuato di Tella. n.5, dec. 2000, p.38-50.

SITTE, C. A Construção das Cidades segundo seus Princípios Artísticos. São Paulo: editora Ática, 1992.

SOLÀ-MORALES, Manuel. Las formas de crecimiento urbano. Barcelona: Ediciones UPC, 1997.

. Préface. In : PANERAl et al. Formes Urbaines : de l'îlot à la Barre. Paris: Éditions Paranthèses, 2001.

SOLSONA, Justo; CIPRIANI, Alejandro. Justo Solsona : entrevistas, apuntes para una autobiografía. Buenos Aires: Ed. Infinito, 1997.

SOUZA, G. B. Re-dire et dé-dire: le nouvel urbanisme en Europe. Dissertação. Université de Paris VIII, Paris, 2004.

De los desdoblamientos de la Unidad de Vecindad. El espacio comunitário en la Ciudad Policéntrica de Léon Krier. in: Revista Bitácora Urbano-Territorial (Bogotá), v. 10, pp. 8-16, 2006.

STRABUCCHI, Wren. El Silencio Latinoamericano. A propósito de una Mesa Redonda en la IV Bienal de Chile (1983). In: ARS. Santiago de Chile: CEDLA, n.10, p41-43.

SUAREZ, Isidro. Notas sobre el encuentro de Caburga. In: ARS. Santiago: CEDLA, n.5, jul. 1984, p.137-138. 
SZAMBIEN, Werner. Symétrie, goût, caractère. Théorie et terminologie de l'architecture à l'âge classique 1550-1800. Paris : Picard, 1986.

TAFURI, M. Teorias e história da arquitetura. Lisboa: Presença. 1979.

TARRAGÓ, Salvador. Editorial. In: 2c. Barcelona: Grupo 2c, n.19, nov. 1981, p.3

TELLEZ, Germán. Manual Práctico de Latinoamericanidad. In: ARS. Santiago de Chile: CEDLA, n.10, p.74.

TIRONI, Eugenio. Autoritarismo, modernización y marginalidade: el caso de Chile 1973 1989. Santiago: Sur, 1990.

TOBIAS, José Antônio. História das Idéias Estéticas no Brasil. São Paulo: Editorial Grijalbo, 1967

TOCA, Antonio. Más allá del postmoderno, Ediciones G. Pili, 1986. . Una arquitectuta alternativa para latinoamérica. In: ARS. Santiago de Chile: CEDLA, n.10, p.24-28.

Desafios para una Nueva Arquitectura en Latinoamerica. In: CA. Santiago de Chile: Colegio de Arquitectos, n. 65, jul/ago/set 1991, p.22-25

TOCA, Antonio (org). Nueva Arquitectura en América Latina: Presente y Futuro. México: GG, 1990.

TUKIENICZ, Benamy (org). Desenho Urbano I. Anais do I Seminario sobre Desenho Urbano no Brasil. São Paulo: Ed. Projeto, 1984a.

Desenho Urbano II. Anais do I Seminario sobre Desenho Urbano no Brasil. São Paulo: Ed. Projeto, 1984b.

. Desenho Urbano III. Anais do I Seminario sobre Desenho Urbano no Brasil. São Paulo: Ed. Projeto, 1984c.

TUJILLO JARAMILLO, Sérgio. "La arquitectura del ladrillo en Colombia" In: III Encuentro de Arquitectura Latinoamericana. III, Anais...Buenos Aires: CAPBA D III, 1988, p.66-67.

TURNER, John F. C. Vivienda, todo el poder para los usuarios : hacia la economía en la construcción del entorno. Madrid Blume, 1977.

UNGERS, O. M., KOOLHAAS, M., KOLLHOFF, H., OVASKA, A. A., RIEMANN, P. Cities within the city. in: Lotus International. L'isolato urbano /The urban block, № 19, 1978, p.82-97.

UNGERS, O. M. Architecture come theme/ Die Thematisierung der Architektur. Paris: Electra Moniteur, 1983.

VALENZUELA, Patricia. Estudio tipológico de la manzana. Bloque de viviendas en Santiago de Chile. In: BOZA et al. (org). Seminario de Arquitectura Latinoamericana. Nuestro Espacio Urbano: Propuestas Morfológicas. V, 1991. Santiago do Chile. Anais... Santiago do Chile: s.n. 1991. 
VERGARA, Francisco. Viviendas para Santiago. Experiencias del Taller en la Universidad Católica. : ARS. Santiago de Chile: CEDLA, n.7, nov. 1986, p.77-85.

VIDLER, Antony. Histories of the Immediate Present. Inventing Architectural Modernism. Cambridge: MIT Press, 2008.

VILLÀ, Joan, Projetar a Periferia. In: AU. São Paulo: Pini, n.56, out/nov 1994, p.116-117.

VILLAR-CORDOVA, Pedro. En torno de los Cascos Históricos: una aproximación morfológica. In: BOZA et al. (org). Seminario de Arquitectura Latinoamericana. Nuestro Espacio Urbano: Propuestas Morfológicas. V, 1991. Santiago do Chile. Anais... Santiago do Chile: s.n. 1991.

WAISMAN, Marina. La estructura histórica del entorno. Buenos Aires: Ediciones Nueva Visión, 1972.

. El Interior de la Historia. Bogotá: Escala, 1990.

. La arquitectura Decentrada. Bogotá: Escala, 1995.

. Editorial. In: Summarios. Buenos Aires: Ed. Summa, n.22, ago. 1978, p.126-127.

- Reivindicación Mundial de la Crítica. In: CA. Santiago de Chile: Colegio de Arquitectos, n. 36, dez. 1983, p. 30-31.

. Primer Seminario de Arquitectura Latinoamericana. Un auspicioso comienzo. In:

Summa, Buenos Aires: Ediciones Summa, 217, set 1985, p.26-27

Alineación e integración en el traspaso de las ideologías. In: Summa, Buenos Aires: Ediciones Summa, 212, maio 1985, p.?

- Contribución de las disciplinas históricas y de preservación del patrimonio a la definición de una arquitectura regional. In: III Encuentro de Arquitectura Latinoamericana. III, Anais...Buenos Aires: CAPBA D III, 1988, p.7-8.

Breve Diccionario del Regionalista Comprometido. In: III Encuentro de Arquitectura Latinoamericana. III, Anais...Buenos Aires: CAPBA D III, 1988. p.8-10.

Un proyecto de Modernidad. In: Summarios. Buenos Aires: Ed. Summa, n.134, mar/abr 1990, p.18-26.

. La Recuperación de la Sociedad Urbana. La recuperación y renovación de la ciudad histórica. In: IV Encuentro de Arquitectura Latinoamericana/ México. "La Trindad", Tlaxcala. IV, Anais...México: Universidad Autónoma Metropolitana, 1989.

. Para una caracterización de la arquitectura latinoamericana. In: IV Encuentro de Arquitectura Latinoamericana. Conclusiones. III, Anais...México: Universidad Autónoma Metropolitana, 1991, p.27-32.

- Espacio público - Espacio privado. In: BOZA et al. (org). Seminario de Arquitectura Latinoamericana. Nuestro Espacio Urbano: Propuestas Morfológicas. V, 1991. Santiago do Chile. Anais... Santiago do Chile: s.n. 1991. 
. Autobiografía. IN: DANA. Buenos Aires: Instituto Argentino de Investigaciones en Historia de la Arquitectura. n 39/40, 1997, p.8-9.

. Volver a vivir. In: Summarios. Buenos Aires: Ediciones Summa, n.64, abr 1983, p.19-31.

WAISMAN, Marina ; NASELI, César. 10 Arquitectos Latinoamericanos. Sevilha : Junta de Andalucía, 1989.

WISSENBACH, V. Editorial. In: Projeto, São Paulo, n. 53, jul,1983, p.3.

WOLF, José. Ser (ou não ser) América Latina. In: AU. São Paulo: Pini, n. 62, out/nov 1995, p.77-78.

ZEIN, Ruth Verde; FERNANDEZ COX, Cristian. Regional Study Brazil. In: HERRLE, P. e SCHMITZ, S. Constructing Indentity in Contemporany Architecture. Case Studies from the South. Berlim: LIT VERLAG, 2009.

ZEIN, Ruth Verde. Patrimônio e presente na Bienal de Arquitetura do Chile. In: Projeto. São Paulo: Projeto, n. 71. jan. 1985, p.36-43.

. SAL I, II, III... um hábito salutar. In: Projeto. São Paulo: Projeto, n.100, jun, 1987, p.39-40.

. Revistas \& Revistas. In: Projeto. São Paulo: Projeto, no 190, out. 1995, p.90. . Las casas-parrón de Enrique Browne: en el espíritu de la época y del lugar. In:

Summa. Buenos Aires: Ed. Summa, n. 232, dez 1986, p.32.

\section{Anais, Cadernos de Resumos e Convocatórias e Programas de eventos}

BOZA et al. (org). Seminario de Arquitectura Latinoamericana. Nuestro Espacio Urbano: Propuestas Morfológicas. V, 1991. Santiago do Chile. Anais... Santiago do Chile: s.n. 1991.

BOZA, C.; FERNANDEZ COX, C. et al. Convocatoria Encuentro de Caburga. In: ARS. Santiago: CEDLA, n.5, jul. 1984, p.9-10.

BROWNE, Enrique; FERNANDEZ COX, Cristián; MURTINHO, Pedro. Convocatoria del V Seminario de Arquitectura Latinoamericana. Nuestro Espacio Urbano: Propuestas Morfológicas. In: Seminario de Arquitectura Latinoamericana. Nuestro Espacio Urbano: Propuestas Morfológicas. V, Santiago do Chile. Anais... Santiago do Chile : s.n. 1991.

PADRÓN, M. et al. Convocatoria del VI SAL: Aclaratoira de los temas. Caracas: s.n., 1992.

PADRÓN, Martín J et al. (org). Seminario de Arquitectura Latinoamericana. Nuestro arquitectura reciente: conceptos y realizaciones. VI, 1993. Caracas. Ponencias generales... Caracas: Ediciones Fundación Museo de Arquitectura. 1993. 
TOCA, A. et al (org.) IV Encuentro de Arquitectura Latinoamericana/ México. "La Trindad", Tlaxcala. IV, Anais...México: Universidad Autónoma Metropolitana, 1989.

. IV Encuentro de Arquitectura Latinoamericana. Conclusiones. IV, Anais...México: Universidad Autónoma Metropolitana, 1991.

SALMONA, R.; ARANGO, S. et al (org). III Encuentro de Arquitectura Latinoamericana, Manizales. III, Anais...Buenos Aires: CAPBA D III, 1988.

SEGAWA, H.; BRUNA, P. J. V. et al (org). $7^{\circ}$ SAL - Seminário de Arquitetura Latinoamericana. Cidade e Arquitetura: Construindo o amanhã, 7, 1995. Resumos de Comunicações Científicas. São Paulo: FAU/USP, 1995

. 70 SAL - Cidade e arquitetura: Construindo o amanhã. [Convocatória]. São Paulo: s.n, 1995.

Programa Geral de Atividades - $7^{\circ}$ SAL. São Paulo: Assessoria de Eventos Culturais FAU-USP, 1995.

\section{Crônicas e notas de divulgação de eventos de autoria indefinida (de responsabilidade da equipe de redação da revista ou do jornal):}

5a BIENAL de Quito 20 Encuentro de Revistas de Arquitectura. Ecuador 86. In: ARS, Santiago de Chile: CEDLA, n. 7, nov 1986, 111-113.

III ENCUENTRO de Arquitectura Latinoamericana, Manizales, Colombia Memoria, continuidad y nuevos propósitos. In: Summa. Buenos Aires: Ediciones Summa. n.238, jun. de 1987

CONCLUSIONES del Coloquio de Quito. In: Summa. Buenos Aires: Ed. Summa, n. 114, jul. 1977, p.96.

CRÓNICA de SAL II. Latinoamerica: balance y prospectiva. In: Summa. Buenos Aires: Ediciones Summa, n. 235, mar 1987.

EL PROGRAMA definitivo. Bienal Internacional de Arquitectura de Buenos Aires 85. Clarín Arquitectura, Ingenieria, Planeamiento y Diseño. Buenos Aires, Edición Especial, p.16, mai 1985.

FUTURO de las Bienales. Mesa Redonda. In: CA. Santiago do Chile: Colégio de Arquitetos do Chile, n. 52, jun de 1988, p.68.

LA ARQUITECTURA de Chile en Buenos Aires. El Clarin, Buenos Aires, Arquitectura, Ingeniaria, Planeamiento y Diseño, p.3, 24 de jul. de 1984.

PREMIOS de la tercera Bienal de Arquitectura, In: PROA, Bogotá: Ediciones PROA, 314, jan 1983, p.57.

PRIMER Seminario de Arquitectura Latinoamericana. In: Summa, Buenos Aires:

Ediciones Summa, 214, jul 1985, p.24. 
PRIMER Encuentro de Revistas, In: CA. Santiago de Chile: Colegio de Arquitectos, n.42, dez 1985, p.16.

PROA Notícias. In: PROA, Bogotá: Ediciones Proa, n. 351, jun 1986, p.26.

SAL II: Seminarios de Arquitectura Latinoamericana. In: Summa. Buenos Aires: Ediciones Summa, n.236, abr 1987, p. 24-34.

SAL: Em busca de uma modernidade latino-americana. In: Projeto. São Paulo: Projeto, n. 148, dez 1991.

V SEMINARIO de Arquitectura Latinoameriana, SAL. Informe del encuentro. In: PROA. Bogotá: Ediciones Proa, n.409, abr 1992, p.58

\section{Entrevistas/Depoimentos:}

ARANGO, Silvia. Depoimento. [11 de novembro de 2011]. Campinas: Arquivo digital da gravação (1hora e 11min.). Entrevista concedida a Gisela Barcellos de Souza.

BOZA, Cristián. Depoimento. [10 de agosto de 2011]. Santiago do Chile: Arquivo digital da gravação (23min.). Entrevista concedida a Gisela Barcellos de Souza.

BOZA, Cristián. Depoimento. [17 de agosto de 2011]. Santiago do Chile: Arquivo digital da gravação (1hora e 1min.). Entrevista concedida a Gisela Barcellos de Souza.

BOZA, Cristián. Depoimento. [03 de outubro de 2011]. Santiago do Chile: Arquivo digital da gravação (29min.). Entrevista concedida a Gisela Barcellos de Souza.

BOZA, Cristián. Depoimento. [10 de outubro de 2011]. Santiago do Chile: Arquivo digital da gravação (1hora e 12min.). Entrevista concedida a Gisela Barcellos de Souza.

BROWNE, Enrique. Depoimento. [13 de setembro de 2011]. Santiago do Chile: Arquivo digital da gravação (2horas e 1min.). Entrevista concedida a Gisela Barcellos de Souza.

DÍAZ DEL BO, Antonio. Depoimento. [02 de fevereiro de 2012]. Madrid: Texto em arquivo digital (14 páginas). Entrevista concedida a Gisela Barcellos de Souza.

COMAS, Carlos Eduardo Dias. Depoimento. [01 de abril de 2011]. Porto Alegre: Arquivo digital da gravação (4horas e 37min.). Entrevista concedida a Gisela Barcellos de Souza.

ELIASH, Humberto. Depoimento. [06 de julho de 2011]. Santiago do Chile: Arquivo digital da gravação (58min.). Entrevista concedida a Gisela Barcellos de Souza.

ELIASH, Humberto. Depoimento. [18 de julho de 2011]. Santiago do Chile: Arquivo digital da gravação (2horas e 13min.). Entrevista concedida a Gisela Barcellos de Souza.

ELIASH, Humberto. Depoimento. [02 de agosto de 2011]. Santiago do Chile: Arquivo digital da gravação (56min.). Entrevista concedida a Gisela Barcellos de Souza. 
FERNÁNDEZ COX, Cristián. Depoimento. [31 de setembro de 2011]. Santiago do Chile: Arquivo digital da gravação (1hora e 56min.). Entrevista concedida a Gisela Barcellos de Souza.

GUTIÉRREZ, Ramón. Depoimento. [11 de novembro de 2011]. Campinas: Arquivo digital da gravação (1hora e 39min.). Entrevista concedida a Gisela Barcellos de Souza.

OLIVEIRA, Rogério. Depoimento. [30 de março de 2011]. Porto Alegre: Arquivo digital da gravação (1hora e 8min.). Entrevista concedida a Gisela Barcellos de Souza.

MOSCATO, Jorge. Depoimento. [25 de agosto de 2011]. Buenos Aires: Arquivo digital da gravação (2horas e 25min.). Entrevista concedida a Gisela Barcellos de Souza.

MONTES, Fernando. Depoimento. [24 de novembro de 2011]. Santiago do Chile: Arquivo digital da gravação (2hora e $8 \mathrm{~min}$.). Entrevista concedida a Gisela Barcellos de Souza.

MONTES, Fernando. Depoimento. [20 de dezembro de 2011]. Santiago do Chile: Arquivo digital da gravação (1hora e 28min.). Entrevista concedida a Gisela Barcellos de Souza.

MONTES, Fernando. Depoimento. [27 de dezembro de 2011]. Santiago do Chile: Arquivo digital da gravação (58min.). Entrevista concedida a Gisela Barcellos de Souza.

MURTINHO, Pedro. Depoimento. [20 de agosto de 2011]. Santiago do Chile: Arquivo digital da gravação (1hora e 57min.). Entrevista concedida a Gisela Barcellos de Souza.

MURTINHO, Pedro. Depoimento. [20 de outubro de 2011]. Santiago do Chile: Arquivo digital da gravação (1hora e 51min.). Entrevista concedida a Gisela Barcellos de Souza.

RAMíREZ, Jorge. Depoimento. [05 de abril de 2011]. São Paulo: Arquivo digital da gravação (1 hora e 45min.). Entrevista concedida a Gisela Barcellos de Souza.

SAN MARTín, Eduardo. Depoimento. [07 de março de 2012]. Santiago do Chile: Arquivo digital da gravação (38min.). Entrevista concedida a Gisela Barcellos de Souza.

SAN MARTín, Eduardo. Depoimento. [14 de março de 2012]. Santiago do Chile: Arquivo digital da gravação (1hora e 4min.). Entrevista concedida a Gisela Barcellos de Souza.

SAN MARTín, Eduardo. Depoimento. [26 de março de 2012]. Santiago do Chile: Arquivo digital da gravação (22min.). Entrevista concedida a Gisela Barcellos de Souza.

SEGAWA, Hugo Massaki. Depoimento. [06 de abril de 2011]. São Paulo: Arquivo digital da gravação (1hora e 34min.). Entrevista concedida a Gisela Barcellos de Souza.

ZEIN, Ruth Verde. Depoimento. [05 de abril de 2011]. São Paulo: Arquivo digital da gravação (1 hora e 57min.). Entrevista concedida a Gisela Barcellos de Souza. 


\section{Artigos em Microfilmes:}

SWIBURN, Daniel. VIII Bienal de Arquitectura. En Búsqueda de lo próprio. El Mercúrio, Santiago do Chile, p. E10, 22 de set. de 1991.

PIDERIT, Gabriela; SANTIS, Ernesto. Crear, Compartir, Analizar, los verbos que se conjugan el la VIII Bienal. El Mercúrio, Santiago do Chile, Cuaderno VIII Bienal p. 2, 26 de set. de 1991.

PIDERIT, Gabriela; SANTIS, Ernesto. Encuentro retrospectivo para proyectar el futuro. EI Mercúrio, Santiago do Chile, Cuaderno VIII Bienal p. 3-4, 26 de set. de 1991.

PIDERIT, Gabriela; SANTIS, Ernesto. Montaje abierto a todas percepciones culturales. EI Mercúrio, Santiago do Chile, Cuaderno VIII Bienal p. 3-4, 26 de set. de 1991.

MONTERO WARD, Beatriz. Propuestas Concretas para la Ciudad. El Mercúrio, Santiago do Chile, Vivienda y Decoración p. 6, 12 de out. de 1991, p.6

PREMIADOS DE BIENAL. El Mercúrio, Santiago de Chile, Vivienda y Decoración p. 9, 12 de out. de 1991.

\section{Acervos consultados:}

Acervo da Biblioteca da Facultad de Arquitectura, Diseño y Urbanismo da Universidad de Buenos Aires (FADU/UBA), Buenos Aires, Argentina.

Acervo da Biblioteca da Facultad de Arquitectura, Diseño y Estudios Urbanos de la Universidad Católica (FADEU/UC), Santiago, Chile.

Acervo da Biblioteca da Faculdade de Arquitetura e Urbanismo da Universidade de São Paulo (FAU/USP), São Paulo.

Acervo Biblioteca Nacional de Chile, Santiago, Chile

Acervo da Biblioteca Setorial do Curso de Graduação em Arquitetura e Urbanismo da Universidade Federal do Rio Grande do Sul (FAU/UFRGS), Porto Alegre, Brasil.

Acervo do Colegio de Arquitectos, Santiago, Chile.

Acervo administrativo do Curso de Pós-graduação em Arquitetura da Universidade Federal do Rio Grande do Sul (PROPAR/UFRGS), Porto Alegre, Brasil.

Acervo da Biblioteca da Sociedad Central de Arquitectos (SCA), Buenos Aires, Argentina.

Acervo pessoal do arquiteto Carlos Eduardo Comas, São Paulo, Brasil.

Acervo pessoal do arquiteto Cristián Boza, Santiago, Chile.

Acervo pessoal do arquiteto Enrique Browne, Santiago, Chile.

Acervo pessoal do arquiteto Humberto Eliash, Santiago, Chile.

Acervo pessoal do arquiteto Pedro Murtinho, Santiago, Chile.

Acervo pessoal da arquiteta Ruth Verde Zein, São Paulo, Brasil. 
Apêndice A - Eventos e congressos profissionais americanos e latinoamericanos, 1920-2003 
Tessituras híbridas ou o duplo regresso: Encontros latino-americanos e traduções culturais do debate sobre o Retorno à Cidade 
Quadro 1: Eventos e Encontros Profissionais Panamericanos, Latino-Americanos e Ibero-Americanos entre 1920 e 2003.

Fonte: Elaboração da autora a partir de fontes diversas.

\begin{tabular}{|c|c|c|c|c|c|c|c|}
\hline EVENTO & ABRANGÊNCIA & ORGANIZAÇÃO & $1920-1940$ & $1947-1972$ & $1973-1984$ & $1985-1995$ & $1996-2003$ \\
\hline $\begin{array}{l}\text { CONGRESSOS } \\
\text { PAN- } \\
\text { AMERICANOS DE } \\
\text { ARQUITETOS } \\
(\text { CPA })^{1}\end{array}$ & $\begin{array}{l}\text { Continente } \\
\text { americano }\end{array}$ & $\begin{array}{l}\text { Federação } \\
\text { Panamericana de } \\
\text { Associações de } \\
\text { Arquitetos (FPAA) }\end{array}$ & $\begin{array}{l}\text { I - Montevidéu, } \\
\text { Uruguai (1920); } \\
\text { II - Santiago, Chile } \\
\text { (1923); } \\
\text { III - Buenos Aires, } \\
\text { Argentina (1927); } \\
\text { IV - Rio de Janeiro, } \\
\text { Brasil (1930); } \\
\text { V - Montevidéu, } \\
\text { Uruguai (1940) }\end{array}$ & $\begin{array}{l}\text { VI - Lima, Peru (1947); } \\
\text { VII - Havana, Cuba (1950); } \\
\text { VIII- Cidade do México, México } \\
\text { (1952); } \\
\text { IX - Caracaras, Venezuela (1955); } \\
\text { X - Buenos Aires, Argentina (1960); } \\
\text { XI - Washington, EUA (1965) } \\
\text { XII - Bogotá, Colômbia (1968) } \\
\text { XIII- San Juan, Porto Rico (1970) } \\
\text { XIV- São Paulo/Assunção (1972) }\end{array}$ & $\begin{array}{l}\text { XV - Cidade do México, } \\
\text { México (1975); } \\
\text { XVI - Caracas, Venezuela } \\
\text { (1980) } \\
\text { XVII - Panamá, Panamá } \\
\text { (1984); }\end{array}$ & $\begin{array}{l}\text { XVIII- Havana, Cuba (1988); } \\
\text { XIX - Montevidéu, Uruguai } \\
\text { (1992) }\end{array}$ & $\begin{array}{l}\text { XX - Brasília, Brasil (1996); } \\
\text { XXI - Cidade do México, } \\
\text { México (2000). }\end{array}$ \\
\hline $\begin{array}{l}\text { CONGRESSOS } \\
\text { INTERAMERICAN } \\
\text { OS DE } \\
\text { PLANEJAMENTO }^{2}\end{array}$ & $\begin{array}{l}\text { Continente } \\
\text { americano }\end{array}$ & $\begin{array}{l}\text { Sociedade } \\
\text { Interamericana de } \\
\text { Planejamento (SIAP) }\end{array}$ & & $\begin{array}{l}\text { I- Bogotá, Colômbia (1956); } \\
\text { II - Huampani, Peru (1958); } \\
\text { III - San Juan, Porto Rico (1960); } \\
\text { IV - Santiago, Chile (1962); } \\
\text { V - Cidade do México, México } \\
\text { (1964); } \\
\text { VI - Caracas (1966); } \\
\text { VII -Lima (1968); } \\
\text { VIII - Salvador, Brasil (1970); } \\
\text { IX - Bogotá, Colômbia (1972) }\end{array}$ & $\begin{array}{l}\text { X- Panamá, } \\
\text { Panamá(1974); } \\
\text { XI- Guayaquil, Equador } \\
\text { (1976); } \\
\text { XII- Guatemala, } \\
\text { Guatemala (1979) } \\
\text { XIII- Caracas (1980); } \\
\text { XIV- Morelia, México } \\
\text { (1982) }\end{array}$ & $\begin{array}{l}\text { XV - Bogotá, Colômbia } \\
\text { (1985); } \\
\text { XVI - San Juan, Porto Rico } \\
(1988)\end{array}$ & $\begin{array}{l}\text { XVII - San Juan, Porto Rico } \\
(2003)\end{array}$ \\
\hline
\end{tabular}

\footnotetext{
${ }^{1}$ Dados sistematizados a partir de: GUTIÉRREZ, R.; TARTARINI, J.; STAGNO, B. Congresos Panamericanos de Arquitectos, 1920-2000. Aportes para su história. Buenos Aires: CEDODAL e FPAA, 2007.

${ }^{2}$ Dados sistematizados a partir de: CAMACHO, Luís Eduardo. Sociedad Interamericana de Planificación. SIAP 50 años de vida institucional y Programática. In: Revista Bitácora Urbano-Territorial, Bogotá: Universidad Nacional de Colombia, vol.1, n 11,2007, p.268-284.
} 
Quadro 1: Eventos e Encontros Profissionais Panamericanos, Latino-Americanos e Ibero-Americanos entre 1920 e 2003.

Fonte: Elaboração da autora a partir de fontes diversas.

\begin{tabular}{|c|c|c|c|c|c|c|c|}
\hline EVENTO & ABRANGÊNCIA & ORGANIZAÇÃO & $1920-1940$ & $1945-1972$ & $1973-1984$ & $1985-1995$ & $1996-2003$ \\
\hline $\begin{array}{l}\text { CONFERENCIAS } \\
\text { LATINO-AMERICANAS } \\
\text { DE ESCOLAS E } \\
\text { FACULDADES DE } \\
\text { ARQUITETURA (CLEFA) }\end{array}$ & América Latina & $\begin{array}{l}\text { União de } \\
\text { Universidades da } \\
\text { América Latina } \\
\text { (UDUAL) }\end{array}$ & & $\begin{array}{l}\text { I - Santiago, Chile (1959); } \\
\text { II -Cidade do México, México } \\
\text { (1961); } \\
\text { III- Córdoba, Argentina } \\
\text { (1964) } \\
\text { IV- Lima, Peru (1967); } \\
\text { V- Medellín, Colômbia } \\
\text { (1970); } \\
\text { VI-Maracaibo, Venezuela } \\
\text { (1972); }\end{array}$ & $\begin{array}{l}\text { VII - Quito, Equador } \\
\text { (1975) } \\
\text { VIII - Guayaquil, Equador } \\
\text { (1979) } \\
\text { IX- Cidade do México, } \\
\text { México (1981) } \\
\text { X- São Carlos, Brasil } \\
\text { (1983) }\end{array}$ & $\begin{array}{l}\text { XI - Buenos Aires, Argentina (1985); } \\
\text { XII - Cuzco, Peru (1987); } \\
\text { XIII- Guatemala, Equador (1989) } \\
\text { XIV- La Paz, Bolívia (1991) } \\
\text { XV - Havana, Cuba (1993) } \\
\text { XVI - Montevidéu, Uruguai (1995) }\end{array}$ & $\begin{array}{l}\text { XVII- Santiago, Chile (1997); } \\
\text { XVIII- Cidade do México, } \\
\text { México (1999); } \\
\text { XIX- São Paulo, Brasil (2001); } \\
\text { XX- Concepción, Chile (2003); }\end{array}$ \\
\hline $\begin{array}{l}\text { SEMINÁRIOS DE } \\
\text { ARQUITETURA LATINO- } \\
\text { AMERICANA }\end{array}$ & América Latina & $\begin{array}{l}\text { Sem vínculo } \\
\text { institucional } \\
\text { definido. }\end{array}$ & & & & $\begin{array}{l}\text { I-Buenos Aires, Argentina (1985); } \\
\text { II-Buenos Aires, Argentina (1986); } \\
\text { III- Manizales, Colômbia (1987); } \\
\text { IV- Tlaxcala, México (1989); } \\
\text { V- Santiago, Chile (1991); } \\
\text { VI- Caracas, Venezuela (1993); } \\
\text { VII- São Paulo/São Carlos, Brasil } \\
\text { (1995) }\end{array}$ & $\begin{array}{l}\text { VIII - Lima, Peru (1999); } \\
\text { IX - San Juan, Porto Rico } \\
\text { (2001); } \\
\text { X - Montevidéu; Uruguai } \\
\text { (2003) }\end{array}$ \\
\hline $\begin{array}{l}\text { ENCONTROS DE } \\
\text { REVISTAS LATINO- } \\
\text { AMERICANAS }\end{array}$ & América Latina & $\begin{array}{l}\text { Revistas de } \\
\text { Arquitetura } \\
\text { diversas }\end{array}$ & & & & $\begin{array}{l}\text { I-Santiago, Chile (1985); } \\
\text { II-Quito, Equador (1986); } \\
\text { III- Manizales, Colômbia (1987); } \\
\text { IV- Tlaxcala, México (1989); } \\
\text { V- Santiago, Chile (1991); } \\
\text { VI- Caracas, Venezuela (1993); } \\
\text { VII- São Paulo, Brasil (1995) }\end{array}$ & $\begin{array}{l}\text { Nenhum encontro realizado } \\
\text { no período. } \\
\text { O VIII Encontro de Revistas } \\
\text { de Arquiteturas ocorreu } \\
\text { somente, em } 2009 \text {, no } \\
\text { durante a realização do XIII } \\
\text { SAL no Panamá. }\end{array}$ \\
\hline
\end{tabular}

${ }^{3}$ Dados sistematizados a partir de fontes diversas. 
Quadro 1: Eventos e Encontros Profissionais Panamericanos, Latino-Americanos e Ibero-Americanos entre 1920 e 2003.

Fonte: Elaboração da autora a partir de fontes diversas.

\begin{tabular}{|c|c|c|c|c|c|c|c|}
\hline & ABRANGÊNCIA & ORGANIZAÇÃO & $1920-1940$ & $1945-1972$ & $1973-1984$ & $1985-1995$ & $1996-2003$ \\
\hline $\begin{array}{l}\text { Bienais Ibero-americana } \\
\text { de Arquitetura e } \\
\text { Urbanismo (BIAU) }^{4}\end{array}$ & Ibero-América & $\begin{array}{l}\text { Estrutura } \\
\text { funcional e } \\
\text { administrativa } \\
\text { própria da BIAU }\end{array}$ & & & & & $\begin{array}{l}\text { I- Madri, Espanha (1998) } \\
\text { II- Cidade do México. México } \\
\text { (2000) } \\
\text { III - Santiago, Chile (2002) }\end{array}$ \\
\hline
\end{tabular}

Observações: Os intervalos temporais foram definidos de forma a dar conta dos períodos em que os eventos se concentram e a relacioná-los com eventos históricos que foram importantes para a geopolítica do continente. Desta forma tem-se: (1) 1920-1940, intervalo temporal entre os quais ocorre os primeiros cinco Congressos Pan-americanos de Arquitetos, marcado pelo período entre guerras e a crise de 1929; (2) 1947-1972, período em que se dá retomada dos Congressos Pan-americanos de Arquitetos no pós-guerra, em que novos encontros regionais surgem - as reuniões do SIAP, a partir de 1956, e pelas CLEFA, a partir de 1959 - e em que eventos como a Revolução de Cuba, em 1959 e o governo de Salvador Allende no Chile (entre 1971 e 1973) inscrevem a região dentro da disputa da Guerra Fria; (3) 1973-1984, período marcado pelas ditaduras militares no Cone Sul - no Chile em 1973, no Uruguai em 1973, na Argentina em 1976 e no Brasil em 1964 -, apesar da coerção do livre-arbítrio que marcou este período nestes países, os encontros profissionais mantiveram parcialmente sua frequência (apenas há um intervalo maior entre 1974 e 1979); (4) 1985-1995, redemocratização nos países do Cone Sul - Uruguai e Brasil em 1985, Argentina em 1983, Chile em 1990, Paraguai em 1989 -, corresponde ao período áureo dos SAL e dos encontros de revistas; (5) 1996-2003, período em que se observa uma maior distensão na frequência de alguns eventos interamericanos - intervalo de 4 anos entre o VII e o VIII SAL, de 15 anos entre os XVI e XVII Congressos do SIAP e intervalo de 14 anos entre o VII e o VIII Encontro de Revistas - e o aparecimento de outros - BIAU em 1998.

\footnotetext{
${ }^{4}$ A primeira edição, realizada em Madri, foi intitulada de "I Bienal Ibero-americana de Arquitetura e Engenharia Civil”. A partir da segunda edição, realizada na Cidade do México, assume-se o nome "Bienal Ibero-americana de Arquitetura e Urbanismo".
} 
Apêndice B - Registros de apresentações nos SAL entre 1985 e 1995 e participantes recorrentes 



\section{Comissões organizadoras dos SAL de 1985 a 1995}

Quadro 1: Comissões organizadoras dos Seminários de Arquitetura Latino-americana entre 1985 a 1995. Fonte: Dados organizados pela autora a partir dos registros impressos dos seminários (Anais, Cardernos de Resumos, Programas e Crônicas dos eventos).

\begin{tabular}{|c|c|c|c|c|c|c|c|}
\hline 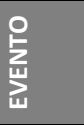 & $\begin{array}{l}\text { I SAL } \\
\text { Buenos } \\
\text { Aires }\end{array}$ & $\begin{array}{c}\text { II SAL } \\
\text { Buenos Aires }\end{array}$ & $\begin{array}{c}\text { III SAL } \\
\text { Manizales }\end{array}$ & $\begin{array}{l}\text { IV SAL } \\
\text { Tlaxcala }\end{array}$ & $\begin{array}{c}\text { V SAL } \\
\text { Santiago }\end{array}$ & $\begin{array}{l}\text { VI SAL } \\
\text { Caracas }\end{array}$ & $\begin{array}{l}\text { VII SAL } \\
\text { São Paulo/ } \\
\text { São Carlos }\end{array}$ \\
\hline 甚 & $\begin{array}{c}20 \text { a } 25 \\
\text { mai. } 1985\end{array}$ & $\begin{array}{c}09 \text { a } 13 \\
\text { Dez. } 1986\end{array}$ & $\begin{array}{c}09 \text { a } 11 \\
\text { mai. } 1987\end{array}$ & $\begin{array}{l}29 \text { mai. a } 2 \\
\text { jun. } 1989\end{array}$ & $\begin{array}{l}7 \text { a } 11 \text { out. } \\
1991\end{array}$ & $\begin{array}{c}25 \text { a } 30 \text { de abr. } \\
1993\end{array}$ & $\begin{array}{c}20 \text { a } 25 \text { ago. } \\
1995\end{array}$ \\
\hline 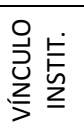 & $\begin{array}{c}\text { Summa / } \\
\text { UBA / } \\
\text { CAYC }\end{array}$ & Summa/UBA & $\begin{array}{c}\text { UNC } \\
\text { Manizales }\end{array}$ & $\begin{array}{c}\text { UAM } \\
\text { Azcapotzalco e } \\
\text { Xochimilco }\end{array}$ & Nenhum & $\begin{array}{c}\text { Museu de } \\
\text { Arquitetura e UCV }\end{array}$ & $\begin{array}{c}\text { USP } \\
\text { São Paulo e } \\
\text { São Carlos }\end{array}$ \\
\hline 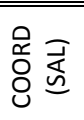 & - & - & $\begin{array}{l}\text { Rogelio } \\
\text { Salmona }\end{array}$ & Antonio Toca & $\begin{array}{c}\text { Cristián } \\
\text { Boza }\end{array}$ & Martín Patrón & Hugo Segawa \\
\hline \multirow{14}{*}{ 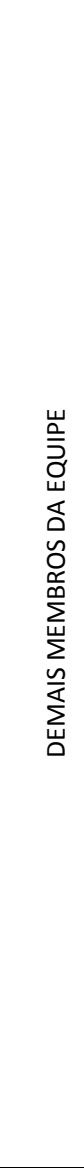 } & $\begin{array}{c}\text { Summa / } \\
\text { UBA }\end{array}$ & $\begin{array}{c}\text { Summa / } \\
\text { UBA }\end{array}$ & $\begin{array}{c}\text { Silvia } \\
\text { Arango }\end{array}$ & $\begin{array}{c}\text { Ernesto Alva } \\
\text { Martínez }\end{array}$ & $\begin{array}{l}\text { Enrique } \\
\text { Browne }\end{array}$ & Marco Negrón & Carlos Martins \\
\hline & & & $\begin{array}{l}\text { Sergio } \\
\text { Trujillo }\end{array}$ & $\begin{array}{c}\text { Carlos } \\
\text { González Lobo }\end{array}$ & $\begin{array}{l}\text { Cristián } \\
\text { Fernández } \\
\text { Cox }\end{array}$ & Roberto Guevara & Hugo Segawa \\
\hline & & & $\begin{array}{c}\text { Ramón } \\
\text { Gutierrez }\end{array}$ & $\begin{array}{l}\text { María Teresa } \\
\text { Ocejo Cázares }\end{array}$ & $\begin{array}{c}\text { Pedro } \\
\text { Murtinho }\end{array}$ & Celina Benatata & $\begin{array}{c}\text { Lúcio Gomes } \\
\text { Machado }\end{array}$ \\
\hline & & & & $\begin{array}{l}\text { Antonio Toca } \\
\text { Fernández }\end{array}$ & $\begin{array}{l}\text { Humberto } \\
\text { Eliash }\end{array}$ & Jorge Rigamonti & $\begin{array}{l}\text { Paulo J. V. } \\
\text { Bruna }\end{array}$ \\
\hline & & & & $\begin{array}{c}\text { Ramón Vargas } \\
\text { Salguero }\end{array}$ & $\begin{array}{l}\text { Eduardo } \\
\text { San Martín }\end{array}$ & Juan Pedro Posani & $\begin{array}{c}\text { Ramón } \\
\text { Gutiérrez } \\
\end{array}$ \\
\hline & & & & $\begin{array}{c}\text { Concepción } \\
\text { Vargas Sánchez }\end{array}$ & $\begin{array}{l}\text { Manuel } \\
\text { Moreno }\end{array}$ & $\begin{array}{c}\text { Silvia Hernandez de } \\
\text { La Sala }\end{array}$ & $\begin{array}{c}\text { Carlos Roberto } \\
\text { Monteiro** }\end{array}$ \\
\hline & & & & & Pilar Garcia & Oscar Tenreiro & $\begin{array}{l}\text { Joaquim } \\
\text { Guedes** }\end{array}$ \\
\hline & & & & & $\begin{array}{l}\text { Cecília } \\
\text { Puga }\end{array}$ & Ramón Gutierrez & $\begin{array}{c}\text { José Luiz Fleury } \\
\text { de Oliveira** }\end{array}$ \\
\hline & & & & & & $\begin{array}{c}\text { Ana Maria Marín/ } \\
\text { Joel Sanz* }\end{array}$ & $\begin{array}{c}\text { Paulo César } \\
\text { Xavier** }\end{array}$ \\
\hline & & & & & & $\begin{array}{c}\text { Gustavo Flores / } \\
\text { Juán José Merchan * }\end{array}$ & $\begin{array}{c}\text { Ubyrajara G. } \\
\text { Gilioli** }\end{array}$ \\
\hline & & & & & & $\begin{array}{c}\text { Lesmes Catañeda / } \\
\text { María Cartola } \\
\text { lbañez* }\end{array}$ & $\begin{array}{l}\text { Ruth Verde } \\
\text { Zein** }\end{array}$ \\
\hline & & & & & & $\begin{array}{l}\text { Abner Colmenares/ } \\
\text { Alberto Navarro* }\end{array}$ & \\
\hline & & & & & & $\begin{array}{l}\text { Willian Niño / } \\
\text { Gilda Scorza* }\end{array}$ & \\
\hline & & & & & & $\begin{array}{l}\text { Alberto Sato/ } \\
\text { Azier Calvo* }\end{array}$ & \\
\hline
\end{tabular}




\section{Personagens assíduas nos SAL entre 1985 e 1995, segundo os registros impressos}

Quadro 2: Personagens recorrentes nos Seminários de Arquitetura Latino-americana entre 1985 a 1995. Fonte: Dados organizados pela autora a partir dos registros impressos dos seminários (Anais, Cardernos de Resumos, Programas e, em caso de inexistência dos 3 primeiros, Crônicas dos eventos)

\begin{tabular}{|c|c|c|c|c|c|c|c|c|c|c|}
\hline & & & SAL I & Conv.BA & SAL II & Sal III & SAL IV & SAL V & SAL VI* & SAL VII \\
\hline \multirow{11}{*}{ 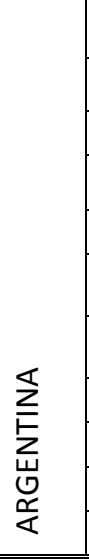 } & Marina Waisman & 7 & debate & assina & palestra & publica & publica & publica & & Palestra \\
\hline & Ramón Gutierrez & 7 & Assistiu $^{2}$ & assina & palestra & publica & publica & debate & org. & palestra \\
\hline & Alberto Petrina & 6 & & assina & & publica & publica & publica & palesta & revistas \\
\hline & Lala Mendez & 6 & debate & assina & organiza & homenagem & revistas & debate & & \\
\hline & Jorge Moscato & 5 & & assina & & publica & Publica $^{1}$ & debate & & debate \\
\hline & César Naselli & 3 & & assina & & & & publica & & publica \\
\hline & Rafael Iglesia & 3 & & assina & & & publica & publica & & \\
\hline & Rolando Schere & 3 & & assina & & & Publica $^{1}$ & apres. & & \\
\hline & Maria Isabel de Larrañaga & 3 & & assina & & & publica & publica & & \\
\hline & Francisco Liernur & 3 & & assina & & & & publica & apres. $^{3}$ & \\
\hline & Adriana Irigoyen & 2 & & & & & publica & publica & & \\
\hline \multirow{8}{*}{$\stackrel{\text { 岂 }}{\text { 殅 }}$} & Enrique Browne $^{4}$ & 6 & palestra & assina & & palestra & palestra & debate & & debate \\
\hline & Cristian Fernández Cox & 6 & & assina & & publica & publica & projeto & palestra & palestra \\
\hline & Cristian Boza & 6 & Región & assina & & publica & publica & debate & palestra & \\
\hline & Eduardo San Martín & 4 & & & & publica & publica & debate $^{5}$ & assistiu $^{6}$ & palestra \\
\hline & Humberto Eliash & 6 & assistiu & assina & & publica & publica & projeto & palestra & debate \\
\hline & Edward Rojas & 3 & & & palestra & & publica & debate & & \\
\hline & Pedro Murtinho & 3 & palestra & assina & & & & projeto & & \\
\hline & Manuel Moreno & 3 & assistiu & assina & & & & debate & palestra & \\
\hline \multirow{6}{*}{ 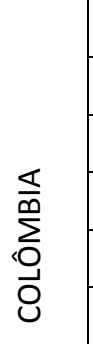 } & Silvia Arango & 7 & & assina & palestra & publica & palestra & debate & palestra & palestra \\
\hline & Salmona & 7 & palestra & assina & palestra & palestra & palestra & 8 bienal & & palestra \\
\hline & Sérgio Trujillo & 4 & & & filme & publica & publica & projeto & & \\
\hline & Alberto Saldarriaga & 2 & & & & publica & publica & & & \\
\hline & Carlos Niño & 2 & & & & publica & & Apres. & & \\
\hline & Jorge Ramírez Nieto $^{7}$ & 4 & & & & & Publica $^{1}$ & Previsto $^{8}$ & revistas & debate \\
\hline \multirow{5}{*}{ 을 } & Antonio Toca & 4 & & & & palestra & org. & 8 bienal & palestra & \\
\hline & Carlos Gonzalez Lobo & 2 & & & & & publica & publica & & \\
\hline & Rodolfo Santa María & 2 & & & & & publica & projeto & & \\
\hline & Louise Noelle & 2 & & & & & publica & & & publica \\
\hline & Ernesto Alba & 2 & & & & & revistas & projeto & & \\
\hline \multirow{4}{*}{$\begin{array}{l}= \\
\bar{n} \\
\substack{\infty \\
\infty}\end{array}$} & Severiano Porto & 4 & palestra & assina & palestra & & & & palestra & \\
\hline & Ruth verde Zein ${ }^{9}$ & 4 & debate & & palestra & palestra & & & & publica \\
\hline & Carlos E. Comas & 4 & & & & publica & publica & apres. $^{10}$ & palestra & \\
\hline & Hugo M. Segawa & 4 & & & & & publica & revistas & revistas & debate \\
\hline 仓’ $\geqq$ & Gustavo Medeiros & 5 & & assina & palestra & publica & & & palestra & debate \\
\hline \multirow{5}{*}{ 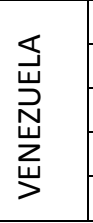 } & Martín Padrón & 3 & & & & & & debate & org. & publica \\
\hline & Wiliam Niño Araque & 3 & & & palestra & & & Apres. & palestra & \\
\hline & Eligia Calderón & 3 & & & & & publica & publica & & publica \\
\hline & Alberto Sato & 2 & & & & & & publica & org. & \\
\hline & Oscar Tenreiro & 2 & & & & & & Apres. & org. & \\
\hline
\end{tabular}




\begin{tabular}{|c|c|c|c|c|c|c|c|c|c|c|}
\hline & & & SALI & Conv.BA & SAL II & Sal III & SAL IV & SAL V & SAL VI* & SAL VII \\
\hline \multirow{3}{*}{ 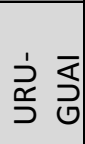 } & Mariano Arana & 5 & palestra & assina & & & publica & 8 bienal & & palestra \\
\hline & Eladio Dieste & 1 & & & & & & prêmio & palestra & \\
\hline & Juan Pedro Margenat & 2 & & & & & & & palestra & publica \\
\hline \multirow{2}{*}{ 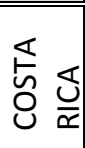 } & Bruno Stagno & 2 & & & & & publica & publica & & \\
\hline & Jorge Grané & 4 & & assina & & & & debate & palestra & publica \\
\hline \multirow{2}{*}{ 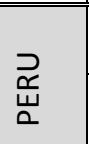 } & Pedro Belaunde M. & 6 & debate & assina & & publica & & debate & palestra & debate \\
\hline & Juvenal Baracco & 5 & debate & assina & & publica & & publica & palestra & \\
\hline 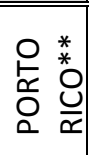 & Andrés Mignucci & 2 & & & & & & & palestra & debate \\
\hline \multirow{3}{*}{ 芯 } & Isabel Rigol & 1 & & & & & & projeto & & \\
\hline & Ricardo Porro & 1 & & & & & & & palestra & \\
\hline & R. Segre & 1 & & & & & & & & palestra \\
\hline \multirow[b]{2}{*}{ 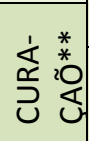 } & Domenico Silvestro & 1 & & & & & & projeto & & \\
\hline & Micheal Newtoro & 1 & & & & & & debate & & \\
\hline \multirow{5}{*}{ 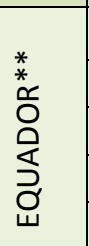 } & Ruben Moreira & 1 & & & & & & & palestra & \\
\hline & Guido Díaz & 1 & & & & publica & & & & \\
\hline & Pablo Lee & 1 & & & & & & publica & & \\
\hline & Alfonson Ortíz C. & 1 & & & & & & debate & & \\
\hline & Dora Arizaga Guzmán & 1 & & & & & & & & debate \\
\hline
\end{tabular}

*Os dados para o VI SAL baseiam-se apenas nas apresentações dos panoramas e das conferências, visto que não houve publicação de anais, nem de caderno de resumos, neste evento.

**Países em que não há participantes recorrentes no período analisado: Não constam registros de mais de uma participação nos SAL de um mesmo profissional entre 1985 e 1995.

${ }^{1}$ Mandou contribuição escrita ao evento, porém, conforme verificado em entrevista, não pode ir apresentar.

${ }^{2}$ Apesar de não reconhecer o I SAL como o evento que fazia parte da programação da I Bienal de Buenos Aires, Gutiérrez assistiu a algumas das palestras deste evento. Cf. GUTIÉRREZ, R. Depoimento. [11 de novembro de 2011], loc. cit.

${ }^{3} \mathrm{O}$ registro de sua participação no VI SAL consta em: "Balance del VI Seminario de Arquitectura Latinoamericana." In: Las Últimas Arquitecturas. Encuentro Reflexión y Crítica. Ponencias y Debates. Buenos Aires: s.l., 1993.

${ }^{4}$ Em depoimento, Enrique Browne confirmou que não foi ao sexto seminário, realizado em Caracas, visto que desde o início da década de 1990 já estava se distanciando dos SAL. Cf BROWNE, E. Depoimento. [13 de setembro de 2011], loc. cit.

${ }^{5}$ Eduardo San Martín fez parte da comissão organizadora e seu nome consta no programa na moderação de debate teórico. Entrento, este arquiteto afirmou em depoimento que não pode participar do evento.

${ }^{6}$ Em entrevista realizada em 26 de março de 2012, Eduardo San Martín afirmou que foi ao evento de Caracas, apesar de não ter apresentado nada.

${ }^{7}$ Apesar de ter registros de impressos que indicam o contrário, Jorge Ramírez Nieto esteve de fato em três eventos do período analisado: o III SAL (como ouvinte); o VI SAL e o VII SAL. Cf. RAMíREZ, Jorge. Depoimento. [05 de abril de 2011], loc. cit. 
${ }^{8}$ A apresentação de Jorge Ramírez estava prevista no V SAL, porém não consta nos Anais. Em entrevista, o arquiteto colombiano confirmou que não pode participar do evento. Cf. RAMíREZ, Jorge. Depoimento. [05 de abril de 2011], loc. cit.

${ }^{9}$ Por motivos de ordem pessoal, Ruth Verde Zein não pode participar pessoalmente dos SAL IV, V e $\mathrm{VI}$, no entanto, confirma em entrevista que esteve em contato com os habitués dos seminários. Cf. ZEIN, Ruth Verde. Depoimento. [05 de abril de 2011], loc. cit.

${ }^{10}$ No programa estava prevista apresentação Rogério de Oliveira, professor da UFRSG, no entanto ele não pode ir e Comas foi em seu lugar, apresentando projeto desenvolvido junto ao PROPAR. Cf COMAS, Carlos Eduardo Dias. Depoimento. [01 de abril de 2011], loc. cit.

\section{Total de apresentações e palestras nos SAL por país entre 1985 e 1995, de acordo com os registros impressos dos eventos}

Quadro 3: Total de contribuições por país registradas nos Seminários de Arquitetura Latino-americana entre 1985 a 1995. Fonte: Dados organizados pela autora a partir dos registros impressos dos seminários (Anais, Cardernos de Resumos, Programas e, em caso de inexistência dos 3 primeiros,Crônicas dos eventos)

\begin{tabular}{|c|c|c|c|c|c|c|c|}
\hline País & $\begin{array}{c}\text { I SAL } \\
\text { B. Aires }\end{array}$ & $\begin{array}{c}\text { II SAL } \\
\text { B. Aires }\end{array}$ & $\begin{array}{c}\text { III SAL } \\
\text { Colombia }\end{array}$ & $\begin{array}{l}\text { IV SAL } \\
\text { México }\end{array}$ & $\begin{array}{c}\text { V SAL* } \\
\text { Chile }\end{array}$ & $\begin{array}{c}\text { VI SAL** } \\
\text { Venezuela }\end{array}$ & $\begin{array}{c}\text { VII SAL } \\
\text { Brasil }\end{array}$ \\
\hline Argentina & debate & 5 & 5 & 18 & 18 & 1 & 12 \\
\hline Bolívia & & 1 & 1 & & & 1 & debate \\
\hline Brasil & 3 & 2 & 2 & 2 & 2 & 2 & 87 \\
\hline Chile & 2 & 1 & 5 & 6 & 8 & 4 & 7 \\
\hline Colômbia & 2 & 3 & 17 & 6 & 5 & 1 & 5 \\
\hline Costa Rica & & & & 1 & 3 & 1 & 1 \\
\hline Cuba & & & & & 1 & 1 & 1 \\
\hline Curaçao & & & & & 1 & & \\
\hline Equador & & & 1 & & 4 & 1 & 1 \\
\hline México & 1 & & 2 & 27 & 5 & 2 & 1 \\
\hline Porto Rico & & & & & & 1 & 1 \\
\hline Peru & debate & & 2 & & 8 & 2 & 1 \\
\hline Uruguai & 1 & & & 1 & & 2 & 5 \\
\hline Venezuela & & 1 & & 1 & 10 & 2 & 3 \\
\hline Total & 9 & 16 & 35 & 61 & $65^{*}$ & $21 * *$ & 128 \\
\hline \multicolumn{8}{|l|}{ Legenda: } \\
\hline \multicolumn{7}{|c|}{ Registrou-se apenas a participação em debate, não houve apresentação ou palestra } & debate \\
\hline \multicolumn{7}{|c|}{ Ausência de registros impressos de participação no evento em questão } & \\
\hline \multicolumn{7}{|c|}{ País com maior número de apresentações resgitradas no evento } & \\
\hline \multicolumn{7}{|c|}{ Número de apresentações do país sede constantes nos anais } & $\mathbf{X X}$ \\
\hline
\end{tabular}

* Para o SAL de Santiago do Chile considerou-se o total de registros de apresentação, ou seja, tanto as apresentações de textos e projetos constantes nos anais, quanto aqueles outros constantes apenas na grade de programação.

**Os dados para o VI SAL baseiam-se apenas nas apresentações dos panoramas e das conferências, visto que não houve publicação de anais, nem de caderno de resumos, neste evento.

\section{Registro de apresentações no I SAL}

\section{PALESTRANTES}

Fonte: Primer Seminario de Arquitectura Latinoamericana [Nota de Divulgação]. In: Summa, Buenos Aires: Ediciones Summa, 212, de mai de 1985. 
Pedro Murtinho (Chile); Enrique Browne (Chile); Mariano Arana (Uruguai); Abrahan Zabludovsky (México); Rogelio Salmona (Colômbia) e Laureano Forero (Colômbia); Joaquim Guedes (Brasil); Assis Reis (Brasil) e Severiano Porto (Brasil); Frederick Cooper* (Peru)

*Não consta entre os participantes finais do evento - cf. WAISMAN, Marina. Primer Seminario de Arquitectura Latinoamericana. Un auspicioso comienzo. In: Summa. Buenos Aires: Ediciones Summa, n. 217, setembro de 1985, p. 26.

\section{MESA ORGANIZADA PELA SUMMA}

Fonte: PRIMER Seminario de Arquitectura Latinoamericana. In: Summa, Buenos Aires: Ediciones Summa, 214, de julho de 1985, p.24.

Como representantes da Summa: Lala Méndez Mosquera (Argentina); Marina Waisman (Argentina); Marcelo Martín (Argentina); Julio Cacciatore (Argentina); Miriam Chandler (Argentina); Juvenal Baracco (Peru); Pedro Belaúnde (Peru) e Ruth Verde Zein (Brasil).

Debatedores -palestrantes:

Pedro Murtinho (Chile); Enrique Browne (Chile); Mariano Arana (Uruguai);Rogelio Salmona (Colômbia) e Laureano Forero (Colômbia); Joaquim Guedes (Brasil); Assis Reis (Brasil) e Severiano Porto (Brasil)

\section{Registro de apresentações no II SAL}

Fonte: Nota de divulgação do II SAL, publicada na revista Summa n. 231, de novembro de 1986.

EXPOSIÇÕES - Local: Archivo y Museo Histórico "Arturo Jauretche" - Banco de la Província de Buenos Aires.

"Arquitectura vernácula do Caribe" (CARIMOS, OEA e Universidad de Puerto Rico)

"História de la Arquitectura Colombiana" (Colegio de Arquitectos de Bogotá)

"Arquitectura Contemporanea en Chiloé" (Taller Puertazul)

AUDIOVISUAIS - Local: Archivo y Museo Histórico "Arturo Jauretche" - Banco de la Provincia de Buenos Aires.

"Uso popular de ladrillos en Colômbia", de Sergio Trujillo

"Tecnicas construtivas para América Latina", da Associação de Moradia Econômica de Córdoba

PALESTRAS - REFLEXÕES A PARTIR DA PRÓPRIA OBRA - Local: FADU/UBA

Rogelio Salmona (Colômbia) - El uso del ladrillo, reflexiones sobre la experiencia profesional y popular

Severiano Porto (Brasil) - La técnica maderera y otras cuestiones

Edward Rojas (Chile) - Arquitectura de Chiloé: Tradición maderera y modernidad

Gustavo Medeiros Anaya (Bolívia) - Arquitectura del Altiplano boliviano

Juan Espinosa Páez** (Equador) - El Município de Quito: Arquitectura en contextos históricos Carlos Gómes de Llarena** (Venezuela) - La recuperación urbana de Caracas: el Parque Vargas

Eduardo Sacriste (Argentina) - La obra de un maestro

José Ignacio Díaz (Argentina) - La conformación de un paisaje urbano. Su obra en Córdoba,

César Carli (Argentina) - Arquitectura del Litoral Argentino

Giancarlo Puppo** (Argentina) - Tradicción constructiva y adecuación al medio

**Juan Espinosa Páez, Carlos Gómes de Llarena e Giancarlo Puppo estavam previstos no programa do SAL, porém, segundo o que consta na crônica deste evento, não participarm de fato. Cf. CRÓNICA de SAL II. Latinoamerica: balance y prospectiva. In: Summa. Buenos Aires: Ediciones Summa, n. 235, março de 1987.

PALESTRANTES - CRÍTICOS - Local: FADU/UBA

Willian Niño (Venezuela) - La construcción de la ciudad. Caracas: deterioro y recuperación Ruth Verde Zein (Brasil) - Antes y después del Movimiento Moderno en Brasil 
Silvia Arango (Colômbia) - Reflexiones de aqui sobre allá: Una visión crítica de la arquitectura internacional

Ramón Gutiérrez (Argentina) - Iberoamérica: integración y ruptura hasta 1930

Marina Waisman (Argentina) - Reflexión crítica sobre herramientas y caminos posibles en la arquitectura latinoamericana

\section{Registro de apresentações no III SAL}

Fonte: SALMONA, R.; ARANGO, S. et. al (org). III Encuentro de Arquitectura Latinoamericana. III, Anais...Buenos Aires: CAPBA D III, 1988.

\section{PALESTRAS INAUGURAIS}

Intervención del Ing. José Oscar Jaramillo en la inauguración del III Encuentro de Arquitectura Latinoamericana - José Oscar Jaramillo (decano/Manizales)

Intervención del Arq. Ramón Gutiérrez en la inauguración del III Encuentro de Arquitectura Latinoamericana - Ramón Gutiérrez (Argentina)

Intervención del Arq. Rogelio Salmona en la inauguración del III Encuentro de Arquitectura Latinoamericana - Rogelio Salmona (Colombia)

Contribución de las disciplinas históricas y de preservación del patrimonio a la definición de una arquitectura regional - Marina Waisman (Argentina)

Arquitecturas en el siglo XXI: Fin de las utopías o su realización? - Ruth Verde Zein (Brasil)

Líneas arquitectónicas contemporáneas en América Latina - Enrique Browne (Chile)

Una Arquitectura Alternativa para Latinoamérica - Antonio Toca (México)

GRUPO A - Historia o historiografía de la arquitectura en Latinoamérica Patrimonio Arquitectónico. Centros Históricos / Teoria y crítica arquitectónica. Dificultades del conocimiento y divulgación de la arquitectura. Nuevos instrumentos conceptuales.

Quadro 4: Total de apresentações por país no Grupo A do III SAL. Fonte: Dados sistematizados pela autora a partir dos Anais do evento - SALMONA, R.; ARANGO, S. et. al (org)., op. cit, 1988.

\begin{tabular}{c|c|c|c|c|c|c|c|c}
\hline $\begin{array}{c}\text { Total de } \\
\text { apresentações }\end{array}$ & Argentina & Brasil & Bolívia & Chile & Colômbia & Equador & México & Peru \\
\hline 10 & 1 & 1 & & 1 & 6 & & & 1 \\
\hline
\end{tabular}

1. Colombia o la necesidad de una cultura arquitectónica Fernando Viviescas M. - Colombia

2. Identidad en la arquitectura Ramón Gutiérrez - Argentina

3. Teoría conservacionista y realidad urbana: el caso excepcional de Popayán German Téllez - Colombia

4. Hacia una modernidad apropiada: factores y desafíos internos Cristian Fernández Cox - Chile

5. Arquitectura sin crítica Dario Ruiz Gómez (historiador) - Colombia

6. El concepto de espacio en la modernidad y perspectivas para América Latina Patricia Nogueira de Echeverry - Colombia

7. Reflexiones acerca de la evolución histórica del pensamiento en el Perú Pedro Belaúnde M. - Peru

8. Sobre la investigación histórica y la arquitectura latinoamericana Carlos Niño Murcia - Colombia

9. Una cierta arquitectura moderna brasileña: experiencia a re-conocer. Carlos Eduardo Dias Comas - Brasil

10. Inventario de patrimonio urbanístico y arquitectónico Lorenzo Fonseca - Colombia 
GRUPO B - Tendencias actuales de la arquitectura en Latinoamérica. Corrientes en cada país. ¿Hay una arquitectura auténtica? Las expresiones regionales. / Internacionalidad y latinoamericanidad. El Posmodernismo. Nuevas técnicas y materiales.

Quadro 5: Total de apresentações por país no Grupo B do III SAL. Fonte: Dados sistematizados pela autora a partir dos Anais do evento - SALMONA, R.; ARANGO, S. et. al (org)., op. cit, 1988.

\begin{tabular}{c|c|c|c|c|c|c|c|c}
\hline $\begin{array}{c}\text { Total de } \\
\text { apresentações }\end{array}$ & Argentina & Brasil & Bolívia & Chile & Colômbia & Equador & México & Peru \\
\hline 10 & 2 & & 1 & & 6 & & 1 & \\
\hline
\end{tabular}

11. Realidad y abstracción en la enseñanza del diseño arquitectónico Juan Carlos Pergolis - Colombia

12. El derecho a la voz: la crítica de la arquitectura.

Antonio Toca F. - México

13. Teoría y crítica de la arquitectura en la ciudad de Medellín Mercedes Lucia Vélez W. - Colombia.

14. Héroes o tumbas. Los destinos de la Arquitectura en la América Latina Alberto Saldarriaga R. - Colombia

15. Arquitectura e identidad en la Argentina Alberto Petrina - Argentina

16. Breve diccionario del regionalista comprometido Marina Waisman - Argentina.

17. Problemática del pensamiento arquitectónico contemporáneo en América Latina Pedro G. Buraglia - Colombia

18. La arquitectura de ladrillos en la Colombia Sergio Trujillo Jaramillo - Colombia

19. Siete Anotaciones para pensar la Arquitectura Latinoamericana Silvia Arango - Colombia.

20. Apuntes para una propuesta Iberoamericana en arquitectura Gustavo Medeiros A. - Bolivia

GRUPO C - La vivienda de periferia, marginal o suburbana, problemas arquitectónicos y urbanos. La autoconstrucción. Los espacios públicos su uso y diseño.

Quadro 6: Total de apresentações por país no Grupo C do III SAL. Fonte: Dados sistematizados pela autora a partir dos Anais do evento - SALMONA, R.; ARANGO, S. et. al (org)., op. cit, 1988.

\begin{tabular}{c|c|c|c|c|c|c|c|c}
\hline $\begin{array}{c}\text { Total de } \\
\text { apresentações }\end{array}$ & Argentina & Brasil & Bolívia & Chile & Colômbia & Equador & México & Peru \\
\hline 9 & 1 & & & 3 & 3 & 1 & & 1 \\
\hline
\end{tabular}

21. Diseño y construcción participativo del Ambiente Humano Oscar Becerra Mejía y María Fernanda Quitana-Colombia

22. El Barrio como punto de partida para reurbanizar la ciudad latino-americana Cristian Boza - Chile

23. El espacio público en los barrios autoconstruidos Jorge Robledo Castillo - Colombia.

24. Arquitectura de la periferia Jorge Moscato - Argentina

25. Dimensión arquitectónica de la periferia urbana Humberto Eliash D. - Chile

26. Arquitectura urgente: la venda urbana $v / s$ la arquitectura Guido Díaz - Equador

27. Reflexiones sobre nuestro compromiso frente al paisaje Martha Cecilia Fajardo P. - Colombia

28. Ponencia sobre la periferia Eduardo San Martín - Chile 
29. La Recomposición de la Ciudad Perdida Juvenal Baracco - Peru

\section{Registro de apresentações no IV SAL}

Fontes: TOCA, A. et al (org). IV Encuentro de Arquitectura Latinoamericana/ México. "La Trindad”, Tlaxcala. IV, Anais...México: Universidad Autónoma Metropolitana, 1989. Bem como: IV Encuentro de Arquitectura Latinoamericana. Conclusiones. IV, Anais...México: Universidad Autónoma Metropolitana, 1991.

\section{CONFERÊNCIAS MAGISTRAIS}

La arquitectura debe prever silencios para que pueda escucharse también la voz de quien la vive Carlos G. Mijares Brancho

Una reflexión como arquitecto latinoamericano - Rogelio Salmona (Colômbia)

De la recuperación y renovación de la ciudad histórica - Mariano Arana (Uruguai)

Reflexiones sobre el proceso del movimiento para una arquitectura latinoamericana - Ramón

Gutiérrez (Argentina)

Para una caracterización de la arquitectura latinoamericana - Marina Waisman (Argentina)

Relatoria General del IV Encuentro de Arquitectura Latinoamericana/México. "La Trinidad",

Tlaxcala - Ramón Gutiérrez (Argentina) - a data de redação é posterior à do evento

\section{MESA 1 - CARACTERÍSTICAS DE LA ARQUITECTURA LATINOAMERICANA}

Quadro 7: Total de apresentações por país no Mesa 1 do IV SAL. Fonte: Dados sistematizados pela autora a partir dos Anais do evento - TOCA, A. et al, op. cit, 1989.

\begin{tabular}{c|c|c|c|c|c|c|c|c}
\hline $\begin{array}{c}\text { Total de } \\
\text { apresentações }\end{array}$ & Argentina & Brasil & Chile & Colômbia & Costa Rica & México & Uruguai & Venezuela \\
\hline 20 & 7 & 2 & 2 & 3 & & 6 & & \\
\hline
\end{tabular}

1. Modernidad apropiada o subversiva modernidad barroca Juan Coll Benegas (Argentina)

2. Identidad arquitectónica: Un análisis tipológico y formal en Santiago de Chile Cristián Boza (Chile)

3. El Diseño de la forma prehispánica en la arquitectura contemporánea Elia Chiki Miyasako Kobashi (México)

4. Identidad Nacional, caracterización arquitectónica Carlos Eduardo Comas (Brasil)

5. Modernidad Apropiada Cristian Fernández Cox (Chile)

6. Arquitectura e identidad: Relaciones de una posición teórica C. González Lobo (Colombia)

7. ¿Cien años de soledad? Identidad y modernidad en la cultura arquitectónica latinoamericana Adrián Gorelik (Argentina)

8. Arquitectura e identidad cultural: el caso de nuestra señora de Fátima, en Buenos Aires Rafael Iglesia (Argentina)

9. La nueva arquitectura Argentina: por una coincidente pluralidad Adriana Irigoyen (Argentina)

10. Características de la Arquitectura Latinoamericana: la Arquitectura del Estado Mexicano Eduardo Langagne (México)

11. La arquitectura y la identidad cultural americana Diego E Lecuona

12. Hacer Arquitectura en la Argentina Jorge Moscato/Rolando Schere (Argentina)

13. Materialización Arquitectónica del encuentro y sincretismos hispano-indígena resultantes, México del siglo XVI Carlos R. Magain (México)

14. La arquitectura vernácula como fuente de inspiración. El caso mexicano Louise Noelle (México) 
15. Arquitectura e identidad, algunas vías

Taller Tenantitla/Pablo Quintero

16. La arquitectura en México. Una arquitectura necesariamente adjetivada Alfonso Ramírez Ponce (México)

17. Tres categorías para el estudio de la arquitectura latinoamericana Jorge Ramos de Dios

18. Arquitectura para todos los días. Una hipótesis Alberto Saldarriaga (Colombia)

19. Dilemas da modernidade e da tradição na arquitetura brasileira Hugo Segawa (Brasil)

20. Características de la arquitectura latinoamericana 'frente al aislamiento, la violencia y el miedo, una interpretación poética' Sergio Trujillo Jaramillo(Colombia)

MESA 2 - DUALIDAD ENTRE DECLARACIÓN TEÓRICA EXPRESA y OBRA

Quadro 8: Total de apresentações por país no Mesa 2 do IV SAL. Fonte: Dados sistematizados pela autora a partir dos Anais do evento - TOCA, A. et al, op. cit, 1989.

\begin{tabular}{c|c|c|c|c|c|c|c|c}
\hline $\begin{array}{c}\text { Total de } \\
\text { apresentações }\end{array}$ & Argentina & Brasil & Chile & Colômbia & Costa Rica & México & Uruguai & Venezuela \\
\hline 15 & 4 & & 3 & 1 & 1 & 5 & & 1 \\
\hline
\end{tabular}

21. Estructura esencial y estructura contingente

Silvia Arango (Colombia)

22. Precisiones Latinoamericanas

Enrique Browne (Chile)

23. La ciudad histórica entre la teoría y la práctica: una reflexión de la utilización de la tipología como instrumento de análisis - Eligia Calderón Trejo (Venezuela)

24. Hacia una posmodernidad propia

Ada Dewes (México)

25. Esquizofrenia arquitectónica. El desencuentro entre la ética y la estética Humberto Eliash (Chile)

26. La arquitectura como entidad cultural. Dualidad entre declaración la teórica expresa y la obra

Raúl Hernández Valadez (México)

27. Transgresión y apropiación en la arquitectura moderna: una experiencia heterodoxa (1930-1940)

María Isabel de Larrañaga (Argentina)

28. Vivienda Social, entre el diseño y la apropiación. De la dualidad entre la Declaración Teórica Expresa y la Obra

Héctor Marcovich (México)

29. Variante creativa del proceso del diseño. Dualidad entre la declaración teórica expresa y la obra Carlos Martner (México)

30. La incidencia de la dialéctica tradición-modernidad en la obra arquitectónica regional: El caso de Chiloé Edward Rojas (Chile)

31. Técnica, Arquitectura y compromiso social: Brasil y Argentina nos anos 60, un contrapunto inconcluso

Gabriela Silvestri (Argentina)

32. Civilización o Barbarie en la cultura arquitectónica argentina, o el deseo de una síntesis incumplida Alberto Petrina (Argentina)

33. Algunas reflexiones acerca de la coherencia entre los decires y los haceres de los arquitectos que buscan reencontrarse con lo nacional y popular Rodolfo Sorondo

34. La modernidad transgredida de la arquitectura mexicana contemporánea 
Pedro C. Sonderéguer (México)

35. Reflexiones sobre mi obra en la Costa Rica

Bruno Stagno (Costa Rica)

MESA 3 - CONSTRUCCIÓN DE LA CIUDAD LATINOAMERICANA DESDE LAS NECESIDADES DE LA SOCIEDAD DE MASAS

Quadro 9: Total de apresentações por país no Mesa 3 do IV SAL. Fonte: Dados sistematizados pela autora a partir dos Anais do evento - TOCA, A. et al, op. cit, 1989.

\begin{tabular}{c|c|c|c|c|c|c|c|c}
\hline $\begin{array}{c}\text { Total de } \\
\text { apresentações }\end{array}$ & Argentina & Brasil & Chile & Colômbia & Costa Rica & México & Uruguai & Venezuela \\
\hline 13 & 5 & & 1 & 1 & & 6 & & \\
\hline
\end{tabular}

36. Vivienda masiva y debate arquitectónico nos años 80: asignatura pendiente Anahi Ballent (Argentina)

37. Megaciudades de fin del milenio Javier Delgado (México)

38. ¿Cómo se construye una ciudad latinoamericana? Héctor de Ezcurra (Argentina)

39. La construcción de la ciudad latinoamericana, desde las necesidades de masas Carlos Gonzáles Lobo (México)

40. La construcción de la periferia. El caso de Chalco, México Daniel Hiernaux (México)

41. La construcción de la ciudad latinoamericana Rafael E. J Iglesias (Argentina)

42. El crecimiento poblacional urbano en la América Latina en el contexto 1920-1980 Patricio Iglesias (México)

43. Perspectivas para la producción del hábitat popular latinoamericano en la etapa de internacionalización (Organización transnacional de la cultura y lo símbolo-OTS) Carlos Levington (Argentina)

44. Una imagen de la ciudad: hacia la una propuesta para conceptuación Jorge Morales Moreno (México)

45. Los monumentos y la ciudad Latinoamericana Jorge Ramírez Nieto (Colombia)

46. Hacia una arquitectura apropiada para la periferia de Santiago. Tres proyectos, tres propuestas Eduardo San Martín (Chile)

47. Procesos y mecanismos sociales que producen la carencia urbana, política emergencial Diana Rosemberg

48. Arquitectura Social: Por una práctica profesional alternativa Taller Vivienda/ UAM - XOCHIMILCO (México)

MESA 4 - LA RECURACIÓN Y RENOVACIÓN DE LA CIUDAD HISTÓRICA

Quadro 10: Total de apresentações por país no Mesa 4 do IV SAL. Fonte: Dados sistematizados pela autora a partir dos Anais do evento - TOCA, A. et al, op. cit, 1989.

\begin{tabular}{c|c|c|c|c|c|c|c|c}
\hline $\begin{array}{c}\text { Total de } \\
\text { apresentações }\end{array}$ & Argentina & Brasil & Chile & Colômbia & Costa Rica & México & Uruguai & Venezuela \\
\hline 9 & 3 & & & & & 9 & & \\
\hline
\end{tabular}

49. El salvamento arqueológico y la conservación del patrimonio cultural de los centros históricos en México

Fernando A. Miranda Flores y José Antonio Contreras R. (México)

50. Los Centros Históricos en la América Latina - un desafío la creatividad

Ramón Gutiérrez (Argentina)

51. Ornamentación del espacio en la ciudad histórica 
Leszek Maluga (México)

52. Orígenes del urbanismo mestizo en la América. Permanencia de la traza urbano en México-Tenochtitlan en el centro histórico de la Ciudad de México

Carlos Mercado Méxier (México)

53. Recuperación o especulación con las ciudades históricas de la América Latina Marco Aurelio Ramírez Camacho (México)

54. Variaciones sobre el centro histórico de la ciudad de México Geraldo G. Sánchez Ruiz. (México)

55. La recuperación de los centros históricos tradicionales y la formación de profesionales Rodolfo Santa María (México)

56. Recuperación comunitaria de un sitio urbano. Ingeniero White, Argentina Raquel C. Sugrañes (Argentina)

57. La Recuperación de la sociedad urbana. La recuperación y renovación de la ciudad histórica

Marina Waisman. (Argentina)

\section{Registro de apresentações no V SAL}

Fonte: BOZA et al. (org). Seminario de Arquitectura Latinoamericana. Nuestro Espacio Urbano: Propuestas Morfológicas. V, 1991. Santiago do Chile. Anais... Santiago do Chile: s.n. 1991.

Quadro 11: Comentaristas e moderadores de mesas teóricas do V SAL, de acordo com o programa. Fonte: BOZA et al. El Programa definitivo. In: BOZA et al (org), op. cit., 1991.

\begin{tabular}{|c|c|c|c|c|c|c|c|c|}
\hline & \multirow{2}{*}{$\begin{array}{l}7 \text { de } \\
\text { out. }\end{array}$} & \multicolumn{2}{|l|}{8 de out } & \multicolumn{2}{|l|}{9 de out. } & \multicolumn{2}{|l|}{10 de out. } & \multirow{2}{*}{$\begin{array}{l}11 \\
\text { de } \\
\text { out. }\end{array}$} \\
\hline & & Bloco A & Bloco B & Bloco A & Bloco B & Bloco A & Bloco B & \\
\hline \multirow{4}{*}{ 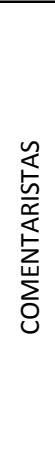 } & \multirow{5}{*}{ 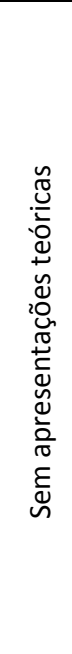 } & $\begin{array}{c}\text { Jaime } \\
\text { Marquez }\end{array}$ & $\begin{array}{c}\text { Pedro } \\
\text { Murtinho }\end{array}$ & Silvia Pirotte & $\begin{array}{c}\text { Rodrigo Pérez } \\
\text { de Arce }\end{array}$ & $\begin{array}{l}\text { Ernesto } \\
\text { Labbé }\end{array}$ & $\begin{array}{c}\text { Lala Méndez } \\
\text { Mosquera } \\
\text { (Argentina) }\end{array}$ & \multirow{5}{*}{ 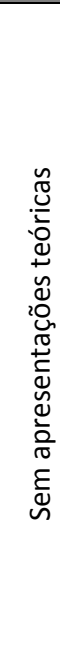 } \\
\hline & & $\begin{array}{l}\text { Leopoldo } \\
\text { Prat }\end{array}$ & Edward Rojas & $\begin{array}{c}\text { Hernán } \\
\text { Montecinos }\end{array}$ & $\begin{array}{c}\text { Rodrigo de la } \\
\text { Cruz }\end{array}$ & Jorge Sabato & $\begin{array}{l}\text { Enrique } \\
\text { Browne }\end{array}$ & \\
\hline & & \multirow{2}{*}{$\begin{array}{l}\text { Gustavo } \\
\text { Munizaga }\end{array}$} & \multirow{2}{*}{$\begin{array}{c}\text { Justo Pastor } \\
\text { Mellado }\end{array}$} & \multirow{2}{*}{ Patrício Gross } & \multirow{2}{*}{$\begin{array}{l}\text { Gunther } \\
\text { Surke }\end{array}$} & Emilio Rivoira & \multirow{2}{*}{$\begin{array}{c}\text { René } \\
\text { Martinez }\end{array}$} & \\
\hline & & & & & & $\begin{array}{c}\text { Dany } \\
\text { Zilberberg }\end{array}$ & & \\
\hline 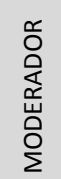 & & Cecilia Puga & $\begin{array}{l}\text { Manuel } \\
\text { Moreno }\end{array}$ & Cristián Boza & $\begin{array}{l}\text { Humberto } \\
\text { Eliash }\end{array}$ & $\begin{array}{c}\text { Eduardo San } \\
\text { Martín }\end{array}$ & $\begin{array}{c}\text { Cristián } \\
\text { Fernández C. }\end{array}$ & \\
\hline
\end{tabular}

APRESENTAÇÃO E COMENTÁRIOS DOS PROJETOS - de acordo com o programa:

Argentina: Jorge Moscato; Brasil: Rogério de Castro Oliveira (não compareceu ao evento, Comas assumiu o papel que Ihe estava previsto); Chile: Fernando Pérez O.; Colômbia: Silvia Arango; Costa Rica: Jorge Grané; Cuba: Daniel Taboada; Curaçao: Micheal Newtoro; Equador: Alfonso Ortiz; México: Ernesto Alva; Peru: Pedro Belaúnde; Venezuela: Martín Padrón

MESA DE ENCERRAMENTO DO V SAL E DA VIII BIENAL - de acordo com o programa: Daniele Vitale (Italia); Carlos Gonzalez Lobos (México); Silvia Arango (Colômbia); Ramón Gutiérrez (Argentina); Victor Escolando (Espanha)

Quadro 12: Total de contribuições no V SAL por país e por tema, constantes nos registros impressos - ver detalhamento no Apêndice C. Fonte: BOZA et al (org), op. cit., 1991. 


\begin{tabular}{|c|c|c|c|c|c|c|c|}
\hline & teóricas & $\begin{array}{l}\text { Cidade } \\
\text { antiga }\end{array}$ & $\begin{array}{l}\text { Cidade } \\
\text { Jardim }\end{array}$ & $\begin{array}{l}\text { Média } \\
\text { Altura }\end{array}$ & Periferia & $\begin{array}{l}\text { s/ } \\
\text { corresp }\end{array}$ & proj./pais \\
\hline Argentina & 9 & 6 & - & - & 2 & 1 & 9 \\
\hline Brasil & & 1 & - & - & 1 & - & 2 \\
\hline Chile & 5 & 1 & 1 & - & 1 & - & 3 \\
\hline Colômbia & 2 & 1 & - & 1 & 1 & - & 3 \\
\hline Costa Rica & 2 & 1 & - & - & - & - & 1 \\
\hline Cuba & & 1 & - & - & - & - & 1 \\
\hline Curaçao & & 1 & - & - & - & - & 1 \\
\hline Equador & 1 & 2 & 1 & - & - & - & 3 \\
\hline México & 1 & 3 & - & - & 1 & - & 4 \\
\hline Peru & 3 & 2 & 1 & 1 & 1 & - & 5 \\
\hline Venezuela & 7 & 1 & - & - & - & 2 & 3 \\
\hline Total & 30 & 20 & 3 & 2 & 7 & 3 & 35 \\
\hline
\end{tabular}

\section{Registro de apresentações no VI SAL}

Fonte: Fonte: PADRÓN, Martín J et al. (org). Seminario de Arquitectura Latinoamericana. Nuestro arquitectura reciente: conceptos y realizaciones. VI, 1993. Caracas. Ponencias generales... Caracas: Ediciones Fundación Museo de Arquitectura. 1993.

[Acervo pessoal de Horacio Torrent]

\section{CONFERÊNCIAS MAGISTRAIS}

Cristián Fernández Cox (Chile)

Eladio Dieste (Uruguai)

Ricardo Porro (Cuba)

Severiano Porto (Brasil)

Teodoro Gonzales de León (México)

\section{CONFERÊNCIAS DOS COORDENADORES POR PAÍS}

1. Genealogía razonada de la actual arquitectura argentina Alberto Petrina (Argentina)

2. Bolivia: Nuestra arquitectura reciente - 1982 a 1992

Gustavo Medeiros, con la colaboración y Jorge Ríos y Javier Bedoya (Bolívia)

3. Arquitectura Brasileña $89 / 92$

Carlos Eduardo Dias Comas (Brasil)

4. Arquitectura reciente en Centroamérica Jorge Grané del Castillo (Costa Rica)

5. Arquitectura de los años $\mathbf{8 0}$ en Colombia Silvia Arango (Colômbia)

6. Arquitectura chilena en el laberinto de la prosperidad Humberto Eliash, Cristián Boza, Manuel Moreno (Chile)

7. Ecuador; Arquitectura reciente, el caso de Quito Rubén Moreira (Equador)

8. Desafíos para la arquitectura mexicana en el próximo milenio Antonio Toca (México)

9. Continuidades y transformaciones de la arquitectura contemporánea en Puerto Rico Andrés Mignucci Giannomi (Porto Rico)

10. Panorama de la Arquitectura Peruana Juvenal Baracco e Pedro Belaúnde (Peru)

11. Arquitectura Uruguaya de los últimos años: un punto de inflexión Juan Pedro Margenat (Uruguai)

12. Panorama desde Venezuela Juan Pedro Posani (Venezuela)

13. La escuela de Caracas. Apuntes para un acercamiento a la arquitectura contemporánea venezolana William Niño Araque (Venezuela) 


\section{Registros de apresentações no VII SAL}

\section{CONFERÊNCIAS GERAIS}

Fonte: PROGRAMA GERAL DE ATIVIDADES $-7^{\circ}$ SAL. São Paulo: Assessoria de Eventos Culturais FAU-USP, 1995. [Programa entregue aos participantes do evento. Acervo pessoal de Horacio Torrent]

Aracy Amaral, Conferência de Abertura em São Paulo (23 de agosto de 1995): João Filgueiras Lima, Conferência em São Paulo (23 de agosto de 1995):

\section{CONFERÊNCIAS E MESAS REDONDAS VINCULADAS ÀS SEÇÕES TEMÁTICAS DO EVENTO:} Fonte: PROGRAMA GERAL DE ATIVIDADES $-7^{\circ}$ SAL. São Paulo: Assessoria de Eventos Culturais FAU-USP, 1995. [Programa entregue aos participantes do evento. Acervo pessoal de Horacio Torrent]

a) TEMA 1 - Cidade e Arquitetura: Modernidade e Contemporaneidade na América Latina (São Carlos, 21 de agosto de 1995)

Conferência de Abertura: Silvia Arango (Colômbia)

Sessões de trabalho:

Passado, Presente e Futuro dos SAL - Apresentação de enquete promovida por Ramón Gutiérrez (Argentina) Mesa redonda:

Andrés Mignucci (Porto Rico), Humberto Eliash (Chile), Jorge Moscato (Argentina), Carlos Martins (Brasil), Henrique Vera (Venezuela)

Moderador: Carlos Monteiro de Andrade (Brasil)

Conferência de encerramento: Cristián Fernández Cox (Chile)

b) TEMA 2 - Teoria, História, Preservação e Projeto Na América Latina Carlos, 22 de agosto de 1995)

Conferência de Abertura: Nestor Goulart Reis Filho (Brasil)

Mesa redonda:

Roberto Segre (Cuba), Lúcio Gomes Machado (Brasil), Pedro Belaúnde (Peru), Enrique Browne (Chile)

Moderador: Gustavo Medeiros (Bolívia)

Sessões de trabalho:

O futuro dos SAL - Coord. Ramón Gutierrez (Argentina)

Pesquisas e Perspectivas de intercâmbio institucional - Coord. Carlos Martins (Brasil)

Conferência de encerramento: Marina Waisman (Argentina)

c) TEMA 3 - Arquitetura e Experiências de Gestão das Cidades Latino-Americanas (São Paulo, 24 de agosto de 1995)

Conferência de Abertura: Mariano Arana (Uruguai)

Mesa redonda:

Braulio Carolo (Brasil/Curitiba), Verena Andreata (Brasil/Rio de Janeiro), Dora Arizaga Guzmán

(Equador/Quito)

Moderador: Joaquim Guedes (Brasil)

Conferência: Paulo Mendes da Rocha (Brasil)

d) TEMA 4 - Habitação Social e Cidade na América Latina (São Paulo, 25 de agosto de 1995)

Conferência de Abertura: Eduardo San Martín (Chile)

Mesa redonda:

Nelson Inda (Uruguai); Ruben Bancroft (Cuba), Joan Villà (Brasil)

Moderador: Horacio Baliero (Argentina)

Conferência: Rogelio Salmona (Colombia) 


\section{EVENTOS PARALELOS:}

Fonte: PROGRAMA GERAL DE ATIVIDADES - $7^{\circ}$ SAL. São Paulo: Assessoria de Eventos Culturais FAU-USP, 1995. [Programa entregue aos participantes do evento. Acervo pessoal de Horacio Torrent]

\section{Encontro de Revistas de Arquitetura - Mesa Redonda}

Adela Garcia Herrera e Jorge Saiz (Espanha), Jorge Ramírez (Colômbia), Hugo Segawa (Brasil), Alberto Petrina (Argentina)

Coordenador: Jorge Grané (Costa Rica)

DOCOMOMO - Mesa Redonda (São Paulo, 23 de agosto de 1995):

Xavier Costa (Espanha), Marco Aurélio F. Gomes (Brasil) Victor Pérez Escolano (Espanha)

UIA BARCELONA 96 - Conferência e vídeos (São Paulo, 24 de agosto de 1995):

Jordi Farrando (Comissário do XIX Congresso da UIA)

\section{APRESENTAÇÕES DE TRABALHOS}

Fonte: SEGAWA, H.; BRUNA, P. J. V. et all (org). $7^{\circ} \mathrm{SAL}$ - Seminário de Arquitetura Latinoamericana. Cidade e Arquitetura: Construindo o amanhã, 7, 1995. Rio de Janeiro. Resumos de Comunicações Científicas. São Paulo: FAU/USP, 1995. [Acervo pessoal de Horacio Torrent]

Quadro 13: Total de apresentações por país no do IIV SAL. Fonte: Dados sistematizados pela autora a partir dos Anais do evento - SEGAWA, H.; BRUNA, P. J. V. et all (org), op. cit, 1995.

\begin{tabular}{c|c|c|c|c|c|c|c|c}
\hline $\begin{array}{c}\text { Total de } \\
\text { apresentações }\end{array}$ & Argentina & Brasil & Chile & Colômbia & s/indent. & México & Uruguai & Venezuela \\
\hline 95 & 7 & 76 & 3 & 3 & 1 & 1 & 3 & 2 \\
\hline
\end{tabular}

1. A Urbes e a identidade Moderna Brasileira Sandra Mara Aggi (FAU - Santos)

2. Aurora e o caso das áreas centrais Adriana Alcântara, Alfredo H. C. de Souza e Ricardo Rabinovitz (Pós-graduação / Universidade Federal da Bahia)

3. Ordenação do território municipal para planejamento Liane Makowski de Oliveira e Almeida (Prefeitura do Município de Jundiaí)

4. Plano diretor de Jundiaí e Zoneamento Urbano e Rural de Jundiaí Liane Makowski de Oliveira e Almeida (Prefeitura do Município de Jundiaí)

5. O espaço do escritório contemporâneo em São Paulo Cláudio Silveira Amaral (Pós-graduação / FAU - Universidade de São Paulo)

6. As concepções de cidade na obra de Rino Levi Renato Luiz Sobral Anelli

7. Projeto de urbanização da comunidade Chácara del Castilho - RJ Arqui Traço Cooperativa

8. Políticas Públicas e Expansão Periférica nas Áreas de Proteção aos Mananciais Renato N. Balbim (LABOPLAN / Universidade de São Paulo)

9. São Paulo, Metrópole Moderna Ana Cláudia Barone e Joana Mello (Bolsista CNPq)

10. Setor Especial de Reestruturaçaõ Urbana "Argos" Marco Antonio Bedin (Prefeitura do Município de Jundiaí)

11. El Muro como definición del espacio urbano. La pérdida del muro y su consecuencia urbanística Micheal Bier

12. La enseñanza de teoría e história y la problemática de preservación y proyecto Juana L. Bustamente e Berta de La Rúa (Universidade Nacional de Córdoba -Argentina)

13. Artigas e a Arquitetura Nacional Miguel Antônio Buzzar (EESC, Universidade de São Paulo)

14. Casas no Brasil: Dimensões de uma práxis em arquitetura Clara Calabria; Carmen Mayrinck, Vera Pires 
15. Tipologia Habitacional e Urbanização de Assentamentos Irregulares no Brasil Clara Calabria; Carmen Mayrinck, Vera Pires

16. Valoración de la arquitetura para la producción en el contexto contemporáneo. La casa de hacienda como cabeza de asentamiento en el entorno productivo.

Eligia Calderón (Facultad de Arquitectura - Universidad de Los Andes, Merida - Venezuela)

17. Projeto Rio $\mathbf{2 0 0 0}$

Eurico Calvente (Universidade de Santa Úrsula)

18. O Abrigo

Eurico Calvente e Mário Saleiro Filho(Universidade de Santa Úrsula)

19. Contextualismo, tipologia e analogia em Aldo Rossi

Martha Machado Campos (Universidade Federal do Espírito Santo)

20. A trama labiríntica: Arquitetura e Cidade

Martha Machado Campos (Universidade Federal do Espírito Santo)

21. Modernidade urbana e modernidade arquitetônica: em busca de uma conceituação

Cândido Malta Campos Neto (Doutorando / FAU - Universidade São Paulo)

22. Da Cidade Unitária à Cidade Utilitária - Alguns pressupostos geográficos para o estudo da urbanização

Ricardo Castillo (Pós-Graduação / FFLCH - Universidade de São Paulo)

23. O Projeto Lagoinha - a perspectiva da reabilitação integrada

Leonardo Barci Castriota (FAU - Universidade Federal de Minas Gerais)

24. Unilabor: Comunidade Cristã e Cidade Industrial

Mauro Claro (Mestrando / FAU - Universidade de São Paulo)

25. A cidade como Museu

Egydio Colombo Filho

26. Las cooperativa de vivenda por ayuda mutua en el uruguay

Centro Cooperativista Uruguayo

27. A criação do habitat moderno no Brasil Industrial - As experiências fabris de Pedra, Camaragibe e Maria Zélia

Telma de Barros Correia (Pós-Graduação / FAU - Universidade de São Paulo)

28. Programa Integrado de Conservación ambiental y desarrollo sustentable de la Cordillera de los Andes

José Pedro de Oliveira Costa e Danilo Silva (FAU - Universidade de São Paulo)

29. Comentários sobre a evolução dos espaços da moradia informal

Lúcia Maria S. Costa e Cristiane Rose de Duarte (FAU - Universidade Federal do Rio de Janeiro)

30. Um espaço político-institucional a reabilitar no projeto contemporâneo da cidade latino-americana

Luiz Carlos Costa (FAU - Universidade de São Paulo)

31. Requalificando a imagem urbana e o espaço dos pedestres Vicente del Rio (FAU - Universidade Federal do Rio de Janeiro)

32. Os guias de referência rápida aos acervos do setor de projetos de arquitetura da biblioteca FAU-Universidade de São Paulo

Flávio Eduardo di Monaco (FAU - Universidade de São Paulo)

33. A igreja do antigo quilombo de Ivaporunduva no vale do Ribeira: Um estudo de caso Paula Fernandes Dias, Clei Alexandre da Silveira, Antônio Fernandes Nascimento Júnior (UNESP/Bauru)

34. Conservação ou invenção? Notas sobre uma relação ambígua Odete Dourado (Mestrado em Arquitetura e Urbanismo / Universidade Federal da Bahia)

35. Desenvolpemos la tierra

Carmen Escobar Urbina e Hugo Pereira Gigogne (Habiterra - Chile)

36. Elementos Fundamentales Constitutivos en la estructura de prospección del nuevo ámbito urbano en Latinoamérica

Pedro Luis Fascioli Foglia (Ex Talleres de la Facultad de Arquitectura, Montevideo Uruguai)

37. Cingapura X Multirão

Joel Pereira Felipe (Universidade de Taubaté) 
38. Multimídia como instrumento de documentação da arquitetura: Palácio Gustavo Capanema - MEC - RJ

Carlos Eduaro Nunes Ferreira e José Ripper Kós (FAU - Universidade Gama Filho e FAU Universidade Federal do Rio de Janeiro)

39. La Comprensión de la arquitectura y la reflexión sobre la modernidad en América Latina Beatriz Garcia Moreno (Pontificia Universidad Javeriana, Santafé de Bogotá - Colômbia)

40. Modernidad y Contemporaneidad em Córdoba. Su Manifestación en la Arquitectura y en la Ciudad

Roberto Ghione (Facultad de Arquitectura, Urbanismo y Diseño da Universidad de Córdoba -Argentina)

41. Reflexiones sobre el uso de la cuadrícula en las ciudades hispanoamericanas significado y limitaciones

Noemi Goytia de Moisset - Argentina

42. Relación Historia y diseño en la práctica proyectual latinoamericana - Un caso de Aplicación

Freddy Guiddy e Maria Teresa Sassi (Facultad de Arquitectura - Universidad Católica de Córdoba - Argentina)

43. O paradigma modernista e a superação de seus problemas Frederico de Holanda (FAU - Universidade de Brasília)

44. Lições da arquitetura brasileira de Lina Bo Bardi Luís Antônio Jorge (EESC - Universidade de São Paulo)

45. Relações entre a percepção da paisagem urbana e a preservação do patrimônio arquitetônico Paula da Cruz Landim y Goya (UNESP / Bauru)

46. Arquitetura e Habitação Popular: Joaquim Cardozo e as casas feitas pelo povo José Tavares Correia de Lira (Doutorando / FAU - Universidade de São Paulo)

47. $O$ ensino e a extensão - universitários gerando pesquisa Regina Esteves Lustosa e Maria do Carmo Zinato (FAU - Universidade Federal de Viçosa)

48. Contribuição ao estudo da cidade brasileira a partir do valor analógico da arquitetura tradicional

Cassia Regina C. de Magaldi (pós-graduação / Pontifícia Universidade Católica - SP)

49. Navegantes de la costa. Arquitectura “estilo barco" en Uruguay, 1935-1945.

Pedro Juan Margenat - Uruguai

50. A imagética de Belém: seguindo os passos da modernidade Ubiraélcio da Silva Malheiros

51. Ainda é válido insistir em utopias?

Fábio Manente (Pós-graduação / FFLCH - Universidade de São Paulo)

52. Qualificação de setores urbanos centrais em cidades médias: Parâmetros para a Regulamentação Urbanística

Enaldo Nunes Marques (Depto. Eng. Civil - Universidade Federal de São Carlos)

53. Análise e avaliação de desempenho de sistemas construtivos habitacionais Ricardo Martucci (EESC - Universidade de São Paulo)

54. Discurso em arquitetura: a crítica nos anos $\mathbf{5 0}$

Clara Luiza Miranda (EESC - UFSC)

55. Aspectos das Relações Ecológicas entre a comunidade Favelada do Jardim Ivone e seu entorno

Olayr Modesto Jr e Antônio Fernandes Nascimento Jr (Faculdade Auxilium de Fil., Ciências de Letras de Lins /SP e UNESP / Bauru)

56. Diversidade e Fragmentação: Pensar a preservação do patrimônio urbano e cultural no planejamento e gestão da cidade

Fernanda Borges Moraes (Escola de Arquitetura - Universidade Federal de Minas Gerais)

57. Planejamento e gestão do espaço: repensando a questão metropolitana Fernanda Borges Moraes (Escola de Arquitetura - Universidade Federal de Minas Gerais)

58. Transformações / reestrutruações no espaço urbano e metropolitano: tendências Fernanda Borges Moraes (Escola de Arquitetura - Universidade Federal de Minas Gerais)

59. Meio ambiente, paisaje y planificación María Dolores Muñoz (Universidad del Bio-bio - Chile) 
60. El proyecto urbano hacia el futuro Latinoamericano: el rol de la imagen de la ciudad e su planificación

César Augusto Naselli - Argentina

61. As iniciativas de um modernista em recife

Guilah Naslavsky (Pós-graduação / FAU - Universidade de São Paulo)

62. Cidadania / Cidade / Moradia - Remodelação de Bairros Populares / 0 caso de Heliópolis

Eulária Portela Negrelo - Brasil

63. Paisagismo produtivo - um novo programa para os espaços livres públicos

Maria Lúcia Neves, Felipe Guaranys e Mônica Bahia Schlee (Fundação Parques e Jardins Prefeitura do Rio de Janeiro)

64. Conciencia histórica y preservación del patrimonio arquitectónico contemporáneo. El caso mexicano Louise Noelle Merelles (Instituto de Investigaciones Estéticas - México)

65. Parque Ecológico de Indaiatuba

Rui Ohtake - São Paulo

66. O mesmo espírito e a linha curva ou "Proust devia explicar isto direito" Marcos Olender (Universidade Federal de Juiz de Fora)

67. O Rio Vermelho. O vir-a-ser cidade dos espaços periféricos na llha de Santa Catarina Lisete Terezinha Assen de Oliveira (Pós-graduação / FAU - Universidade de São Paulo)

68. Lina Bo Bardi: para a construção de uma outra realidade. Estratos de investigação Olivia Fernandes de Oliveira (Mestrado em Arquitetura e Urbanismo / Universidade Federal da Bahia)

69. Intervenciones de la arquitectura moderna en centros de ciudad y estrategias para su reconocimiento cívico en Latinoamérica. La candelaria (Caracas) como caso de estudio Martin J. Padrón e José Manuel da Silva (Universidad Central de Venezuela / Centro Simón Bolivar)

70. Projeto conheça o seu bairro Ana Paula A. Mendes Paes (Prefeitura Municipal de Jundiaí)

71. Renovación Urbana La Paz-Galicia Jose Luis Parodi, Carmen Canoura, Cecilia Lombardo, Mabel Oliveira, Mercedes Medina

72. Sistema modular, metálico, insdustrializado para viviendas Rosauris Perez Magallanes e José Rafael Oráa (Universidad Central de Venezuela)

73. Arquitetura Moderna Brasileira 1920/1940 - questões para discussão Maria Lucia Bressan Pinheiro (FAU - Universidade de São Paulo)

74. Influencias evidentes e influencias sutiles Jorge V. Ramirez Nieto (Universidad Nacional de Colombia)

75. Los intramuros de la ciudad: la estrutura urbana de Lima en el s. XIX Gabriel Ramón Joffré (PROLAM / Universidade de São Paulo)

76. Modelos de história e a "prática" de arquitetura Paulo Romano Reschilian (Universidade de Taubaté)

77. Cartografias de la identidad Fabio Restrepo Hernández - Colômbia

78. Preservação da Unidade Histórico-Cultural do Ambiente Urbano Gustavo Rocha Filho (FAU - Universidade de São Paulo)

79. Construção de habitações com gerenciamento do usuário e emprego de ajuda mútua. 0 FUNAPS comunitário Reinaldo Ronconi (EESC / Universidade de São Paulo)

80. A nova circunstância Ana Paula Baltazar Santos (Pós-graduação / Universidade Federal de Minas Gerais)

81. A importância da história para a arquitetura Ana Paula Baltazar Santos (Pós-graduação / Universidade Federal de Minas Gerais)

82. O Conselho Municipal de Urbanismo e Meio Ambiente na formulação de um Sistema de Planejamento Urbano em Niterói: Uma avaliação Luis Fernando Valverde Salandia (Secretaria Municipal de Urbanismo, Niterói - RJ)

83. México: Arquitetura e cidade no relato de quatro viajantes europeus 
Valéria Salgueiro (Escola de Arquitetura e Urbanismo/ Universidade Federal de Minas Gerais)

84. Avaliando novas edificações em entornos históricos Andréa da Rosa Sampaio (Universidade Federal Fluminense)

85. A gestão da paisagem - uma experiência pioneira em São Paulo Euler Sandeville Junior e Yasuko Tominaga (Pós-Graduação / FAU - Universidade de São Paulo)

86. Cidade contemporânea: nova família, novas formas de morar, nova arquitetura da habitação?: Contribuições para o debate Maria Josefina Gabriel Sant'anna (IFCH / UERJ)

87. Uma experiência de gestión ambiental urbana: el programa de parques urbanos del MINVU Francisco Schmidt (Comisión de Planificación en infraestructura de Transportes, Chile)

88. Solo criado: Instrumento complementar de ordenamento do solo? Observações a partir de uma simulação para o município de Niterói-RJ Rodrigo Valente Serra (IPPUR / RJ)

89. Desconstrução do modelo epucsiano de Salvador Naia Alban Suarez (Pós-Graduação / Universidade Federal de Bahia)

90. Vila agrícola auto-sustentável para populações carentes Paulo Sergio Teixeira; Eliana Marta Escovar; Ricardo Freitas Calejo e Roberto Rampazzo Gamarato

91. A questão da habitação no Brasil - o papel da universidade. A Criação de um Núcleo de Pesquisas para Habitação da Universidade de Brasília Fernando Edmundo Chermond Vidal (Faculdade de Tecnologia / Universidade de Brasília)

92. O espaço da utopia no espaço real: Cidades imaginárias e a Cidade Universitária Marco Antonio Xavier - Brasil

93. Arquitetura e Desenho Urbano como instrumento de conscientização Maria do Carmo Zinato (Universidade Federal de Viçosa)

94. Por uma crítica arbitrária Ruth Verde Zein (Revista Projeto - UNIP)

95. Programa de Revitalización del Patrimonio Arquitectónico y Urbano de Bahía Blanca. Argentina José Maria Zinconi (Universidad Nacional de Buenos Aires/ Argentina)

\section{Signatários da Convocatória de Buenos Aires}

FONTE : GUTIÉRREZ, Ramón et al (org). Arquitectura Latinoamericana. Pensamiento y Propuesta. México: UAM/Unidad de Xochimilco. 1991.

Argentina: Alfonso Acosta, Hugo Addesso, Marcelo Ades, Ricardo Alexander, Miguel Asencio, Oscar Balestieri, Horacio Baliero, Horacio Berretta, Carlos Blanco, Sandro Borghini, Juan Manuel Borthagaray, Nora Bricchetto, Julio Cacciatore, Enrique Cadaveira, César Carli, Eduardo Casado, Claudio Caveri, Carmen Córdova, Juan Manuel Cortizas, Raúl Di Lullo, Alejandro Delucchi, José Ignacio Díaz, Enrique Dimant, Roberto Doberti, Jorge do Porto, Héctor Echechuri, Beatriz Escudero, Héctor de Ezcurra, Mederico Faivre, Cristina Fernández, Roberto Fernández, Raimundo Flah, María Elena Foglia, Roberto Frangella, Martha Fujol, Carlos Gainza, Rodolfo Gallardo, Miguel Angel Garavaglia, Freddy Garay, Enrique García Espil, Francisco García Vázquez, Lorenzo Gigli, Mario González, Guillermo Gregorio, Ramón Gutiérrez, Margarita Guzmán, José Guzmán, Jorge Hampton, Iván Hernández Larguía, Carlos Hilger, Jorge Huarte, Rafael Iglesia, Fernando Jaime, Irene Joselevich, Julio Keselman, Cocó de Larrañaga, Pancho Liernur, Rodolfo Livingston, Jackie Lugones, Juan Manuel Llauró, Marisa Magnin, Juan Carlos Mantero, Marcelo Martín, Eduardo Masllorens, Lala Méndez Mosquera, Guillermo Mérega, Julio Middagh, Juan Molina y Vedia, Enrique Monaldi, Luis Morea, Jorge Moscato, Rodolfo Morello, Osvaldo Moro, César Naselli, Alberto Nicolini, Graciela Novoa, Horacio Pando, Miguel Panetta, Tomás Pardina, Marco Pasinato, Alberto de Paula, Víctor Pelli, Augusto Penedo, Luis Poreyrá, Alberto Petrina, Osvaldo Pons, Ricardo Ponte, Pablo Pschepiurca, Giancarlo Puppo, Fito Rimedio, Emilio Rivoira, Jorge Sabato, Mario Sabugo, Eduardo Sacriste, Diana Saiegh, Ricardo Salim, Daniel Schávelzon, Rolando Schere, Cacho Soler, 
Jaime Sorin, Rodolfo Sorondo, Alberto Spadoni, Esteban Urruty, Celia Ursini, Claudia Utard, Carlos Viarenghi, Graciela Viñuales, Juan Carlos Virili, Marina Waisman, Eduardo Yarke, Daniel Zylberberg.

Bolívia: Gustavo Medeiros Anaya.

Brasil: María Luiza de Carvalho, Severiano Porto.

Colômbia: Silvia Arango, Laureano Forero, Rogelio Salmona.

Costa Rica: Hernán Cordero, Jorge Grané.

Chile: Cristián Boza, Enrique Browne, Gonzalo Cerda, Humberto Eliash, Raúl Farrú, Cristián Fernández Cox, Hans Fox, Eugenio Garcés, Víctor Gubbins, Angel Hernández, Alex Moreno, Manuel Moreno, Patricio Morgado, Pedro Murtinho Larrain, José Riesco, Pilar Urrejola.

Equador: Rolando Moya, Patricio Villalba.

Paraguai: Jorge Rubiani.

Peru: Juvenal Baracco, Pedro Belaúnde, Augusto Ortiz de Zevallos.

Uruguai: Mariano Arana, Ramiro Bascans, H.E. Benech, Antonio Cravotto, Eladio Dieste, Lorenzo Garabelli, José Luis Livni, Rafael Lorente, Tomas Sprechmann.

\section{Signatários do Acordo de Santiago - I Encontro de Revistas Latinoamericanas de arquitetura, Chile, 1985}

FONTE : GUTIÉRREZ, Ramón et al (org). Arquitectura Latinoamericana. Pensamiento y Propuesta. México: UAM/Unidad de Xochimilco. 1991.

- Iván Reimondi (Argentina: a/mbiente);

- Ramón Gutiérrez (Argentina: Documentos de Arquitectura Nacional y Americana director);

- Alberto Petrina (Argentina: SCA, Revista de la Sociedad Central de Arquitectos de Buenos Aires);

- Lala Méndez Mosquera (Argentina: Summa);

- Juan Molina y Vedia (Argentina: Trama);

- Alfredo Rezzoagli (Argentina: Trama);

- María Luiza de Carvalho (Brasil: Módulo)

- Vicente Wissenbach (Brasil: Projeto).

- Silvia Arango (Colômbia: representando as revistas Escala,Hito e Proa)

- Hernán Cordero (Costa Rica: Habitar)

- Alex Moreno (Chile: Arq. Revista de la Universidad Católica de Chile);

- Hans Fox (Chile: Arquitecturas del Sur);

- Humberto Eliash (Chile : Ars);

- Raúl Farré (Chile : Auca);

- Jaime Márquez Rojas (Chile : CA, Revista Oficial del Colegio de Arquitectos de Chile); Enrique Browne (Chile : Taller América) ;

- Cristián Fernández Cox (Chile : Taller América)

- Rolando Moya (Equador: Trama).

- Joan Busquets (Espanha: UR, Urbanismo Revista)

- Pedro Belaúnde (Peru: Habitar).

- Julio César Gaeta (Uruguai: Arquitectura, Revista de la Sociedad de Arquitectos del Uruguay; Trazo, Revista del Centro de Estudiantes de Arquitectura).

- Gabriel Martínez (Uruguai: Arquitectura, Revista de la Sociedad de Arquitectos del Uruguay; Trazo, Revista del Centro de Estudiantes de Arquitectura) 
- Carlos Velázquez (Uruguai: Arquitectura, Revista de la Sociedad de Arquitectos del Uruguay; Trazo, Revista del Centro de Estudiantes de Arquitectura)

\section{Signatários do Acordo do II Encontro de Revistas Latinoamericanas de arquitetura - Equador, 1986}

Fonte: 5a BIENAL de Quito 2ㅇ Encuentro de Revistas de Arquitectura. Ecuador 86. In: ARS, Santiago de Chile: CEDLA, n. 7, nov. 1986, 111-113.

- Julio Gaeta (Uruguai: Trazo )

- José Manuel López (México: Artefacto)

- Sergio Trujillo (Colômbia: Hito, Escala e PROA)

- Alfonso Ortíz, (Equador: Habitar)

- Luis Rodríguez (México: Cuadernos de Diseño)

- Jaime Márquez (Chile: CA)

- Cristián Boza (Chile: ARS)

- Alex Moreno (Chile: ARQ)

- Hernán Cordero (Costa Rica: Habitar)

- Paul Aguilar (Equador: Taller)

- Rolando Moya (Equador: Trama)

- Rubens Stagno (Uruguai: Revista de la Sociedad de Arquitectos de Uruguay, Revista de la Facultad de Arquitectura, Arquitemas)

- Maurico Rivero-Borrel (México: Revista Arquitectura y Sociedad)

\section{Signatários do Acordo IV Encontro de Revistas Latinoamericanas de arquitetura, México, 1989.}

FONTE : GUTIÉRREZ, Ramón et al (org). Arquitectura Latinoamericana. Pensamiento y Propuesta. México: UAM/Unidad de Xochimilco. 1991.

- Jorge Grané (Costa Rica: Habitar, Revista del Colegio, Módulo)

- Lala Méndez Mosquera (Argentina: SUMMA, SUMMA/Colección Temática, SUMMARIOS)

- Frederico García Barba e María Nieves Febles Benítez (Espanha: BASA)

- Rodolfo Santa María e Carlos Finck (México: Diseño UAM)

- Ramón Gutiérrez (Argentina: DANA)

- María Teresa Ocejo C.; Blanca Amaro Sánchez; Eladio Gaxiola; Rafael López Rangel (México: Cuadernos de Arquitectura Latinoamericana)

- Hugo Segawa (Brasil: Projeto)

- Daniel Rodriguez (Uruguai: Trazo)

- Miguel Canale

- Gonzalo Cerda B. (Chile: Arquitecturas del Sur del Bio-Bio)

- José Manuel López (México: Artefacto)

- Jorge Morales (México: Gutemberg Dos)

- Sergio Trujillo Jaramillo (Colombia: HITO e PROA)

- Rubens Stagno (Uruguai: Revista de la Sociedad de Arquitectos de Uruguay, Revista de la Facultad de Arquitectura)

- David Eduardo Serna M (Colombia: ESCALA)

- Ernesto Alva Martínez (México: Cuadernos de Arquitectura UNAM)

- Eduardo San Martín (Chile: Revista CA)

- Cristián Boza e Huberto Eliash (Chile: ARS e ARQ)

- Alberto Petrina (Argentina: SCA e Revista Arquitectura Anales del Instituto Iberoamericano) 


\section{Apêndice C- Escrutínio dos artigos e projetos constantes nos Anais do V SAL}





\section{Súmula da análise de conteúdo dos textos constantes nos Anais do V SAL.}

Quadro 14: Súmula da análise de conteúdo dos textos daArgentina constantes nos Anais do V SAL

\begin{tabular}{|c|c|c|c|c|c|}
\hline to & autor & Título & $\begin{array}{l}\text { Identidade/ } \\
\text { regionalismo }\end{array}$ & Tipo-morfologia & $\begin{array}{l}\text { Especificidade da Cidade latino- } \\
\text { americana }\end{array}$ \\
\hline & Alberto Petrina & Introducción a una continuidad & $\begin{array}{l}\text { FOCO - vanguardas e destruição do } \\
\text { próprio }\end{array}$ & & $\begin{array}{l}\text { Breve menção - harmonia e equilíbrio } \\
\text { durante } 400 \text { anos. }\end{array}$ \\
\hline & Rafael Iglesia & $\begin{array}{l}\text { Identidad cultural y construcción del } \\
\text { hábitat: orientándose en el laberinto }\end{array}$ & $\begin{array}{l}\text { FOCO - identidade como processo } \\
\text { dialético (permanências e mutações) }\end{array}$ & $\begin{array}{l}\text { Aborda brevemente -construção } \\
\text { cultural do habitat }\end{array}$ & \\
\hline & Cesar Naselli & La forma urbana de nuestras ciudades & Breve menção & $\begin{array}{l}\text { FOCO - critica abordagem por situações } \\
\text { urbanas - cidade como palimpsesto }\end{array}$ & $\begin{array}{l}\text { FOCO - modelos europeus e norte- } \\
\text { americanos não funcionam. }\end{array}$ \\
\hline & Adriana Irigoyen & $\begin{array}{l}\text { Mesclar es Humano. Apuntes para una } \\
\text { historia de transculturación y } \\
\text { eclecticismo }\end{array}$ & $\begin{array}{l}\text { FOCO - discute os processos de } \\
\text { transculturação e a falsa oposição entre } \\
\text { tradição e modernidade }\end{array}$ & $\begin{array}{l}\text { Breve menção - tipo participa na } \\
\text { constituição da identidade. }\end{array}$ & \\
\hline & $\begin{array}{l}\text { Maria Isabel de } \\
\text { Larrañaga }\end{array}$ & $\begin{array}{l}\text { Modernidad heteroxia y región: el caso } \\
\text { de Buenos Aires 1930-1940 }\end{array}$ & $\begin{array}{l}\text { Aborda brevemente- adaptações e } \\
\text { apropriações }\end{array}$ & & \\
\hline 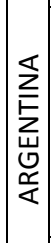 & $\begin{array}{l}\text { Margarita } \\
\text { Gutman, Gladys } \\
\text { Peres Ferrando, } \\
\text { Jorge Trancon y } \\
\text { Ana María } \\
\text { Facciolo(coord.) }\end{array}$ & $\begin{array}{l}\text { Rehabilitación de los pueblos históricos } \\
\text { de la provincia de Buenos Aires }\end{array}$ & Memorial de Proposta de plano setorial $p$ & ra centro histórico consta como apresenta & o também no programa \\
\hline & Francisco Liernur & $\begin{array}{l}\text { Requien para la plaza y la fabrica: notas } \\
\text { sobre la metropolis contemporánea en } \\
\text { América Latina }\end{array}$ & & & $\begin{array}{l}\text { FOCO - as metrópoles latino-americana não } \\
\text { são tão distintas das europeias }\end{array}$ \\
\hline & Marina Waisman & Espacio público - Espacio privado & Breve menção & $\begin{array}{l}\text { Aborda brevemente - constituição dos } \\
\text { espaços públicos (porém enfatiza } \\
\text { aspectos de apropriação e significado) }\end{array}$ & $\begin{array}{l}\text { FOCO - privatização dos espaços coletivos } \\
\text { como fenômeno mundial que se manifesta } \\
\text { também nas cidades latino-americanas. }\end{array}$ \\
\hline & $\begin{array}{l}\text { Raquel Sugrañez } \\
\text { e Jorge Tartani }\end{array}$ & Revitalización de Ejes Urbanos & \multicolumn{3}{|c|}{ NÃO CONSTA NOS ANAIS, APENAS NO PROGRAMA } \\
\hline & Rolando Schere & Plan de Revitalización de la Av. de Mayo & \multicolumn{3}{|c|}{ NÃO CONSTA NOS ANAIS, APENAS NO PROGRAMA } \\
\hline
\end{tabular}




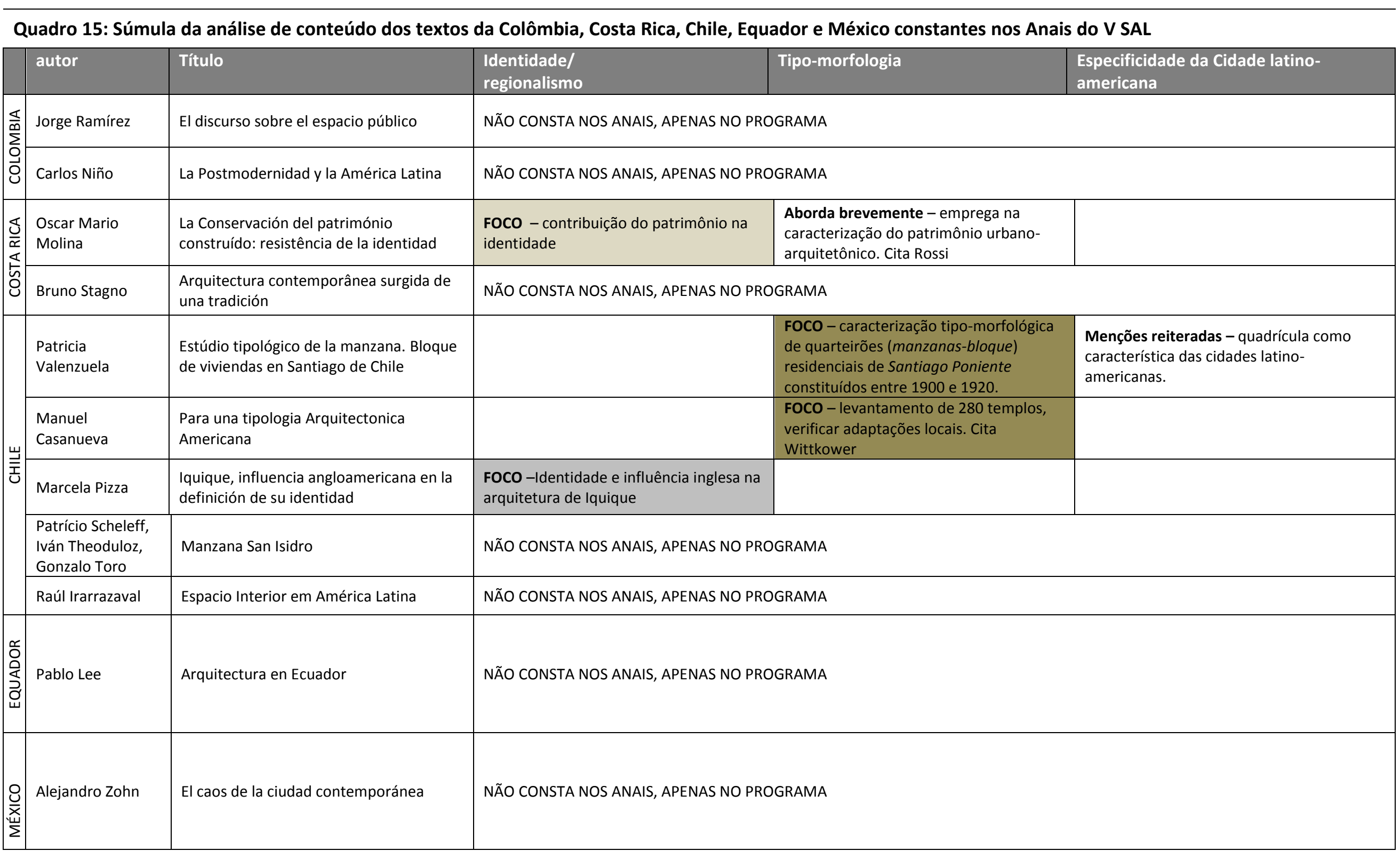


Quadro 15: Súmula da análise de conteúdo dos textos do Peru e da Venezuela constantes nos anais do V SAL

\begin{tabular}{|c|c|c|c|c|c|}
\hline & autor & Título & $\begin{array}{l}\text { Identidade/ } \\
\text { regionalismo }\end{array}$ & Tipo-morfologia & $\begin{array}{l}\text { Especificidade da Cidade latino- } \\
\text { americana }\end{array}$ \\
\hline \multirow{4}{*}{$\underset{\substack{\Psi \\
\alpha}}{\stackrel{P}{a}}$} & $\begin{array}{l}\text { Pedro Villar- } \\
\text { Cordova } \\
\text { Icochea }\end{array}$ & $\begin{array}{l}\text { En torno a los Cascos históricos: una } \\
\text { aproximación morfologica }\end{array}$ & & $\begin{array}{l}\text { FOCO - critica a predileção pela } \\
\text { classificação tipológica em centros } \\
\text { históricos. Defende uma abordagem } \\
\text { morfológica mais ampla que coloque o } \\
\text { habitante no centro da análise. Cita } \\
\text { Lynch }\end{array}$ & $\begin{array}{l}\text { Breve menção - tipologia como } \\
\text { instrumento mais adequado a cidades que } \\
\text { não crescem ou crescem pouco que } \\
\text { identifica na Europa e nos EUA. }\end{array}$ \\
\hline & Juvenal Baracco & $\begin{array}{l}\text { Objetos urbanos: las máscaras de la } \\
\text { ciudad } \\
\text { (Consta nos anais, porém não aparece na } \\
\text { grade da programação) }\end{array}$ & & $\begin{array}{l}\text { FOCO: necessidade cultural de limites - } \\
\text { valores comuns mais ou menos } \\
\text { invariáveis - para compreensão do } \\
\text { território. Esta ordem, estabelecida pela } \\
\text { razão e pelo poder, se traduz em formas } \\
\text { concretas na cidade }\end{array}$ & \\
\hline & $\begin{array}{l}\text { Jorge Balerdi } \\
\text { Arrarte }\end{array}$ & $\begin{array}{l}\text { Proyecto Barranco: la Transformación } \\
\text { morfológica de un barrio histórico }\end{array}$ & $\begin{array}{l}\text { Breve menção: importância do } \\
\text { patrimônio para identidade cultural. }\end{array}$ & $\begin{array}{l}\text { FOCO- tipo-morfológia como apoio para } \\
\text { o projeto de proteção e conservação do } \\
\text { bairro Barranco (realizado em 1985-88, } \\
\text { em parceria com a Universidad Ricardo } \\
\text { de Palma). O interesse pela preservação } \\
\text { deste bairro teria sido motivado pelos } \\
\text { estudos realizados junto ao Taller de } \\
\text { Diseño } 5 \text { de Juvenal Baracco em } 1976 .\end{array}$ & $\begin{array}{l}\text { Breve menção: problemas correntes na } \\
\text { proteção e conservação de centros } \\
\text { históricos latino-americanos (J. Hardoy) }\end{array}$ \\
\hline & Freddy Cooper & Urbanismo racional, Lima & \multicolumn{3}{|c|}{ NÃO CONSTA NOS ANAIS, APENAS NO PROGRAMA } \\
\hline 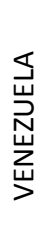 & Alberto Sato & Caos y Utopia en Caracas Moderna & & $\begin{array}{l}\text { FOCO - O arranha-céu e o centro } \\
\text { comercial como dois tipos arquitetônicos } \\
\text { associados a utopias modernizadoras } \\
\text { que negam a cidade e visam a substituí- } \\
\text { la, sem chegar a constituir "cidades } \\
\text { dentro da cidade" }\end{array}$ & $\begin{array}{l}\text { Breve menção à possibilidade de extensão } \\
\text { das reflexões sobre Caracas para as demais } \\
\text { cidades latino-americnas. }\end{array}$ \\
\hline
\end{tabular}




\section{Quadro 16: Súmula da análise de conteúdo dos textos de Venezuela constantes nos anais do V SAL}

\begin{tabular}{|c|c|c|c|c|c|}
\hline & autor & título & $\begin{array}{l}\text { Identidade/ } \\
\text { regionalismo }\end{array}$ & Tipo-morfologia & $\begin{array}{l}\text { Especificidade da Cidade latino- } \\
\text { americana }\end{array}$ \\
\hline & Mirian Salas & $\begin{array}{l}\text { Estudio de las posibilidades de } \\
\text { interaccion entre el urbanismo y el } \\
\text { diseño arquitetônico como clave para un } \\
\text { mejoramiento del espacio y forma de las } \\
\text { ciudades venezoelanas. Los planes } \\
\text { especiales }\end{array}$ & & $\begin{array}{l}\text { FOCO: definição de bases que permitam } \\
\text { a incorporação de parâmetros tipo- } \\
\text { morfológicos e qualitativos nos Planos } \\
\text { Especiais venezuelanos. Cita Rossi, } \\
\text { Aymonimo, Rowe e Marina Waisman. }\end{array}$ & \\
\hline$\underset{\Psi}{\rightleftarrows}$ & $\begin{array}{l}\text { Silvia } \\
\text { Hernandez de } \\
\text { Lasala }\end{array}$ & $\begin{array}{l}\text { Violaciones sucesivas: evolución histórica } \\
\text { de la morfología urbana de la avenida } \\
\text { bolivar de Caracas después del plan } \\
\text { monumental de } 1939 \\
\text { (Consta nos anais, porém não aparece na } \\
\text { grade da programação) }\end{array}$ & & $\begin{array}{l}\text { FOCO: aborda a conformação } \\
\text { morfológica de parte da cidade na qual } \\
\text { se encontra a Av. Bolívar, fruto do plano } \\
\text { monumental de 1939. Descreve as } \\
\text { transformações e violações sucessivas } \\
\text { daquela proposta até a sua recuperação } \\
\text { ao final dos anos } 1980 .\end{array}$ & $\begin{array}{l}\text { Breve menção: nada é eterno ou } \\
\text { impossível, sobretudo em uma cidade de } \\
\text { um país latino-americano. }\end{array}$ \\
\hline$\stackrel{\vec{W}}{\stackrel{\mathrm{W}}{>}}$ & $\begin{array}{l}\text { Silvia } \\
\text { Hernández de } \\
\text { Lasala }\end{array}$ & $\begin{array}{l}\text { Academicismo y modernidad. Dos } \\
\text { propuestas simultaneas en la Venezuela } \\
\text { Contemporanea. La arquitectura para la } \\
\text { educación superior de Luis Malaussena y } \\
\text { Carlos Raúl Villanueva em um Sector } \\
\text { Central de Caracas, 1945-1960 }\end{array}$ & $\begin{array}{l}\text { Breve menção: } \\
\text { Complexidade que subjaz a nossas } \\
\text { cidades nos identifica, é reflexo de nossa } \\
\text { história. }\end{array}$ & $\begin{array}{l}\text { Aborda brevemente: definição de tipo, } \\
\text { caráter e morfologia urbana ao comparar } \\
\text { o projeto eclético Academia Militar à } \\
\text { Cidade Universitária de Villanueva. Cita } \\
\text { Quatremère de Quincy apud Moneo }\end{array}$ & $\begin{array}{l}\text { Aborda Brevemente: } \\
\text { Complexidade do espaço urbano nas } \\
\text { cidades latino-americanas: propostas } \\
\text { apresentam defasagens históricas nas } \\
\text { respostas formais. }\end{array}$ \\
\hline & Eligia Calderón & $\begin{array}{l}\text { Pequeños Centros Poblados, Territorio y } \\
\text { Paisage }\end{array}$ & \multicolumn{3}{|c|}{ NÃO CONSTA NOS ANAIS, APENAS NO PROGRAMA } \\
\hline & Willian Niño & La ciudad como museo & \multicolumn{3}{|c|}{ NÃO CONSTA NOS ANAIS, APENAS NO PROGRAMA } \\
\hline & Oscar Tenreiro & Crisis en la Ciudad Moderna & \multicolumn{3}{|c|}{ NÃO CONSTA NOS ANAIS, APENAS NO PROGRAMA } \\
\hline
\end{tabular}


Intervenções em situações urbanas de cidade antiga com fachada contínua.

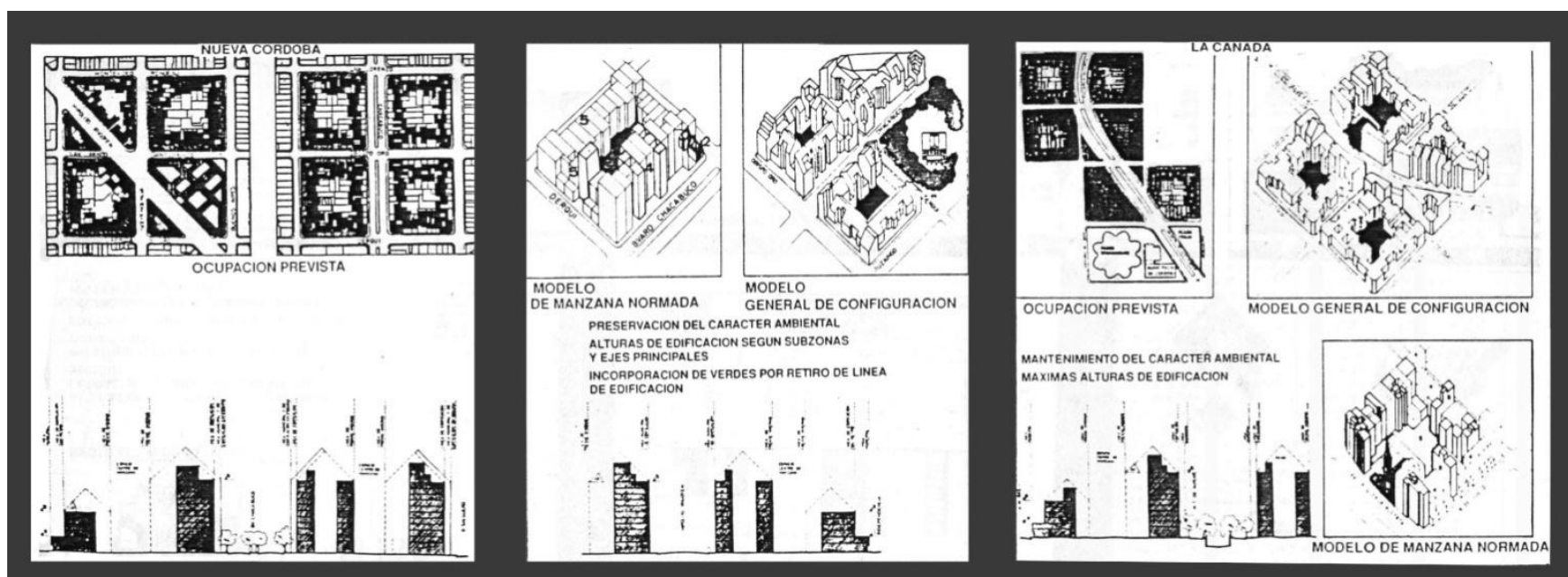

Ocupación del suelo y preservación de ámbitos históricos en el área central - Municipalidade de Córdoba

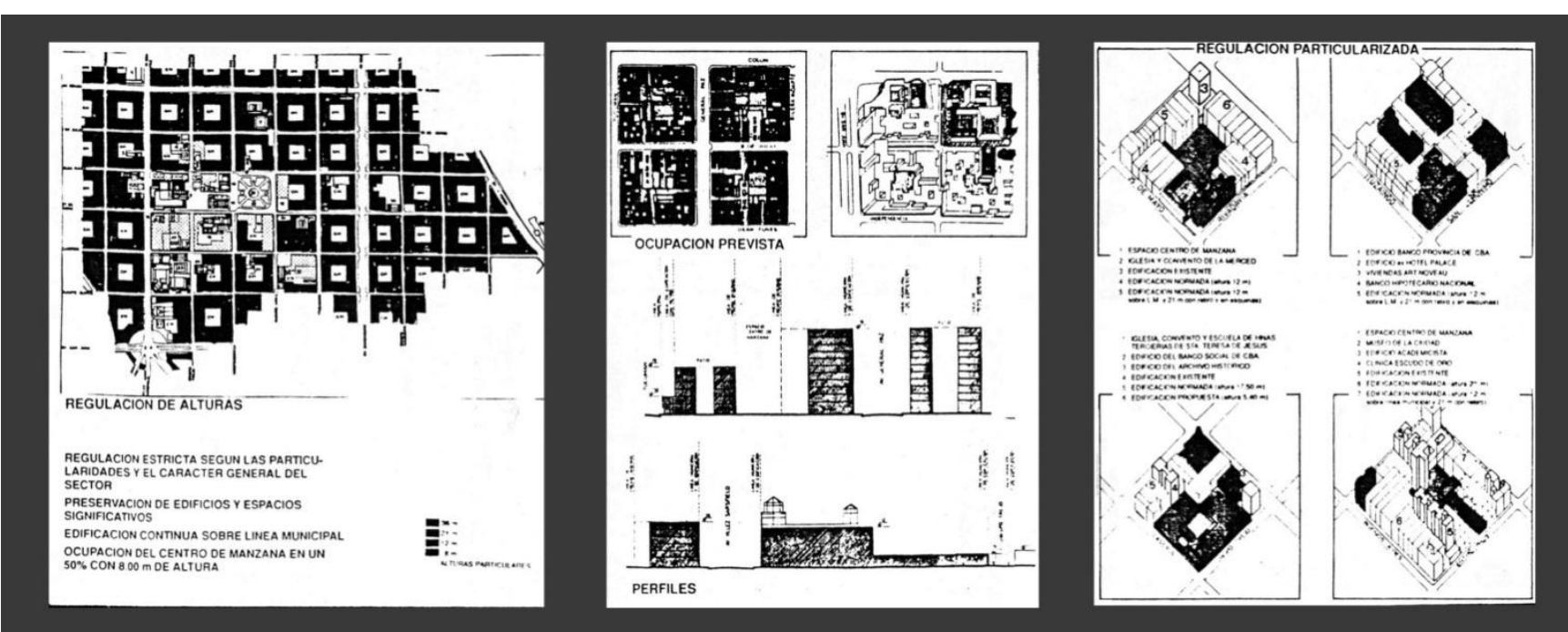

Ocupación del suelo y preservación de ámbitos históricos en el área central - Municipalidade de Córdoba 
Quadro 17: Análise dos projetos constantes nos registros do V SAL que se enquadram em situações urbanas de "cidade antiga com fachada contínua"

\begin{tabular}{|c|c|c|c|c|c|c|c|c|}
\hline & Autores & Título & $\begin{array}{l}\text { Especificidades da } \\
\text { área de intervenção }\end{array}$ & $\begin{array}{l}\text { Caracterização geral } \\
\text { da proposta }\end{array}$ & Pop. da cidade 1990 & Área de intervenção & $\begin{array}{l}\text { Aspectos } \\
\text { morfológicos }\end{array}$ & $\begin{array}{l}\text { Forma de } \\
\text { viabilização }\end{array}$ \\
\hline 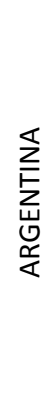 & $\begin{array}{l}\text { Margarita Gutman, } \\
\text { Gladys Perez } \\
\text { Ferrando, Jorge } \\
\text { Trancon }\end{array}$ & $\begin{array}{l}\text { Rehabilitación de los } \\
\text { pueblos históricos de } \\
\text { la provincia de } \\
\text { Buenos Aires } \\
\text { (não consta no } \\
\text { programa) }\end{array}$ & $\begin{array}{l}\text { Povoados históricos } \\
\text { da província de } \\
\text { Buenos Aires em } \\
\text { situação de } \\
\text { deterioramento. }\end{array}$ & $\begin{array}{l}\text { Formulação de } \\
\text { pequenos projetos de } \\
\text { restauro e } \\
\text { reabilitação. } \\
\text { Constituição e } \\
\text { capacitação de } \\
\text { equipes locais para } \\
\text { gestão do programa. } \\
\text { Projeto-Piloto: Capilla } \\
\text { del Señor }\end{array}$ & povoados & Sem menção & Sem menção & $\begin{array}{l}\text { Programa (Província } \\
\text { de Buenos Aires e } \\
\text { IIED-AL) }\end{array}$ \\
\hline 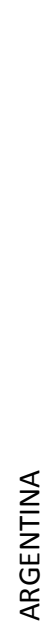 & $\begin{array}{l}\text { Municipalidade de } \\
\text { Córdoba }\end{array}$ & $\begin{array}{l}\text { Ocupación del suelo y } \\
\text { preservación de } \\
\text { ámbitos históricos en } \\
\text { el área central } \\
\text { (consta com nome } \\
\text { distinto no } \\
\text { programa) }\end{array}$ & $\begin{array}{l}\text { Normas anteriores } \\
\text { falhavam na falta de } \\
\text { uma visão } \\
\text { abrangente da área } \\
\text { central de Córdoba }\end{array}$ & $\begin{array}{l}\text { Estratégia e } \\
\text { parâmetros de } \\
\text { edificação } \\
\text { pormenorizados para } \\
\text { o centro histórico. } \\
\text { Destaque para as } \\
\text { áreas do entorno de } \\
\text { La Cañada e da Plaza } \\
\text { San Martín. }\end{array}$ & $\begin{array}{l}1,18 \text { milhões de } \\
\text { habitantes }\end{array}$ & $\begin{array}{l}\text { Centro histórico de } \\
\text { Córdoba }\end{array}$ & $\begin{array}{l}\text { Leitura tipo- } \\
\text { morfológica da } \\
\text { situação preexistente } \\
\text { que destaca o } \\
\text { significado de La } \\
\text { cañada como ruptura } \\
\text { na ortogonalidade. } \\
\text { Parâmetros edilícios: } \\
\text { liberação do espaço } \\
\text { central do } \\
\text { quarteirão, } \\
\text { edificações alinhadas } \\
\text { à rua e utilização de } \\
\text { perfis padrão entre } \\
\text { outros. }\end{array}$ & Norma \\
\hline
\end{tabular}




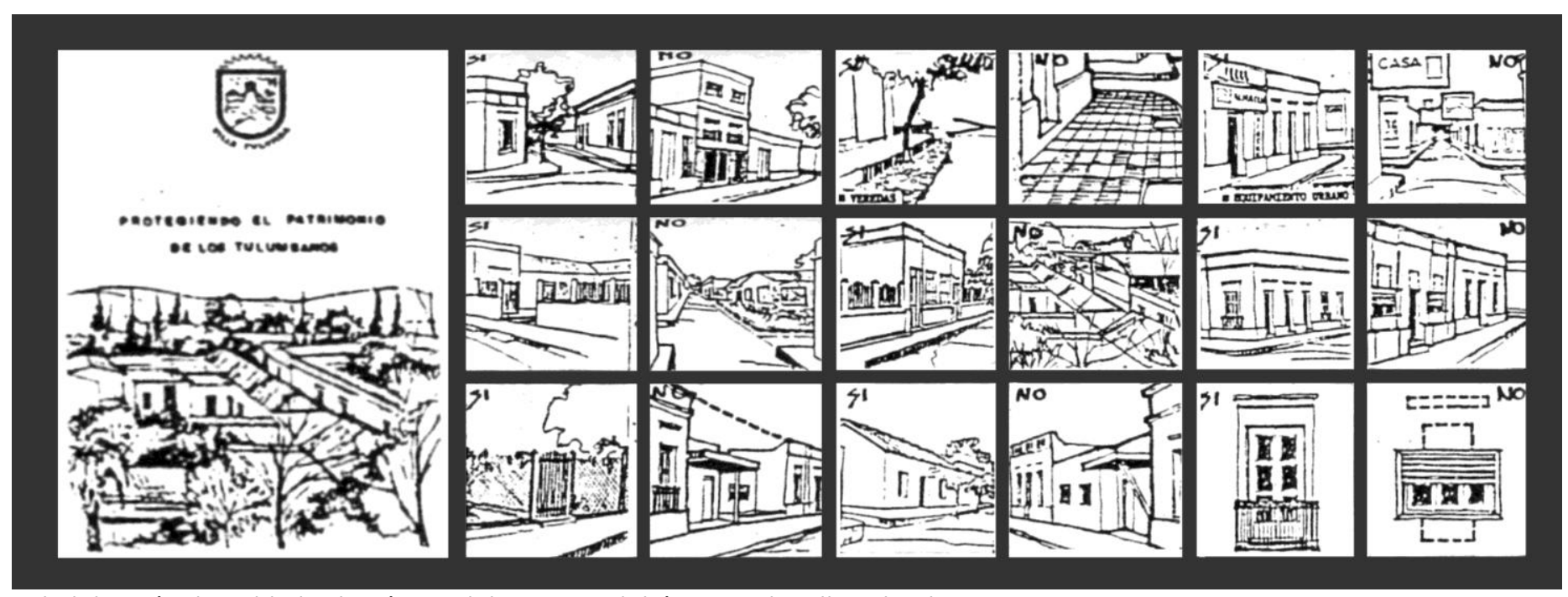

Rehabilitación de poblados históricos del norte cordobés. Caso de Villa Tulumba

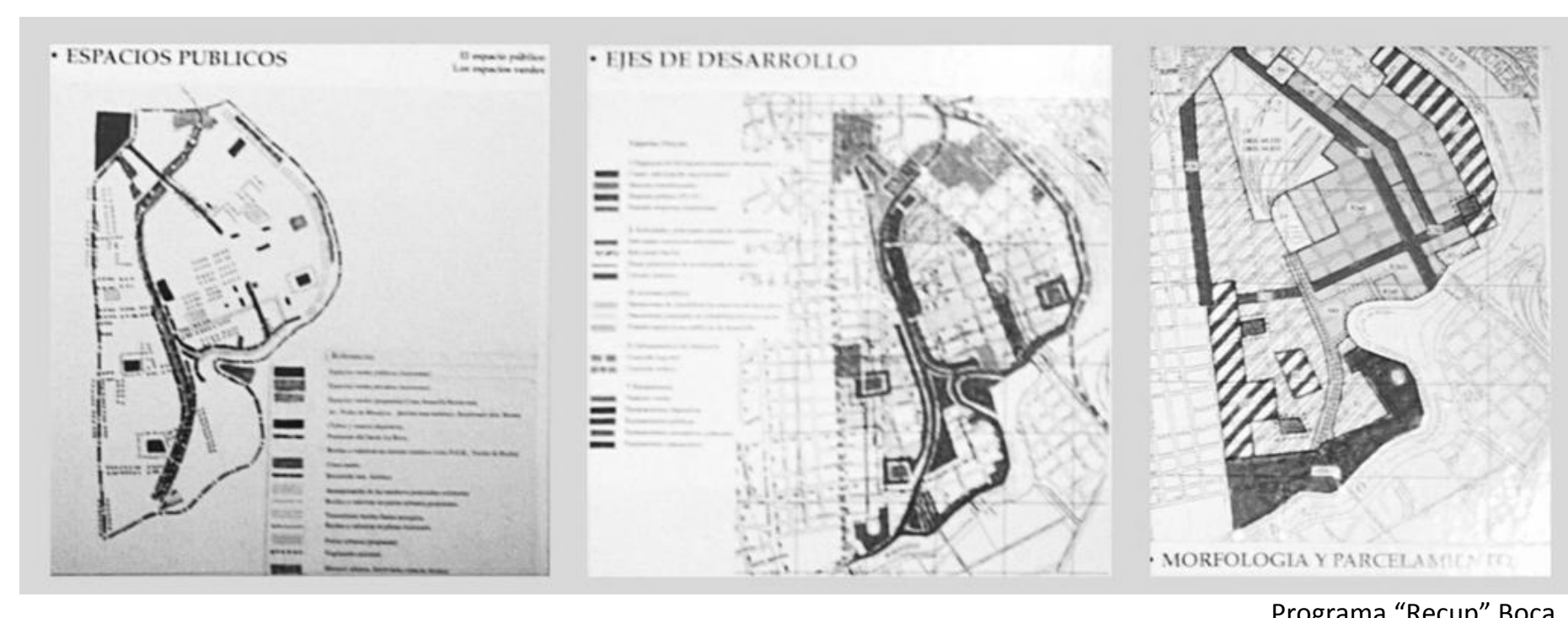


Quadro 17 (Continuação): Análise dos projetos constantes nos registros do V SAL que se enquadram em situações urbanas de "cidade antiga com fachada contínua"

\begin{tabular}{|c|c|c|c|c|c|c|c|c|}
\hline & Autores & Título & $\begin{array}{l}\text { Especificidades da } \\
\text { área de intervenção }\end{array}$ & $\begin{array}{l}\text { Caracterização geral } \\
\text { da proposta }\end{array}$ & Pop. da cidade 1990 & Área de intervenção & $\begin{array}{l}\text { Aspectos } \\
\text { morfológicos }\end{array}$ & Forma de viabilização \\
\hline 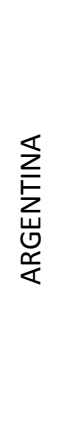 & $\begin{array}{l}\text { Maria Elena Foglia, } \\
\text { Noemi Goytia, F. } \\
\text { Guidi, C. Naselli, S. } \\
\text { Rossi }\end{array}$ & $\begin{array}{l}\text { Rehabilitación de } \\
\text { poblados históricos } \\
\text { del norte cordobés. } \\
\text { Caso de Villa Tulumba }\end{array}$ & $\begin{array}{l}\text { Povoados históricos } \\
\text { da província de } \\
\text { Córdoba como traços } \\
\text { constitutivos da } \\
\text { identidade regional. } \\
\text { Estagnação } \\
\text { econômica e } \\
\text { diminuição da } \\
\text { população colocam } \\
\text { em risco preservação } \\
\text { do patrimônio }\end{array}$ & $\begin{array}{l}\text { Preservação do } \\
\text { patrimônio e difusão } \\
\text { de seu significado } \\
\text { regional através da } \\
\text { inserção do povoado } \\
\text { em um sistema de } \\
\text { circuitos turístico- } \\
\text { culturais }\end{array}$ & povoado & $\begin{array}{l}\text { Área do povoado, } \\
\text { com indicação de } \\
\text { projetos pontuais. }\end{array}$ & $\begin{array}{l}\text { Leitura dos aspectos } \\
\text { tipo-morfológicos do } \\
\text { povoado. Parâmetros } \\
\text { para a reabilitação de } \\
\text { edifícios, } \\
\text { reconhecimento dos } \\
\text { tipos urbano- } \\
\text { arquitetônicos } \\
\text { existentes como } \\
\text { condicionantes os } \\
\text { futuros. }\end{array}$ & $\begin{array}{l}\text { Fundamentos para } \\
\text { futuras normas, } \\
\text { indicação de projetos } \\
\text { de restauro e } \\
\text { requalificação. }\end{array}$ \\
\hline 妾 & $\begin{array}{l}\text { Municipalidade de } \\
\text { Buenos Aires } \\
\text { Margarita Charriero } \\
\text { (coord) }\end{array}$ & $\begin{array}{l}\text { Programa "Recup" } \\
\text { Boca }\end{array}$ & $\begin{array}{l}\text { Degradação do bairro } \\
\text { La Boca de Buenos } \\
\text { Aires em termos: } \\
\text { ambientais } \\
\text { (inundações), } \\
\text { socioeconômicos } \\
\text { (decadência } \\
\text { industrial, restrições } \\
\text { a residências, etc) e } \\
\text { urbano (degradação } \\
\text { do patrimônio, } \\
\text { segregação espacial, } \\
\text { etc). Intervenção } \\
\text { existente não se } \\
\text { integra com o bairro }\end{array}$ & $\begin{array}{l}\text { Proposta com seis } \\
\text { eixos de } \\
\text { desenvolvimento que } \\
\text { abordam diferentes } \\
\text { aspectos da situação } \\
\text { identificada, } \\
\text { viabilizados através } \\
\text { de norma que visa } \\
\text { legitimar a } \\
\text { coexistência entre } \\
\text { indústrias e } \\
\text { habitações e } \\
\text { recuperar os padrões } \\
\text { morfológicos do local. } \\
\text { Propõe também a } \\
\text { reabilitação de } \\
\text { cortiços. }\end{array}$ & 2,96 milhões & $\begin{array}{l}\text { Bairro La Boca, com } \\
\text { detalhamento de } \\
\text { intervenção em área } \\
\text { de aproximadamente } \\
6 \text { hectares }\end{array}$ & $\begin{array}{l}\text { Leitura tipo- } \\
\text { morfológica do } \\
\text { tecido urbano de La } \\
\text { Boca. Manutenção } \\
\text { dos padrões } \\
\text { morfológicos } \\
\text { encontrados no local } \\
\text { - baixa altura e alta } \\
\text { densidade. }\end{array}$ & norma \\
\hline
\end{tabular}




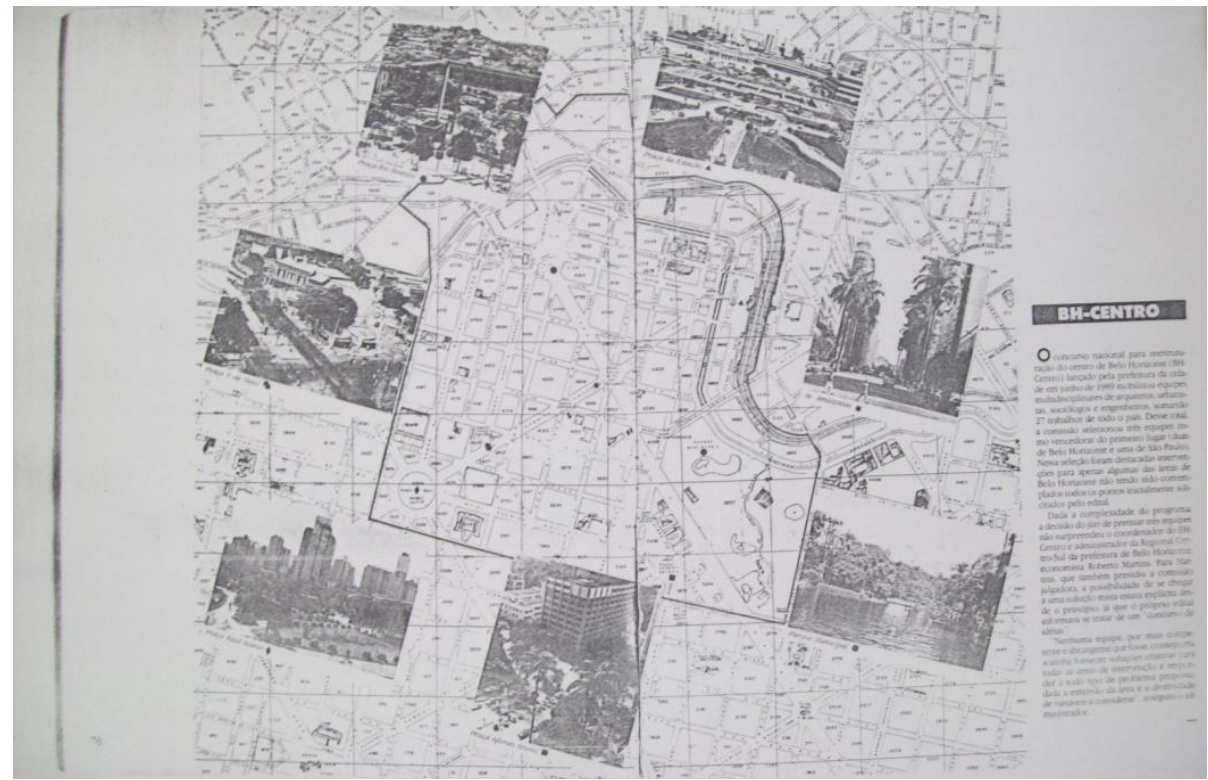

Intervención en centro consolidado, Belo Horizonte.
Intervención en centro consolidado, Belo Horizonte.

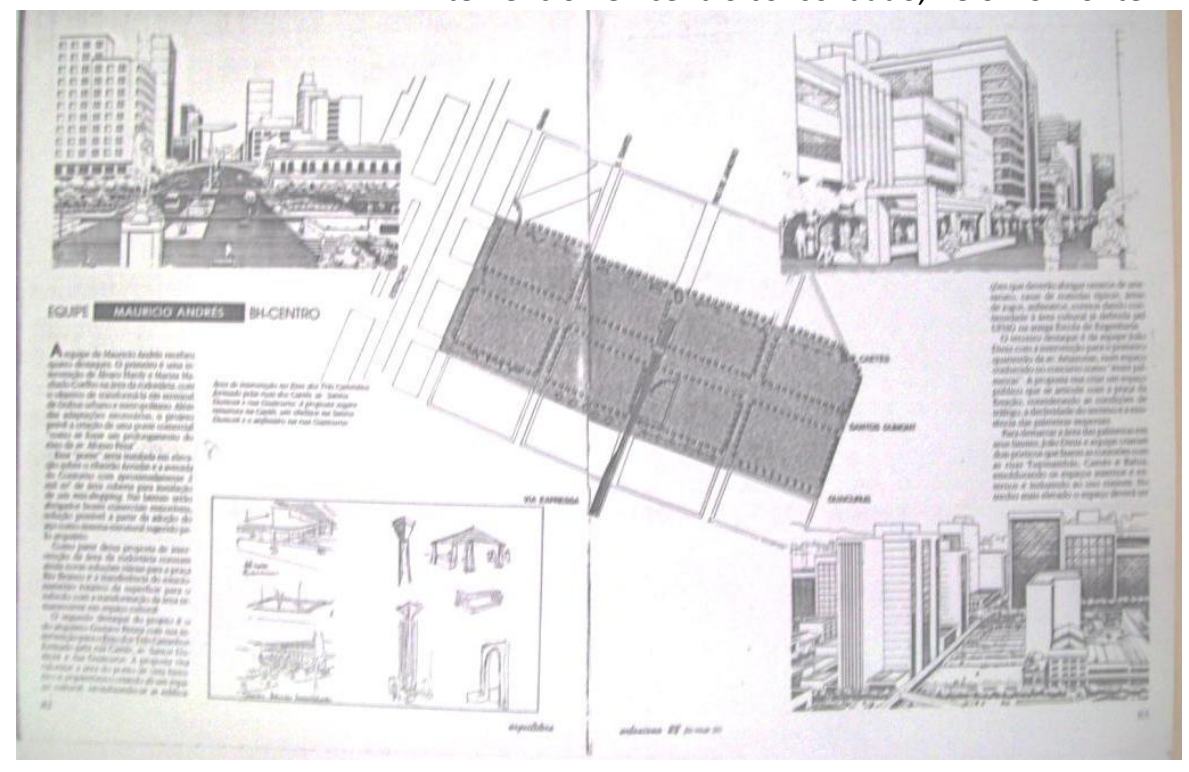




\section{Quadro 17 (Continuação): Análise dos projetos constantes nos registros do V SAL que se enquadram em situações urbanas de "cidade antiga com fachada contínua"}

\begin{tabular}{|c|c|c|c|c|c|c|c|c|}
\hline & Autores & Título & $\begin{array}{l}\text { Especificidades da } \\
\text { área de intervenção }\end{array}$ & $\begin{array}{l}\text { Caracterização geral } \\
\text { da proposta }\end{array}$ & Pop. da cidade 1990 & Área de intervenção & $\begin{array}{l}\text { Aspectos } \\
\text { morfológicos }\end{array}$ & Forma de viabilização \\
\hline \multirow{2}{*}{ 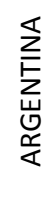 } & Alícia Santaló & San Telmo & \multirow{2}{*}{\multicolumn{6}{|c|}{ NÃO CONSTA NOS ANAIS, APENAS NA PROGRAMAÇÃO }} \\
\hline & Freddy Garay & Puerto Madero & & & & & & \\
\hline$\underset{\substack{\infty \\
\frac{\infty}{\infty}}}{\overline{\bar{u}}}$ & $\begin{array}{l}\text { Álvaro Hardy, Mariza } \\
\text { Machado, Eolo Maia, } \\
\text { Flávio Grillo, Jô } \\
\text { Vasconcellos, } \\
\text { Gustavo Pena, } \\
\text { Adalgisa Mesquita, } \\
\text { Alessandro Marques, } \\
\text { Délio Cardoso, } \\
\text { Eduardo Bretal, Jason } \\
\text { Barroso Santa Rosa, } \\
\text { Ruy Lopes Teixeira } \\
\text { Filho, Antônio } \\
\text { Cupertino Teixeira, } \\
\text { Antônio Almeida, } \\
\text { João Diniz, Márcia } \\
\text { Campos Moreira, } \\
\text { Maria da Graça } \\
\text { Moura. }\end{array}$ & $\begin{array}{l}\text { Intervención en } \\
\text { centro consolidado, } \\
\text { Belo Horizonte. }\end{array}$ & $\begin{array}{l}\text { Projeto motivado por } \\
\text { concurso organizado } \\
\text { pela Prefeitura } \\
\text { Municipal de Belo } \\
\text { Horizonte em } 1989 \text {. } \\
\text { Projeto 3834, um dos } \\
\text { vencedores do } \\
\text { concurso. }\end{array}$ & $\begin{array}{l}\text { Intervenção urbana } \\
\text { através de projetos } \\
\text { pontuais (edifício- } \\
\text { ponte conectando a } \\
\text { estação rodoviária ao } \\
\text { terminal de ônibus } \\
\text { locados nas margens } \\
\text { opostas do rio, } \\
\text { intervenções em } \\
\text { espaços públicos, } \\
\text { etc.) Detalhamento } \\
\text { de projetos para os } \\
\text { calçadões do entorno } \\
\text { da Praça Sete de } \\
\text { Setembro, contratado } \\
\text { pela prefeitura após o } \\
\text { concurso. }\end{array}$ & 2,56 milhões & $\begin{array}{l}\text { Centro de Belo } \\
\text { Horizonte/conjunto } \\
\text { de intervenções } \\
\text { pontuais }\end{array}$ & $\begin{array}{l}\text { Ênfase em aspectos } \\
\text { perceptivos e visuais. } \\
\text { Redesenho de } \\
\text { espaços públicos com } \\
\text { inserção de } \\
\text { mobiliário urbano. }\end{array}$ & Projetos pontuais. \\
\hline
\end{tabular}




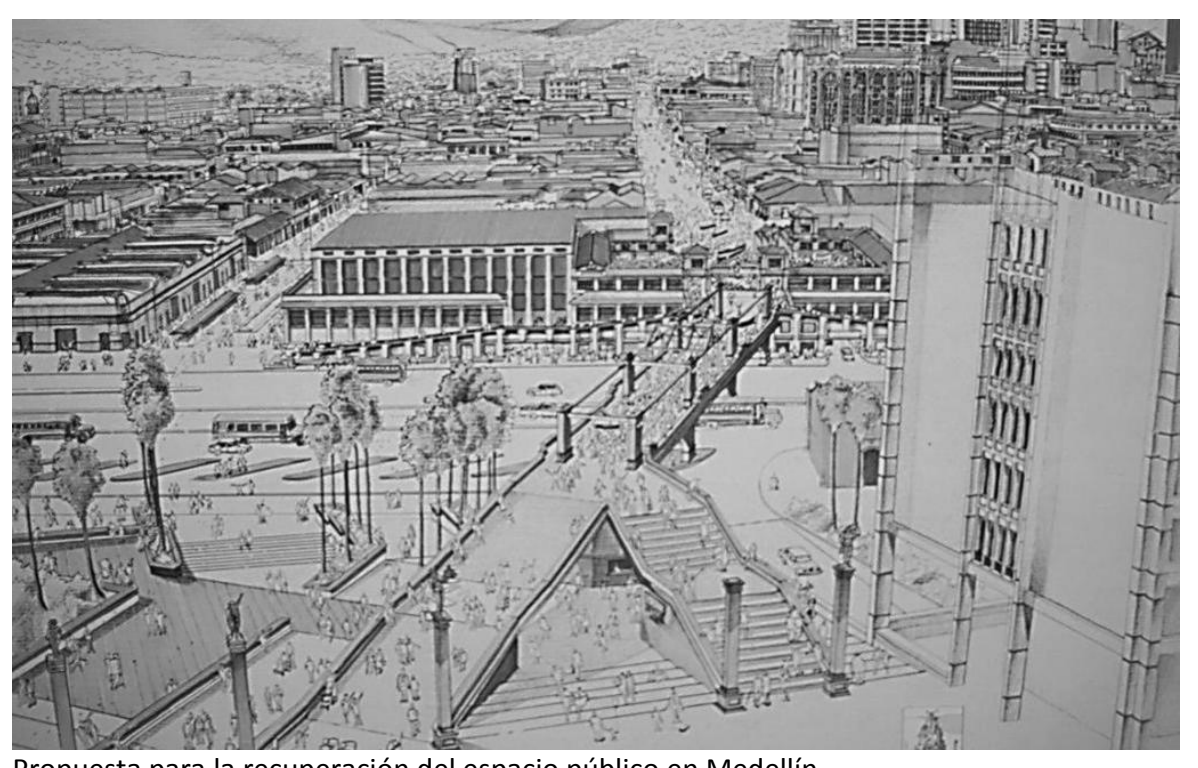

Propuesta para la recuperación del espacio público en Medellín

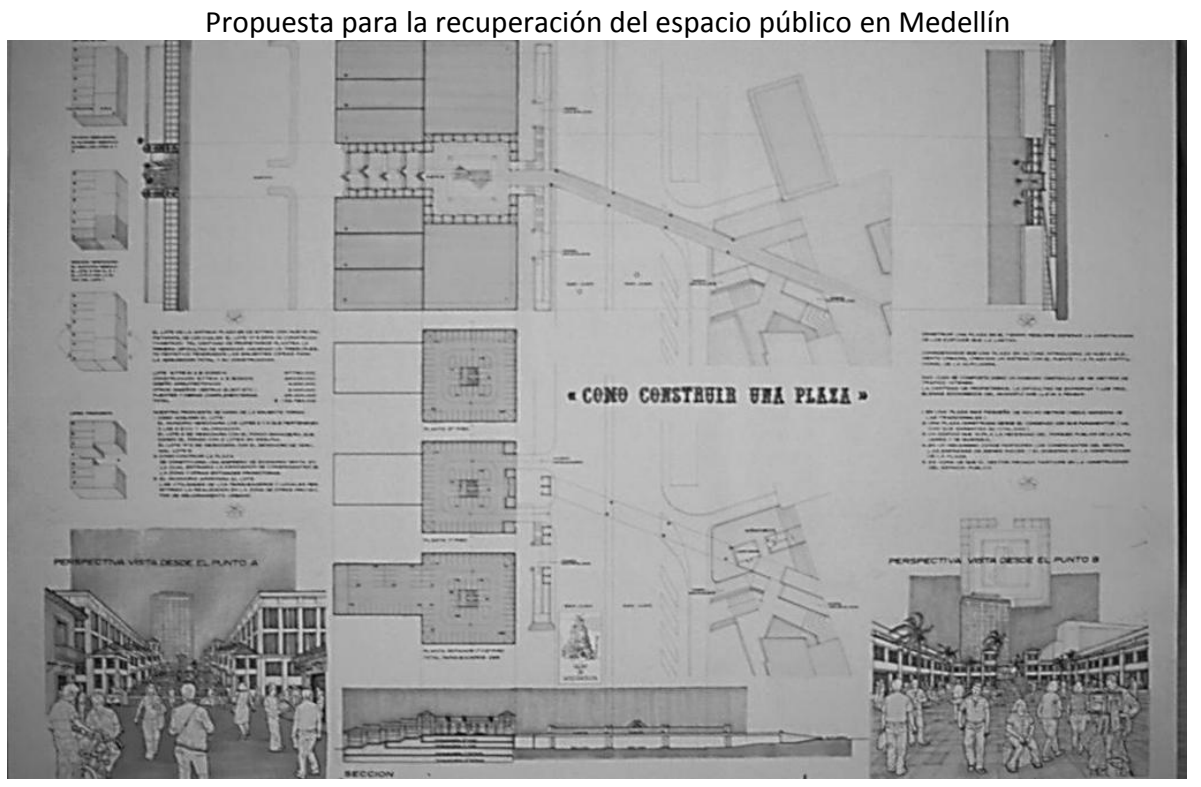


Quadro 17 (Continuação): Análise dos projetos constantes nos registros do V SAL que se enquadram em situações urbanas de "cidade antiga com fachada contínua"

\begin{tabular}{|c|c|c|c|c|c|c|c|c|}
\hline & Autores & Título & $\begin{array}{l}\text { Especificidades da } \\
\text { área de intervenção }\end{array}$ & $\begin{array}{l}\text { Caracterização geral } \\
\text { da proposta }\end{array}$ & Pop. da cidade 1990 & Área de intervenção & $\begin{array}{l}\text { Aspectos } \\
\text { morfológicos }\end{array}$ & Forma de viabilização \\
\hline 岂 & $\begin{array}{l}\text { Murtinho y Asociados } \\
\text { Arquitectos; Cristián } \\
\text { Fernández y } \\
\text { Asociados } \\
\text { Arquitectos; } \\
\text { Manuel Fernández }\end{array}$ & $\begin{array}{l}\text { Propuesta de } \\
\text { normativa urbana: } \\
\text { barrio Santiago } \\
\text { Poniente }\end{array}$ & $\begin{array}{l}\text { Área de expansão } \\
\text { urbana de Santiago } \\
\text { do século XIX e início } \\
\text { do século XX em } \\
\text { decadência } \\
\text { econômica e } \\
\text { separada do centro } \\
\text { histórico pela Av. } \\
\text { Norte Sur. }\end{array}$ & $\begin{array}{l}\text { Revisão das normas } \\
\text { edilííias existentes } \\
\text { que ampliavam as } \\
\text { possibilidades } \\
\text { construtivas } \\
\text { rompendo com os } \\
\text { padrões morfológicos } \\
\text { da área. Proposta visa } \\
\text { manter potencial } \\
\text { construtivo } \\
\text { recuperando a borda } \\
\text { edificada e o miolo } \\
\text { livre do quarteirão. }\end{array}$ & 4,72 milhões & $\begin{array}{l}\text { Verificação dos } \\
\text { parâmetros edilícios } \\
\text { em } 6 \text { hectares }\end{array}$ & $\begin{array}{l}\text { Leitura tipo- } \\
\text { morfológica do } \\
\text { entorno e proposta } \\
\text { que visa recuperar o } \\
\text { quarteirão com a } \\
\text { borda edificada e o } \\
\text { miolo livre. }\end{array}$ & $\begin{array}{l}\text { Plano de massas } \\
\text { como apoio para } \\
\text { revisão das normas. }\end{array}$ \\
\hline 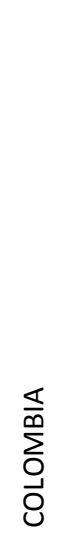 & Ramiro Henao V. & $\begin{array}{l}\text { Propuesta para la } \\
\text { recuperación del } \\
\text { espacio público }\end{array}$ & $\begin{array}{l}\text { Setor Guayaquil do } \\
\text { centro histórico da } \\
\text { cidade de Medellín, } \\
\text { bairro de comércio } \\
\text { popular, no qual se } \\
\text { localizava o } \\
\text { mercando público 'El } \\
\text { Pedrero", removido } \\
\text { em } 1984 \text {. }\end{array}$ & $\begin{array}{l}\text { O projeto visa } \\
\text { conectar a atividade } \\
\text { comercial do bairro } \\
\text { com o centro cívico } \\
\text { da municipalidade de } \\
\text { Medellín e do } \\
\text { governo de Antioquia } \\
\text { através de uma praça } \\
\text { elevada com mercado } \\
\text { e estacionamento no } \\
\text { térreo. }\end{array}$ & 1,6 milhões & $\begin{array}{l}\text { Intervenção em área } \\
\text { um pouco menor que } \\
4 \text { hectares. }\end{array}$ & $\begin{array}{l}\text { Breve indicações de } \\
\text { leitura. } \\
\text { Reverberações do } \\
\text { debate da tipo- } \\
\text { morfologia aparecem } \\
\text { na descrição do } \\
\text { projeto. O tamanho } \\
\text { original da praça é } \\
\text { reduzido para se } \\
\text { aproximar daquele } \\
\text { das "cidades } \\
\text { tradicionais" (dito } \\
40 X 40 \text { no texto) }\end{array}$ & Projeto pontual \\
\hline
\end{tabular}



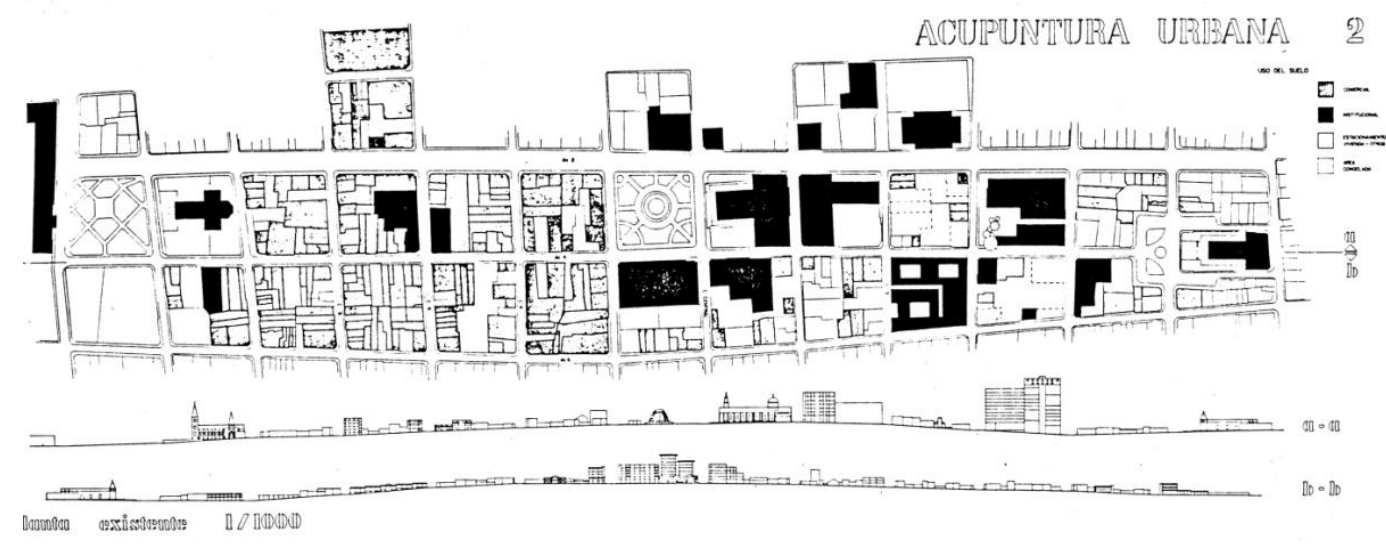

Acupuntura urbana - Bruno Stagno et al.
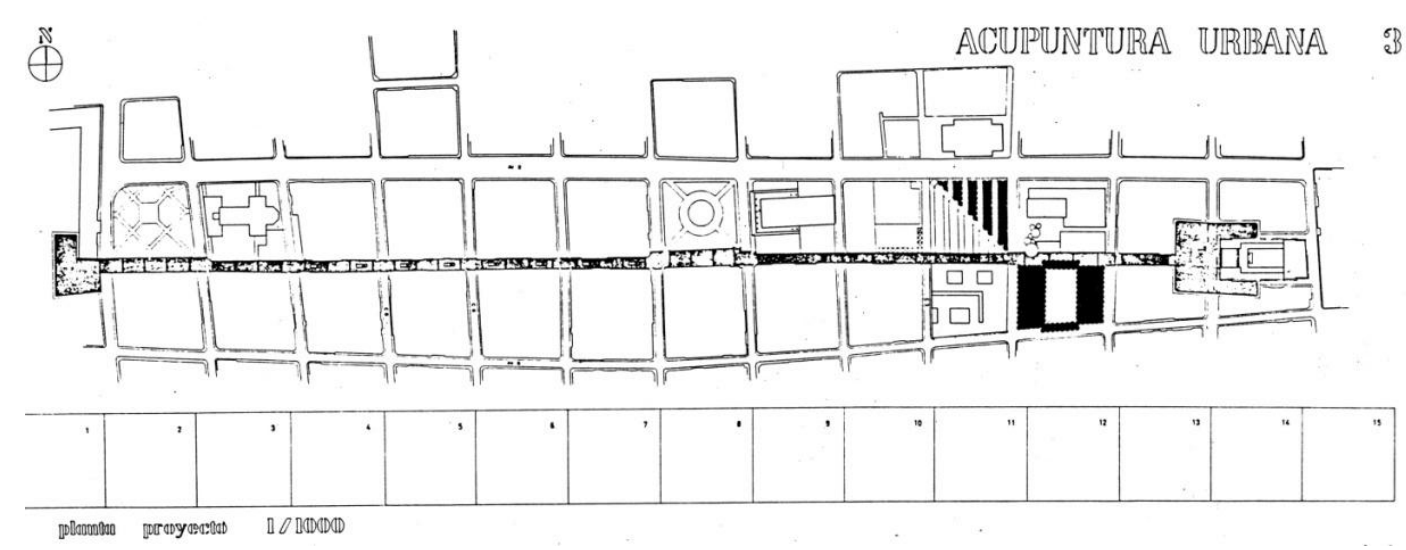

Acupuntura urbana - Bruno Stagno et al.

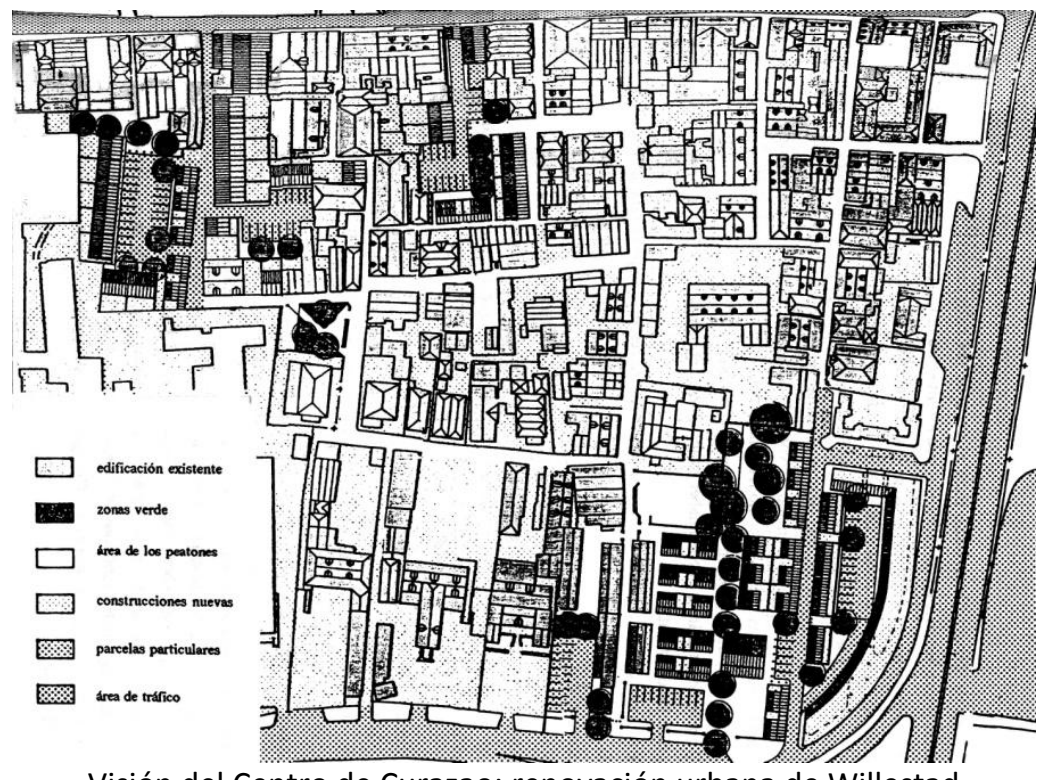

Visión del Centro de Curazao: renovación urbana de Willestad 


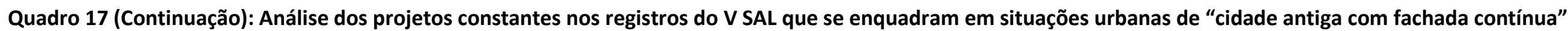

\begin{tabular}{|c|c|c|c|c|c|c|c|c|}
\hline & Autores & Título & $\begin{array}{l}\text { Especificidades da } \\
\text { área de intervenção }\end{array}$ & $\begin{array}{l}\text { Caracterização geral } \\
\text { da proposta }\end{array}$ & Pop. da cidade 1990 & Área de intervenção & $\begin{array}{l}\text { Aspectos } \\
\text { morfológicos }\end{array}$ & Forma de viabilização \\
\hline 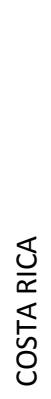 & $\begin{array}{l}\text { Bruno Stagno, } \\
\text { Richard Woodbrige, } \\
\text { Miklos Galambos, } \\
\text { Sylviane Gohuey, } \\
\text { Carlos Araya, Javier } \\
\text { Jarquín }\end{array}$ & $\begin{array}{l}\text { Acupuntura urbana } \\
\text { (consta com nome } \\
\text { distinto no programa) }\end{array}$ & $\begin{array}{l}\text { Centro de San José } \\
\text { em processo de } \\
\text { deterioramento e } \\
\text { abandono, } \\
\text { seccionado em duas } \\
\text { partes pela } 2^{a} a \\
\text { Avenida }\end{array}$ & $\begin{array}{l}\text { O projeto propõe um } \\
\text { segundo eixo de } \\
\text { atração, paralelo à 2ạ } \\
\text { Avenida, mediante a } \\
\text { inserção de } \\
\text { intervenções } \\
\text { pontuais (espaços } \\
\text { para cultura, parque, } \\
\text { promoção de usos } \\
\text { noturnos). }\end{array}$ & $\begin{array}{l}\text { Não há dado para o } \\
\text { período: em } 1985 \\
\text { havia } 745 \text { mil na } \\
\text { região metropolitana } \\
\text { de San José e, em } \\
\text { 2000, havia 1,04 } \\
\text { milhões. }\end{array}$ & $\begin{array}{l}\text { Aproximadamente } 13 \\
\text { hectares. }\end{array}$ & Sem menção & Projetos pontuais \\
\hline 高 & Isabel Rigol & 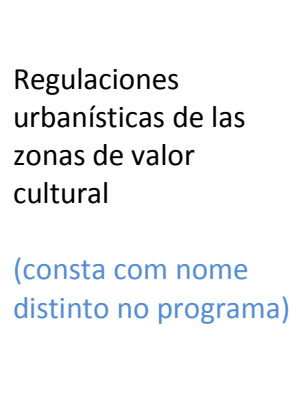 & $\begin{array}{l}\text { Setor Catedral-Plaza } \\
\text { Vieja, local em que se } \\
\text { concentram os } \\
\text { principais } \\
\text { monumentos de } \\
\text { Habana Vieja, } \\
\text { declarada Patrimônio } \\
\text { da Humanidade pela } \\
\text { UNESCO em } 1982\end{array}$ & $\begin{array}{l}\text { Definição de } \\
\text { princípios para } \\
\text { restauração do } \\
\text { centro histórico de } \\
\text { Habana Vieja e } \\
\text { exposição do projeto } \\
\text { para a Plaza Vieja, } \\
\text { uma das } 5 \text { grandes } \\
\text { praças de Habana } \\
\text { Vieja. }\end{array}$ & $\begin{array}{l}102 \text { mil habitantes } \\
\text { em Havana Vieja } \\
\text { (1989). 2,1milhões } \\
\text { em Havana. }\end{array}$ & $\begin{array}{l}\text { Maior que } 10 \\
\text { hectares }\end{array}$ & $\begin{array}{l}\text { Descrição dos } \\
\text { aspectos } \\
\text { morfológicos do } \\
\text { centro histórico }\end{array}$ & $\begin{array}{l}\text { Programa para } \\
\text { restauração - } \\
\text { campanha } \\
\text { internacional. }\end{array}$ \\
\hline 导 & $\begin{array}{l}\text { Domenico Silvestro e } \\
\text { Ronny Lobo }\end{array}$ & $\begin{array}{l}\text { Visión del Centro de } \\
\text { Curazao: renovación } \\
\text { urbana de Willestad }\end{array}$ & $\begin{array}{l}\text { Otrobanda, bairro do } \\
\text { centro histórico de } \\
\text { Willemstad. }\end{array}$ & $\begin{array}{l}\text { Projeto ganhador do } \\
\text { concurso (organizado } \\
\text { pela Fundação Kas } \\
\text { Popular) que se } \\
\text { insere dentro de } \\
\text { estratégia para } \\
\text { renovação do centro } \\
\text { histórico de } \\
\text { Willemstad através } \\
\text { da promoção de } \\
\text { habitação no interior } \\
\text { de seu tecido urbano. }\end{array}$ & $\begin{array}{l}\text { Menos de } 100 \text { mil } \\
\text { habitantes. }\end{array}$ & $\begin{array}{l}\text { A área de intervenção } \\
\text { corresponde aos } \\
\text { limites estabelecidos } \\
\text { pela convocatória. }\end{array}$ & $\begin{array}{l}\text { Breve descrição } \\
\text { morfológica do setor } \\
\text { de otrobanda, ênfase } \\
\text { em seus callejones. }\end{array}$ & $\begin{array}{l}\text { Projeto de } 32 \\
\text { habitações dentro do } \\
\text { centro histórico }\end{array}$ \\
\hline
\end{tabular}




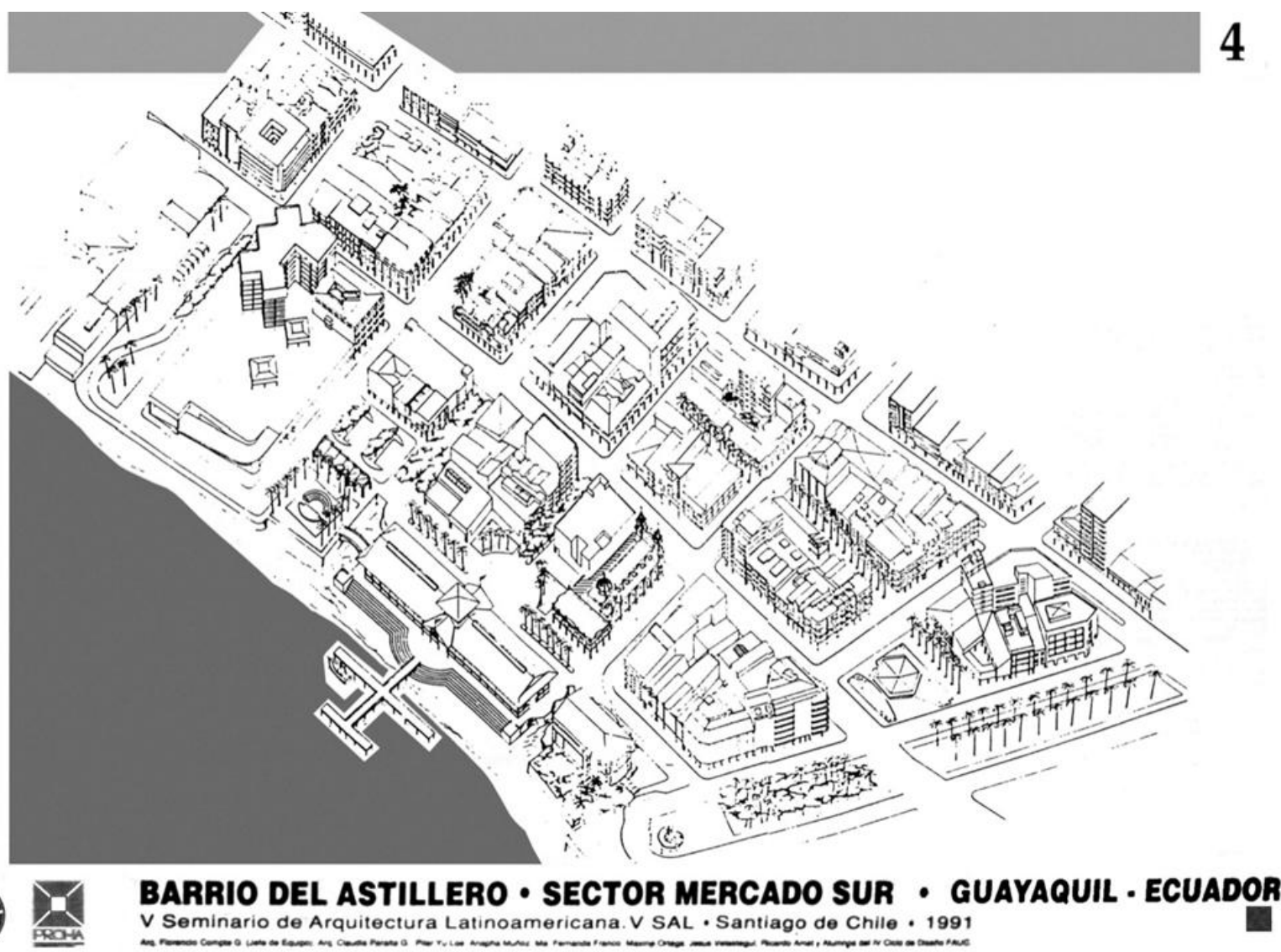

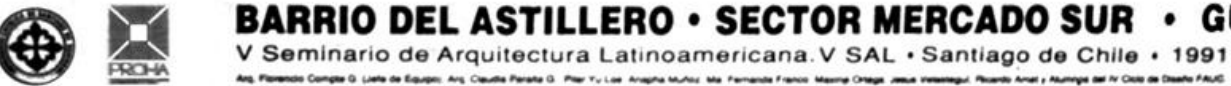




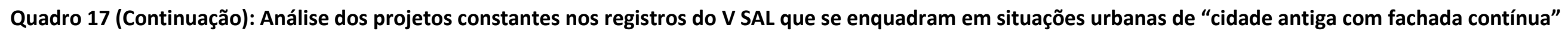

\begin{tabular}{|c|c|c|c|c|c|c|c|c|}
\hline & Autores & Título & $\begin{array}{l}\text { Especificidades da } \\
\text { área de intervenção }\end{array}$ & $\begin{array}{l}\text { Caracterização geral } \\
\text { da proposta }\end{array}$ & Pop. da cidade 1990 & Área de intervenção & $\begin{array}{l}\text { Aspectos } \\
\text { morfológicos }\end{array}$ & Forma de viabilização \\
\hline 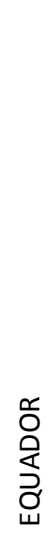 & $\begin{array}{l}\text { Florencio Compte G. } \\
\text { (coord); Claudai } \\
\text { Perana G.; Pilar } \\
\text { Yulos, Anapha } \\
\text { Muñoz; María } \\
\text { Fernanda Franco; } \\
\text { Marina Ortega; Jesús } \\
\text { Velastegui; Ricardo } \\
\text { Amat e alunos da } \\
\text { FAUC }\end{array}$ & $\begin{array}{l}\text { Barrio del Astillero, } \\
\text { Sector Sur, Guayaquil } \\
\text { (consta com nome } \\
\text { distinto no } \\
\text { programa) }\end{array}$ & $\begin{array}{l}\text { Setor histórico na } \\
\text { parte sul do centro } \\
\text { de Guayaquil, frente } \\
\text { ao rio Guayas, com o } \\
\text { patrimônio edificado } \\
\text { em processo de } \\
\text { deterioramento. }\end{array}$ & $\begin{array}{l}\text { Propõe-se a } \\
\text { classificação das } \\
\text { edificações de acordo } \\
\text { com o grau de } \\
\text { prioridade de } \\
\text { restauração, além da } \\
\text { criação de novos } \\
\text { espaços espaços } \\
\text { públicos (áreas de } \\
\text { calçadão, espaços } \\
\text { junto ao rio e novas } \\
\text { hierarquizações nas } \\
\text { vias) }\end{array}$ & 1,5 milhões & 10 hectáres & $\begin{array}{l}\text { Breves menções ao } \\
\text { longo do texto ao } \\
\text { fato de ser necessária } \\
\text { a recuperação da } \\
\text { unidade morfológica } \\
\text { e tipológica da área, } \\
\text { sem buscar } \\
\text { caracterizá-la }\end{array}$ & Normas para o setor \\
\hline 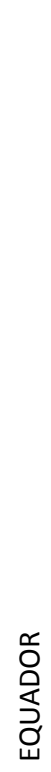 & $\begin{array}{l}\text { Pablo Lee T (coord); } \\
\text { Mônica Hinostroza } \\
\text { A.; Rafael } \\
\text { Armendánz. Pilar Yu; } \\
\text { Marcela Salazar; } \\
\text { Ricardo Bohorquez; } \\
\text { Consuna Agudo; } \\
\text { Jesús Velastegui; } \\
\text { Ricardo Amal e } \\
\text { alunos da FAUC }\end{array}$ & $\begin{array}{l}\text { Área Histórica Barrio } \\
\text { las Peñas, Guayaquil }\end{array}$ & $\begin{array}{l}\text { Setor de interesse } \\
\text { histórico de } \\
\text { Guayaquil (área de } \\
\text { fundação da cidade) } \\
\text { junto ao Rio Guayas. } \\
\text { Caracteriza-se pela } \\
\text { presença de grandes } \\
\text { edificações em } \\
\text { desuso ( } 30 \% \text { da } \\
\text { área), pelo } \\
\text { deterioramento do } \\
\text { patrimônio } \\
\text { arquitetônico e } \\
\text { urbano, pela } \\
\text { presença de vazios } \\
\text { urbanos (13\% da } \\
\text { área) e de } \\
\text { assentamentos } \\
\text { periféricos junto aos } \\
\text { morros. }\end{array}$ & $\begin{array}{l}\text { Propõe-se a } \\
\text { revalorização do } \\
\text { patrimônio; a } \\
\text { articulação entre } \\
\text { parques em praças } \\
\text { existentes; fomentar } \\
\text { atividades ao redor } \\
\text { dos monumentos e } \\
\text { das praças, } \\
\text { reabilitando edifícios } \\
\text { abandonados e } \\
\text { facilitar o acesso aos } \\
\text { assentamentos dos } \\
\text { morros. }\end{array}$ & 1,5 milhões & 10 hectares & $\begin{array}{l}\text { Menção ao fato de a } \\
\text { estrutura morfológica } \\
\text { não estar } \\
\text { consolidada. }\end{array}$ & $\begin{array}{l}\text { Normas para Las Peñas e } \\
\text { seu entorno }\end{array}$ \\
\hline
\end{tabular}




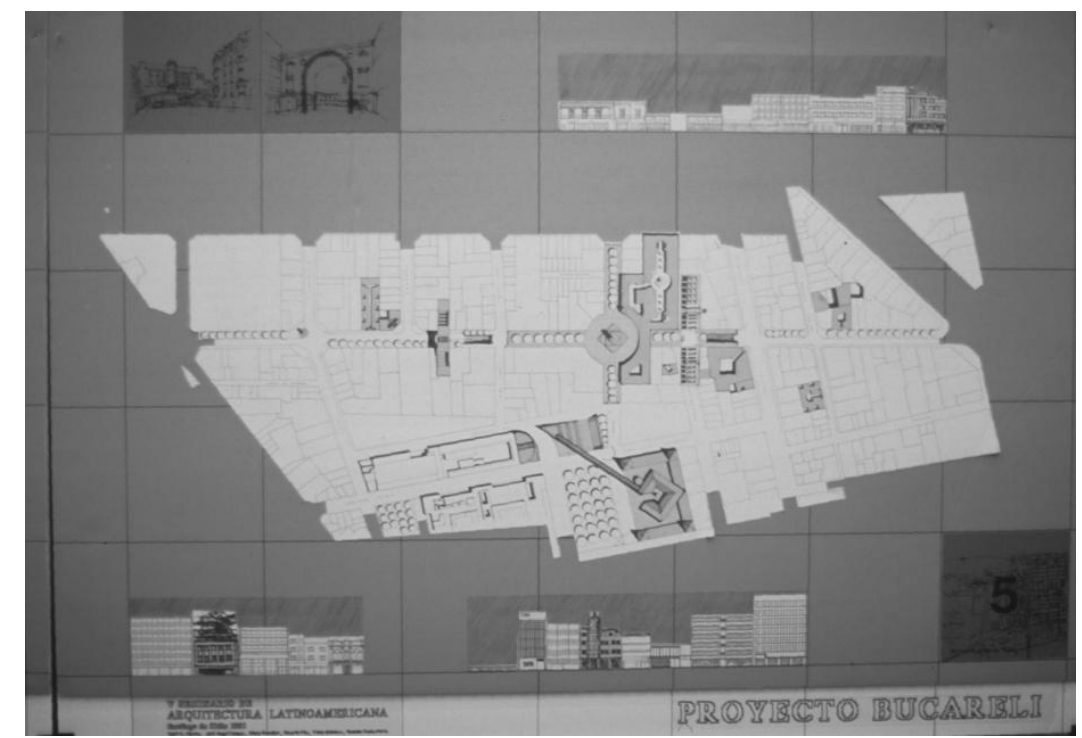

Proyecto Bucareli

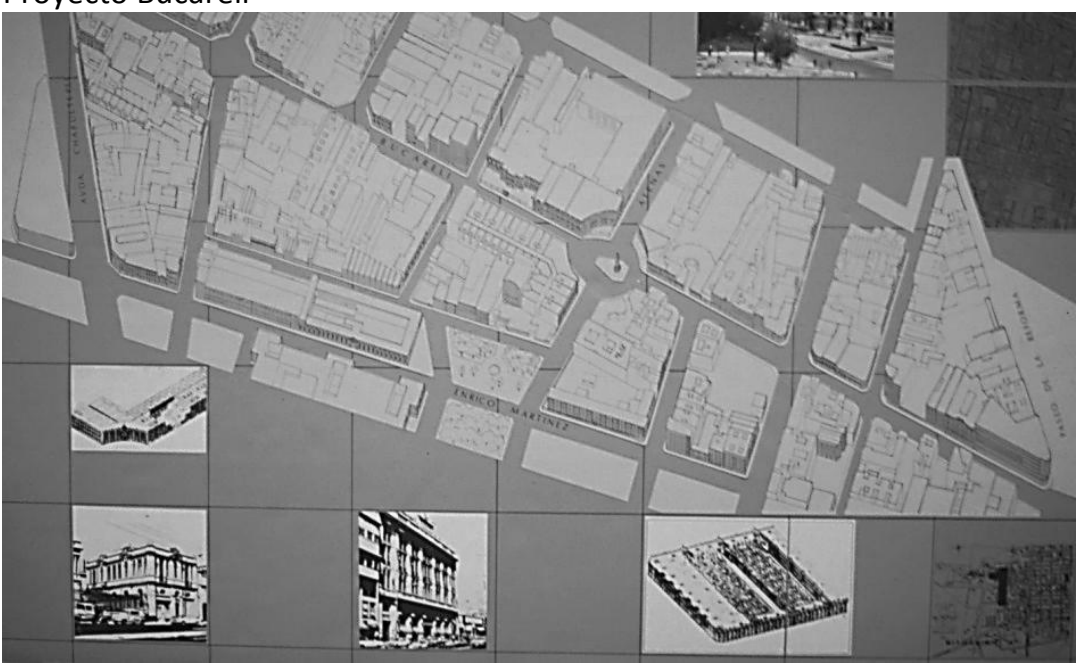

Rescatar la idendidad Barrial de la Ciudad - Rafael Rangel Lopez

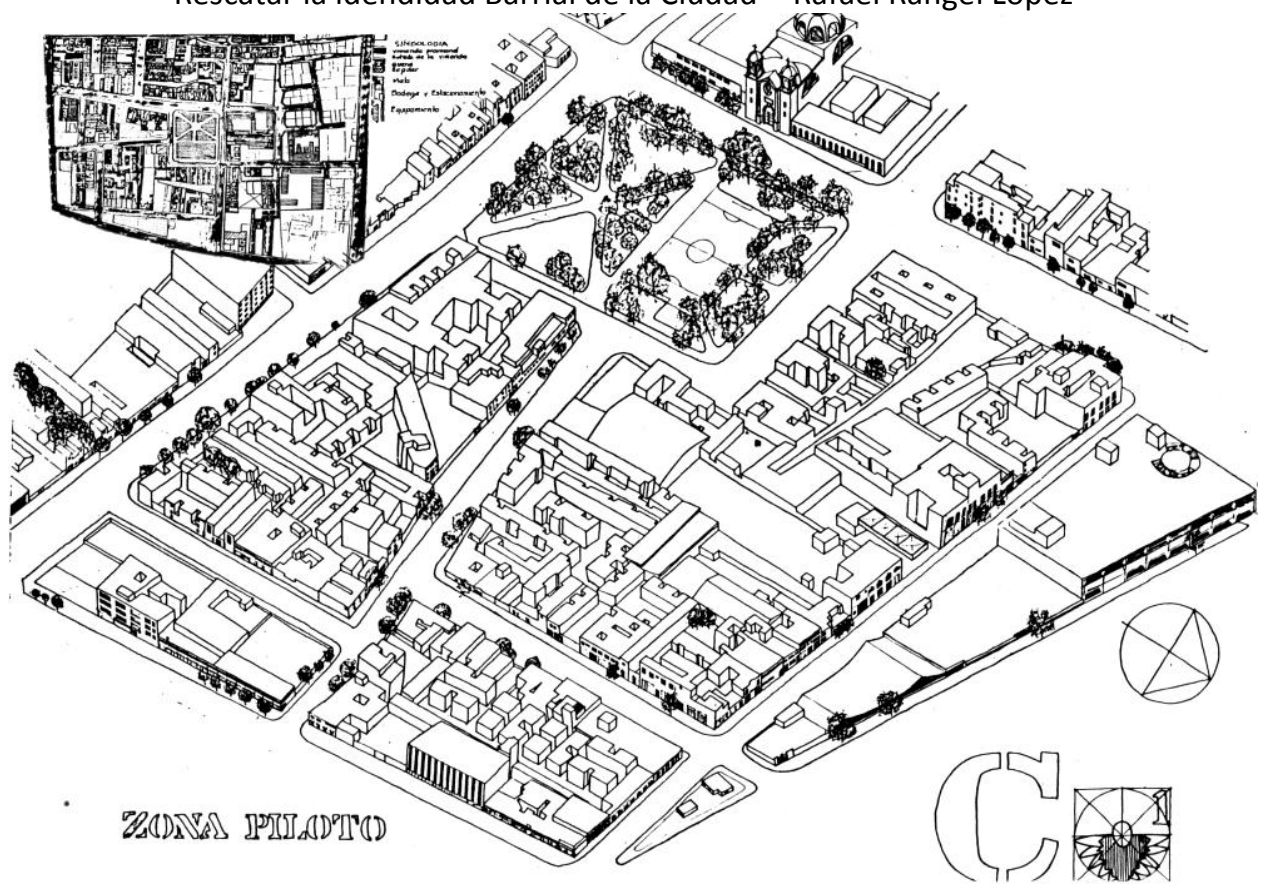




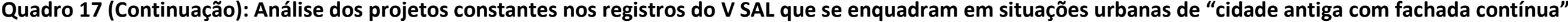

\begin{tabular}{|c|c|c|c|c|c|c|c|c|}
\hline & Autores & Título & $\begin{array}{l}\text { Especificidades da } \\
\text { área de intervenção }\end{array}$ & $\begin{array}{l}\text { Caracterização geral } \\
\text { da proposta }\end{array}$ & Pop. da cidade 1990 & Área de intervenção & Aspectos morfológicos & Forma de viabilização \\
\hline 얼 & $\begin{array}{l}\text { José Angeli Campos, } \\
\text { Alicia González, } \\
\text { Ricardo Pita, Pablo } \\
\text { Quintero, Rodolfo } \\
\text { Santa María }\end{array}$ & $\begin{array}{l}\text { Proyecto Bucareli } \\
\text { (não consta no } \\
\text { programa) }\end{array}$ & $\begin{array}{l}\text { Aérea histórica da } \\
\text { Cidade do México, } \\
\text { junto a Avenida } \\
\text { Bucareli, aberta pela } \\
\text { coroa espanhola no } \\
\text { séc. XVIII. }\end{array}$ & $\begin{array}{l}\text { Intervenções no } \\
\text { espaço público e } \\
\text { definição de normas } \\
\text { que definem } \\
\text { parâmetros para as } \\
\text { novas edificações de } \\
\text { acordo com o } \\
\text { patrimônio edilício } \\
\text { existente: alturas, } \\
\text { alinhamento junto à } \\
\text { rua, fachada } \\
\text { contínua, etc. }\end{array}$ & 20 milhões & $\begin{array}{l}\text { Área um pouco maior } \\
\text { que } 10 \text { hectares. }\end{array}$ & $\begin{array}{l}\text { Referências Rossianas: } \\
\text { a estrutura urbana } \\
\text { como artefato, a } \\
\text { permanência do } \\
\text { traçado urbano; } \\
\text { recuperação dos tipos } \\
\text { edilícios como } \\
\text { construções históricas } \\
\text { e coletivas. }\end{array}$ & normas \\
\hline 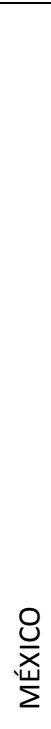 & Rafael Rangel Lopez & $\begin{array}{l}\text { Rescatar la idendidad } \\
\text { Barrial de la Ciudad }\end{array}$ & $\begin{array}{l}\text { Bairro Los Angeles no } \\
\text { centro histórico da } \\
\text { Ciudad do México }\end{array}$ & $\begin{array}{l}\text { Propõe o resgate da } \\
\text { identidade do bairro } \\
\text { Utiliza parte do } \\
\text { bairro Los Angeles } \\
\text { como zona piloto } \\
\text { para experimentação } \\
\text { das normas: } \\
\text { redesenho de } \\
\text { espaços públicos, } \\
\text { novos equipamentos, } \\
\text { restauro e reciclgem } \\
\text { do patrimônio } \\
\text { existente, diminuição } \\
\text { do fluxo de veículos } \\
\text { no interior do bairro, } \\
\text { tipo-morfologia } \\
\text { existente como } \\
\text { parâmetro para as } \\
\text { normas. }\end{array}$ & 20 milhões & $\begin{array}{l}\text { Experimentação em } \\
\text { área de } \\
\text { aproximadamente } 5 \\
\text { hectares }\end{array}$ & $\begin{array}{l}\text { Leitura simplifica de } \\
\text { aspectos tipo- } \\
\text { morfológicos do bairro } \\
\text { Los Angeles, somada a } \\
\text { leitura dos aspectos } \\
\text { sócioeconômicos. } \\
\text { Afirmação do bairro } \\
\text { como princípio para } \\
\text { intervenção na cidade. }\end{array}$ & $\begin{array}{l}\text { Plano de massas como } \\
\text { base para normas }\end{array}$ \\
\hline
\end{tabular}




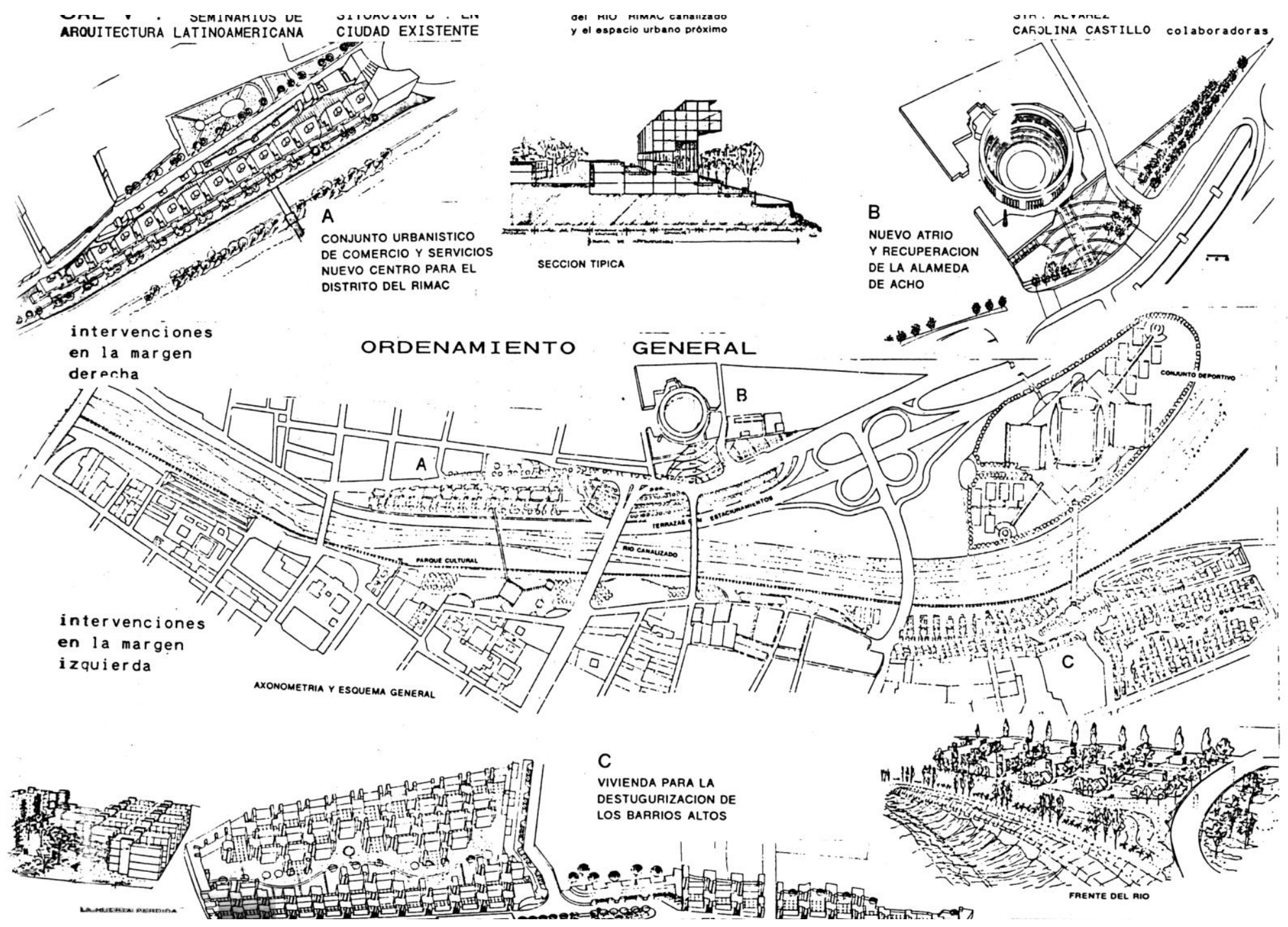

Los espacios del Rio - Augusto Ortiz de Zeballos; Luis Delgado Galimberti 


\section{Quadro 17 (Continuação): Análise dos projetos constantes nos registros do V SAL que se enquadram em situações urbanas de "cidade antiga com fachada contínua"}

\begin{tabular}{|c|c|c|c|c|c|c|c|c|}
\hline & Autores & Título & $\begin{array}{l}\text { Especificidades da área } \\
\text { de intervenção }\end{array}$ & $\begin{array}{l}\text { Caracterização } \\
\text { geral da proposta }\end{array}$ & $\begin{array}{l}\text { Pop. da cidade } \\
1990\end{array}$ & $\begin{array}{l}\text { Área de } \\
\text { intervenção }\end{array}$ & $\begin{array}{l}\text { Aspectos } \\
\text { morfológicos }\end{array}$ & Forma de viabilização \\
\hline 얼 & $\begin{array}{l}\text { Ernesto Alva, } \\
\text { Alejadro Zahn, } \\
\text { Agustin Parodi }\end{array}$ & $\begin{array}{l}\text { Intervención en } \\
\text { situación urbana } \\
\text { de ciudad antigua } \\
\text { con fachada } \\
\text { continua } \\
\text { (não consta no } \\
\text { programa) }\end{array}$ & $\begin{array}{l}\text { Centro histórico de } \\
\text { Guadalajara, junto à } \\
\text { praça das Armas e a } \\
\text { Catedral. São apontados } \\
\text { como problemas: a } \\
\text { diferença entre as alturas } \\
\text { das edificações históricas } \\
\text { e aquelas de edifícios } \\
\text { verticais construídos nos } \\
\text { anos 1950; a grande } \\
\text { afluência de veículos e } \\
\text { pedestres e } \\
\text { subaproveitamento } \\
\text { construtivo da área. }\end{array}$ & $\begin{array}{l}\text { A proposta prevê a } \\
\text { articulação das } \\
\text { diferentes alturas, } \\
\text { definido um plano } \\
\text { frontal com altura } \\
\text { menor, a partir do } \\
\text { qual se dá o } \\
\text { escalonamento do } \\
\text { potencial } \\
\text { construtivo. } \\
\text { Concebe-se } \\
\text { também uma rede } \\
\text { elevada para } \\
\text { circulação do } \\
\text { pedestre. }\end{array}$ & 1,65 milhões & $\begin{array}{l}\text { Aproximadamente } \\
10 \text { hectares }\end{array}$ & $\begin{array}{l}\text { Aspectos visuais } \\
\text { (limpeza de } \\
\text { fachadas, } \\
\text { percepção a partir } \\
\text { da rua), têm maior } \\
\text { importância na } \\
\text { justificativa do } \\
\text { projeto, }\end{array}$ & $\begin{array}{l}\text { Plano de massas como base para } \\
\text { normas }\end{array}$ \\
\hline 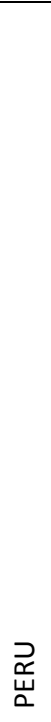 & $\begin{array}{l}\text { Augusto Ortiz de } \\
\text { Zeballos; Luis } \\
\text { Delgado Galimberti }\end{array}$ & $\begin{array}{l}\text { Los espacios del } \\
\text { Rio }\end{array}$ & $\begin{array}{l}\text { Margens do rio Rimac } \\
\text { cujo antigo parque deu } \\
\text { espaço a vias expressas. } \\
\text { A área de intervenção } \\
\text { situa-se junto ao centro } \\
\text { histórico de Lima - que } \\
\text { foi paulatinamente } \\
\text { perdendo seus espaços } \\
\text { públicos e seu } \\
\text { patrimônio - no qual as } \\
\text { margens do rio } \\
\text { representam o único } \\
\text { espaço livre possível. }\end{array}$ & $\begin{array}{l}\text { O projeto tira } \\
\text { partido das áreas } \\
\text { sobressalientes às } \\
\text { margens do rio } \\
\text { após } \\
\text { implementação de } \\
\text { projeto de sua } \\
\text { canalização, as } \\
\text { quais utiliza para } \\
\text { proposição de um } \\
\text { novo plano de } \\
\text { massas para as } \\
\text { frente d'água, } \\
\text { transformando o } \\
\text { rio no espaço } \\
\text { principal da cidade. } \\
\text { Edificações } \\
\text { definem o espaço } \\
\text { público. }\end{array}$ & $\begin{array}{l}6,7 \text { milhões na } \\
\text { região } \\
\text { metropolitana. }\end{array}$ & $\begin{array}{l}\text { Um pouco mais } \\
\text { que } 10 \text { hectares }\end{array}$ & $\begin{array}{l}\text { Traçado da } \\
\text { proposta recupera } \\
\text { morforlogia } \\
\text { urbana do centro } \\
\text { de Lima e do } \\
\text { distritro Rimac. } \\
\text { Busca } \\
\text { "especificidade } \\
\text { limenha" na } \\
\text { mescla de tipos } \\
\text { urbano- } \\
\text { arquitetônicos. }\end{array}$ & 'Projeto urbano \\
\hline
\end{tabular}




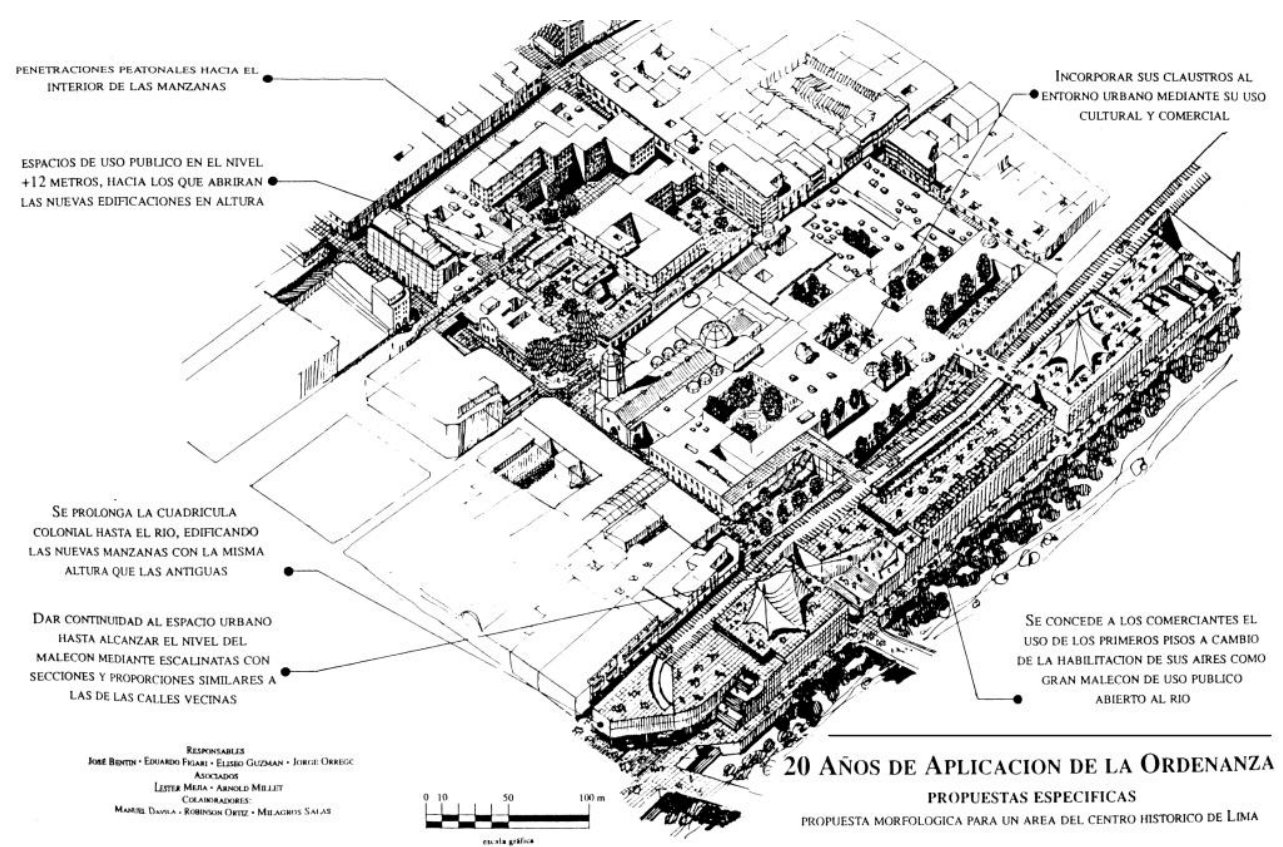

Propuesta morfológica para un área del centro histórico de Lima

Plan de rescate y revitalización de Chacao

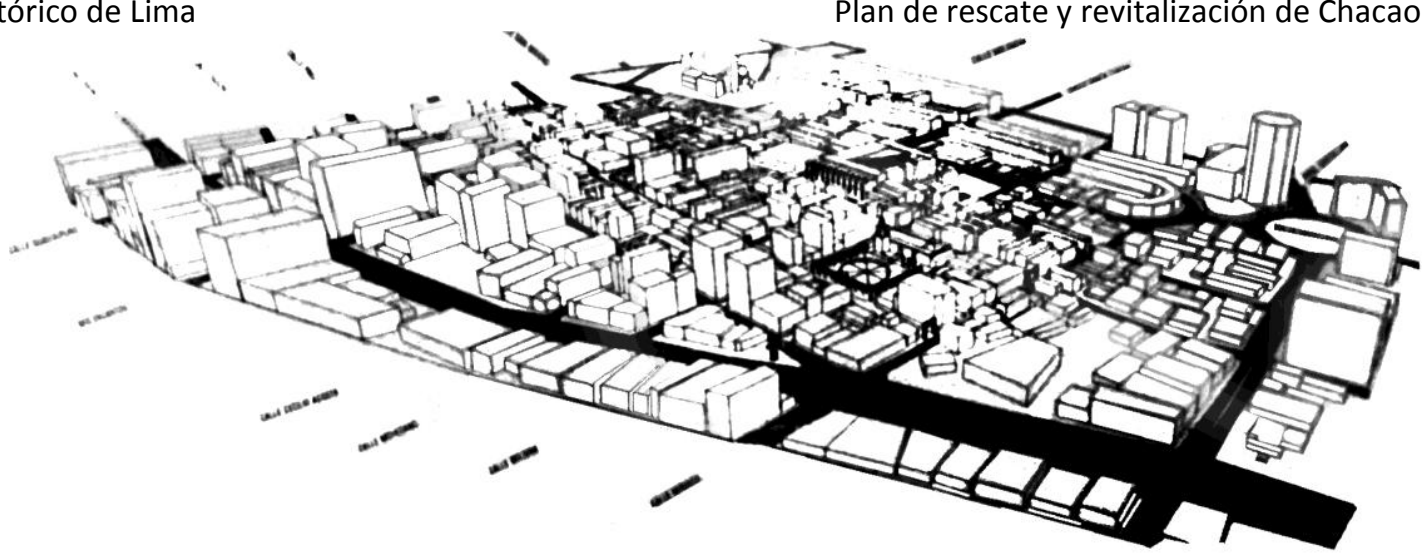




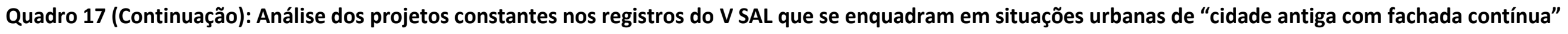

\begin{tabular}{|c|c|c|c|c|c|c|c|c|}
\hline & Autores & Título & $\begin{array}{l}\text { Especificidades da } \\
\text { área de intervenção }\end{array}$ & $\begin{array}{l}\text { Caracterização geral } \\
\text { da proposta }\end{array}$ & Pop. da cidade 1990 & Área de intervenção & $\begin{array}{l}\text { Aspectos } \\
\text { morfológicos }\end{array}$ & $\begin{array}{l}\text { Forma de } \\
\text { viabilização }\end{array}$ \\
\hline 룸 & $\begin{array}{l}\text { José Bentin, Eduardo } \\
\text { Figari, Eliseo Guzman, } \\
\text { Jorge Orrego }\end{array}$ & $\begin{array}{l}\text { Propuesta } \\
\text { morfológica para un } \\
\text { área del centro } \\
\text { histórico de Lima }\end{array}$ & $\begin{array}{l}\text { Área do centro } \\
\text { histórico de Lima. } \\
\text { Incompatibilidade } \\
\text { entre as leis de uso e } \\
\text { ocupação e as de } \\
\text { patrimônio. Na área } \\
\text { de intervenção } \\
\text { coexistem o conjunto } \\
\text { do Convento de } \\
\text { Santo Domingo, uma } \\
\text { plataforma junto ao } \\
\text { rio (resultante de um } \\
\text { projeto inacabado) } \\
\text { ocupada por } \\
\text { comerciantes } \\
\text { ambulantes e o } \\
\text { quarteirão típico } \\
\text { colonial. }\end{array}$ & $\begin{array}{l}\text { A proposta propõe: } \\
\text { transformar em áreas } \\
\text { de uso público o } \\
\text { interior dos } \\
\text { quarteirões; articular } \\
\text { os monumentos } \\
\text { através dos espaços } \\
\text { públicos; dar } \\
\text { continuidade à } \\
\text { quadrícula colonial } \\
\text { até o rio; incorporar a } \\
\text { plataforma em } \\
\text { desuso com comércio } \\
\text { nos dois primeiros } \\
\text { pisos e como grande } \\
\text { espaço público junto } \\
\text { ao rio e criar ruas } \\
\text { elevadas para } \\
\text { pedestres. }\end{array}$ & $\begin{array}{l}6,7 \text { milhões na região } \\
\text { metropolitana. }\end{array}$ & $\begin{array}{l}\text { Um pouco menos } \\
\text { que } 4 \text { hectares }\end{array}$ & $\begin{array}{l}\text { Menção à } \\
\text { necessidade de uma } \\
\text { normativa } \\
\text { morfológica e a } \\
\text { quadrícula colonial. } \\
\text { Não há leitura dos } \\
\text { aspectos tipo- } \\
\text { morfológicos }\end{array}$ & $\begin{array}{l}\text { Plano de Massa como } \\
\text { base para norma. }\end{array}$ \\
\hline 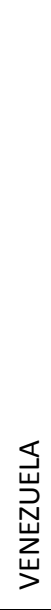 & Frank Marcano R & $\begin{array}{l}\text { Plan de rescate y } \\
\text { revitalización de } \\
\text { Chacao }\end{array}$ & $\begin{array}{l}\text { Antigo vilarejo do } \\
\text { séc. XVIII, hoje bairro } \\
\text { de Caracas que } \\
\text { consolidou sua forma } \\
\text { urbana nos anos } \\
1950 \text { com edificações } \\
\text { de } 6 \text { pav. e fachada } \\
\text { contínua. Diversidade } \\
\text { no tecido urbano de } \\
\text { Chacao: a oeste } \\
\text { novas edificações de } \\
14 \text { pavimentos, ao } \\
\text { norte área de baixa } \\
\text { densidade com } \\
\text { edificações em } \\
\text { deterioramento. }\end{array}$ & $\begin{array}{l}\text { A proposta diferencia } \\
\text { intervenções de } \\
\text { repercussão geral } \\
\text { (regularização de } \\
\text { espaços públicos, } \\
\text { normas), das ações } \\
\text { de caráter específico } \\
\text { e pontuais que se } \\
\text { destinam às unidades } \\
\text { morfológicas } \\
\text { identificadas. }\end{array}$ & $\begin{array}{l}1,8 \text { milhões em } \\
\text { Caracas e } 3,12 \\
\text { milhões na região } \\
\text { metropolitana }\end{array}$ & $\begin{array}{l}\text { Maior que } 10 \\
\text { hectares (bairro) }\end{array}$ & $\begin{array}{l}\text { Caracteriza quatro } \\
\text { diferentes unidades } \\
\text { morfológicas }\end{array}$ & $\begin{array}{l}\text { Intervenções } \\
\text { "catalizadoras" em } \\
\text { espaços públicos } \\
\text { somadas a princípios } \\
\text { para revisão das } \\
\text { normas urbanísticas }\end{array}$ \\
\hline
\end{tabular}


Intervenções em situações urbanas com trama urbana tipo cidade-jardim.

\section{Quadro 18: Análise dos projetos constantes nos registros do V SAL que se enquadram em situações urbanas de "trama urbana tipo cidade-jardim"}

\begin{tabular}{|c|c|c|c|c|c|c|c|c|}
\hline & Autores & Título & $\begin{array}{l}\text { Especificidades da } \\
\text { área de intervenção }\end{array}$ & $\begin{array}{l}\text { Caracterização geral } \\
\text { da proposta }\end{array}$ & Pop. da cidade 1990 & Área de intervenção & $\begin{array}{l}\text { Aspectos } \\
\text { morfológicos }\end{array}$ & $\begin{array}{l}\text { Forma de } \\
\text { viabilização }\end{array}$ \\
\hline 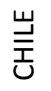 & Germán Bahnen & Providencia & \multicolumn{6}{|c|}{ NÃO CONSTA NOS ANAIS, SOMENTE NA PROGRAMAÇÃO } \\
\hline 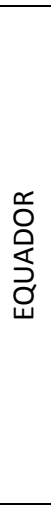 & $\begin{array}{l}\text { Alexandra Crespo, } \\
\text { Graciela Avalos, Silvio } \\
\text { Albarrán, Rodrigo } \\
\text { Torres, Paul Aguilar }\end{array}$ & La Mariscal & $\begin{array}{l}\text { Bairro "Mariscal } \\
\text { Sucre" de Quito, que } \\
\text { data da década de } \\
1930 \text { e cuja } \\
\text { urbanização } \\
\text { reverberava ideário } \\
\text { da cidade-jardim. As } \\
\text { características } \\
\text { originais do tecido e } \\
\text { das edificações do } \\
\text { bairro foram se } \\
\text { perdendo com o } \\
\text { passar dos anos }\end{array}$ & $\begin{array}{l}\text { Normas específicas } \\
\text { visam recuperar as } \\
\text { características } \\
\text { originais do setor } \\
\text { urbano, melhorando } \\
\text { as condições } \\
\text { morfológicas e } \\
\text { ambientais do } \\
\text { entorno e } \\
\text { reabilitando } \\
\text { edificações }\end{array}$ & 1,1 milhões & $\begin{array}{l}\text { Área maior que } 10 \\
\text { hectares }\end{array}$ & $\begin{array}{l}\text { Descrição do tecido } \\
\text { urbano que } \\
\text { caracterizava } \\
\text { Mariscal, em } \\
\text { oposição ao tecido de } \\
\text { Quito do centro } \\
\text { histórico. }\end{array}$ & $\begin{array}{l}\text { Normas de uso e } \\
\text { ocupação específicas }\end{array}$ \\
\hline 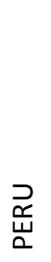 & $\begin{array}{l}\text { Raul Florez, Reynaldo } \\
\text { Ledgard }\end{array}$ & $\begin{array}{l}\text { San Miguel } \\
\text { (maranga) } \\
\text { (Não consta no } \\
\text { programa) }\end{array}$ & $\begin{array}{l}\text { Antigo balneário de } \\
\text { Lima, com } \\
\text { configuração de } \\
\text { loteamento jardim. }\end{array}$ & $\begin{array}{l}\text { Propõe-se a } \\
\text { densificação da área } \\
\text { com a manutenção } \\
\text { da estrutura } \\
\text { fundiária existente }\end{array}$ & $\begin{array}{l}6,7 \text { milhões na região } \\
\text { metropolitana. }\end{array}$ & $\begin{array}{l}\text { Aproximadamente } 7 \\
\text { hectares }\end{array}$ & Sem menção & Sem menção \\
\hline
\end{tabular}




\section{Intervenções em situações urbanas com edificação isolada de média altura.}

\section{Quadro 19:Análise dos projetos constantes nos registros do V SAL que se enquadram em situações urbanas " com edificação isolada de média altura"}

\begin{tabular}{|c|c|c|c|c|c|c|c|c|}
\hline & Autores & Título & $\begin{array}{l}\text { Especificidades da } \\
\text { área de intervenção }\end{array}$ & $\begin{array}{l}\text { Caracterização geral } \\
\text { da proposta }\end{array}$ & Pop. da cidade 1990 & Área de intervenção & $\begin{array}{l}\text { Aspectos } \\
\text { morfológicos }\end{array}$ & $\begin{array}{l}\text { Forma de } \\
\text { viabilização }\end{array}$ \\
\hline $\begin{array}{l}\frac{1}{0} \\
\sum_{0}^{0} \\
\text { Oல }\end{array}$ & $\begin{array}{l}\text { Sérgio Trujillo } \\
\text { Jaramillo e Juan } \\
\text { Manuel Gutierrez } \\
\text { Alvarez }\end{array}$ & $\begin{array}{l}\text { Proyecto de } \\
\text { Agrupaciones de } \\
\text { lotes y diseño de } \\
\text { áreas comunales } \\
\text { Ciudad Salitre }\end{array}$ & $\begin{array}{l}\text { Ciudad Salitre, bairro } \\
\text { projetado em área de } \\
250 \text { hectares, recente } \\
\text { de ocupação em } \\
\text { Bogotá - área que } \\
\text { permaneceu como a } \\
\text { fazenda "El Salitre" } \\
\text { até } 1987 .\end{array}$ & $\begin{array}{l}\text { Projeto de } \\
\text { agrupamento de } \\
\text { lotes a fim de } \\
\text { permitir o desenho } \\
\text { de edifícios- } \\
\text { quarteirões com } 5 \\
\text { pavimentos e áreas } \\
\text { comuns em seu } \\
\text { interior Unificação } \\
\text { das áreas comuns }\end{array}$ & 4,95 milhões & $\begin{array}{l}\text { Experimentação em } \\
\text { área menor que } 4 \\
\text { hectares }\end{array}$ & $\begin{array}{l}\text { Não há menção no } \\
\text { memorial, no } \\
\text { entanto, o projeto } \\
\text { tem como base a } \\
\text { recuperação do } \\
\text { quarteirão com } \\
\text { fachada contínua, } \\
\text { alta densidade e } \\
\text { baixa altura. }\end{array}$ & $\begin{array}{l}\text { Desenho de } \\
\text { repertórios de } \\
\text { soluções possíveis a } \\
\text { fim de facilitar a } \\
\text { interpretação das } \\
\text { normas. Legislação } \\
\text { específica para cada } \\
\text { agrupação. }\end{array}$ \\
\hline 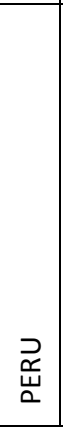 & $\begin{array}{l}\text { Fernando Correa } \\
\text { Millar, Manuel } \\
\text { Riveiro D’Angelo, } \\
\text { Manuel Zubiate Vidal }\end{array}$ & $\begin{array}{l}\text { Área de ciudad } \\
\text { existente con } \\
\text { edificacion aislada de } \\
\text { altura media. Distrito } \\
\text { de San Isidro } \\
\text { (não consta na } \\
\text { programação) }\end{array}$ & $\begin{array}{l}\text { Distrito da região } \\
\text { metropolitana de } \\
\text { Lima, no qual se } \\
\text { localiza a classe mais } \\
\text { abastada, formado } \\
\text { por uma série de } \\
\text { subcentros. A área de } \\
\text { intervenção é um } \\
\text { destes subcentros. }\end{array}$ & $\begin{array}{l}\text { A proposta tem por } \\
\text { objetivo aproveitar a } \\
\text { facilidade acesso do } \\
\text { centro metropolitano } \\
\text { a partir da área de } \\
\text { intervenção para } \\
\text { torná-lo em lugar } \\
\text { central em San Isidro, } \\
\text { aumentando as } \\
\text { densidades e as } \\
\text { atividades terciárias. }\end{array}$ & $\begin{array}{l}6,7 \text { milhões na região } \\
\text { metropolitana. }\end{array}$ & $\begin{array}{l}\text { Não há menção ao } \\
\text { tamanho da área de } \\
\text { intervenção, nem } \\
\text { desenho que permita } \\
\text { avalia-la }\end{array}$ & $\begin{array}{l}\text { Apenas uma única } \\
\text { menção ao tamanho } \\
\text { de lote característico } \\
\text { da área }\end{array}$ & $\begin{array}{l}\text { Normas e } \\
\text { participação do } \\
\text { capital privado. }\end{array}$ \\
\hline
\end{tabular}




\section{Intervenções em situações urbanas com características de periferia marginal.}

Quadro 20: Análise dos projetos constantes nos registros do V SAL que se enquadram em situações urbanas de "periferia marginal"

\begin{tabular}{|c|c|c|c|c|c|c|c|c|}
\hline & Autores & Título & $\begin{array}{l}\text { Especificidades da } \\
\text { área de intervenção }\end{array}$ & $\begin{array}{l}\text { Caracterização geral } \\
\text { da proposta }\end{array}$ & Pop. da cidade & Área de intervenção & $\begin{array}{l}\text { Aspectos } \\
\text { morfológicos }\end{array}$ & $\begin{array}{l}\text { Forma de } \\
\text { viabilização }\end{array}$ \\
\hline \multirow[t]{2}{*}{ 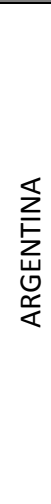 } & $\begin{array}{l}\text { Província de Buenos } \\
\text { Aires. Dirección de } \\
\text { obras e urbanización. } \\
\text { Carlos A Dodero } \\
\text { (coord) }\end{array}$ & $\begin{array}{l}\text { Proyecto de } \\
\text { desarrollo urbano } \\
\text { SNIAFA, propuesta } \\
\text { morfológica (trabajo } \\
\text { en Elaboración }\end{array}$ & $\begin{array}{l}\text { Área de antiga } \\
\text { fábrica em setor } \\
\text { periférico da região } \\
\text { metropolitana de } \\
\text { Buenos Aires - em } \\
\text { Berazategui (entre } \\
\text { buenos aires e la } \\
\text { Plata) - que } \\
\text { constituia uma } \\
\text { barreira o } \\
\text { crescimento urbano. }\end{array}$ & $\begin{array}{l}\text { Propõe-se uma nova } \\
\text { área de centralidade, } \\
\text { com a reciclagem de } \\
\text { alguns edifícios } \\
\text { industriais e a criação } \\
\text { de novas áreas } \\
\text { residenciais } \\
\text { recuperando a } \\
\text { cuadrícula. }\end{array}$ & $\begin{array}{l}11 \text { milhões de } \\
\text { habitantes na região } \\
\text { metropolitana de } \\
\text { Buenos Aires }\end{array}$ & $\begin{array}{l}\text { Lote da antiga } \\
\text { fábrica SNIFA: } 73 \\
\text { hectares }\end{array}$ & $\begin{array}{l}\text { Leitura do tipo- } \\
\text { morfológica do } \\
\text { tecido urbano de } \\
\text { Berazategui (local de } \\
\text { inserção da área de } \\
\text { intervenção). } \\
\text { Proposta em } \\
\text { recuperar a } \\
\text { quadrícula } \\
\text { (“tipologia del } \\
\text { amanzanamiento") }\end{array}$ & $\begin{array}{l}\text { Projeto urbano } \\
\text { inserido em plano } \\
\text { diretor }\end{array}$ \\
\hline & Miguel Baudizzone & Barrio SIderca & \multicolumn{6}{|c|}{ NÃO CONSTA NOS ANAIS, SOMENTE NA PROGRAMAÇÃO } \\
\hline 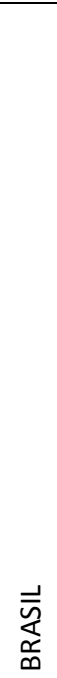 & $\begin{array}{l}\text { Carlos Eduardo } \\
\text { Comas, } \\
\text { Glenio Bohrer, Marta } \\
\text { Peixouto, Roni } \\
\text { Anzolch }\end{array}$ & $\begin{array}{l}\text { Uma superquadra } \\
\text { periférica de Porto } \\
\text { Alegre } \\
\text { (não consta nos Anais } \\
\text { nem na } \\
\text { programação. Há } \\
\text { menções em crônicas } \\
\text { do evento na AU e no } \\
\text { El Mercurio. O } \\
\text { projeto apresentado } \\
\text { foi localizado em } \\
\text { arquivo do PROPAR e } \\
\text { sua autenticidade foi } \\
\text { confirmada por } \\
\text { Carlos E. Comas em } \\
\text { entrevista). }\end{array}$ & $\begin{array}{l}\text { Gleba SOPAL } \\
\text { (Sociedade Ônibus de } \\
\text { Porto Alegre) inserida } \\
\text { em área periférica e } \\
\text { rarefeita de Porto } \\
\text { Alegre, junto à } \\
\text { invasão regularizada, } \\
\text { loteamento de classe } \\
\text { média baixa e } \\
\text { indústria de biscoito. } \\
\text { O crescimento desta } \\
\text { área se deu } \\
\text { polarizado pelo Porto } \\
\text { Seco de Porto Alegre, } \\
\text { na década de } 1980 .\end{array}$ & $\begin{array}{l}\text { Proposta de } \\
\text { urbanização com uso } \\
\text { misto que tira partido } \\
\text { de rua projetada pela } \\
\text { prefeitura em área } \\
\text { de invasão } \\
\text { (população relocada } \\
\text { no projeto). } \\
\text { Reestruturação da } \\
\text { estrutura fundiária e } \\
\text { ampliação do } \\
\text { potencial construtivo } \\
\text { com redução das } \\
\text { alturas permissíveis } \\
\text { (4 a } 2 \text { pavimentos). }\end{array}$ & 1,12 milhões & 8 hectares & $\begin{array}{l}\text { Leitura dos aspectos } \\
\text { morfológicos } \\
\text { existentes. Proposta } \\
\text { busca identidade } \\
\text { morfológica em } \\
\text { relação ao entorno. } \\
\text { Utilização de } \\
\text { diferentes tipos } \\
\text { edilícios: "redents", } \\
\text { edifícios em "U" e } \\
\text { outros. }\end{array}$ & $\begin{array}{l}\text { Plano de massas } \\
\text { proposto como base } \\
\text { para revisão das } \\
\text { normas existentes. }\end{array}$ \\
\hline
\end{tabular}


Quadro 20 (continuação): Análise dos projetos constantes nos registros do V SAL que se enquadram em situações urbanas de "periferia marginal"

\begin{tabular}{|c|c|c|c|c|c|c|c|c|}
\hline & Autores & Título & $\begin{array}{l}\text { Especificidades da } \\
\text { área de intervenção }\end{array}$ & $\begin{array}{l}\text { Caracterização geral } \\
\text { da proposta }\end{array}$ & Pop. da cidade 1990 & Área de intervenção & $\begin{array}{l}\text { Aspectos } \\
\text { morfológicos }\end{array}$ & $\begin{array}{l}\text { Forma de } \\
\text { viabilização }\end{array}$ \\
\hline 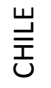 & Francisco Vergara & Los Sauces & \multicolumn{6}{|c|}{ NÃO CONSTA NOS ANAIS, SOMENTE NA PROGRAMAÇÃO } \\
\hline 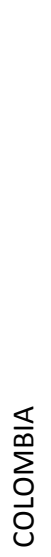 & $\begin{array}{l}\text { Taller Urbano, } \\
\text { Municipalidade de } \\
\text { Bogotá }\end{array}$ & $\begin{array}{l}\text { Gérmenes de Ciudad. } \\
\text { Desarollo integral de } \\
\text { asentamientos } \\
\text { populares urbanos }\end{array}$ & $\begin{array}{l}\text { Projetos para quatro } \\
\text { "bairros ilegais" de } \\
\text { Bogotá: Compartir, } \\
\text { La Gaitana, Naciones } \\
\text { Unidas e Juan Pablo II }\end{array}$ & $\begin{array}{l}\text { Projetos que } \\
\text { envolvem o } \\
\text { provimento de } \\
\text { infraestrutura, } \\
\text { equipamentos } \\
\text { comunitários na } \\
\text { configuração de } \\
\text { espaços públicos em } \\
\text { "bairros ilegais". }\end{array}$ & 4,95 milhões & $\begin{array}{l}\text { Intervenções em } \\
\text { áreas pontuais, } \\
\text { algumas com de } 4 \\
\text { hectares }\end{array}$ & $\begin{array}{l}\text { Breve descrição da } \\
\text { constituição dos } \\
\text { espaços livres em } \\
\text { bairros ilegais. } \\
\text { Tipificação das } \\
\text { soluções adotadas: } \\
\text { dispersas ao longo de } \\
\text { uma rua; } \\
\text { concentradas em um } \\
\text { espaço público } \\
\text { principal ou ambas } \\
\text { as soluções } \\
\text { combinadas }\end{array}$ & $\begin{array}{l}\text { Programa da } \\
\text { Municipalidade de } \\
\text { Bogotá e do PNUD } \\
\text { para viabilização de } \\
\text { projetos com a } \\
\text { parceria da } \\
\text { comunidade. }\end{array}$ \\
\hline$\frac{\stackrel{O}{\frac{U}{x}}}{\stackrel{u}{\Sigma}}$ & $\begin{array}{l}\text { Carlos González } \\
\text { Lobo, Macario } \\
\text { Aguirre, Rodolfo } \\
\text { Barragán, Luis Garcia } \\
\text { Galiano, Alfonso } \\
\text { Govela, María } \\
\text { Eugenia Hurtado, } \\
\text { Calos Mijares, Teresa } \\
\text { Ocejo }\end{array}$ & $\begin{array}{l}\text { La Ciudad de la } \\
\text { Periferia: Mixquic }\end{array}$ & $\begin{array}{l}\text { Mixquic, povoado } \\
\text { histórico situado } \\
\text { junto à Cidade do } \\
\text { México, } \\
\text { transformado em } \\
\text { cidade periférica pelo } \\
\text { crescimento daquela. }\end{array}$ & $\begin{array}{l}\text { Propõe-se o controle } \\
\text { do crescimento que } \\
\text { tende a envolver o } \\
\text { povoado, } \\
\text { conservando seu } \\
\text { patrimônio histórico } \\
\text { e ecológico (agrícola), } \\
\text { através do } \\
\text { estabelecimento de } \\
\text { uma borda urbana e } \\
\text { agrária em forma de } \\
\text { duplo anel a fim de } \\
\text { assimilar o } \\
\text { crescimento } \\
\text { endógeno e exógeno }\end{array}$ & $\begin{array}{l}20 \text { milhões na região } \\
\text { metropolitana da } \\
\text { Cidade do México }\end{array}$ & $\begin{array}{l}\text { povoado maior que } \\
10 \text { hectares. }\end{array}$ & $\begin{array}{l}\text { Visa contribuir para } \\
\text { a teoria da } \\
\text { arquitetura da } \\
\text { cidade na periferia. } \\
\text { Caracteriza três tipos } \\
\text { de crescimento } \\
\text { (fractal, tentacular e } \\
\text { espasmódico). } \\
\text { Caracterização do } \\
\text { crescimento urbano, } \\
\text { dos tipos edilícios e } \\
\text { da morfologia } \\
\text { urbana em Mixquic. }\end{array}$ & $\begin{array}{l}\text { Plano de massas } \\
\text { como base para } \\
\text { normas }\end{array}$ \\
\hline
\end{tabular}




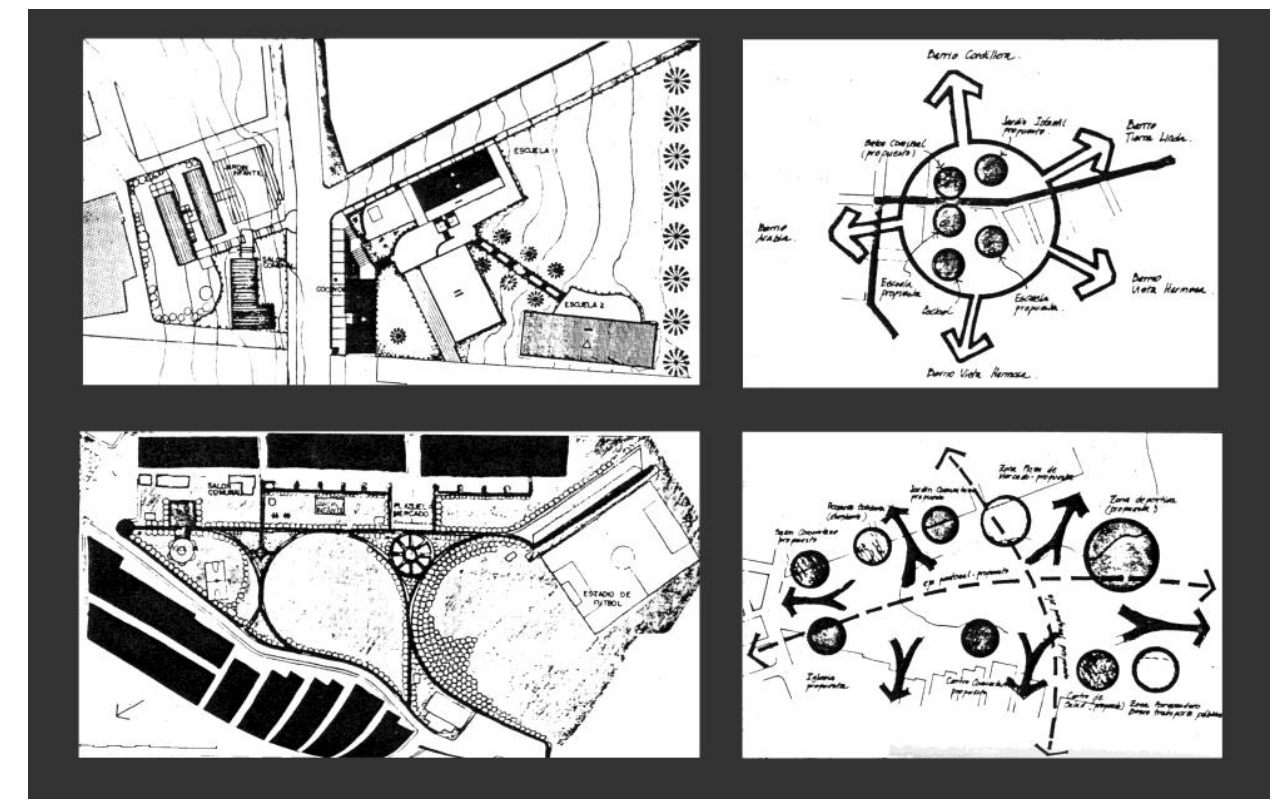

Gérmenes de Ciudad. Desarollo integral de asentamientos populares urbanos
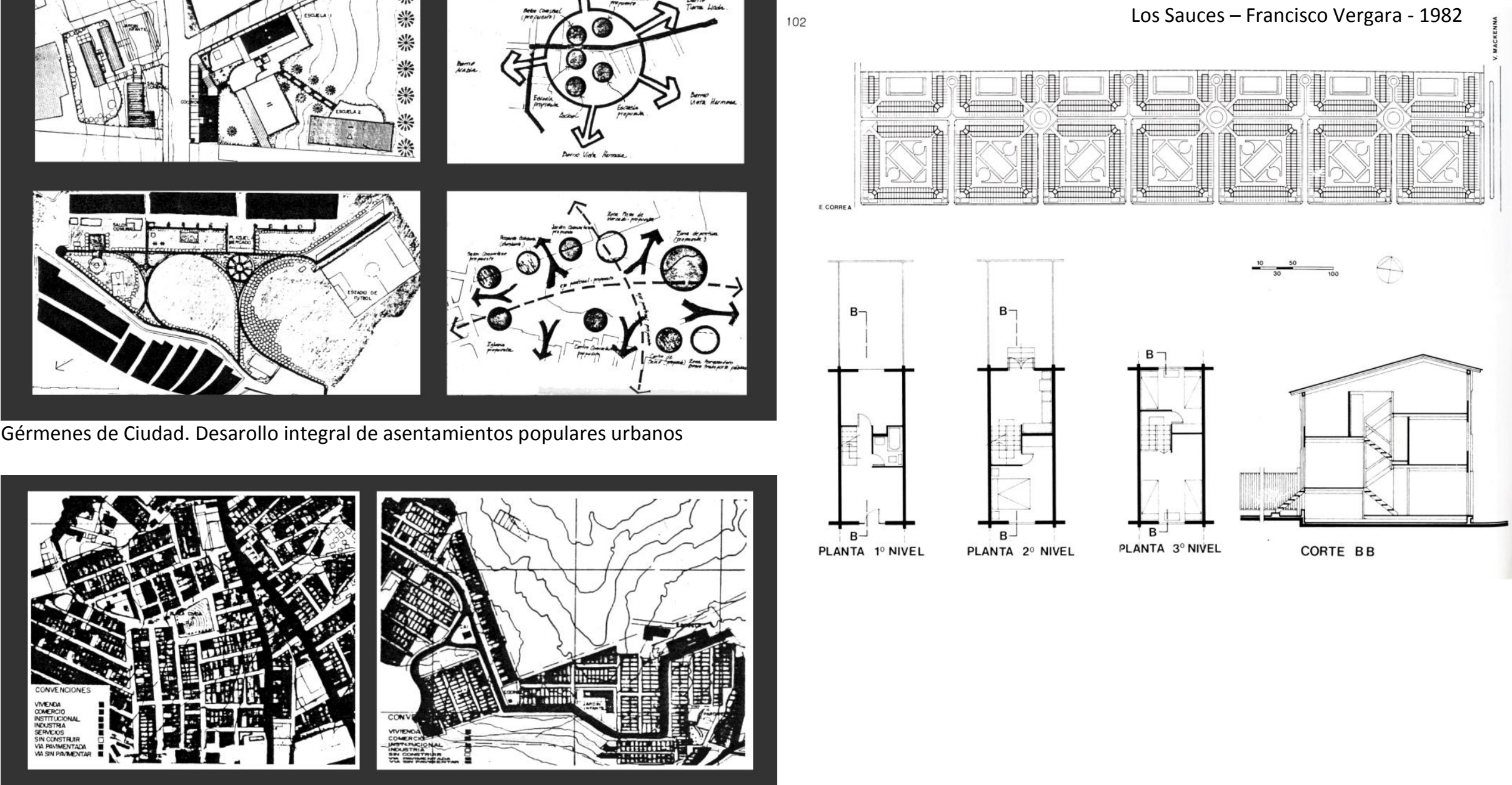
Quadro 20 (continuação): Análise dos projetos constantes nos registros do V SAL que se enquadram em situações urbanas de "periferia marginal"

\begin{tabular}{|c|c|c|c|c|c|c|c|c|}
\hline & Autores & Título & $\begin{array}{l}\text { Especificidades da } \\
\text { área de intervenção }\end{array}$ & $\begin{array}{l}\text { Caracterização geral } \\
\text { da proposta }\end{array}$ & Pop. da cidade 1990 & Área de intervenção & $\begin{array}{l}\text { Aspectos } \\
\text { morfológicos }\end{array}$ & $\begin{array}{l}\text { Forma de } \\
\text { viabilização }\end{array}$ \\
\hline 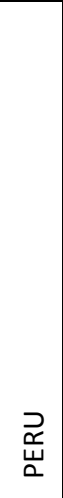 & $\begin{array}{l}\text { Liliana Miranda Sara; } \\
\text { Martha Lazarte } \\
\text { Salinas }\end{array}$ & $\begin{array}{l}\text { El Centro Popular, } \\
\text { Finaciero y de } \\
\text { servicios del cono sur } \\
\text { de Lima } \\
\text { Metropolitana - San } \\
\text { Juan de Miraflores } \\
\text { (não consta na } \\
\text { programação) }\end{array}$ & $\begin{array}{l}\text { San Juan de } \\
\text { Miraflores, bairro } \\
\text { popular deteriorado } \\
\text { de Lima, em que há } \\
\text { grande número de } \\
\text { comerciantes } \\
\text { ambulantes e de } \\
\text { pessoas que } \\
\text { converteram suas } \\
\text { casas em local de } \\
\text { trabalho. }\end{array}$ & $\begin{array}{l}\text { A proposta envolve } \\
\text { obras e normas no } \\
\text { sentido de } \\
\text { articulação urbana } \\
\text { (transportes de } \\
\text { massa e relocação do } \\
\text { comércio ambulante } \\
\text { para liberação das } \\
\text { vias) e consolidação } \\
\text { e densificação do } \\
\text { bairro de atividades } \\
\text { mixtas, reabilitação } \\
\text { de espaços públicos }\end{array}$ & $\begin{array}{l}6,7 \text { milhões na região } \\
\text { metropolitana. }\end{array}$ & $\begin{array}{l}\text { Bairro maior que } 10 \\
\text { hectares }\end{array}$ & Sem menção & $\begin{array}{l}\text { Sugestão Programas, } \\
\text { obras e parâmetros } \\
\text { para normas }\end{array}$ \\
\hline
\end{tabular}

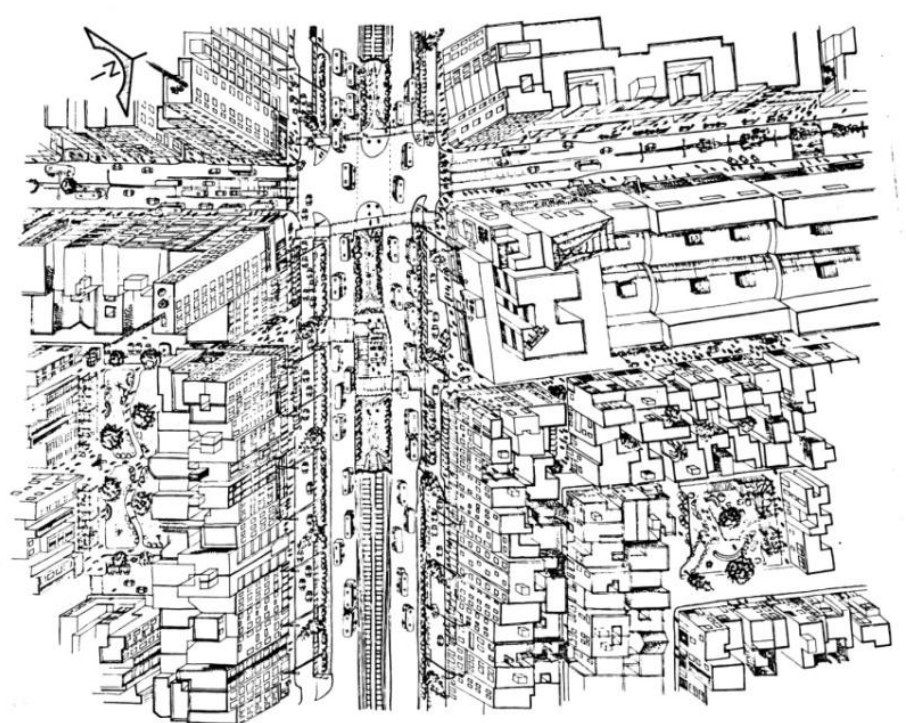

El Centro Popular, Finaciero y de servicios del cono sur de Lima Metropolitana - San Juan de Miraflores 
Intervenções que não correspondem diretamente às situações urbanas da convocatória.

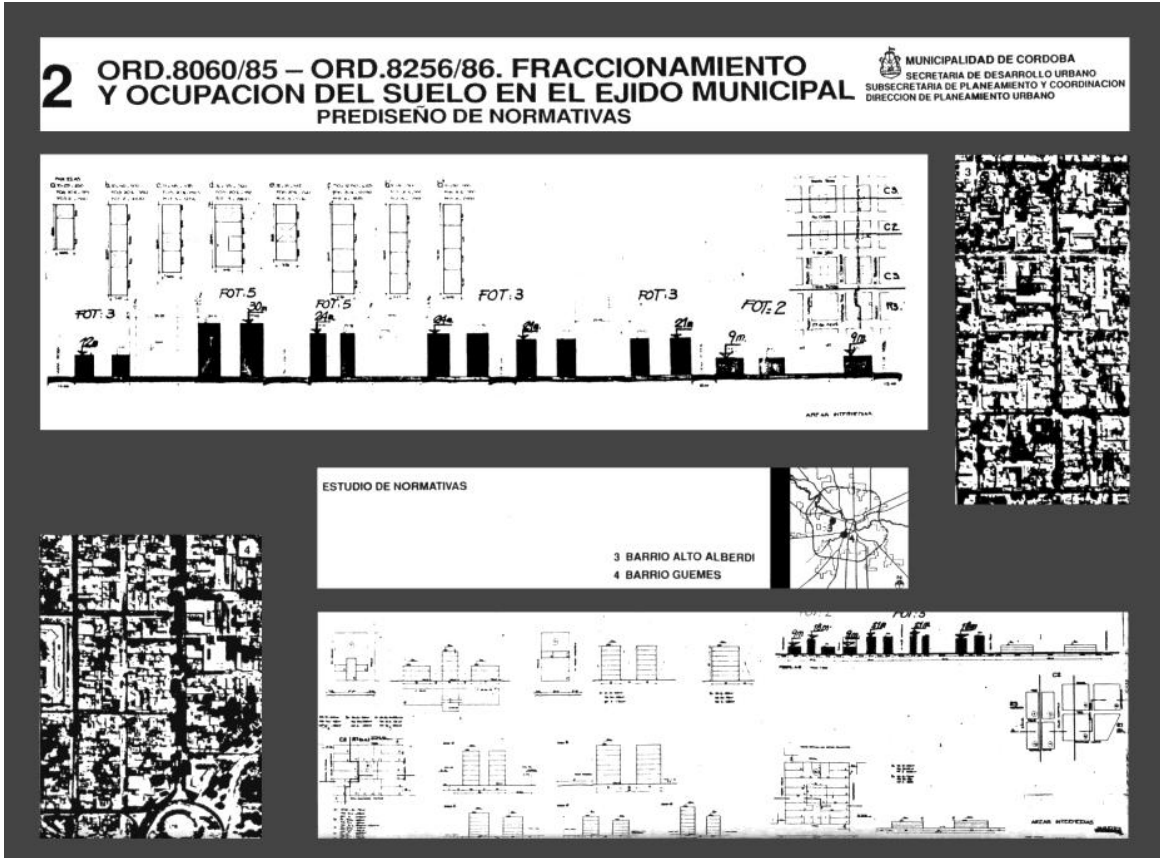

Fraccionamiento y ocupación del suelo municipal Ord.8060/85 - Municipalidade de Córdoba
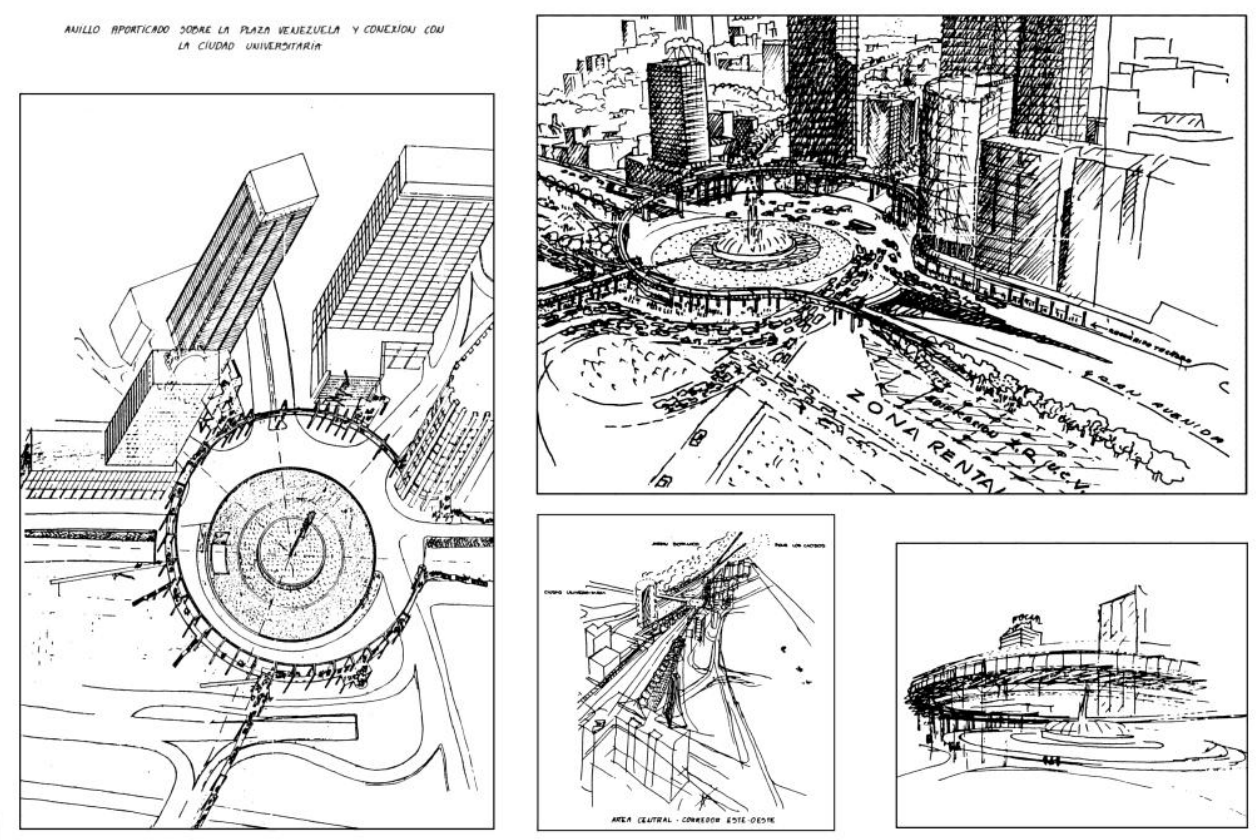

Proyecto: Plaza Venezuela - UCV - Domenico Silvestro; S. Sansone; J.Lobato; M.Mariani; L. Vera; C. Ojeda 


\section{Quadro 21: Análise dos projetos constantes nos registros do V SAL que não se enquadram em nenhuma das situações urbanas definidas pela convocatória}

\begin{tabular}{|c|c|c|c|c|c|c|c|c|}
\hline & Autores & Título & $\begin{array}{l}\text { Especificidades da } \\
\text { área de intervenção }\end{array}$ & $\begin{array}{l}\text { Caracterização geral } \\
\text { da proposta }\end{array}$ & Pop. da cidade 1990 & Área de intervenção & $\begin{array}{l}\text { Aspectos } \\
\text { morfológicos }\end{array}$ & $\begin{array}{l}\text { Forma de } \\
\text { viabilização }\end{array}$ \\
\hline 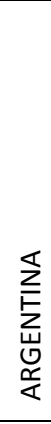 & $\begin{array}{l}\text { Municipalidade de } \\
\text { Córdoba }\end{array}$ & $\begin{array}{l}\text { Fraccionamiento y } \\
\text { ocupación del suelo } \\
\text { municipal } \\
\text { Ord.8060/85 } \\
\text { (consta com nome } \\
\text { distinto na } \\
\text { programação) }\end{array}$ & $\begin{array}{l}\text { Revisão das normas } \\
\text { existentes que } \\
\text { permitiam altas } \\
\text { densidades de forma } \\
\text { indiscriminada }\end{array}$ & $\begin{array}{l}\text { Normas que visam } \\
\text { concretizar um } \\
\text { conceito estrutural } \\
\text { para Córdoba, } \\
\text { constituído por } \\
\text { corredores } \\
\text { estruturais. } \\
\text { Recuperação do rio } \\
\text { Suquia e } \\
\text { estruturação de setor } \\
\text { periférico. }\end{array}$ & $\begin{array}{l}1,18 \text { milhões de } \\
\text { habitantes }\end{array}$ & $\begin{array}{l}\text { Toda a cidade, } \\
\text { estudo por bairros - } \\
\text { áreas do séc. XIX e } \\
\text { início do séc. XX, } \\
\text { setor urbano } \\
\text { periférico. }\end{array}$ & $\begin{array}{l}\text { Leitura da estrutura } \\
\text { urbana da cidade. } \\
\text { Parâmetros } \\
\text { pormenorizados dos } \\
\text { tipos de } \\
\text { parcelamentos e de } \\
\text { volumetrias das } \\
\text { permissíveis. }\end{array}$ & normas \\
\hline 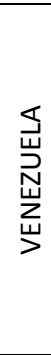 & $\begin{array}{l}\text { Domenico Silvestro; } \\
\text { S. Sansone; J.Lobato; } \\
\text { M.Mariani; L. Vera; C. } \\
\text { Ojeda }\end{array}$ & $\begin{array}{l}\text { Proyecto: Plaza } \\
\text { Venezuela - UCV } \\
\text { (consta com nome } \\
\text { distinto na } \\
\text { programação) }\end{array}$ & $\begin{array}{l}\text { Praça Venezuela, em } \\
\text { Caracas, entre } \\
\text { Universidad Central } \\
\text { de Venezuela (UCV) e } \\
\text { área verticalizada da } \\
\text { cidade, junto a qual } \\
\text { passam vias de } \\
\text { trânsito expresso e } \\
\text { metrô. }\end{array}$ & $\begin{array}{l}\text { Projeto visa } \\
\text { contectar a praça à } \\
\text { UCV e facilitar o } \\
\text { acesso ao Parque los } \\
\text { Caobos }\end{array}$ & $\begin{array}{l}1,8 \text { milhões em } \\
\text { Caracas e } 3,12 \\
\text { milhões na região } \\
\text { metropolitana }\end{array}$ & $\begin{array}{l}\text { Menor que } 4 \\
\text { hectares }\end{array}$ & $\begin{array}{l}\text { Menção à praça } \\
\text { como fato urbano }\end{array}$ & $\begin{array}{l}\text { Projeto de } \\
\text { reconfiguração de } \\
\text { espaço público }\end{array}$ \\
\hline 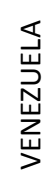 & Max Pedomonte & $\begin{array}{l}\text { Renovación Urbana a } \\
\text { través del metro de } \\
\text { Caracas: el caso de } \\
\text { "LaHoyada" }\end{array}$ & \multicolumn{6}{|c|}{ NÃO CONSTA NOS ANAIS, SOMENTE NA PROGRAMAÇÃO } \\
\hline
\end{tabular}





\section{Apêndice D - Análise serial de vestígios de contatos latino-americanos através de revistas especializadas}





\section{Revista Summa (Argentina): 1970 a 1992}

Período de vigência da revista: 1965 a 1992

Números por ano: 12

Números analisados: do no 22 (jan/fev 1970) ao nº 300 (Mai/ Jun/ Jul/ Ago/Set. 1992)

Número de textos que compõem o corpus de textos críticos: 74

Número de reportagens que compõem o corpus de reportagens: 68

Gráfico 1: Textos críticos que demonstram a existência de vínculos latino-americanos na revista SUMMA entre 1970 e 1992.

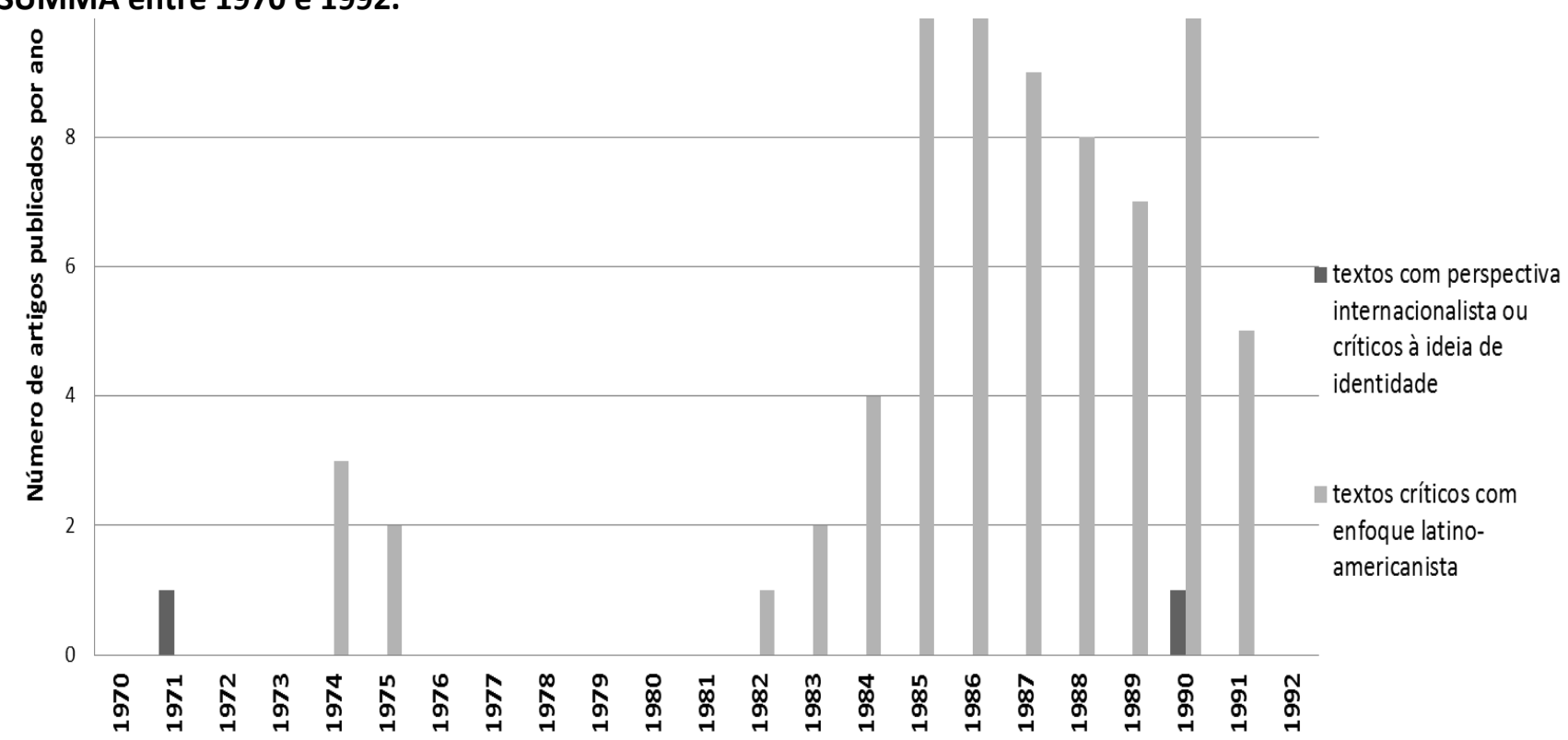

Fonte: Elaboração do autor com base em levantamento realizado a partir da análise longitudinal das edições da Summa entre 1970 e 1992.

Gráfico 2: Reportagens sobre eventos e projetos publicadas na revista SUMMA entre 1967 e 1992 que testemunham o interesse na discussão da arquitetura e/ou do urbanismo latino-americanos.

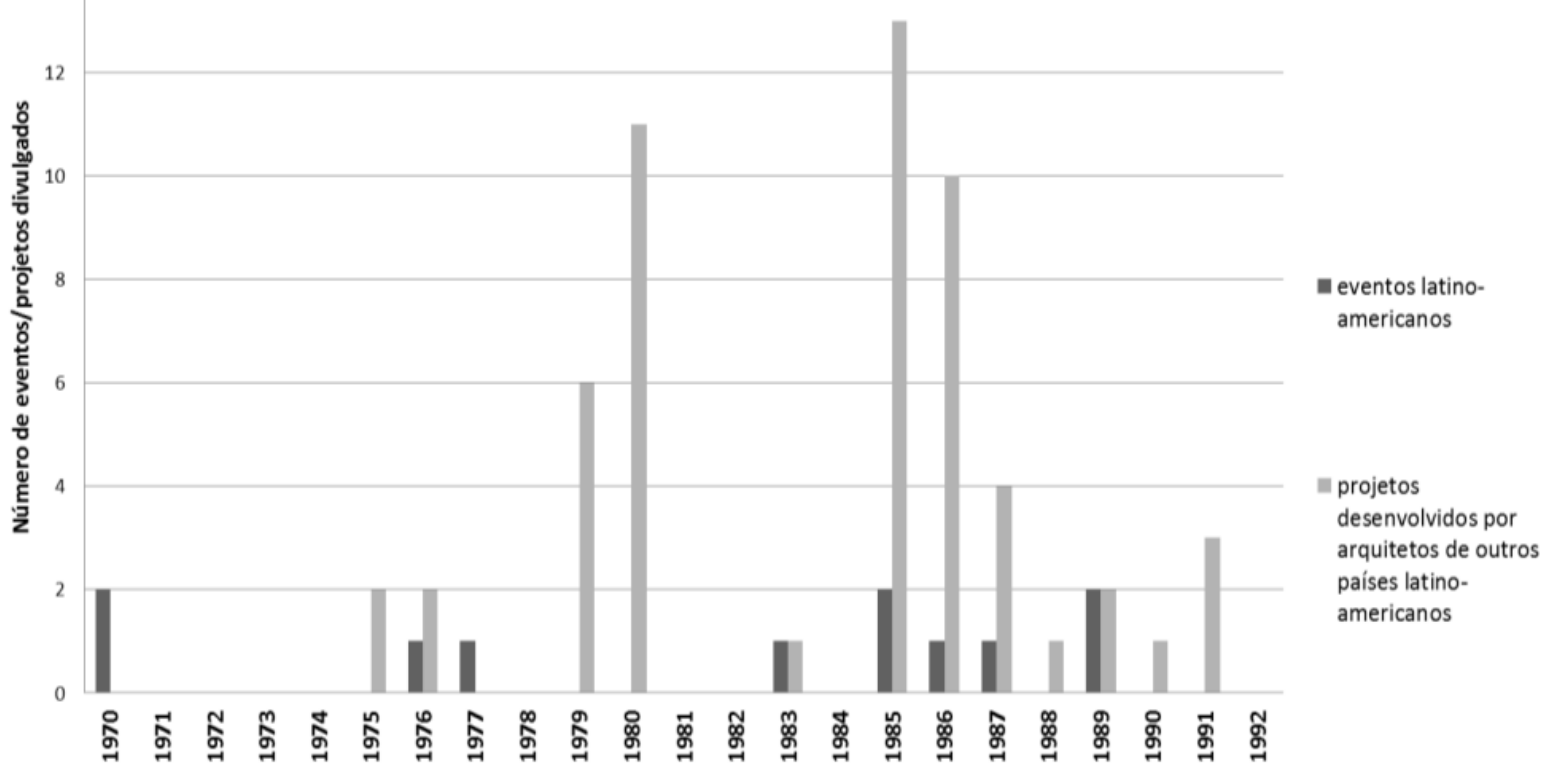

Fonte: Elaboração do autor com base em levantamento realizado a partir da análise longitudinal das edições da Summa entre 1967 e 1992. 


\section{Cadernos Summarios (Argentina): 1978 a 1990}

Período de vigência da revista: 1976 a 1990

Média de edições por ano: 5 a 6

Números analisados: no 15 (jan 1978) ao no135 (Mai/ Jun. 1990)

Número de textos que compõem o corpus de textos críticos: 47

Número de reportagens que compõem o corpus de reportagens: 35

Gráfico 3: Textos críticos que demonstram a existência de vínculos latino-americanos nos CADERNOS SUMMARIOS entre 1978 e 1990.

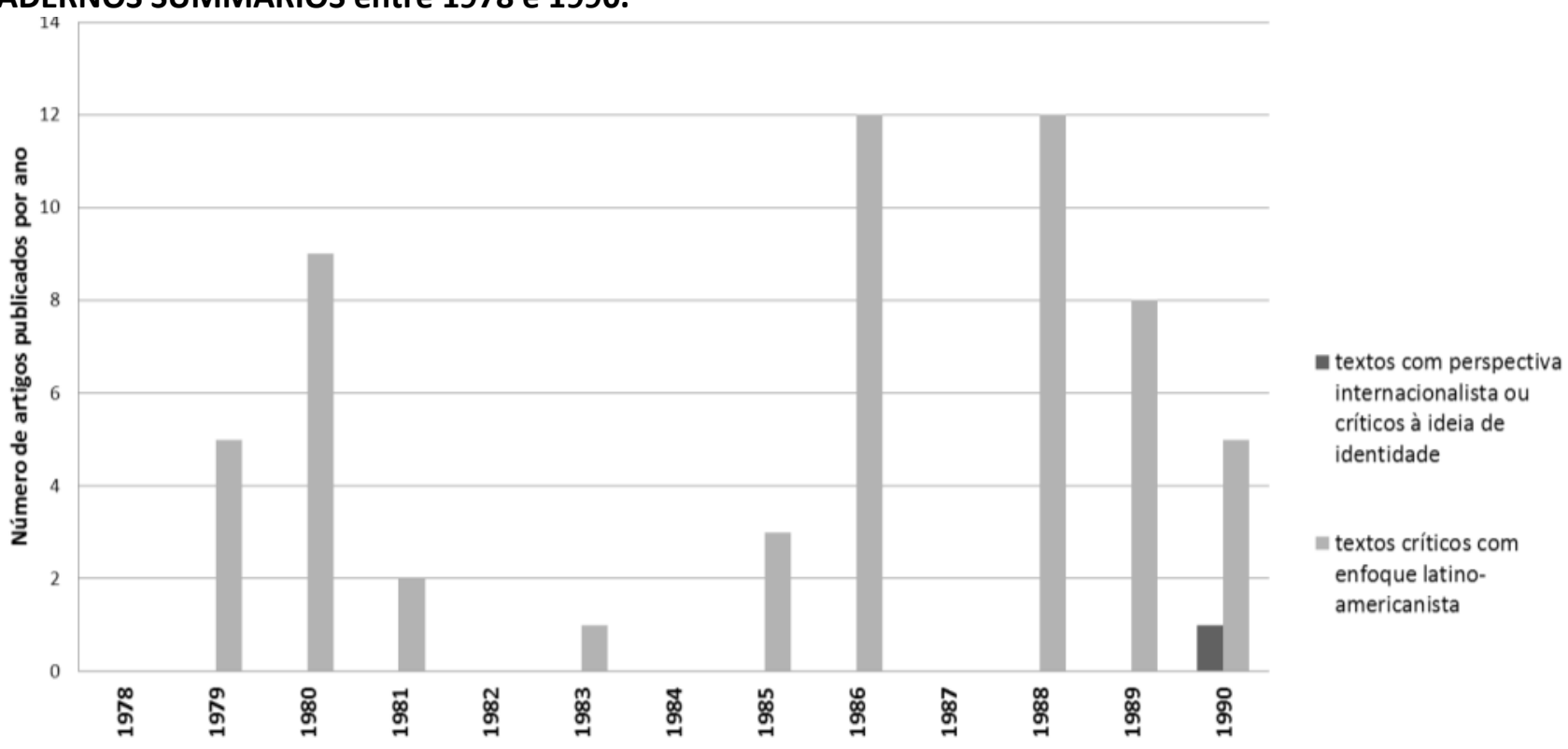

Fonte: Elaboração do autor com base em levantamento realizado a partir da análise longitudinal das edições dos Cadernos Summarios entre 1978 e 1990.

Gráfico 4: Reportagens sobre eventos e projetos publicadas nos Cadernos Summarios entre 1978 e 1990 que testemunham o interesse na discussão da arquitetura e/ou do urbanismo latinoamericanos.

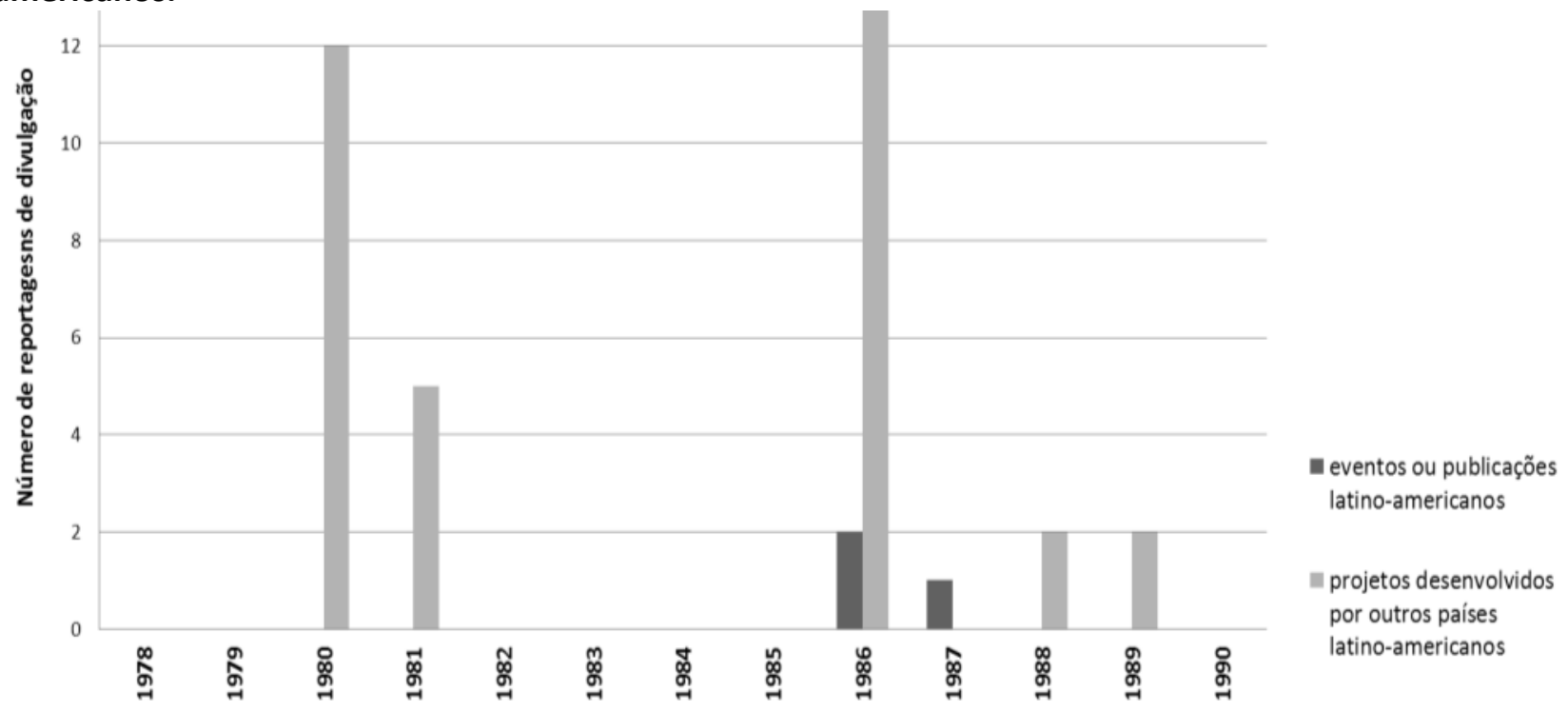

Fonte: Elaboração do autor com base em levantamento realizado a partir da análise longitudinal das edições dos Cadernos Summarios entre 1978 e 1990. 
Revista Summa + (Argentina): 1993 a 1997

Período de vigência do periódico: 1993 até hoje

Média de edições por ano: 6

Números analisados: $\mathrm{n}^{\circ} 1$ (jun/jul 1993) ao $\mathrm{n}^{\circ} 25$ (abr/mai 1997)

Número de textos que compõem o corpus de textos críticos: 21

Número de reportagens que compõem o corpus de reportagens: 21

Gráfico 5: Textos críticos que demonstram a existência de vínculos latino-americanos revista Summa Más entre 1993 e 1997.

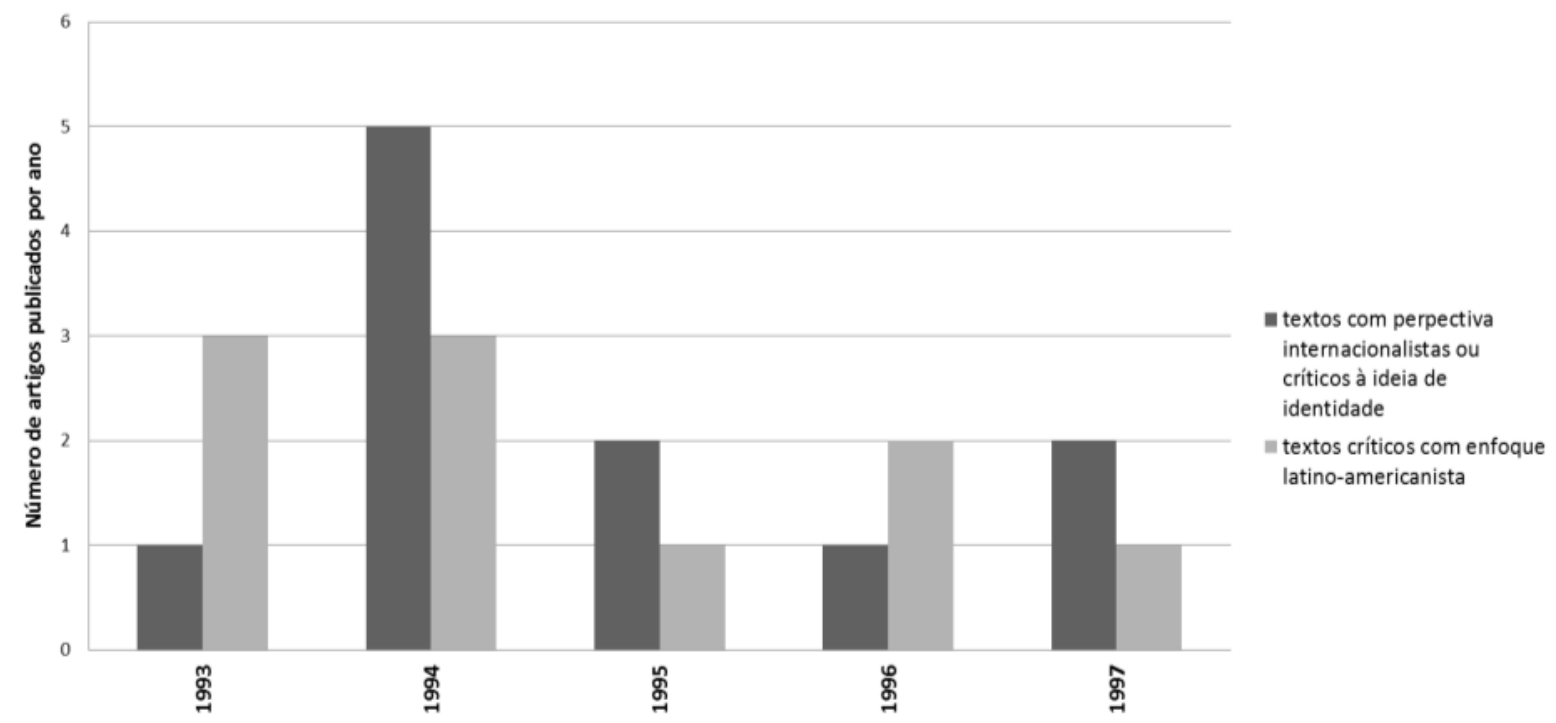

Fonte: Elaboração do autor com base em levantamento realizado a partir da análise longitudinal das edições da revista Summa Más entre 1993 e 1997.

Gráfico 6: Reportagens sobre eventos e projetos publicadas na revista Summa Más entre 1993 e 1997 que testemunham o interesse na discussão da arquitetura e/ou do urbanismo latinoamericanos.

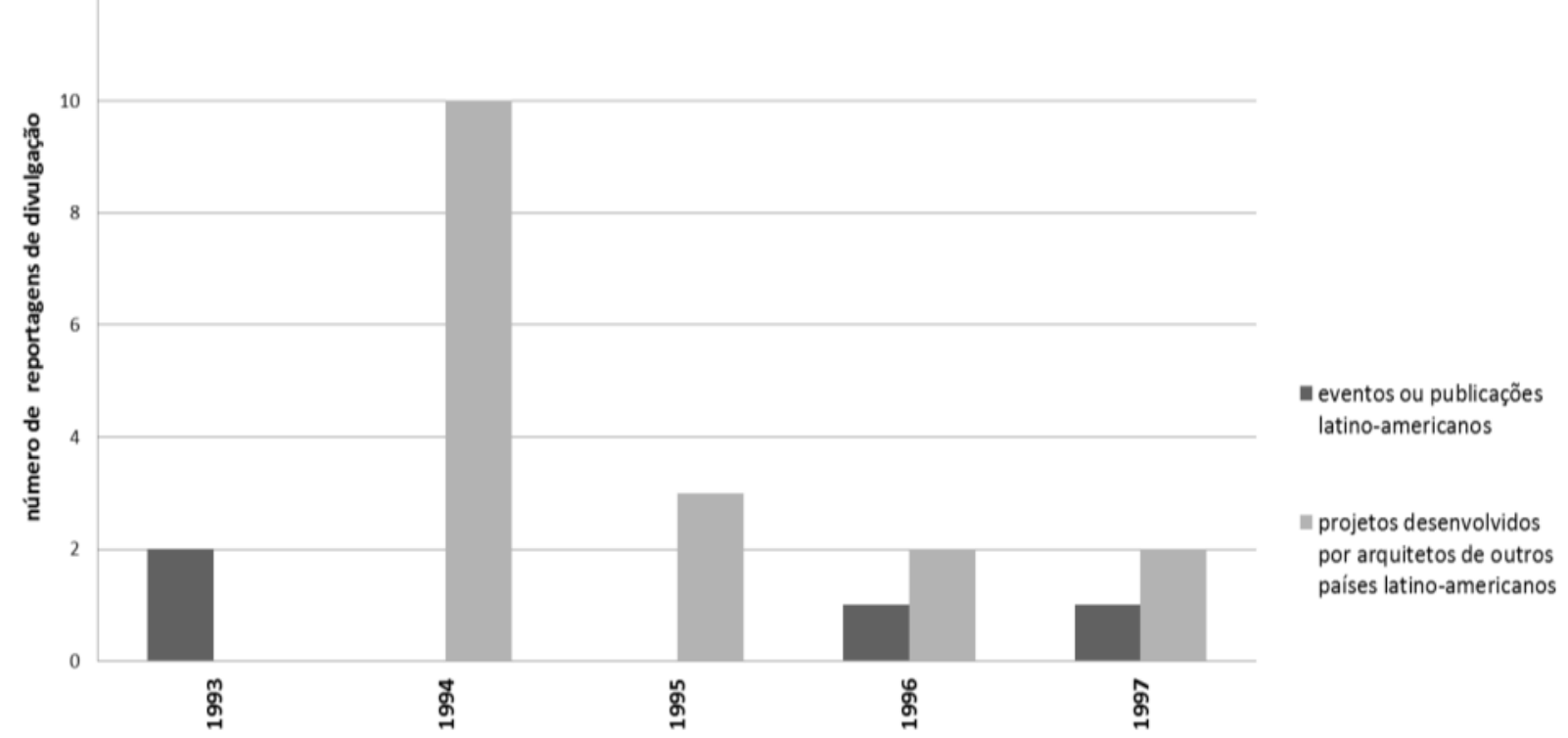

Fonte: Elaboração do autor com base em levantamento realizado a partir da análise longitudinal das edições da revista Summa Más entre 1993 e 1997.

\section{Revista Projeto (Brasil): 1977 a 1997}

Período de vigência do periódico: 1977 até hoje 
Média de edições por ano: 12

Números analisados: no 1 (jan/fev 1977) a 204 (jan 1997)

Número de textos que compõem o corpus de textos críticos: 139

Número de reportagens que compõem o corpus de reportagens: 159

Gráfico 7: Textos críticos que demonstram a existência de vínculos latino-americanos revista Projeto entre 1977 e 1997.

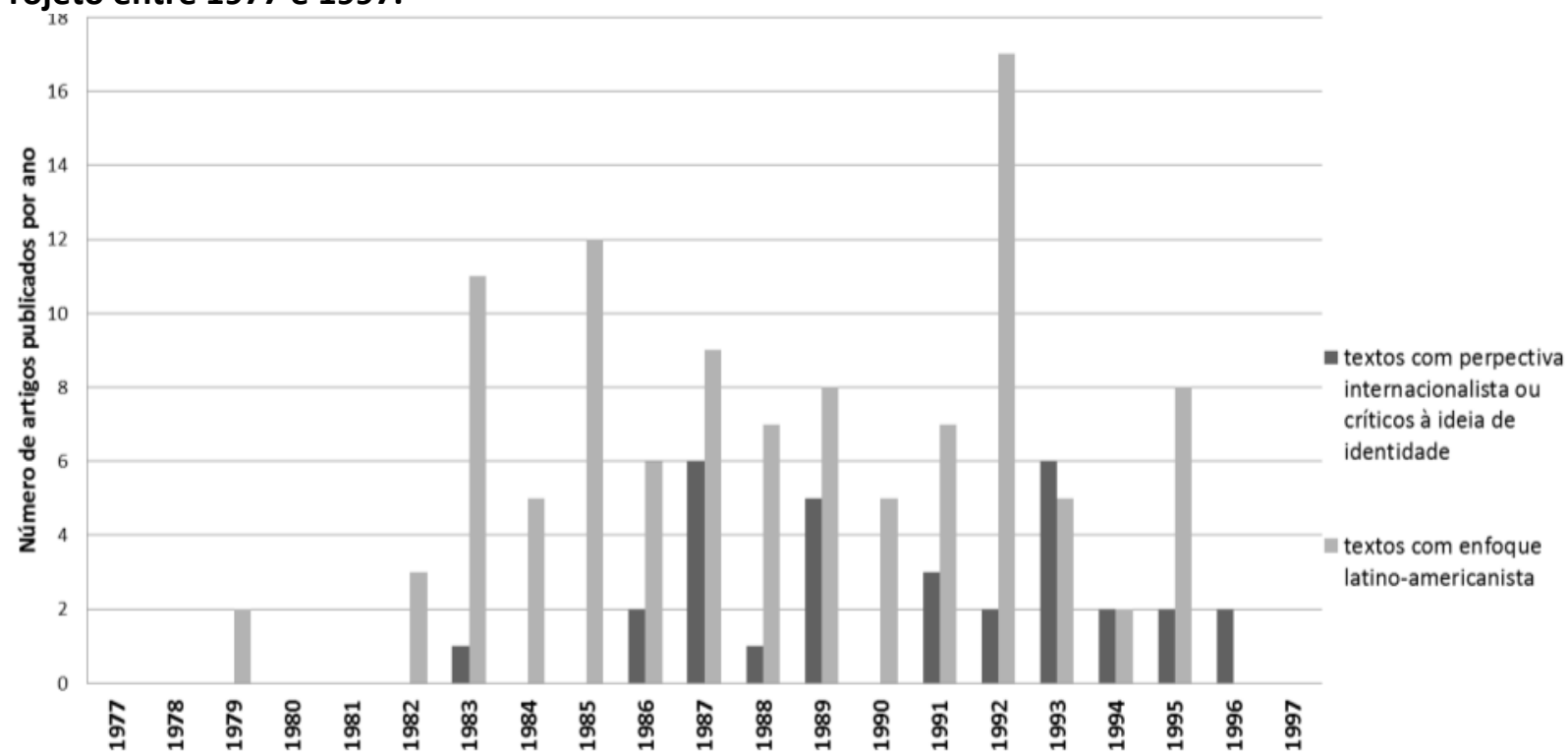

Fonte: Elaboração do autor com base em levantamento realizado a partir da análise longitudinal das edições da revista Projeto entre 1977 e 1997.

Gráfico 8: Reportagens sobre eventos e projetos publicadas na revista Projeto entre 1977 e 1997 que testemunham o interesse na discussão da arquitetura e/ou do urbanismo latino-americanos.

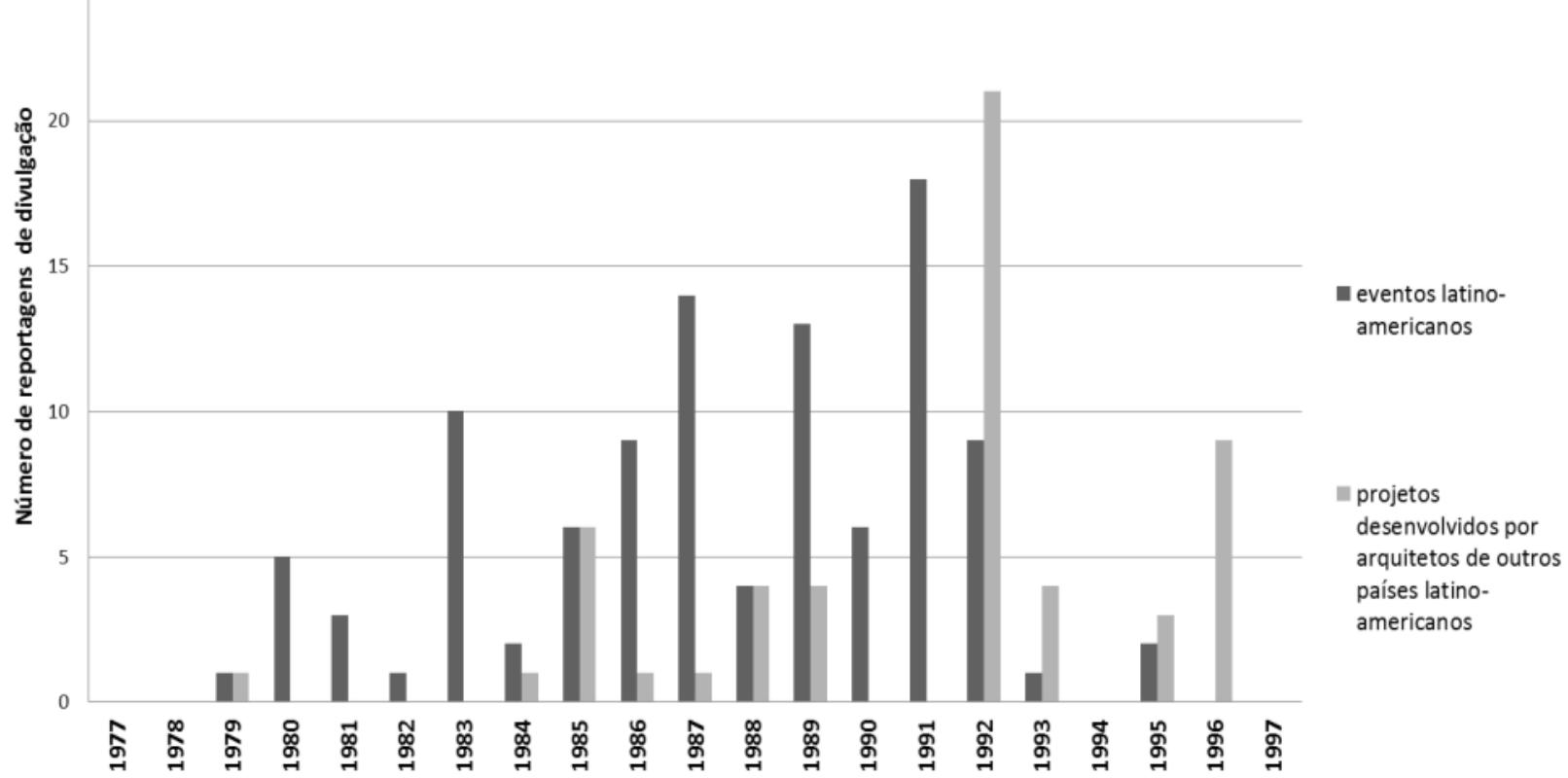

Fonte: Elaboração do autor com base em levantamento realizado a partir da análise longitudinal das edições da revista Projeto entre 1977 e 1997.

\section{Revista AU (Brasil): 1985 a 1998}

Período de vigência do periódico: 1985 até hoje 
Média de edições por ano: 6

Números analisados: no3 (fev 1986) ao no80 (out/nov 1998)

Número de textos que compõem o corpus de textos críticos: 83

Número de reportagens que compõem o corpus de reportagens: 112

Gráfico 9: Textos críticos que demonstram a existência de vínculos latino-americanos revista AU entre 1985 e 1998.

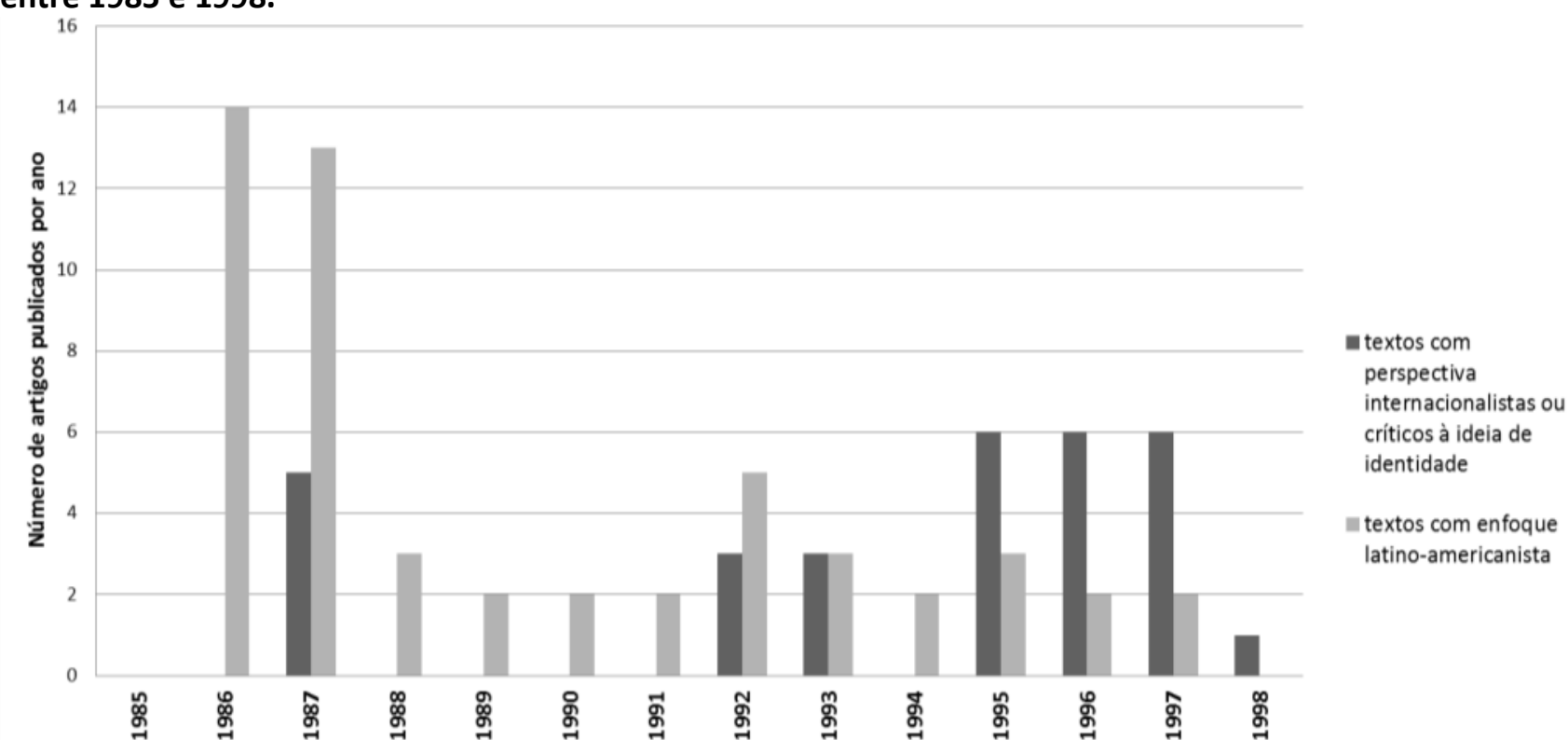

Fonte: Elaboração do autor com base em levantamento realizado a partir da análise longitudinal das edições da revista AU entre 1985 e 1998.

Gráfico 10: Reportagens sobre eventos e projetos publicadas na revista Projeto entre 1985 e 1997 que testemunham o interesse na discussão da arquitetura e/ou do urbanismo latino-americanos.

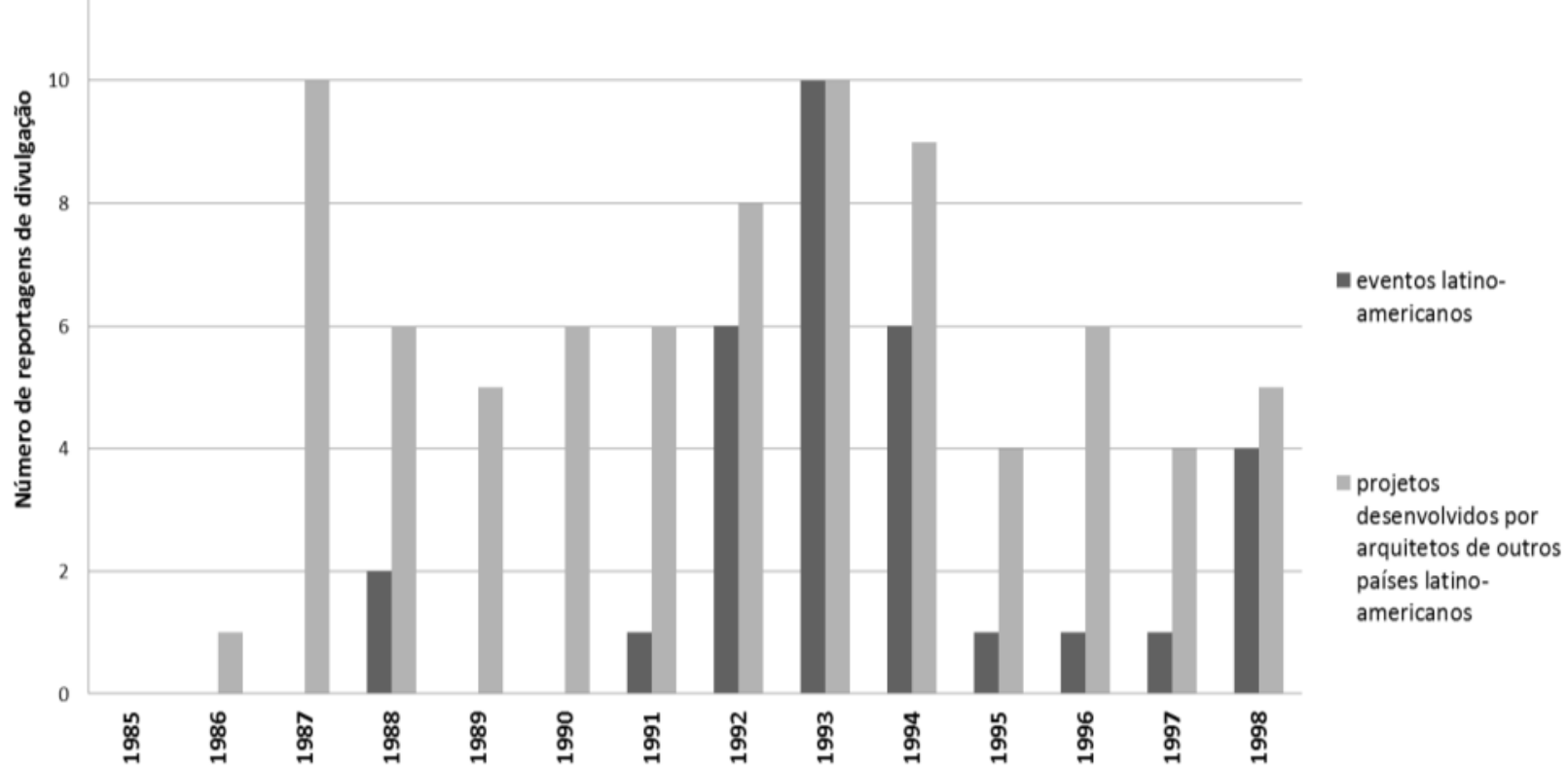

Fonte: Elaboração do autor com base em levantamento realizado a partir da análise longitudinal das edições da revista AU entre 1985 e 1998.

\section{Revista CA (Chile): 1978 a 1997}

Período de vigência do periódico: 1976 até hoje

Média de edições por ano: 3 a 4 números 
Números analisados: $n^{\circ} 22$ (dez de 1978) ao $n^{\circ} 91$ (out/dez 1997)

Número de textos que compõem o corpus de textos críticos: 75

Número de reportagens que compõem o corpus de reportagens: 29

Gráfico 11: Textos críticos que demonstram a existência de vínculos latino-americanos revista CA entre 1978 e 1997.

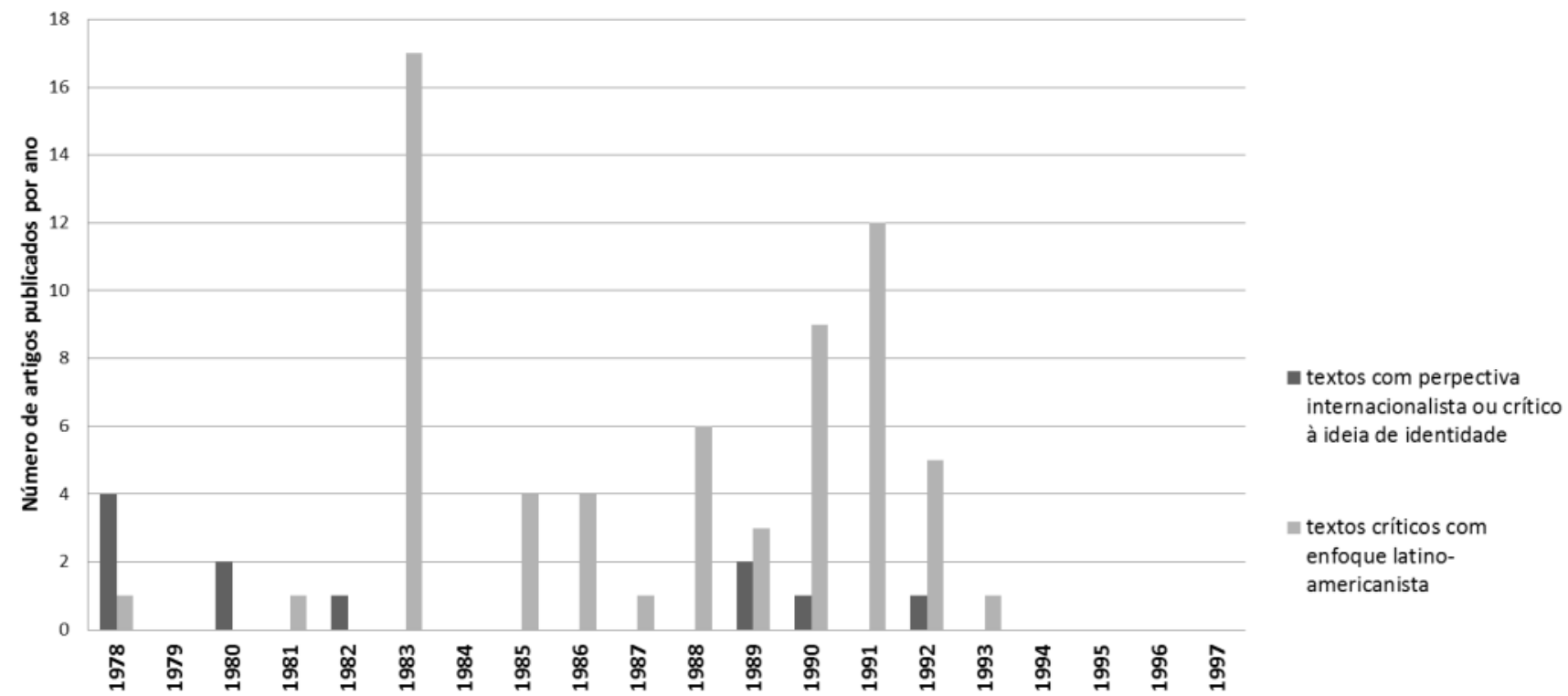

Fonte: Elaboração do autor com base em levantamento realizado a partir da análise longitudinal das edições da revista CA entre 1978 e 1997.

Gráfico 12: Reportagens sobre eventos e projetos publicadas na revista CA entre 1978 e 1997 que testemunham o interesse na discussão da arquitetura e/ou do urbanismo latino-americanos.

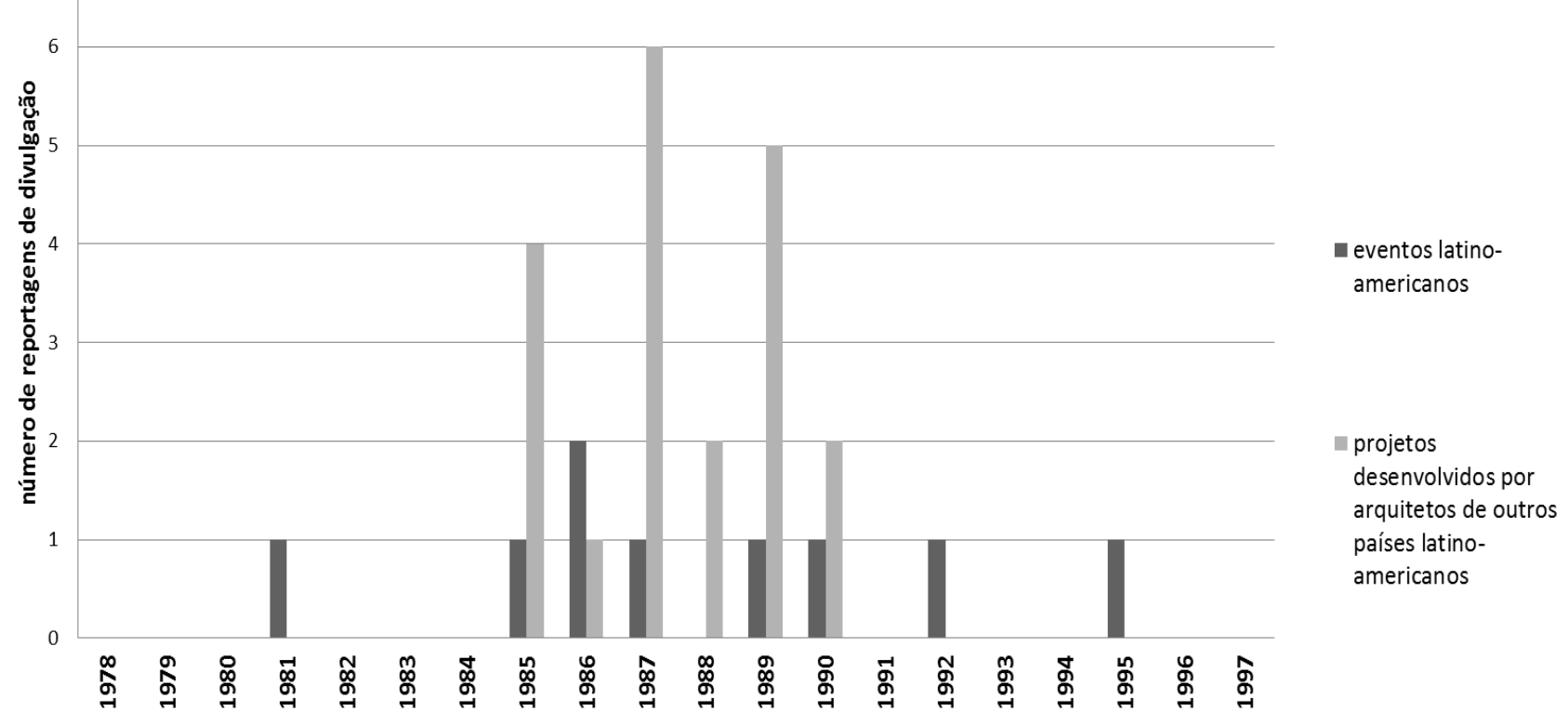

Fonte: Elaboração do autor com base em levantamento realizado a partir da análise longitudinal das edições da revista CA entre 1978 e 1997.

\section{Revista ARS (Chile): 1978 a 1989}

Período de vigência do periódico: 1978 a 1989

Média de edições por ano: 1

Números analisados: no1 (ago 1978) ao no 11 (jul 1989) 
Número de textos que compõem o corpus de textos críticos: 47

Número de reportagens que compõem o corpus de reportagens: 33

Gráfico 13: Textos críticos que demonstram a existência de vínculos latino-americanos revista ARS entre 1978 e 1989.

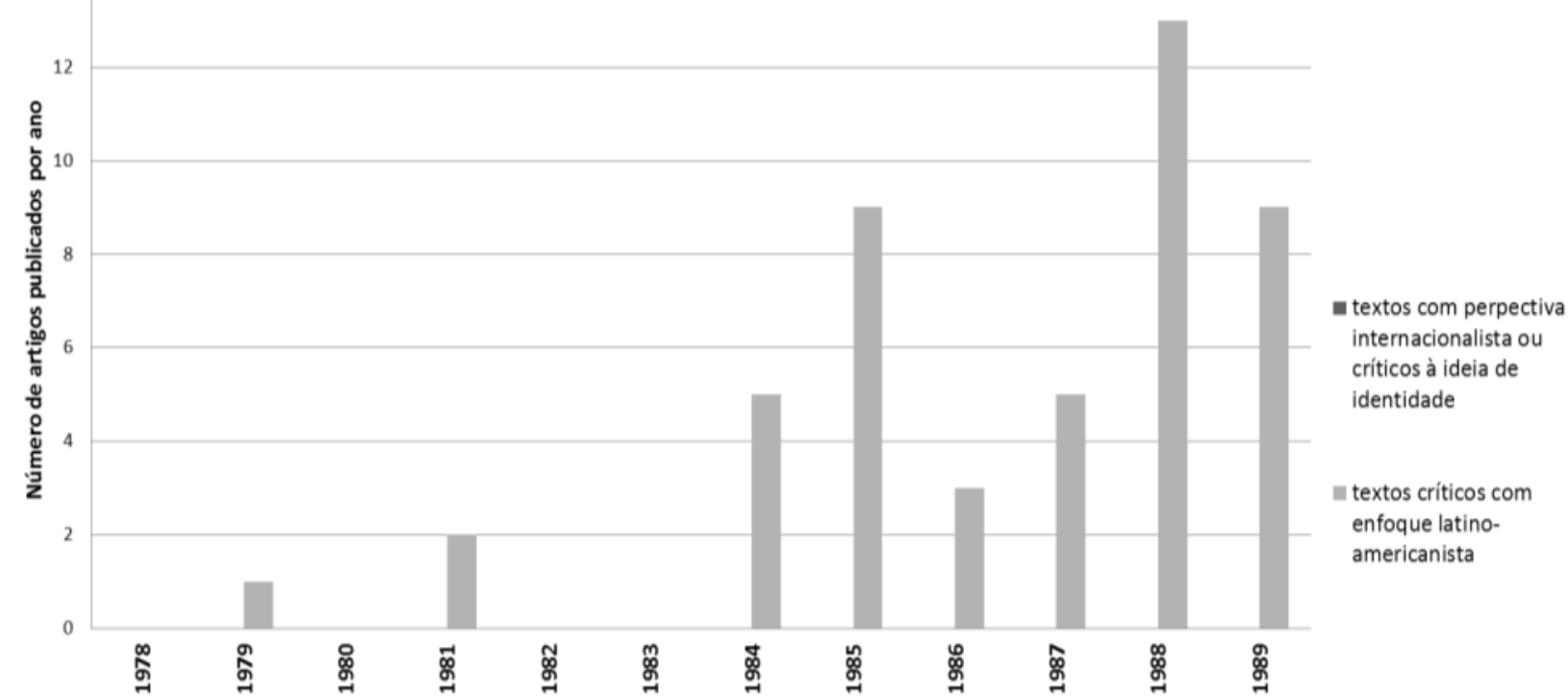

Fonte: Elaboração do autor com base em levantamento realizado a partir da análise longitudinal das edições da revista ARS entre 1978 e 1989.

Gráfico 14: Reportagens sobre eventos e projetos publicadas na revista ARS entre 1978 e 1989 que testemunham o interesse na discussão da arquitetura e/ou do urbanismo latino-americanos.

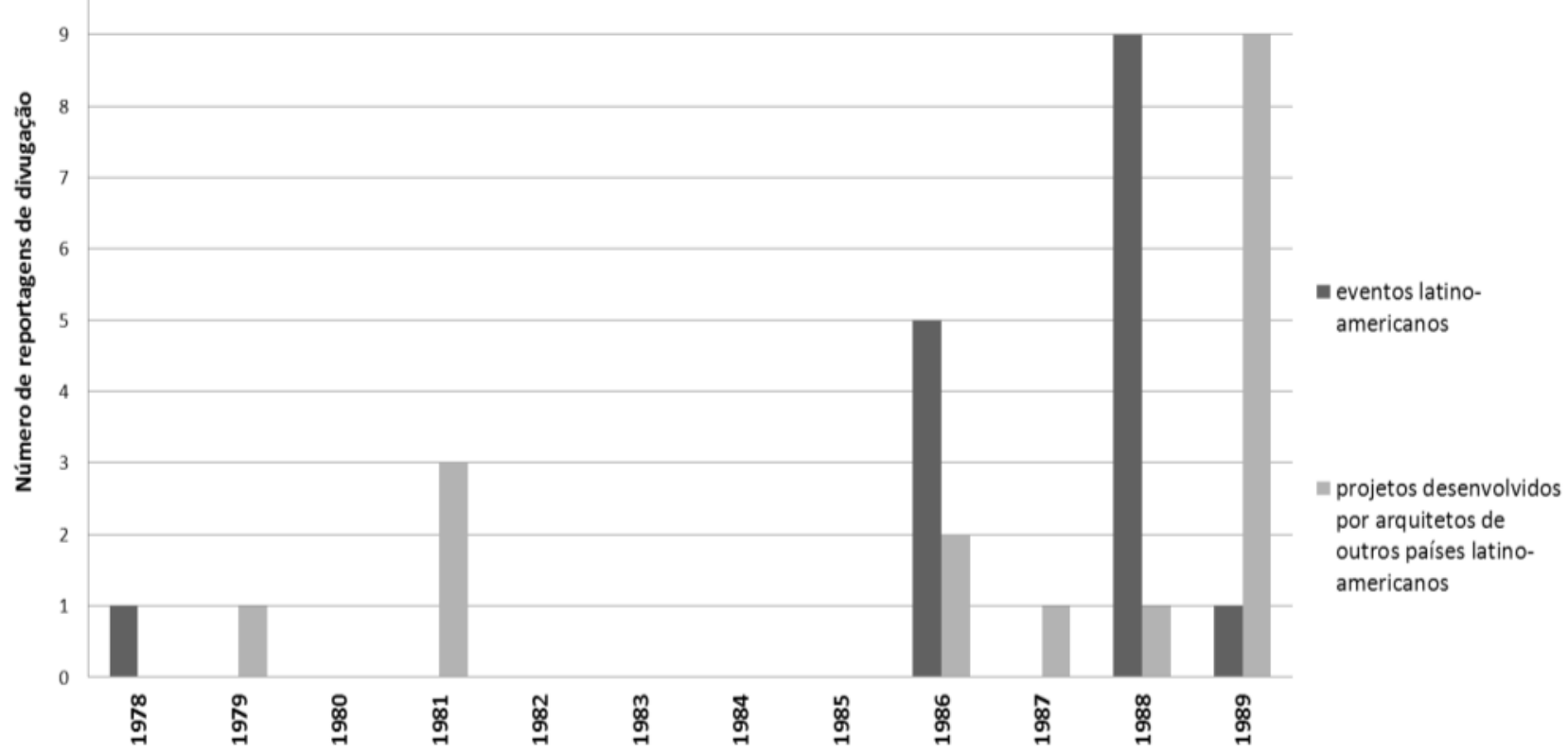

Fonte: Elaboração do autor com base em levantamento realizado a partir da análise longitudinal das edições da revista ARS entre 1978 e 1989.

\section{Revista ESCALA (Colombia): 1980 a 1994}

Período de vigência do periódico: de 1962 até hoje

Média de edições por ano: 4 a 5

Números analisados: do no 100 (1980) ao no 166 (1994)

Número de textos que compõem o corpus de textos críticos: 4 
Número de reportagens que compõem o corpus de reportagens: 34

Gráfico 15: Textos críticos que demonstram a existência de vínculos latino-americanos revista ESCALA entre 1980 e 1994.

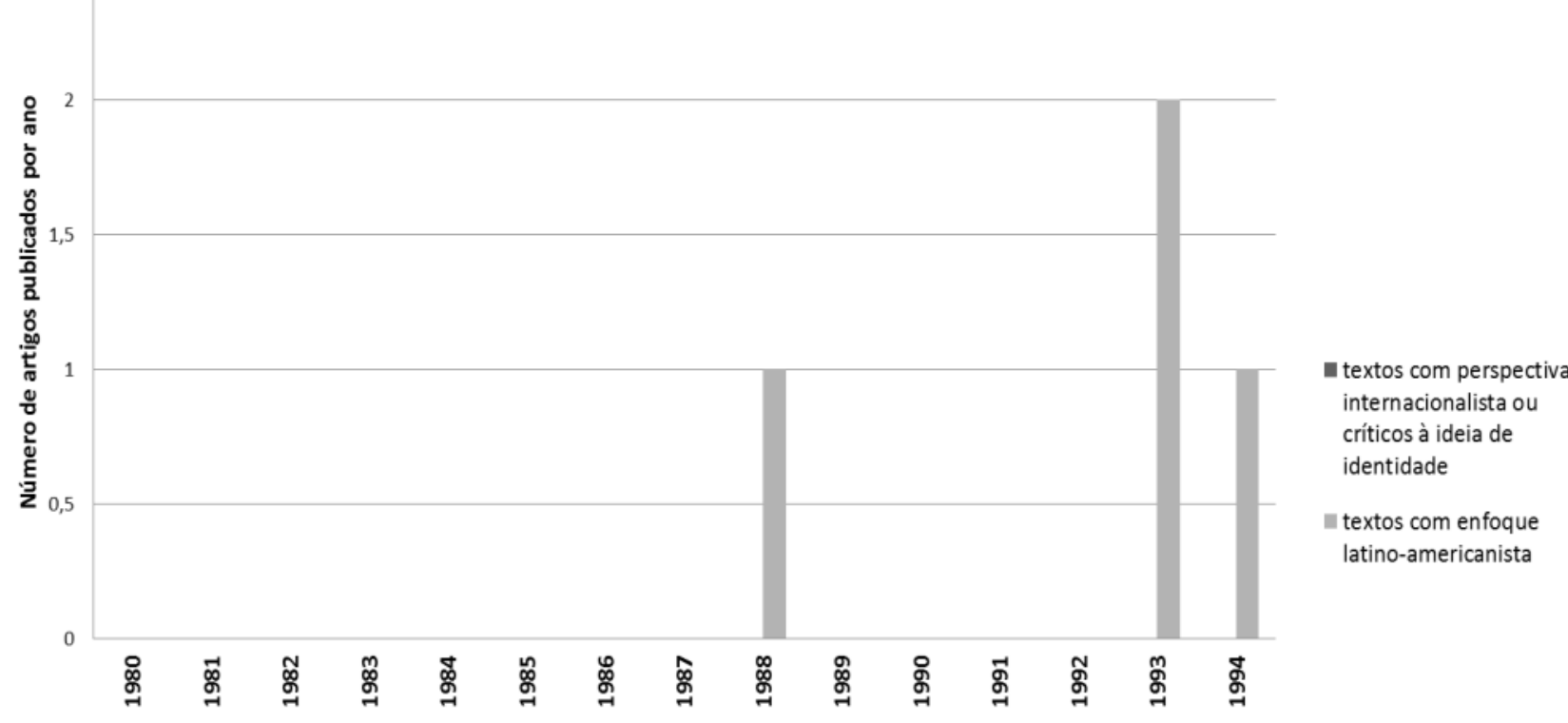

Fonte: Elaboração do autor com base em levantamento realizado a partir da análise longitudinal das edições da revista ESCALA entre 1980 e 1994.

Gráfico 16: Reportagens sobre eventos e projetos publicadas na revista ESCALA entre 1980 e 1994 que testemunham o interesse na discussão da arquitetura e/ou do urbanismo latino-americanos.

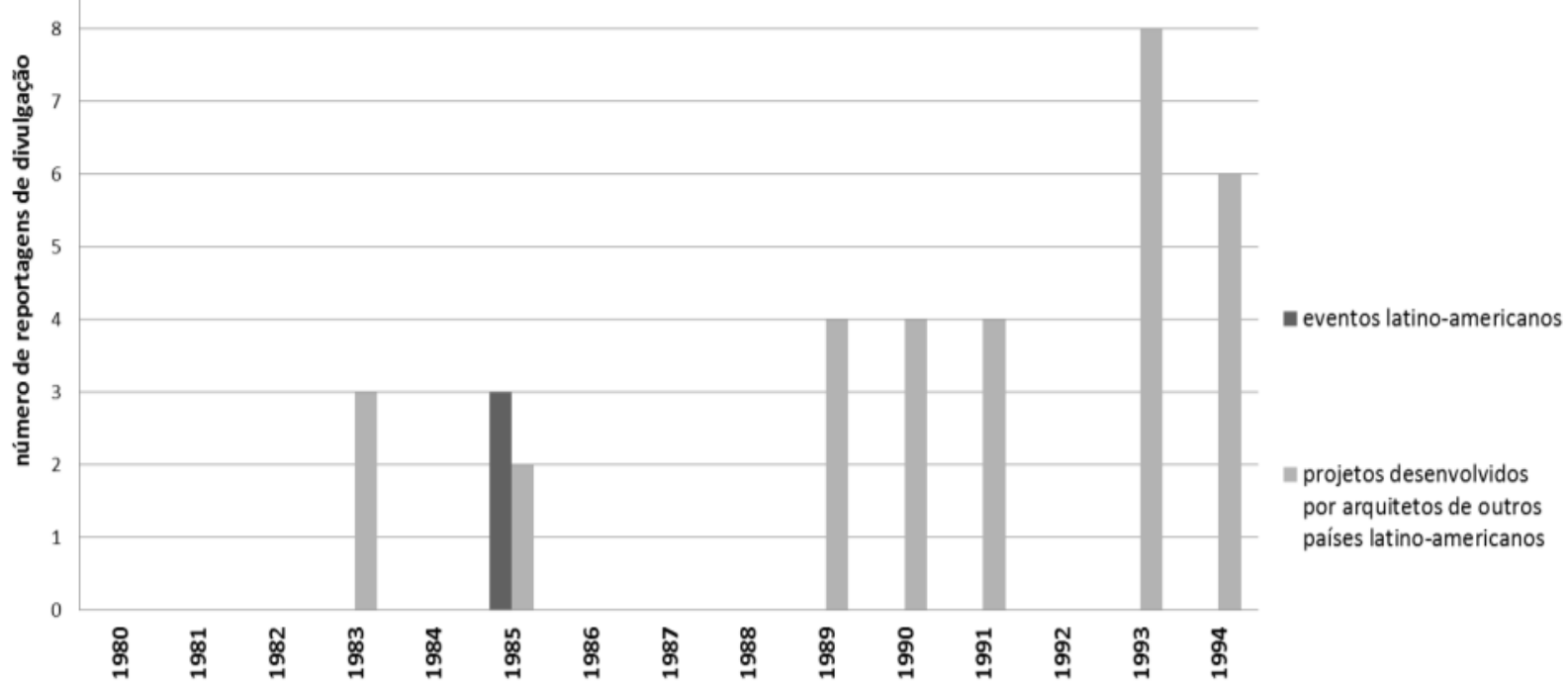

Fonte: Elaboração do autor com base em levantamento realizado a partir da análise longitudinal das edições da revista ESCALA entre 1980 e 1994.

\section{Revista PROA (Colombia): 1980 a 1995}

Período de vigência do periódico: de 1946 até hoje

Média de edições por ano: 9

Números analisados: no 288 (fev 1980) ao no 427 (dez 1995)

Número de textos que compõem o corpus de textos críticos: 42

Número de reportagens que compõem o corpus de reportagens: 93 
Gráfico 17: Textos críticos que demonstram a existência de vínculos latino-americanos revista PROA entre 1980 e 1995.

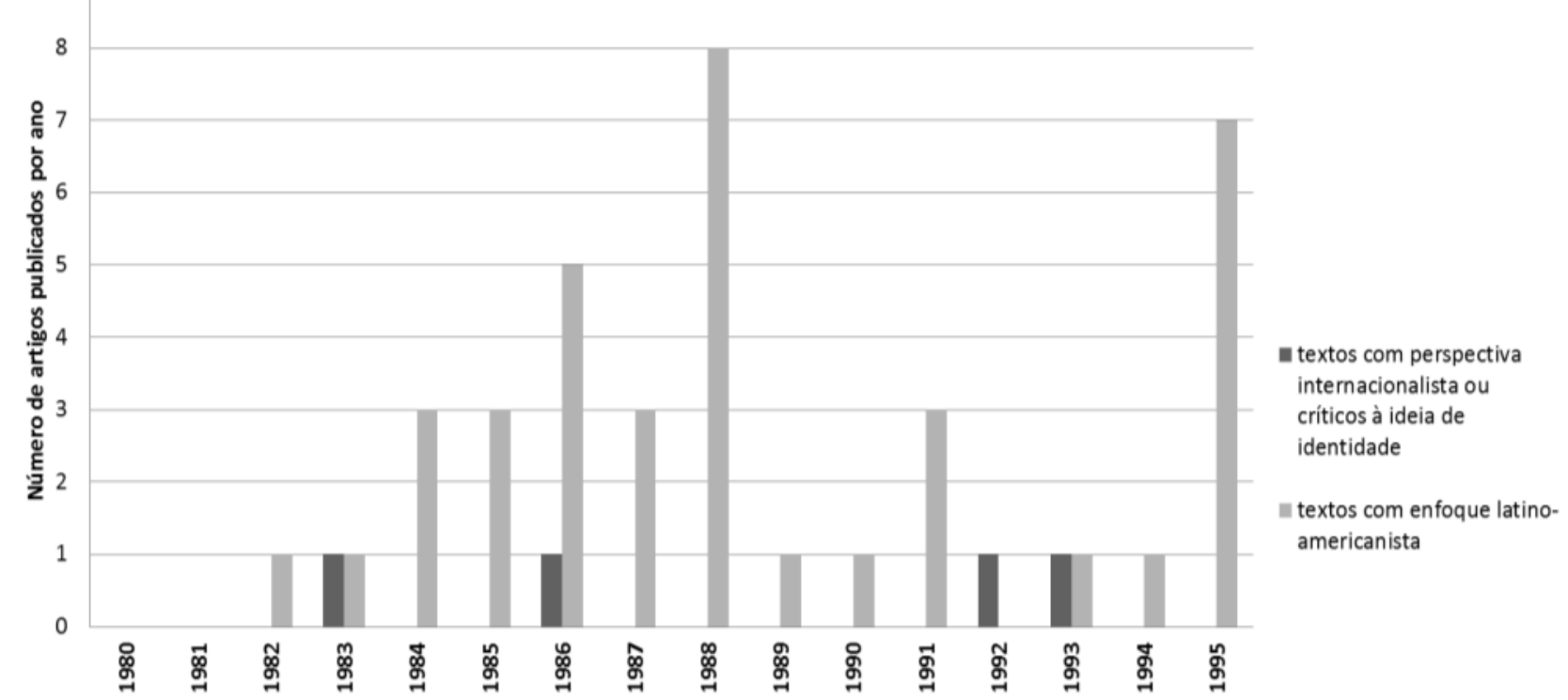

Fonte: Elaboração do autor com base em levantamento realizado a partir da análise longitudinal das edições da revista PROA entre 1980 e 1995.

Gráfico 18: Reportagens sobre eventos e projetos publicadas na revista PROA entre 1980 e 1995 que testemunham o interesse na discussão da arquitetura e/ou do urbanismo latino-americanos.

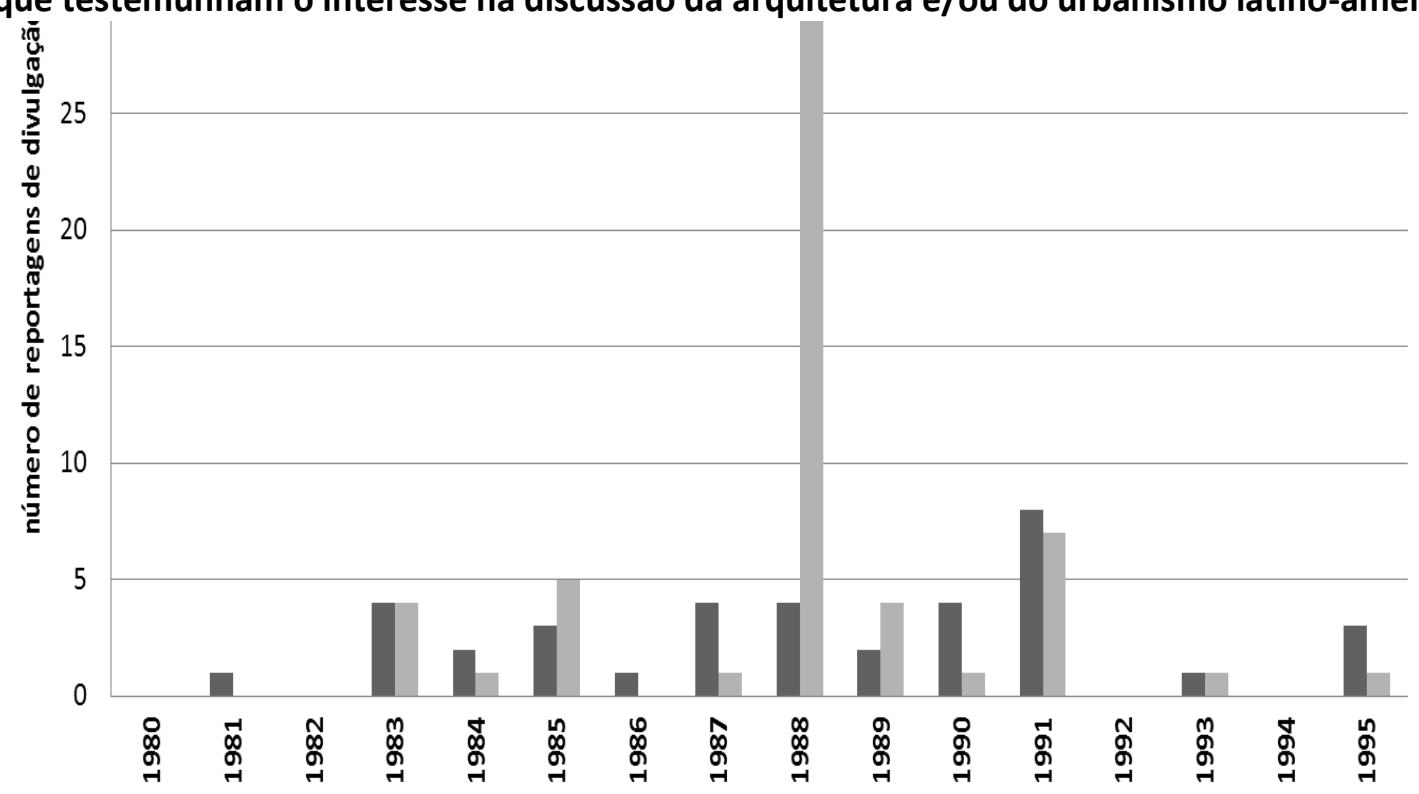

- eventos ou publicações latino-americanos

- projetos desenvolvidos por arquitetos de outros países latino-americanos

Fonte: Elaboração do autor com base em levantamento realizado a partir da análise longitudinal das edições da revista PROA entre 1980 e 1995. 